ISBN: 978-65-86361-66-7

\title{
TÓPIBOS EM
}

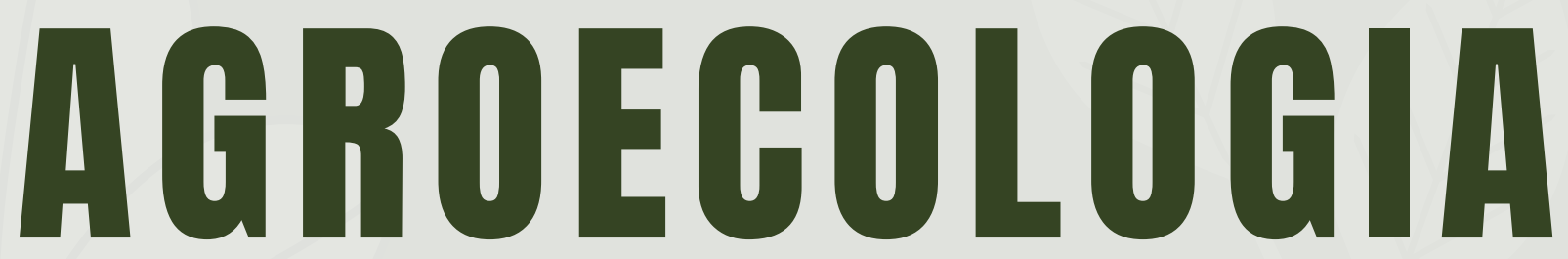

\section{Volume II - 2020}

\section{ORGANIZADORES:}

\author{
OTACILIO JOSE P. RANGEL \\ ANA PAULA CANDIDO G. BERILLI \\ APARECIDA DE FATIMA M. DE OLIVEIRA \\ DANIELLE INÁCIO ALVES \\ JEANE DE ALMEIDA ALVES \\ JEFERSON LUIZ FERRARI \\ MAURICIO NOVAES SOUZA \\ MONIQUE MOREIRA MOULIN \\ PEDRO PIERRO MENDONÇA
}




\section{TÓPICOS EM \\ AGROECOLOGIA \\ Volume II - 2020}

Programa de Pós-Graduação em Agroecologia Edifes Alegre-ES

ACADÊMICO 


Programa de Pós-Graduação em
Agroecologia (PPGA)
Instituto Federal do Espírito Santo (Ifes) -
Campus de Alegre
Rodovia ES 482, km 47, Cx. Postal-47,
Distrito de Rive, Alegre-ES
Telefone: $\quad$ (28)
www.ppga.alegre.ifes.edu.br

Reitor: Jadir Jose Pela

Pró-Reitor de Administração e Orçamento: Lezi José Ferreira

Pró-Reitor de Desenvolvimento Institucional: Luciano de Oliveira Toledo

Pró-Reitora de Ensino: Adriana Pionttkovsky Barcellos

Pró-Reitor de Extensão: Renato Tannure Rotta de Almeida

Pró-Reitor de Pesquisa e Pós-Graduação: André Romero da Silva

Coordenador da Edifes: Adonai José Lacruz

\section{Comissão de Editoração}

Otacilio José Passos Rangel, Ana Paula

Candido Gabriel Berilli, Aparecida de Fátima

Madella de Oliveira, Danielle Inácio Alves, Jeane de Almeida Alves, Jéferson Luiz

Ferrari, Maurício Novaes Souza, Monique Moreira Moulin, Pedro Pierro Mendonça

Revisão Textual

Ana Paula Candido Gabriel Berilli

Aparecida de Fátima Madella de Oliveira

Jéferson Luiz Ferrari

Luciano Menini

Maurício Novaes Souza

Monique Moreira Moulin

Otacílio José Passos Rangel

Pedro Pierro Mendonça

Renato Ribeiro Passos

\section{Editoração Eletrônica}

Programa de Pós-Graduação em Agroecologia (PPGA), Ifes-Campus de Alegre

\section{Capa}

Assessoria de Comunicação Social - Ifes

\section{Normalização Bibliográfica}

Danielle Inácio Alves

Jeane de Almeida Alves

Dados Internacionais de Catalogação-na-Publicação (CIP)

Biblioteca Monsenhor José Bellotti - Ifes campus de Alegre

T674

Tópicos em agroecologia, vol. II [recurso eletrônico] / Otacílio José

Passos Rangel ... [et.al] (organizador). - Alegre: Instituto Federal de

Educação, Ciência e Tecnologia do Espírito Santo, 2020.

$450 \mathrm{f}$. il.

ISBN: 978-65-86361-66-7

Inclui bibliografias.

formato: livro digital (e-book PDF)

veiculação: digital

1. Ecologia agrícola - Pesquisa. 2. Agricultura - Sustentabilidade. I.

Rangel,Otacílio José Passos, org. II. Berilli, Ana Paula Candido Gabriel, org. III. Oliveira, Maria de Fátima Madella, org. IV. Alves, Danielle Inácio, org. V. Alves, Jeane de Almeida, org. VI. Ferrari, Jéferson Luiz, org. VII. Novaes, Maurício, org. VIII. Moulim, Monique Moreira, org. IX. Mendonça, Pedro Pierro, org.

elaborada por Aline Kuplich - CRB-6/ES 540

@2020 Instituto Federal do Espírito Santo

Todos os direitos reservados.

É permitida a reprodução parcial desta obra, desde que citada a fonte.

O conteúdo dos textos é de inteira responsabilidade dos autores. 


\section{Prefácio}

Neste mês, novembro de 2020, o Programa de Pós-Graduação em Agroecologia (PPGA) do Ifes - Campus do Alegre, ES, lança o segundo volume do livro "Tópicos em Agroecologia". Essa edição visa dar continuidade à brilhante iniciativa do Professor Otacílio José Passos Rangel, com a contribuição dos professores, alunos, ex-alunos e servidores técnicoadministrativos do PPGA! Considerando a necessidade de publicações nos dias atuais para o crescimento de nosso Mestrado, será um importante veículo para o sucesso e difusão dos trabalhos aqui desenvolvidos. Cabe considerar que será disponibilizado para download gratuito.

Pois bem, além do contentamento de poder participar da equipe técnica que compõe a Comissão de editoração do referido livro, tive outra feliz surpresa: ser convidado para escrever o seu prefácio!

Indiscutivelmente, o convite para tal tarefa feito pelo Professor Otacílio, com a aprovação de toda a Comissão, fez-me sentir afagado e, ainda mais, ao saber que a homenagem póstuma do ano seria à Ana Primavesi, pioneira nos estudos em agroecologia no Brasil, que faleceu em janeiro deste ano de 2020. Dessa forma, foi com enorme satisfação que acolhi o convite e, sem exagero, aceitá-lo foi um enorme prazer: pelo fato em si, e também por permitir mexer com memórias do meu passado universitário.

Afinal, conheci essa brilhante professora e pesquisadora quando cursava Agronomia na Universidade Federal de Viçosa (UFV). Fazia a disciplina Solos I, com o professor Roberto Novais - o ano era 1977, quando ouvi pela primeira vez, por um amigo, comentários sobre "uma mulher-agrônoma que se chamava Primavesi". Comentou que tinha uma proposta diferenciada de agricultura, mais sustentável, para os trópicos - contrário a tudo que se apregoava naquela época, auge da Revolução Verde. Considerando que a UFV foi um dos berços do modelo tecnológico proposto, com o qual nunca me identifiquei, fiquei motivado por conhecer sua obra.

Lembro-me que no mesmo dia visitei a Cooperativa da UFV e comprei um de seus livros "Manejo ecológico de pastagens". Mais tarde, em 1980, adquiri o famoso "Manejo ecológico do solo", que repousa em minha pequena biblioteca há 40 anos! Portanto, desde meu período de graduação, sinto enorme respeito, carinho e grande admiração pela Professora Primavesi, que o merece de todos os agroecólogos, estudantes, professores, pesquisadores e produtores rurais, com destaque aos de base familiar de produção: não apenas do Brasil, mas de todo o mundo. 
Lembro que ao começar a leitura do referido livro, se dava de forma tão agradável, que quando percebi era madrugada, quase na hora da ordenha! De formato diferenciado, não tinha o "peso" e a "densidade" dos clássicos livros técnicos. Como dizia meu grande Professor Casali, é um livro de amor e poesia, que trata de algo há muito entre nós está adormecido: o respeito aos homens, às plantas e aos animais em sua dignidade - que ultrapassa a vida no interior do solo e alcança os microrganismos, tão desconhecidos à época, mas fundamentais para a vida do solo; infelizmente, visto por muitos, de mera forma utilitária.

Formado, fui trabalhar onde nasci e vivi minhas infância e adolescência, na propriedade da minha família em Castelo, ES. O ano era 1981, auge do "sucesso" da Revolução Verde no Brasil e no Mundo. Contudo, mesmo sendo agrônomo formado no modelo clássico daquele período, nunca tive "simpatia" pelo uso dos agrotóxicos. Quando pequeno, lembro-me de que não havia uso intensivo de agroquímicos: usavam-se chás para curar os males animais e preparados para as doenças das plantas; entretanto, já se usava o famoso "HCB" - era manuseado até por crianças, sem cuidado algum!

Bem, para aqueles que não conhecem o início de sua história: quem foi Ana Maria Primavesi e qual a sua importância? Segue um pequeno resumo de sua biografia, extraído, resumido e modificado de textos acadêmicos e de seus livros "Histórias de vida e agroecologia", "Manual do solo vivo" e a "Extraordinária vida de Ana Maria Primavesi"; este último, uma biografia de sua obra.

Ana Maria Baronesa Primavesi nasceu em 3 de outubro de 1920, no castelo Pichlhofen, distrito de St Georgen ob Judenburg, no estado da Estíria, Áustria, como primeira filha do Barão Sigmund Conrad e sua esposa Clara. Depois de cursar o primário em seu distrito, em 1935, foi para o Sacré Coeur, em Graz, onde foi aluna no internato. Fez os últimos anos do ginásio em Dresden, onde concluiu seus estudos básicos, sendo mandada para o serviço Arbeitsdienst, no leste da Prússia, "um grande desestímulo imposto pelos nazistas a quem queria continuar os estudos"; depois de nove meses entrou na Universidade Agrícola de Viena, concluindo em 1942

Doutorou-se em Cultura de Solos e Nutrição Vegetal: durante o período em que esteve na universidade, foi mandada para Lodz, Polônia, para ajudar na transferência de refugiados judeus durante a guerra. Em Metz, Lorena, trabalhou em uma fábrica, por imposições do governo nazista aos estudantes. De 1943 até ao final da guerra, trabalhou no Conselho de Pesquisa da Universidade com pesquisas sobre ar frio. Foi presa como ato de segurança dos ingleses e trabalhou nessa época como intérprete e tipista na FSS (Serviço Secreto dos Ingleses), em um campo de concentração em Wolfsberg. Quando foi solta, disseram-Ihe que aquilo fora um engano.

Primavesi trabalhava com Johannes Görbing, farmacêutico de formação, mas o que o atraía mesmo era a botânica e a química, principalmente a química dos alimentos. Ele 
conquistara o seu respeito por sua humildade e porque, em sua espontaneidade, ensinava àqueles estudantes a pensar e a questionar aspectos que nunca cogitaram. Aquela lógica tão simples e tão verdadeira, sutil e arrebatadora tomavam Primavesi, e um entusiasmo cresceu em seu íntimo, a partir de um dado caso.

Esse seu professor, Görbing, que havia residido em Aleppo, no norte da Síria, e fora trabalhar como médico de um regimento, um episódio despertou sua curiosidade: os turcos, tendo roubado trigo para fazer pão, mostravam-se meio "loucos" com sua ingestão: Görbing questionou-os. Além da curiosidade, havia a responsabilidade de responder como médico de seu regimento: "O que há em seu cereal?" Descobriu que um fungo e outra planta estavam misturados à farinha, levando-o a pensar: se o homem se alimenta das plantas, direta ou indiretamente, e o que sente está diretamente associado ao que come, então era o solo que deveria ser o bem mais precioso de todos, pois dele as plantas retiram os nutrientes e deles depende a saúde em toda a teia alimentar.

Tudo era tão simples e lógico; mesmo assim, era um segredo para a maioria. Primavesi nunca mais se desvencilharia daquela experiência, daquele professor e daquela tarde. Arriscam-se dizer que ali nascia a grande engenheira agrônoma Ana Maria Primavesi. Foi a partir do contato com Johannes Görbing, "O Profeta", como o chamavam - justamente porque não entendiam as relações que ele fazia entre solo-planta-animais -, que Primavesi passou a ressignificar seus aprendizados e a conectá-los, já exercendo o que hoje se chamam de agroecologia, mas que para ela ainda não tinha um nome, somente uma conduta!

Em 1944, Primavesi foi convidada pelo professor F. Sekera para trabalhar como uma de suas assistentes no Instituto de Ciência do Solo e Nutrição Vegetal da Universidade de Viena. Naquele ano concluiu seu doutorado e aprofundou seus conhecimentos sobre micronutrientes e deficiências minerais. Afirmava que o solo não é um suporte para adubos, água de irrigação e culturas, mas um organismo vivo, cujo esqueleto é a parte mineral, os órgãos são os micróbios que ali vivem e o sangue é a solução aquosa que circula por ele. Respira como qualquer outro organismo vivo e possui temperatura própria. Necessita tanto das plantas como as plantas necessitam dele.

Em 1946 casou-se com o fazendeiro, diplomata e também doutor Artur Barão Primavesi e, com poucos recursos financeiros, em 1948 vieram para o Brasil. Artur conseguiu um trabalho na Secretaria de Agricultura em São Paulo como superintendente para o plantio de trigo. Ana acompanhou o marido nos primeiros anos por onde havia trabalho. Moraram em Itapetininga (SP), Passos (MG), Itaberá (SP), São Paulo (SP) e Santa Maria (RS). Por todo esse tempo, Artur contou com a assessoria da esposa em todos os trabalhos que atuou.

Lecionou na Universidade de Santa Maria, RS, instituição na qual Artur fundou o Instituto de Solos e Culturas e criou o primeiro curso de pós-graduação (Produtividade e Conservação do Solo); também trouxe para a cidade o Segundo Congresso de Biologia de Solos da América 
Latina patrocinado pela UNESCO. Nos anos da década de 1960, escreveu um clássico da agroecologia tropical publicado originalmente em dois volumes: "A Biocenose do solo na produção vegetal \& Deficiências minerais" - foi um dos primeiros estudos brasileiros a analisar a importância do solo como organismo vivo e não apenas como suporte para as plantas: temática que seria o grande mote de toda a vida e obra de Primavesi. Até esse período, não havia na literatura uma obra que tratasse cientificamente a vida do solo e a relação entre seus componentes e a planta.

O casal Primavesi, no laboratório da Universidade de Santa Maria, 1962, revolucionou a agricultura tropical ao diferenciá-la da prática de clima temperado. Ana Primavesi cravou os alicerces do que ficou conhecido como "Agroecologia" - ciência agronômica que considera o solo um organismo vivo. Ao mesmo tempo em que brilhavam por sua extrema capacidade e formação acadêmica, os Primavesi geravam desconforto e inveja em alguns colegas. Além disso, defendiam um enfoque muito diferente do que aqui se fazia. Grande parte da prática agrícola se espelhava no que se fazia na América do Norte e Europa: os Primavesi deixavam claro que em clima tropical as condições eram outras. Para cada clima, um tipo de solo, um tipo de trato. Esse confronto ideológico não se restringiu somente à Universidade. Ana Primavesi teria que defender suas ideias sempre, sem trégua.

O fato é que a fama dessa doutora, em sentido amplo, extrapolou as paredes da Universidade. Ela passou a auxiliar pessoas que a procuravam pedindo ajuda para diversas doenças. Não adiantava dizer que ela não era médica e que a "Doutora" devia-se a um título acadêmico. "Doutora é Doutora", respondiam! Assim, ela indicava ervas, chás e todo tipo de plantas que poderiam amenizar os problemas. Mal não fariam, porque eram naturais, assim como se utilizam os alimentos para nossa nutrição. Acontece que ela sempre acertava, a fama crescia e mais e mais pessoas a esperavam na porta de sua casa quando voltava da Universidade.

Nessa época, Primavesi vinha escrevendo seu livro "Manejo ecológico do solo". Nele, condensava tudo que sabia, de forma que todos os conceitos se integrassem, numa visão sistêmica e ecológica. A primeira dificuldade que percebeu foi encontrar uma editora - era um livro de conteúdo "revolucionário", diziam. Contudo, mais uma vez, sua estrela brilhou - a editora Nobel queria um livro agrícola com o qual pudesse iniciar suas publicações nessa área; e Ana Primavesi se adiantou: "O livro é bastante polêmico" - era tudo o que a editora queria. Assim, em 1980, o livro foi lançado e tem sido vendido com sucesso até aos dias atuais.

Muito criticada e combatida por suas ideias ecológicas, que dispensam uso de agrotóxicos e questiona o uso da adubação química, Ana seguia resolvida: "Tenho certeza do que estou falando". E cada vez mais pessoas se voltam aos seus livros e ensinamentos, frustradas com a baixa produtividade de suas terras, buscando na agroecologia o retorno às suas próprias 
essências, na ação recíproca do plantar e colher, sem explorar os solos, mas sim manejandoo como um organismo vivo. A agroecologia trabalha com sistemas e ciclos de maneira holístico-sistêmica.

Procura eliminar as causas dos problemas e não apenas combater os sintomas que voltam enquanto as causas perduram. Nenhum processo pode ser isolado do outro, tudo é dependente e interdependente, e o homem se vê como parte de um sistema, não acima dele. Assim, deve prover a terra de tudo que ela precisa; e, no caso das terras dos trópicos, de muita matéria orgânica para alimentar os microrganismos: estes sim, os grandes responsáveis pela fertilidade dos solos.

Se hoje a agroecologia condensa todo o conhecimento para se chegar a uma prática agrícola que garanta não só alimentos a todos os sapiens deste planeta, como também a manutenção de sua vida, é sobre os estudos de Ana Primavesi que ela se fundamenta. Contudo, veja quanta simplicidade - quando perguntada o que acha disso tudo, ela respondia: "Eu não fiz nada sozinha".

Nos dias atuais, sabe-se que a Ecologia é um ramo da Biologia que estuda as relações entre os organismos vivos e entre os organismos e seus ambientes. Dessa forma, Agroecologia é uma parte da ecologia que visa a integração equilibrada entre as atividades agrícolas e o meio ambiente. Dessa forma, a "Agroecologia" é então a realização de atividades agrícolas condizentes com o meio ambiente, respeitando as relações entre os organismos vivos e entre os organismos e seus ambientes. É cultivar o que se deseja colher de forma que não atrapalhe estas relações, que de acordo com Primavesi, são fundamentais para que o solo funcione do melhor forma possível: adsorva a água que a ele chega (permeabilidade), germine as sementes ou permita o crescimento de mudas ali plantadas (fertilidade), e que essas plantas sejam fortes e saudáveis (rico em nutrientes).

Tudo isso se faz possível graças à existência dos microrganismos que vivem na camada mais superficial do solo (como são chamados os primeiros $20-30 \mathrm{~cm}$ de profundidade do solo - o topsoil). Primavesi explica que apenas os solos que possuem grãos de terra "agregados" têm estas qualidades: permeabilidade, fertilidade e riqueza em nutrientes, o que ela chama de "solo vivo".

Em 2006, à época professor no CEFET-RIO POMBA, honrosamente, participei da criação do primeiro curso de Tecnologia em Agroecologia do Brasil e, dois anos depois, Bacharelado em Agroecologia. Em 2007, organizamos o "I Encontro de Agroecologia" de nossa Instituição, como acontece até aos dias atuais - hoje um consagrado evento. Como em todos os eventos, sempre há um convidado especial: pois bem, nesse encontro foi exatamente a Professora Ana Primavesi. Lembro-me que quando a vi, tão perto, cumprimentei-a, dei um abraço, e senti uma profunda e inenarrável emoção. Ela tinha jeito de avó! Tão gentil e carinhosa. Sua palestra durou mais de 3 horas que, de fato, foi um agradável bate-papo! Ficou conosco por 
dois dias - visitou o campo, o pátio de compostagem, o horto, a horta, o restaurante universitário, enfim, muita conversa e, quanta simplicidade!

Cabe considerar que suas palestras eram disputadíssimas - era requisitada muito mais do que daria conta de comparecer. Primavesi era multifunções: cuidava da casa, das plantações, dos animais, escrevia para periódicos, respondia cartas, lia todas as publicações que the caíam nas mãos, elaborava palestras e cursos, fazia experimentos e cuidava das compras, vendas, estocagens e manuseios. Sempre acordava bem cedo e preservou o hábito de dormir uns quinze minutos depois do almoço, no mínimo, hábito herdado de seus pais. Recebia estagiários, que queriam aprender com ela sobre agricultura orgânica, sobre ecologia.

Hoje, pode-se afirmar que Primavesi contribuiu de forma significativa para resgatar a autoconfiança do produtor rural. Durante anos se incutiu ao agricultor que ele não entende nada, simplesmente porque não consegue interpretar análises químicas do solo. Diziam que era semianalfabeto, porque nem sempre podia ler e escrever como os agrônomos e que devia perguntar sempre "o que fazer" - aí, invariavelmente, recebiam uma receita para comprar máquinas e insumos.

Contudo, há de se perguntar: não foi exatamente o agricultor que financiou a industrialização? A profissão do agricultor é de ser escrivão ou de cultivar a terra? A cidade vive do campo ou o campo vive da cidade? Comem-se alimentos ou comem-se dinheiro? As frutas crescem em árvores ou em torres de televisão?

Nesse modelo proposto por Primavesi, a Agroecologia, o agricultor para de perguntar "o que faço", e passa a questionar: "Por que ocorre?" Assim, ocorre uma mudança na clássica situação e, ninguém sabe ou pode responder a essa pergunta - somente ele, com suas observações, tem de descobri-lo: observar, pensar, experimentar... assim, de repente, ele produzirá melhor. Começa a ganhar autoconfiança, acredita no que ele vê, pensa e faz; ele produzirá mais, com menor custo, que a mais tecnificada agricultura química, aquela do modelo convencional de produção. Então, como diz meu grande amigo Newton Campos, do Sítio Jaqueira Agroecologia, ele se dá conta: não é escrivão, mas é produtor de alimentos junto com a natureza que Deus fez, respeitando as leis eternas, acreditando em si.

A professora Primavesi ensina:

"O manejo ecológico das pastagens deve considerar TODOS OS FATORES DE UM LUGAR, uma vez que "eco" significa lugar. Deve manter o equilíbrio entre o gado adaptado; a vegetação e sua capacidade de produzir forragem boa neste solo; a influência do gado sobre a vegetação e da vegetação sobre o gado; os fatores do solo em consideração à vegetação e ao gado, com sua estrutura, riqueza mineral, microvida e fauna-terrícola, que inclui as minhocas, bem como a influência do clima. O manejo é ecológico quando consegue manter em equilíbrio todos os fatores de um lugar ou restabelecer o equilíbrio favorável entre eles, para que não haja decadência do ecossistema e para que proporcione as condições melhores possíveis ao gado. Para isso, necessita-se de muita observação, bom senso, dedicação e muito amor pelo trabalho. Mas, compensa!" 
Nos dias atuais se perguntam: agroecologia é o modelo de produção "de volta ao passado" ou é o "futuro"? O fato é que a questão agrária e a agroecologia não deve ser visualizada apenas como modelo de produção e uso de pacotes tecnológicos! Vai muito além da etimologia de modelos de agronegócios: como dizia meu grande mestre Sebastião Pinheiro, que também faleceu nesse ano de 2020, é um caminho da luz e esperança para o Futuro.

Finalizando, lembro a fala da professora Ana Maria Primavesi: "O homem é o que a terra, ou o solo, faz dele".

Agradeço ao Professor Otacilio José Passos Rangel, por me proporcionar esse momento de pesquisa e reflexão sobre meu passado e a história da Agroecologia, que se confunde com a vida da brilhante professora Primavesi; ao Coordenador do PPGA, Professor Luciano Menini; à Coordenadora da Pós lato sensu em Agroecologia e sustentabilidade, Professora Madella; aos colegas professores e técnico-administrativos; e aos meus inestimáveis orientados e alunos do PPGA. Sucesso para todos! Que nos próximos anos floresçam novos volumes dos "Tópicos em Agroecologia"!

Forte abraço,

Alegre, novembro de 2020.

Professor Maurício Novaes Souza

Instituto Federal do Espírito Santo - Campus de Alegre 


\section{Apresentação}

O livro "Tópicos em Agroecologia" faz parte de um processo amplo de reflexão sobre a importância da agroecologia na agricultura que vem sendo desencadeado por uma demanda de produtores e consumidores por produtos com qualidade e segurança alimentar. Esse livro tem por objetivo aprofundar algumas constatações iniciais desse debate em curso sobre as práticas agrícolas e sua relação com o meio ambiente, homem e alimento.

Essa segunda edição vem para consolidar a série de livros produzidos pelo Programa de Pós-graduação em Agroecologia (PPGA) do Instituto Federal do Espírito Santo Campus de Alegre. Os autores desta coletânea, sob diferentes perspectivas, apontam o papel estratégico da agroecologia na agricultura contemporânea, reafirmando o conhecimento científico como ponto indispensável no enfrentamento e na superação dos vários problemas ambientais, sociais e econômicos vivenciados pela maioria dos pequenos agricultores em nosso país.

Nessa edição são abordados diferentes temas com preceitos agroecológicos de natureza técnica e científica. Os capítulos são elaborados por docentes, discentes e colaboradores do PPGA, planejados de forma apresentar ao leitor os princípios e bases da agroecologia, enquanto campo de conhecimento científico validado por trabalhos acadêmicos.

Nossos agradecimentos aos membros da comissão organizadora do livro, aos docentes, discentes e demais colaboradores pela dedicação na construção dessa obra e a editora Edifes pela parceria.

Professor Luciano Menini

Coordenador do Programa de Pós-Graduação em Agroecologia Instituto Federal do Espirito Santo - Campus de Alegre 


\section{Autores}

\section{Alberto Chambela Neto}

Dr. Professor do Instituto Federal do Espírito Santo - Campus Santa Teresa, Rod ES 080, km 93, São João de Petrópolis, CEP: 29650-000, Santa Teresa-ES. chambela@ifes.edu.br

\section{Alciro Lamao Lazzarini}

Me. em Agroecologia pelo Programa de Pós-Graduação em Agroecologia do Instituto Federal do Espírito Santo - Campus de Alegre, Coordenador do CRDR Litoral Sul do Instituto Capixaba de Pesquisa Assistência Técnica e Extensão Rural, Fazenda Experimental do Incaper, CEP: 29240-000, Alfredo Chaves-ES. lazzarinial@incaper.es.gov.br

\section{Aldemar Polonini Moreli}

Dr. Professor do Instituto Federal do Espírito Santo - Campus Venda Nova do Imigrante, Rua Elizabeth Minete Perim, 500, Bairro São Rafael, CEP: 29375-000, Venda Nova do Imigrante-ES. aldemar.moreli@ifes.edu.br

\section{Alex Justino Zacarias}

Mestrando em Agroecologia pelo Programa de Pós-Graduação em Agroecologia do Instituto Federal do Espírito Santo - Campus de Alegre. Caixa Postal 47, CEP: 29500000, Alegre-ES. alexjustino12@gmail.com

\section{Alexandre Cristiano Santos Júnior}

Dr. Professor do Instituto Federal do Espírito Santo - Campus de Alegre, Caixa Postal 47, CEP: 29500-000, Alegre-ES. alexandre.cristiano@ifes.edu.br

\section{Alexandre Rosa dos Santos}

Dr. Professor da Universidade Federal do Espírito Santo - Campus de Alegre, Caixa Postal 16, CEP: 29500-000, Alegre-ES. alexandre.santos@pq.cnpq.br.

\section{Alice Dela Costa Caliman}

Graduanda em Ciência e Tecnologia de Alimento pelo Instituto Federal do Espírito Santo - Campus Venda Nova do Imigrante, Rua Elizabeth Minete Perim, 500, Bairro São Rafael, CEP: 29375-000, Venda Nova do Imigrante-ES. alice.caliman@gmail.com

\section{Aline Marchiori Crespo}

Mestranda pelo Programa de Pós-Graduação em Agroecologia do Ifes - Campus de Alegre, Caixa Postal 47, CEP: 29500-000, Alegre-ES. alinemcrespo@gmail.com 


\title{
Amanda Faé Sartori
}

Mestranda pelo Programa de Pós-Graduação em Produção Vegetal da Universidade Federal do Espírito Santo, Caixa Postal 16, CEP: 29500-000, Alegre-ES. amandafs@hotmail.com

\section{Ana Cláudia Heblling Meira}

Dra. Professora do Instituto Federal do Espírito Santo - Campus de Alegre, Caixa Postal 47, CEP: 29500-000, Alegre-ES. anaclaudia@ufes.edu.br

\section{Ana Paula Cândido Gabriel Berilli}

Dra. Professora do Instituto Federal do Espírito Santo - Campus de Alegre, Caixa Postal 47, CEP: 29500-000, Alegre-ES. anapaulacg@gmail.com

\section{André Oliveira Souza}

Me. Professor do Instituto Federal do Espírito Santo - Campus de Alegre, Caixa Postal 47, CEP: 29500-000, Alegre-ES. andreolisouza@gmail.com

\section{Andréa Ferreira da Costa}

Dra. Pesquisadora do Centro de Pesquisa e Desenvolvimento, Instituto Capixaba de Pesquisa, Assistência Técnica e Extensão Rural, Fazenda do Estado, Rodovia BR 262, CEP: 29000-000, Domingos Martins -ES. andrea.costa.uenf@gmail.com

\section{Antônio Teixeira do Amaral Júnior}

Dr. Professor Associado do Laboratório de Melhoramento Genético Vegetal da Universidade Estadual do Norte Fluminense Darcy Ribeiro, CEP: 28013-602, Campos dos Goytacazes-RJ. amaraluenf@gmail.com

\section{Aparecida de Fátima Madella-Oliveira}

Dra. Professora do Instituto Federal do Espírito Santo - Campus de Alegre, Caixa Postal 47, CEP: 29500-000, Alegre-ES. amadella@ifes.edu.br

\section{Arildo Sebastião Silva}

Me. em Agroecologia pelo Programa de Pós-Graduação em Agroecologia do Instituto Federal do Espírito Santo - Campus de Alegre, Caixa Postal 47, CEP: 29500-000, Alegre-ES. arildos.silva@gmail.com

\section{Arun Dilipkumar Jani}

Ph.D. State Agronomist, USDA - Natural Resources Conservation Service, Ecological Sciences Division, Zip Code 97232, Portland, Oregon, USA. arun.jani@usda.gov

\author{
Atanásio Alves do Amaral \\ Dr. Professor do Instituto Federal do Espírito Santo - Campus de Alegre, Caixa Postal \\ 47, CEP: 29500-000, Alegre-ES. atanasio.ifes@gmail.com

\section{Bruna Dias Gomes Brilhante} \\ Me. em Genética e Melhoramento de Plantas pela Universidade Federal do Espírito \\ Santo, Caixa Postal 16, CEP: 29500-000, Alegre-ES. brunabrilhante@hotmail.com
}




\section{Cíntia dos Santos Bento}

Dra. Professor da Universidade Federal do Espírito, Caixa Postal 16, CEP: 29500000, Alegre-ES. cdossantosbento@hotmail.com

\section{Claudio Martins de Almeida}

Graduando em Agronomia pela Universidade Estadual do Norte Fluminense Darcy Ribeiro, CEP: 28013-602, Campos dos Goytacazes-RJ. claudio@pq.uenf.br

\section{Dalila da Costa Gonçalves}

Mestranda em Agroecologia pelo Programa de Pós-Graduação em Agroecologia do Instituto Federal do Espírito Santo - Campus de Alegre, Caixa Postal 47, CEP: 29500000, Alegre-ES. dalilant@hotmail.com

\section{Davi Salgado de Senna}

Me. em Agroecologia pelo Programa de Pós-Graduação em Agroecologia do Instituto Federal do Espírito Santo - Campus de Alegre, Caixa Postal 47, CEP: 29500-000, Alegre-ES.davi_ssenna@yahoo.com

\section{Dayvson Dansi Rodrigues}

Mestrando em Agroecologia pelo Programa de Pós-Graduação em Agroecologia do Ifes - Campus de Alegre, Caixa Postal 47, CEP: 29500-000, Alegre-ES. dansibio@gmail.com

\section{Ednaldo da Silva Araújo}

Dr. Pesquisador da Embrapa Agrobiologia, CEP: 23890-000, Seropédica-RJ. brednaldo.araujo@embrapa.br

\section{Evandro de Andrade Siqueira}

Me. Professor do Instituto Federal do Espírito Santo - Campus Venda Nova do Imigrante, Rua Elizabeth Minete Perim, 500, Bairro São Rafael, CEP: 29375-000, Venda Nova do Imigrante-ES. evandro.siqueira@ifes.edu.br

\section{Fábio Luiz Partelli}

Dr. Professor da Universidade Federal do Espírito Santo, Departamento de Ciências Agrárias e Biológicas, BR 101 Norte, Km. 60, Bairro Litorâneo, CEP: 29932-540, São Mateus-ES. partelli@yahoo.com.br

\section{Felipe Vaz Andrade}

Dr. Professor da Universidade Federal do Espírito Santo - Campus de Alegre, Caixa Postal 16, CEP: 29500-000, Alegre-ES. felipevazandrade@gmail.com

\section{Fernanda Vargas Valadares}

Me. em Agroecologia pelo Programa de Pós-Graduação em Agroecologia do Instituto Federal do Espírito Santo - Campus de Alegre, Caixa Postal 47, CEP: 29500-000, Alegre-ES. fernanda_valladares@hotmail.com 


\section{Gabriel Permanhane da Silva}

Pós-graduando em Agroecologia e Sustentabilidade pelo Instituto Federal do Espírito Santo - Campus de Alegre, Caixa Postal 47, CEP: 29500-000, Alegre-ES. permanhaneg@gmail.com

\section{Geisa Corrêa Louback}

Mestranda em Agroecologia pelo Programa de Pós-Graduação em Agroecologia do Instituto Federal do Espírito Santo - Campus de Alegre, Caixa Postal 47, CEP: 29500000, Alegre-ES. geisa.louback1980@gmail.com

\section{Geraldo José Alves Dutra}

Me. em Agroecologia pelo Programa de Pós-Graduação em Agroecologia do Instituto Federal do Espírito Santo - Campus de Alegre, Caixa Postal 47, CEP: 29500-000, Alegre-ES. geraldodutra7@yahoo.com.br

\section{Grazielli de Paula Pirovani}

Mestranda em Agroecologia pelo Programa de Pós-Graduação em Agroecologia do Instituto Federal do Espírito Santo - Campus de Alegre, Caixa Postal 47, CEP: 29500000, Alegre-ES. grazipirovani@gmail.com

\section{Gustavo Haddad Souza Vieira}

Dr. Professor do Instituto Federal do Espírito Santo - Campus Santa Teresa. Rod ES 080, km 93, São João de Petrópolis, CEP: 29650-000, Santa Teresa-ES. ghsv@ifes.edu.br

\section{Isabel Inácio de Moraes Souza}

Me. em Agroecologia pelo Programa de Pós-Graduação em Agroecologia do Instituto Federal do Espírito Santo - Campus de Alegre, Caixa Postal 47, CEP: 29500-000, Alegre-ES. isabel.inacio51@hotmail.com

\section{Ismail Ramalho Haddade}

Dr. Professor do Instituto Federal do Espírito Santo - Campus Santa Teresa, Rod ES 080, km 93, São João de Petrópolis, CEP: 29650-000. ihaddade@ifes.edu.br

\section{Janaina Ribeiro Costa Rouws}

Dra. Pesquisadora da Embrapa Agrobiologia, CEP: 23890-000, Seropédica-RJ. janaina.rouws@embrapa.br

\section{João Batista Pavesi Simão}

Dr. Professor do Instituto Federal do Espírito Santo - Campus de Alegre, Caixa Postal 47, CEP: 29500-000, Alegre-ES. jbpavesi@gmail.com

\section{Jaqueline Rodrigues Cindra de Lima Souza}

Me. em Agroecologia pelo Programa de Pós-Graduação em Agroecologia do Instituto Federal do Espírito Santo - Campus de Alegre, Caixa Postal 47, CEP: 29500-000, Alegre-ES. jrsouza@ifes.edu.br. 


\section{Jéferson Luiz Ferrari}

Dr. Professor do Instituto Federal do Espírito Santo - Campus de Alegre, Caixa Postal 47, CEP: 29.500-000, Alegre-ES. ferrarij|@ifes.edu.br

\section{João Batista Silva Araújo}

Dr. Pesquisador do Instituto Capixaba de Pesquisa, Assistência Técnica e Extensão Rural, CEP: 29323-000, Pacotuba, Cachoeiro de Itapemirim-ES. joaoaraujovni@gmail.com

\section{João Victor Nascimento Tardim}

Graduando em Engenharia de Aquicultura pelo Instituto Federal do Espírito Santo Campus de Alegre, Caixa Postal 47, CEP: 29500-000, Alegre-ES jvntardim@gmail.com

\section{José Dias de Souza Neto}

Técnico do Laboratório de Genética e Biologia Molecular do Instituto Federal do Espírito Santo - Campus de Alegre, Caixa Postal 47, CEP: 29500-000, Alegre-ES. jdiassneto@gmail.com

\section{José Salazar Zanuncio Junior}

Dr. Pesquisador do Centro de Pesquisa e Desenvolvimento, Instituto Capixaba de Pesquisa, Assistência Técnica e Extensão Rural - Fazenda do Estado, Rodovia BR 262, CEP: 29000-000, Domingos Martins-ES. jose.zanuncio@incaper.es.gov.br

\section{Joyce Garcia Silva}

Graduanda em Engenharia de Aquicultura pelo Instituto Federal do Espírito Santo Campus de Alegre, Caixa Postal 47, CEP: 29500-000, Alegre-ES. joyce_g_silva@hotmail.com

\section{Júlio Cezar Machado Baptestini}

Dr. Professor do Instituto Federal do Espírito Santo - Campus de Alegre, Caixa Postal 47, CEP: 29500-000, Alegre-ES. julio.baptestini@ifes.edu.br

\section{Kíssila França Lima}

Me. em Agroecologia pelo Programa de Pós-Graduação em Agroecologia do Instituto Federal do Espírito Santo-Campus de Alegre-ES. kissilalima03@gmail.com

\section{Laís Gertrudes Fontana Silva}

Mestrando em Agroecologia pelo Programa de Pós-Graduação em Agricultura Tropical da Universidade Federal do Espírito Santo, CEP: 29932-540, São MateusES. laiisfontana@hotmail.com

\section{Larícia Olária Emerick Silva}

Me. em Genética e Melhoramento do Programa de Pós-Graduação em Genética e Melhoramento da Universidade Federal do Espírito Santo, Caixa Postal 16, CEP: 29500-000, Alegre-ES. lariciaemerick@gmail.com 


\section{Larissa de Carvalho Nascimento}

Técnica do Laboratório de Genética e Biologia Molecular do Instituto Federal do Espírito Santo - Campus de Alegre, Caixa Postal 47, CEP: 29500-000, Alegre-ES. larissacn1@hotmail.com

\section{Larissa lonara Silva Paula}

Engenheira Agrônoma pelo Instituto Federal do Espírito Santo - Campus Santa Teresa, Rod ES 080, km 93, CEP: 29650-000. São João de Petrópolis-ES. larissaionarasilvapaula@gmail.com

\section{Layon Carvalho de Assis}

Graduando em Engenharia de Aquicultura pelo Instituto Federal do Espírito Santo Campus de Alegre, Caixa Postal 47, CEP: 29500-000, Alegre-ES. layoncdeassis@gmail.com

\section{Lazaro Renilton Emerick Silva}

Tecnólogo em Cafeicultura pelo Instituto Federal do Espírito Santo - Campus de Alegre, Caixa Postal 47, CEP: 29500-000, Alegre-ES. lazaroemerick2@outlook.com

\section{Leandro Heitor Rangel}

Mestrando em Produção Vegetal pelo Programa de Pós-Graduação em Produção Vegetal da Universidade Norte Fluminense Darcy Ribeiro, CEP: 28013-600, Campos dos Goytacazes-RJ. leandroheitor_18@hotmail.com

\section{Leonardo Demier Cardoso}

Dr. Professor do Instituto Federal do Espírito Santo - Campus Piúma, Piúma-ES. leonardodemier@hotmail.com

\section{Leonardo Martineli}

Me. em Agroecologia pelo Programa de Pós-Graduação em Agroecologia do Instituto Federal do Espírito Santo - Campus de Alegre, Caixa Postal 47, CEP: 29500-000, Alegre-ES. leonardo.martineli@ifes.edu.br

\section{Leticia Rigo Tavares}

Pós-graduanda em Agroecologia e Sustentabilidade pelo Instituto Federal do Espírito Santo - Campus de Alegre, Caixa Postal 47, CEP: 29500-000, Alegre-ES. leticiarigot@hotmail.com

\section{Lillya Mattedi}

Graduanda em Agronomia pelo Instituto Federal do Espírito Santo - Campus Santa Teresa, Rod ES 080, km 93, CEP: 29650-000. São João de Petrópolis-ES. lillyamattedi2013@gmail.com

\section{Lorena Abdalla de Oliveira Prata Guimarães}

Dra. Professora do Instituto Federal do Espírito Santo - Campus Centro-Serrano, CEP: 29645-000, Caramuru, Santa Maria de Jetibá-ES. lorena.guimaraes@ifes.edu.br 


\section{Lorenza Bandeira de Paula}

Me. em Agroecologia pelo Programa de Pós-Graduação em Agroecologia do Instituto Federal do Espírito Santo - Campus de Alegre, Caixa Postal 47, CEP: 29500000, Alegre-ES. Iorenzabandeira@hotmail.com

\section{Lorenzo Montovaneli Lazzarini}

Graduando em Agronomia pela Universidade Estadual do Norte Fluminense Darcy Ribeiro, CEP: 28013-602, Campos dos Goytacazes-RJ. I.lazzarini14@gmail.com

\section{Lucas Alves Rodrigues}

Me. em Agroecologia pelo Programa de Pós-Graduação em Agroecologia do Instituto Federal do Espírito Santo - Campus de Alegre, Caixa Postal 47, CEP: 29500-000, Alegre-ES. rodriguesdelazari.edu@gmail.com

\section{Lucas Louzada Pereira}

Dr. Professor do Instituto Federal do Espírito Santo - Campus Venda Nova do Imigrante, Rua Elizabeth Minete Perim, 500, Bairro São Rafael, CEP: 29375-000, Venda Nova do Imigrante-ES. lucas.pereira@ifes.edu.br

\section{Luciana Alves Parreira}

Dra. Professora da Universidade Federal do Espírito Santo - Campus de Alegre, Caixa Postal 16, CEP: 29500-000, Alegre-ES. lucianap.ufes@gmail.com

\section{Luciano Menini}

Dr. Professor do Instituto Federal do Espírito Santo - Campus de Alegre, Caixa Postal 47, CEP: 29500-000, Alegre-ES. Imenini@ifes.edu.br

\section{Luiza Aparecida Campos de Paula}

Mestranda em Ciências Veterinárias pela Universidade Federal do Espírito Santo Campus de Alegre, Caixa Postal 16, CEP: 29500-000, Alegre-ES. luzpaula.campos@gmail.com

\section{Lusinerio Prezotti}

Dr. Professor do Instituto Federal do Espírito Santo - Campus Santa Teresa. Rod ES 080, km 93, São João de Petrópolis, CEP: 29650-000, Santa Teresa-ES. lusineriop@ifes.edu.br

\section{Marcelo Meneguelli Campos}

Engenheiro Agronômico pela Universidade Federal do Espírito Santo - Campus de Alegre, Caixa Postal 16, CEP: 29500-000, Alegre-ES. marcelo@ecomaisambiental.com.br

\section{Marcus Vinícius Souza Silva}

Me. em Agroecologia pelo Programa de Pós-Graduação em Agroecologia do Instituto Federal do Espírito Santo - Campus de Alegre, Caixa Postal 47, CEP: 29500-000, Alegre-ES. marcusvinicius.mvss@gmail.com 


\section{Maria Angélica Alves da Silva Souza}

Me. Especialista em Agroecologia e Sustentabilidade e Pedagoga. Área do Ifes Campus Guarapari, Alameda Francisco Vieira Simões, 720 - Aeroporto, CEP: 29216795, Guarapari-ES. maria.souza@ifes.edu.br

\section{Mário Euclides Pechara da Costa Jaeggi}

Doutorando em Produção Vegetal pela Universidade Estadual Norte Fluminense Darcy Ribeiro, CEP: 28013-600, Campos dos Goytacazes-RJ. mariopechara@hotmail.com

\section{Mário Wesley Paiva Zanetti}

Técnico Agrícola pelo Instituto Federal do Espírito Santo - Campus de Alegre, Caixa Postal 47, CEP: 29500-000, Alegre-ES. mario_pezao@yahoo.com.br

\section{Marliane de Cássia Soares da Silva}

Dra. Pesquisadora da Universidade Federal de Viçosa, Departamento de Microbiologia, Avenida Ph Rolfs, S/N, CEP: 36570-000, Viçosa-MG. mcassiabio@yahoo.com.br

\section{Marta dos Santos Freire Ricci}

Dra. Pesquisadora da Embrapa Agrobiologia, CEP: 23890-000, Seropédica-RJ. marta.ricci@embrapa.br

\section{Maurício José Fornazier}

Dr. Pesquisador do Centro de Pesquisa e Desenvolvimento, Instituto Capixaba de Pesquisa, Assistência Técnica e Extensão Rural, Fazenda do Estado, Rodovia BR 262, CEP: 29000-000, Domingos Martins-ES. mauriciofornazier@gmail.com

\section{Maurício Novaes Souza}

Dr. Professor do Instituto Federal do Espírito Santo - Campus de Alegre, Caixa Postal 47, CEP: 29500-000, Alegre-ES. mauricio.novaes@ifes.edu.br

\section{Monique Moreira Moulin}

Dra. Professora do Instituto Federal do Espírito Santo - Campus de Alegre, Caixa Postal 47, CEP: 29500-000, Alegre-ES.mmmoulin@ifes.edu.br

\section{Nadhyla Pião Felberg}

Engenheira Agronoma pelo Instituto Federal do Espirito Santo - Campus Itapina, CEP: 29717-000, Itapina-ES. nadhyla.felberg@gmail.com

\section{Otacilio José Passos Rangel}

Dr. Professor do Instituto Federal do Espírito Santo - Campus de Alegre, Caixa Postal 47, CEP: 29500-000, Alegre-ES. otaciliorangel@gmail.com 


\section{Paola de Oliveira Santos}

Graduanda em Engenharia de Aquicultura do Instituto Federal do Espírito Santo Campus de Alegre, Caixa Postal 47, CEP: 29500-000, Alegre - ES paolamanfredini111@gmail.com

\section{Paola Honorato Salla}

Engenheira Agrônoma pelo Instituto Feral do Espírito Santo - Campus Santa Teresa, Rod ES 080, km 93, São João de Petrópolis, CEP: 29650-000, Santa Teresa-ES. paola.hsalla@gmail.com

\section{Paola Alfonsa Lo Mônaco}

Dra. Professora do Instituto Federal do Espírito Santo - Campus Santa Teresa. Rod ES 080, km 93, São João de Petrópolis, CEP: 29650-000, Santa Teresa-ES. paolalomonaco2004@yahoo.com.br

\section{Paulo Prates Junior}

Dr. Pesquisador na Universidade Federal de Viçosa, Departamento de Microbiologia, Avenida $\mathrm{Ph}$ Rolfs, S/N, CEP: 36570-000, Viçosa-MG. junior_prates2005@yahoo.com.br

\section{Pedro Pierro Mendonça}

Dr. Professor do Instituto Federal do Espírito santo - Campus de Alegre. Caixa Postal 47, CEP: 29500-000. Alegre - ES. ppierrom@gmail.com

\section{Rafael de Almeida}

Mestrando em Agroecologia pelo Programa de Pós-Graduação em Agroecologia do Instituto Federal do Espírito Santo, CEP: 29500-000, Alegre-ES. rafael.t.dealmeida@gmail.com

\section{Rafael Nunes de Almeida}

Me. em Agroecologia pelo Programa de Pós-Graduação em Agroecologia do Instituto Federal do Espírito Santo - Campus de Alegre, Caixa Postal 47, CEP: 29500-000, Alegre-ES. almeida.rna94@gmail.com

\section{Raissa Olmo Lacerda Pirovani}

Graduada em Ciências Biológicas pelo Instituto Federal do Espírito Santo - Campus de Alegre, Caixa Postal 47, CEP: 29500-000, Alegre-ES. raissaolmo@hotmail.com

\section{Rebyson Bissaco Guidinelle}

Me. e Doutorando do Programa de Pós-Graduação em Produção Vegetal da Universidade Federal do Espírito Santo, Caixa Postal 16, CEP: 29500-000, AlegreES. rebysonguidinelle@gmail.com

\section{Renato Ribeiro Passos}

Dr. Professor da Universidade Federal do Espírito Santo - Campus de Alegre, Caixa Postal 16, CEP: 29500-000, Alegre-ES. Bolsista de Produtividade em Pesquisa do CNPq. renatoribeiropassos@hotmail.com 


\section{Rodrigo Junior Nandorf}

Graduando em Agronomia pelo Instituto Federal do Espírito Santo - Campus Santa Teresa, Rod ES 080, km 93, São João de Petrópolis, CEP: 29650-000. rodrigojrnandorf@gmail.com

\section{Rogério Carvalho Guarçoni}

Dr. Pesquisador do Centro de Pesquisa e Desenvolvimento, Instituto Capixaba de Pesquisa, Assistência Técnica e Extensão Rural, Fazenda do Estado, Rodovia BR 262, CEP: 29000-000, Domingos Martins-ES. rogerio.guarconi@incaper.es.gov.br

\section{Ronaldo Willian da Silva}

Me. e Doutorando do Programa de Pós-Graduação em Produção Vegetal da Universidade Federal do Espírito Santo, Caixa Postal 16, CEP: 29500-000, AlegreES.ronaldo_willian1@hotmail.com

\section{Rosana Rodrigues}

Dra. Professora da Universidade Estadual do Norte Fluminense Darcy Ribeiro, CEP: 28013-600, Campos dos Goytacazes-RJ. anadigues@gmail.com

\section{Rosimeire Barboza Bispo}

Doutoranda pelo Programa de Pós-Graduação em Genética e Melhoramento de Plantas da Universidade Estadual do Norte Fluminense Darcy Ribeiro, CEP: 28013602, Campos dos Goytacazes-RJ. rosimeirebarboza1@hotmail.com

\section{Samuel Henrique Kamphorst}

Dr. em Genética e Melhoramento de Plantas e Pós-Doutorando pela Universidade Estadual do Norte Fluminense Darcy Ribeiro, CEP: 28013-600, Campos dos Goytacazes-RJ. samuelkampho@hotmail.com

\section{Savio da Silva Berilli}

Dr. Professor do Instituto Federal do Espírito Santo - Campus de Alegre, Caixa Postal 47, CEP: 29500-000, Alegre-ES. savio.berilli@ifes.edu.br

\section{Silvia Pope de Araújo}

Doutoranda do Programa de Ciências de Alimentos da Universidade Federal do Rio de Janeiro-RJ. silviapopedearaujo@gmail.com

\section{Tais Rizzo Moreira}

Doutoranda pela Universidade Federal do Espírito Santo, Centro de Ciências Agrárias e Engenharias, Av. Gov. Lindemberg, 316, CEP: 29550-000, Jerônimo Monteiro-ES. taisr.moreira@hotmail.com

\section{Talles de Oliveira Santos}

Me. em Genética e Melhoramento de Plantas pela Universidade Estadual do Norte Fluminense Darcy Ribeiro, CEP: 28013-600, Campos dos Goytacazes-RJ. tallesdeoliveeira@live.com 


\section{Telma Machado de Oliveira Peluzio}

Dra. Professora do Instituto Federal do Espírito Santo - Campus de Alegre, Caixa Postal 47, CEP: 29500-000, Alegre-ES. tmpeluzio@ifes.edu.br

\section{Tércio da Silva de Souza}

Dr. Professor do Instituto Federal do Espírito Santo - Campus de Alegre, Caixa Postal 47, CEP: 29500-000, Alegre-ES. tssouzai@ifes.edu.br

\section{Thiago Lopes Rozado}

Me. Engenheiro Agrônomo do Instituto Federal do Espírito Santo - Campus Santa Teresa. Rod ES 080, km 93, São João de Petrópolis, CEP: 29650-000, Santa TeresaES. thiagolopesmil@gmail.com

\section{Valter Jário de Lima}

Doutorando em Genética e Melhoramento de Plantas pelo programa de PósGraduação em Genética e Melhoramento de Plantas da Universidade Estadual do Norte Fluminense Darcy Ribeiro, CEP: 28013-602, Campos dos Goytacazes-RJ. valter_jario@hotmail.com

\section{Vanessa Sessa Dian}

Mestranda em Agroecologia pelo Programa de Pós-Graduação em Agroecologia do Instituto Federal do Espírito Santo - Campus de Alegre, Caixa Postal 47, CEP: 29500000, Alegre-ES. vanessasessa2@gmail.com

\section{Venan Vieira dos Anjos}

Graduando em Engenharia de Aquicultura pelo Instituto Federal do Espírito Santo Campus de Alegre, Caixa Postal 47, CEP: 29500-000, Alegre-ES vieira.venan@gmail.com

\section{Victor Dias Pirovani}

Dr. Professor do Instituto Federal do Espírito Santo - Campus de Alegre, Caixa Postal 47, CEP: 29500-000, Alegre-ES. victor.pirovani@ifes.edu.br

\section{Vinicius de Freitas Mateus}

Pós-graduando em Agroecologia e Sustentabilidade do Instituto Federal do Espírito Santo - Campus de Alegre, Caixa Postal 47, CEP: 29500-000, Alegre-ES. viniciusfreitas20@yahoo.com.br

\section{Waylson Zancanella Quartezani}

Dr. Professor do Instituto Federal do Espírito Santo - Campus Montanha, CEP: 29890000, Montanha-ES. waylson.quartezani@ifes.edu.br

\section{Wesley Braga de Aguiar}

Mestrando em Agroecologia pelo Programa de Pós-Graduação em Agroecologia do Instituto Federal do Espírito Santo - Campus de Alegre, Caixa Postal 47, CEP: 29500000, Alegre-ES. wesleyaguiarbraga@gmail.com 


\section{Wilian Rodrigues Ribeiro}

Doutorando do Programa de Pós-Graduação em Produção Vegetal da Universidade Federal do Espírito Santo, Caixa Postal 16, CEP: 29500-000, Alegre-ES. wilianrodrigues@msn.com

\section{Willian dos Santos Gomes}

Me. e Doutorando na Universidade Federal do Espírito Santo, Departamento de Genética e Melhoramento, Alto Universitário, S/N Guararema, CEP: 29500-000, Alegre-ES.gwill.bio@gmail.com

\section{Yuri Ferreira Quirido Veiga}

Graduado em Ciências Biológicas pelo Instituto Federal do Espírito Santo - Campus de Alegre, Caixa Postal 47, CEP: 29500-000, Alegre-ES. yfqv@hotmail.com 


\section{Sumário}

\section{Capítulo 1}

Transição agroecológica: intervenções necessárias e suas externalidades

Dayvson Dansi Rodrigues, Maurício Novaes Souza, Ana Cláudia Heblling Meira, Maria Angélica Alves da Silva Souza, Aline Marchiori Crespo, Geisa Corrêa Louback, 28

\section{Capítulo 2}

O sistema agroflorestal "Taungya" na recuperação de áreas degradadas

Gabriel Permanhane da Silva, Leticia Rigo Tavares, Vinicius de Freitas Mateus, Telma Machado de Oliveira Peluzio, Atanásio Alves do Amaral e Maurício Novaes Souza, 47

\section{Capítulo 3}

Microbacia hidrográfica do córrego vagalume: um olhar crítico para a sua paisagem Geraldo José Alves Dutra, Marcus Vinícius Souza Silva, Mário Wesley Paiva Zanetti, Jéferson Luiz Ferrari, 65

\section{Capítulo 4}

Arborização de cafezais: diversificação do sistema e melhoria da qualidade de bebida

Isabel Inácio de Moraes Souza, Maurício Novaes Souza, Mário Euclides Pechara da Costa Jaeggi, Marta dos Santos Freire Ricci, João Batista Pavesi Simão, Janaina Ribeiro Costa Rouws, Ednaldo da Silva Araújo, 85

\section{Capítulo 5}

Proposições para melhoria das formas de manejo e qualidade do café conilon

Lucas Louzada Pereira, Alice Dela Costa Caliman, Fábio Luiz Partelli, Marliane de Cássia Soares da Silva, Paulo Prates Junior, Aldemar Polonini Moreli, Willian dos Santos Gomes, 101

\section{Capítulo 6}

GT biplot aplicado ao estudo da diversidade de variedades de pimentas do gênero Capsicum do Estado do Espírito Santo

Bruna Dias Gomes Brilhante, Talles de Oliveira Santos, Larícia O. Emerick Silva, Fernanda V. Valadares, Ana Paula Cândido Gabriel Berilli, Larissa de Carvalho Nascimento, Cíntia dos S. Bento, Rosana Rodrigues, Monique Moreira Moulin, 119 


\section{Capítulo 7}

Estratégias de seleção de genótipos superiores para produção de grãos de milho sob seleção recorrente recíproca

Fernanda Vargas Valadares, Larícia Olária Emerick Silva, Rafael Nunes de Almeida, Lazaro Renilton Emerick Silva, Leandro Heitor Rangel, José Dias de Souza Neto, Larissa de Carvalho Nascimento, Savio da Silva Berilli, Paola Alfonsa Lo Mônaco, Monique Moreira Moulin, Ana Paula Candido Gabriel Berilli, 139

\section{Capítulo 8}

Caracterização morfológica e bromatológica de genótipos de pimenta (Capsicum spp.) coletados no Estado do Espírito Santo

Yuri Ferreira Quirido Veiga, Talles de Oliveira Santos, Raissa Olmo Lacerda Pirovani, Rafael de Almeida, Larissa de Carvalho Nascimento, José Dias de Souza Neto, Alexandre Cristiano Santos Júnior, Monique Moreira Moulin, 153

\section{Capítulo 9}

Estudo da diversidade genética de variedades de milho-pipoca em ambiente com déficit hídrico com base em descritores morfológicos, fisiológicos e radiculares Talles de Oliveira Santos, Antônio Teixeira do Amaral Júnior, Rosimeire Barboza Bispo, Valter Jário de Lima, Samuel Henrique Kamphorst, Monique Moreira Moulin, 172

\section{Capítulo 10}

Produção sustentável da cultura da banana: estratégias de manejo alternativo da broca-do-rizoma Cosmopolites sordidus (Germar) (Coleoptera: Curculionidae)

Alciro Lamao Lazzarini, José Salazar Zanuncio Junior, Rogério Carvalho Guarçoni Lorenzo Montovaneli Lazzarini, Claudio Martins de Almeida, Maurício José Fornazier, Andréa Ferreira da Costa, 194

\section{Capítulo 11}

Aplicações tecnológicas para subprodutos do processamento da graviola Jaqueline Rodrigues Cindra de Lima Souza, Luciano Menini, Tércio da Silva de Souza, Luciana Alves Parreira, 209

\section{Capítulo 12}

Manejo agroecológico do ácaro rajado -Tetranychus urticae

Kíssila França Lima, Luciano Menini, Victor Dias Pirovani, Luciana Alves Parreira, 220

\section{Capítulo 13}

Produção de cafés especiais e sua relação com as condições edafoclimáticas: uma abordagem introdutória ao tema

Lucas Louzada Pereira, Aldemar Polonini Moreli, Evandro de Andrade Siqueira, Rogério Carvalho Guarçoni, Alexandre Rosa dos Santos, Tais Rizzo Moreira, 232 


\section{Capítulo 14}

Implantação de sistema agroflorestal sucessional como alternativa para recuperação de áreas degradadas

Lorenza Bandeira de Paula, Otacilio José Passos Rangel, Lorena Abdalla de Oliveira Prata Guimarães, Renato Ribeiro Passos, André Oliveira Souza, Júlio Cezar Machado Baptestini, 249

\section{Capítulo 15}

Dinâmica e degradação dos pesticidas no solo: uma ameaça eminente a sustentabilidade dos sistemas agrícolas

Dalila da Costa Gonçalves, Wilian Rodrigues Ribeiro, Alex Justino Zacarias, Geisa Corrêa Louback, Rafael de Almeida, Vanessa Sessa Dian, Otacílio José P. Rangel, 264

\section{Capítulo 16}

Umidade e temperatura do solo: efeitos da cobertura morta e do tipo de preparo Gustavo Haddad Souza Vieira, Arildo Sebastião Silva, Lusinerio Prezotti, Paola Alfonsa Vieira Lo Monaco, Ana Paula Candido Gabriel Berilli, Savio da Silva Berilli, Arun Dilipkumar Jani, 279

\section{Capítulo 17}

Água residuária de suinocultura e sistema plantio direto: efeitos em propriedades do solo cultivado com milho

Otacílio José Passos Rangel, Gustavo Haddad Souza Vieira, Marcus Vinícius Souza Silva ${ }^{3}$ Rebyson Bissaco Guidinelle, Júlio Cezar Machado Baptestini, Renato Ribeiro Passos, André Oliveira Souza, Thiago Lopes Rosado, Paola Alfonsa Vieira Lo Monaco, Ana Paula Candido Gabriel Berilli, Sávio da Silva Berilli, 296

\section{Capítulo 18}

Cafeeiro conilon em sistema agroflorestal: qualidade física do solo e carbono orgânico

Davi Salgado de Senna, Renato Ribeiro Passos, Otacílio José P. Rangel, João Batista Silva Araújo, Alex Justino Zacarias, Jéferson Luiz Ferrari, André Oliveira Souza, 316

\section{Capítulo 19}

Dinâmica do fósforo em solos tropicais e manejo da adubação organomineral fosfatada

Ronaldo Willian da Silva, Renato Ribeiro Passos, Otacílio José Passos Rangel, Felipe Vaz Andrade, Amanda Faé Sartori, 337 


\section{Capítulo 20}

Tratamento de água residuária da suinocultura em sistemas alagados construídos cultivados com capim Jiggs

Paola Alfonsa Vieira Lo Monaco, Gustavo Haddad Souza Vieira, Ismail Ramalho Haddade, Sávio da Silva Berilli, Ana Paula Cândido Berilli, Rodrigo Junior Nandorf, Lillya Mattedi, Thiago Lopes Rozado, Alberto Chambela Netto, 356

\section{Capítulo 21}

Resíduos da vitivinicultura como componente de substratos para produção de mudas de pepino

Paola Honorato Salla, Paola Alfonsa Vieira Lo Monaco, Larissa lonara Silva Paula, Gustavo Haddad Souza Vieira, Ismail Ramalho Haddade, Sávio da Silva Berilli, Ana Paula Candido Gabriel Berilli, Lillya Mattedi, Rodrigo Junior Nandorf, Alberto Chambela Neto, 368

\section{Capítulo 22}

Reaproveitamento do lodo de curtume como fonte de adubação alternativa para produção de mudas de café conilon no estado do Espírito Santo

Leonardo Martineli, Sávio da Silva Berilli, Lucas Alves Rodrigues, Ana Paula Cândido Gabriel Berilli, Paola Alfonsa Vieira Lo Monaco, Gustavo Haddad Souza Vieira, 380

\section{Capítulo 23}

Uso do vinhoto associado ao lodo de curtume como fertilizante foliar na produção de mudas de café conilon

Lucas Alves Rodrigues, Sávio da Silva Berilli, Ana Paula Candido Gabriel Berilli, Waylson Zancanella Quartezani, Laís Gertrudes Fontana Silva, Nadhyla Pião Felberg, Paola Alfonsa Vieira Lo Monaco, Gustavo Haddad Souza Vieira, 389

\section{Capítulo 24}

Gerenciamento de resíduos da cadeia produtiva de pescado e seu uso sustentável Paola de Oliveira Santos, João Victor Nascimento Tardim, Venan Vieira dos Anjos, Layon Carvalho de Assis, Joyce Garcia Silva, Luiza Aparecida Campos de Paula, Silvia Pope de Araújo, Leonardo Demier Cardoso, Alberto Chambela Neto, Pedro Pierro Mendonça, 408

\section{Capítulo 25}

Aplicação de ingredientes alternativos na formulação de rações para peixes de corte na perspectiva agroecológica

João Victor Nascimento Tardim, Paola de Oliveira Santos, Venan Vieira dos Anjos, Layon Carvalho de Assis, Joyce Garcia Silva, Luiza Aparecida Campos de Paula, Silvia Pope de Araújo, Leonardo Demier Cardoso, Alberto Chambela Neto, Pedro Pierro Mendonça, 420 


\section{Capítulo 26}

Uma alternativa para o bem-estar de vacas leiteiras: uso de óleos essenciais para o controle da mastite e carrapatos

Grazielli de Paula Pirovani, Wesley Braga de Aguiar, Aparecida de Fátima MadellaOliveira, 438 


\title{
Capítulo 1
}

\section{Transição agroecológica: intervenções necessárias e suas externalidades}

\author{
Dayvson Dansi Rodrigues ${ }^{1}$, Maurício Novaes Souza², Ana Cláudia Heblling Meira², \\ Maria Angélica Alves da Silva Souza ${ }^{3}$, Aline Marchiori Crespo¹, Geisa Corrêa Louback¹
}

\section{Introdução}

A Agroecologia é uma ciência que exige um enfoque holístico e uma abordagem sistêmica, reconhecendo as relações indissociáveis entre sociedade/indivíduo/natureza/ economia/cultura/política a partir de um enfoque multidisciplinar, ou mesmo transdisciplinar.

O enfoque holístico e uma abordagem sistêmica da Agroecologia são observados por meio da falta ou da presença de alguns atributos, tais como: educação crítica, assistência técnica, conservação da natureza, serviços públicos de saneamento, assistência social, saúde preventiva, associação e interdependência. Está claro que a produção agropecuária não deve ser planejada sob a dimensão apenas técnico-agronômica, visão que causa a situação precária de muitas propriedades pequenas, deve considerar, fundamentalmente, as dimensões ecológica, socioeconômica, cultural e sócio-política, de forma integrada (UNESP, 2014).

Apesar do questionamento se os efeitos danosos dos modelos convencionais de desenvolvimento e de agricultura chegaram aos seus limites, sabe-se que os monocultivos baseados na Revolução Verde têm originado um conjunto de externalidades causadoras da crise socioambiental sem precedente na história da humanidade (CAPORAL et al., 2009; GONCALVES et al., 2019).

O objetivo do presente artigo é analisar os impactos e externalidades negativas causadas pelo modelo convencional de agricultura e o papel da agroecologia neste contexto, fazendo o questionamento sobre como este campo do conhecimento poderia contribuir para uma transição ou mudança de paradigma.

\footnotetext{
${ }^{1}$ Mestrandos pelo Programa de Pós-Graduação em Agroecologia do Ifes - Campus de Alegre, Caixa Postal 47, CEP: 29500-000, Alegre, ES. E-mail: dansibio@gmail.com; alinemcrespo@gmail.com; geisa.louback1980@gmail.com

${ }_{2}^{2}$ Drs. Professores do Ifes - Campus de Alegre, Caixa Postal 47, CEP: 29500-000, Alegre-ES. E-mail: mauricios.novaes@ifes.edu.br; anaclaudia@ufes.edu.br

${ }^{3}$ Me. Especialista em Agroecologia e Sustentabilidade e Pedagoga. Ifes - Campus Guarapari, Alameda Francisco Vieira Simões, 720 - Aeroporto, CEP: 29216-795, Guarapari-ES. maria.souza@ifes.edu.br
} 
Dayvson Dansi Rodrigues et al.

\section{Desenvolvimento}

A elaboração do presente trabalho foi realizada com base em revisão de literatura, do tipo narrativa, por meio de artigos, livros, reportagens, vídeos e músicas pesquisados durante o estudo na disciplina "Agroecologia", ministrada pelo Professor Dr Maurício Novaes Souza; e "Tópicos especiais: Agricultura e sustentabilidade", ministrada pela Prof. ${ }^{\text {a }}$ Dra Ana Cláudia Heblling Meira, durante o no decorrer do curso de Mestrado Profissional em Agroecologia.

O texto aborda, inicialmente, alguns argumentos favoráveis ao modelo convencional de agricultura e apresenta retrata referências que mostram outros pontos de vista, sobre os custos e as externalidades aos quais as populações e o ambiente são submetidos. $O$ presente texto também expõe apresenta um Estudo de Caso com uma breve caracterização de duas famílias que vivem no meio rural e desenvolvem atividades agropecuárias diversas, bem como serviços fora das propriedades, buscando relacionar suas condições socioeconômicas aos conhecimentos da agroecologia.

Também, menciona os aspectos relacionados à produção agroecológica e o exemplo da produção de hortaliças, que possui grande importância na agricultura familiar ou camponesa, por ser desenvolvida em ciclos curtos, ser intensiva em mão de obra e possibilitar maior agregação de valor ao produto final. Apresenta questões relacionadas à necessidade de melhoria quanto à dimensão social e, finalmente, indica algumas intervenções necessárias para a transição agroecológica.

\section{Impactos negativos do modelo de agricultura convencional}

Existem muitos discursos de enaltecimento ao modelo capitalista. Um deles apresenta dados mostrando que há 200 anos, 90\% da população mundial viviam com menos de dois dólares americanos; nos dias atuais, apenas $11 \%$ da população vivem com essa renda! Esse discurso conclui que "a única forma de governar o mundo é implantando o capitalismo em todo o planeta", pois, "dados da riqueza mundial nos mostram como a humanidade caminha da quase absoluta miséria para a sua erradicação daqui alguns anos." (RANKING DOS POLÍTICOS, 2020, np.).

No entanto, o referido documento apresenta como parâmetro apenas o valor financeiro, que de fato, demonstra que tenha havido significativa elevação. Contudo, é o único argumento enfatizado em toda a sua apresentação. Há outras formas de se avaliar a melhoria das condições de vida humana, por exemplo, considerar o balanço energético (saldo entre a entrada e a saída de recursos da economia) e os aspectos relacionados ao bem-estar socioambiental. Somado a esse fato, o capitalismo vem sendo criticado por 
explorar os trabalhadores causando danos à saúde em troca de baixos salários (questões sociais), esgotar/degradar os recursos naturais (ambientais) e distribuir de maneira desigual a riqueza produzida (social). Por essas questões, a contestação ao sistema capitalista é central na agroecologia (GONCALVES et al., 2019).

Neste momento de pandemia pelo COVID-19, observa-se que boa parte da economia do mundo está estagnada e ou com baixa produção! No entanto, há grande quantidade de capital, investidores ansiosos para aplicar o patrimônio e gerar mais lucro. Isso mostra como o modelo capitalista atual, baseado no consumo ininterrupto, é frágil e insustentável, em um mundo onde os recursos naturais, base do processo produtivo, são limitados (SOUZA et al., 2020).

Outro exemplo que tenta justificar essa visão do modelo convencional, referente à evolução da agricultura brasileira, é a análise constante da Figura 1, que mostra um aumento de $70 \%$ da área cultivada: de 37 milhões de ha utilizados para produção agropecuária, em 1977, para 62 milhões, em 2017; a produtividade teve um aumento de $250 \%$; a produção foi elevada em 500\%; e esse aumento de produtividade evitou a necessidade de aumento da área plantada em 150 milhões de ha.

Cabe ressaltar que, a partir da criação da Empresa Brasileira de Pesquisa Agropecuária Embrapa, em 197 em 1973, o governo brasileiro também criou políticas específicas para aumentar a produção, bem como a produtividade, incluindo investimentos públicos em pesquisa e desenvolvimento, extensão rural, crédito farto; mas associado a um "pacote tecnológico" muito questionado nos dias atuais.

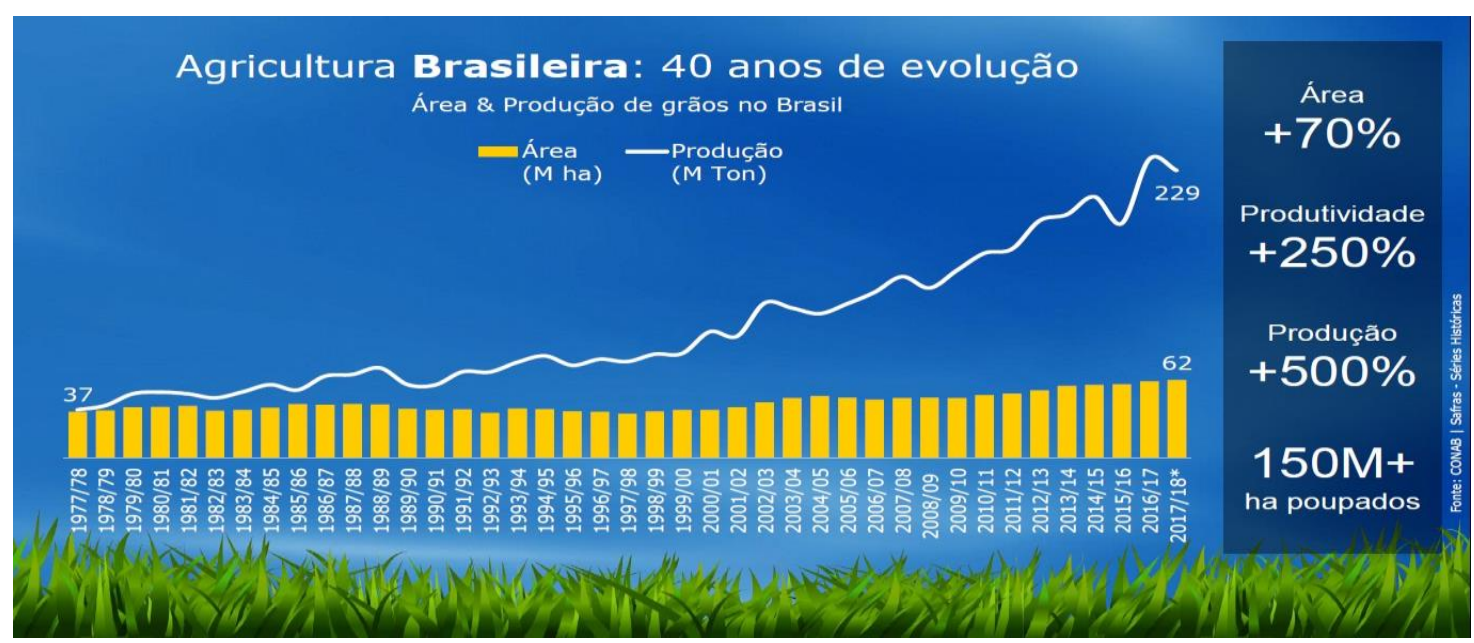

Figura 1. Quarenta (40) anos de evolução da agricultura brasileira.

Fonte: Conab / Safras - séries históricas (2019).

Os produtores, agrônomos, economistas, entre outros, afirmam que esse modelo teve um importante viés ambiental, pelo fato do aumento de produtividade ter poupado o uso de 150 milhões de ha para a produção agrícola, área que seria, teoricamente, usada para 
preservação ambiental. Ressalta-se que as informações apresentadas na Figura 1 consideram um aspecto importante, a área, mas outros fatores não são considerados como os danos ambientais (perda de biodiversidade, esgotamento de recursos naturais e poluição) e os danos sociais (êxodo rural, empobrecimento das famílias, crescimento precário de zonas urbanas e aumento da violência).

A continuidade do modelo de produção convencional também é observada com o lançamento da cultivar de café conilon (Conquista ES 8152) pelo Instituto Capixaba de Pesquisa, Assistência Técnica e Extensão Rural (INCAPER). Uma cultivar desenvolvida para os ambientes quentes do Espírito Santo, suportando altas temperaturas e a insolação intensa, planta vigorosa e tolerante à seca, com moderada resistência à ferrugem. Propagada por sementes, supera a produtividade de outras cultivares, apresenta menor custo de implantação que as clonais devido ao menor preço de mudas, melhor pegamento e menos necessidade de irrigação (INCAPER, 2019).

Apesar dessas vantagens, os insumos, especialmente o adubo mineral, aumentaram demasiadamente o custo de produção, prejudicando a capacidade de o produtor investir. Assim, esse exemplo evidencia as características clássicas do modelo convencional, que eleva a produtividade, mas baseia-se na dependência de caros insumos exógenos à propriedade, além da degradação pelo esgotamento dos solos e dos recursos hídricos.

O argumento de que o Brasil tem $66 \%$ de áreas "preservadas" parece indicar uma imagem positiva do país, mostrando que o País fez tudo isso respeitando o meio ambiente. No entanto, a maior parte da área preservada está em terras indígenas e na Amazônia, áreas onde o ciclo tradicional de alteração de uso do solo ainda não ocorreu - são áreas à espera da exploração da madeira, seguida da pecuária, para a chegada da soja (DARANCO et al., 2012; SCHREIBER, 2019; TEIXEIRA, 2019).

A fome continua sendo um grave problema, não sendo cumprida a promessa da Revolução Verde. Esta agricultura está baseada na ideia de crescimento econômico, permanente e ilimitado, marcada por um voraz consumo de recursos naturais não renováveis. Considera as produções familiares e tradicionais "atrasadas", o que deve ser abandonado, incorporando ensinamentos da modernização. Além disso, desconsidera os princípios ecológicos: fluxo de energia, interdependência, ciclos ecológicos, diversidade, associação (CAPRA, 1996), e é também uma grande emissora de carbono pela degradação do solo (GONCALVES et al., 2019).

Na Figura 2 é possível observar uma clássica área produtiva no Cerrado brasileiro: área totalmente desmatada, com o uso de tecnologia de ponta, mas implantado o sistema de monoculturas com soja ou milho, com baixa diversidade Tal condição reduz a resistência e a resiliência dos agroecossistemas (SOUZA, 2018). 
Dayvson Dansi Rodrigues et al.

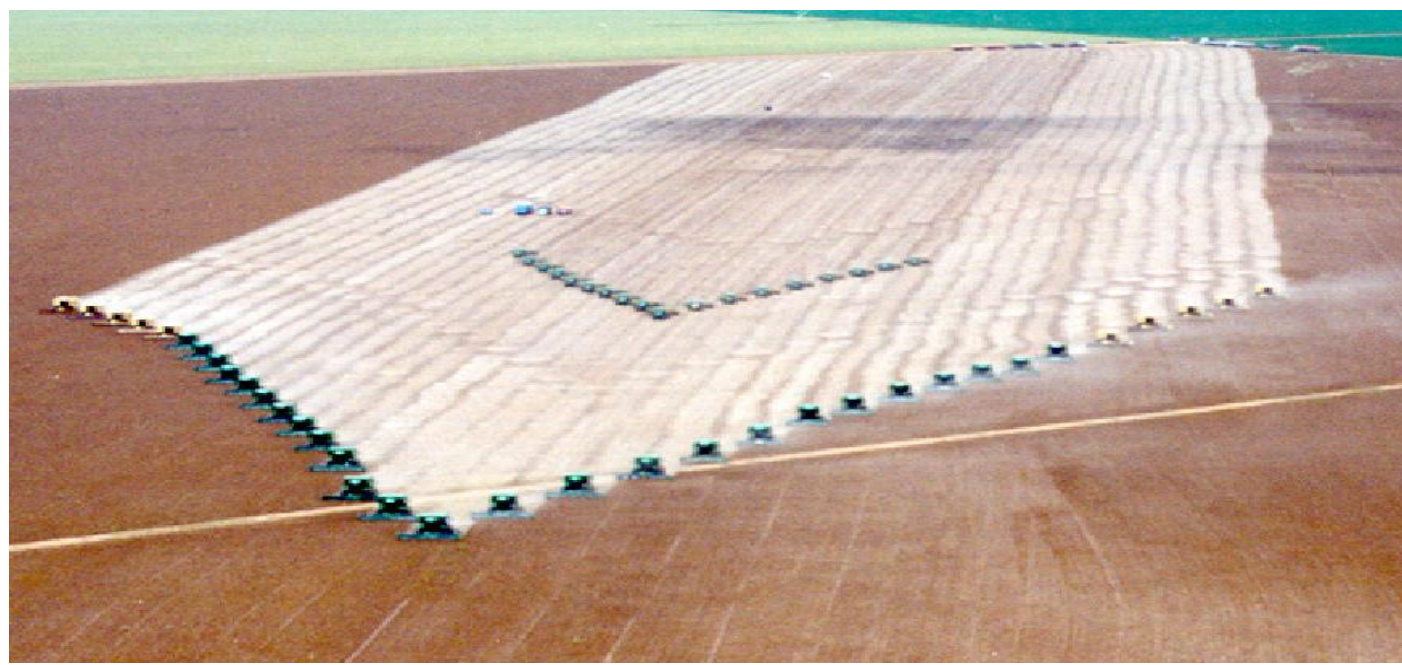

Figura 2. Monoculturas de soja e milho.

Fonte: EMBRAPA (2002), citado por Souza (2018).

O censo do Instituto Brasileiro de Geografia e Estatística - IBGE (2017) mostra que, no meio rural brasileiro, há o predomínio da população masculina, na faixa etária situada entre 30 a 60 anos. Apresenta também uma redução do número de pessoas ocupadas na agropecuária, o que pode ameaçar a sucessão no campo, pois apenas 5,5\% tem idade inferior a 30 anos. A população jovem e as mulheres estão em outras atividades, urbanas comerciais e industriais, mostrando sua exclusão da agricultura (Figura 3).

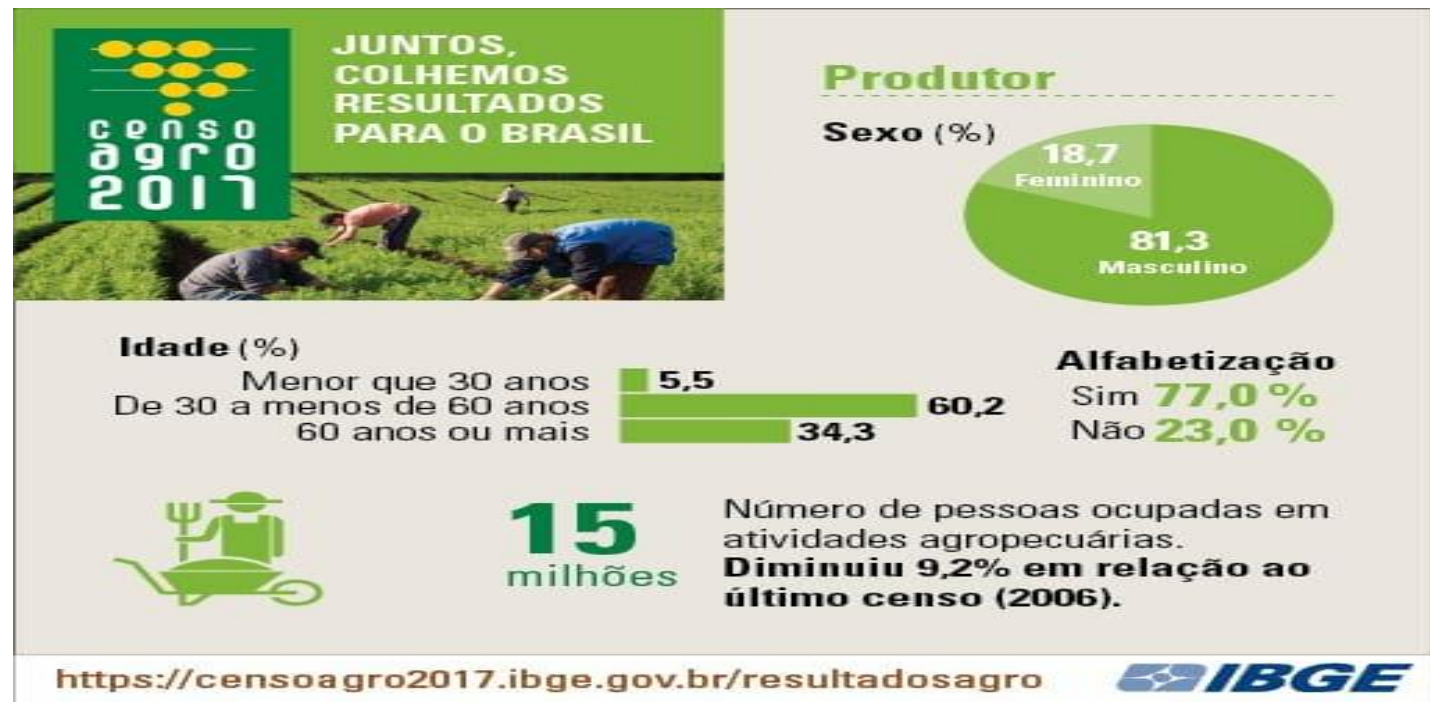

Figura 3. Idade, gênero e alfabetização no meio rural.

Fonte: IBGE (2017).

Os dados, mostrados na Figura 3, mostram que a maior parte dos estabelecimentos rurais no Brasil é composta por pequenas propriedades, que não é o foco das tecnologias propostas pela Revolução Verde - são os excluídos desse modelo, que representam aproximadamente $25 \%$, daqueles $81,50 \%$ das propriedades rurais do Brasil, com áreas inferiores a 50 ha (Figura 4). 


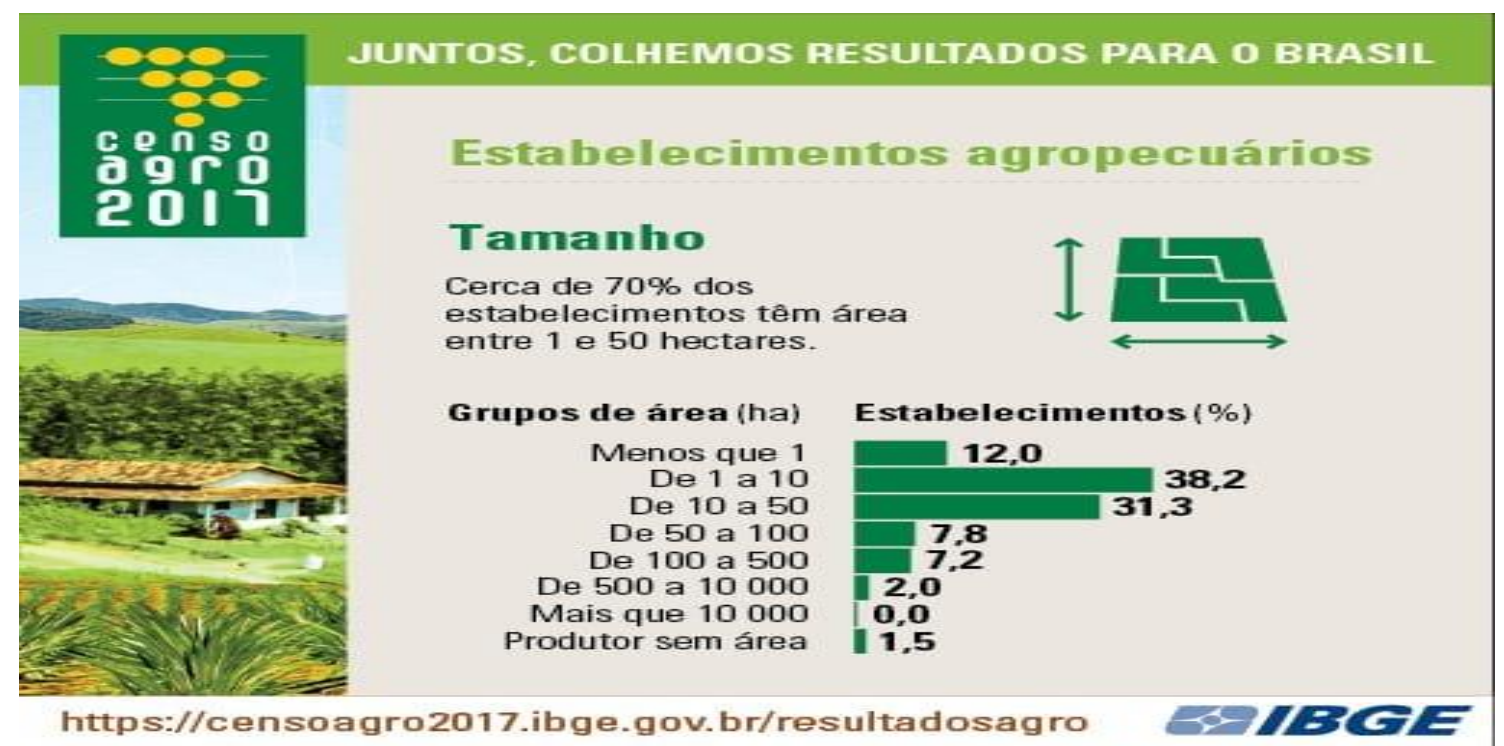

Figura 4. Estabelecimentos agropecuários no Censo 2017.

Fonte: IBGE (2017).

A agroecologia pode contribuir com esses estabelecimentos por meio da prevenção do colapso da agricultura familiar, tornando-a mais sustentável e produtiva, por meio de estratégias de desenvolvimento que: a) melhorem a qualidade de vida; b) aumentem a produtividade da terra com tecnologias de baixo custo; e c) gere trabalho e renda via tecnologias apropriadas (SOUZA, 2018).

Percebe-se que o argumento sobre o sucesso do modelo convencional desconsidera as externalidades negativas do (a): fome, erosão, contaminação de água, solo, alimentos, destruição dos biomas e empobrecimento das populações. Portanto, a abordagem com uma visão holística/sistêmica deve ser considerada em contraposição à visão limitada em se considerar apenas os aspectos físicos, tais como: área usada, produção e produtividade (GONCALVES et al., 2019; ZACARIAS e SOUZA, 2019).

O aumento da produção e da produtividade agrícola, e o aumento de produtos na pauta de exportação, relativamente na mesma área de produção, foi um aspecto positivo do que ficou conhecida como Revolução Verde. No entanto, essas vantagens são contestadas pelos danos ambientais e socioeconômicos não internalizados nesse tipo de produção. Os danos ambientais e a exclusão de grandes parcelas da população do acesso à terra, trabalho, alimento (comunidades tradicionais, indígenas e familiares), mostrou que esse modelo de produção convencional privilegia apenas alguns grupos de interesse.

Essa produção é focada na exportação de commodities e, ou, destinada à alimentação animal, prejudicando o abastecimento interno da população. A monocultura devasta os biomas biodiversos brasileiros. Práticas de conservação do solo e da água também não são priorizadas, tais como o plantio em nível, o plantio direto, a rotação de culturas, o manejo do 
Dayvson Dansi Rodrigues et al.

mato nas lavouras, a proteção das áreas de nascentes e a manutenção das áreas de preservação ambiental com espécies nativas, gerando externalidades socioambientais negativas.

\section{Externalidades geradas pelo modelo convencional de produção}

Os problemas gerados, indiretamente, são denominados "externalidades": são efeitos das atividades humanas no bem-estar de outras pessoas e empresas, que podem ser desejáveis (positivas) ou desfavoráveis (negativas). De acordo com Contador (1981), uma externalidade existe quando a provisão de bens e serviços para um grupo torna possível a outro grupo receber algum benefício sem pagar por ele, ou incorrer em prejuízos sem a devida compensação. Para Souza (2018), isto caracteriza os danos causados pelos problemas advindos da utilização inadequada dos recursos em regime de livre acesso, ou seja, na ausência de limitação e de controle de acesso, por exemplo, o a água dos rios ou o ar atmosférico.

A externalidade aumenta em casos de recursos naturais limitados, como agricultura irrigada, exploração de pastagens, florestas e recursos pesqueiros. As externalidades resultam da definição imprecisa do direito de propriedade, pois a poluição lançada sobre bens comuns como a água é feita porque não existe direito de propriedade sobre tais bens, sendo os custos sociais diferentes dos custos privados (SOUZA, 2004).

Os mercados são ineficientes em distribuir recursos na presença de externalidades por não registrar os custos de negociação. O empreendedor tende a não fornecer a externalidade positiva desejada e a gerar mais externalidade negativa do que a suportável pela sociedade, impedindo a eficiência econômica na dimensão social. Portanto, os interesses privados vão divergir dos valores socioambientais, compreendendo-se porque os custos de externalidades não são internalizados voluntariamente pelo mercado (SOUZA, 2018).

Observa-se que a pobreza é uma das externalidades geradas pelo modelo convencional de produção, popularmente conhecido por agronegócio, decorrente da acumulação de terras, exclusão dos pequenos produtores das pesquisas, assistência técnica, políticas públicas e financiamentos. Trata-se de definição do campo econômico. As atividades humanas feitas em situação de pobreza extrema também podem ser causadoras de impactos negativos e danos ambientais e sociais, como o consumo de recursos naturais acima da capacidade de suporte e ocupando áreas de preservação: lenha, caça, pesca, indústria e serviços (DIAMOND, 2007; SOUZA, 2015; 2018). 
Dayvson Dansi Rodrigues et al.

A Revolução Verde e o agronegócio também interferiram no acesso aos recursos naturais e alteraram as culturas locais, pela introdução da mecanização, uso sementes modificadas e uso intensivo de agroquímicos, além de ser um modelo de agricultura sustentado por elevados subsídios. Isso prejudicou o equilíbrio ecológico e a liberdade das populações locais, os recursos ambientais (sementes, ar, água, solo, entre outros) são apropriados e patenteados, obrigando as populações tradicionais a pagar por seu uso. O futuro deve ser de sociedades sustentáveis, que parem de usurpar os bens naturais e contribuam para o bem social. O Brasil, País de biodiversidade de importância global, tem a oportunidade de exercer papel central nessa transição para esse necessário novo modelo político e econômico. O planejamento deve ser feito pensando em sete gerações que receberão os impactos das ações no futuro, como faziam as sociedades antecessoras (SHIVA, 2012).

Aproximadamente $82 \%$ (Figura 4), quase quatro milhões de propriedades, estão em crise - em $25 \%$ delas seus proprietários vivem abaixo da linha da pobreza (caracterizada por rendimentos inferiores a $\mathrm{R} \$ 70,00$ pessoa $^{-1}$ mês $^{-1}$ (GLOBO RURAL, 2011). Os efeitos danosos dos modelos convencionais de desenvolvimento e de agricultura chegaram aos seus limites? Apesar de autores apresentarem tal dúvida, sabe-se que os monocultivos do modelo convencional são responsáveis pelas externalidades que levaram a atual crise socioambiental (SOUZA et al., 2014; ZACARIAS e SOUZA, 2019).

Dessa forma, ao invés de acabar com a fome, agravou a situação: interviu e destruiu os diferentes biomas e ecossistemas; aumentou a perda de solos por erosão e se estabeleceram processos de desertificação; exportou nutrientes e reduziu a fertilidade do solo e a quantidade de água; poluiu e contaminou os aquíferos - córregos, rios e mares; e pior, contaminou os alimentos com níveis altíssimos de agrotóxicos. Tais externalidades justificam a mudança de paradigma para alternativas e estratégias voltadas aos princípios sugeridos pela agroecologia para combater a fome, produzindo alimentos saudáveis e com respeitos aos aspectos socioambientais.

Harari (2018) afirma que há um desafio representado por um colapso ecológico, além da remota possibilidade de uma guerra nuclear, pela desestabilidade do delicado equilíbrio ecológico da biosfera pela insustentável extração de recursos naturais e lançamento de resíduos no meio ambiente. Cita o exemplo da agricultura, que se baseia na fertilização artificial excessiva, resultando na contaminação dos recursos hídricos, o que pode comprometer os fundamentos da civilização humana.

Segundo Harari (2018), a mudança climática é a maior ameaça para a estabilidade do período Holoceno - que permitiu o desenvolvimento da agricultura, das cidades e das sociedades complexas. Mudança que pode alcançar um ponto irreversível, mesmo que as emissões e demais medidas sejam adotadas. 
Dayvson Dansi Rodrigues et al.

Outro exemplo são os "rios voadores", fluxos aéreos de água (vapor) oriundos de áreas tropicais do Oceano Atlântico, e alimentados pela umidade resultante da evapotranspiração da Floresta Amazônica. Tal fenômeno ocorre a uma altura de até dois quilômetros, podendo transportar mais água do que o Rio Amazonas, contribuindo para a formação de chuvas a mais de três mil km de distância, produzindo chuvas no sul, sudeste e centro-oeste do Brasil, no Uruguai, no Paraguai e no norte da Argentina, sendo vitais para a produção agrícola e a qualidade de vida de milhões de pessoas na América Latina - inclusive considerando os aspectos econômico-financeiros. Esse fenômeno natural, da formação dos rios voadores, está ameaçado: talvez de forma irreversível, pela ocupação desordenada e desmatamento da região amazônica (PESQUISA FAPESP, 2015; BBC NEWS BRASIL, 2017).

\section{Estudo de caso: duas "diferentes" famílias do meio rural}

Observa-se um conjunto de problemas relacionado à agricultura convencional, tais como pobreza, sucessão e gênero. Num contexto como esse, as gerações seguintes tendem a não seguir os pais no campo, pois estes não apresentem satisfação/realização e, ou, sucesso, o que não quer dizer riqueza, mas de qualidade de vida e bem-estar.

Uma das visões sobre o rural brasileiro e modelos de produção é evidenciada em duas matérias jornalísticas: de uma família que reside no município de Sítio do Mato, BA (PIB = $\mathrm{R} \$$ 6.704,29 (2017); e IDMH = 0,564 - baixo (2010), segundo IBGE, 2017) (GLOBO RURAL, 2013) e o da Família Kern, município de São Carlos, SC (PIB = R \$ 30.543,63 (2017); IDMH = 0,769 (2010) - alto) (GLOBO RURAL, 2018).

A tabela 1 auxilia a perceber as diferenças entre os modelos de produção rural e as demais diferenças entre as famílias. As duas propriedades são diferentes quanto ao modelo de produção, evidenciando os benefícios da implantação do modelo agroecológico e dos impactos e externalidades negativos gerados pelo modelo convencional sobre as comunidades rurais afetadas. Cabe considerar que a família do Sítio do Mato está localizada na Bahia, um dos locais de pior IDH do Brasil, onde $50 \%$ da população vive em estado de extrema pobreza, sem acesso a recursos financeiros e assistência técnica. Por outro lado, a família Kern, que se localiza em Santa Catarina e adota o modelo agroecológico de produção, recebe assistência técnica regularmente. 
Dayvson Dansi Rodrigues et al.

Tabela 1. Diferenças entre as famílias do Município de Sítio do Mato e Família Kern, de acordo com atributos selecionados.

\begin{tabular}{|c|c|c|}
\hline Atributo & Família do Sítio do Mato & Família Kern \\
\hline $\begin{array}{l}1 \text { - Capital } \\
\text { social }\end{array}$ & $\begin{array}{l}\text { Baixa autoconfiança e confiança } \\
\text { social, sem associativismo e redes } \\
\text { de responsabilidade social. }\end{array}$ & $\begin{array}{l}\text { Confiança social, associação para } \\
\text { conservação de sementes e divisão de } \\
\text { produção e acesso à rede de } \\
\text { responsabilidade social. }\end{array}$ \\
\hline $\begin{array}{l}2 \text { - Capital } \\
\text { cultural }\end{array}$ & $\begin{array}{l}\text { Avós e pais sem estudo. Os filhos } \\
\text { em situação precária na escola e no } \\
\text { transporte. Falta de apoio em casa. }\end{array}$ & $\begin{array}{l}\text { Todos têm algum aprendizado, como a } \\
\text { agroecologia e a música. Os filhos } \\
\text { estudam na escola e em casa. } \\
\text { Herdaram conhecimentos e bens dos } \\
\text { antecessores. }\end{array}$ \\
\hline 3 - Ecológico & $\begin{array}{l}\text { Tenta imitar o modelo agroquímico: } \\
\text { monocultura, solo nu, animais e } \\
\text { plantas não adaptados ao local, sem } \\
\text { técnicas de conservação da água. }\end{array}$ & $\begin{array}{l}\text { Modelo tradicional/familiar com } \\
\text { aplicação de técnicas agroecológicas: } \\
\text { policultura, conservação de sementes } \\
\text { crioulas, horta mandala com animais, } \\
\text { uso de recursos locais, diversidade de } \\
\text { animais e plantas, diversidade de } \\
\text { ambientes, conservação da água. }\end{array}$ \\
\hline 4 - Econômico & $\begin{array}{l}\text { Pobreza extrema, trabalho precário } \\
\text { fora da propriedade. }\end{array}$ & $\begin{array}{l}\text { Renda suficiente. Alimentação } \\
\text { produzida atende à família e o } \\
\text { excedente contribui com a economia. } \\
\text { Trabalho externo gera renda. }\end{array}$ \\
\hline 5-Saúde & $\begin{array}{l}\text { Falta de saneamento e boas } \\
\text { práticas. Alimentação deficiente. } \\
\text { Condições precárias de moradia e } \\
\text { transporte. Falta de acesso aos } \\
\text { serviços públicos. }\end{array}$ & $\begin{array}{l}\text { Possui saneamento, água limpa, acesso } \\
\text { a serviços públicos. Moradia e } \\
\text { alimentação adequada. }\end{array}$ \\
\hline $\begin{array}{l}6 \text { - Assistência } \\
\text { Técnica }\end{array}$ & Não recebe. & $\begin{array}{l}\text { Assistência na } \\
\text { comercialização. }\end{array}$ \\
\hline
\end{tabular}

Fonte: Adaptado de Fundação Oswaldo Cruz (2020).

A família do Sítio do Mato, quanto ao capital social, apresenta baixa autoconfiança, sem associativismo e redes de responsabilidade social; enquanto a Família Kern, associou-se para conservação de sementes e divisão de produção, além de acessar redes de responsabilidade social.

O capital cultural da Família do Sítio do Mato é muito reduzido - avós e pais sem estudo; os filhos em situação precária na escola e no transporte; e falta de apoio em casa. $\mathrm{Na}$ Família Kern, nesse atributo, todos têm algum aprendizado, como a agroecologia e a música; os filhos estudam na escola e em casa; herdaram conhecimentos e bens de seus antecessores.

No aspecto ecológico, a família do Sítio do Mato representa o modelo agroquímico: monocultura, solo descoberto, animais e plantas não adaptados ao local, sem técnicas de conservação da água e do solo. Já o modelo de produção da segunda família, é marcado 
Dayvson Dansi Rodrigues et al.

pela aplicação de técnicas agroecológicas: policultura, conservação de sementes crioulas, horta em sistema "mandala" com animais, uso de recursos locais, diversidade de animais e plantas, diversidade de ambientes, conservação do solo e da água.

A família do Sítio do Mato também sofre com falta de saneamento e boas práticas. Alimentação deficiente. Condições precárias de moradia e transporte. Falta de acesso aos serviços públicos. Situação bem diferente do saneamento, água limpa, acesso aos serviços públicos, moradia e alimentação adequada da família Kern - além da assistência técnica efetiva e de qualidade que estes recebem, e aqueles não.

A agricultura pode ser sustentável em todos os aspectos: ambiental, social e econômico, com o uso das práticas conservacionistas que podem ser observadas na família Kern. A Agroecologia e seus preceitos teve importância no "sucesso" da Família Kern, pois aplicam os princípios e conceitos de ecologia nas técnicas de manejo dos recursos naturais, praticam organização e solidariedade intra e Inter geracional, que alimentam as relações de interações e responsabilidades mútuas influenciando positivamente no processo de coevolução e transformação pessoal. Promove, ainda, o desenvolvimento rural mais democrático, menos agressivo ao meio ambiente e às pessoas, com inclusão social, autogestão, proporcionando melhores oportunidades e condição de vida.

Quanto à região do Sítio do Mato, seria viável implementar o modelo agroecológico: desde que sejam superadas as limitações quanto ao capital social, capital cultural, degradação ecológica, exclusão econômica, falta de serviços públicos de saúde e, fundamentalmente: acesso à educação, à assistência técnica e ao crédito. Para isso, faz-se fundamental o desenvolvimento de políticas públicas direcionadas para produtores com esse perfil.

\section{Agroecologia, olericultura e o paradigma dos agroquímicos}

Atualmente, o paradigma agroquímico é aceito quase sem questionamentos, estruturado por oportunismo: as tecnologias são promovidas e consolidadas ideologicamente. A biotecnologia na agricultura, controlada por grandes corporações transnacionais, causará danos irreversíveis do que aqueles sofridos até o presente momento, aumentando a dependência e a dominação sobre os agricultores que sobreviverem a esse modelo de custos elevados, e impondo limitações de escolhas para o consumidor (LUTZENBERGER, 2001; SOUZA, 2018; ZACARIAS e SOUZA, 2019).

Esses mesmos autores ainda alertam que essas corporações insistem em que não há outra saída, apesar de saberem que existe alternativa - melhores, saudáveis e sustentáveis financeira e economicamente. A agricultura deve encontrar caminhos para se afastar dos 
Dayvson Dansi Rodrigues et al.

agroquímicos, posto que já há um estoque razoável de conhecimentos necessários, como demonstram os milhares de agricultores orgânicos e, ou, agroecológicos, em todo o mundo. Contudo, infelizmente, a indústria com cultivares mais produtivos e resistentes, quando associados ao uso de seus agrotóxicos, persevera em vender tais pacotes, obrigando o agricultor a usar produtos químicos e tornando-os cada vez mais dependentes (ROMAN e SOUZA, 2014; SOUZA, 2018).

Percebe-se que a revolução verde e o agronegócio retiraram o acesso aos recursos naturais e às culturas locais pela introdução de sementes modificadas e o uso de agroquímicos, uma agricultura baseada em fortes subsídios. Isso reduziu o equilíbrio ecológico e a liberdade das populações locais, na medida em que os recursos ambientais (sementes, ar, água, solo, etc.) são apropriados e patenteados, obrigando as populações a adquiri-los (SHIVA, 2003; CAPORAL et al., 2009; ZACARIAS e SOUZA, 2019).

A produção de olerícolas é um exemplo, com evidente importância econômica, considerando o aumento de produção e produtividade no Brasil e no Mundo (FAO, 2018), com grande participação na agricultura familiar brasileira e crescimento devido à busca de alimentação saudável (EMBRAPA, 2010).

A agroecologia deve buscar a transição de agroecossistemas ditos modernos ou tecnificados para um modelo que se baseie em princípios ecológicos, construindo um novo sistema com estrutura e função semelhante ao ecossistema da região biogeográfica em que se encontra, entre eles: reduzir o uso de insumos comerciais; usar recursos renováveis endógenos e aumentar a ciclagem de nutrientes (ALTIERI, 2004; FEIDEN, 2005; ZACARIAS e SOUZA, 2019).

$\mathrm{Na}$ olericultura, esses elementos básicos de uma estratégia agroecológica justificam a busca por novas fontes alternativas de substratos, por exemplo, que pode beneficiar a maioria dos cultivos de hortaliças no Brasil. Essa atividade é praticada em pequena escala, majoritariamente, por agricultores de produção familiar - seus rendimentos são prejudicados pelos elevados custos dos substratos comerciais (BAITELLE et al., 2018; MENEGHELLI et al., 2018).

\section{Agroecologia e a dimensão social}

A música "Curvas do rio" do famoso cantor, compositor erudito, "sertanês", o baiano Elomar Mello, representa bem as questões da Agroecologia. Sua letra descreve a vida dura e árdua da maioria dos brasileiros do campo, que se completa com o amor e união das famílias mais humildes. A música conta a história de um chefe de família do sertão que sai 
Dayvson Dansi Rodrigues et al.

em busca de melhorias para a sua família e promete voltar, pois é preciso ir e a terra precisa descansar (MELLO, 1979).

Percebe-se que cada povo tem a sua história, cultura, costumes e identidade. Os indivíduos não podem ser tratados como se fossem iguais, homogeneamente, sob o risco de se reduzir as pessoas a meros consumidores. Os povos tradicionais, por exemplo, não tratam a terra como se fosse apenas um fator de produção, percebem os recursos naturais como seus ancestrais. Questionam a razão, a ciência e a filosofia ocidental, sempre voltadas para a produtividade, a economia, as novas técnicas de produção, meramente instrumental (KRENAK, 2020).

Podem-se observar, como exemplo, as fases da vida humana: desde a concepção, a divisão celular, a transformação de embrião ao feto e seu desenvolvimento até o seu nascimento, mostra o sofisticado processo - para alguns, é simplesmente produto da criação divina (RAMOS, 2006); outros tentam entender a vida sob vários aspectos, além do biológico, o que nos coloca limites por meio da bioética. O ciclo de vida humano lembra o aspecto evolutivo, a interação com o ambiente e as demais espécies, a ecologia, compondo a diversidade com os demais organismos.

Essas várias visões do mundo podem ser discutidas em círculos de cultura, os quais permitem que todos fiquem numa posição de igualdade, sem hierarquia, trabalhando a relação da horizontalidade. No caso da educação, o professor ou mediador, facilita os debates e a troca de informações: um animador do debate. O aprendiz é visto como alguém que está em processo de construção do conhecimento. O diálogo tem o papel, nesse contexto, de encontrar as respostas para as questões, considerando a realidade do aluno ou do membro de uma dada associação, por exemplo (SHIVA, 2012).

Há questões que causam perplexidade nos dias atuais, como o fato de alguém querer uma vida simples e digna, com moradia e alimentação adequadas, o que garante uma vida feliz. Contudo, uma fábula árabe conta que, ao dispor de noventa e nove moedas, o servente do rei deu mais atenção à busca pela centésima moeda em detrimento do uso das noventa e nove que tinham para usar em coisas simples que the fazia feliz. Assim, começou a fazer parte do grupo chamado Clube 99, formado por pessoas que se ocupam apenas em produzir e lucrar, abrindo mão de uma vida de princípios ecológicos e partilha (SITE DO PASTOR, [s.d.]).

Essa visão ou padrão de consumo das classes sociais favorecidas pela economia ocidental (da extração de materiais ao descarte dos produtos sem limites, linearmente), resulta em diferentes impactos e externalidades ambientais e sociais, que afetam diversos países, demonstrando a necessidade de conversão para sistemas mais sustentáveis e justos (FOX, 2007; PRIMAVESI, 2008; MARTINS et al., 2013). O trabalho do Coletivo Agroecológico do Instituto Federal Sudeste de Minas, campus Rio Pomba, por exemplo, é 
Dayvson Dansi Rodrigues et al.

motivador ao mostrar que é possível mudar, pois os conhecimentos da agroecologia aplicados resgatam conhecimentos tradicionais, com elementos essenciais e contribuem com uma vida mais digna e saudável (SILVA et al., 2016).

Os paradigmas demandam longos períodos de tempo para sua superação, o que pode ser acelerado por processos educativos que estimulem a curiosidade, geração de ideias, a melhoria contínua e o conhecimento de mudanças de diferentes organizações e pessoas (PRIMAVESI, 2008; SOUZA, 2014; 2018).

Assim, o objetivo de projetos de intervenção agroecológicos não deve ser a conversão de um sistema de produção de uma família para um sistema observado em outra com mais insumos e recursos externos. Parece que a quebra de paradigma está em não seguir esses modelos, mas promover uma conversão que reconheça o contexto de cada grupo, o bioma em que esta inserida, a biodiversidade e os recursos disponíveis, os aspectos sociais e econômicos. A aplicação dos conhecimentos e técnicas baseados em princípios ecológicos e éticos pode ajudar cada família a ser protagonista do seu processo de conversão para um modelo de produção mais sustentável (MARTINS e SOUZA, 2013; SOUZA et al, 2014).

Sabe-se que a imposição da agricultura moderna causou a perda de costumes e técnicas de manejo tradicionais, como o sistema de mutirões nas comunidades rurais, com troca de serviço e partilha. O trabalho do Coletivo Agroecológico no município de Rio Pomba-MG, formado por estudantes e profissionais formados do Curso de Agroecologia do IF Sudeste de Minas - Campus Rio Pomba, mostra como a Agroecologia pode resgatar práticas rurais tradicionais e como os mutirões contribuem com a mão de obra nas propriedades e de formação e disseminação dos conhecimentos agroecológicos (DESCOUT, 2016; SILVA et al., 2016).

\section{Caminhos necessários}

É necessária uma contabilidade de custos real para internalizar os custos externalizados de nossos sistemas alimentares, criando condições equitativas para alimentos provenientes de produção sustentável. Os governos tomaram medidas rápidas no COVID-19, também precisam tomar medidas decisivas para combater as mudanças climáticas e a degradação de nossos recursos naturais. É necessária uma transição para dietas saudáveis e sustentáveis em todo o mundo. Precisam cuidar de nossas paisagens produtivas ou "paisagens de alimentos", não apenas para proteger a natureza, nossas águas e solos, mas também para salvar os meios de subsistência das pessoas ${ }^{1}$.

1 Mensagens chaves do Digital Forum: Food without Farmers, compartilhada por e-mail aos participantes. Disponível em: $<$ https://events.globallandscapesforum.org/digital-forum-food-without-farmers/> 
Dayvson Dansi Rodrigues et al.

A distribuição de renda, por sua vez, deve ocorrer na dimensão econômica por meio do acesso à terra, reforma agrária, fortalecimento das economias locais. No aspecto social, a agroecologia pode promover a maior diversidade cultural, étnica, de gênero, valorizar o conhecimento tradicional. Na dimensão ambiental é necessário respeitar todas as formas de vida, ecossistemas e princípios ecológicos, além da conexão espiritual, que também é importante (PALUDO e COSTABEBER, 2012; UNESP, 2014; SANTOS et al., 2015; GONÇALVES et al., 2019).

Fica evidente que o agronegócio empresarial não atendeu esses aspectos. Estes seriam o destaque das informações governamentais e propagandas do próprio agronegócio, caso fossem satisfeitos. Por outro lado, a produção, a área e o lucro são os argumentos que justificam a manutenção da forma de produção convencional. A agroecologia tem o potencial de mudar essa realidade, tendo como público-alvo os agricultores familiares e toda a população consumidora que poderia ter acesso à produção agroecológica, fomentando a transição do sistema convencional, por meio das políticas públicas.

\section{Considerações finais}

Está claro que o modelo de produção convencional é causador de degradação em diferentes dimensões (ambiental, econômica e social) e os impactos e externalidades desse modelo perdurarão por décadas. A partir dessa dura realidade, percebem-se os desafios a serem enfrentados para creditar o pensamento agroecológico.

As propostas de melhoria de vida, via exclusivamente pelo mercado (por meio de empreendimentos, empregos e renda), têm suas limitações e não são voltadas para a diversidade de ambientes e bem-estar das comunidades. Há muito conhecimento sobre o que é necessário para se recuperar e mantiver os agroecossistemas em condição de equilíbrio natural (homeostase) - a agroecologia sugere resgatar esses saberes e validá-los por meio de pesquisas acadêmicas.

A agroecologia se baseia em métodos, processos e conhecimentos necessários para o desenvolvimento agrícola produtivo, ambientalmente consistente e viável economicamente. Para isso, há de se priorizar o conhecimento empírico e local dos produtores, bem como sua aplicação e socialização no desenvolvimento agroecológico da agricultura. Este modelo de produção promove o equilíbrio entre espécies vegetais, luz solar, solos, umidade e os organismos presentes que coexistem no ambiente: juntos compõem o agroecossistema produtivo. Neste contexto, destaca-se um importante ponto da Agroecologia: produzir utilizando as práticas conservacionistas de manejo de água e solo, ampliando a biodiversidade e a preservação ambiental. 
Dayvson Dansi Rodrigues et al.

A reflexão sobre as duas famílias citadas no texto indica que projetos de intervenção agroecológicos não devem buscar a simples conversão de um sistema de produção de uma família para um sistema observado em outra, com insumos e recursos exógenos. A mudança ocorrerá reconhecendo o contexto de cada grupo: o seu bioma, a sua biodiversidade e os seus recursos disponíveis, bem como os aspectos sociais e econômicos, ajudando cada família a ser protagonista da sua conversão para uma situação mais sustentável.

A população consumidora precisa compreender a importância da produção agroecológica. Atualmente, o mercado de consumo é crescente, em todo o mundo. Entretanto, faz-se fundamental verificar um panorama fidedigno do mercado de orgânicos, no que tange os aspectos produtivos, mercadológicos e sociais. Além disso, organizar os dados das propriedades e direcionar para uma análise mais precisa sobre o cenário da produção, consumo e importância socioeconômica para a agricultura familiar.

Dessa forma, faz-se necessário e fundamental elaborar políticas públicas direcionadas aos agricultores familiares, que favoreçam a assistência técnica, financie a produção e estimule a comercialização. Campanhas junto à população consumidora, divulgando os benefícios para saúde e o bem-estar da família e da comunidade, são necessárias para promover acesso e estimular a produção agroecológica. Com essas atitudes, será fomentada a transição do modelo convencional insustentável, favorecido pelas atuais políticas públicas, para o modelo sustentável de produção agroecológica.

\section{Referências}

BBC NEWS BRASIL. O que são os "rios voadores" que distribuem a água da Amazônia BBC News Brasil, 2017. Disponível em: <https://www.bbc.com/portuguese/brasil41118902>. Acesso em: 16 abr. 2020.

CAPORAL, F. R.; COSTABEBER, J. A.; PAULUS, G. Agroecologia : uma ciência do campo da complexidade. Brasília: Paulus, 2009. 111p.

CAPRA, F. A teia da vida. Tradução: Newton Roberval Eichemberg. São Paulo: Cultrix, 1996.

CONTADOR, C. R. Avaliação social de projetos. São Paulo: Atlas, 1981. 301p.

DARONCO, C.; MELO, A. C. G.; MACHADO, J. A. R. Consórcio de espécies nativas da floresta estacional semidecidual com mandioca (Manihot sculenta Crantz) para restauração de mata ciliar, Revista Árvore, Viçosa-MG, v. 36, n. 2, p. 291-299, 2012.

DESCOUT, O. Multirões: vídeo realizado pelo Coletivo Agroecológico de Rio Pomba. Rio Pomba, 2016. Disponível em: <https://www.youtube.com/watch?v=b_7Yztus2gE>. Acesso em: 26 abr. 2020. 
Dayvson Dansi Rodrigues et al.

DIAMOND, J. Colapso: como as sociedades escolhem os fracassos ou sucessos. Tradução: Alexandre Raposo. 5. ed. Rio de Janeiro: Record, 2007.

FOX, L. A história das coisas. Disponível em: <https://www.youtube.com/watch? V=xEgPp1VGWsM>. Acesso em: 26 abr. 2020.

FUNDAÇÃO OSWALDO CRUZ. Capital social. Disponível em: <http://www.sites.epsjv. fiocruz.br/dicionario/verbetes/capsoc.html>. Acesso em: 10 ago. 2020.

GONCALVES, D. C.; CRESPO, A. M.; FERREIRA, C. C.; CARRICO, I. G. H.; SOUZA, M. N.; RIBEIRO, W. R. A agroecologia como ferramenta ao fortalecimento da agricultura familiar. Revista UNIVAP, v. 1, p. 342-357, 2019.

GLOBO RURAL. Cerca de $25 \%$ da população rural vive em situação de pobreza extrema. Disponível em: <http://g1.globo.com/economia/agronegocios/noticia/2011/12/ cerca-de-25-da-populacao-rural-vive-em-situacao-de-pobreza-extrema.html>. Acesso em: 8 ago. 2020.

GLOBO RURAL. Sítio do Mato - BA. Programa Globo Rural, 2013. Disponível em: $<$ https://www.youtube.com/watch?v=|80LrpqxE78\&t=67s>. Acesso em: 10 abr. 2020

GLOBO RURAL. Família Kern cuida da preservação de sementes tradicioanais, 2018. Disponível em: <https://www. youtube.com/watch?v=KMfSK7ev7dY\&t=7s>. Acesso em: 10 abr. 2020.

GONCALVES, D. C.; CRESPO, A. M.; FERREIRA, C. C.; CARRICO, I. G. H.; SOUZA, M. N.; RIBEIRO, W. R. A agroecologia como ferramenta ao fortalecimento da agricultura familiar. Revista da UNIVAP. , v. 1, p. 342 - 357, 2019.

HARARI, Y. N. 21 lições para o século 21. Tradução: Paulo Geiger. 1. ed. São Paulo: Companhia das Letras, 2018. 432p.

INSTITUTO BRASILEIRO DE GEOGRAFIA E ESTATÍSTICA - IBGE. Censo Agro 2017 Resultados definitivos. Disponível em: <https://censos.ibge.gov.br/ agro/2017/templates/censo_agro/resultadosagro/index.html>. Acesso em: 8 ago. 2020.

INSTITUTO CAPIXABA DE PESQUISA, ASSISTÊNCIA TÉCNICA E EXTENSÃO RURAL INCAPER. "Conquista ES8152": Cultivar melhorada de café conilon propagada por sementes para o Espírito Santo. Vitórialncaper, jun. 2019. Disponível em: $<$ https://biblioteca.incaper.es.gov.br/digital/bitstream/123456789/3580/1/Nova-variedadeConilon-Conquista-ES8152-Incaper.pdf>. Acesso em: 4 maio 2020.

KRENAK, A. Conversa SELVAGEM - Ailton Krenak e Marcelo Gleiser, 2020. Disponível em: <https://www.youtube.com/watch?v=xeAl7GDOefg>. Acesso em: 17 abr. 2020.

LUTZENBERGER, J. A. O absurdo da agricultura. Estudos avançados, v. 15, n. 43, p. 6174, 2001.

MARTINS, M. C.; ROMARCO, M. L.; SOUZA, M. N. Uma análise da implantação da integração lavoura pecuária floresta (ILPF) na microrregião de Viçosa, Minas Gerais. Boletim de Pesquisa do Programa de Pós-Graduação em Extensão Rural da UFV, v. 4, p. 154-163, 2013.

MARTINS, M. C.; SOUZA, M. N. Uma análise das variáveis do desenvolvimento rural sustentável no uso da Integração Lavoura Pecuária e Floresta (ILPF) em municípios da 
Dayvson Dansi Rodrigues et al.

Zona da Mata de Minas Gerais. Multifuncionalidades sustentáveis no campo: Agricultura, pecuária e florestas, v. 5, p. 10-15, 2013.

MELLO, E. F. Curvas do rio, 1979. Disponível em: <https://www.youtube.com/watch? V=X2_cXe1205g >. Acesso em: 7 ago. 2020.

PALUDO, R.; COSTABEBER, J. A. Sistemas agroflorestais como estratégia de desenvolvimento rural em diferentes biomas brasileiros. Revista Brasileira de Agroecologia, v. 7, n. 2, p. 63-76, 2012.

PESQUISA FAPESP. Rain dance - Understanding water shortage, jan. 2015. Disponível em: <https://www.youtube.com/watch?v=JDdvd-XC_sl>. Acesso em: 15 abr. 2020.

PRIMAVESI, A. M. Agroecologia e manejo do solo. Revista Agriculturas, v. 5, n. 3, p. 7-10, 2008.

RANKING DOS POLÍTICOS. A riqueza do mundo nos últimos 200 anos, 2020. Disponível em: <https://www.youtube.com/watch?v=rlzc_wiPJLs>. Acesso em: 4 maio. 2020.

ROMAN, R. M.; SOUZA, M. A. A. S. Dynamic o systems and the modeling with the use STELLA. Academic Journal Database, v. 4, p. 23-37, 2014.

SANTOS, M. V.; SILVA, D. V.; FONSECA, D. M.; REIS, M. R.; FERREIRA, L. R.; OLIVEIRA NETO, S. N.; OLIVEIRA, F. L. R. Componentes produtivos do milho sob diferentes manejos de plantas daninhas e arranjos de plantio em sistema agrossilvipastoril. Ciência Rural, v. 45, n. 9, 2015.

SCHREIBER, M. Cientistas questionam "guru ambiental de Bolsonaro" que coloca Brasil como líder em preservação. Disponível em: <https://www.bbc.com/portuguese/ brasil-49081586>. Acesso em: 7 ago. 2020.

SHIVA, V. Monoculturas da mente: perspectivas da biodiversidade e da biotecnologia. São Paulo: Gaia, Agrária (São Paulo. Online), v. 17, p. 132-137, 2003.

SHIVA, V. Sustentabilidade, biodiversidade e preservação de sementes. Entrevista concedida para a Conferência Fronteiras do Pensamento, 2012. Disponível em: <https://www.youtube.com/watch?v=R-oGus9EWRk>. Acesso em: 15 abr. 2020.

SILVA, A. B.; VIEIRA, A. S. D.; IANASE, A. M.; SILVA, M. M. Ação Coletiva Para a Transição Agroecológica - Mutirões Como Ferramenta Para a Construção da Agroecologia na Zona Rural de Rio Pomba. Cadernos de Agroecologia. Anais... 2016. Disponível em: $<$ http://revistas.aba-agroecologia.org.br/index. php/cad/article/view/22372>. Acesso em: 26 abr. 2020.

SITE DO PASTOR. Clube 99 - Belíssima fábula árabe sobre insatisfação. Disponível em: <https://www.sitedopastor.com.br/clube-99/>. Acesso em: 26 abr. 2020.

SOUZA, I. I. de M.; ARAÚJO, E. da S.; JAEGGI, M. E. P. C.; SIMÃO, J. B. P.; ROUWS, J. R. C.; SOUZA, M. N. Effect of afforestation of arabica coffee on the physical and sensorial quality of the bean. Journal of Experimental Agriculture International, v. 42, n. 7, p. 133$143,2020$.

SOUZA, M. N. Degradação antrópica e procedimentos de recuperação ambiental. Balti, Moldova, Europe: Novas Edições Acadêmicas, v. 1000, 2018. 376 p. 
SOUZA, M. N. Degradação e recuperação ambiental e desenvolvimento sustentável. Viçosa: UFV, 2004. 371p.

SOUZA, M. N. Mudanças no uso do solo e da água e a gestão dos recursos naturais. Frankfurt, Alemanha: Novas Edições Acadêmicas, v. 5000, 2015. 376 p.

SOUZA, M. N.; MANTOVANI, E. C.; ORELLANA GONZÁLEZ, A. M. G.; SANCHEZ ROMAN, R. M.; SOUZA, M. A. A. S. Dynamic o systems and the modeling with the use STELLA. Academic Journals Database, v. 4, p. 23-37, 2014.

TEIXEIRA, G. Censo agropecuário desautoriza pesquisa da Embrapa sobre a preservação da vegetação nativa nos imóveis rurais - articulação nacional de agroecologia, 2019. Disponível em: <https:// agroecologia.org.br/2019/01/14/censoagropecuario-desautoriza-pesquisa-da-embrapa-sobre-a-preservacao-da-vegetacao-nativanos-imoveis-rurais/>. Acesso em: 7 ago. 2020

UNIVERSIDADE ESTADUAL PAULISTA "JÚLIO DE MESQUITA" - UNESP. Ecoideias 01/06/2014 - Agroecologia - YouTube, 2014. Disponível em: <https://www.youtube.com/watch?v=fhLgOcdQgv0\&t=518s>. Acesso em: 26 abr. 2020.

ZACARIAS, A. J.; SOUZA, M. N. Recuperação de área degradada de monocultura intensiva no estado do Espírito Santo. Revista UNIVAP, v. 1, n. 87, p. 234-242, 2019. 


\section{Capítulo 2}

\section{O sistema agroflorestal "Taungya” na recuperação de áreas degradadas}

Gabriel Permanhane da Silva ${ }^{1}$, Leticia Rigo Tavares1, Vinicius de Freitas Mateus ${ }^{1}$, Telma

Machado de Oliveira Peluzio², Atanásio Alves do Amaral ${ }^{3}$, Maurício Novaes Souza ${ }^{3}$

\section{Introdução}

Os problemas ambientais, inerentes às atividades antrópicas, são tão antigos quanto à existência humana: a novidade é a sua escala, dimensão e a emergente consciência ambiental por parte da população. Ao longo do tempo, fatores naturais tiveram e têm influência sobre a vegetação original, substituindo espécies e alterando a dominância: porém, em um processo gradual e espontâneo. Com o desenvolvimento tecnológico acelerado das últimas décadas foi quebrado, pelo fator antrópico, essa dinâmica natural das formações, suprimindo-as, reduzindo a biodiversidade, criando em seus lugares paisagens altamente modificadas, em formas não sincronizadas com o ambiente. Geralmente, essas alterações são nocivas - reduzem a resistência e a resiliência dos ecossistemas (SOUZA et al., 2014; SOUZA, 2018).

Soma-se a esse fato, nas últimas décadas, o crescimento acelerado da população mundial demandando acréscimo das áreas plantadas para atender a pendência crescente por alimentos. Por outro lado, acresce a percepção pela necessidade de preservação e, ou, conservação ambiental. Cabe considerar, contudo, que há uma percepção difusa por parte da sociedade no sentido de que as áreas disponíveis para o plantio devem ser priorizadas para a agricultura, visando a produção de alimentos. Dessa forma, as atividades agropecuárias têm se estabelecido, em algumas situações, em áreas inadequadas à produção, causando impactos ambientais negativos e provocando a sua degradação. Nesse contexto, apesar de impor-se a ampliação da área de plantio e, ou, o aumento de produtividade das áreas em produção, faz-se fundamental a recuperação das áreas degradadas (RAD) e o uso de práticas conservacionistas, como aquelas recomendas pelo modelo agroecológico de produção (MARTINS et al., 2013).

\footnotetext{
${ }^{1}$ Pós-graduandos em Agroecologia e Sustentabilidade pelo Instituto Federal do Espírito Santo Campus de Alegre, Caixa Postal 47, CEP: 29500-000, Alegre-ES. E-mail: permanhaneg@gmail.com; leticiarigot@hotmail.com; viniciusfreitas20@yahoo.com.br

2Dra. Professora do Instituto Federal do Espírito Santo - Campus de Alegre, Caixa Postal 47, CEP: 29500-000, Alegre-ES. E-mail: tmpeluzio@ifes.edu.br

${ }^{3}$ Drs. Professores do Instituto Federal do Espírito Santo - Campus de Alegre, Caixa Postal 47, CEP: 29500-000, Alegre-ES. E-mail: atanasio.ifes@gmail.com; mauricios.novaes@gmail.com
} 
Assim, renova-se o interesse pelos sistemas agroflorestais (SAF's), uma modalidade de uso da terra praticada em todas as partes do mundo desde tempos remotos. Os SAF's têm por objetivo aumentar a produtividade da terra e sua receita e, também, proporcionarem maior biodiversidade e a manutenção, ou mesmo o aumento, da capacidade de suporte, fundamentais à sustentabilidade, favorecendo, também, a recuperação de áreas degradadas. Dentro das atividades agropecuárias e florestais, os SAF's têm sido considerados como alternativas sustentáveis aos sistemas intensivos de produção (MARTINS e SOUZA, 2013).

Por definição, os SAF's são um arranjo espacial do uso da terra, onde espécies perenes são combinadas com cultivos agrícolas ou animais (NAIR, 1993), maximizando a diversidade de espécies e interações ecológicas locais (ABDO et al., 2008; MARTINOTTO et al., 2012; ZACARIAS e SOUZA, 2019).

A implantação desses sistemas, por meio da manutenção da biodiversidade, pode atuar sobre os parâmetros físico-químicos e biológicos do solo, redução da erosão e benefícios socioculturais e econômicos (RODRIGUES et al., 2008; LIMA et al., 2010).

$\mathrm{Na}$ atividade cafeeira, por exemplo, as lavouras cultivadas em manejo a pleno sol, em pouco tempo se convertem em improdutivas devido ao aumento de temperatura e redução da precipitação. Tal condição vem contribuindo para o desenvolvimento de práticas de manejo que proporcionem a atenuação dos eventos climáticos extremos sobre o cafeeiro, como a arborização, que apresenta, também, diversos benefícios edafoclimáticos, tais como a ciclagem de nutrientes, menor degradação da matéria orgânica, controle térmico dentro da lavoura, controle de quebra-vento, proteção do solo e retenção de água (GONÇALVES et al., 2019; ZACARIAS e SOUZA, 2019)

Entretanto, apesar dos benefícios que os sistemas agroflorestais têm a oferecer, lamentavelmente ainda são pouco implantados em larga escala no Brasil e, quando praticados, restringem-se a áreas marginais dentro das propriedades de pequenos produtores ou em áreas já degradadas (FERNANDES et al., 1994; SOUZA, 2019).

Conforme a legislação ambiental, todas as propriedades rurais devem resguardar parte de sua área, a qual deve ser mantida vegetada, sendo denominada Reserva Florestal Legal (RFL) ou Reserva Legal (RL). Essas áreas são mantidas com o propósito de conservação da biodiversidade local e manutenção das relações ecológicas, sendo plausíveis de exploração econômica, vedado o corte raso, desde que praticada de forma sustentável (CAMPOS et al., 2002; COSTA FILHO e NARDINI, 2002; SOUZA, 2018).

Contudo, ações de proteção ambiental, como as $R L$, são costumeiramente encaradas com resistência por parte dos proprietários, o que pode ser justificado pela falta de familiaridade e preparo para técnicas de restauração (CULLEN JR. et al., 2003; AGYEMAN et al., 2003; ZACARIAS e SOUZA, 2019). A aversão é potencializada pela crença de que as 
áreas demarcadas como RL ou Áreas de Preservação Permanente (APP's) são "terras improdutivas" e um empecilho para o aproveitamento máximo da propriedade (VALLADARES-PÁDUA e PRADO, 1997; SOUZA, 2015).

Dessa forma, é importante que soluções que aliem preservação e recuperação de áreas degradadas à consequente melhoria de vida, sejam apresentadas aos produtores rurais (RODRIGUES et al., 2007). Uma alternativa para essa demanda pode ser o consórcio de culturas agrícolas com as espécies florestais, ao menos na fase de implantação da floresta, que pode tornar o processo financeiramente mais atraente e menos dispendioso para 0 proprietário (DURIGAN, 1999; ZACARIAS e SOUZA, 2019).

A utilização de SAF's em projetos de reflorestamento para adequação legal das propriedades rurais tem respaldo legal e abre um vasto leque de possibilidades de modelos e disponibilidade de espécies exóticas e nativas para a implantação: seja em reservas legais ou em APP's (BRASIL, 2012a; BRASIL, 2012b).

Perseguindo o objetivo de recuperação de áreas degradadas, o sistema agroflorestal "Taungya", prática agroecológica, pode contribuir consideravelmente para a implantação e sucesso do processo. Este sistema promove uma maior ciclagem de nutrientes, refletindo na melhoria da qualidade nutricional do solo, pela presença das raízes e deposição de serapilheira (VAZ, 2002), aliadas a um baixo custo.

Nesse sistema, prevê-se a possibilidade de utilização da área continuamente por culturas agrícolas (alimentares ou frutíferas) após cada ciclo de pousio. Propõe-se uma mistura de espécies florestais nativas de crescimento rápido, consorciadas com culturas alimentares. Parte do componente arbóreo perene poderá ser constituída por diferentes frutíferas adaptadas às condições locais, de porte não necessariamente alto, capazes de contribuir à dieta alimentar dos agricultores (MARTINS et al., 2013).

Há de se considerar que, como o número de publicações científicas vem sofrendo um aumento exponencial desde o início do século 20, torna-se necessário que qualquer cientista procure saber a literatura disponível relacionada ao assunto do seu problema de pesquisa. Para isso, na fase inicial da sua elaboração, é necessário fazer a referida revisão bibliográfica do assunto, com os seguintes objetivos (SERRANO, 1996; SENA, 2003 citados por SOUZA, 2004):

- Saber se alguém já publicou as respostas à questão em pauta, para decidir da pertinência de repetir uma investigação com objetivos idênticos;

- Adquirir conhecimento básico e atualizado sobre o assunto objeto da pesquisa;

- Saber quais os métodos utilizados em investigações similares, para decidir sobre o melhor método a utilizar; e 
- Quando se pretende enveredar por um estudo de desenho experimental ou analítico, no qual lançam-se hipóteses sobre a associação entre variáveis, a revisão bibliográfica permite enquadrar o estudo num modelo de causalidade e, assim, diferenciar quais serão as variáveis de exposição, de resposta e, sobretudo, as variáveis interferentes.

Há de se considerar, ainda, que os artigos de revisão, assim como outras categorias de artigos científicos, são uma forma de pesquisa que utilizam de fontes de informações bibliográficas ou eletrônicas para obtenção de resultados de pesquisas de outros autores, com o objetivo de fundamentar teoricamente um determinado objetivo. Para esse fim, duas (2) categorias de artigos denominados de revisão são encontradas na literatura: As revisões narrativas e as revisões sistemáticas, que embora sob a denominação de "Revisão", têm características e objetivos diferentes (ROTHER, 2020).

No presente trabalho, utilizou-se a revisão narrativa. Essa categoria de artigos, de acordo com essa mesma autora, tem um papel fundamental para a educação continuada, pois, permitem ao leitor adquirir e atualizar o conhecimento sobre uma temática específica em curto espaço de tempo; porém, não possuem metodologia que permitam a reprodução dos dados e nem fornecem respostas quantitativas para questões específicas. São considerados artigos de revisão narrativos e são qualitativos. Um artigo de "Revisão Narrativa" é constituído de: Introdução, Desenvolvimento (texto dividido em seções definidas pelo autor com títulos e subtítulos de acordo com as abordagens do assunto), Comentários e Referências.

No presente trabalho, para se realizar a presente revisão narrativa, foram considerados alguns critérios e princípios relevantes (CERVO e BERVIAN, 1972; RUIZ, 1996 citados por SOUZA, 2004):

- Tempo - considerando o período disponível, é fundamental administrá-lo para fazer uma boa revisão bibliográfica. Deve ser despendido, criteriosamente, procurando, selecionando e lendo diversos artigos, que incitem novos questionamentos e incrementem o projeto e a sua importância.

- Contatos iniciais - inicialmente, devem ser procurados pesquisadores da área escolhida que forneçam sugestões úteis para o direcionamento da pesquisa. Nos cursos de pósgraduação, à medida que as disciplinas selecionadas comecem a ser cursadas, os professores e conselheiros passam a auxiliar sobre quais obras consultar. A participação em seminários, palestras e cursos de grupos que trabalham com o mesmo assunto, bem como a utilização da "internet", é útil para o enriquecimento da pesquisa.

- Biblioteca - as bibliotecas pesquisadas contribuem não somente com os periódicos, mas também com os recursos necessários à revisão bibliográfica. Atualmente, os principais recursos estão na "internet" e, com o auxílio de índices, permitem um sistema de busca de artigos por meio de palavras-chave de obras publicadas em várias partes do mundo. Para a 
melhor eficiência da pesquisa bibliográfica, deve-se utilizar uma forma sequencial de busca, com palavras-chave de termos específicos, evitando prejudicar a objetividade do trabalho. $O$ acervo de textos escrito é dividido em duas classes de obras (CERVO e BERVIAN, 1972; RUIZ, 1996 citados por SOUZA, 2004):

- Fontes - são os textos originais ou textos de primeira mão sobre determinado assunto. A partir desses textos, pela importância que tiveram ou que Ihes atribuíram, gerou toda a literatura, mais ou menos ampla; $\mathrm{e}$

- Bibliografia ou trabalhos - é o conjunto das produções escritas para esclarecer as fontes, ou seja, qualquer estudo científico com o objetivo de divulgá-las, analisá-las, refutálas ou para estabelecê-las. Logo, é toda a literatura originária de determinada fonte ou a respeito de determinado assunto. Este trabalho, o que deve ser uma regra para toda a pesquisa bibliográfica, abrangeu fontes e bibliografias sobre o assunto em exame.

- Tendências e preferências pessoais - os assuntos devem ser escolhidos de acordo com a necessidade e também satisfazendo a linha de tendências e preferências pessoais. Esse aspecto é fundamental para a motivação, a dedicação, o empenho, a perseverança e a decisão para superar obstáculos e promover os ajustes necessários ao assunto.

- Relevância - devem ser escolhidos os assuntos de maior relevância, que possam trazer contribuição efetiva para a área pesquisada. Visar-se-ão contribuições objetivas para esclarecer melhor o problema, buscando cobrir lacunas existentes no tema considerado relevante, pelo seu conteúdo e pela sua atualidade.

Por essas circunstâncias, o presente estudo teve como objetivo realizar uma revisão bibliográfica narrativa acerca do uso "SAF Taungya" como prática agroecológica conservacionista com foco na recuperação de áreas degradadas, seus benefícios ambientais e financeiros de implantação, além da apresentação de experiências já executadas em estudos anteriores.

\section{Breve histórico do Taungya}

O manejo integrado de espécies florestais com culturas agrícolas tem como objetivo maximizar da produção por unidade de área em certo intervalo de tempo (EHIAGBONARE, 2006), sendo batizado de Taungya e classificado como sistema agroflorestal (MAC DICKEN e VERGARA, 1990; DUBOIS, 2008).

O sistema Taungya nos trópicos é considerado como um precursor da agrossilvicultura. A palavra teve origem em Mianmar (Birmânia) e tem como significado "o cultivo em colinas" (BLANFORD, 1958). 
Inicialmente, era um termo que os moradores locais utilizavam para o plantio itinerante e que, posteriormente, passou a ser utilizado para descrever o método de implantação de espécies florestais. Em 1856, a Birmânia, até então parte da Índia britânica, estava passando por um período de plantio itinerante generalizado, com a progressiva invasão de reservas florestais, culminando em vários processos judiciais contra os moradores. Neste mesmo período, o botânico alemão Dietrich Brandis estava no país e, percebendo a situação e as consequências que isso estava causando, inovou a forma de cultivo na gestão dos recursos madeireiros e incentivou a prática da "regeneração da teca (Tectona grandis) com a assistência da Taungya" (BLANFORD, 1958), tendo como base o sistema alemão de Waldfeldbau, na qual consistia o cultivo de culturas nas florestas (NAIR, 1993).

Após duas décadas da implantação do cultivo sugerido por Brandis, o sistema era eficaz suficientemente para que as plantações de teca fossem estabelecidas a um custo reduzido. Os moradores locais que tiveram o direito de fazer o cultivo agrícola nos estágios iniciais do estabelecimento da floresta, passaram a respeitar os limites do cultivo, e assim, não eram mais acusados em processos judiciais. Os aldeões ainda contribuíram para o crescimento de florestas com a semeadura de teca. A partir dessa situação, o sistema Taungya logo foi introduzido em outras regiões da Índia britânica, bem como rompeu barreiras e foi estabelecido na Ásia, África e América Latina (NAIR, 1993).

$\mathrm{Na}$ África, esse sistema era conhecido como "Shambia", onde espécies agrícolas, principalmente o milho, eram cultivadas paralelas as espécies florestais, transformando o solo da área de cultivo (SCHLONVOIGT, 1998).

No Brasil, o sistema é voltado para a produção de madeira como produto final, consorciando as espécies florestais com culturas como milho (Zea mays), arrozeiro (Oryza sativa L.), feijoeiro (Phaseolus sp.) e mandioca (Manihot esculenta Crantz), nos primeiros anos de cultivo ou até o estabelecimento das copas das árvores (VALERI et al., 2003). De acordo com Martins e Souza (2013), SAF Taungya também tem sido usado para reduzir o custo de formação de povoamentos florestais, com a associação temporária de cultivos agrícolas de ciclo curto, durante o estabelecimento da cultura florestal - no Brasil e em vários países do mundo, envolvendo diversas espécies florestais. Tal sucesso se deve, principalmente, a sua fácil adaptabilidade, não envolvendo mudanças drásticas no sistema tradicional empregado pelo produtor, por afetar pouco a demanda por mão de obra e por reduzir os custos de preparo do solo e de manutenção. Os principais gêneros de árvores plantadas sob esse método são o Pinus e o Eucalyptus. 


\section{Benefícios e externalidades ambientais do SAF Taungya}

A consorciação entre os componentes florestais e agrícolas, além do objetivo de produzir e gerar renda, pode ser utilizado para a proteção dos recursos naturais, devido ao aumento na complexidade das relações ecológicas que o sistema proporciona, protegendo o solo contra erosão e mantendo o microclima local (VALLADARES-PÁDUA e PRADO,1997).

A diversificação das espécies florestais, arbustivas e herbáceas em um sistema agroflorestal para recuperação ambiental beneficia o solo, de forma que, melhora os aspectos físicos e, consequentemente, contribui para uma maior absorção de água e disponibilidade de nutrientes (ALVES, 2009).

O SAF Taungya é altamente recomendado em processos de reflorestamento: não somente pela possibilidade de custear a implantação das espécies arbóreas através da comercialização dos cultivos agrícolas, mas também por oferecer as melhores taxas de crescimento e sobrevivência das árvores devido a limpeza e aplicação de fertilizantes no cultivo agrícola. Outro fator ambiental relevante no sistema de Taungya é o aumento da disponibilidade de nutrientes no solo, em especial o nitrogênio, quando o consórcio é feito junto a espécies da família Fabaceae, plantas ricas desse nutriente, que é fundamental para o desenvolvimento dos vegetais (NAIR, 1993).

Além disso, os SAF's também podem ser eficientes no controle de espécies exóticas invasoras (ROSÁRIO et al., 2006). Os benefícios ambientais proporcionados pelos diferentes sistemas evidenciam que o Taungya se destaca por promover sustentabilidade e rentabilidade ao mesmo tempo.

\section{Retorno financeiro obtidos com a implantação do SAF Taungya}

Existe uma colisão constante entre aqueles que defendem práticas convencionais e aqueles que buscam metodologias novas na produção de alimentos na agricultura. Em meio a essa turbulência de ideias, os SAF's surgem como uma alternativa que possibilita maior sustentabilidade neste ramo (FERRAZ, 2003; PALUDO e COSTABEBER, 2012).

A implantação de SAF's na recuperação de áreas degradadas em propriedades rurais pode ser um atrativo para o produtor, pois quando o sistema é implantado e possui um manejo adequado, contribui para geração de renda, dependendo dos valores de mercado (ALVES, 2009; SOUZA, 2018).

Desta forma, contornar o processo de degradação ambiental, significa adotar práticas agrícolas que aliem a preservação ao retorno econômico, especialmente para o pequeno produtor rural (MONTAGNINI, 1992; DUBOIS et al., 1996; SOUZA, 2018). 
Porém, para se implantar um projeto de reflorestamento pelo sistema Taungya, é preciso estar atento à fatores ecológicos e socioeconômicos, tal qual a seleção das espécies agrícolas que possam ser usadas em consorciação com a floresta (VERDUZCO, 1970), dado que, para a combinação compatível das culturas, deve-se levar em conta aspectos nutricionais, físicos e morfológicos (FERNANDES et al., 1994).

Estudos já realizados experimentando consórcios entre árvores e culturas agrícolas (SCHREINER e BALLONI, 1986; SILVA et al., 2012; SANTOS et al., 2015), relatam o retorno financeiro significativo das despesas com mudas de espécies madeireiras para 0 reflorestamento, por meio da comercialização dos produtos agrícolas.

A partir de uma experiência feita em um assentamento de reforma agrária no Pontal do Paranapanema, em São Paulo, observou-se que áreas de $R L$ são viáveis de serem trabalhadas com sistemas agroflorestais, pois proporcionam fonte de renda, qualidade alimentar e estabelece mão de obra no campo para as famílias locais (LEITE et al., 2006).

Mas, para que o objetivo financeiro se concretize, é importante que aconteçam análises econômico-financeiras, visto que, é por meio dessas análises que será possível garantir os recursos da produção, bem como recomendar opções de cultivo que gerem benefícios (CALVO e GÓMEZ, 2000).

Propondo-se à seleção de espécies arbóreas e arbustivas para composição de sistema Taungya, a EMBRAPA/RO está avaliando o desempenho agronômico de leguminosas para recuperação de solos degradados e de múltiplos usos. Entre as espécies avaliadas, as mais promissoras foram as do gênero Inga e Acacia. A produção de madeira (taxi-branco) de boa qualidade, que proporcione a redução de queimas e perda de nutrientes, a diminuição do tempo de pousio e o aumento de rendimento ao pequeno produtor (fins energéticos), está sendo objeto de estudo no Amapá, em áreas abandonadas pela agricultura migratória (MARTINS e SOUZA, 2013).

$O$ rendimento financeiro pode ainda ser um indicador de sustentabilidade em SAF's, sendo de fundamental importância, pois o valor concedido por meio dos cultivos agrícolas e o comércio permitem monitorar o sistema ao longo dos anos (DANIEL, 2000).

\section{Experiências da implantação do SAF Taungya na recuperação de áreas degradadas no Brasil}

De acordo com Souza (2018), o estabelecimento das estratégias a serem adotadas no processo de RAD se fundamenta na caracterização do ambiente atual e na construção de cenários pré e pós-degradação. A recuperação ambiental (RA) não pode ser assumida como um fato isolado: além do interesse do produtor e, ou, empreendedor, o processo deve 
envolver a totalidade das relações físicas, biológicas, políticas, sociais, econômicas, tecnológicas e culturais na qual a área está inserida.

Para Macedo (1993) e Souza (2018), os SAF's podem ser utilizados em RAD e paisagens fragmentadas pelas atividades agropecuárias, inclusive em áreas consideradas de preservação permanente. Uma proposta para assegurar a conservação desses remanescentes, seria a utilização de uma parte dessa área para manejo sustentado da floresta, visando o uso coletivo, deixando outra parte para preservação permanente.

De acordo com Franco (2000), para determinar a área destinada ao manejo sustentado, deverão ser feitos estudos da composição florística, regeneração natural e estrutura fitossociológica da floresta, visando a manutenção da biodiversidade e produtividade, sabendo que esse comportamento irá promover uma diminuição da pressão sobre os remanescentes florestais. Conforme Nair (1993), no Brasil, as experiências com a utilização do SAF Taungya ainda se concentram em poucos estudos, apesar desse tipo de manejo ser considerado eficiente na restauração de áreas com algum grau de degradação.

Do ponto de vista agronômico, para uma eficiente recuperação de áreas degradadas, é necessário englobar alguns critérios básicos, tais como: retenção de nutrientes, sustentabilidade do ecossistema e interações biológicas (EWEL, 1987; MARTINS e SOUZA, 2013). Os SAF's podem melhorar a fertilidade do solo, principalmente devido a maior produção de fitomassa (RESCK et al., 1996). Além disso, o estabelecimento inicial da cobertura vegetal atua como proteção mecânica contra os agentes erosivos (ANDRADE et al.; COSTA e FARIA, 1995) e como mecanismo regulador da ciclagem de nutrientes contidos na serapilheira (HEANEY e PROCTOR, 1989; ANDRADE e FARIA, 1996; ANDRADE e FARIA,1997; COSTA et al., 2002).

Dentro dos critérios propostos para esta revisão, foram encontradas apenas cinco experiências de aplicação de Taungya em recuperação de áreas degradadas no Brasil, descritas em cinco trabalhos publicados (Tabela 1). Todos foram realizados nos estados do Rio de Janeiro e São Paulo, entre os anos de 2007 e 2016, tendo como foco a recuperação de áreas de Reserva Legal e Matas Ciliares, enquadradas como Áreas de Preservação Permanente.

As culturas agrícolas mais utilizadas foram de ciclo curto, destacando-se o milho, o feijão e a mandioca. Todos os trabalhos utilizaram uma grande variedade de espécies florestais nativas de cada região de estudo, tendo por objetivo final o reflorestamento, sem intenção de aproveitamento madeireiro. 
Tabela 1. Resumo das principais experiências no Brasil na implantação do SAF Taungya na recuperação de áreas degradadas

\begin{tabular}{|c|c|c|c|c|c|}
\hline Autores & UF & $\begin{array}{l}\text { Objetivo } \\
\text { Final }\end{array}$ & Consórcio & Resultados Ambientais & Resultados Econômicos \\
\hline $\begin{array}{l}\text { Rodrigues } \\
\text { et al. (2007) }\end{array}$ & SP & $\begin{array}{c}\text { Restauração } \\
\text { de Reserva Legal }\end{array}$ & $\begin{array}{c}\text { Milho, mamona, } \\
\text { mandioca, amendoim e } \\
\text { feijão/ espécies nativas }\end{array}$ & Não avaliado & $\begin{array}{l}\text { Balanço econômico final com } \\
\text { tendência a ficar negativo }\end{array}$ \\
\hline $\begin{array}{l}\text { Rodrigues } \\
\text { et al. (2008) }\end{array}$ & SP & $\begin{array}{c}\text { Restauração } \\
\text { de Reserva Legal }\end{array}$ & $\begin{array}{l}\text { Milho, feijão,maxixe, } \\
\text { quiabo e abóbora/ } \\
\text { espécies nativas }\end{array}$ & Não avaliado & $\begin{array}{l}\text { Maior diversidade de } \\
\text { espécies e época favorável de } \\
\text { plantio tende a dar maior } \\
\text { retorno financeiro }\end{array}$ \\
\hline $\begin{array}{r}\text { Daronco } \\
\text { et al. (2012) }\end{array}$ & SP & $\begin{array}{l}\text { Restauração } \\
\text { de mata ciliar }\end{array}$ & $\begin{array}{c}\text { Mandioca/ espécies } \\
\text { nativas }\end{array}$ & $\begin{array}{l}\text { O consórcio com mandioca } \\
\text { ocorreu sem nenhum prejuízo } \\
\text { as espécies florestais }\end{array}$ & $\begin{array}{l}\text { Custo final } 19 \% \text { menor que o } \\
\text { de restauração em um sistema } \\
\text { tradicional }\end{array}$ \\
\hline $\begin{array}{l}\text { Freitas et } \\
\text { al. (2014) }\end{array}$ & RJ & $\begin{array}{l}\text { Restauração } \\
\text { de mata ciliar }\end{array}$ & $\begin{array}{l}\text { Não identificado/ } \\
\text { espécies nativas }\end{array}$ & $\begin{array}{l}\text { O SAF Taungya resultou em } \\
\text { elevados valores de matéria } \\
\text { orgânica, maior CTC e } \\
\text { Saturação de Bases do solo }\end{array}$ & Não avaliado \\
\hline $\begin{array}{l}\text { Oliveira et } \\
\text { al. (2016) }\end{array}$ & RJ & $\begin{array}{l}\text { Restauração } \\
\text { de mata ciliar }\end{array}$ & $\begin{array}{l}\text { Milho e feijão/ } \\
\text { espécies nativas }\end{array}$ & $\begin{array}{l}\text { A sobrevivência das espécies } \\
\text { florestais não foi afetada pelo } \\
\text { consórcio }\end{array}$ & $\begin{array}{l}\text { Custo de implantação e } \\
\text { manutenção } 88 \% \text { maior no } \\
\text { Taungya do que no plantio } \\
\text { convencional }\end{array}$ \\
\hline
\end{tabular}

Fonte: Os Autores. 
Os resultados ambientais foram analisados em três dos experimentos. Daronco et al., (2012) e Oliveira et al. (2016) analisaram possíveis influências da cultura agrícola sobre o desenvolvimento das mudas florestais, e não encontraram nenhuma evidência de prejuízo. Freitas et al. (2014) analisaram o solo submetido ao plantio convencional em comparação ao modelo Taungya, encontrando melhores indicadores de qualidade do solo no SAF.

Três dos experimentos fizeram as análises do balanço econômico das operações. Daronco et al. (2012) tiveram um custo final da implementação do reflorestamento 19\% menor quando comparado ao modelo tradicional, graças à produção agrícola nas entrelinhas.

Por outro lado, os outros estudos não tiveram um saldo econômico positivo. Oliveira et al. (2016) tiveram custos $88 \%$ maiores no modelo Taungya do que no sistema tradicional. Rodrigues et al. (2007; 2008) tiveram tendência a resultados negativos por produtividade insuficiente para cobrir os gastos de implementação, superando estes valores e gerando algum lucro para os produtores envolvidos por pagamento de diárias na implementação e manutenção do projeto. Os autores justificam que o custo elevado é devido principalmente as diferenças nas operações de plantio, manejo, colheita e os insumos (fertilizantes) de um SAF para um plantio convencional.

Conforme o estudo feito por Rodrigues (2008), acerca dos indicadores econômicos a partir da implantação do SAF Taungya na recuperação de Reserva Legal, duas famílias se destacaram com relação aos indicadores econômicos. Uma delas, trabalhou com maior diversidade de espécies agrícolas, e obteve sucesso no retorno financeiro. Outra família cultivando apenas milho e feijão, obteve a maior produção quando comparada as outras, inclusive as que utilizaram as mesmas espécies. Para este caso, levantam-se algumas hipóteses, como a escolha da época mais favorável ao plantio e desenvolvimento da cultura, e também a escolha do espaçamento entre plantas, ou alguma característica intrínseca do terreno que facilitou o desenvolvimento da cultura, seja por maior retenção de água ou melhorando a fertilidade, a utilização do método de cultivo individual ou consorciado e ainda a soma de mais de um desses fatores.

O cultivo de milho, feijão e mandioca consorciados proporciona melhor aproveitamento da área cultivada, redução no ataque de pragas e doenças, possibilitando a utilização da mandioca na alimentação animal e ou humana, a proteção ao solo por meio de sua cobertura e ainda fixa nitrogênio por meio de associações simbióticas entre bactérias fixadoras de nitrogênio e as raízes do feijão, consequentemente melhorando a fertilidade do solo (MOREIRA, 2017).

Destaca-se o sucesso apresentado nos estudos de Rodrigues $(2007 ; 2008)$ acerca do subsídio de mudas e do custo de implantação; logo é possível fazer uma correlação com a 
importância de políticas públicas com esse intuito, aliando a preservação ambiental com garantia de geração de renda para os pequenos agricultores.

A experiência na recuperação de áreas degradadas utilizando-se SAF, ainda é um processo de elevado custo financeiro, que conta com iniciativas recentes e metodologias ainda em fase de testes, os quais são importantes persistirem, para que erros no plantio e prejuízos possam ser evitados (RODRIGUES et al., 2007).

Os processos relacionados com a recuperação florestal de áreas degradadas também têm sido alvo de diferentes projetos pertencentes ao Programa de Ecologia Florestal do Instituto de Pesquisa Ambiental da Amazônia (PPG Eco/INPA). Vários estudos têm avaliado os processos relativos ao estabelecimento de árvores em pastagens improdutivas e abandonadas da Amazônia Oriental, bem como as espécies vegetais e animais que atuam como barreira à recuperação da floresta ou que são facilitadoras deste processo (IPAM, 2003 citado por SOUZA, 2018).

As experiências aqui referidas, mesmo que pouco expressivas diante do cenário nacional, levantam a escassez de resultados iniciais e posteriores de estudos utilizando o SAF Taungya como medida de recuperação ambiental. Como já foi discutido por Rodrigues et al. (2007), os sistemas agroflorestais estão em fase de testes. Contudo, é preciso que ocorra uma aproximação dos pesquisadores junto com os agricultores e que estes sejam apresentados a uma alternativa que permitam que eles estejam de acordo com a lei e que possam obter algum tipo de retorno financeiro, sendo a alternativa promissora pautada na agroecologia.

\section{Considerações finais}

A pesquisa mostra que sistemas agroflorestais conduzidos adequadamente são ferramentas importantes no contexto da agricultura sustentável. Constituem também abordagens viáveis nas ações de recuperação de áreas degradadas.

Do ponto de vista social e econômico, vários autores apontam vantagens, tais como: a) aumento das oportunidades de renda por unidade de área; b) maior variedade de produtos e, ou, serviços; c) melhoria da alimentação e nutrição humana, principalmente no contexto da agricultura familiar; d) diversidade de culturas e redução de riscos; e) amortização de custos de plantio e condução florestal; f) melhoria da distribuição de renda e mão-de-obra rural; g) redução de algumas práticas culturais do sistema convencional; h) contribuição no manejo de paisagens e outras.

No entanto, como foi observado nessa revisão, ainda são necessários estudos mais aprofundados em diversos aspectos relacionados ao SAF Taungya, como ciclagem de 
nutrientes, ciclo hidrológico, análises econômicas, espécies potenciais, o componente animal, erosão e incidência de pragas e doenças, para que se possam definir melhor os indicadores de sustentabilidade para estes sistemas. Mas, há que se considerar, que tal sistema tem chamado a atenção nos últimos anos por apresentar uma gama de aspectos vantajosos aos sistemas tradicionais de cultivo - em nenhum dos estudos descritos utilizando o SAF Taungya, obtiveram-se resultados negativos no quesito desenvolvimento das espécies arbóreas, quando comparado ao sistema de plantio convencional.

Do ponto de vista financeiro, os resultados são inconsistentes, variando entre uma notável redução de despesas a um provável aumento de gastos de retorno incerto, estando sujeito à influência de fatores ambientais e edafoclimáticos, assim como qualquer outro tipo de produção convencional. Contudo, parte dos custos da implantação das espécies arbóreas utilizadas foi abatida, demonstrando a viabilidade do sistema - mesmo que ainda não seja possível pagar todos os custos.

A utilização do SAF Taungya proporciona benefícios ambientais relevantes, como aumento na disponibilidade de nutrientes, proteção do solo, estabilização ambiental, aliada a produção de culturas agrícolas, que suprem o valor gasto inicial na implantação do sistema, notadamente na recuperação de matas ciliares, sem evidências concretas de qualquer influência negativa sobre o desenvolvimento da floresta.

Estudos envolvendo Taungya na recuperação de áreas degradadas são escassos e se encontram em fase inicial, sendo necessárias novas experiências, com outros tipos de consórcio, e em regiões e condições climáticas, ambientais e socioeconômicas diferentes, para se chegar a conclusões concretas sobre a viabilidade econômica dos projetos.

Entretanto, conforme se verificou ao longo deste trabalho, são muitos os fatores, tanto bióticos quanto abióticos, que estão envolvidos dentro desse sistema (isto sem abordar os aspectos de ordem socioeconômica), que como prática agroecológica que busca ser sustentável, muitas das interações possíveis de ser encontradas em um SAF Taungya ainda não foram estudadas. A potencialidade deste sistema de aliar aspectos ecológicos de ecossistemas naturais com a exploração agrícola estimula a realização de mais estudos.

Entretanto, mediante a grande aceitação e adoção por parte dos agricultores em diversas regiões, é necessário um trabalho de difusão dos sistemas já definidos, com a participação dos agricultores em todo o processo, com enfoque sistêmico e resgatando a importância das árvores no sistema de produção, particularmente pela deposição de serapilheira e matéria orgânica ao solo.

Encontrar métodos de aplicação do SAF Taungya, de forma a garantir retorno financeiro para o produtor, pode significar uma grande facilitação na recuperação de áreas degradadas e adequação ambiental em propriedades rurais no Brasil. Vale ressaltar a necessidade de assistência técnica especializada para acompanhar todos os passos do projeto: desde a 
determinação das espécies florestais e agrícolas que deverão ser utilizadas, até o momento da colheita e comercialização. O ideal é que o fornecimento dessa mão de obra especializada fosse realizada por meio da iniciativa pública - principalmente para os pequenos produtores familiares.

\section{Referências}

ABDO, M. T. V. N.; VALERI, S. V.; MARTINS, A. L. M. Sistemas agroflorestais e agricultura familiar: uma parceria interessante. Revista Tecnologia \& Inovação Agropecuária, v. 1, n. 2., p. 79-96, 2008.

AGYEMAN, V. K.; MARFO, K.A.; KASANGA, K.R. E.; DANSO, A. B.A.; YEBOAH, O. M., AGYEMAN F. Revising the taungya plantation system: new revenue-sharing proposals from Ghana. Unasylva, v. 54, n. 1, p. 40-43, 2003.

ALVES, L. M. Sistemas Agroflorestais (SAF's) na restauração de ambientes degradados. Material didático apresentado ao programa de pós-graduação em ecologia aplicada ao manejo e conservação dos recursos naturais como parte das exigências para conclusão da disciplina "Estágio em docência". UFJF, 2009. Disponível em: <http://www.ufj.br/ecologia/files/2009/11/Est\%C3\%A1 gio-Doc\%C3\% AAncia-LUCIANA.pdf>. Acesso em: 10 out. 2019.

ANDRADE, A. G.; COSTA, G. S.; FARIA, S. M. de. Produção e qualidade de serapilheira de leguminosas arbóreas usadas na recuperação de solos degradados. In: XXV CONGRESSO BRASILEIRO DE CIÊNCIA DO SOLO, 25. Viçosa, 1995. Resumos expandidos..., p. 20332035, 1995.

BRASIL. Lei no 12.651, de 25 de maio de 2012. Ministério do Meio Ambiente, Brasília, 2012. Disponível em: <http://www.planalto.gov.br/ccivil_03/_ato2011-2014/2012/lei/ |12651.htm>. Acesso em: 27 set. 2019a.

BRASIL. Decreto no 7.830, de 17 de outubro de 2012. Brasília, 2012. Disponível em: <http://www.planalto.gov.br/ccivil_03/_Ato2011-2014/2012/>. Acesso em: 27 set. 2019b.

CAMPOS, J. B.; COSTA FILHO, L. V.; NARDINE, M. M. Recuperação da reserva legal e a conservação da biodiversidade. Cadernos de Biodiversidade, v.3, n.1, p.1-3, 2002.

CALVO, G.; GÓMEZ, M. Economía de sistemas agroforestales: aplicaciónes practicas del análisis económico financeiro em sistemas agroforestales. Costa Rica: Centro Agronómico Tropical de Investigación y Enseñanza, 2000.

COSTA, G. S.; ANDRADE, A. G.; FARIA, S. M. de. Ciclagem de nutrientes em um plantio de Acacia magium com seis anos de idade. In: CONGRESSO LATINO AMERICANO DE CIÊNCIA DO SOLO, 13., Águas de Lindóia, 1996. Anais...Solo-suelo 96: trabalhos. Piracicaba: SBCS/SLCS, 1996.

COSTA, G. S.; ANDRADE, A. G.; FARIA, S. M. de. Aporte de nutrientes pela serapilheira de Mimosa caesalpiniifolia (Sabiá) com seis anos de idade. In: SIMPÓSIO NACIONAL DE RECUPERAÇÃO DE ÁREAS DEGRADADAS, 3., Resumos expandidos... Ouro Preto MG, 1997. p. 344-349. 
CULLEN JÚNIOR, L.; BELTRAME, T. P.; LIMA, J. F.; PADUA, C. V.; PADUA, S. M. Trampolins ecológicos e zonas de benefício múltiplo: ferramentas agroflorestais para a conservação de paisagens rurais fragmentadas na Floresta Atlântica Brasileira. Revista Natureza \& Conservação, v. 1, n. 1, p. 37-46, 2003.

DANIEL, O.; COUTO, L.; GARCIA, R.; PASSOS, C. A. M. Proposta de um conjunto mínimo de indicadores sócio-econômicos para o monitoramento da sustentabilidade em Sistemas Agroflorestais. Revista Árvore, Viçosa, MG, v. 24, n. 3, p. 283-290, 2000.

DARONCO, C.; MELO, A. C. G.; MACHADO, J. A. R. Consórcio de espécies nativas da floresta estacional semidecidual com mandioca (Manihot sculenta Crantz) para restauração de mata ciliar. Revista Árvore, Viçosa, MG, v. 36, n. 2, p. 291-299, 2012.

DUBOIS, J. Classificação e breve caracterização de SAFs e práticas agroflorestais. In: MAY, P. H.; TROVATTO, C. M. M. (Coord.). Manual agroflorestal para a Mata Atlântica. Brasília: Ministério do Desenvolvimento Agrário, Secretaria da Agricultura Familiar, p. 15-62, 2008.

DURIGAN, G. Técnicas silviculturais aplicadas à restauração de ecossistemas. In: SIMPÓSIO SOBRE RESTAURAÇÃO ECOLÓGICA DE ECOSSISTEMAS NATURAIS, 1. 1999, Piracicaba. Anais... Piracicaba: ESALQ/USP, 1999.

EHIAGBONARE, J. E. Effect of taungya on regeneration of endemic forest tree species in Nigeria: edo State Nigeria as a case study. African Journal of Biotechnology, v. 5, n. 18, p. 1608-1611, 2006.

EWEL, J. J. Restoration is the ultimate test for ecological theory. In: JORDAN III, W.; FERNANDES, E. N.; BONETTI FILHO, R. Z.; SILVA, E. Avaliação de impactos ambientais de Sistemas Agroflorestais. CONGRESSO BRASILEIRO SOBRE SISTEMAS AGROFLORESTAIS, 1., 1994, Porto Velho. Anais... Colombo: EMBRAPA, v. 2., p. 361-372, 1994.

FERRAZ, J. M. G. As dimensões da sustentabilidade e seus indicadores. In: MARQUES, J. F.; SKORUPA, L. A.; FERRAZ, J. M. G. (Eds.). Indicadores de sustentabilidade em agroecossistemas. Jaguariúna: EMBRAPA, 2003.

FRANCO, F. S. Sistemas Agroflorestais: uma contribuição para a conservação dos recursos naturais na Zona da Mata de Minas Gerais. Viçosa, 2000. 147 f. Tese (Doutorado em Ciência Florestal) - Universidade Federal de Viçosa, 2000.

FREITAS, T. J.; BARROSO, D. G.; RODRIGUES, L. A.; ANDRADE, A. G. Fertilidade e microbiologia do solo na recuperação de matas ciliares. XX Congreso Latinoamericano y XVI Congreso Peruano de la Ciencia del Suelo. Anais... 2014.

GILPIN, M. E.; ABER, J. D. Restoration ecology. Cambridge: Cambridge Univ. Press, p. 31-33, 1987.

GONCALVES, D. C.; CRESPO, A. M.; FERREIRA, C. C.; CARRICO, I. G. H.; SOUZA, M. N.; RIBEIRO, W. R. A agroecologia como ferramenta ao fortalecimento da agricultura familiar. Revista UNIVAP, v. 1, p. 342-357, 2019.

HEANEY, A.; PROCTOR, J. Chemical elements in litter in forests on Volcán Barva, Costa Rica. In: PROCTOR, J. (Ed.) Mineral nutrients in tropical forest and savanna ecosystems. British Ecological Society, p. 255-272, 1989. 
LEITE, A. Z. Diagnóstico sócio-ambiental de um assentamento com áreas de vegetação secundária no Pontal do Paranapanema: potencialidades para sistemas agroflorestais. In: CONGRESSO BRASILEIRO DE SISTEMAS AGROFLORESTAIS, 6., 2006, Campos dos Goytacazes. Anais... Campos dos Goytacazes: UENF, 2006.

LIMA, S. S.; LEITE, L. F. C.; AQUINO, A. M.; OlIVEIRA, F. C.; CASTRO, A. A. J. F. Estoques da serrapilheira acumulada e teores de nutrientes em Argissolo sob manejo agroflorestal no norte do Piauí. Revista Árvore, v. 34, n. 1, p. 75-84, 2010.

MAC DICKEN, K. G.; VERGARA, N. T. Introduction to agroforestry. In: MAC DICKEN, K. G.; VERGARA, N. T. Agroforestry: classification and management. New York: John Wiley \& Sons, 1990. p. 1-30.

MACEDO, R. L. G. Conservação e utilização sustentável da biodiversidade tropical através de sistemas agroflorestais. In: ENCONTRO NACIONAL DE ESTUDOS SOBRE O MEIO AMBIENTE, 4, 1993, Cuiabá. Anais... Cuiabá: UFMT, 1993. p.245-250.

MARTINOTTO, F.; MARTINOTTO C.; COELHO, M. F. B.; AZEVEDO, R. A. B.; ALBUQUERQUE, M. C. F. Sobrevivência e crescimento inicial de espécies arbóreas nativas do Cerrado em consórcio com mandioca. Pesquisa Agropecuária Brasileira, Brasília, v. 47, n. 1, p. 22-29, 2012.

MARTINS, M. C.; ROMARCO, M. L.; SOUZA, M. N. Uma análise da implantação da integração lavoura pecuária floresta (ILPF) na microrregião de Viçosa, Minas Gerais. Boletim de Pesquisa do Programa de Pós-Graduação em Extensão Rural da UFV, v. 4, p. 154-163, 2013.

MARTINS, M. C.; SOUZA, M. N. Uma análise das variáveis do desenvolvimento rural sustentável no uso da Integração Lavoura Pecuária e Floresta (ILPF) em municípios da Zona da Mata de Minas Gerais. Multifuncionalidades sustentáveis no campo: Agricultura, pecuária e florestas, v. 5, p. 10-15, 2013.

MONTAGNINI, F. Sistemas agroflorestais: princípios y aplicaciones em los trópicos. 2. Ed. Ver. Aum. San José: Organización para Estúdios Tropicales, 1992. 622p.

MOREIRA, V. R. da R. Fichas Agroecológicas - Produção Vegetal: consórcio de milho, feijão e mandioca, 2017. CONSÓRCIO DE MILHO, FEIJÃO E MANDIOCA. Disponível em: $<$ http://agroecologia.gov.br/sites/default/files/publicacoes/8-consorcio-de-milho-feijao-emandioca.pdf>. Acesso em: 22 jun. 2020.

NAIR, P. K. R. An introduction to agroforestry. Dordrecht. Boston: Kluwer Academic Publishers/ICRAF,,1993. 499p.

OLIVEIRA, T. J. F.; BARROSO, D. G.; ANDRADE, A. G.; FREITAS, S. J. Consórcio de espécies nativas da mata atlântica com milho e feijão para revegetação de mata ciliar na região noroeste Fluminense. Floresta, Curitiba, PR, v. 46, n. 3, p. 315- 324, 2016.

PALUDO, R.; COSTABEBER, J. A. Sistemas agroflorestais como estratégia de desenvolvimento rural em diferentes biomas brasileiros. Revista Brasileira de Agroecologia, v. 7, n. 2, p. 63-76, 2012.

RESCK, D. V. S.; GOMES, A. C.; RODRIGUES, D. C.; SANTOS, A. L. G. dos; SILVA, J. E. da. Influência do uso e manejo do solo na produção de $\mathrm{CO}_{2}$ em diferentes agroecossistemas na região dos cerrados. In: CONGRESSO LATINO AMERICANO DE CIÊNCIA DO SOLO, 
13. Anais... Águas de Lindóia, 1996. Solo-suelo 96: trabalhos. Piracicaba: SBCS/SLCS, 1996.

RODRIGUES, E. R.; CULLEN JR., L.; BELTRAME, T. P.; MOSCOGLIATO, A. V.; SILVA, I. C. Avaliação econômica de sistemas agroflorestais implantados para a recuperação de Reserva Legal no Pontal do Paranapanema, São Paulo. Revista Árvore, v. 31, p. 941-948, 2007.

RODRIGUES, E. R.; CULLEN JR., L.; MOSCOGLIATO, A. V.; BELTRAME, T. P. O uso do sistema agroflorestal Taungya na restauração de reservas legais: indicadores econômicos. Floresta, Curitiba, v. 38, n. 3, p. 517-525, 2008.

ROSÁRIO, A. A. S.; PENEIREIRO, F. M.; GONÇALO, E. N.; OLIVEIRA, A. C.; BRILHANTE, N. A. Avaliação técnica do plantio adensado em sistemas agroflorestais com relação ao controle de plantas invasoras, 2006. Disponível em: $<$ http://agrofloresta.net/static/artigos/plantio_adensado_saf_peneireiro.pdf $>$. Acesso em: 28 set. 2019 .

SANTOS, M. V.; SILVA, D. V.; FONSECA, D. M.; REIS, M. R.; FERREIRA, L. R.; OLIVEIRA NETO, S. N.; OLIVEIRA, F. L. R. Componentes produtivos do milho sob diferentes manejos de plantas daninhas e arranjos de plantio em sistema agrossilvipastoril. Ciência Rural, v. 45, n. 9, p. 998-1000, 2015.

SCHLONVOIGT, A. Sistemas taungya. Turrialba: CATIE, n. 42, 1998. 116p.

SCHREINER, H. G.; BALLONI, E. A. Consórcio das culturas de feijão (Phaseolus vulgaris L.) e eucalipto (Eucalyptus grandis W. Hill ex Maiden) no Sudeste do Brasil. Boletim de Pesquisa Florestal, p. 83-104, 1986.

SILVA, C. P. de C.; COELHO JUNIOR, L. M.; OLIVEIRA, A. D.; SCOLFORO, J. R. S.; REZENDE, J. L. P.; LIMA, I. C. G. Economic analysis of agroforestry systems with candeia. Cerne, Lavras, v. 18, n. 4, p. 585-594, 2012.

SOUZA, M. N. Degradação Antrópica e Procedimentos de Recuperação Ambiental. Balti, Moldova, Europe: Novas Edições Acadêmicas, 2018, v. 1000. 376p.

SOUZA, M. N. Degradação e Recuperação Ambiental e Desenvolvimento Sustentável. Viçosa, 2004. 371 f. Dissertação (Mestrado em Ciência Florestal) - Universidade Federal de Viçosa, 2004.

SOUZA, M. N. Mudanças no uso do solo e da água e a gestão dos recursos naturais. Frankfurt, Alemanha: Novas Edições Acadêmicas, v. 5000, 2015. 371 p.

SOUZA, M. N.; MANTOVANI, E. C.; ORELLANA GONZÁLEZ, A. M. G.; SANCHEZ ROMAN, R. M.; SOUZA, M. A. A. S. Dynamic o systems and the modeling with the use STELLA. Academic journals database, v. 4, p. 23-37, 2014.

ROTHER, E. T. Revisão sistemática X revisão narrativa. Acta paul. enferm., v. 20, n. 2, p. 2-9, 2007. Disponível em: <https://www.scielo.br/scielo.php?script=sci_arttext\&pid=S010321002007000200001\#: :text=A\%20revis\%C3\% A30\%20 sistem\% $\quad$ C3\%A 1tica\%2C\%20ao\%20contrario,na\%20revis\%C3\%A3o\%22(2)>. Acesso em: 25 set. 2020.

VALLADARES-PÁDUA, C.; PRADO, C. F. Resgatando a grande reserva do Pontal do Paranapanema: Reforma agrária e conservação de biodiversidade. In: CONGRESSO 
BRASILEIRO DE UNIDADES DE CONSERVAÇÃO, 1997, Curitiba. Anais... Curitiba: UNILIVRE/REDEPROUC/IAP, p.783-792, 1997.

VALERI, S. V.; POLITANO, W; SENO, K. C. A.; BARRETO, A. L. N. M. Manejo e recuperação florestal. Jaboticabal, Funep. 2003. 180 p.

VAZ, P. Sistemas agroflorestais como opção de manejo para microbacias. Informe Agropecuário, v. 21, n. 207, p. 75-81, 2000.

VERDUZCO, G. J. Incremento de las especies valiosas por el sistema "Taungya". Bosques, México, v. 7, n. 1, p. 28-31, 1970.

ZACARIAS, A. J.; SOUZA, M. N. Recuperação de área degradada de monocultura intensiva no estado do Espírito Santo. Revista UNIVAP, v.1, n. 87, p. 234-242, 2019. 


\title{
Capítulo 3
}

\section{Microbacia hidrográfica do córrego vagalume: um olhar crítico para a sua paisagem}

\begin{abstract}
Geraldo José Alves Dutraํ, Marcus Vinícius Souza Silva ${ }^{1}$, Mário Wesley Paiva Zanetti², Jéferson Luiz Ferrari ${ }^{3}$
\end{abstract}

\section{Introdução}

Desde a colonização do Brasil, a Mata Atlântica brasileira, bioma de floresta tropical considerado um hotspot de biodiversidade vem sendo descaracterizada por processos naturais e por atividades antrópicas, que impactam de forma negativa o bioma (BRANNSTROM, 2015). Os impactos antrópicos decorrem por diversos motivos e, entre eles, está a necessidade da produção de alimentos, a geração de riquezas materiais e a edificação de aglomerados urbanos. Ressalta-se que o ser humano dependia - e ainda depende - da natureza para alimentar-se, saciar a sede, aquecer-se, abrigar-se, enfim, atender as suas necessidades fisiológicas e manter-se vivo (DUTRA, 2019).

Em 2010, a Fundação SOS Mata Atlântica informou que no Estado do Espírito Santo possuía 11\% de cobertura original (SOS MATA ATLÂNTICA/INPE, 2010) e, atualmente, segundo a última edição do Atlas dos Remanescentes Florestais da Mata Atlântica, (SOS MATA ATLÂNTICA, 2020), relativa ao período de 2018 a 2019, o Estado apresenta somente $10,5 \%$ da Mata Atlântica original, fato extremamente preocupante. No Caparaó Capixaba, localizado a Sudoeste do Espírito Santo (ESPÍRITO SANTO, 2011), limítrofe com os Estados do Rio de Janeiro e Minas Gerais, a realidade de desflorestamento não é diferente do restante do Estado do Espírito Santo. Gobbo et al. (2013) asseveram que a Serra do Caparaó é uma das mais representativas áreas de preservação da Mata Atlântica em solo capixaba. A exemplo dos outros municípios caparaoenses, ocorreu intenso processo de desmatamento da vegetação nativa para a implantação das atividades agropecuárias. Um desses municípios é Alegre-ES, que, atualmente, totaliza apenas $8,57 \%$ da cobertura original de Mata Atlântica (SOS MATA ATLÂNTICA, 2020). Também é comum a drenagem de brejos, o pisoteio do gado nas nascentes, a capina exagerada nas lavouras de café, ausência de matas ciliares e de mata de topo de morro. Isso contribui para um cenário

${ }^{1}$ Me. em Agroecologia pelo Programa de Pós-Graduação em Agroecologia do Instituto Federal do Espírito Santo - Campus de Alegre, Caixa Postal 1622, CEP: 29510-000, Alegre-ES. E-mail: geraldodutra7@yahoo.com.br; marcusvinicius.mvss@gmail.com

${ }^{2}$ Técnico Agrícola pelo Instituto Federal do Espírito Santo - Campus de Alegre, Alegre-ES. E-mail: mario_pezao@yahoo.com.br

${ }^{3}$ Dr. Professor do Instituto Federal do Espírito Santo - Campus de Alegre, Caixa Postal 47, CEP: 29500-000, Alegre-ES. E-mail: ferrarijl@ifes.edu.br 
desfavorável quanto à preservação dos recursos hídricos, e, consequentemente, da segurança hídrica em Alegre (SENNA et al. 2015). Soma-se a isso o lançamento in natura de esgoto sanitário nos cursos d'água e o uso abusivo de agrotóxicos.

A questão da segurança hídrica no município de Alegre é bastante delicada. Isso porque sua sede é abastecida por córregos que compõem a Microbacia Hidrográfica do Córrego Jerusalém (MBHCJ), muito degradada pela ocupação desordenada do solo, desde os primeiros tropeiros que chegaram ao atual município de Alegre, no início do século XIX, mais precisamente no ano de 1815 (OLIVEIRA, 2009).

Em estudos realizados na MBHCJ, Venturin (2011) atesta mais que isso: denuncia que, do total de $67,88 \mathrm{~km}^{2}$ da microbacia, $65,57 \%$ é ocupada com pastagens; $13,84 \%$; com cafezais; 10,05\%; são remanescentes florestais secundários; 4,93\%; de capoeiras; as estradas não pavimentadas ocupam uma área de 2,62\%, e, 0,99\% são solos expostos.

Ressalta-se que a MBHCJ é uma das formadoras da Microbacia Hidrográfica do Rio Alegre, pertence a Bacia Hidrográfica do Rio Itapemirim, e é formada principalmente pelos Ribeirões Vargem Alegre, Cachoeira Alta e Jerusalém, e, pelos córregos Jacutinga, Estevão, Monte Belo, Roncador, Santa Rita, Santo Antônio e Vagalume (SANTOS et al., 2004; RIBEIRO et al., 2010). O córrego Vagalume abastece com água potável o distrito de Celina-Alegre-Região do Caparaó Capixaba e, a jusante, deságua no córrego Cucui, um dos contribuintes da MBHCJ, que por sua vez abastece a sede do município de Alegre.

Apesar de 'paisagem' ser entendida cotidianamente como sendo formada apenas por elementos naturais, omitindo-se por vezes a contribuição dos elementos culturais, e de estar associada aos estudos apenas de geógrafos e geólogos, ela é, segundo Martins (2007), uma nova fonte para observação e interpretação também dos historiadores ambientais e especialistas de outros campos das ciências naturais. O planejamento e a atuação sobre a paisagem devem levar em conta uma visão integrada dos elementos naturais e dos processos das atividades humanas, essenciais para a compreensão do espaço como um todo, e do cuidado necessário com a exploração dos recursos naturais, cabendo ao ser humano manter, elevar ou reduzir a qualidade da paisagem (FAJARDO, 2010; AUGUSTO, 2016).

Neste contexto, o objetivo do estudo foi caracterizar a Microbacia Hidrográfica do Córrego Vagalume (MBHCV), em relação ao uso e ocupação do solo, e apontar práticas agroecológicas que possam mitigar a degradação ambiental da microbacia. 


\section{Metodologia}

A MBHCV fica localizada no distrito de Celina, município de Alegre - Região do Caparaó Capixaba-ES, nas coordenadas geográficas $2^{\circ} 45^{\prime} 28^{\prime \prime S}$ e $41^{\circ} 36^{\prime} 15^{\prime \prime} \mathrm{O}$. Tem, aproximadamente, 254 ha e altitude média de 700 metros (Figura 1).

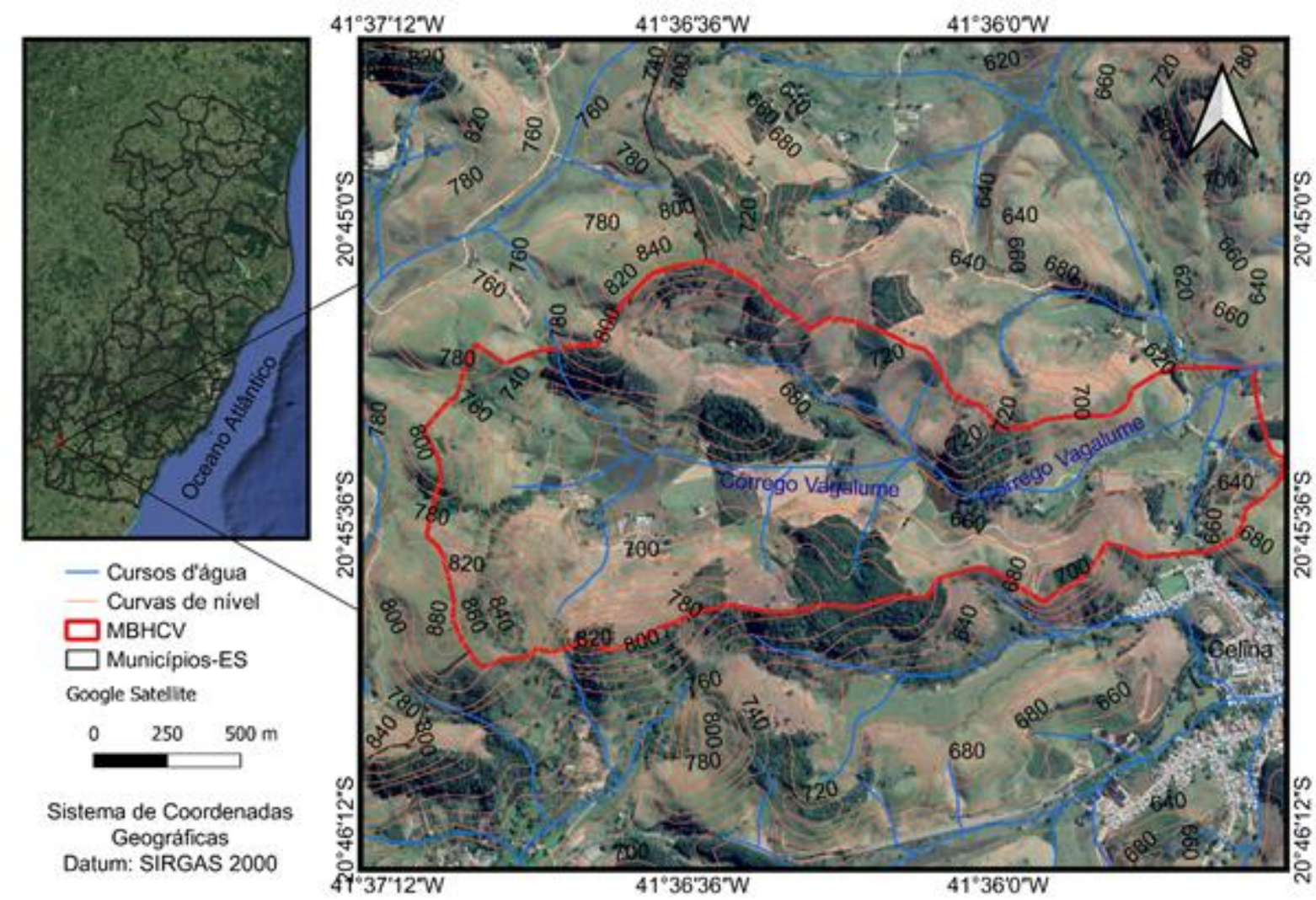

Figura 1. Localização e altimetria da Microbacia Hidrográfica do Córrego Vagalume em relação ao estado do Espírito Santo.

Fonte: Os Autores a partir dos dados do Geobases (2019).

O relevo em Celina é considerado como montanhoso a forte ondulado, com altitudes entre 570 a 900 metros de altitude, com solos Latossolo Vermelho-Amarelo distrófico, com extrema pobreza química e vegetação original formada por Floresta Subperenifólia caracterizada por formação densa, rica em espécies vegetais (LANI; RESENDE; RESENDE, 2001).

A caracterização da MBHCV foi realizada no segundo semestre de 2016, e fez parte das atividades acadêmicas realizadas na disciplina de Conservação do Solo e da Água, durante o Curso do Mestrado Profissional em Agroecologia do Instituto Federal do Espírito Santo (Ifes) - Campus de Alegre.

O estudo crítico da paisagem da MBHCV compreendeu atividades de campo e atividades auxiliadas por computador, por meio do uso de Sistema de Informação 
Geográfica (SIG). As atividades de campo foram realizadas em três etapas. Na primeira etapa foi realizada uma abordagem com moradores da microbacia para explicar-lhes as intenções dos estudos propostos. Na segunda etapa foi realizada in loco a caracterização da MBHCV, sob um olhar dialético da ocupação e uso do solo, e, na terceira etapa, os dados foram compilados e traduzidos. Para os estudiosos da História Ambiental as investigações realizadas em campo são imprescindíveis, pois a coletânea de fatos históricos das relações entre os homens e a natureza é lida na própria paisagem (MARTINS, 2007).

Dos nove proprietários de terras na microbacia, cinco foram previamente contatados durante a primeira etapa, mas apenas um, o senhor L.H.A. 45, estava presente durante a caracterização feita a campo. Além do diálogo e troca de informações com o referido senhor, foram realizadas fotografias da microbacia, visando ilustrar a ocupação e uso da paisagem. As fotografias, como afirma Coelho (2014), são suportes que guardam as marcas do passado. E são essas 'marcas' que se propuseram estudar.

As atividades de SIG foram feitas no QGIS Desktop (SHERMAN et al., 2018), tomando como base os seguintes dados geográficos: uma imagem de satélite, de alta resolução espacial, referente a data de 6/7/2019, e os arquivos vetoriais, no formato shapefile, dos municípios do Espírito Santo, das curvas de nível e da hidrografia (GEOBASES, 2019). Todos os dados foram reprojetados para o Datum Sirgas 2000.

O mapeamento do uso e ocupação do solo da MBHCV compreendeu nove classes (Quadro 1) e foi realizado pela técnica da fotointerpretação, utilizando a escala de 1:500 e padrões de forma, cor, textura, tonalidade e contexto das classes (FAUSTINO et al., 2019). 
Quadro 1. Chave de fotointerpretação utilizada para realizar a mapeamento do uso e ocupação do solo da MBHCV, Alegre, ES.

\begin{tabular}{|c|c|c|}
\hline Classe de uso e ocupação & Descrição & $\begin{array}{l}\text { Aspecto da classe } \\
\text { na imagem }\end{array}$ \\
\hline Área de agricultura & $\begin{array}{c}\text { Cultivo de café, eucalipto, } \\
\text { milho, etc }\end{array}$ & \\
\hline Construções & Casas e construções rurais & \\
\hline Corpos hídricos & Represa, lagoa, etc & \\
\hline Estrada pavimentada & Rodovia estadual & \\
\hline Estrada não-pavimentada & Estrada rural & \\
\hline Fragmentos florestais & $\begin{array}{c}\text { Remanescentes florestais e } \\
\text { árvores }\end{array}$ & \\
\hline Solo exposto & Solo sem cobertura vegetal & \\
\hline Pastagem & Pastagem nativa e cultivada & \\
\hline Várzea & Áreas úmidas, brejo, etc & \\
\hline
\end{tabular}

Fonte: Os Autores.

\section{Resultados e discussão}

A ocupação e uso do solo da MBHCV se dá basicamente por atividades econômicas ligadas a cafeicultura, pecuária de leite e de corte, criação de equídeos e aves domésticas, cultivo de hortaliças, pomares e capineiras, além da estrada principal, apesar do predomínio das pastagens na paisagem (Figuras 2, 3 e 4). 


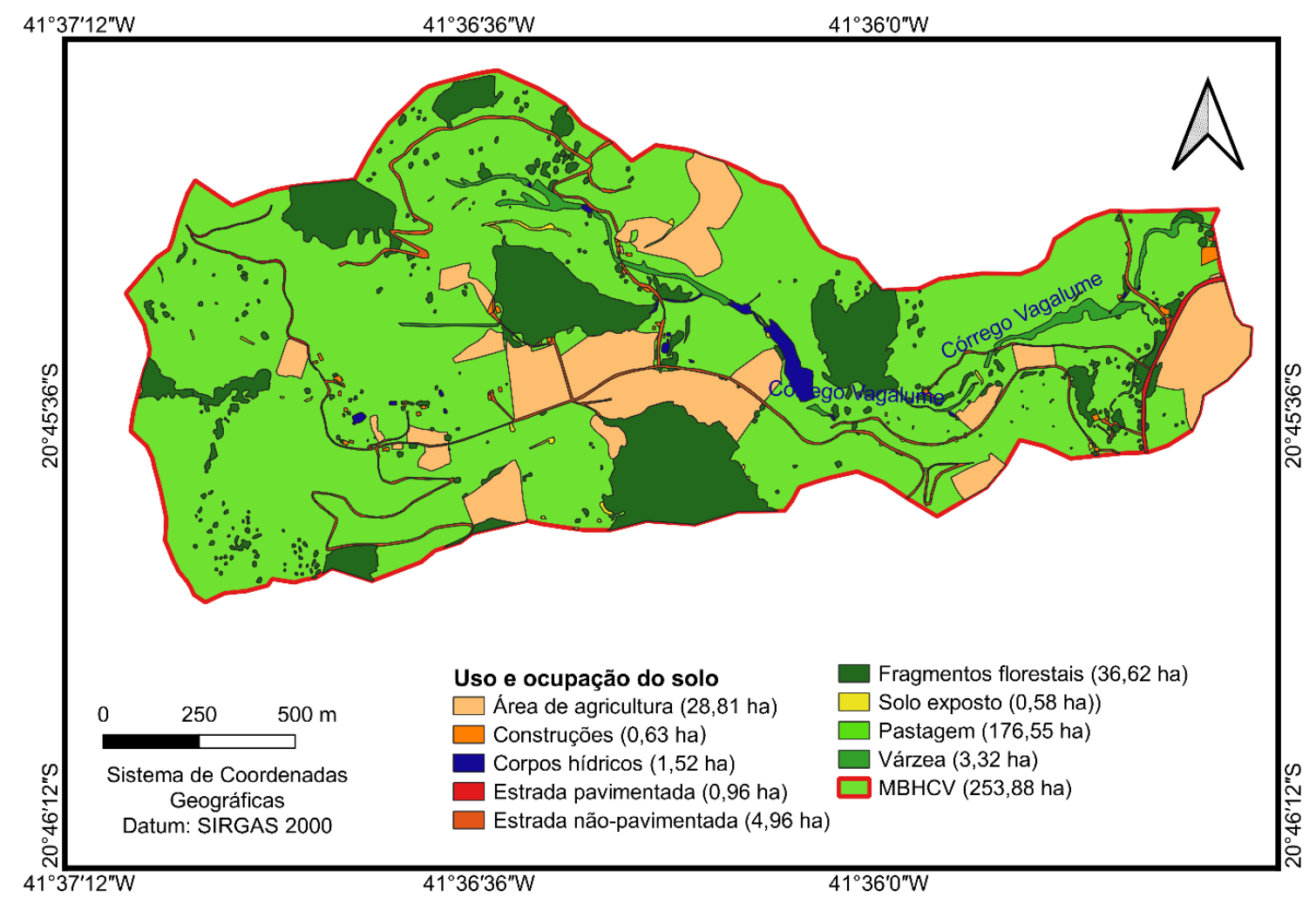

Figura 2. Uso e ocupação do solo na Microbacia Hidrográfica do Córrego Vagalume. Fonte: Os Autores.

As pastagens ocupam significativa área da MBHCV (Figura 2 e Figura 3), cerca de 70\%, antes tomadas, em sua maioria, com o cultivo de cafezais.

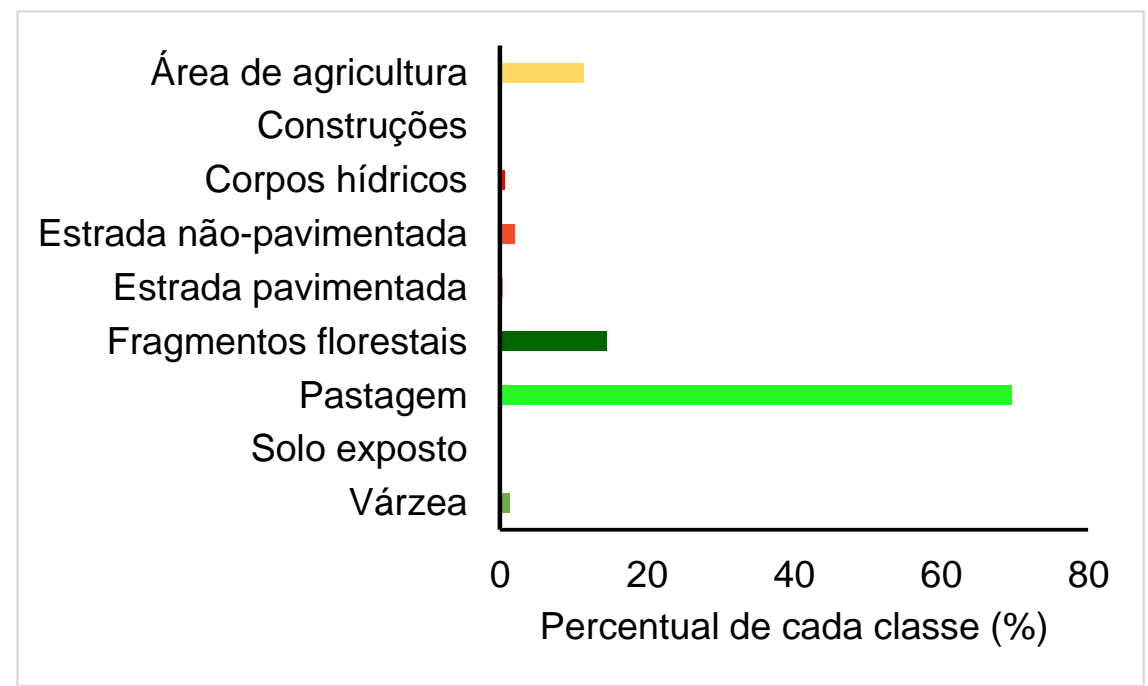

Figura 3. Representação percentual de cada classe de uso e ocupação do solo na Microbacia Hidrográfica do Córrego Vagalume.

Fonte: Os Autores. 

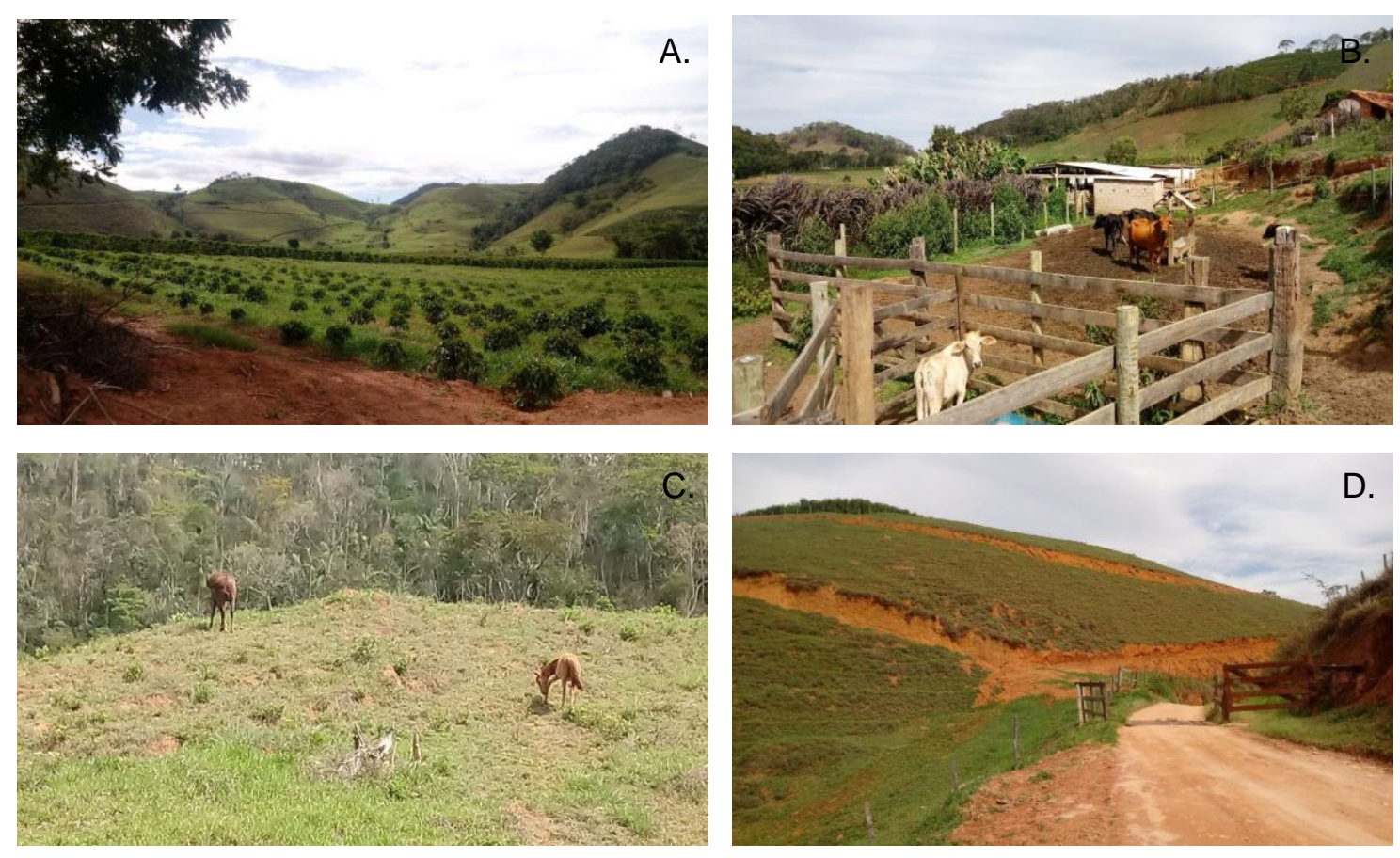

Figura 4. Paisagem da Microbacia Hidrográfica do Córrego Vagalume: A. Atividade de cafeicultura; B. Atividade de pecuária leiteira; C. Criação de equídeos; D. Estrada principal na microbacia.

Fonte: Os Autores.

Verificou-se que os plantios de milho, com adoção de práticas culturais como aração e gradagem, estão em Áreas de Preservação Permanente (APP) de curso d'água, em praticamente toda a microbacia. Na maioria das propriedades, também há o plantio de capineiras, canaviais e pomares, sendo parte desses plantios, feitos em APP e em Áreas de Reserva Legal (Figura 5). Segundo o Código Florestal (BRASIL, 2012), o local é inadequado para essa atividade, pois esse tipo de atividade praticada nessa área desrespeita os limites legais de uso do solo. 

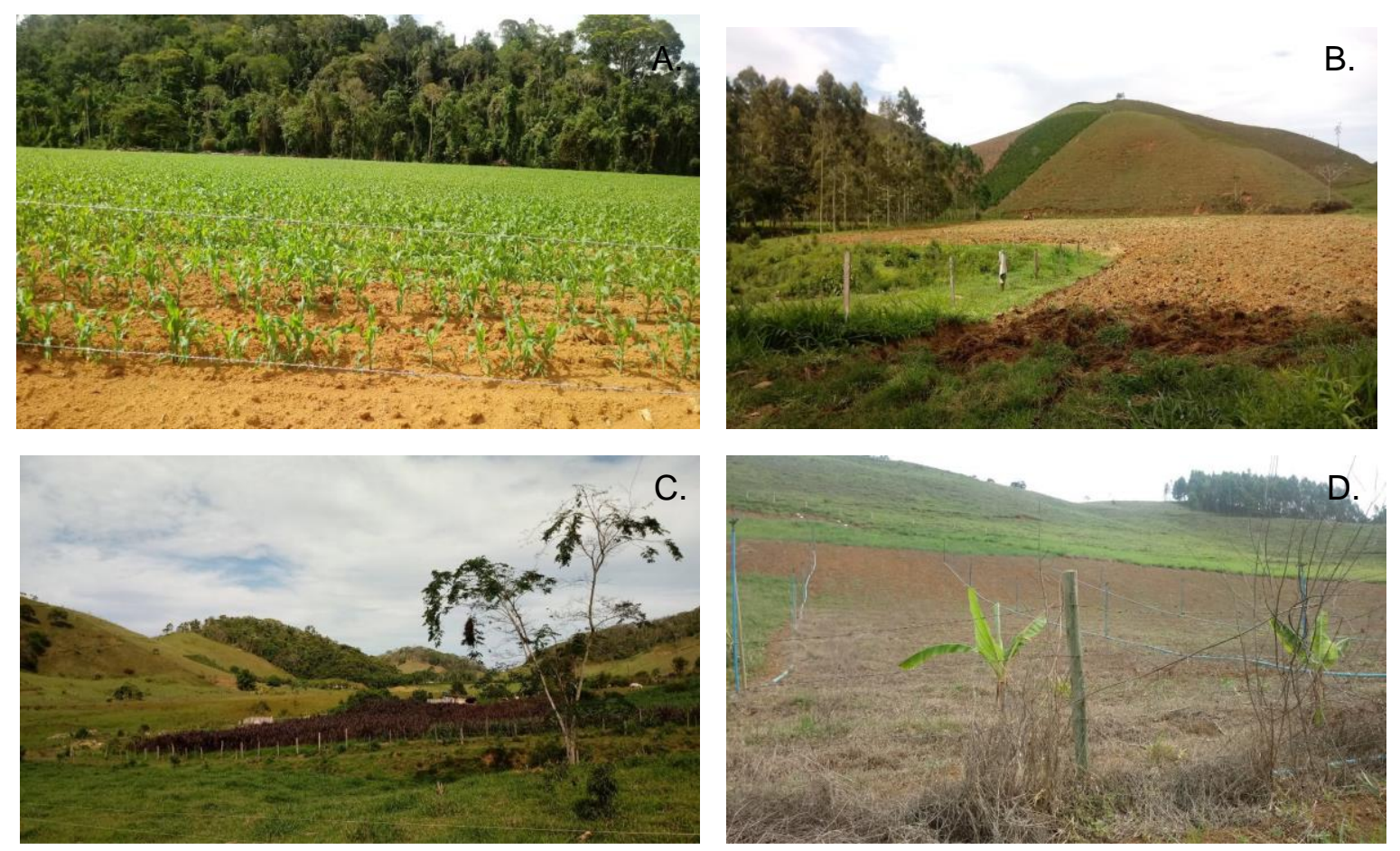

Figura 5. Paisagem da Microbacia Hidrográfica do Córrego Vagalume: A. Plantação de milho em área de APP; B. Aração e gradagem em área de APP de curso d'água; C. Capineira em APP de curso d'água; D. Área Irrigada por aspersão.

Fonte: Os Autores.

As APP, previstas no Código Florestal (BRASIL, 2012), têm a função fundamental de proteger o meio ambiente e assegurar-Ihe a continuidade e o seu papel de proporcionar o bem-estar das populações humanas (RIBEIRO, 2010). Apesar do caráter antropocêntrico do Código Florestal, voltada apenas para beneficiar o ser humano, a lei tem valia incontestável na preservação/conservação da natureza. Uma alternativa viável na gestão do solo e da água da MBHCV é o emprego de práticas agroecológicas, utilizadas como ferramenta metodológica e como base técnica para o manejo desses elementos naturais na microbacia, considerando suas especificidades e peculiaridades e a relação ética entre os homens, e do ser humano na sua intervenção consciente no meio ambiente (CAPORAL, 2016).

Vale destacar que a agroecologia orienta á estratégias de desenvolvimento rural mais sustentável e de transição para estilos de agriculturas mais sustentáveis, como uma contribuição para a vida das atuais e das futuras gerações neste planeta de recursos limitados.

Algumas propriedades fazem uso de irrigação por aspersão, porém sem um projeto de manejo para o uso da água (Figura 5). O excesso de água no solo pode acarretar perdas significativas desse elemento, comprometer o desenvolvimento da cultura agrícola e gerar gastos financeiros desnecessários. O mau dimensionamento do uso da água na microbacia pode contribuir para a diminuição do volume de água que chega a barragem, localizada a 
jusante desses plantios, sobretudo em períodos de estiagem. Isso reflete negativamente no volume de água captado pelo Serviço Autônomo de Água e Esgoto (SAAE) e, posteriormente, fornecido ao distrito de Celina.

Há também produção de hortaliças que geram renda e são consumidas pelas famílias dos proprietários e utilizadas na alimentação do gado e de aves domésticas (Figura 6). A produção excedente é comercializada principalmente nos pequenos mercadinhos no distrito de Celina.
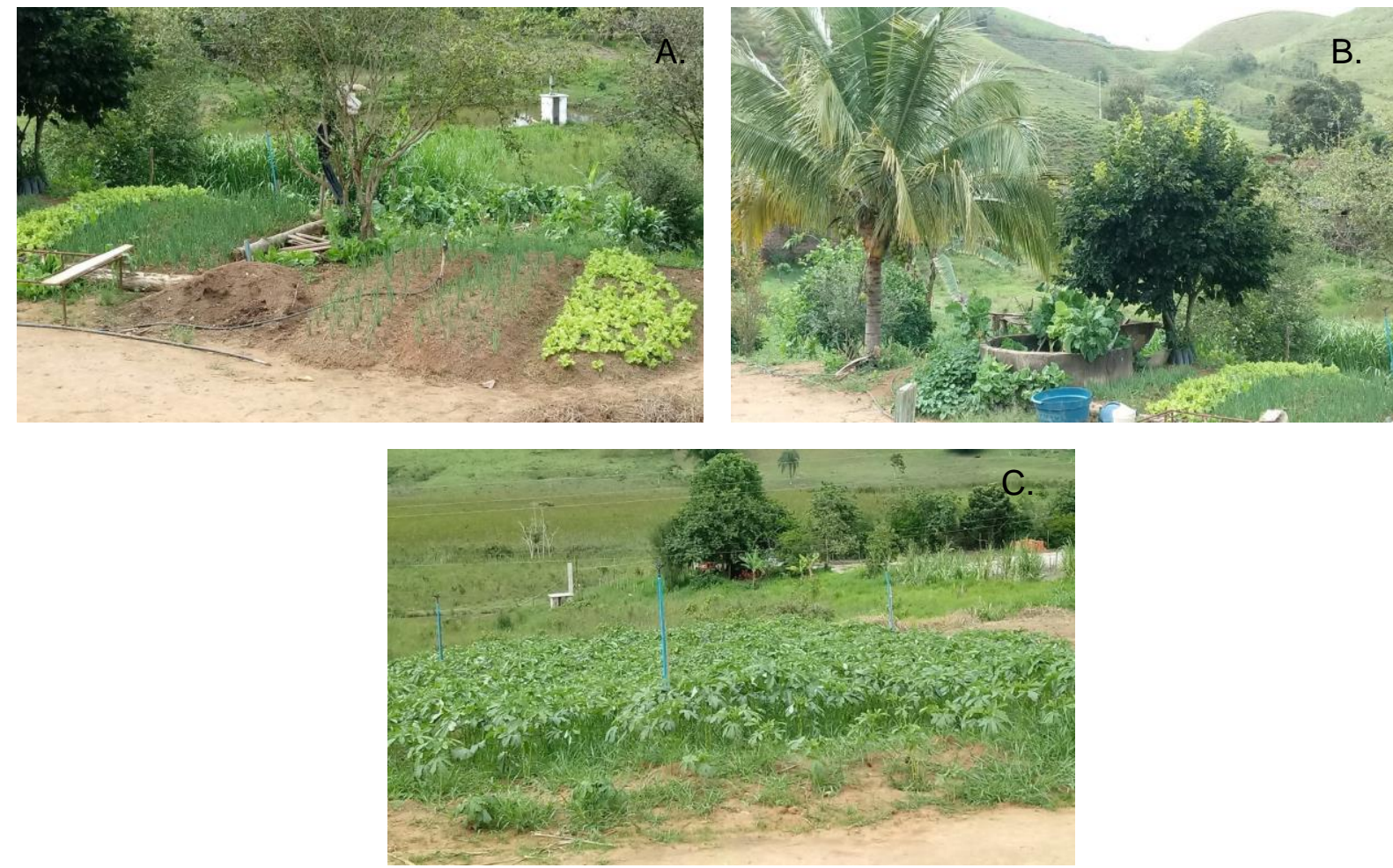

Figura 6. Paisagem da Microbacia Hidrográfica do Córrego Vagalume: A. Horta localizada no quintal de uma das propriedades; B. Pomar localizado no quintal de uma das propriedades; C. Plantação de quiabo com uso de irrigação.

Fonte: Os Autores.

Em simetria com grande parte da Região do Caparaó, a MBHCV apresenta declividade acentuada, com presença de ravinas devido a carência de práticas conservacionistas do solo. O gado tem acesso livre às APP de topos de morros. Há pequenos fragmentos de vegetação nativa em trechos isolados nos topos de morro, na margem esquerda do córrego Vagalume e nas áreas ciliares da microbacia (Figura 7). Como apresentado na Figura 2, a MBHCV é composta por 176,55 ha de pastagens, incluindo APP de topo de morro. Porquanto represente ocupação tão significativa na microbacia, há de se salientar a importância dos serviços ambientais dos topos de morro. Eles proporcionam infiltração das águas pluviais, diminuem o escoamento superficial e potencialmente a erosão - são áreas preferenciais de recarga de aquífero (ALMEIDA e PAULA, 2018). Além disso, preservam a 
paisagem, mantém a estabilidade geológica, a biodiversidade e o tráfego da fauna e da flora.

As matas ciliares são florestas e outras formas de vegetação existentes no entorno nas nascentes, rios, lagos, lagoas e reservatórios. Seus benefícios são diversos: preservam a qualidade das águas, funcionando como filtros; garantem a infiltração da água da chuva nos lençóis freáticos; controlam os processos erosivos; atuam como corredores ecológicos, conectando as florestas e favorecendo a movimentação da fauna e a dispersão da flora; controlam pragas e doenças dos cultivos agrícolas, servindo como barreiras naturais, e, atuam na regulação da temperatura dos corpos hídricos (MEIRA et al., 2013).
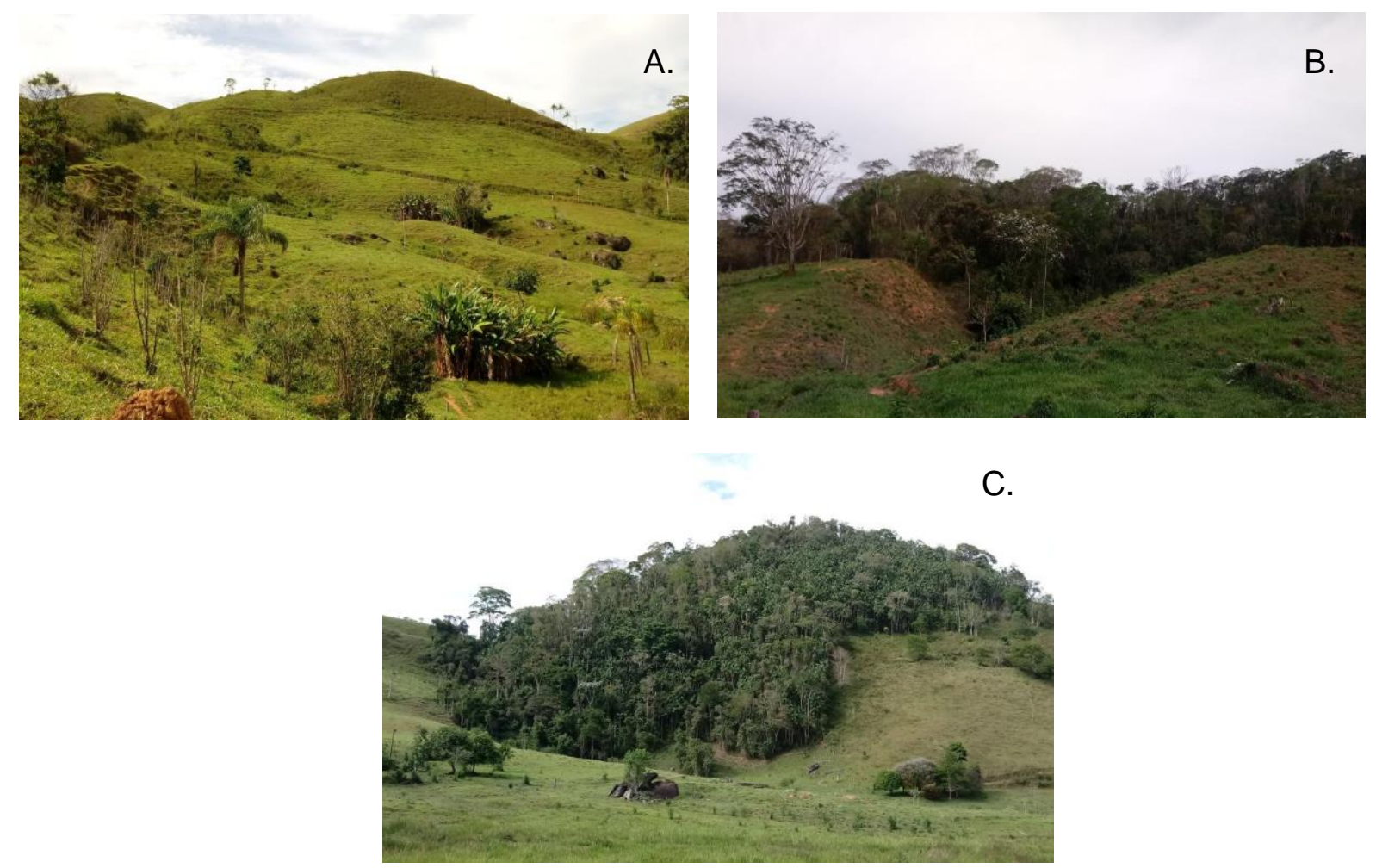

Figura 7. Paisagem da Microbacia Hidrográfica do Córrego Vagalume: A. APP de topo de morro sem cobertura florestal; B. Vegetação florestal em APP de topo de moro; C. Mata ciliar existente na microbacia.

Fonte: Os Autores.

Se por um lado é importante considerar a importância da pecuária como uma das principais atividades econômicas em toda região do Caparaó e na MBHCV em particular, por outro lado, os impactos ambientais são evidentes. A atividade pecuária tem significativa contribuição na degradação ambiental das APP, pois é comum remover-se a vegetação para implantação do pasto, desencadeando com isso uma série de problemas ambientais (JUNIOR et al., 2012). Em estudos apresentados na obra 'Estratificação de Ambientes com Base nas Classes de Solos e outros Atributos na Bacia do Rio Itapemirim, Espírito Santo', Lani, Resende e Resende (2011) destacam que a ausência quase completa de matas em 
áreas mais declivosas demonstravam a pressão do uso do solo nessa região, sendo inapropriada para pecuária extensiva, com severos efeitos da erosão.

As queimadas anuais nas pastagens, realizadas normalmente durante o período de estiagem, também são práticas comuns em toda microbacia (Figura 8). A crença dos pecuaristas é de que após as queimadas a brotação é mais vigorosa. Em curto prazo o efeito pode parecer positivo, pois o pasto, renovado, oferece capim macio para o gado se alimentar e a área ficar limpa de plantas invasoras. Porém, essa prática provoca a exaustão do solo com o passar dos anos (FREITAS e CANI, 2016).

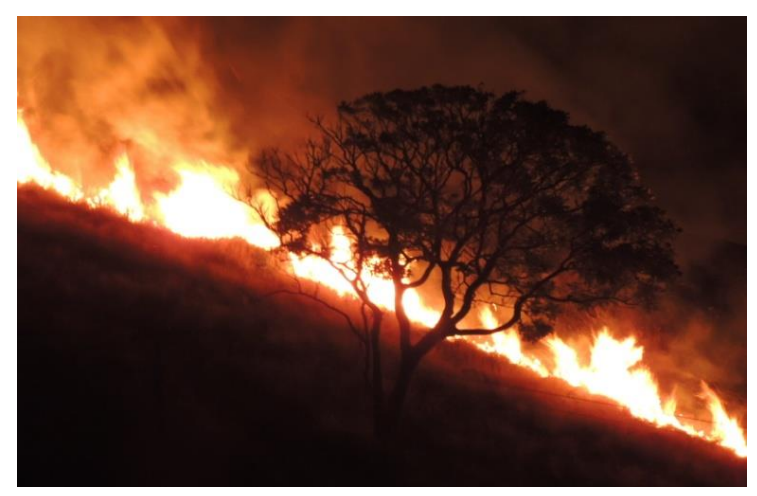

Figura 8. Queimada em pastagem da MBHCV, no ano de 2014.

Fonte: Livro Entre Águas - Memórias Fotográficas (2015).

Em longo prazo os resultados das queimadas são desastrosos. Do ponto de vista agronômico podem trazer consequências incalculáveis, como a eliminação de nutrientes como o potássio, fósforo e nitrogênio; morte de microrganismos, redução da umidade e compactação do solo; causa erosão e outras formas de degradação; aumenta a liberação de dióxido de carbono, uma das principais causas do aquecimento global; poluem nascentes, águas subterrâneas, córregos e rios com cinzas, e pode destruir habitats naturais (REDIN et al., 2011).

Notou-se que, no fundo do vale da microbacia, há três nascentes que fornecem água para as residências (Figura 9). Tais nascentes estão circundadas apenas por bananeiras e por pequeno fragmento de vegetação arbórea, sem nenhum isolamento, ambas com sinais de pisoteio de gado e evidente compactação do solo. Como consequência, pode haver redução na capacidade de infiltração e retenção da água. As nascentes são responsáveis pela origem dos córregos e rios, que delimitados pelo relevo formam as bacias hidrográficas que deságuam no mar (MEIRA et al., 2015). 

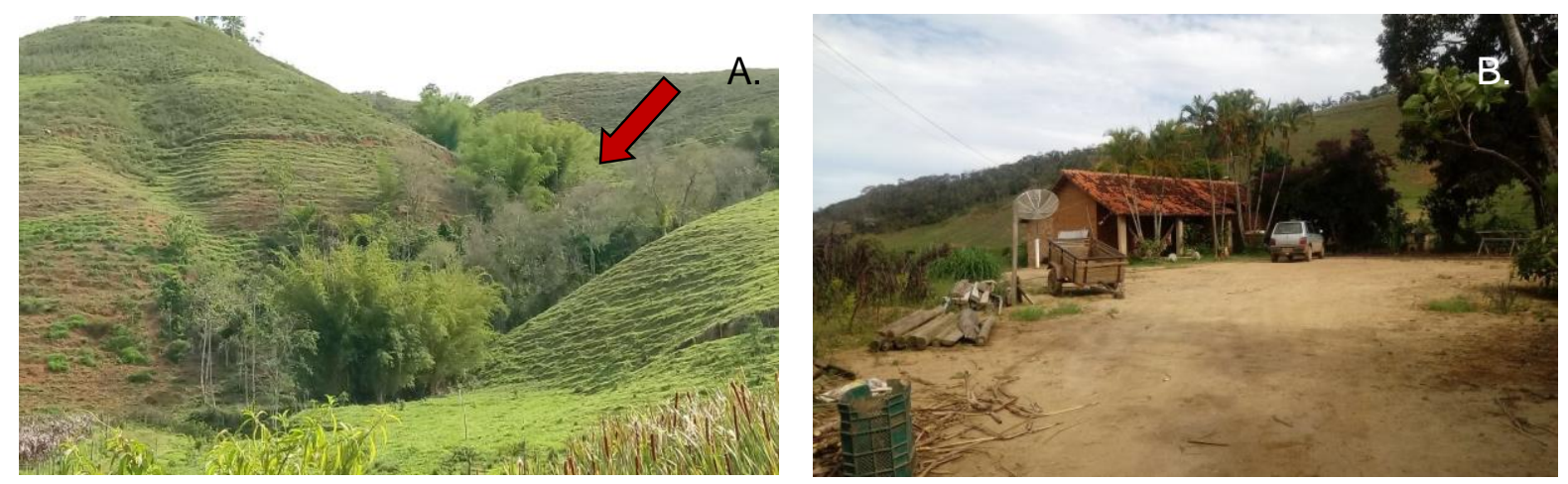

Figura 9. Paisagem da Microbacia Hidrográfica do Córrego Vagalume: A. Local onde está localizada uma das nascentes na microbacia; B. Umas das residências abastecida pela nascente.

Fonte: Os Autores.

Segundo depoimento do senhor L.H.A. a água da nascente é destinada à dessedentação humana e dos animais, e para uso doméstico nas residências dos proprietários e na limpeza dos currais. As APP de curso d'água, incluindo as várzeas, apresentam sinais de degradação, sem cobertura florestal e com livre acesso ao gado, além de significativo assoreamento e presença de vegetação exótica, como o braquiária e a taboa nesses ambientes (Figura 10).
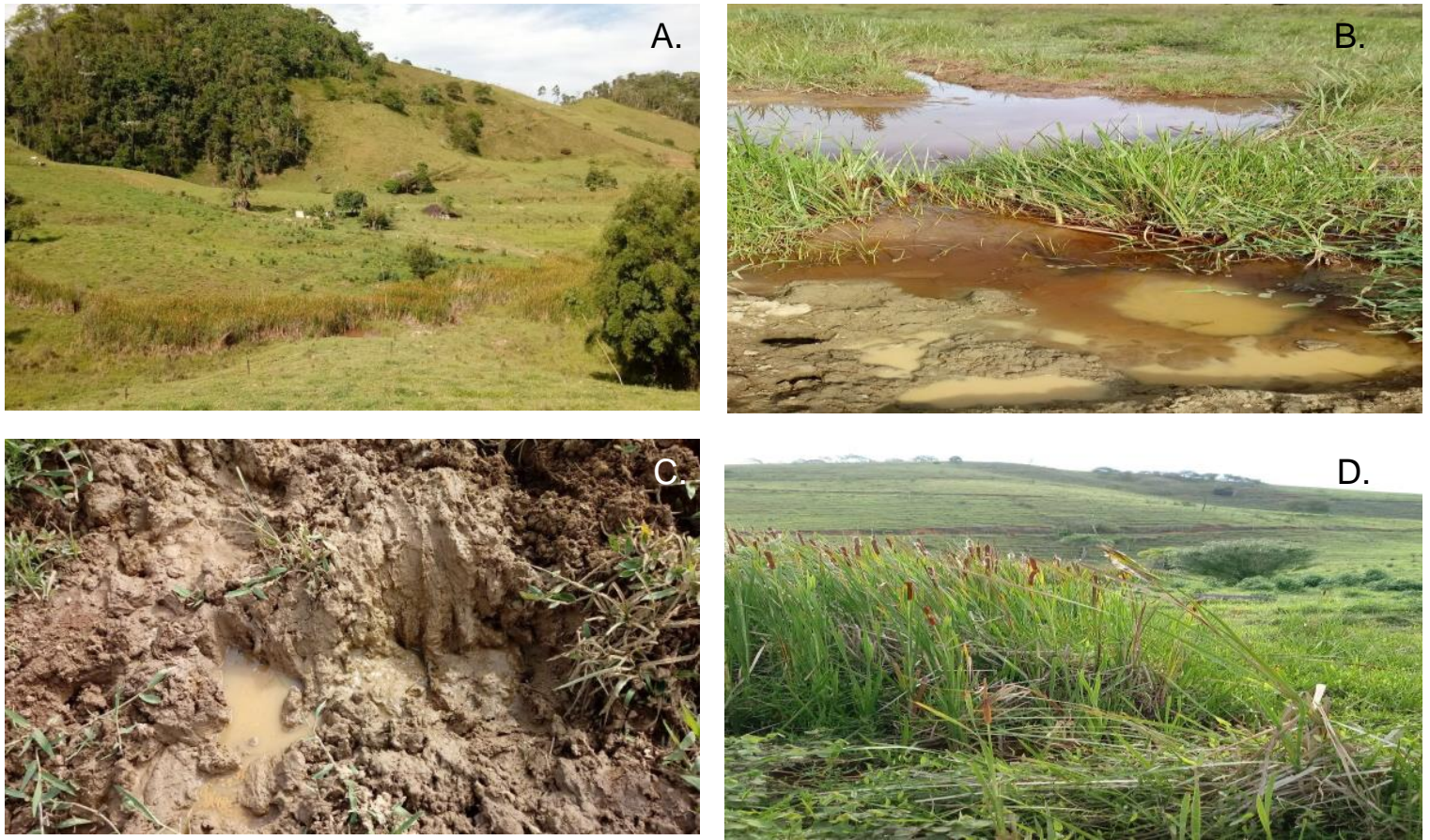

Figura 10. Paisagem da Microbacia Hidrográfica do Córrego Vagalume: A. Área alagada na microbacia; B. APP de curso d'água sem cobertura florestal e sem isolamento; C. Marca de pisoteio do gado; D. Brejo com presença de taboa.

Fonte: Os Autores. 
Essas APP são importantes para evitar que partículas de solo cheguem à calha dos córregos e rios, evitando assim assoreamentos. Apesar do Código Florestal proibir o cultivo ou a ocupação das áreas de várzea, considerando-as APP, essa questão precisa ser melhor discutida.

O assoreamento, consequência do deslocamento dos solos desprotegidos, com transporte e acúmulo de sedimentos e do chorume de curral despejado in natura dentro do curso d'água, reduz a calha do córrego e compromete a vegetação subaquática (Figura 11).

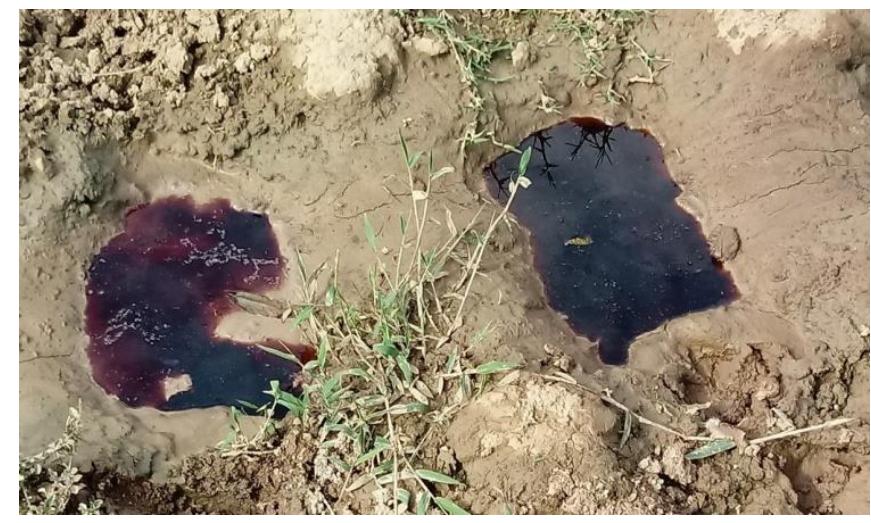

Figura 11. Paisagem da Microbacia Hidrográfica do Córrego Vagalume: Chorume de curral chegando ao curso d'água.

Fonte: Os Autores.

Estes fatores somados podem, com o decorrer do tempo, comprometer as funções ambientais das APP, diminuir significativamente ou mesmo encerrar as atividades das nascentes, pois as áreas de contribuição ficam com a capacidade de infiltração de água reduzidas. É fundamental que todos que residam nas proximidades das APP, proprietários rurais ou não, estejam conscientes sobre a importância da utilização correta dos recursos naturais e da preservação dessas áreas (BORGES e REZENDE, 2012).

Como os proprietários não se encontravam nas propriedades, não foi possível verificar a destinação dos esgotos sanitários. Em depoimento, o senhor L.H.A. disse que apenas algumas casas possuem fossas do tipo sumidouro, construídas de forma bem rústica, feitas a partir de um buraco escavado no chão. O problema deste tipo de fossa é que em algum momento pode haver contaminação do lençol freático e, ou, do curso hídrico. Ele informou que gostaria de trocar a fossa, do tipo sumidouro, existente na propriedade, por uma fossa biodigestora, pois ouviu falar a respeito de seus benefícios, por meio de pessoas que participaram do Projeto Plantadores de Água, desenvolvido em Alegre, nos anos de 2013 a 2015. Projeto este construído sobre os pilares do movimento social, com 'experimentação participativa', que permitiu a troca de experiências, a busca conjunta por soluções adaptadas 
ao território e o aumento da consciência sobre a o uso da água e a gestão de recursos hídricos (SHUBO et al., 2019).

A fossa séptica biodigestora consiste na implantação de um sistema de biodigestão anaeróbico usado para tratar somente o esgoto sanitário (água negra, como é denominada) produzido por uma família de até cinco pessoas (Figura 12). A fossa séptica elimina possíveis contaminantes do solo e da água, além da melhoria do saneamento das propriedades e comunidades rurais (MEIRA et. al., 2013).

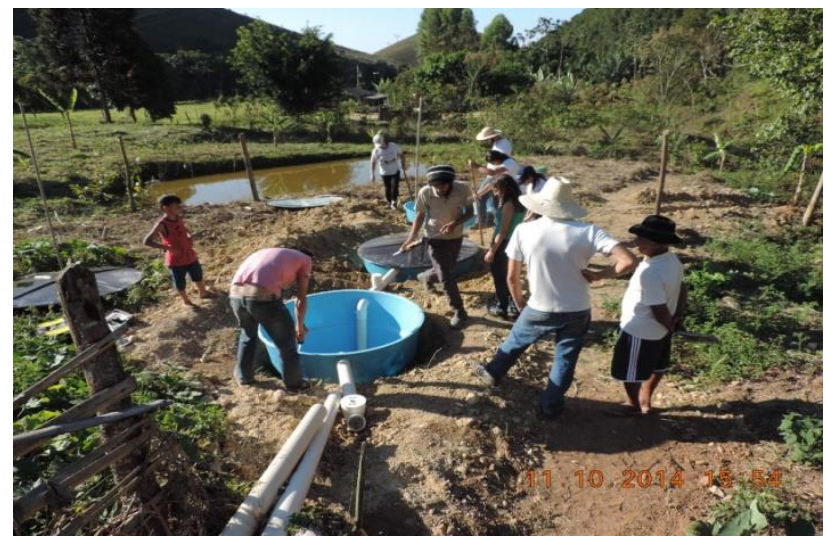

Figura 12. Implantação de fossa biodigestora durante o desenvolvimento do Projeto Plantadores de Água.

Fonte: Arquivo Projeto Plantadores de Água (2015).

Essa tecnologia social, além de não poluir o meio ambiente, proporciona economia para o agricultor, pois o biofertilizante de excelente qualidade gerado no processo de decomposição do material coletado, pode ser usado na agricultura, com restrição no uso direto nas hortaliças.

Ressalta-se que a água que abastece a sede do distrito de Celina é captada em um ponto do córrego Vagalume, e tratada a jusante numa Estação de Tratamento de Água (ETA), gerenciada pelo Serviço Autônomo de Água e Esgoto (SAAE) de Alegre. Segundo informações do escritório do SAAE, essa ETA atende no ano de 2020 a 905 ligações residenciais e comerciais no distrito. Porém, diante do longo período de estiagem que precedeu esse estudo na microbacia, e de décadas de reclamações por parte dos moradores de Celina de que a água fornecida em suas residências estava constantemente suja e cheia de partículas sólidas, o SAAE aumentou no segundo semestre do ano de 2016 o dimensionamento da barragem de captação de água, visando solucionar esse problema. Contudo, a nova barragem não apresenta técnicas de conservação, com os taludes sem proteção, sem cobertura vegetal, permitindo que parte do solo seja carreado para dentro da barragem e do curso d'água (Figura 13). 

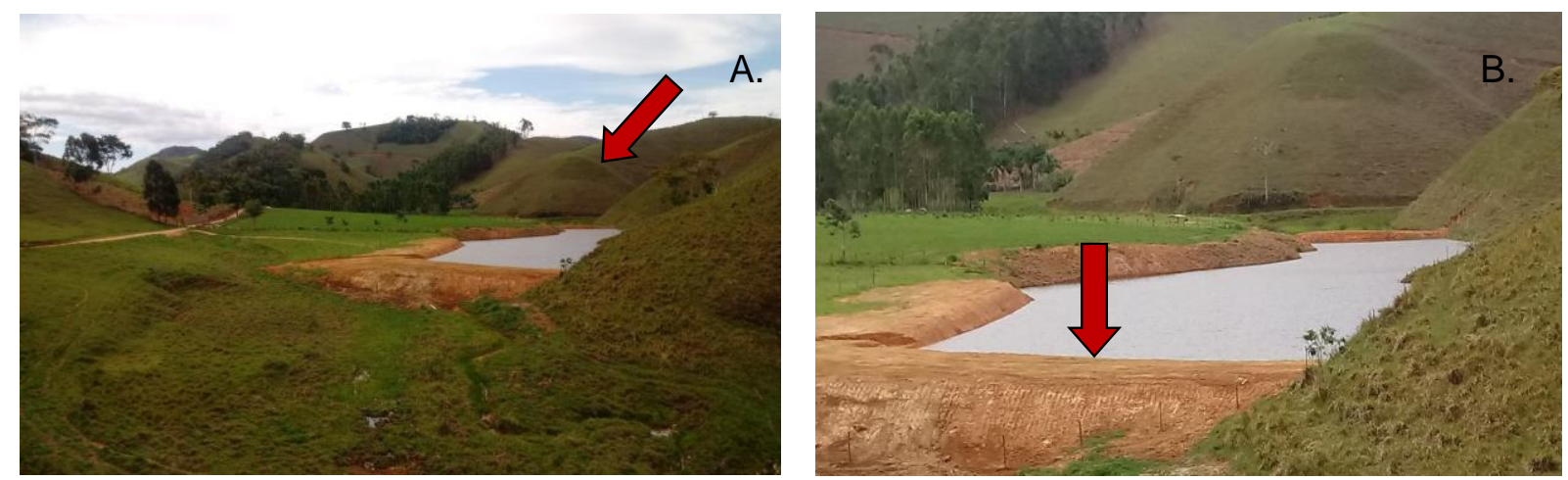

Figura 13. Paisagem da Microbacia Hidrográfica do Córrego Vagalume: A. Barragem para captação de água de Celina; B. Solo desprotegido, podendo assorear a barragem. Fonte: Os Autores.

Observou-se, também, durante os estudos, vestígios de uso de agrotóxicos em diversos pontos na microbacia: seja nas margens das estradas, nos cafezais e nos pomares de citros. Em sua maioria, o produto utilizado foi o Round'up. Esses vestígios são evidenciados pela vegetação amarelada, cor característica de uso desse herbicida (Figura 14).
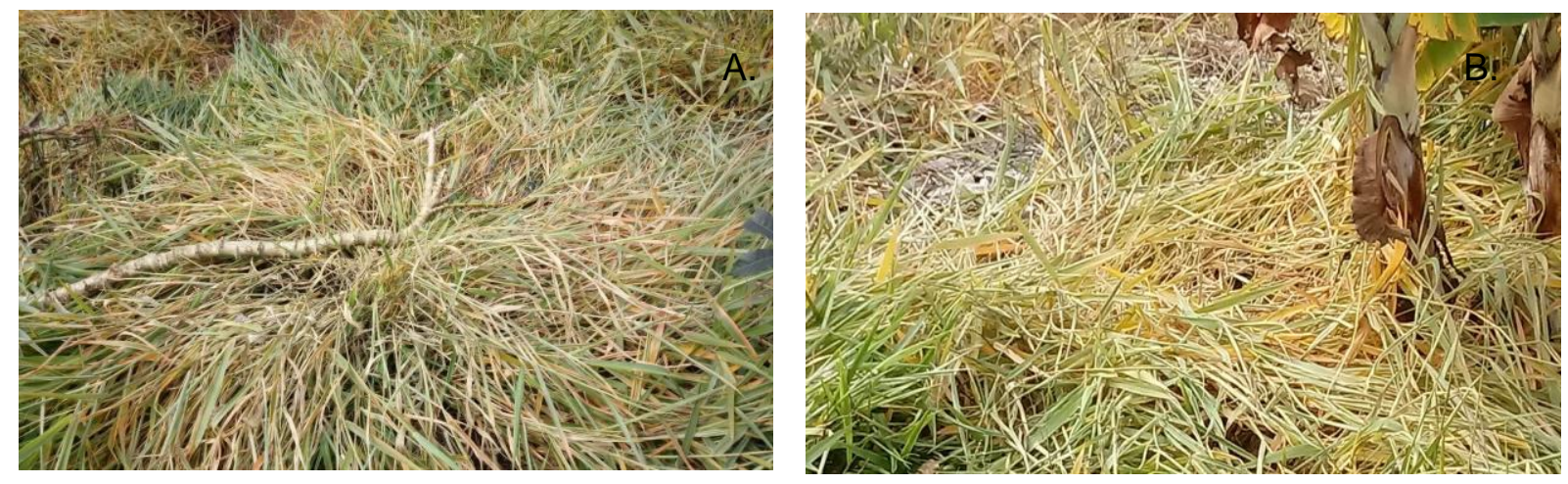

Figura 14. Paisagem da Microbacia Hidrográfica do Córrego Vagalume: A. Vestígio de uso Rond'up na pastagem; B. Vestígio de uso de Rand'up no pomar.

Fonte: Os Autores.

Segundo L.H.A., a prática do uso de agrotóxicos é comum em todas as propriedades da microbacia. O perigo de contaminação da água da sede do distrito de Celina é evidente, considerando que a captação e distribuição da água fica a jusante dessas propriedades. No passado recente e por alguns anos consecutivos foi feito o plantio de tomates bem próximo da barragem de captação de água de Celina. Ainda que respeitada a distância legal para essa atividade, os resíduos de agroquímicos como os fungicidas, tão comuns nesse tipo de cultura agrícola, podem chegar no curso d'água. Não se pode negar que os agrotóxicos tem potencial para aumentar a produtividade agrícola e auxiliar no controle de diversas doenças. Todavia, seu uso desordenado provoca diversos impactos sobre o meio ambiente, podendo alcançar os ambientes aquáticos (SOARES et al., 2017). 
As técnicas de conservação na estrada principal da microbacia e nos carreadores são pouco comuns. A única exceção é a construção de 19 caixas secas em uma estrada desativada na propriedade do senhor L.H.A. (Figura 15). Essas caixas secas foram construídas com o apoio do Serviço Autônomo de Água e Esgoto de Alegre (SAAE, 2017).

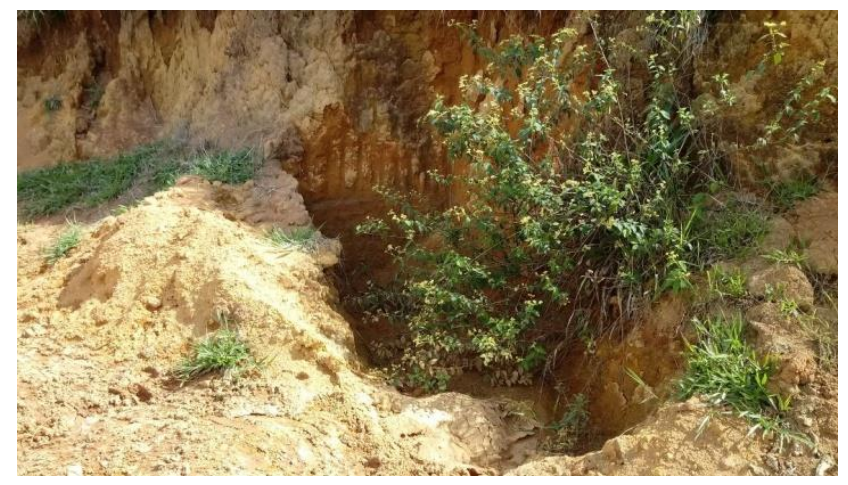

Figura 15. Caixa seca construída em estrada desativada.

Fonte: Os Autores.

No momento do estudo as caixas estavam cheias de terra, necessitando de limpeza para cumprir sua função. Para manutenção das caixas secas e construção de novas caixas o senhor L.H.A solicitou ajuda ao poder público municipal, mas não teve o pedido atendido até a data em que este estudo foi realizado.

A construção de caixas secas nas estradas rurais é de relevante importância para a gestão do solo e da água. É uma tecnologia social que contribui para diminuir a degradação das estradas, reduz os efeitos da erosão, aumenta o armazenamento de água, abastecendo assim, de forma lenta, o lençol freático, favorecendo, assim maior vazão nas nascentes (MEIRA et al., 2013). É uma estocagem de água da chuva instalado na margem de estradas rurais (DADALTO et al., 2016).

Para a melhoria da paisagem da MBHCV, da qualidade de vida dos produtores e dos moradores de Celina, usuários da água que vem dessa microbacia, urge o emprego de práticas agroecológicas como o cumprimento das legislações vigentes que respeitem as áreas de APP, fazendo-se os plantios em outras áreas; reflorestamento das áreas ciliares e os topos de morros e não permitir o acesso do gado nessas áreas e nas áreas brejosas; isolamento das nascentes; diminuição ou substituição dos agrotóxicos por produtos como caldas naturais, plantas com poder de evitar ou repelir insetos e plantas daninhas (vegetação espontânea), emprego de controle biológico e uso de fungos entomopatogênicos, o uso de aves para controle de insetos; construção de fossas sépticas e/ou biodigestoras nas residências e nos currais, e, a construção de terraços e de caixas secas, refletindo positivamente na infiltração de água no lençol freáticos. 
Importante também um processo de educação ambiental contínuo junto aos proprietários da microbacia, no sentido de orientação, de esclarecimento sobre os malefícios das queimadas nas pastagens, sobre a gestão do solo e da água e de políticas públicas que sensibilizem os moradores para as necessárias práticas agroecológicas na MBHCV, bem como para a construção e execução de projetos que melhorem a paisagem na microbacia. Algumas políticas oferecerem à produção agroecológica, formas de se estabelecer, e de constituir-se como uma alternativa de sustentabilidade para o meio rural, sendo a Agroecologia um caminho conciliatório entre a agricultura familiar e a sustentabilidade para o espaço rural, por estar baseada em uma estratégia científica de desenvolvimento rural sustentável que minimiza os afetos das ações humanas sobre o meio ambiente (SANTOS et al., 2014).

\section{Considerações finais}

O estudo revelou que a MBHCV apresenta uma série de impactos ambientais causados, sobretudo, pelas atividades econômicas da agricultura e da pecuária, realizadas de forma degradatória: atividades agrícolas em APP; uso de agrotóxicos; nascentes desprotegidas; poucas caixas secas; irrigação sem estudo técnico; esgoto sanitário doméstico e de curral despejado in natura no curso d'água; estradas sem manejo correto; pisoteio do gado em áreas brejosas; ausência de cobertura florestal nos topos e moro a nas áreas ciliares, e, prática de queimadas nas pastagens.

Verificou-se também que as ações conservacionistas para a reversão desse quadro na paisagem da microbacia são modestas, levando-se em conta sua importância no abastecimento a sede do distrito de Celina com água potável.

A mitigação dos impactos negativos na MBHCV é necessária e possível, desde que a gestão do modelo vigente das atividades econômicas, desenvolvidas na microbacia, sejam realizadas de forma diferente daquelas praticadas até então. Uma alternativa viável é o emprego de práticas agroecológicas, que possibilita conciliar a utilização do solo e da água para fins econômicos e a conservação ambiental, sendo esta elementar tanto para a sustentabilidade das atividades econômicas, quanto para o bem estar humano e de outras formas de vida na microbacia. 


\section{Agradecimentos}

Ao proprietário rural, senhor L. H. A., por ter contribuído com o estudo e nos conduzido por toda a microbacia, e a Fundação de Amparo à Pesquisa e Inovação do Espírito Santo (FAPES), pelo apoio financeiro ao primeiro autor deste trabalho, bolsista durante o mestrado.

\section{Referências}

ALMEIDA, A. M. de; PAULA, E. V. de. Áreas de preservação permanente de topos: das alterações na legislação brasileira às suas diferentes interpretações. Confins. Revue franco-brésilienne de géographie/Revista franco-brasilera de geografia, n. 37, p. 1-21, 2018.

AUGUSTO, R. C. A cartografia de paisagens e a perspectiva geossistêmica como subsídios ao planejamento ambiental. Revista Tamoios, v. 12, n. 1, p. 144-153, 2016.

BORGES, L. A. C.; REZENDE, J. L. P. Áreas protegidas no interior de propriedades rurais: a questão das APP e RL. Floresta e Ambiente, v. 18, n. 2, p. 210-222, 2012.

BRANNSTROM, C. A Ferro e Fogo, história ambiental e a Geografia brasileira: um diálogo por inventar. Revista Brasileira de Geografia, v. 61, n. 1, p. 109-125, 2016.

BRASIL. Lei 12.651, de 25 de Maio de 2012. Código Florestal Brasileiro. Brasília: Presidência da República. Disponível em: <http://www.planalto.gov.br/ccivil_03/_ato20112014/2012/lei/l12651.htm>. Acesso em: 31 ago. 2020.

CAPORAL, F. R. Poderá a agroecologia responder aos cincos axiomas da sustentabilidade? Revista Brasileira de Agroecologia (Online), v. 11, p. 390-402, 2016.

COELHO, L. C. Fotografias de uma paisagem: Porto Alegre, entre permanências e rupturas. REVISTA E-METROPOLIS, v. 5, p. 76-81, 2014.

DADALTO, G. G.; HENRIQUE DE SÁ PAYE, H. de. S; ALIAMAR COMÉRIO, A.; BATISTA, $R$. Tecnologias de conservação e armazenamento de água em propriedades rurais. Incaper em Revista, Vitória, v. 6 e 7, n. 4, p. 42-50, 2016.

DUTRA, G. J. A. A relação socioambiental do Alegre-microrregião do Caparaó-ES a partir do século XIX e no projeto Plantadores de Água (2013-2015): uma análise no âmbito da história ambiental. Alegre, 2019. 119 p. Dissertação. (Mestrado Profissional em Agroecologia) - Instituto Federal do Espírito Santo. Alegre, 2019.

ESPÌRITO SANTO (Estado). Lei no 9.768. Dispõe sobre a definição das Microrregiões e Macrorregiões de Planejamento no Estado do Espírito Santo. Diário Oficial, Vitória, 2011. Disponível em: <http://www3.al.es.gov.br/Arquivo/Documents/legislacao/html/LO9768.html>. Acesso em: 20 jul. 2020.

FAJARDO, S. Considerações sobre o espaço rural a partir do enfoque econômico da paisagem e do território. Revista Caminhos da Geografia, v. 11, n. 34. p. 225-234, 2010. 
FAUSTINO, F. J. S.; XAVIER, T. K. D.; FERREIRA, A. I. S. Plataforma web para fotointerpretação de imagens panorâmicas aéreas e terrestres. Geoambiente On-line, n. 35, p. 203-217, 2019.

FREITAS, L. A. L.; CANI, P. C. A trajetória da pecuária capixaba. In: DADALTO, G. G. et al. Transformação da agricultura capixaba: 50 anos. Raiz Comunica, Vitória, p. 38-41, 2016.

GOBBO, S. D. A.; GARCIA, R. F.; AMARAL, A. A.; EUGENIO, F. C.; ALVAREZ, C. R. S.; LUPPI, A. S. L. Uso da terra no entorno do PARNA-Caparaó: preocupação com incêndios florestais. FLORAM - Revista Floresta e Ambiente, v. 10, p. 145-159, 2013.

JUNIOR, B. S. G.; COUTO, D. R.; SOUZA, F. B. C.; JUNIOR, G. D. S.; SANTOS, A. R. Perda de solo por erosão hídrica em áreas de preservação permanente na microbacia hidrográfica córrego do Horizonte, Alegre, Espírito Santo. Engenharia Ambiental, v. 9, n. 2, p. 21-34, 2012.

LANI, J. L.; RESENDE, S. B. de; RESENDE, M. Estratificação de Ambientes com Base nas Classes de Solos e outros Atributos na Bacia do Rio Itapemirim, Espírito Santo. Revista Ceres, v. 48, p. 239-261, 2001.

MARTINS, M. L. História e meio ambiente. São Paulo: Annablume, 2007.

MEIRA, A. C. H; SOUZA, D. S. de; SENNA, D. S. de; KOBI, H. B. de; VERNEGUE, H. S.; MACHADO, L. C. A.; CAMPOS, N. B.; MONTEIRO, R, B.; SANTOS, R. A. B.; LIMA, U. A. Capacitação de Multiplicadores para o Plantio de Água. 1a ed. Alegre-ES, p.10, 2013.

MEIRA, A. C. H.; SENNA, D. S. de; DUTRA, G. J. A.; KOBI, H. B.; CAMPOS, N. B. Entre Águas: memórias fotográficas. Cachoeiro de Itapemirim-ES: Gracal, 2015.

OLIVEIRA, Z. C. de. Abertura do caminho de Arripiados à última cachoeira do Rio Itapemirim: a saga de uma expedição desbravadora e a origem do topônimo da cidade de Alegre, ES, segundo o "Diário de João do Monte da Fonseca". Jornal A Palavra, Alegre, v. 1, n. 1, p. 21, 2009.

PROJETO PLANTADORES DE ÁGUA. Materiais audiovisuais. 2015. Sindicato dos Trabalhadores Rurais de Alegre. Alegre, 2020.

REDIN, M.; SANTOS, G. D. F. D.; MIGUEL, P.; DENEGA, G. L.; LUPATINI, M.; DONEDA, A.; SOUZA, E. L. D. Impactos da queima sobre atributos químicos, físicos e biológicos do solo. Ciência Florestal, v. 21, n. 2, p. 381-392, 2011.

RIBEIRO, C. A. A. S.; SILVA, M. L. da; SOARES, N. S.; ROCHA, R. R. C.; OLIVEIRA, A. M. S. Valoração das Áreas de Preservação Permanente na Bacia do Rio Alegre-ES. Floresta e Ambiente, v. 17, n.1, p.63-72, 2010.

SANTOS, C. F. dos; SIQUEIRA, E. S.; ARAÚJO, I. T. de; MAIA, Z. M. G. A agroecologia como perspectiva de sustentabilidade na agricultura familiar. Revista Ambiente e Sociedade, v. 17, n. 2, 2014.

SANTOS, G. M. A. D.; VIANA, W. B. O.; YAMADA, C. M.; LOUZADA, L. R. O.; BREDA, P. H. M. 2, SANTOS, A. R.; OLIVEIRA, O. M.; SANTOS, E. M.; PELUZIO, T. M. O. Análise hidrológica da bacia hidrográfica do ribeirão Jerusalém, ES. Anais... XII Encontro Latino Americano de Iniciação Científica e VIII Encontro Latino Americano de Pós-Graduação, Universidade do Vale do Paraíba. p 1. 2004. 
SENNA, D. S. KOBI, H. B.; DUTRA, G. J. A.; CARVALHO, S. A.; MACHADO, L. C. A.; CAMPOS, N. B.; MEIRA, A. C. H. Projeto Plantadores de Água. In: BOLDRINI, E. B.; LACERDA, L.; CASSILHA, M. F. (Orgs.). Floresta, água e clima: boas práticas nos biomas brasileiros. 1 ed. p. 116-119. ADEMADAN, Curitiba, 2015.

SERVIÇO AUTONOMO DE ÁGUA E ESGOTO DE ALEGRE. Relatório de obras/serviços executados- primeiro trimestre de 2017. Disponível em: <http://saaealegrees.com.br/wpcontent/uploads/2017/03/relatorio-de-atividades-1.pdf>. Acesso em: 25 jul. 2020.

SHERMAN, E.G. et al. Sistema de informações geográficas do QGIS. Projeto Código Aberto Geospatial Foundation. 2019. Disponível em: <http://qgis.osgeo.org>. Acesso em: 10 jul. 2019.

SHUBO, T.; DUTRA, G.; MONTENEGRO, S. G. Water Farmers - An Aquifer Recharge Case Study in 4 Caparaó, Brazil. In: 10th International Symposium on Managed Aquifer Recharge (ISMAR10), Paper for ISMAR10 symposium. Topic No: 1, 2019, Madrid. Anais:...Proceedings of the 10th International Symposium on Managed Aquifer Recharge (ISMAR10) 2019

Disponível em: https://www.researchgate.net/profile/Enrique_Escalante/publication/337732505_ISMAR10_I NTERNATIONAL_SYMPOSIUM_ON_MANAGED_AQUIFER_RECHARGE_ABSTRACTS_B OOK PROGRAM 2019/links/5de788ee299bf10bc33d9a05/ISMAR10-INTERNATIONALSYMPOSIUM-ON-MANAGED-AQUIFER-RECHARGE-ABSTRACTS-BOOK-PROGRAM2019.pdf>. Acesso em: 01 out. 2020.

\section{SISTEMA INTEGRADO DE BASES GEOESPACIAIS DO ESTADO DO ESPÍRITO SANTO/INSTITUTO ESTADUAL DE MEIO AMBIENTE E RECURSOS HÍDRICOS (GEOBASES/IEMA). Dados geográficos: Download. Disponível em: < https://geobases.es.gov.br/ >. Acesso em: 15 jul. 2019.}

SOARES, D. F.; FARIA, A. M.; ROSA, A. H. Análise de risco de contaminação de águas subterrâneas por resíduos de agrotóxicos no município de Campo Novo do Parecis (MT), Brasil. Engenharia Sanitária e Ambiental, v. 22, n. 2, p. 277-284, 2017.

SOS Mata Atlântica/INPE: Atlas dos Remanescentes Florestais da Mata Atlântica Período 2008-2010. Disponível em:<mapas.sosma.org.br/site_media/dowload/atlasrelatorio2008-2010parcial.pdf>. Acesso em: 02 ago. 2011.

Atlas dos Remanescentes Florestais da Mata Atlântica -Período 2018-2019. Disponível em:< https://www.sosma.org.br/iniciativa/atlas-da-mata-atlantica/>. Acesso em: 21 ago. 2020.

VENTURIN, G. H. Diagnóstico físico conservacionista da bacia hidrográfica do ribeirão Jerusalém, Alegre-ES. Jerônimo Monteiro, 2011. 95 p. Dissertação. (Mestrado em Ciência Florestal) - Universidade Federal do Espírito Santo, 2011. 


\section{Capítulo 4}

\section{Arborização de cafezais: diversificação do sistema e melhoria da qualidade de bebida}

Isabel Inácio de Moraes Souza ${ }^{1}$, Maurício Novaes Souza² ${ }^{2}$ Mário Euclides Pechara da Costa Jaeggi $^{3}$, Marta dos Santos Freire Ricci', João Batista Pavesi Simão², Janaina Ribeiro Costa Rouws $^{4}$, Ednaldo da Silva Araújo ${ }^{4}$

\section{Introdução}

O café se apresenta como uma das bebidas mais antigas e apreciadas do mundo. Depois da água, o café é a bebida mais consumida no Brasil (BESSA e TADEU, 2015). Apesar desse destaque e de um passado glorioso, atualmente a cultura é impactada pela falta de interesse político e econômico (PIMENTA et al., 2008).

Mesmo assim, o Brasil lidera a produção cafeeira mundial, com destaque para as espécies de Coffea arabica L. (café arábica), com $75 \%$ da produção, e Coffea canephora Pierre (café robusta), correspondendo a $25 \%$ do total produzido (CONAB, 2020. Essas espécies têm características diferentes de arquitetura, comportamento, manejo, qualidade de bebida e participação na economia da cafeicultura. A atividade representa uma importante parcela do PIB nacional, e proporciona emprego e renda para muitas famílias, cumprindo importante função social (TEIXEIRA et al., 2004).

A espécie Coffea arabica L. é predominante nos estados das regiões de Minas Gerais, considerado o maior produtor nacional, seguido pelos estados de São Paulo, Espírito Santo, Bahia, Rondônia, Paraná, Rio de Janeiro, Goiás, Mato Grosso, Amazonas e Pará. O Coffea canephora tem destaque no estado do Espírito Santo, sendo o responsável por mais de 75\% da produção nacional (CONAB, 2019).

A cafeicultura brasileira é constituída por extensas áreas de monocultura a pleno sol, não levando em consideração o fato de o cafeeiro ser uma espécie que tem origem em florestas caducifólias do continente africano, ou seja, seu crescimento e desenvolvimento ocorrem a meia sombra (MIRANDA, 1999; RICCI et al., 2006; OLIVEIRA, 2012).

${ }^{1}$ Me. em Agroecologia pelo Programa de Pós-Graduação em Agroecologia do Instituto Federal do Espírito Santo - Campus de Alegre, Caixa Postal 47, CEP: 29500-000, Alegre-ES. E-mail: isabel.inacio51@hotmail.com

2Drs. Professores do Instituto Federal do Espírito Santo - Campus de Alegre, Caixa Postal 47, CEP: 29500-000, Alegre-ES. E-mail: jbpavesi@gmail.com, mauriciosnovaes@ifes.edu.br;

${ }^{3}$ Doutorando em Produção Vegetal pela Universidade Estadual Norte Fluminense Darcy Ribeiro. Email: mariopechara@hotmail.com

${ }^{4}$ Drs. Pesquisadores da Embrapa Agrobiologia, CEP: 23890-000, Seropédica, RJ, Email: marta.ricci@embrapa.br, janaina.rouws@embrapa.br, ednaldo.araujo@embrapa.br 
Diversos fatores vêm afetando a produção do café brasileiro, tais como a redução no valor de mercado, principalmente devido à maior competição mundial, à crescente demanda por um produto com melhor qualidade de bebida, o que tem se mostrado fundamental para o sucesso da atividade, bem como pelas condições climáticas adversas, consequência do aquecimento global e do manejo (PIMENTA et al., 2008; DAMATTA et al., 2010).

Diante do exposto, é urgente a necessidade de se aprimorar as técnicas de manejo da cultura do café. De acordo com Matiello (1995), Vaast (2006) e Souza (2018), a arborização do cafeeiro pode garantir a sustentabilidade da produção e a melhoria da qualidade da bebida. Além disso, a arborização pode proporcionar equilíbrio ecológico e ambiental, permite aumentar o processo de ciclagem de nutrientes dentro do sistema, além de melhorar o controle térmico dentro da lavoura.

Dessa forma, a arborização contribui para a geração de impactos socioambientais e externalidades positivas, culminando na geração de uma renda secundária, a partir da exploração das espécies consorciadas. Há de se considerar ainda, que quando o cafeeiro é cultivado a pleno sol, a produção de frutos apresenta grande oscilação, por conta da alta dependência de adubação, além da aumentar a suscetibilidade das plantas ao ataque de pragas e doenças (ALVARENGA, 2004; SOUZA, 2018).

O presente capítulo demonstra que o cultivo arborizado é uma alternativa interessante para os cafeicultores tanto da espécie arábica como conilon. Pode-se destacar que o clima tropical presente no Brasil e nas diferentes regiões de cultivo, proporciona microclimas específicos para cada região e, a depender do manejo, podem atenuar a radiação nos cafezais e, consequentemente, a redução da temperatura.

O objetivo deste capítulo é discorrer sobre os benefícios e a importância da arborização para a cafeicultura nacional.

\section{Origem da arborização (sombreamento) do cafezal}

O café tem origem em sub-bosques da Etiópia, encontrando-se originalmente em equilíbrio com ambientes de clima ameno, a meia sombra. De acordo com Jaramillo-Botero et al. (2006), o cafeeiro consorciado com árvores (diversificado) é um dos sistemas mais antigos de produção de café no mundo, particularmente difundido na Colômbia, Costa Rica, Guatemala, El Salvador e México; também, na região Norte e Nordeste do Brasil. No entanto, esses autores destacam que a arborização ou diversificação dos cafezais, associada ao baixo uso de tecnologias, contribuía, em regra, para um menor nível de produtividade alcançada.

Em busca do aumento da produção, a arborização foi sendo cada vez mais desprestigiada. Assim, o cafeeiro foi disseminado pelo mundo e, ao longo dos anos, sofreu grandes alterações 
Isabel Inácio de Moraes Souza et al.

em sua base genética e comportamental, de modo que nas últimas décadas é, predominantemente, plantado em áreas a pleno sol (MIRANDA, 1999; OLIVEIRA, 2012).

O distanciamento da condição de cultivo, em relação àquela observada na região de origem do café, pode aumentar a vulnerabilidade da cultura e dos produtores de café nos cenários futuros de mudanças climáticas e contribuir para a redução da qualidade da bebida. Souza (2020a) demonstrou que a qualidade do café, física e sensorial, é influenciada pelo sistema de cultivo (arborizado e a pleno sol), sendo que o grau de influência depende do tipo de planta companheira. Considerando que o café tem o preço associado a sua qualidade, a arborização do cafeeiro, quando bem planejada e conduzida, pode trazer benefícios ambientais e econômicos à cafeicultura.

\section{Efeito da arborização na produtividade e na qualidade do café}

Projeções climáticas para o século XXI apontam para um aumento de temperatura e eventos climáticos extremos. A centralização dos gases de efeito estufa causa alterações nos elementos atmosféricos. Se as estimativas de temperatura estiverem corretas, a temperatura média poderá aumentar entre $1^{\circ} \mathrm{C}$ e $5,8^{\circ} \mathrm{C}$. Estes valores trariam grandes impactos para a cafeicultura e para os recursos naturais (COLTRI et al., 2015).

Alguns autores discutem estratégias para a redução desta vulnerabilidade ambiental, econômica e social, nas quais o retorno da arborização (PINTO et al., 2008) poderá originar, além de benefícios ecológicos e econômicos (PERFECTO et al., 1996), uma estabilidade na variabilidade do microclima dos plantios.

O cafeeiro pertence ao grupo de plantas C3, sendo adaptado a ambientes amenos e úmidos, possuindo adaptações fisiológicas e morfológicas para áreas de sombreamento (BRAUN et al., 2007). Sendo assim, muitos são os estudos relacionados aos efeitos da disponibilidade luminosa para a lavoura de café (FREITAS et al., 2003; RICCI et al., 2006; VAAST et al., 2006; GOMES et al., 2008; MORAIS et al., 2008; COELHO et al., 2010; LEMOS et al., 2010). Entretanto, em cada uma das situações surgem novas indagações sobre qual será o nível ideal de sombreamento. Contudo, todas as informações geradas são importantes, pois garantem o aprimoramento de seu cultivo.

Alguns autores definem que o limite máximo aceitável de sombreamento em cafeeiros está entre 40 e 70\% (KUMAR e TIESZEN, 1980; MUSCHLER, 1997). Mas, de acordo com DaMatta (2004), o sombreamento do cafeeiro em regiões tropicais deve corresponder a $20 \%$ da superfície. No entanto, esses níveis podem se adequar aos novos cenários proporcionados pelas mudanças climáticas, chegando até a $40 \%$. Há de se considerar, contudo, que o 
excesso de sombreamento pode ser prejudicial a sua produtividade, que também pode ser influenciada pela cultivar utilizada.

O déficit hídrico e a alta radiação solar também são alguns dos principais fatores ambientais que limitam o crescimento e a produtividade do cafeeiro (CHAVES et al., 2009). Em ambientes a pleno sol, a aclimatação e o regime hídrico podem ser ainda mais severos ao desenvolvimento fenológico e produtivo do cafeeiro (GALLÉ e FELLER, 2007).

A arborização é utilizada como atenuante da ação direta da radiação solar sobre o cafeeiro, com o objetivo de evitar a saturação de luz nas folhas decorrentes de alterações fisiológicas e, inclusive, a deterioração dos compostos foliares, conhecido como efeito escaldadura (ALVARENGA e GUIMARÃES, 1998). Todavia, a presença de árvores ajuda na conservação da umidade devido à serapilheira que se forma na superfície do solo proveniente da queda das folhas, além de aumentar a capacidade de absorção e infiltração de água no solo (MUSCHLER, 2000; BARBERA-CASTILLO, 2001).

Para a conservação do solo e da água, por meio do manejo da lavoura cafeeira, recomendam-se práticas conservacionistas fundamentadas em três princípios básicos: aumento da cobertura vegetal, que reduz a desagregação e transporte de partículas do solo; aumento da infiltração de água no solo que reduz o escoamento superficial e as perdas de água e solo e; aumento da rugosidade do terreno, que auxilia a reduzir a velocidade e o volume do escoamento superficial e ajuda a aprisionar os sedimentos da erosão. Esses são os princípios básicos de conservação sugeridos pela cafeicultura agroecológica (SOUZA, 2015).

Nesse novo cenário proporcionado pelo aumento de temperatura, os benefícios da arborização estão diretamente relacionados à agroecologia. Esta ciência busca o equilíbrio da produção e do ambiente, de maneira sustentável e harmoniosa, incluindo os três pilares da sustentabilidade, que abarcam os aspectos ambiental, social e econômico. A produção de cafeeiros arborizados tem como principal característica um redesenho da propriedade, visto que a arborização não está presente no modelo convencional existente (LOPES, 2012).

O café arborizado se distingue do café a pleno sol desde o plantio. Ricci et al. (2006) e Tatagiba et al. (2010), avaliando o crescimento de mudas de cafeeiro sobre diferentes níveis de radiação, observaram um aumento na área foliar do cafeeiro em ambientes sombreados. Fernandes (1986) destacou a melhoria do aspecto vegetativo do cafeeiro por conta da maior área fotossintética, além do aumento da área foliar, aumento do número de ramos primários e secundários e menor incidência da seca de ponteiros. Segundo Matiello (1995), em lavouras sombreadas é nítida a diminuição da desfolha dos cafeeiros, a presença de plantas mais vigorosas, a maior proteção da lavoura contra os ventos, o menor ataque de bicho-mineiro, a maior preservação da biodiversidade, o melhor controle térmico dentro da lavoura, maior 
proteção da lavoura contra geadas e/ou altas temperaturas, além da diminuição da bianualidade da produção entre as safras sucessivas.

\section{Estudo de caso: Efeito da arborização na produtividade e na qualidade do café na Região do Caparaó}

Souza et al. (2020b) avaliaram a influência dos sistemas de produção de café arábica a pleno sol e arborizado, com espécies distintas, em aspectos qualitativos, que compreendem a classificação física e sensorial do grão. O estudo foi realizado na região do Caparaó, que compreende uma parte da região sudoeste do Espírito Santo e das Matas de Minas Gerais. Para realização do experimento foram selecionadas nove propriedades que apresentavam simultaneamente uma lavoura de café com a variedade Catuaí Vermelho IAC 44 a pleno sol e uma arborizada.

As unidades experimentais foram constituídas de lotes de sete litros de café cereja, colhidos de forma seletiva, no terço médio de 20 plantas escolhidas de forma aleatória, tanto em sistema a pleno sol, quanto sob sombreamento. Ao todo foram utilizadas 9 amostras originadas de lavouras a pleno sol e 10 de lavouras arborizadas com diferentes espécies, tais como cedro, eucalipto, palmito, policultura (caracterizado pelo sombreamento com espécies frutíferas e madeireiras) e banana.

Depois de colhidas, as amostras foram transportadas no mesmo dia para unidade experimental de café do Instituto Federal do Espírito Santo campus de Alegre, onde foram lavadas e secas até atingirem umidade ideal de $11 \%$ em terreiro suspenso. Em seguida, foram beneficiadas, classificadas e degustadas no Laboratório de Classificação e Degustação de Café do IFES. Aplicou-se a análise estatística multivariada aos dados por meio da geração de gráficos de análise de componentes principais e de agrupamento (dendrogramas).

Os resultados demonstraram que as diferentes formas de se conduzir as lavouras de café na região do Caparaó interferirem em aspectos físicos dos grãos e sensoriais da bebida. De modo geral, o sombreamento provocou alterações no microclima de cada lavoura, de forma diferente em cada propriedade, acarretando em menos ou mais defeitos, grupos de granulometria e melhor qualidade de bebida em determinado modelo, enquanto lavouras a pleno sol apresentaram notas médias para todas as variáveis abordadas (SOUZA et al., 2020b). Os autores observaram que os tratamentos cedro e eucalipto foram os sistemas que apresentaram, de uma maneira geral, menores porcentagens de defeitos.

É possível visualizar, no dendrograma gerado a partir dos caracteres de defeitos do café (Figura 1), a formação de dois grupos distintos de tratamentos, quando se observa a linha vertical de corte que foi traçada arbitrariamente na distância de ligação de 50\% considerando- 
se os saltos nas distâncias. Quanto menor à distância, maior a semelhança entre os tratamentos. Assim, o primeiro grupo de cafés representa os tratamentos: solteiro (pleno sol), palmito, banana e policultura, e o segundo grupo de tratamentos é formado por cedro e eucalipto.

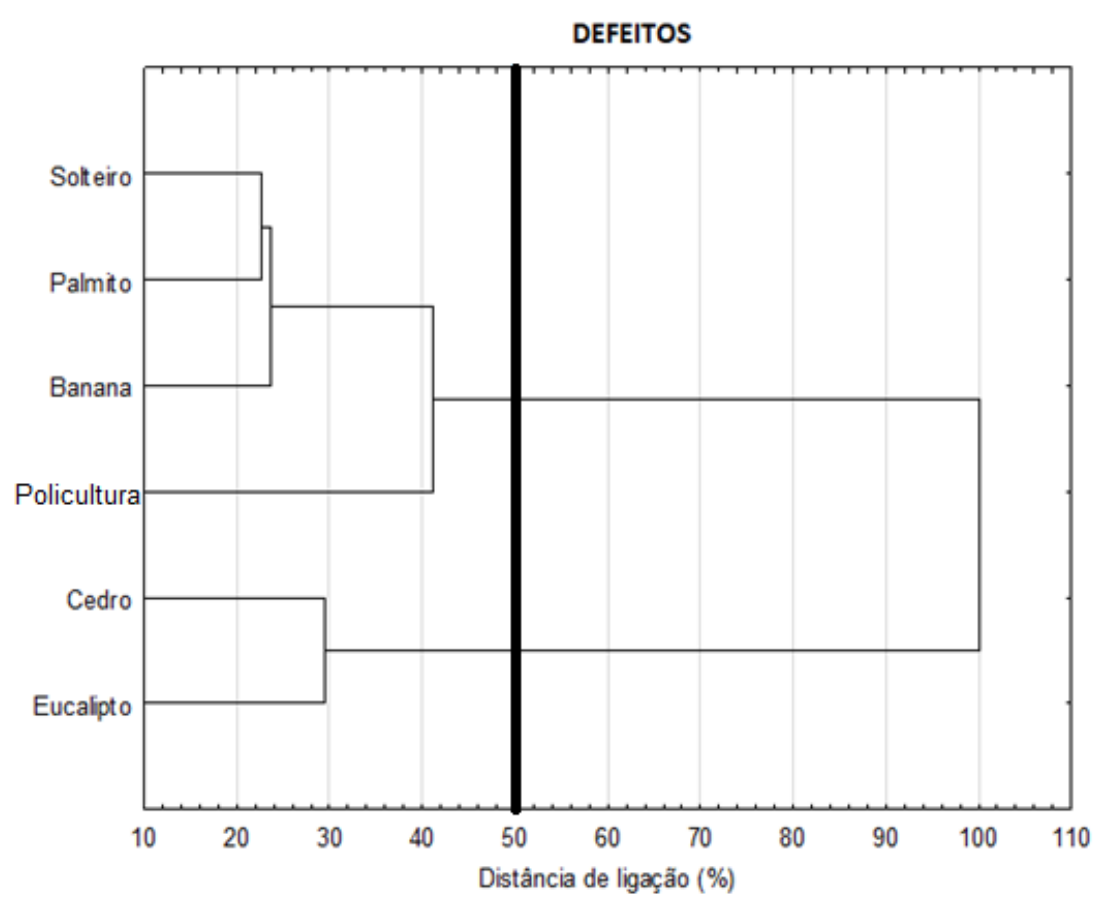

Figura 1. Dendrograma de agrupamento dos cultivos de cafés dos tipos solteiro (pleno sol) e arborizados com banana, cedro, eucalipto, palmito e policultura usando as variáveis: porcentagem de grãos ardidos (\%ARD), de conchas (\%CON), quebrados (\%QUEB), mal granados (\%M.GRA), broca limpa (\%B.LIM), broca suja (\%B.SU) e broca rendada (\%B.REN), por meio do método de Ward e distância euclidiana como medida de parecença.

Fonte: Souza et al. (2020b).

O dendrograma gerado a partir dos caracteres de granulometria do café possibilitou a formação de quatro grupos distintos (Figura 2). O grupo 1, correspondeu aos tratamentos cedro e eucalipto, que apresentaram-se igualmente responsáveis pela maior granulometria dos grãos de café quando comparados aos outros cultivos. O grupo 2 permitiu a junção dos tratamentos de café solteiro e arborizado com banana. Já o tratamento palmito e policultura ficaram isolados em um grupo cada.

Estes resultados permitem verificar a semelhança entre os tratamentos pertencentes ao mesmo grupo com relação à granulometria. 


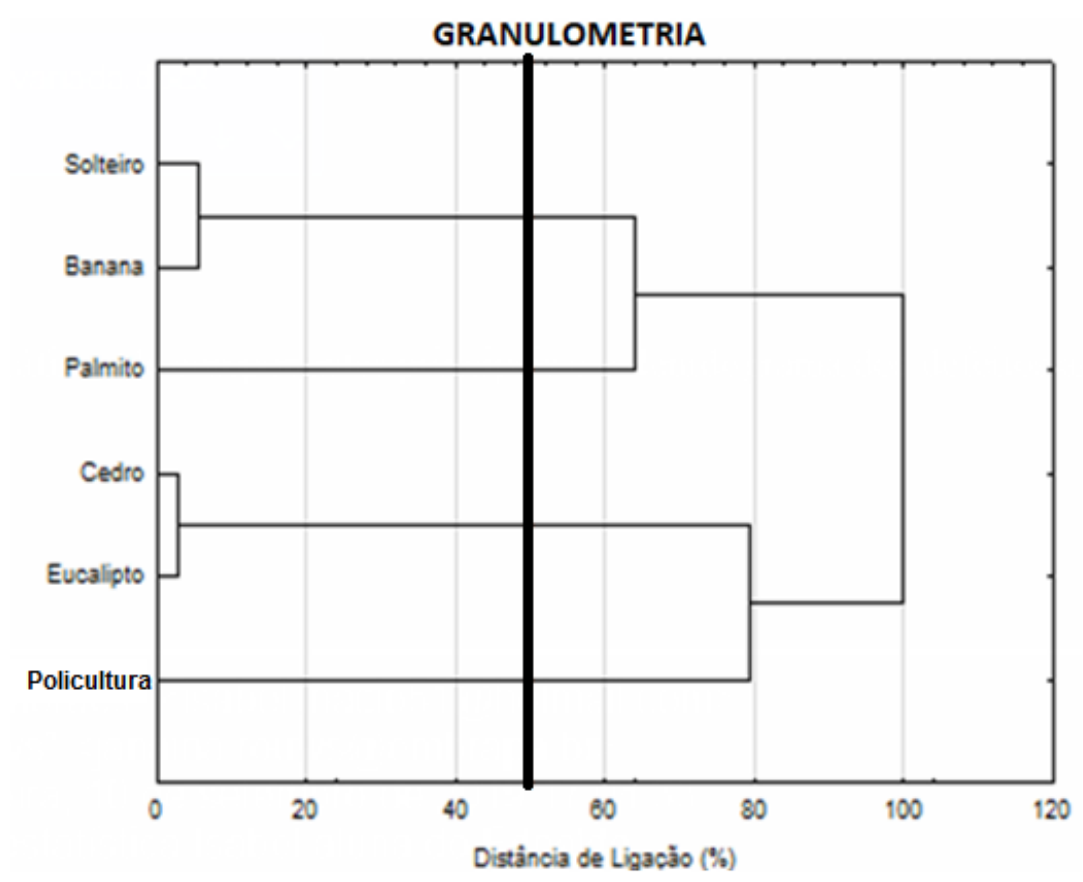

Figura 2. Dendrograma de agrupamento dos cultivos de cafés dos tipos solteiro e arborizados com banana, cedro, eucalipto, palmito e policultura, usando as variáveis granulométricas: porcentagem de chato miúdo (\%CMi), de chato médio (\%CM), chato graúdo (\%CG), moca miúdo (\%MMi), moca médio (\%MM) e moca graúdo (\%MG), por meio do método de Ward e distância euclidiana como medida de parecença.

Fonte: Souza et al. (2020b).

Quanto a análise sensorial, os autores destacam que o café proveniente do cultivo em policultura tende a se relacionar à melhor avaliação de todas as características avaliadas, acarretando em uma melhor qualidade de bebida do café.

A figura 3 representa os resultados da análise sensorial do café pela análise de dendrograma. Nesta figura, é possível observar a formação de dois grupos, o grupo 1, contendo os tratamentos solteiro, cedro, palmito e banana, e o grupo 2 contendo os tratamentos policultura e eucalipto, havendo semelhanças com relação a avaliação sensorial dentro de cada grupo. 


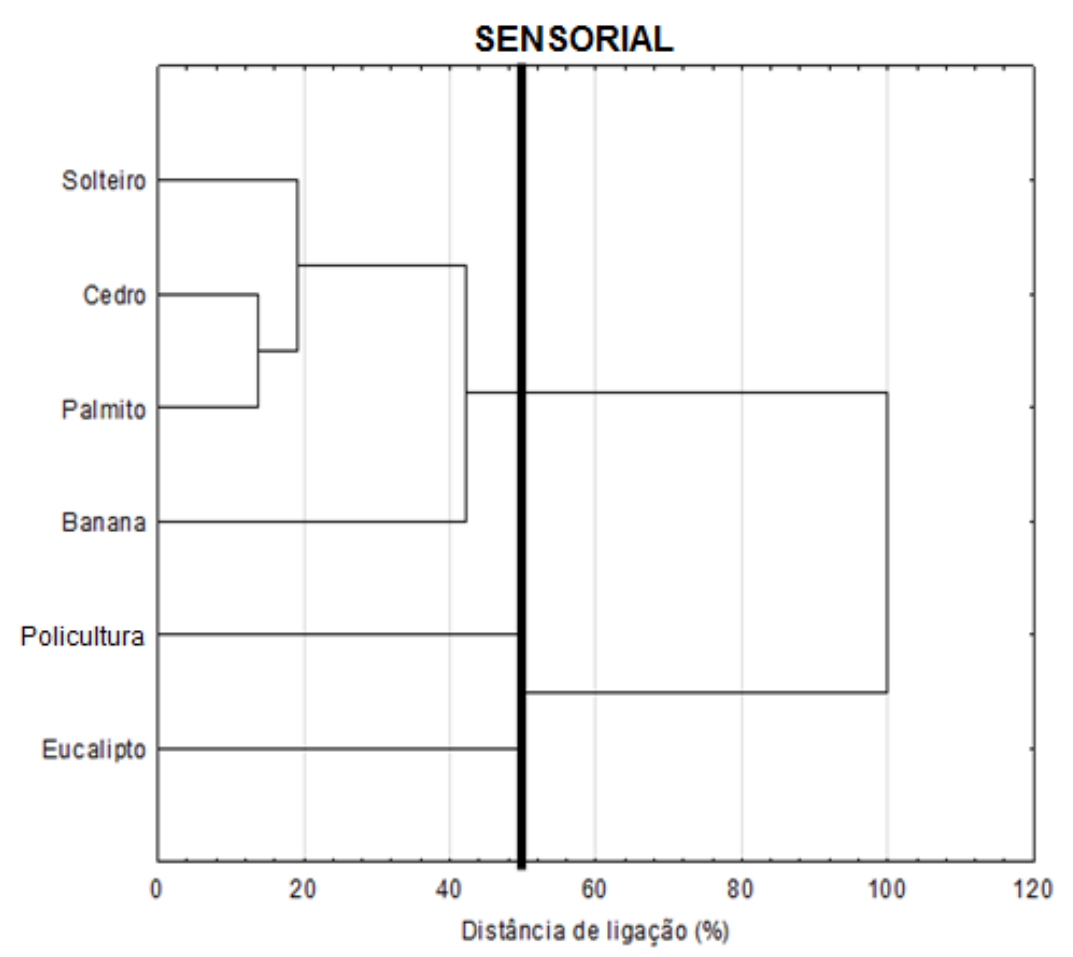

Figura 3. Dendrograma de agrupamento dos cultivos de cafés dos tipos solteiro e arborizados com banana, cedro, eucalipto, palmito e policultura usando as variáveis sensoriais: fragrância e aroma (FRAR), sabor (SAB), finalização (FIN), corpo (CORP) e geral (GER) por meio do método de Ward e distância euclidiana como medida de parecença.

Fonte: Souza et al. (2020b).

Os autores concluíram que nas condições experimentais acima descritas, a qualidade do café, física e sensorial, é influenciada pelo sistema de cultivo (arborizado e a pleno sol), sendo que, o grau de influência é dependente do tipo de planta companheira. Os sistemas de café em cultivo arborizado com cedro e eucalipto apresentaram o menor número de defeitos em grãos crus e maior proporção de grãos chato graúdo (\%CG). O tratamento de café arborizado com policultura apresentou maior porcentagem de moca graúdo (\%MG). O cultivo de café arborizado com policultura apresenta ainda melhor qualidade sensorial, quando comparado aos demais consórcios estudados, seguido do sistema de cultivo arborizado com eucalipto.

A arborização apresenta outros pontos positivos tais como a maior ciclagem de nutrientes, à diminuição da taxa de decomposição da matéria orgânica devido à redução da temperatura incidente no solo, à redução do risco de erosão, maior presença de raízes, a maior ocorrência de controladores naturais de pragas e doenças, ocupação da mão de obra na entressafra e, principalmente, a conservação do meio ambiente (RODRIGUES et al., 2001).

A utilização de um componente arbóreo também pode contribuir para o custeio econômico da lavoura de café. Isso tem grande importância em períodos de preços reduzidos da saca de café no mercado, normalmente ocasionada pela grande oferta do produto (ALVARENGA e GUIMARÃES, 1998). 
Vários autores confirmam a rentabilidade da arborização, como Pinto de Sá et al. (2008), que demonstram a viabilidade financeira dos sistemas agroflorestais. Rodigherí (1997) cita a importância de espécies florestais como "poupanças verdes". Já a arborização do cafeeiro com espécies frutíferas demanda um maior manejo, por se tratarem de culturas mais exigentes. Porém, além contribuir com o sombreamento, reduz o custo do manejo do cafezal, ao gerar renda extra nos períodos em que os preços do café estão baixos no mercado mundial (PEZZOPANE et al., 2010).

A arborização do cafezal tem influência na qualidade física e sensorial do café. Segundo Matiello (2002), quando os frutos se encontram em ambientes parcialmente sombreados ocorre uma maturação mais lenta dos frutos durante todo seu estágio fenológico. Este período de prolongamento da maturação dos frutos dá aos grãos mais tempo para se prepararem, concentrando e metabolizando todos os nutrientes para o enchimento dos grãos, e todos os açúcares necessários para o estágio 'cereja' de maturação dos frutos, refletindo no ápice de doçura. Também é observado o maior peso dos grãos e maior granulometria.

Os grãos de café produzidos em sistema de manejo arborizado apresentam maior atividade de antioxidantes, de compostos fenólicos totais e maior presença de ácidos clorogênicos, além de se destacar o comparecimento de mais açúcares totais, como frutose, sacarose e glicose, que são de fundamental interesse para o mercado internacional e para os de cafés especiais (SOMPORN et al., 2012). Em lavouras conduzidas a pleno sol, devido a alta incidência de luz solar, muitas vezes os grãos passam do estágio verde para seco, devido à queima dos tecidos da casca do fruto. Contudo, pesquisas relatam a redução de produtividade do cafezal em sistemas sombreados, apesar de apresentar, na maioria dos casos, melhor qualidade de bebida (VAAST et al., 2006).

A implantação de lavouras cafeeiras em consórcio com espécies arbóreas, a meia sombra, é apontada como uma opção para a melhoria da qualidade física e sensorial do café (BOSSELMANN et al., 2009; LÄDERACH et al., 2011; STEIMAN et al., 2011), sendo de grande importância para os consumidores e tornando a cafeicultura mais competitiva e rentável (ABIC, 2016). Para Matiello (2002), quando a maturação dos frutos ocorre de forma mais lenta, existe a possibilidade de maior porcentagem de frutos a serem descascados e despolpados, o que permite plenamente a adoção de uma pós-colheita por via úmida, acarretando excelentes resultados sensoriais.

Os benefícios da sombra são explicados principalmente pela redução de estresse induzido pelo calor na planta e por um prolongamento do período de maturação dos frutos (MORAIS et al., 2006; BOSSELMANN et al., 2009; STEIMAN et al., 2011). Contudo, plantas de café cultivadas sob sombras densas, com baixo nível de radiação, podem apresentar uma menor qualidade sensorial da bebida (BOSSELMANN et al., 2009). 
Mancuso (2013) considera o cultivo de café arborizado uma alternativa viável para a produção de um café superior, desde que seja em equilíbrio, e também pelo incremento da renda, carecendo ainda de estudos para a escolha das espécies e variedades do consórcio em cada região, para que haja uma produção satisfatória e viável economicamente.

\section{Espécies utilizadas na arborização do café}

A arborização em consórcio com cafeeiro e uma prática agroflorestal (MONTAGNINI, 1992), devido ao envolvimento de uma cultura agrícola com árvores, conforme conceito proposto por NAIR (1989).

Alguns pesquisadores estabelecem o sombreamento como uma prática de consórcio de plantas arbóreas entre os cafeeiros em proporções delimitadas, com o objetivo de minimizar o excesso de insolação (LAZZARINI, 1962). Em contraposição, autores como (CAMARGO et al., 1985; MIGUEL et al., 1995; MALAVOLTA, 2000) indicam o mesmo manejo, porém a partir de níveis menores de sombra, com a finalidade de que a cultura de interesse, no caso o cafeeiro, receba uma quantidade de radiação suficiente para que não haja impactos negativos na produção e ao mesmo tempo gere condições microclimáticas favoráveis ao desenvolvimento da cultura.

A arborização obtém o conceito de complementaridade em que a cultura agrícola e a arbórea, ao invés de competir pelos recursos do meio, se beneficiariam uma com as outras. No entanto, cabe destacar que, quando inseridas árvores no sistema, a influência pode ser positiva ou negativa. Segundo Sanchez (1995), o método de manejo entre as interações de luz, água e nutrientes é de extrema relevância para favorecer a complementaridade entre as espécies, ao invés da competição pelos recursos do meio.

Os consórcios mais utilizados no Brasil estão relacionados às árvores para produção de madeira, como algumas espécies de mogno, cedro, grevílea e seringueiras, além de frutíferas, como a bananeira, policulturas e ainda espécies de leguminosas (JARAMILLO-BOTERO et al., 2006; RICCl et al., 2006).

As plantas da família Fabaceae (Leguminosas) contribuem com o fornecimento de nitrogênio derivado do processo de Fixação Biológica de Nitrogênio do ar atmosférico (FBN). Contudo, é importante lembrar que é necessário atentar para um manejo de poda das leguminosas, de forma que proporcione sincronismo entre a liberação de $\mathrm{N}$ pela decomposição do material da poda e a demanda de $\mathrm{N}$ pela cultura do cafeeiro. De acordo com Bergo et al., (2006), Paulo et al., (2006) e Matos et al., (2011), quando a leguminosa é podada tardiamente, pode comprometer o retorno do cafeeiro em termos de produtividade e, consequentemente, o retorno econômico esperado. Nesse sentido propõem-se a antecipação 
da poda das leguminosas para o início do período das chuvas (ARAÚJO et al., 2007) e a diminuição do período de consórcio com as leguminosas (ARAÚJO et al., 2007; BARRELA, 2010), visando a redução da competição e a mineralização do $N$ antes que os frutos dos cafeeiros estejam formados.

A poda das leguminosas tem duas funções: ralear o dossel para manter o nível de sombreamento adequado e servir como adubação verde para o cafeeiro.

\section{Considerações finais}

A arborização apresenta diversos benefícios ambientais, dentre eles, benefícios nas características agronômicas e fenológicas, tais como o melhor aspecto dos cafeeiros, maior tamanho de folhas e frutos, a diminuição da bianualidade da produção, menor ataque de pragas e doenças devido a maior diversidade e maior equilíbrio ecológico.

A arborização apresenta também diversos benefícios edafoclimáticos, tais como a maior ciclagem de nutrientes, a menor degradação da matéria orgânica, maior controle térmico dentro da lavoura, maior controle do vento (quebra-vento), maior proteção do solo e maior retenção de água.

Sobre os benefícios econômicos e sociais, pode-se destacar a demanda por mão de obra na entressafra, o incremento de renda ao produtor devido à melhor qualidade do café, além de proporcionar renda extra por conta das outras culturas utilizadas em consórcio com o cafeeiro.

A condição de arborização das lavouras cafeeiras está diretamente ligada à agroecologia. Pois, a agroecologia busca a sinergia e o equilíbrio do ecossistema, bem como das culturas e de todos os atores e fatores que contribuem para a produção e para garantir a sustentabilidade familiar no ambiente rural. Com a arborização, além da valorização do pequeno produtor, ocorre a possibilidade de renda extra e a diversidade de culturas, fatores que concorrem para potencializar a sustentabilidade no campo.

\section{Referências}

ALVARENGA, M. I. N.; GUIMARÃES, P. T. G. Arborização como componente da sustentabilidade da lavoura cafeeira. Lavras: Empresa de Pesquisa Agropecuária de Minas Gerais - EPAMIG. n. 80, abril, 1998 (Circular Técnica).

ALVARENGA, A. de P.; VALE, R. S. do.; COUTO, L.; ANGELI, F.; VALE, F. do.; VALE, A. B. do. Aspectos fisiológicos da cultura do café e seu potencial produtivo em sistemas agroflorestais. Agrossilvicultura, v. 1, n. 2, p. 195-202, 2004.

ARAÚJJ, J. B. S., BALBINO, J. W. S. Manejo de guandu (Cajanus cajan (L.) Millsp) sob dois tipos de poda em lavoura cafeeira. Coffee Science, Lavras, v. 2, p. 61-68, 2007. 
ASSOCIAÇÃO BRASILEIRA DA INDÚSTRIA DO CAFÉ - ABIC. Estudo de Qualidade Café Conilon. 2006. Disponível em: < https://www.abic.com.br/>. Acesso em: 30 mar. 2016.

BARBERA-CASTILLO, N. M. Diversidad de especies de hormigasen sistemas agroforestales contrastantes de café, em Turrialba, Costa Rica. 2001. 99f. Dissertação (Mestrado) - Centro Agronómico Tropical de Investigación y Enseñanza, Turrialba, Costa Rica, 2001.

BARRELLA, T. P. Manejo de espécies de leguminosas em cafezal sob cultivo orgânico. Viçosa, MG. 2010. 95 f. Tese (Doutorado em Fitotecnia) - Universidade Federal de Viçosa UFV, Viçosa, 2010.

BERGO, C. L., PACHECO, E. P., MENDONÇA, H. A., MARINHO, J. T. S. Avaliação de espécies leguminosas na formação de cafezais no segmento da agricultura familiar no Acre. Acta Amazonica, Manaus, v. 36, n. 1, p. 19-24, 2006.

BESSA, F.; TADEU, L. Café é a segunda bebida mais consumida no Brasil. Embrapa notícias, 19/03/2015. Disponível em: <https://www.embrapa.br/busca-de-noticias//noticia/2574254/cafe-e-a-segunda-bebida-mais-consumida-no-brasil/>. Acesso em: 27 mar. 2019.

BOSSELMANN, A. S.; DONS, K.; OBERTHUR, T.; OLSEN, C.S.; RÆBILD, A.; USMA, H. The influence of shade trees on coffee quality in small holder coffee agroforestry systems in Southern Colômbia. Agriculture, Ecosystemsand Environment, v. 129, p. 253-260, 2009.

BRAUN. H.; ZONTA, J. H.; LIMA, J. S. S.; REIS, E. F. Produção de mudas de café 'conilon' propagadas vegetativamente em diferentes níveis de sombreamento. IDESIA. Chile. v. 25, n. 3, p. 85-91, 2007.

CAMARGO, A. P. O clima e a cafeicultura no Brasil. Informe Agropecuário, Belo Horizonte, v. 11, n. 126, p. $13-26,1985$.

CHAVES, M. M.; FLEXAS, J.; PINHEIRO, C. Photosynthesis under drought and salt stress: regulation mechanisms from whole plant to cell. Annals of Botany, Oxford, v. 103, n. 4, p. 551-560, 2009.

COELHO, R. A.; MATSUMOTO, S. N.; LEMOS, C. L.; SOUZA, F. A. Nível de sombreamento, umidade do solo e morfologia do cafeeiro em sistemas agroflorestais. Revista Ceres, Viçosa, v. 57, n. 1, p. 95-102, 2010.

COLTRI, P. P.; ALFONSI, W. M. V.; VANUCCI, A. L.; GONÇALVES, R. R. V.; JUNIOR, J. Z.; PINTO, H. S. Simulação da temperatura e umidade relativa do café arábica em sistemas arborizados e a pleno sol. IX Simpósio de Pesquisa dos Cafés do Brasil. Curitiba, PR. 2015.

COMPANHIA NACIONAL DE ABASTECIMENTO - CONAB. Acompanhamento da safra brasileira: café. Brasília, v. 6, n. 3, p. 1-54, 2020.

COMPANHIA NACIONAL DE ABASTECIMENTO - CONAB. Acompanhamento da safra brasileira: café, Brasília. 2019. Disponível em: <http://www.agricultura.gov.br>. Acesso em: 28 mar. 2019.

DAMATTA, F.M. Ecophysiological constraints on the production of shaded and unshaded coffee: a review. Field Crops Research v. 86, n. 2-3, p. 99-114, 2004. 
DAMATTA, F. M., GRANDIS, A.; ARENQUE, B. C.; BUCKERIDGE, M. S. Impacts of climate changes on crop physiology and food quality. Food Research International, Kidlington, v. 43, n. 7, p. 1814-1823. 2010.

FERNANDES, D. R. Manejo do cafezal. In: RENA, A. B.; MALAVOLTA, E.; ROCHA, M.; YAMADA, T. Cultura do cafeeiro. Piracicaba: Associação Brasileira para a Pesquisa de Potassa e do Fosfato, 1986. p. 275-301.

FREITAS, R. B.; OLIVEIRA, L. E. M.; DELÚ FILHO, N.; SOARES, A. M. Influência de diferentes níveis de sombreamento no comportamento fisiológico de cultivares de café (Coffea arabica L.). Ciência e Agrotecnologia, Lavras, v. 27, n. 4, p. 804-810. 2003.

GALLÉ, A.; FELLER, U. Changes of photosynthetic traits in beech saplings (Fagus sylvatica) under severe drought stress and during recovery. Physiologia Plantarum, Copenhagen, v. 131, n. 3, p. 412-421, Nov. 2007.

GOMES, I. A. C.; CASTRO, E. M.; SOARES, A. M.; ALVES, J. D.; ALVARENGA, M. I. N.; ALVES, E.; BARBOSA, J. P. R. A. D.; FRIES, D. D. Alterações morfofisiológicas em folhas de Coffea arabica L. cv, "Oeiras" sob influência do sombreamento por Acacia mangium Willd. Ciência Rural, Santa Maria, v. 38, n. 1, p. 109-115, 2008.

JARAMILLO-BOTERO, C.; MARTINEZ, H. E. P.; SANTOS, R. H. S. Características do café (Coffea arabica L.) sombreado no norte da américa latina e no Brasil: análise comparativa. Coffee Science, Lavras, v. 1, n. 2, p. 94-102, jul./dez. 2006.

KUMAR, D; TIESZEN, L.L. Photosynthesis in Coffea arabica: effects of light and temperature. Experimental Agriculture, v. 16, p.13-19, 1980.

LÄDERACH, P.; OBERTHUR, T.; COOK, S.; IZA, M. E.; POHLAN, J. A.; FISHER, M.; LECHUGA, R. R. Manejo agronômico sistemático para melhorar a qualidade do café. Pesquisas Field Crops. p. 321-329. 2011.

LAZZARINI, W. A cafeicultura no Brasil. In: Instituto brasileiro do café - IBC. Curso de economia cafeeira. 1962. t.1, p. 169-268.

LEMOS, C. L.; MATSUMOTO, S. N.; VIANA, A. E. S.; COELHO, R. A.; CÉSAR, F. R. C. F. Metabolismo de nitrogênio em dois sistemas de cultivo de café sob veranico da estação úmida. Revista Ceres, Viçosa, v. 57, p. 4-41, 2010.

LOPES, P. R.; ARAÚJO, K. C. S.; FERRAZ, J. M. G.; LOPES, I. M.; FERNANDES, L. G. Produção de café agroecológico no sul de Minas Gerais: sistemas alternativos à produção intensiva em agroquímicos. Revista Brasileira de Agroecologia, v. 7, n. 1, p. 25-38, 2012.

MALAVOLTA, E. História do café no Brasil: agronomia agricultura e comercialização. São Paulo: Ceres, 2000. 464 p.

MANCUSO, C. A. M.; SORATTO, P. R.; PERDONÁ, J. M. Produção de Café Sombreado. Colloquium Agrariae, v. 9, n.1, p. 31-44, jan-jun. 2013.

MATIELLO, J. B.; SANTINATO, R.; GARCIA, A. W. R.; ALMEIDA, S. R.; FERNANDES, D. R. Cutura de café no Brasil: novo manual de recomendações. Rio de Janeiro, RJ e Varginha, MG: MAPA/PROCAFÉ, 2002. 434 p. 
MATIELLO, J. B. Sistemas de Produção na Cafeicultura Moderna, Tecnologias de Plantio adensado, renque mecanizado, arborização e recuperação de cafezais. 1. ed. Rio de Janeiro: MM Produções Gráficas 1995. 102p.

MATOS, E. S.; MENDONÇA, E. S.; CARDOSO, I. M.; LIMA, P. C.; FREESE, D. Decomposition and nutrient release of leguminous plants in coffee agroforestry systems. Revista Brasileira de Ciência do Solo, Viçosa, v. 35, p. 141-149, 2011.

Miguel, A. E.; MATIELLO, J. B.; CAMARGO, A. P.; ALMEIDA, S. R.; GUIMARÃES, E. S. Efeitos da arborização de cafezal com Grevílea robusta nas temperaturas do ar e na umidade do solo - Parte II. In: Congresso brasileiro de pesquisas cafeeiras, 21. 1995, Caxambú, PROCAFE/DENAC. 1995. p. 55-57.

MIRANDA. E. M.; PEREIRA. R. C. A.; BERGO, C. L.; Comportamento de seis linhagens de café (Coffea arabica L.) Em condições de sombreamento e a pleno sol no estado do acre, brasil. Ciência e Agrotecnologia, Lavras, v. 23, n. 1, p. 62-69, jan./mar., 1999.

MONTAGNINI, F. Sistemas Agroforestales: principios y aplicaciones en los trópicos. 2. ed. San José: OET. 1992. 622 p.

MORAIS, H.; CARAMORI, P.H.; RIBEIRO, A.M.A.; GOMES, J.C.; KOGUISHI, M.S. Microclimatic characterization and productivity of coffee plants grown under shade of pigeon pea in Southern Brazil. Pesquisa Agropecuária Brasileira, v. 41, n. 5, p. 763-770, 2006.

MORAIS, H. Desenvolvimento de gemas florais, florada, fotossíntese e produtividade de cafeeiros em condição de sombreamento. Pesquisa Agropecuária Brasileira, Brasília, v. 43, n. 4, p. 465-472, 2008.

MUSCHLER, R. G. Shade or sun for ecologically sustainable coffee production: a summary of environmental key factors. In: III Semana Científica del Centro Agronómico Tropical de Investigación y Enseñanza. 1997, Turrialba, Costa Rica: CATIE, 1997. v. 3, p.109112.

MUSCHLER, R. G. Árboles em cafetales. Turrialba, Costa Rica: Catie/ GTZ, 2000. 139p. (Módulo de enseñanza agroforestal, 5).

NAIR, P. K. R. Agroforestry systems in the tropics. Dordrecht: Kluwer, 1989. 664p.

OLIVEIRA, P. I.; OLIVEIRA, L. C.; MOURA, C. S. F. T. Cultura de café: histórico, classificação botânica e fases de crescimento. Revista Faculdade Montes Belos, v. 5, n. 4, agosto 2012.

PAULO, E. M.; BERTON, R. S.; CAVICHIOLI, J. C.; BULISANI, E. A.; KASAI, F. S. Produtividade do cafeeiro Mundo Novo enxertado e submetido à adubação verde antes e após recepa da lavoura. Bragantia, Campinas, v. 65, n. 1, p. 115-120, 2006.

PERFECTO, I.; RICE, R. G.; VOORT, E. M. van der. Shade coffee: a disappearing refuge for biodiversity. BioScience, [S.I.], v. 46, n. 8, p. 598-608, 1996.

PEZZOPANE, J. R. M.; MARSETTI, M. M. S.; SOUZA, J. M.; PEZZOPANE, J. E. M. Condições microclimáticas em cultivo de café conilon a pleno sol e arborizado com nogueira macadâmia. Ciência Rural, Santa Maria, v. 40, n. 6, p. 1257-1263, 2010.

PIMENTA, C. J.; PEREIRA, M. C.; CHALFOUM, S. M.; ANGELÍCO, C. L.; MARTINS, R. T. Avaliação físico-quimica e de qualidade do café (Coffea arabica L.) submetido a diferentes 
tempos de espera para secagem. Revista Brasileira de Armazenamento, Viçosa - Especial Café, MG, n. 10, p. 29-35, 2008.

PINTO DE SÁ, C.; OLIVEIRA, T. K.; BAYMA, M. M. A.; OLIVEIRA, L. C. Caracterização e análise da rentabilidade financeira de um modelo de sistema agroflorestal desenvolvido em parceria com produtores do Reca. Rio Branco. Acre. 2008. (Circular Técnico).

RICCI, M. S. F.; COSTA, J. R.; PINTO, A. N.; SANTOS, V. L. S. Cultivo orgânico de cultivares de café a pleno sol e sombreado. Pesquisa Agropecuária Brasileira, Brasília, v. 41, n. 4, p. 569-575, 2006.

RODIGHERI, H. R. Rentabilidade econômica comparativa entre plantios florestais e sistemas agroflorestais com erva-mate, eucalipto e pinus e as culturas do feijão, milho, soja e trigo. Embrapa Floresta. Colombo, Paraná. 1997. 36 p.

RODRIGUES, V. G. S.; COSTA, R. S. C; LEÔNIDAS, F. C.; FREITAS, J. C. Arborização em lavouras de café: experiência de agricultores em rondônia - Brasil. In: SIMPÓSIO DE PESQUISA DOS CAFÉS DO BRASIL, 2. 2001. Vitória- ES. Anais eletrônicos... Vitória: ES, p. 1612-1617, 2001.

SANCHEZ, P. A. Science in agroforestry. Agroforestry Systems, Dordrecht, v. 30, p. 5-55, 1995.

SOMPORN, C.; KAMTUO, A.; THEERAKULPISUTB P.; SIRIAMORNPUNC, S. Effect of shading on yield, sugar content, phenolic acids and antioxidant property of coffee beans (Coffea arabica L. cv. Catimor) harvested from north-eastern Thailand. Journal Science of Food and Agriculture, v. 92, p. 1956-1963, 2012.

SOUZA, M. N. Mudanças no uso do solo e da água e a gestão dos recursos naturais. Frankfurt, Alemanha: Novas Edições Acadêmicas, v. 5000, 2015. 376p.

SOUZA, M. N. Degradação antrópica e procedimentos de recuperação ambiental. Balti, Moldova, Europe: Novas Edições Acadêmicas, v. 1000, 2018. 376p.

SOUZA, T. S. Qualidade da bebida do café conilon consorciado com diferentes espécies arbóreas e frutíferas, sob manejo orgânico. 2018. 57 f. Dissertação (mestrado) - Programa de Pós-Graduação em Agroecologia do Instituto Federal do Espírito Santo - Campus de Alegre, Alegre, 2018.

SOUZA, I. I. M. Aspectos qualitativos de café arábica em cultivo arborizado e a pleno sol na região do Caparaó. 2020. Dissertação (Mestrado em Agroecologia). Programa de Pós-Graduação em Agroecologia do Instituto Federal do Espírito Santo - Campus de Alegre. 2020a.

SOUZA, I. I. M.; ARAÚJO, E. S.; JAEGGI, M. E. P. C.; SIMÃO, J. B. P.; ROUWS, J. R. C.; SOUZA, M. N. Effect of afforestation of arabica coffee on the physical and sensorial quality of the bean. Journal of Experimental Agriculture International, v. 42, p. 133-143, 2020b.

STEIMAN, S.; IDOL, T.; BITTENBENDER, H.C.; GAUTZ, L. Shade coffee in Hawai'i Exploring some aspects of quality, growth, yield, and nutrition. Scientia Horticulturae, v. 128, p. 152-158, 2011.

TATAGIBA, S. D.; SANTOS, E. A.; PEZZOPANE, J. E. M.; REIS, E. F. Mudas de Coffea canephora cultivadas sombreadas e a pleno sol. Engenharia na Agricultura, Viçosa, v. 18, n. 3, p. 219-226, 2010. 
TEIXEIRA, M. M.; QUEIROZ, D. M.; PINTO, F. A. C. Passo a passo para se obter café de qualidade. Viçosa- MG-CPT- 2004. 168p.

VAAST, P.; BERTRAND, B.; GUYOT, B.; GE'NARD, M. Fruit thinning and shade influence bean characteristics and beverage quality of coffee (Coffea arabica L.) under optimal conditions. Journal Science of Food and Agriculture, v. 86, p. 197-204, 2006. 


\section{Capítulo 5}

\section{Proposições para melhoria das formas de manejo e qualidade do café conilon}

Lucas Louzada Pereira ${ }^{1}$, Alice Dela Costa Caliman², Fábio Luiz Partelli³, Marliane de Cássia Soares da Silva ${ }^{4}$, Paulo Prates Junior ${ }^{4}$, Aldemar Polonini Moreli ${ }^{1}$, Willian dos Santos Gomes ${ }^{5}$

\section{Introdução}

O café Coffea sp. é originário da África, sendo o Coffea arabica da Etiópia e Coffea canephora do Congo, constituindo assim as duas espécies de maior importância econômica na produção de café no mundo, se comparada a muitas outras espécies de café pertencentes ao gênero Coffea encontradas na literatura (AGNOLETTI, 2015).

O café foi introduzido no Brasil no século XVIII e desde então a cafeicultura tornou-se destaque na atividade agrícola e econômica do país, sendo suplanta na década de 70 pela industrialização do país. O Estado Espírito Santo é o maior produtor de Coffea canephora, cognominada como café conilon, e é responsável por mais de $75 \%$ do conilon produzido no Brasil (SOUZA, 2018).

Tradicionalmente, o cultivo de Coffea arabica L. era predominante no mundo e no Brasil. Entretanto, em meados do século XIX, um surto de ferrugem dizimou grande parte dos cafeeiros do sul e leste da Ásia, ocasionando na introdução do Coffea canephora como alvo de novos estudos, por apresentar características mais resistentes ao surto e demais fatores abióticos (VAN DER VOSSEN, 1985).

${ }^{1}$ Drs. Professores do Instituto Federal do Espírito Santo - Campus Venda Nova do Imigrante, Rua Elizabeth Minete Perim, 500, Bairro São Rafael, CEP: 29375-000, Venda Nova do Imigrante - ES. Email: lucas.pereira@ifes.edu.br; aldemar.moreli@ifes.edu.br

${ }^{2}$ Graduanda em Ciência e Tecnologia de Alimentos pelo Instituto Federal do Espírito Santo - Campus Venda Nova do Imigrante, Rua Elizabeth Minete Perim, 500, Bairro São Rafael, CEP: 29375-000, Venda Nova do Imigrante - ES. E-mail: alice.caliman@gmail.com

${ }^{3}$ Dr. Professor da Universidade Federal do Espírito Santo, Departamento de Ciências Agrárias e Biológicas, BR 101 Norte, Km. 60, Bairro Litorâneo, CEP: 29932-540, São Mateus, ES. E-mail: partell@yahoo.com.br

${ }^{4}$ Drs. Pesquisadores da Universidade Federal de Viçosa, Departamento de Microbiologia, Avenida Ph Rolfs, S/N, CEP: 36570-000, Viçosa-MG. mcassiabio@yahoo.com.br; junior_prates2005@yahoo.com.br

${ }_{5}^{5}$ Me. Doutorando pela Universidade Federal do Espírito Santo, Departamento de Genética e Melhoramento, Alto Universitário, S/N Guararema, CEP: 29500-000, Alegre - ES. E-mail: gwill.bio@gmail.com 
O Coffea canephora teve sua introdução no Espírito Santo em meados de 1920. O primeiro plantio ocorreu no município de Cachoeiro de Itapemirim e expandiu-se para a região norte do estado. O café robusta tornou-se a principal espécie do gênero cultivada no estado desde então devido a sua alta resistência a pragas e doenças, grande produtividade e ser de fácil adaptação em baixas altitudes e temperaturas elevadas (FERRÃO et al., 2015).

O Coffea canephora apresenta características distintas do Coffea arabica L., como grãos menores e mais arredondados, com cultivo mais simples e barato, já que as plantas são mais resistentes a doenças e pragas que afetam o cafeeiro, suportar climas mais quentes e facilidade de cultivo em baixas altitudes (MAXIMINO, 2018).

A qualidade da bebida do café torna-se vinculada aos atributos químicos, físicos e sensoriais, podendo sofrer interferências em função do local de cultivo, dos fatores genéticos, das condições de manejo de campo, dos microrganismos presentes no solo e nos frutos, e por fim, dos processos de pós-colheita (AGNOLETTI, 2015; TOMAZ et al., 2019).

Por apresentar maior teor de sólidos solúveis e rendimento que o café arábica, o conilon é parte fundamental na composição de blends ${ }^{1}$, participando com mais de $80 \%$ na composição na indústria (FONSECA et al., 2015),

Atrelado ao aumento do consumo do café em todo o mundo, observa-se também o acréscimo da demanda por cafés especiais de alta qualidade. Nesse cenário, o conilon tem sido foco de muitos estudos referentes a evolução de qualidade, o que vem contribuindo significativamente para a participação do café robusta no mercado de cafés de qualidade.

Com base no breve arcabouço descrito, este capítulo apresenta uma sistematização a respeito da cafeicultura do Coffea canephora, buscando explorar aspectos históricos, produtivos e qualitativos. Provendo um recorte estrutural a respeito desta variedade e assim, elaborar uma discussão sobre novas formas de manejo, especialmente com foco no sistema agroecológico, de modo que seja possível propor uma discussão a respeito do uso de microrganismos nas práticas de manejo e processamento do café conilon, com foco em qualidade e sustentabilidade.

\footnotetext{
${ }^{1}$ Blend: mistura de café que é realizada pela indústria para adequação de um determinado perfil sensorial, seja para manutenção da qualidade ou equilíbrio de atributos em função do mercado consumidor, tendo com base parâmetros de qualidade.
} 


\section{Importância econômica do café robusta}

O Brasil se apresenta como o maior produtor e exportador de café no mercado mundial e ocupa a segunda posição entre os países consumidores da bebida (ABIC, 2018), movimentando no ano de 2017 UU \$ 5,2 bilhões, o que demostra a relevância desse produto para o desenvolvimento econômico do país.

Neste contexto, encontra-se o estado do Espírito Santo, que é o $2^{\circ}$ maior produtor brasileiro de café, responsável por $22 \%$ de toda produção nacional. Esse café é oriundo em sua maioria (73\%) da agricultura de base familiar, onde se encontra 53 mil famílias produzindo café arábica e 78 mil famílias café conilon.

A cafeicultura destaca-se como uma importante atividade agrícola por participar diretamente no desenvolvimento tanto econômico como social do Brasil, atuando na geração de emprego pelo uso da mão de obra e a manutenção do homem no campo (HERZOG et al., 2020).

Uma das demandas tecnológicas da espécie é a falta de definição de um padrão de bebida, o que tem levado a inverdades sobre o uso do café conilon. Como exemplo a expansão do café solúvel associado ao crescente mercado de blends, o café robusta vem ganhado novos olhares e uma maior expressão na participação desse mercado. Assim, é de conhecimento tácito científico, que a qualidade do café é resultado da soma de fatores como: características edafoclimáticas, cultivares, condução e manejo da lavoura, colheita, tipo de processamento, secagem e armazenamento (CARVALHO e CHALFOUN, 1985; CARVALHO et al., 1994).

Observa-se que na maioria dos fatores citados, o produtor rural deve desempenhar um papel de grande responsabilidade para com o resultado da qualidade final, visto que é ele quem deve ter conhecimento para praticar de forma correta a condução de manejo, colheita e processos de pós-colheita. Contudo, existe um número significativo de produtores que são carentes de informação e estrutura para a produção de café de qualidade (BARROS, et.al, 2017), o que dificulta sua inserção em um mercado cada vez mais exigente e inovador.

Considerando que os produtos tecnológicos entregues à agricultura, são quase sempre advindos de pesquisas desenvolvidas por agentes públicos (universidades, institutos e centros de pesquisa), o produtor assume um papel indispensável nessa situação, uma que o volume de informação e conhecimento dispostos nos meios de comunicação em massa, como a internet, devem desempenhar um papel de ajuda e suporte a informação, para que os produtores possam ter em mãos, tecnologias e processos, que os auxiliem no manejo e produção de um café com qualidade e sustentabilidade. 


\section{Histórico de qualidade do café conilon}

A crescente procura pela qualidade configura um cenário denominado de terceira onda na produção de cafés, onde através desse mercado pode-se observar a proximidade do cliente com o produtor, facilitando assim o acesso a uma gama de informações referentes ao produto, como dados de safra e lotes específicos, proporcionando rastreabilidade e a relação direta entre produtores e compradores. Esse conjunto de ações permitiu o aprimoramento do processo produtivo, favorecendo o desenvolvimento de novas técnicas, buscando a qualidade em todas as etapas da cadeia produtiva (ALVES, 2019).

Desde o princípio, quando o café conilon foi introduzido na cafeicultura, ele tem sido debelado a inúmeras restrições principalmente no que diz respeito a comercialização e remuneração com agregação, como observado no caso do café arábica.

Muitos fatores podem ser associados a estes problemas estruturais, como exemplo disso, falta de um padrão global para a bebida, preconceito internacional em relação ao consumo puro do café Canephora, baixa aplicação de tecnologias de melhoria de qualidade no pós colheita (PEREIRA et al., 2019), o que tem contribuído para que inverdades sobre o uso do conilon ainda existam, tais como que a matéria prima só possui serventia para blends, e que se misturado ao café arábica, ocasiona na queda de qualidade do mesmo (TEIXEIRA, 2015).

A respeito da qualidade final vinculada ao café conilon/robusta, o melhoramento genético é um grande aliado na melhoria da qualidade, tendo em vista programas de melhoramento, que visam entregar ao produtor, variedades que sejam voltadas para a elevada produção, resistência a pragas e doenças, com padrão de qualidade internacional.

Seguido pela forma adequada de manejo das lavouras, considerando o potencial de uso da microbiota das raízes, do solo e dos frutos, seja na forma de proteção de cultivo, fixação de nitrogênio ou nos processos de fermentação. Pois, na decorrência da produção, a colheita e o pós-colheita são fatores críticos na produção de café conilon de qualidade. Para poder acompanhar o aumento progressivo do consumo de cafés especiais, tornou-se necessário a adaptação das atividades ligadas aos processos de produção com qualidade, para assim, conseguir suprir a demanda do mercado, se preocupando em produzir um café conilon de melhor qualidade (PEREIRA, 2019).

Os atributos físicos, químicos e sensoriais, denominam a trinca a respeito da qualidade do café, para atender a mercados diversos, com diferentes tipos de consumidores, cada vez mais tecnologias de pós-colheita estão sendo incorporadas ao universo de produção do café conilon (PEREIRA et al., 2019). Entretanto novas ações devem ser consideradas na produção de café conilon de qualidade, principalmente a respeito das formas de manejo e condução das lavouras. No cenário atual, torna-se evidente o aumento pela busca por processos que tornem possível agregar mais qualidade na produção de alimentos especiais, em conjunto, o 
café conilon torna-se participativo neste sistema, onde processos estão sendo desenvolvidos para melhoria constante da qualidade, seja física ou sensorial (PEREIRA et al., 2019).

\section{Melhoramento genético do café conilon}

O melhoramento genético em diferentes espécies, tem como principal objetivo o desenvolvimento de cultivares capazes de apresentar alta produtividade, estabilidade de produção e qualidade do produto respondendo as demandas dos produtores e consumidores (FERRÃO, 2018).

As diversas reproduções que arranjam as distintas variedades da espécie $C$. canephora despontam uma diversidade genética em relação às características agronômicas, morfológicas e fisiológicas (DRUMOND NETO, 2017).
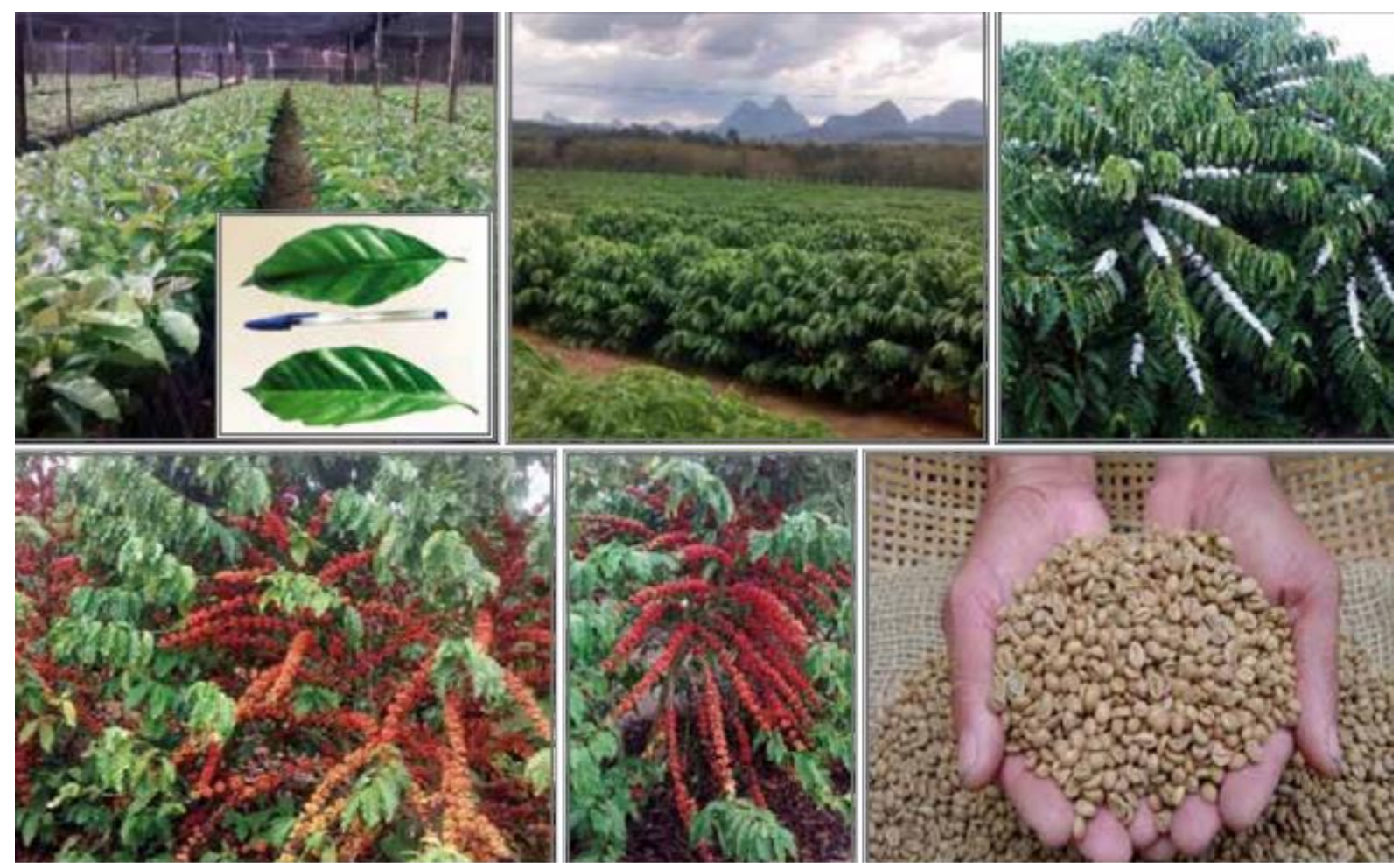

Figura 1: Aspectos ilustrativos da arquitetura do café conilon.

Fonte: INCAPER e Romário Gava Ferrão.

Segundo Ferrão (2018), o principal problema que dificulta a atividade cafeeira do café robusta no estado do Espírito Santo é a seca. Uma planta que apresenta tolerância a seca consegue suportar a condições desfavoráveis, resistir e deixar progênie, sendo capaz de manter suas funções numa situação de carência hídrica.

Ao decorrer dos anos, as pesquisas e estudos assim como o melhoramento genético relacionados à espécie conilon antepuseram a melhoria da produtividade e no quesito qualitativo associavam principalmente a maturação homogênea dos frutos (DRUMOND NETO, 2017). 
Nos principais setores brasileiros de produção de cafés canephora muitos materiais estão sendo cultivados em múltiplos ambientes distintos, e carecem de estudos para a identificação das características agronômicas e as características das características sensoriais da bebida. De tal modo, tanto o produtor como a indústria poderão estabelecer táticas para expandir o café canephora nos mercados consumidores (DRUMOND NETO, 2017).

\section{Aplicação de microrganismos para melhoria da qualidade do café conilon}

As populações microbianas desenvolvem-se em vários hábitats, interagindo e modificando aspectos químicos e físicos do ambiente. Neste processo, podem colonizar vários substratos, modificando-os por meio da excreção de seus produtos metabólicos.

Os grãos de café (casca, polpa e semente) servem de substrato para o desenvolvimento de bactérias, leveduras e fungos filamentosos, suprindo-os de fontes de carbono e nitrogênio, por apresentarem celulose, hemicelulose, pectinas, açúcares redutores, sacarose, amido, óleos, proteínas, ácidos e cafeína. A diversidade microbiana presente nos grãos de café depende de fatores ambientais da região de cultivo, como: umidade, temperatura, época do ano, população do solo e variedade do café cultivado e forma de manejo da cultura (SILVA et al., 2000).

O primeiro estudo a relatar a incidência dos microrganismos correlacionados com a perda de qualidade do café data de 1936, publicado por Krug (1940), onde o autor identificou micélio de fusárium em grãos de café.

Quando estes microrganismos atuam, eles podem promover ações fermentativas que podem ser benéficas ou não à qualidade do café. Sobre o mesocarpo, Yamada (1999) aborda que a ação dos microrganismos endofíticos e seus produtos metabólicos em frutos de café pode afetar negativa ou positivamente a expressão da qualidade final da bebida do café e estes microrganismos somados aos epifíticos, de ocorrência natural em frutos de café, desempenham um papel importante na produção de metabólitos secundários, que interferem positiva ou negativamente na qualidade do café (SANTOS, 2008).

Os microrganismos endofíticos são descritos por atuarem primeiramente na superfície, para penetrar no hospedeiro, atuando de forma interna no tecido da planta, sendo descritos pela primeira vez por Bary (1866). Por mais de um século eles foram quase que ignorados, principalmente devido ao fato de que se conhecia muito pouco sobre suas reais funções no interior dos vegetais e por não produzirem em seus hospedeiros estruturas externas visíveis. Talvez, por isso, microrganismos benéficos que colonizam o interior do hospedeiro e que formam estruturas visíveis são intensamente estudados (NETO et al.; 2002). 
Assim, até pouco tempo, a ação dos microrganismos como suporte na proteção de cultivo, melhoria da qualidade, aplicação de técnicas de fermentação era pouco relativizada em estudos científicos com essa finalidade. Tendência essa que tem sido modificada nos últimos anos, com aplicação destes agentes na melhoria das formas de manejo ambiental das lavouras e mais recentemente, no processamento e fermentação do café conilon.

\section{Fungos micorrízicos arbusculares e sua potencial de melhoria de qualidade para o cafeeiro}

As raízes de cerca de $80 \%$ das plantas são conhecidas por formarem simbioses mutualísticas com Fungos Micorrizicos Arbusculares (FMA) (BRUNDRETT e TEDERSOO, 2018), que são microrganismos biotróficos obrigatórios e pertencem ao filo Glomeromycota (SMITH e SMITH 2008). Esta associação é chamada de micorrizas e significa raízes e fungos, do grego: mykes que tem sentido de fungo e rhiza que denota raiz. Os FMAs produzem estruturas reprodutivas típicas, de natureza assexual, denominadas glomerosporos, que apresentam alta diversidade estrutural (GOTO e MAIA, 2006) (Figura 1).

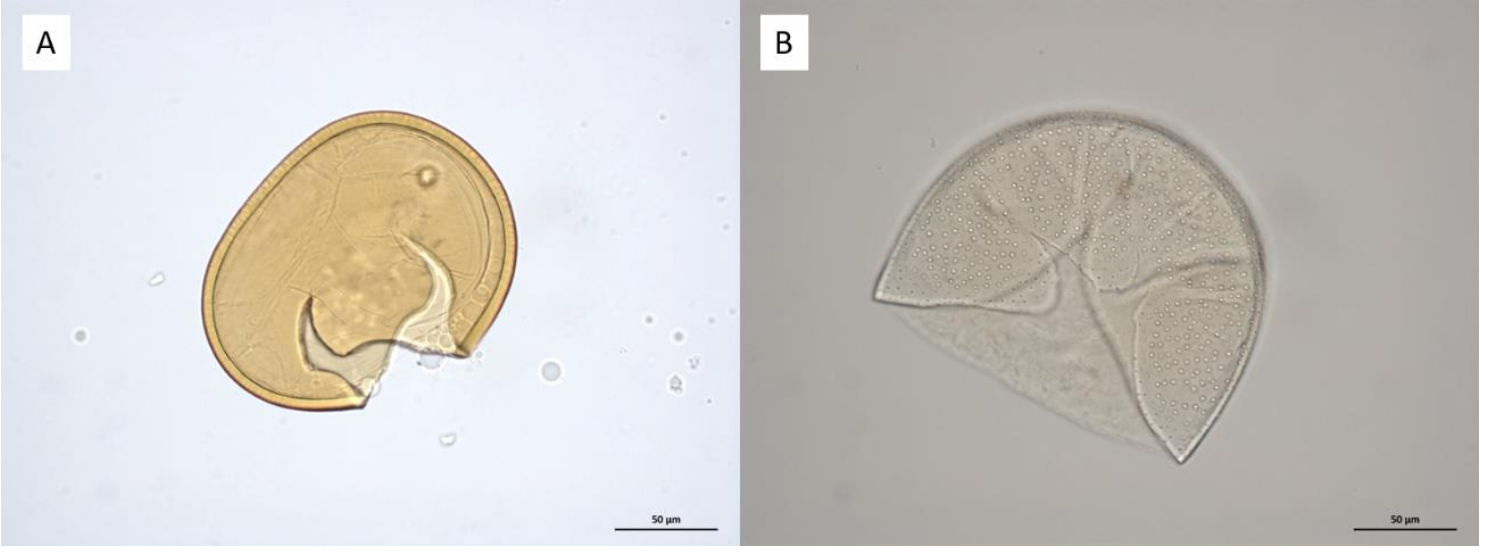

Figura 2: Glomerosporos de fungos micorrízicos arbusculares coletados em plantações de café: (A) Acaulospora mellea e (B) Acaulospora alpina.

Fonte: Prates Junior et al. (2019).

Os FMA apresentam papel multifuncional em ambientes naturais e agrícolas, pois auxiliam na absorção de macronutrientes como o fósforo e o nitrogênio (TIAN et al., 2010; HAJONG et al., 2013; VERGARA et al., 2019), contribuindo para a nutrição da planta.

Esses microrganismos também desempenham um importante papel na indução de resistência nas plantas, através de modificação nas cascatas hormonais, como a ativação sistêmica de defesas dependentes do ácido jasmônico (POZO et al., 2007; JUNG et al., 2012; FORMENTI e RASMANN, et al., 2019). A rede de micélios no solo formado pelas hifas de FMA pode funcionar como um canal de comunicação subterrâneo planta-planta, através do 
qual a resistência a doenças e os sinais de defesa induzidos podem ser transferidos entre plantas saudáveis e infectadas por patógenos, levando a ativação de defesas antes das plantas saudáveis serem atacadas (SONG et al., 2010).

Os FMA afetam a indução de defesa de plantas por herbívoros acima e abaixo do solo (MEIER e HUNTER, 2018). Nesse sentido, o manejo e/ou inoculação de FMA pode reduzir a aplicação de fertilizantes e pesticidas já que podem melhorar a saúde das plantas, a resistência a patógenos, a exemplo do Fusarium, e aumento a tolerância a estresse abiótico (GIANINAZZI et al., 2010; TIAN et al., 2010; OKADA e MATSUBARA, 2012; HAJONG et al., 2013).

Dentre as diversas culturas de importância agronômica que estabelecem associação com os FMA, o café se destaca desde a formação das mudas e, em condições de campo são altamente dependentes de micorrizas (ANDRADE et al., 2009).

A inoculação com FMA favorece o crescimento inicial dessas plantas (FONSECA, 2019), resultando em benefício para as mudas (FRANÇA et al., 2014), visto que o cafeeiro apresenta elevada dependência micorrízica (SIQUEIRA et al., 1993). Além disso, pode ocasionar em maior produtividade, indicando que a inoculação de mudas de café com FMA pode representar uma economia considerável de fertilizantes para a produção de café no Brasil (SIQUEIRA et al., 1998). A inoculação de FMA afeta a fisiologia do cafeeiro, aumentando a taxa fotossintética, a condutância estomática, a transpiração, o carbono consumido e a eficiência do uso da água (CRUZ et al., 2020). Os efeitos benéficos das micorrizas sobre o estado nutricional das plantas e sobre a capacidade dessas plantas de resistir a diferentes estresses ambientais tornam esses micosimbiontes um fator chave para a agricultura sustentável (ANDRADE et al., 2009).

Entretanto, a composição da comunidade de FMA no solo e nas raízes de plantas de cafés é afetada pelas condições edafoclimáticas, práticas culturais, localidade e período de amostragem (ANDRADE et al., 2009; PRATES-JUNIOR et al., 2019).

O monocultivo de café pode reduzir a riqueza de microrganismos do solo e os diferentes sistemas de cultivo provocam alterações nas populações microbianas do solo quando comparado com o ambiente de mata nativa (FERREIRA et al., 2017; ZHAO et al, 2018).

Os sistemas agroflorestais (SAF) de café aumentam a atividade microbiana no solo (COLMENARES et al., 2016). Nesses sistemas, observou-se maior diversidade de FMA em raízes de Coffea arabica comparada com outros sistemas de manejo (BEENHOUWER et al., 2015).

O cultivo de café em consorcio com diferentes espécies de árvores utilizadas no sombreamento mostra maior abundância e diversidade de FMA porque aumenta a abundância e a diversidade de plantas (MULETA et al., 2007; DOBO et al., 2018). Isso indica que o sistema de manejo agroecológico mantém maior diversidade de FMA, sendo inclusive 
semelhante a diversidade da mata natural, em comparação com os sistemas convencionais (Figura 2) (PRATES JUNIOR et al., 2019).

Em sistema agroflorestal, a utilização de árvores de macaúba, por exemplo, modifica o microclima da lavoura cafeeira, proporcionando redução da temperatura e da intensidade, disponibilidade de radiação fotossinteticamente ativa e aumento da produtividade (MOREIRA et al., 2018), o que pode favorecer a comunidade de FMA.

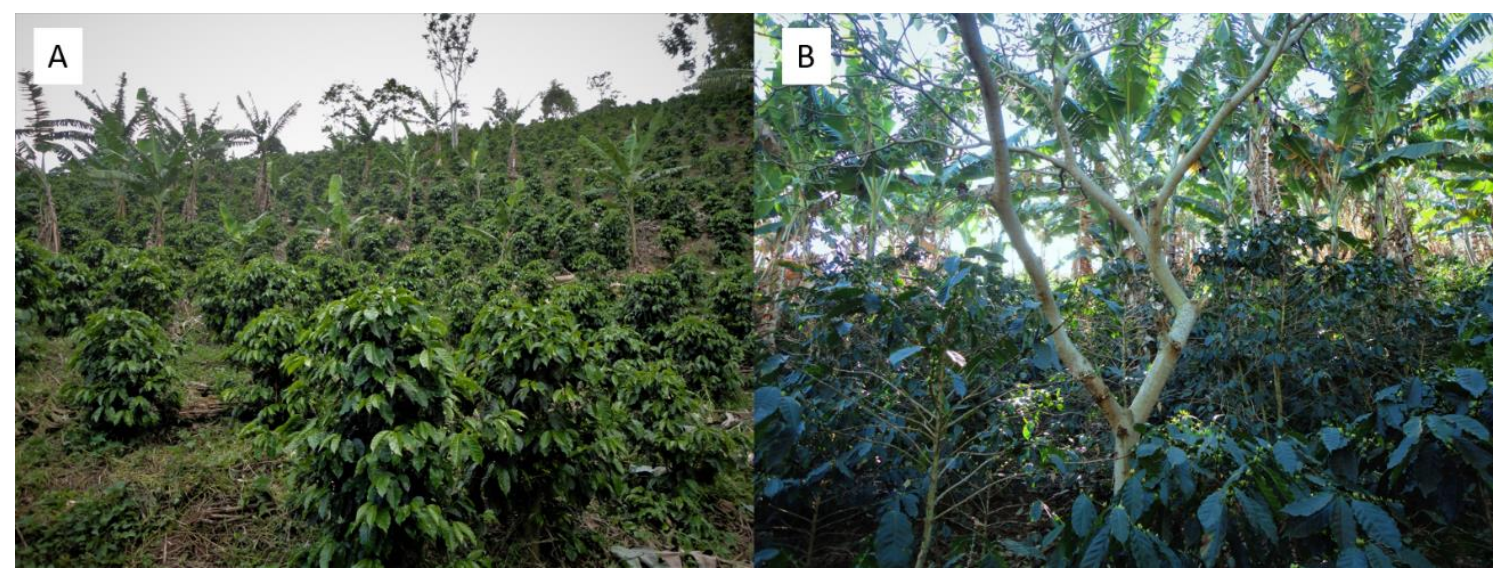

Figura 3: Produção de café em sistema agroflorestal com bananeiras $(A)$ e árvores nativas $(B)$ em Araponga, Minas Gerais, Brasil.

Fonte: Prates Júnior et al. (2019).

Os FMA podem auxiliar na saúde da planta e na qualidade do solo e, assim, de maneira indireta resultar em maior segurança alimentar e nutricional para os consumidores. Em plantas inoculadas com FMA pode ocorrer o aumento nas concentrações de aminoácidos, compostos fenólicos e ácido clorogênico (CECCARELLI et al., 2010; OKADA e MATSUBARA, 2012). O aumento na produção de compostos secundários, a exemplo de polifenóis e antocianinas foi verificado em inhame (Dioscorea spp.) inoculado com FMA (LU et al., 2015); bem como foi constatado o aumento nos teores de nutrientes em frutos de morangueiro inoculados, incluindo as concentrações de K e Cu e compostos fenólicos (CASTELLANOS-MORALES et al., 2010).

Em solos distróficos, sobretudo aqueles com baixos teores de fósforo, o plantio de mudas micorrizadas pode contribuir para uma melhor nutrição no campo, e melhorar a resistência ao estresse hídrico (FONSECA, 2019). O uso de inóculos micorrízicos em viveiros de café pode ser uma tecnologia promissora para a produção de mudas de café saudáveis e vigorosas, aumentando assim a sobrevivência após o transplante de campo (Andrade et al., 2009). A inoculação dessas mudas com FMA selecionados e a aplicação de doses baixas a moderadas de $P$ no plantio é altamente vantajosa para a produção de café nesses solos de baixa fertilidade no Brasil (SIQUEIRA et al., 1998). O que torna a seleção de FMA eficaz para 
condições edafoclimáticas predeterminadas, sendo um pré-requisito para se obter a resposta positiva desejada da associação em campo (ANDRADE et al., 2009).

Diante do exposto, verificamos que os FMA têm importante papel no aumento da sustentabilidade dos sistemas de produção de café e afetam direta ou indiretamente a qualidade da bebida. Assim, devem ser favorecidos como uma ferramenta capaz de ampliar a segurança alimentar e nutricional relacionada a produção e consumo de café.

\section{Microbiota bacteriana associada ao Coffea canephora e seu potencial de aplicação na qualidade}

O cafeeiro Conilon (Coffea canephora) é considerado uma planta rústica, sendo tolerante a seca e a doenças, é amplamente cultivada em regiões de altitudes inferiores e temperaturas mais elevadas. Economicamente, a importância do café conilon deve-se ao fato de servir como matéria prima básica para a indústria de café solúvel, sendo um componente importante na composição de blends com o café arábica nas indústrias de torrefação (FONSECA et al., 2015).

$\mathrm{Na}$ composição química do mesocarpo mucilaginoso dos frutos maduros, estão os açúcares simples, polissacarídeos complexo, proteínas, lipídeos e minerais, fazendo do café um substrato propício para o crescimento e desenvolvimento de microrganismos como leveduras, fungos e bactérias. As bactérias por sua vez, constituem como importantes contribuidores no estímulo para o crescimento das plantas, no aumento da resistência a pragas e doenças e a condições ambientais adversas, como o estresse hídrico. Além disso são capazes de produzir compostos percursores de atributos sensoriais distintos que colaboram para as caracterizações organolépticas da bebida (MIGUEL et al., 2013).

A interação planta-microrganismo pode ocorrer em várias partes das plantas, como sementes, óvulos, frutos, caules, folhas, raízes, tubérculos, botões, flores e inflorescências (ZHANG et al., 2006). Dessa forma, torna-se necessário o conhecimento da diversidade microbiana para a compreensão das interações, sobretudo com a espécie conilon, onde o assunto ainda é pouco explorado, bem como as vias metabólicas funcionais e produtos do metabolismo microbiano gerados a utilização destes.

Em um estudo conduzido por Miguel et al. (2013), foram analisados a diversidade bacteriana endofítica em frutos de Coffea canephora. Entre os isolados identificados, está o gênero Bacillus, conhecidos por colonizarem várias plantas e promoverem seu crescimento por meio da produção de giberelinas e auxinas, característica marcante do isolado B. pumilus (FORCHETTI et al., 2007). Deste gênero também foram identificados as espécies $B$. thuringiensis e $B$. subtilis, comumente associados como eficientes agentes de controle 
biológico contra a Hemileia vastatrix, causadora da ferrugem no café ( HADDAD et al., 2013; CACEFO et al., 2016). Também nesse estudo foi identificado a espécie Klebsiella oxytoca, um importante agente contribuidor de processos fermentativos no café, uma vez que exerce significativa atividade pectnolítica. Em trabalhos genéticos, seu DNA tem sido usado, inclusive, na construção de transposons, contendo o gene da enzima pectato liase (poligalacturonato transeliminase) (WALKER et al., 1987).

$\mathrm{Na}$ mesma linha, Djossou et al. (2011) estudando a microbiota do Coffea canephora, relataram o potencial do isolado Lactobacillus plantarum como inibidor de crescimento de Aspergillus carbonarius, uma importante espécie fúngica produtora de micotoxinas prejudiciais à segurança alimentar, como as aflatoxinas, tricotecenos, fumonisina e ocratoxina A. Tal efeito também foi evidenciado por Gerez et al. (2014) que observaram uma redução de $60 \%$ dos níveis de ocratoxina quando inoculado a espécie Lactobacillus plantarum.

Embora a expectativa sobre a funcionalidade de algumas bactérias associadas à microbiota do Coffea canephora seja promissora, ainda há poucas referências sobre a potencialidade das bactérias na melhoria sensorial. A seguir exemplo da diversidade de estudos existentes com Coffea arabica (SILVA et al., 2000; LEONG et al., 2014; ELHALIS et al. 2020), torna-se necessário mais trabalhos que examinem o impacto do crescimento microbiano e do metabolismo na qualidade do café conilon, especialmente no sabor.

Dessa forma, compreender tais fatores são de grande importância não apenas para o campo de pesquisa em questão, mas também para que cafeicultores tenham à disposição uma tecnologia que permita contribuir com a qualidade de seu produto.

Através da crescente demanda por cafés especiais, torna-se notório que a qualidade advém e é dependente dos avanços relacionados com as pesquisas e inovação tecnológica, sendo influenciados diretamente pelas práticas de manejo cultural com as quais, a compreensão a respeito da ação dos microrganismos possui forte apelo científico, visando otimização da qualidade final do café conilon.

Assim, estudos sobre a qualidade física e sensorial realizados por Sturm e Ferreira (2012), em cafés Coffea canephora em relação à altitude, estádio de maturação e pós-colheita mostram que os cafés apresentaram diferenças qualitativas da bebida entre altitudes. Estes resultados evidenciam a necessidade de compreensão dos fatores ecológicos vinculados ao manejo do café conilon.

Segundo Pereira et al. (2019), com o aumento da tecnologia empregada nas lavouras, novos métodos têm sido aderidos na melhoria da qualidade do fruto do cafeeiro, principalmente no que se diz respeito ao pós-colheita. A fermentação controlada como ferramenta de melhoria da qualidade no café surge como fator positivo no aumento da curva de aromas e sabores especiais, e constitui uma etapa do processamento via úmida, que visa 
a retirada total ou parcial da polpa/mucilagem do café que também pode ser realizada mecanicamente.

O café apresenta uma microbiota particularmente complexa, podendo ser formada por bactérias, leveduras e fungos filamentosos, e dentre esses, determinados microrganismos podem produzir enzimas que atuam na antecipação da retirada da mucilagem e, contribuindo para o processo de fermentação, como as leveduras (PEREIRA, 2018). Torna-se notório o impacto da admissão de tecnologias de processamento via úmida assegurada do controle de fermentação, da inserção de novas maneiras de se processar e produzir o café conilon, com o objetivo de alcançar condições de otimização da curva de qualidade com a elaboração de novos perfis sensoriais (PEREIRA et al., 2019).

Fonseca (2011) reforça que se deve também observar as propriedades químicas presentes nos produtos a serem cultivados para o aproveitamento comercial alimentar, dentre elas os teores de cafeína, trigonelina, ácidos clorogênicos, sólidos solúveis e lipídios.

As propriedades químicas têm sido foco de estudos para que se possa caracterizar os compostos que formam os sabores e aromas presentes na bebida, assim como apontar os responsáveis pelas percepções de sensações boas e ruins. A identificação da composição química do café pode ser feita em diversas formas de análise, dentre essas, as análises cromatográficas e as bromatológicas onde são possíveis realizar análise de umidade, cinza, lipídeos, acidez, pH, sólidos solúveis, açúcares, compostos fenólicos (NOIA, 2017).

\section{Considerações finais}

Apesar da importância econômica do cultivo e melhoramento do conilon, o progresso tecnológico é limitado em comparação com outras culturas. Portanto, novas metodologias para a seleção de variedades de café com características agronômicas e de qualidade de xícara desejáveis são urgentemente necessárias. Com base nos fatores já mencionados que influenciam diretamente na qualidade final do produto como a interação e aplicação de microrganismos, bem como a composição química e o manejo do cafeeiro, o próximo desafio será aliar essas informações para desenvolver novas estratégias de melhoramento para permitir a seleção de variedades de plantas com características agronômicas e sensoriais desejáveis.

Atualmente, os principais programas de melhoramento genético de conilon se concentram em resolver problemas relacionados à produtividade e resistência à fatores bióticos e abióticos. No entanto, informações que correlacionem marcadores genéticos com a qualidade de xícara geralmente é pobre. Dessa forma, o próximo passo têm sido investigar diferentes materiais genéticos de Coffea canephora nos aspectos químicos, físicos, sensoriais e de 
interação planta-microrganismo e correlacionar com uma abordagem metabolômica, afim de identificar metabólitos altamente herdáveis que estejam relacionados à qualidade da xícara. Assim, com o desenvolvimento dessas tecnologias espera-se que em um futuro próximo o agricultor tenha acesso a novas variedades de café conilon com vasta variedade sensorial e apta para atender diferentes mercados consumidores.

\section{Agradecimentos}

Os autores agradecem à Cooperativa de Crédito de Livre Admissão Sul Serrana do Espírito Santo - Sicoob (23186000886201801), à Coordenação de Aperfeiçoamento de Pessoal de Nível Superior - CAPES e ao Conselho Nacional de Desenvolvimento Científico e Tecnológico - CNPq, ao Instituto Federal do Espírito Santo, pelo apoio a pesquisa, por meio do edital PRPPG no. 10/2019 - Programa Produtividade Pesquisador - PPP, ao Programa de PósGraduação em Agroecologia (PPGA) do Ifes - Campus de Alegre, bem como o Instituto Capixaba de Assistência Técnica e Extensão Rural - INCAPER, e a Universidade Federal do Espírito Santo pela colaboração na pesquisa.

\section{Referências}

ANDRADE, S. A. L.; MAZZAFERA, P. SCHIAVINATO. Arbuscular mycorrhizal association in coffee. The Journal of Agricultural Science, v. 147, n. 2, p. 105, 2009.

ASSOCIÇÃO BRASILEIRA DA INDÚSTRIA DE CAFÉ - ABIC. 0 café brasileiro na atualidade. 2018. Disponível: <http://abic.com.br/o-cafe/historia> Acesso: 28 agosto 2020.

AGNOLETTI, B. Z. Avaliação das propriedades físico-químicas de café arábica (Coffea arabica) e conilon (Coffea canephora) classificados quanto à qualidade da bebida. Dissertação (Ciência e Tecnologia de Alimentos) - Universidade Federal do Espírito Santo. 2015.

BEENHOUWER, M.; MULETA, D.; PEETERS, B.; VAN GEEL, M.; LIEVENS, B.; HONNAY, $O$. DNA pyrosequencing evidence for large diversity differences between natural and managed coffee mycorrhizal fungal communities. Agronomy for Sustainable Development, v. 35, n. 1, p. 241-249, 2015.

BRUNDRETT, M. C.; TEDERSOO, L. Evolutionary history of mycorrhizal symbioses and global host plant diversity. New Phytologist, v. 220, n. 4, p. 1108-1115, 2018.

BARROS, E. D. A., DE FREITAS, M. A., ALMEIDA, L. D. A.; MOURA-ALMEIDA, F. M. Análise sobre o conhecimento dos produtores rurais de lbatiba-ES sobre as alternativas de póscolheita que agregam valor ao café arábica produzido. 2017.

BARY, A. de. Morphologie physiologie der pilze, flechten und myxomyceten. Handbook of Physiological Botany, Leipzig, v. 2, 1866. 
CARVALHO, V. D.; CHALFOUN, S. M. Aspectos qualitativos do café. Informe Agropecuário, Belo Horizonte, v. 11, n. 126, p. 79-92, 1985.

CARVALHO, V. D.; CHAGAS, S.; CHALFOUN, S.; BORTREL, N.; JUSTE JÚNIOR, E. S. G. Relação entre a composição físico-química dos grãos de café beneficiado e a qualidade da bebida do café. Pesquisa Agropecuária Brasileira, Brasília, v. 29, n. 3, 1994.

CASTELLANOS-MORALES, V.; VILLEGAS, J.; WENDELIN, S.; VIERHEILIG, H.; EDER, R.; CÁRDENAS-NAVARRO, R. Root colonisation by the arbuscular mycorrhizal fungus Glomus intraradices alters the quality of strawberry fruits (Fragaria $x$ Ananassa Duch.) at different nitrogen levels. Journal of the Science of Food and Agriculture, v. 90, n. 11, p. 1774-1782, 2010.

CECCARELLI, N.; CURADI, M.; MARTELLONI, L.; SBRANA, C.; PICCIARELLI, P.; GIOVANNETTI, M. Mycorrhizal colonization impacts on phenolic content and antioxidant properties of artichoke leaves and flower heads two years after field transplant. Plant and Soil, v. 335, n. 1-2, p. 311-323, 2010.

COLMENARES, C. H.; SILVA, A.; MOGOLLÓN, Á. M. Impacts of different coffee systems on soil microbial populations at different altitudes in Villavicencio (Colombia). Agronomía Colombiana, v. 34, n. 2, p. 285-291, 2016.

CRUZ, R. S.; ARAÚJO, F. H. V.; FRANÇA, A. C.; SARDINHA, L. T.; MACHADO, C. M. M. Physiological responses of Coffea arabica cultivars in association with arbuscular mycorrhizal fungi. Coffee Science, 15:e151641

CACEFO, V.; ARAÚJO, F. F. de; PACHECO, A. C. Biological control of Hemileia vastatrix berk. \& broome with bacillus subtilis cohn and biochemical changes in the coffee. Coffe Science, v. 11, n. 4, p. 567-574, 2016.

DJOSSOU, O.; PERRAUD-GAIME, I.; LAKHAL MIRLEAU, F.; RODRIGUEZ-SERRANO, G.; KAROU, G.; NIAMKE, S.; OUZARI, I.; BOUDABOUS, A.; ROUSSOS, S. Robusta coffee beans post-harvest microflora: Lactobacillus plantarum sp. as potential antagonist of Aspergillus carbonarius. Anaerobe, v. 17, n. 6, p. 267-272, dez. 2011.

DOBO, B.; ASEFA, F.; ASFAW, Z. Effect of tree-enset-coffee based agro-forestry practices on arbuscular mycorrhizal fungi (AMF) species diversity and spore density. Agroforestry systems, v. 92, n. 2, p. 525-540, 2018.

ELHALIS, H.; COX, J.; ZHAO, J. Ecological diversity, evolution and metabolism of microbial communities in the wet fermentation of Australian coffee beans. International Journal of Food Microbiology, v. 321, p. 108544, 2020.

FERREIRA, E. D. B.; STONE, L. F.; MARTIN-DIDONET, C. C. G. Population and microbial activity of the soil under an agro-ecological production system. Revista Ciência Agronômica, v. 48 , n. 1, p. 22-31, 2017.

FONSECA, A.; SAKIYMA, N.; BORÉM, A. Café conilon: do plantio à colheita. Viçosa, MG: UFV, p. 257, 2015.

FONSECA, A. J.; FREITAS, A. F. D.; CARVALHO, G. R.; CARNEIRO, M. A. C.; VILELA, D. J. M.; FASSIO, L. D. O. Arbuscular mycorrhizal fungus on the initial growth and nutrition of Coffea arabica L. genotypes. Ciência e Agrotecnologia, v. 43, 2019. 
FRANÇA, A. C.; CARVALHO, F. P.; FRANCO, M. H. R.; AVELAR, M.; SOUZA, B. P.; STÜRMER, S. L. Crescimento de mudas de cafeeiro inoculadas com fungos micorrízicos arbusculares. Agrária - Revista Brasileira de Ciências Agrárias v.9, n.4, p.506-511, 2014.

FORMENTI, L.; RASMANN, S. Mycorrhizal fungi enhance resistance to herbivores in tomato plants with reduced jasmonic acid production. Agronomy, v. 9, n. 3, p. 131, 2019.

GIANINAZZI, S.; GOLLOTTE, A.; BINET, M. N.; VAN TUINEN, D.; REDECKER, D.; WIPF, D. Agroecology: the key role of arbuscular mycorrhizas in ecosystem services. Mycorrhiza, $\mathrm{V}$. 20, n. 8, p. 519-530, 2010.

GOTO, B. T; MAIA, L. C. Glomerospores: a new denomination for the spores of Glomeromycota, a group molecularly distinct from the Zygomycota. Mycotaxon, v. 96, n. 4, p. 129-132, 2006.

GEREZ, C. L.; DALLAGNOL, A.; PONSONE, L.; CHULZE, S. Ochratoxin A production by Aspergillus niger: effect of water activity and a biopreserver formulated with Lactobacillus plantarum CRL 778. Food Control, 2014.

HADDAD, F.; SARAIVA, R. M.; MIZUBUTI, E. S.; ROMEIRO, R. S.; MAFFIA, L. A. Antifungal compounds as a mechanism to control Hemileia vastatrix by antagonistic bacteria. Tropical Plant Pathology, v. 38, n. 5, p. 398-405, 2013.

HAJONG, S.; KUMARIA, S.; TANDON, P. Comparative study of key phosphorus and nitrogen metabolizing enzymes in mycorrhizal and non-mycorrhizal plants of Dendrobium chrysanthum Wall. ex Lindl. Acta physiologiae plantarum, v. 35, n. 7, p. 2311-2322, 2013.

HERZOG, T. T; SILVA, M. B; FACCO, A. G. Análise do índice de sustentabilidade da produção de café conilon. Revista em Agronegócios e Meio Ambiente, v. 13, n. 1, 2020.

KRUG III, H. P. Cafés Duros III. Relação entre a porcentagem de microrganismos e qualidade do café. Revista do Instituto do Café, v. 27, p. 1827-1831, 1940.

JUNG, S. C.; MARTINEZ-MEDINA, A.; LOPEZ-RAEZ, J. A.; POZO, M. J. Mycorrhiza-induced resistance and priming of plant defenses. Journal of chemical ecology, v. 38, n. 6, p. 651664, 2012.

LU, F.; LEE, C.; WANG, C. The influence of arbuscular mycorrhizal fungi inoculation on yam (Dioscorea spp.) tuber weights and secondary metabolite content. PeerJ, v. 3, p. e1266, 2015.

LEONG, K. H.; CHEN, Y. S.; PAN, S. F.; CHEN, J. J.; WU, H. C.; CHANG, Y. C.; YANAGIDA, $F$. Diversity of lactic acid bacteria associated with fresh coffee cherries in taiwan. Current Microbiology, v. 68, n. 4, p. 440-447, 2014.

MEIER, A. R.; HUNTER, M.D. Arbuscular mycorrhizal fungi mediate herbivore-induction of plant defenses differently above and belowground. Oikos, v. 127, n. 12, p. 1759-1775, 2018.

MIGUEL, P. S. B.; DELVAUX, J. C.; DE OLIVEIRA, M. N. V.; MONTEIRO, L. C. P.; COSTA, M. D.; TOTOLA, M. R.; BORGES, A. C. Diversity of endophytic bacteria in the fruits of Coffea canephora. African Journal of Microbiology Research, v. 7, n. 7, p. 586-594, 2013.

MOREIRA, S. L.; PIRES, C. V.; MARCATTI, G. E.; SANTOS, R. H.; IMBUZEIRO, H. M.; FERNANDES, R. B. Intercropping of coffee with the palm tree, macauba, can mitigate climate change effects. Agricultural and Forest Meteorology, v. 256, p. 379-390, 2018. 
MULETA, D.; ASSEFA, F.; NEMOMISSA, S.; GRANHALL, U. Composition of coffee shade tree species and density of indigenous arbuscular mycorrhizal fungi (AMF) spores in Bonga natural coffee forest, southwestern Ethiopia. Forest ecology and management, v. 241, n. 13, p. 145-154, 2007.

NETO, P. A. S. P.; AZEVEDO, J. L.; ARAÚJO, W. L. Microrganismos endofíticos: Interação com plantas e potencial biotecnológico. Biotecnologia Ciência \& Desenvolvimento, n. 29, 2002.

NOIA, L. Discriminação da qualidade de cafés conilon por atributos físico-químicos. Dissertação de Mestrado. Universidade Federal do Espírito Santo. 2018.

PEREIRA, L. L. Novas abordagens para produção de cafés especiais a partir do processamento via-úmida. Tese de doutorado. Universidade Federal do Rio Grande do Sul. 2017.

OKADA, T.; MATSUBARA, Y. Tolerance to Fusarium root rot and the changes in free amino acid contents in mycorrhizal asparagus plants. HortScience, v. 47, n. 6, p. 751-754, 2012.

PRATES JÚNIOR, P.; MOREIRA, B. C.; DA SILVA, M. D. C. S.; VELOSO, T. G. R.; STÜRMER, S. L.; FERNANDES, R. B. A.; KASUYA, M. Agroecological coffee management increases arbuscular mycorrhizal fungi diversity. PloS one, v. 14, n. 1, p. e0209093, 2019.

POZO, M. J.; AZCÓN-AGUILAR, C. Unraveling mycorrhiza-induced resistance. Current opinion in plant biology, v. 10, n. 4, p. 393-398, 2007.

PEREIRA, P. V. Dinâmica microbiana e aspectos físicos e químicos de café conilon (Coffea canephora Pierre ex Froehner) cultivado em diferentes ambientes e processado por via natural. Dissertação de Mestrado. Universidade Federal do Espírito Santo, 2018.

PEREIRA, L. L.; MORELI, A. P.; MOREIRA, T. R.; CATEN, C. S. TEN; MARCATE, J. P. P.; DEBONA, D. G.; GUARÇONI, R. C. Improvement of the quality of brazilian conilon through wet processing: a sensorial perspective. Agricultural Sciences, v. 10, n. 03, p. 395-411, 2019.

PEREIRA, L. L.; MORELI, A. P.; JÚNIOR, D. B.; DE SOUSA, L. H. B. P.; MARCATE, J. P. P.; DE OLIVEIRA, G. F.; GUARÇONI, R. C. CONSTRUÇÃO DE PERFIL SENSORIAL PARA O CAFÉ CONILON FERMENTADO. Revista Ifes Ciência, v. 5, n. 2, p. 242-252, 2019.

ROCHA, R. B.; TEIXEIRA, A. L.; RAMALHO, A. R.; SOUZA, F. D. F. Melhoramento de Coffea canephora - considerações e metodologias. In: MARCOLAN, A. L.; ESPINDULA, M. (Eds.). Café na Amazônia. Brasília, DF: EMBRAPA, v. 1, p.217-236, 2015.

SANTOS, T. M. A. Diversidade genética de bactérias endofíticas associadas a frutos de café (Coffea arabica L.). Dissertação (Mestrado em Microbiologia Agrícola)-Universidade Federal de Viçosa, Viçosa, Minas Gerais, 2008.

SILVA, C. F.; SCHWAN, R. F.; ABREU. L. M. Microbiota de frutos maduros de café (Coffea arabica L.) na fase inicial de secagem. In: SIMPÓSIO DE PESQUISA DOS CAFÉS DO BRASIL, $1 ., 2000.2000 .2$ Disponível <http://www.sapc.embrapa.br/arquivos/consorcio/spcb_anais/simposio1/Indust26.pdf>. Acesso em: 30 ago. 2020.

SILVA, C. F.; SCHWAN, R. F.; SOUSA DIAS, Ë.; WHEALS, A. E. Microbial diversity during 
maturation and natural processing of coffee cherries of Coffea arabica in Brazil. International Journal of Food Microbiology, v. 60, n. 2-3, p. 251-260, 2000.

SIQUEIRA, J. O.; SAGGIN-JÚNIOR, O. J.; FLORES-AYLAS, W. W.; GUIMARÃES, P. T. Arbuscular mycorrhizal inoculation and superphosphate application influence plant development and yield of coffee in Brazil. Mycorrhiza, v. 7, n. 6, p. 293-300, 1998.

SIQUEIRA, J. O.; COLOZZI-FILHO, A.; SAGGIN-JÚNIOR, O. J.; GUIMARAES, P. T. G.; OLIVEIRA, E; Crescimento de mudas e produção do cafeeiro sob influência de fungos micorrízicos e superfosfato. Revista Brasileira de Ciência do Solo v. 17, n.1. p. 53-60, 1993.

SMITH, S. E.; SMITH, F. A. Roles of arbuscular mycorrhizas in plant nutrition and growth: new paradigms from cellular to ecosystem scales. Annual review of plant biology, v. 62, p. 227250, 2011.

SOUZA, T. S. de. Qualidade da bebida do café conilon orgânico consorciado com diferentes espécies arbóreas e frutíferas. Dissertação (Mestrado em Agroecologia) Instituto Federal do Espírito Santo, Alegre, Espírito Santo 2018.

SONG, Y. Y.; ZENG, R. S.; XU, J. F.; LI, J.; SHEN, X.; YIHLDEGO, W.G. Interplant communication of tomato plants through underground common mycorrhizal networks. PloS one, v. 5, n. 10, p. e13324, 2010.

STURM, A. F. Qualidade física e sensorial de Coffea canephora L. relacionadas á altitude, estádio de maturação e preparo pós-colheita. 2013. Dissertação de Mestrado. Universidade Federal do Espírito Santo.

TEIXEIRA, M. M.; DAHER, F. D. A.; CORTEZ, J.; DE TOLEDO, J. L. Padrão de bebida para o café conilon. In: FERRÃO, R. G.; FONSECA, A. F. A. da.; BRAGANÇA, S. M.; FERRÃO, M. A. G.; DE MUNER, L. H. (Eds.). Café conilon. Vitória: INCAPER. p. 530-537, 2015.

TOMAZ, M. A. Perfil químico e sensorial de grãos de diferentes genótipos de Coffea canephora. 2019. Dissertação de Mestrado. Universidade Federal do Espírito Santo.

TIAN, C.; KASIBORSKI, B.; KOUL, R.; LAMMERS, P. J.; BÜCKING, H.; SHACHAR-HILL, Y. Regulation of the nitrogen transfer pathway in the arbuscular mycorrhizal symbiosis: gene characterization and the coordination of expression with nitrogen flux. Plant physiology, v. 153, n. 3, p. 1175-1187, 2010.

VAN DER VOSSEN, H. A. M. Coffea selection and breeding. In: CLIFFORD, M. N.; WILLSON, K. C. (Eds.). Coffe: botany, biochemistry and production of beans and beverage. London: Croom Helm, Westport Conn, 1985. p. 48-96.

VERGARA, C.; ARAUJO, K. E. C.; SOUZA, S. R. D.; SCHULTZ, N.; SAGGIN JÚNIOR, O. J.; SPERANDIO, M. V. L.; ZILLI, J. E. Plant-mycorrhizal fungi interaction and response to inoculation with different growth-promoting fungi. Pesquisa Agropecuária Brasileira, v. 54, 2019.

YAMADA, C. M. Detecção de microrganismos endofíticos em frutos de café. Dissertação (Mestrado em Microbiologia Agrícola) - Universidade Federal de Viçosa, Viçosa, Minas Gerais, 1999. 
ZHAO, Q.; XIONG, W.; XING, Y.; SUN, Y.; LIN, X.; DONG, Y. Long-term coffee monoculture alters soil chemical properties and microbial communities. Scientific reports, v. 8, n. 1, p. 1$11,2018$.

ZHANG, H. W.; SONG, Y. C.; TAN, R. X. Biology and chemistry of endophytes. Natural Product Reports, v. 23, n. 5, p. 753, 2006. 


\title{
Capítulo 6
}

\section{GT biplot aplicado ao estudo da diversidade de variedades de pimentas do gênero Capsicum do Estado do Espírito Santo}

\author{
Bruna Dias Gomes Brilhante ${ }^{1}$, Talles de Oliveira Santos², Larícia Olária Emerick Silva ${ }^{1}$, \\ Fernanda Vargas Valadares ${ }^{2}$, Ana Paula Cândido Gabriel Berilli ${ }^{3}$, Larissa de Carvalho \\ Nascimento ${ }^{4}$, Cíntia dos Santos Bento ${ }^{5}$, Rosana Rodrigues ${ }^{6}$, Monique Moreira Moulin ${ }^{3}$
}

\section{Introdução}

O gênero Capsicum pertence à família Solanaceae e possui 37 espécies. Entretanto, esse número pode ser reduzido, pois, existe a perspectiva das espécies $C$. geminifolium e C. ciliatum serem retiradas do gênero Capsicum (RODRIGUES et al., 2016). As espécies são agrupadas em diferentes categorias de acordo com o nível de exploração pelo homem, sendo: domesticadas (amplamente cultivadas), semidomesticadas (pouco cultivadas) e silvestres (não cultivadas comercialmente) (CARVALHO et al., 2006).

Os maiores produtores de pimentas do gênero Capsicum in natura no mundo são: a China (15 milhões de toneladas/ano), o México (2,8 milhões de toneladas/ano) e a Turquia (1,9 milhões de toneladas/ano). Para pimentas desidratadas, os países que se destacam são a Índia (1,3 milhões de toneladas/ano), a China (275 mil toneladas/ano) e o Paquistão (164 mil toneladas/ano) (FAO, 2018). O cultivo de pimenta no Brasil ocorre em quase todas as regiões e os principais estados produtores são Minas Gerais, Goiás, São Paulo, Ceará e Rio Grande do Sul (COSTA et al., 2008). Ainda existe muita dificuldade de se estimar com exatidão os dados acerca do consumo e produção de pimentas no Brasil, principalmente pelo fato do mercado consumidor ser dividido em diversos segmentos com distintas formas de uso e consumo (COSTA et al., 2008).

\footnotetext{
1 Me. em Genética e Melhoramento de Plantas pela Universidade Federal do Espírito Santo, Caixa Postal 16, CEP: 29500-000, Alegre-ES. E-mail: brunabrilhante@hotmail.com, lariciaemerick@hotmail.com

2 Me. em Genética e Melhoramento de Plantas pela Universidade Estadual do Norte Fluminense Darcy Ribeiro, CEP: 28013-600, Campos dos Goytacazes-RJ. E-mail: tallesdeoliveeira@live.com; fernanda_valladares@hotmail.com

${ }^{3}$ Dr.as Professoras do Instituto Federal do Espírito Santo - Campus de Alegre, Caixa Postal 47, CEP: 29500-000, Alegre-ES. E-mail: mmmoulin@ifes.edu.br; ana.berilli@ifes.edu.br

${ }^{4}$ Técnico do Laboratório de Genética e Biologia Molecular do Instituto Federal do Espírito Santo Campus de Alegre, Caixa Postal 47, CEP: 29500-000, Alegre-ES. E-mail: Iarissacn1@hotmail.com

${ }^{5}$ Dr. Professor da Universidade Federal do Espírito, Caixa Postal 16, CEP: 29500-000, Alegre-ES. Email: cdossantosbento@hotmail.com

6 Dr. Professor da Universidade Estadual do Norte Fluminense Darcy Ribeiro, CEP: 28013-600, Campos dos Goytacazes-RJ. E-mail: anadigues@gmail.com
} 
Um dos segmentos mais importantes da produção e comercialização de Capsicum no Brasil está no ramo da agricultura familiar, onde as pimentas são comercializadas em feiras e comércios locais, principalmente em sua forma in natura. As comunidades rurais podem, nesse sentido, contribuir para o uso e conservação de germoplasma adaptado aos ecossistemas agrícolas das comunidades produtoras, que pode ser também denominada conservação on farm (MOULIN et al., 2012). O Sul do Espírito Santo destaca-se pela intensa atividade da agricultura familiar, que garante renda a muitas famílias. As pimentas do gênero Capsicum fazem parte da oferta da gama de produtos dessas famílias, portanto, há nessas propriedades a manutenção da variabilidade genética da cultura em questão.

Por ser considerado um gênero que possui grande diversidade e relevante importância econômica faz-se necessária a realização de estudos acerca de sua diversidade genética, uma vez que as informações a respeito da diversidade local podem garantir a manutenção da variabilidade detida pelos produtores, evitando a ocorrência de erosão genética e, consequentemente, garantindo a segurança alimentar. Para a agroecologia, a conservação, caracterização e uso de sementes vindouras da agricultura familiar são de extrema relevância. Nessa perspectiva, a caracterização morfoagronômica é a forma mais acessível para a avaliação da diversidade genética em um banco de germoplasma, e tem como base dados botânicos de fácil detecção ou mensuração.

A análise biplot de genótipos $x$ caracteres (GT Biplot) vêm se destacando dentre as metodologias de análise multivariada para estudos de germoplasma, pois avalia genótipos baseados em múltiplas características e identifica aquelas superiores dentre as variáveis estudadas e que possam ser utilizadas no programa de melhoramento (MOHAMMADI e AMRI, 2013) e, comparada aos métodos existentes, essa abordagem é gráfica, objetiva, eficaz e direta (YAN e FRÉGEAU-REID, 2018). Os gráficos gerados por esta análise permitem a visualização rápida e prática dos genótipos superiores, da estabilidade fenotípica e permite, também, detectar caracteres menos importantes (redundantes) em um programa de melhoramento, bem como identificar os mais adequados para a seleção indireta de um caráter desejável (YAN, 2001), o que implica em uma seleção rigorosa para obter os ganhos desejados (OLIVEIRA et al., 2018).

Nessa perspectiva, julgou-se oportuno o desenvolvimento desse trabalho, que teve como objetivo proceder com a caracterização de 69 acessos de Capsicum spp. pertencentes ao Banco de Germoplasma do Ifes - Campus de Alegre, com a finalidade de estimar a variabilidade genotípica e fenotípica existente entre esses acessos. 


\section{Metodologia}

\section{Material vegetal, condições de cultivo e delineamento experimental}

Foram avaliados 69 acessos de pimenta do Banco de Germoplasma do Instituto Federal do Espírito Santo (Ifes) - Campus de Alegre, Espírito Santo (Tabela 1). Os acessos foram coletados junto a agricultores familiares do Espírito Santo e de feiras livres nos municípios de Alegre, Piaçu, Cachoeiro de Itapemirim, Venda Nova do Imigrante, Anchieta, Alfredo Chaves e Domingos Martins, além de intercâmbio com o Banco Ativo de Germoplasma (BAG) da Universidade Estadual do Norte Fluminense Darcy Ribeiro (UENF) e cinco genótipos comerciais.

Tabela 1. Dados de passaporte de 69 acessos de Capsicum spp. pertencentes ao Banco de Germoplasma do Ifes - Campus de Alegre.

\begin{tabular}{|c|c|c|c|c|}
\hline \multicolumn{2}{|c|}{ Acessos } & Nome popular & Procedência & Espécie \\
\hline 1 & IFCA 01 & $\begin{array}{c}\text { Pimenta dedo-de- } \\
\text { moça }\end{array}$ & Colatina & Capsicum baccatum var. pendulum \\
\hline 2 & IFCA 02 & Pimenta de cheiro & Colatina & Capsicum chinense Jacq. \\
\hline 3 & IFCA 03 & Pimenta & Domingos Martins & Capsicum chinense Jacq. \\
\hline 4 & IFCA 04 & Pimenta biquinho & Domingos Martins & Capsicum chinense Jacq. \\
\hline 5 & IFCA 05 & $\begin{array}{l}\text { Pimenta dedo-de- } \\
\text { moça }\end{array}$ & Piaçu & Capsicum baccatum var. pendulum \\
\hline 6 & IFCA 06 & $\begin{array}{l}\text { Pimenta dedo-de- } \\
\text { moça }\end{array}$ & Piaçu & Capsicum baccatum var. pendulum \\
\hline 7 & IFCA 07 & Pimenta pitanga & Alegre & Capsicum chinense Jacq. \\
\hline 8 & IFCA 08 & Pimenta & Alegre & Capsicum chinense Jacq. \\
\hline 9 & IFCA 09 & Pimenta & Comercial & Capsicum chinense Jacq. \\
\hline 10 & IFCA 10 & Pimenta & Alegre & Capsicum baccatum var. pendulum \\
\hline 11 & IFCA 12 & $\begin{array}{l}\text { Pimenta dedo-de- } \\
\text { moça }\end{array}$ & Alegre & Capsicum baccatum var. pendulum \\
\hline 12 & IFCA 13 & $\begin{array}{c}\text { Pimenta inca red } \\
\text { drop }\end{array}$ & Alegre & Capsicum chinense Jacq. \\
\hline 13 & IFCA 14 & Pimenta malagueta & Alegre & Capsicum frutescens \\
\hline 14 & IFCA 16 & Pimenta & Alegre & Capsicum baccatum var. pendulum \\
\hline 15 & IFCA 17 & Pimenta & Alegre & Capsicum chinense Jacq. \\
\hline 16 & IFCA 22 & Pimenta & Alfredo Chaves & Capsicum chinense Jacq. \\
\hline 17 & IFCA 23 & Pimenta & Alfredo Chaves & Capsicum chinense Jacq. \\
\hline 18 & IFCA 24 & Pimenta & Anchieta & Capsicum baccatum var. pendulum \\
\hline 19 & IFCA 25 & $\begin{array}{l}\text { Pimenta bode- } \\
\text { amarela }\end{array}$ & Alfredo Chaves & Capsicum chinense Jacq. \\
\hline 20 & IFCA 26 & Pimenta Murupi & Alfredo Chaves & Capsicum chinense Jacq. \\
\hline 21 & IFCA 27 & Pimenta & Anchieta & Capsicum baccatum var. pendulum \\
\hline 22 & IFCA 28 & Pimenta malagueta & Anchieta & Capsicum frutescens \\
\hline 23 & IFCA 31 & Pimenta & Anchieta & C. annuum var. glabriusculum \\
\hline 24 & IFCA 32 & Pimenta & Anchieta & Capsicum chinense Jacq. \\
\hline 25 & IFCA 33 & Pimenta de cheiro & Anchieta & Capsicum chinense Jacq. \\
\hline
\end{tabular}


Pimenta

Pimenta biquinho

Pimenta de cheiro

Pimenta de cheiro

Pimenta

Pimenta biquinho

Pimenta

Pimenta biquinho

Pimenta de cheiro

Pimenta de cheiro

Pimenta de cheiro Pimenta

Pimenta biquinho

Pimenta dedo-demoça

Pimenta Cambuci Pimenta

Pimenta malagueta

Pimenta de cheiro Pimenta

Pimenta Cambuci Pimenta

Pimenta dedo-demoça

Pimenta

Pimenta biquinho Pimenta

Pimenta dedo-demoça

Pimenta

Pimenta dedo-demoça

Pimenta dedo-demoça

Pimenta malagueta

Pimenta biquinho

Pimenta dedo-demoça

Pimenta dedo-demoça

Pimenta Cambuci

Pimenta dedo-demoça

Pimenta Cambuci

Pimenta de cheiro Pimenta

Pimenta malagueta

Pimenta dedo-demoça

Pimenta malagueta

Pimenta bodevermelha
Anchieta

Anchieta

Anchieta

Anchieta

Anchieta

Anchieta

Anchieta

Anchieta

Anchieta

Anchieta

Alegre

Alegre

Alegre

Alegre

Comercial

Piaçu

Cachoeiro de Itapemirim

BAG Uenf

BAG Uenf

BAG Uenf

BAG Uenf

BAG Uenf

BAG Uenf

BAG Uenf

BAG Uenf

BAG Uenf

BAG Uenf

BAG Uenf

BAG Uenf

BAG Uenf

Alegre

Piaçu

BAG Uenf

BAG Uenf

BAG Uenf

Alegre

Venda Nova do Imigrante

Venda Nova do Imigrante

Cachoeiro de Itapemirim

Alegre

Alegre

Comercial
Capsicum chinense Jacq.

Capsicum chinense Jacq.

Capsicum chinense Jacq.

Capsicum chinense Jacq.

Capsicum chinense Jacq.

Capsicum chinense Jacq.

Capsicum chinense Jacq.

Capsicum chinense Jacq.

Capsicum chinense Jacq.

Capsicum chinense Jacq.

Capsicum chinense Jacq.

Capsicum chinense Jacq.

Capsicum chinense Jacq.

Capsicum baccatum var. pendulum

Capsicum baccatum var. pendulum

Capsicum chinense Jacq.

Capsicum frutescens

Capsicum chinense Jacq.

Capsicum chinense Jacq.

Capsicum baccatum var. pendulum

Capsicum baccatum var. pendulum

Capsicum baccatum var. pendulum

Capsicum chinense Jacq.

Capsicum chinense Jacq.

Capsicum annuum

Capsicum baccatum var. pendulum

Capsicum chinense Jacq.

Capsicum baccatum var. pendulum

Capsicum baccatum var. pendulum

Capsicum frutescens

Capsicum chinense Jacq.

Capsicum baccatum var. pendulum

Capsicum baccatum var. pendulum

Capsicum baccatum var. pendulum

Capsicum baccatum var. pendulum

Capsicum baccatum var. pendulum

Capsicum chinense Jacq.

Capsicum chinense Jacq.

Capsicum frutescens

Capsicum baccatum var. pendulum

Capsicum frutescens

Capsicum chinense Jacq. 


\begin{tabular}{|c|c|c|c|c|}
\hline 68 & IFCA 100 & Pimenta malagueta & Comercial & Capsicum frutescens \\
\hline 69 & IFCA 101 & $\begin{array}{c}\text { Pimenta dedo-de- } \\
\text { moça }\end{array}$ & Comercial & Capsicum baccatum var. pendulum \\
\hline
\end{tabular}

Fonte: Os Autores.

Os experimentos foram conduzidos na Fazenda Experimental "Caixa D’água" do Ifes -

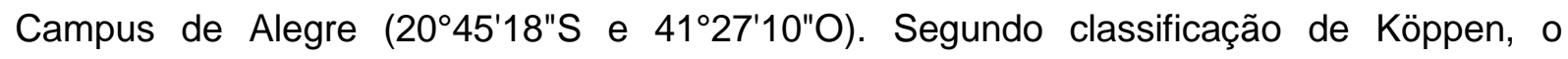
ambiente de estudo é caracterizado como clima subtropical úmido (Cwa), apresentando temperatura e precipitação médias anuais de $23,1^{\circ} \mathrm{C}$ e $1.341 \mathrm{~mm}$, respectivamente (LIMA et al., 2008).

A semeadura dos 69 acessos ocorreu no dia 28 de maio de 2017, no delineamento de blocos casualizados com quatro repetições, totalizando 276 parcelas experimentais. $O$ plantio foi realizado em tubetes de poliestireno para mudas contendo substrato preparado nas seguintes proporções totais: 10 litros de solo, 4 litros de esterco bovino curtido e peneirado, $25 \mathrm{~g}$ de calcário e $6 \mathrm{~g}$ de cloreto de potássio. A germinação e o desenvolvimento das mudas foram acompanhados diariamente e a irrigação com turno de rega diário, geralmente pela manhã. Os tubetes foram mantidos em casa de vegetação até o transplantio para o campo, no estádio de quatro a seis pares de folhas definitivas. No campo, as plantas foram dispostas no espaçamento de $1,0 \mathrm{~m}$ entre linhas e 0,5 m entre plantas.

Foi realizada análise físico-química e granulométrica do solo da área experimental para cálculo da necessidade de corretivos e fertilizantes. Foi realizada uma adubação de cobertura 30 dias após o plantio. Utilizou-se $3 \mathrm{~g}$ da formulação NPK 25-00-20. Todos os tratos culturais utilizados seguiram as recomendações de Filgueira (2012) para a cultura da pimenta.

\section{Caracterização morfoagronômica}

Os acessos foram caracterizados com base em descritores morfoagronômicos específicos para Capsicum da Bioversity International (IPGRI, 1995). Dos 39 descritores utilizados, oito se baseiam em caracteres quantitativos e 23 se baseiam em características qualitativas.

Os caracteres quantitativos estudados foram: altura da planta (AP); diâmetro da copa (DCO); diâmetro do caule (DCA); comprimento da folha (CF); comprimento do fruto (CFR); diâmetro do fruto (DFR); massa fresca do fruto (MFF); e espessura do pericarpo (EP). Para a caracterização e avaliação dos descritores de fruto utilizaram-se cinco frutos de cada parcela. 
Os caracteres AP, DCO foram aferidos em campo e com auxílio de uma trena metálica e expressos em cm. Já DCA, foi mensurada em campo com auxílio de um paquímetro digital e expresso em $\mathrm{mm}$. A AP foi mensurada quando $50 \%$ das plantas apresentarem frutos maduros, medindo-se da superfície do solo até o ponto mais alto da planta. O DCO foi medido após a primeira colheita entre os pontos mais largos da copa, enquanto o DCA foi medido na parte mediana da primeira bifurcação.

Já o caráter relacionado à folha - CF - foi avaliado ex situ, por meio da coleta de cinco folhas totalmente desenvolvidas, com auxílio de um paquímetro digital, expresso em $\mathrm{cm}$. $\mathrm{O}$ caráter CFR foi determinado na região longitudinal dos frutos com auxílio de um paquímetro, expresso em mm. DFR foi mensurado com paquímetro digital o maior diâmetro do fruto e expresso em mm. A MFF foi avaliada no estágio de fruto maduro, com auxílio de uma balança de precisão, expresso em $\mathrm{g}$. A EP, dada em $\mathrm{mm}$, foi mensurada na maior espessura da polpa do fruto após um corte transversal.

Os caracteres qualitativos avaliados foram hábito de crescimento da planta, forma da folha, cor da antera, cor da corola, cor da mancha da corola, cor do filamento, constrição anelar do cálice, cor do fruto no estádio intermediário, cor do fruto no estágio maduro, forma do fruto e presença ou ausência de capsaicina.

Para a determinação indireta de capsaicina nas amostras foi realizado um teste que consistiu no preparo de uma solução contendo $920 \mathrm{ml}$ de vanadato de amônio $(9,2 \mathrm{~g}$ de vanadato de amônio dissolvido em $920 \mathrm{ml}$ de água destilada) e $138 \mathrm{ml}$ de ácido clorídrico. Posteriormente, foram adicionados $15 \mathrm{~mL}$ dessa solução aos 69 tubos de ensaio contendo fragmentos das placentas dos frutos, onde permaneceram em repouso por 14 horas. $A$ reação proporcionou visualização das glândulas presentes no tecido placentário que contêm capsaicina, as quais ficaram caracterizadas por uma coloração castanha, de acordo com o método utilizado por Riva (2006).

\section{Análises estatísticas}

Os descritores quantitativos foram submetidos à análise de variância, de acordo com o delineamento em blocos casualizados, conforme o modelo estatístico: $Y_{i j}=\mu+g_{i}+b_{j}+\varepsilon_{i j}$, onde $Y_{i j}$ : valor observado para a variável em estudo referente ao genótipo $i$ no bloco $j$; $\mu$ : média geral; $g_{i}$ : efeito atribuído ao i-ésimo genótipo; $b_{j}$ : efeito do j-ésimo bloco; $\varepsilon_{i j}$ : erro experimental associado à observação $Y_{i j}$.

Verificada a diferença significativa entre os acessos em nível de $5 \%$ pelo teste $\mathrm{F}$ para as variáveis estudadas, procedeu-se com agrupamento de médias pelo método de Scott-Knott ao nível de $5 \%$ de significância. 
A divergência entre os acessos foi estimada por meio da matriz de dissimilaridade, obtida pelo método de Gower (1971), considerando os dados quantitativos e qualitativos. O agrupamento dos genótipos foi realizado considerando o método UPGMA. As análises estatístico-genéticas foram realizadas com o auxílio do programa Genes (CRUZ, 2013).

Para a análise de GT Biplot, o modelo utilizado foi: $\frac{T_{i j}-\hat{T}_{i j}}{S_{j}}=\lambda_{1} \zeta_{i 1} \tau_{j 1}+\lambda_{2} \zeta_{i 2} \tau_{j 2}+\varepsilon_{i j}$, onde: $T_{i j}$ é o valor médio do genótipo $i$ para a característica $j ; T_{i j}$ representa a média de todos os genótipos na característica $j ; S_{j}$ é a estimativa de desvio-padrão; $\lambda_{1}$ e $\lambda_{2}$ representam os valores singulares para PC1 e PC2, respectivamente; $\zeta_{i 1}$ e $\zeta_{i 2}$ representam os scores da PC1 e PC2 para o genótipo $i$; $\tau_{j 1}$ e $\tau_{j 2}$ representam os scores da PC1 e PC2 para a característica $j ; \varepsilon_{i j}$ é o resíduo do modelo associado à performance do genótipo e da característica. A análise foi realizada com auxílio do software RStudio (R CORE TEAM, 2020) - pacote GGEbiplotGUI (YAN, 2001).

\section{Resultados e discussões}

Todos os genótipos apresentaram diferenças significativas para as variáveis quantitativas pelo teste $F(p \leq 0,01)$ evidenciando a ampla variabilidade entre os acessos estudados. $O$ menor valor para o coeficiente de variação foi para a variável de comprimento do fruto com $23,41 \%$, ao passo que o diâmetro do fruto apresentou o maior valor - 37,99\% - (Tabela 2 ).

Tabela 2. Análise de variância para oito características quantitativas avaliadas em 69 acessos de Capsicum spp. pertencentes ao Banco de Germoplasma do Ifes - Campus de Alegre.

\begin{tabular}{ccccc}
\hline & \multicolumn{2}{c}{ Quadrados Médios } & & \\
\cline { 2 - 3 } Característica & $\begin{array}{c}\text { Genótipo } \\
(\mathrm{GL}=68)\end{array}$ & $\begin{array}{c}\text { Resíduo } \\
(\mathrm{GL}=136)\end{array}$ & Média & CV (\%) \\
& $775,15^{* *}$ & 157,3 & 53,06 & 23,71 \\
Altura da planta & $1116,08^{* *}$ & 327 & 63,43 & 28,51 \\
Diâmetro da copa & $63,71^{* *}$ & 24,05 & 17,42 & 28,15 \\
Diâmetro do caule & $10,92^{* *}$ & 6,54 & 8,77 & 29,15 \\
Comprimento da folha & $356,55^{* *}$ & 20,74 & 4,6 & 23,41 \\
Comprimento do fruto & $122,05^{* *}$ & 5,47 & 19,45 & 37,99 \\
Diâmetro do fruto & $50,75^{* *}$ & 1,75 & 3,81 & 34,76 \\
Massa fresca do fruto & $1,67^{* *}$ & 0,26 & 1,87 & 27,35 \\
\hline Espessura do pericarpo &
\end{tabular}

** significativo ao nível de $1 \%$ de probabilidade pelo teste F. GL: graus de liberdade; CV: coeficiente de variação (\%).

Fonte: Os Autores. 
A altura de planta variou entre 19,7cm (IFCA 31) e 95,7cm (IFCA 93), enquanto o diâmetro da copa apresentou valores entre 10,50 (IFCA 51) e 105,67cm (IFCA 59). O diâmetro do caule variou entre 6,8 mm (IFCA 31) a 29,2 mm (IFCA 55). O comprimento de folha variou entre $3,45 \mathrm{~cm}$ (IFCA 40) a 15,22 cm (IFCA 37).

O descritor comprimento do fruto foi o que apresentou a maior variação, com valores entre $1,07 \mathrm{~cm}$ (IFCA 22) a 12,79 cm (IFCA 67). O diâmetro do fruto reuniu as médias dos acessos em sete grupos com variação entre 49,5 mm (IFCA 51) e 3,95 mm (IFCA 14). De modo geral, os acessos de $C$. frutescens obtiveram os menores valores para essas variáveis, o que é comum para espécie, que abrange as pimentas do tipo "malagueta" que são muito utilizadas para produção de molhos, considerando que o tamanho reduzido de seus frutos e alto teor de capsaicina são características preponderantes para sua finalidade. Desse modo, esses acessos se destacam para indicação de variedades para o mercado de condimentos.

Para a característica de massa fresca do fruto, os valores apresentaram grande variação, tendo valores entre 0,38 g (IFCA 100) a 30,94 g (IFCA 33). De modo geral os frutos dos acessos de $C$. baccatum var. pendulum, apresentaram os maiores valores para a característica, fato que é comum para essa variedade. A exemplo disso cita-se o acesso IFCA 33 (30,94 g), IFCA 67 (22,33 g), IFCA 82 (21,22 g) e IFCA 51 (20,56 g). Já os acessos pertencentes à espécie $C$. frutescens foram os que apresentaram os menores valores para essa característica, o que é consolidado na literatura, visto que essa espécie abrange as pimentas do tipo "malagueta" que, devido ao seu tamanho reduzido, possuem menor massa.

Já a espessura do pericarpo agrupou os genótipos em quatro classes, com valores entre $0,35 \mathrm{~mm}$ e 4,33 $\mathrm{mm}$. Os maiores valores para essa característica foram encontrados nos acessos IFCA 38 (4,33 mm), IFCA 13 (3,56 mm), IFCA 10 (3,56 mm), IFCA 92 (3,52 mm), IFCA 24 (3,28 mm) e IFCA $16(3,28 \mathrm{~mm})$. Segundo Abud et al. (2018), pimentas com pericarpos mais espessos possuem maior importância para o mercado de consumo dos frutos in natura, haja vista que essa característica confere maior resistência aos frutos nos tratos pós-colheita e garante aparência mais apreciada pelos consumidores.

Em contrapartida, Lannes et al. (2007) afirma que, frutos menores, como os de $C$. chinense, apresentam menor espessura do pericarpo e maior concentração de sólidos solúveis totais, tendo estes grandes apelos para a desidratação e produção de páprica. Nesse sentido, destacam-se os acessos IFCA 100, IFCA 95, IFCA 55, IFCA 28, IFCA 93, IFCA 40, IFCA 57 e IFCA 72, que apresentaram os menores valores para a característica de espessura do pericarpo e tamanho de fruto.

Quanto aos caracteres qualitativos, constatou-se que hábito de crescimento intermediário foi encontrado em $82,6 \%$ dos acessos enquanto $14,5 \%$ apresentaram hábito de crescimento 
ereto e 2,9\% prostrado. Esse descritor está diretamente relacionado com o manejo da cultura, visto que plantas de porte mais elevado e copa pequena podem vir a precisar de tutoramento. Plantas prostradas dificultam o manejo de tratos culturais como capinas e pulverizações (MELO et al., 2014).

O formato das folhas variou entre oval (49,3\%), deltoide (44,9\%) e lanceolada (5,8\%). Na análise de coloração dos frutos, observou-se que os frutos, no estádio intermediário, apresentaram coloração variando entre laranja $(78,2 \%)$, amarelo $(10,3 \%)$ verde $(7,2 \%)$, roxo escuro (2,9\%) e vermelho (1,4\%). Já no estádio maduro, $43,5 \%$ dos acessos possuem frutos vermelhos médio, 34,8\% vermelho escuro, 5,8\% laranja, 4,3\% laranja pálido, 4,3\% vermelho claro, 2,9\% amarelo limão e 2,9\% amarelo alaranjado. A ocorrência de diversas classes fenotípicas para as variáveis de fruto é decorrente da variabilidade genética existente entre os acessos entre e dentro de cada espécie. Essa variação na coloração dos frutos também foi reportada por Sudré et al. (2010), estudando acessos de Capsicum spp. Observações similares, relacionadas à coloração dos frutos, também foram realizadas por Cardoso et al. (2018), Martinez et al. (2017) e Leite et al. (2016) estudando germoplasma de C. baccatum; por Baba et al. (2016) em C. chinense; Carvalho et al. (2017) em C. frutescens e Nahak et al. (2018) em C. annuum.

Houve, também, variação quanto ao formato dos frutos. O formato triangular e alongado foram os que mais ocorreram com $39,1 \%$ e $36,2 \%$, respectivamente, seguido do formato bloco $(11,6 \%)$, redondo $(8,7 \%)$ e campanulado $(4,4 \%)$. Soares et al. (2018) e Neitzke et al. (2016) estudando genótipos de Capsicum spp. também encontraram todas essas classes para o formato dos frutos.

A capsaicina esteve presente em $75,4 \%$ dos acessos e ausente nos $24,6 \%$ restantes. Essa substância é o alcaloide encontrado em maior quantidade na placenta dos frutos de pimenta e é um dos principais compostos responsáveis pela sua pungência. A avaliação qualitativa de capsaicina para caracterização de bancos de germoplasma de pimenta já foi realizada por outros autores, tais como Riva-Souza et al. (2009) e Moulin et al. (2015).

A análise de genótipo vs. características (GT) biplot representou $65,20 \%$ da variação entre os genótipos para as características estudadas. De acordo com Yang et al. (2009), os dois primeiros componentes principais (PCs) devem explicar mais de $60 \%$ da variação dos dados, pressuposto este que foi atendido nesse trabalho, sugerindo que os gráficos gerados representaram eficientemente a variação dos dados, possibilitando a interpretação segura dos fenômenos estudados.

O gráfico Biplot Which Won Where (Figura 1) apresenta um conjunto de linhas perpendiculares, que o divide em vários grupos de características. Os genótipos que se apresentam no vértice do polígono formado para cada grupo de características são aqueles 
com melhor média geral para o grupo, já aqueles no interior dos polígonos são os menos responsivos para as características avaliadas (YAN, 2001). Logo, o genótipo 25 (IFCA 33) foi o destaque para o primeiro grupo de caraterísticas (EP, MFF e DFR), logo, apresenta maiores valores de espessura do pericarpo, massa fresca do fruto e diâmetro do fruto. Para o segundo grupo de características (CFR e CF), destacou-se o genótipo 51 (IFCA 67), possuindo valores elevados de comprimento de fruto e folha. Já para o terceiro grupo de características (AP, DCO e DCA), destacaram-se os genótipos 42 (IFCA 55) e 66 (IFCA 95), sendo possível inferir o destaque desses genótipos para altura de plantas, diâmetro da copa e caule.

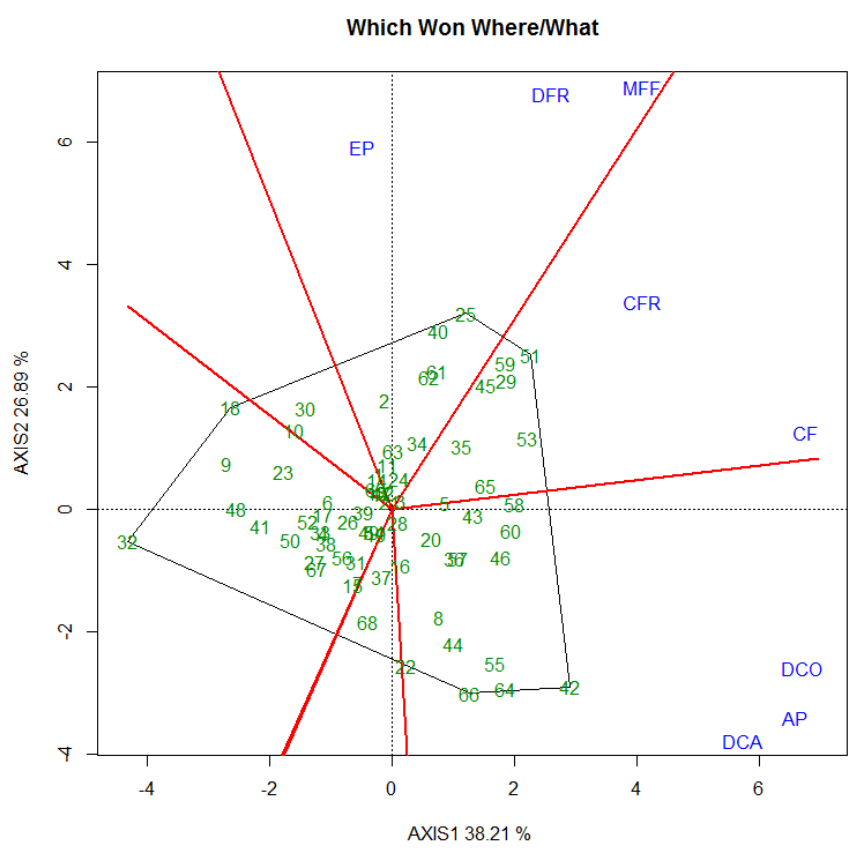

Figura 1. Gráfico Which Won Where da análise GT Biplot. EP: espessura do pericarpo; DFR: diâmetro do fruto; MFF: massa fresca do fruto; CFR: comprimento do fruto; CF: comprimento da folha; DCO: diâmetro da copa; AP: altura da planta; DCA: diâmetro do caule.

Fonte: Os Autores.

$\mathrm{Na}$ análise biplot de means vs. stability (Figura 2) o desempenho é definido como o vetor mais longo do componente principal 1 (PC1), representado por aquele com a seta indicando o genótipo ideal, que se localiza próximo ao círculo concêntrico. Já os genótipos localizados para a direita da linha vertical, são aqueles com desempenho superior à média geral dos caracteres estudados, ao passo que os genótipos localizados à esquerda, apresentam desempenho inferior. Já a estabilidade, pode ser observada por meio do componente principal 2 (PC2), pois quanto menor a projeção (linha tracejada) de um determinado genótipo, mais próximo ele se torna do centro do biplot, apresentando melhor estabilidade para as características avaliadas. Dessa forma, genótipos ideais, devem possuir elevado 
valor de PC1 (elevado rendimento) e baixo valor de PC2 (alta estabilidade) (YAN e RAJCAN, 2001).

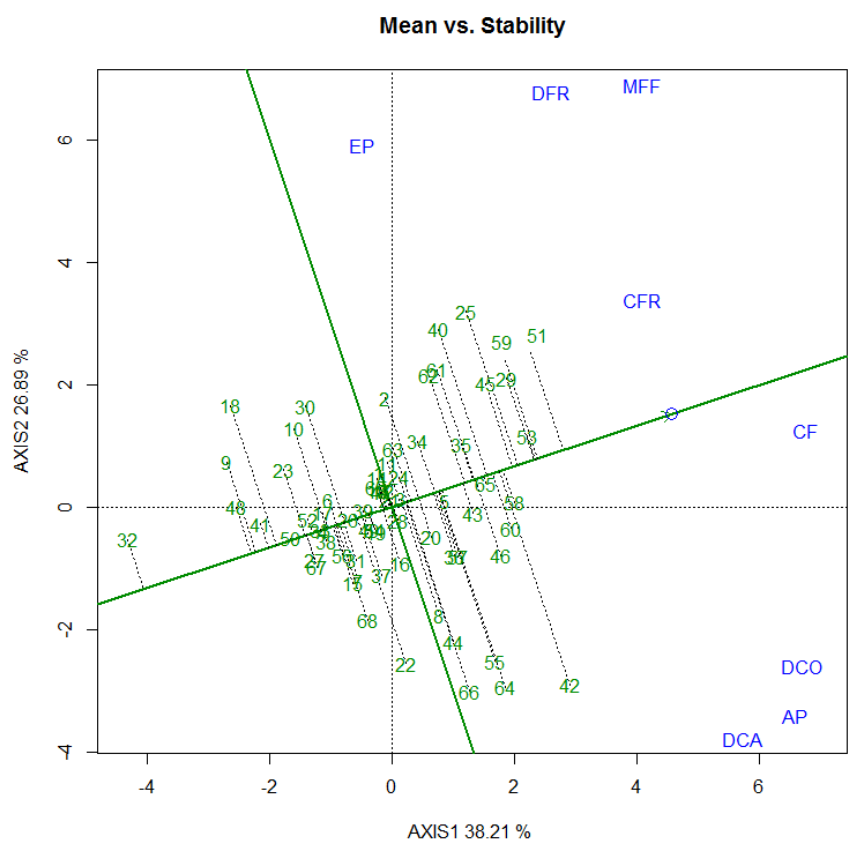

Figura 2. Gráfico Mean vs. Stability da análise GT Biplot. EP: espessura do pericarpo; DFR: diâmetro do fruto; MFF: massa fresca do fruto; CFR: comprimento do fruto; CF: comprimento da folha; DCO: diâmetro da copa; AP: altura da planta; DCA: diâmetro do caule.

Fonte: Os Autores.

Com base nisso, o genótipo 51 (IFCA 67) foi aquele que mais se aproximou do genótipo ideal, considerando seu rendimento para as variáveis estudadas, seguido pelos genótipos 59 (IFCA 82), 58 (IFCA 81) e 29 (IFCA 37), respectivamente. Todavia, o melhoramento de plantas deve basear-se não somente no desempenho elevado dos genótipos para as características de interesse, mas também na capacidade de um genótipo de apresentar resultados similares em outros ambientes diferentes dos estudados, isto é, estabilidade fenotípica. Nesse sentido, o acesso IFCA 81, apesar rendimento menor, seria o mais indicado visto que sua projeção de estabilidade no gráfico foi consideravelmente melhor.

$\mathrm{Na}$ análise "discriminativeness vs. representativeness" do biplot (Figura 3), as habilidades discriminatórias, e de representatividade das características são informações importantes para um programa de melhoramento. A habilidade de uma característica em discriminar um genótipo é destacada pelo tamanho do vetor (linha tracejada). Quanto mais longo o vetor, mais discriminante é a característica (YAN et al., 2007).

As variáveis mais representativas são as que formam os menores ângulos com a linha que apresenta o círculo formado com a seta (YAN e TINKER, 2006). Portanto, a variável ideal deve ser capaz de discriminar os genótipos e representar as demais características, 
dessa forma, deve apresentar alto PC1 (maior capacidade discriminatória) e baixo PC2 (maior representatividade) (YAN e TINKER, 2006).

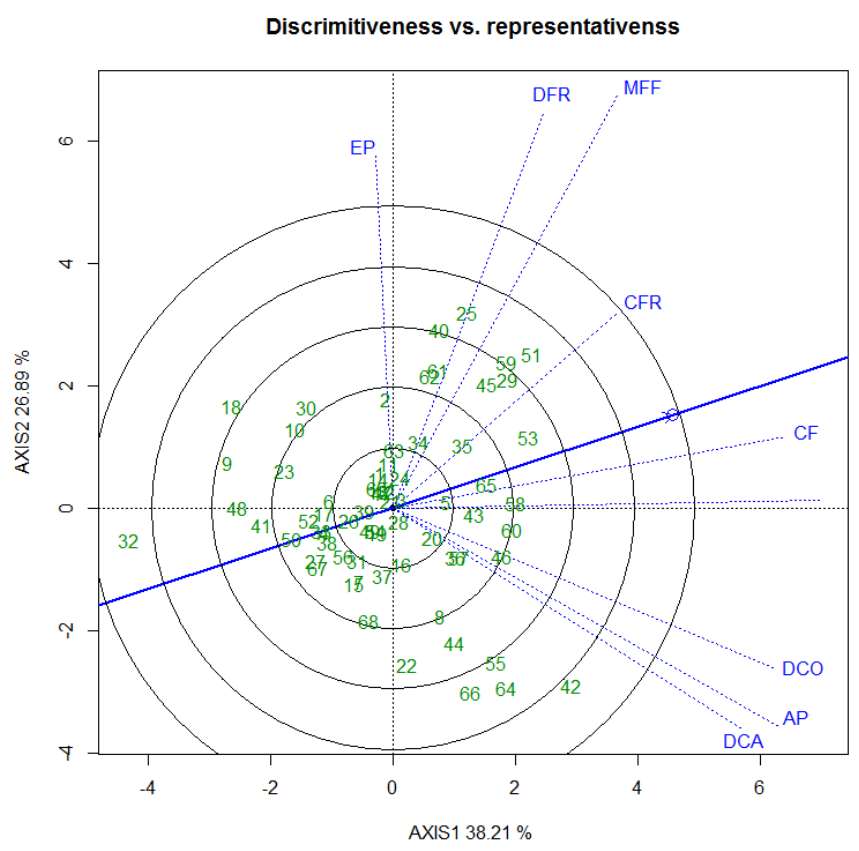

Figura 3. Gráfico discriminativeness vs. representativeness da análise GT Biplot. EP: espessura do pericarpo; DFR: diâmetro do fruto; MFF: massa fresca do fruto; CFR: comprimento do fruto; CF: comprimento da folha; DCO: diâmetro da copa; AP: altura da planta; DCA: diâmetro do caule.

Fonte: Os Autores.

Nesse sentido, as variáveis que se sobressaíram foram MFF, DFR, CFR e CF, com potencialidade para maiores discriminação e representatividade, favorecendo a seleção de genótipos para um pool de características de elevado interesse para o melhoramento de Capsicum. Por outro lado, EP, DCO, AP, DCA se mostram menos eficientes, pois apresentam discriminância considerável, porém pouca representatividade. Além disso, são características de difícil mensuração uma vez que exige grande demanda de trabalho em campo, o que dificulta o processo de melhoramento.

O agrupamento dos acessos representado pelo dendrograma (Figura 4) reuniu os acessos em sete grupos. Verifica-se que os grupos formados apresentam correlação com a divisão por espécies dos acessos (Figura 5), entretanto não foi possível observar correlação entre a distância genética e distância geográfica dos acessos coletados.

No grupo I foram alocados quatro acessos da espécie C. baccatum var. pendulum morfotipo "cambuci", a saber: IFCA 51, IFCA 58, IFCA 82 e IFCA 90. Pimentas desse morfotipo, também conhecidadas como "chapéu-de-bispo", foram inicialmente classificadas como C. baccatum var. umbilicatum de Hunziker e Barbosa (1998), baseada em descritores 
morfológicos (Albrecht et al., 2012). Porém, Carvalho e Bianchetti (2008) consideram um tipo morfológico típico de C. baccatum var. pendulum. Semelhante a classificação de Carvalho e Bianchetti (2008), na análise morfoagronômica neste trabalho, os acessos do tipo "cambuci" agruparam-se isoladamente de outros acessos de C. baccatum var. pendulum presentes no estudo. 


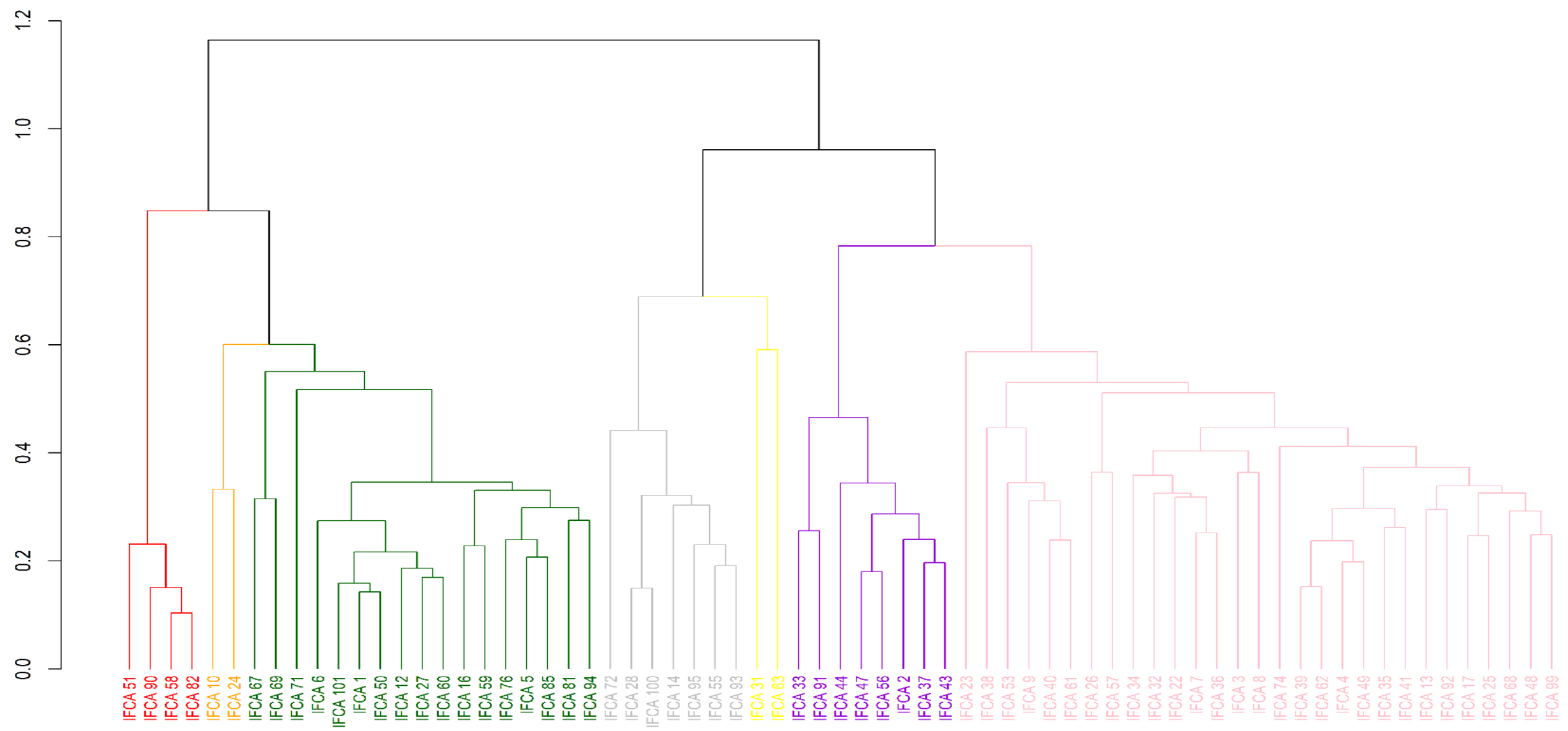

Figura 4. Dendrograma de dissimilaridade genética entre 69 acessos de Capsicum spp. obtido pelo método hierárquico de médias ponderadas (UPGMA), com base no algoritmo de Gower.

Fonte: Os Autores. 
O grupo II (IFCA 10 e IFCA 24), alocou dois acessos de C. baccatum var. pendulum, sendo bem semelhantes quanto a maioria das características avaliadas. No Grupo III, reuniram-se dezessete acessos de C. baccatum var. pendulum, sendo: IFCA 1, IFCA 5, IFCA 6, IFCA 12, IFCA 16, IFCA 27, IFCA 50, IFCA 59, IFCA 60, IFCA 67, IFCA 69, IFCA 71, IFCA 76, IFCA 81, IFCA 85, IFCA 94 e IFCA 101. Um total de $88 \%$ dos acessos alocados nesse grupo pertence ao morfotipo "dedo-de-moça" (Figura 5).

Os acessos IFCA 14, IFCA 28, IFCA 55, IFCA 72, IFCA 93, IFCA 95 e IFCA 100, da espécie $C$. frutescens, compõem o grupo IV. O hábito de crescimento de suas plantas é ereto e são os acessos de maior altura de planta, com frutos pequenos, espessura do pericarpo e massa fresca do fruto inferiores quando comparados aos acessos de outras espécies.

O Grupo V alocou os acessos IFCA 31 e IFCA 63, únicos representantes das espécies $C$. annuum var. glabriusculum e $C$. annuum, respectivamente. O acesso IFCA 31 possui coloração da antera violeta, corola roxa, ausência de mancha na corola, cor do filamento violeta, cor do fruto no estágio intermediário roxo escuro e vermelho escuro no estágio maduro. Já o acesso IFCA 63 possui corola branca sem nenhum tipo de mancha, atributos próprios da espécie.

No grupo VI, alocaram-se somente acessos de C. chinense (IFCA 2, IFCA 17, IFCA 33, IFCA 37, IFCA 43, IFCA 44, IFCA 56 e IFCA 91), conhecidos popularmente como "pimentade-cheiro" (Figura 5). Esses acessos apresentam a constrição anelar do cálice, característica predominante da espécie, posição da flor intermediária. Quanto aos frutos, a maior parte, varia entre laranja no estágio intermediário e vermelho-escuro no estágio maduro.

O grupo VII reuniu 29 acessos de $C$. chinense, correspondendo a $42 \%$ do total, a saber: IFCA 03, IFCA 04, IFCA 07, IFCA 08, IFCA 09, IFCA 13, IFCA 17, IFCA 22, IFCA 23, IFCA 25, IFCA 26, IFCA 32, IFCA 34, IFCA 35, IFCA 36, IFCA 38, IFCA 39, IFCA 40, IFCA 41, IFCA 48, IFCA 49, IFCA 53, IFCA 57, IFCA 61, IFCA 62, IFCA 68, IFCA 74, IFCA 92 e IFCA 99. Essa espécie é caracterizada por apresentar maior variação fenotípica dos frutos quanto ao formato, cor e tamanho quando comparada com as demais espécies domesticadas. Destaca-se nesse grupo a reunião de sete acessos do morfotipo "biquinho" (Figura 5), dos quais em cinco (IFCA 26, IFCA 35, IFCA 39, IFCA 41 e IFCA 74) não foi detectada a substância capsaicina, sendo esses promissores para o melhoramento de plantas visando cultivares menos pungentes. Os outros dois acessos (IFCA 9 e IFCA 40) são potenciais para fins ornamentais devido a sua baixa estatura e diâmetro da copa. Destaca-se ainda nesse grupo o acesso IFCA 26 - morfotipo "murupi" - comumente encontrado na região amazônica. Esse morfotipo se difere da maioria dos acessos de $C$. chinense, por apresentar frutos alongados e porte da planta mais elevado. Fonseca et al. (2008) caracterizando 
morfologicamente acessos de C. chinense no estado do Amazonas observaram, inclusive, proximidade de acessos "murupi" com acessos de "dedo-de-moça" da espécie C. baccatum var. pendulum devido a semelhança no formato de seus frutos.

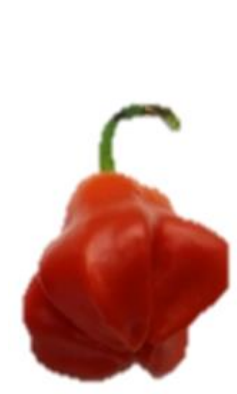

IFCA 51

\section{Grupo I}

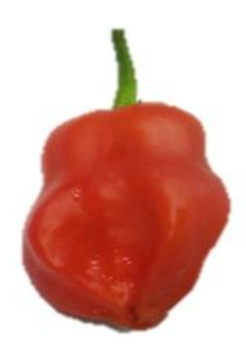

IFCA 90

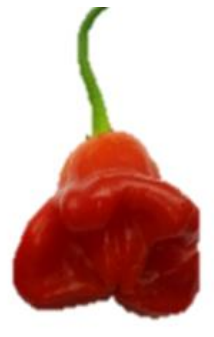

IFCA 58

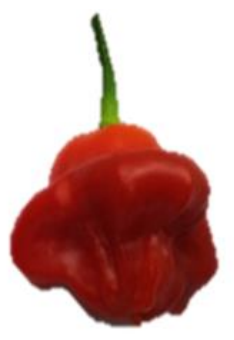

IFCA 82
Grupo II

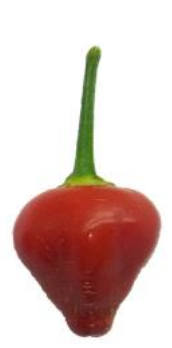

IFCA 10

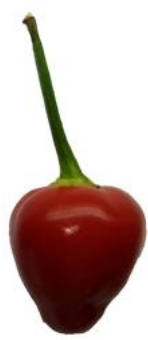

IFCA 24

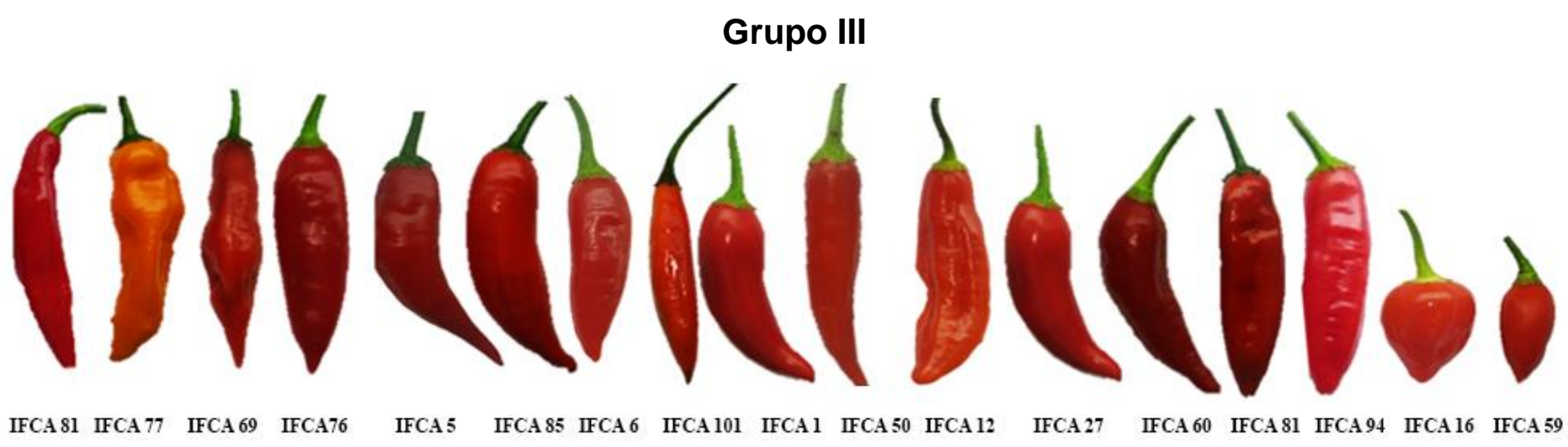

Grupo IV

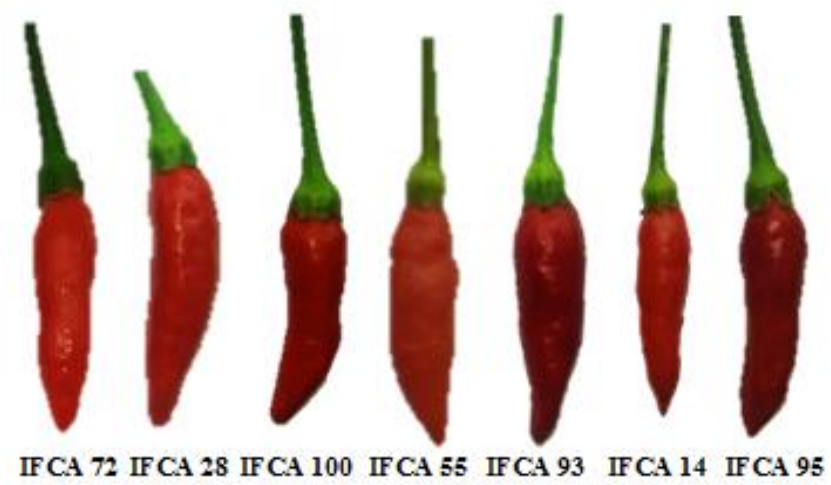

Grupo V

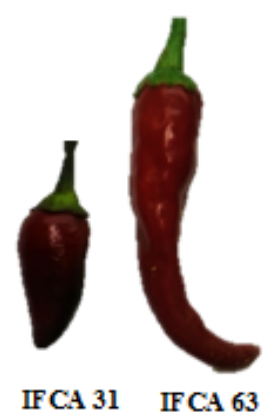




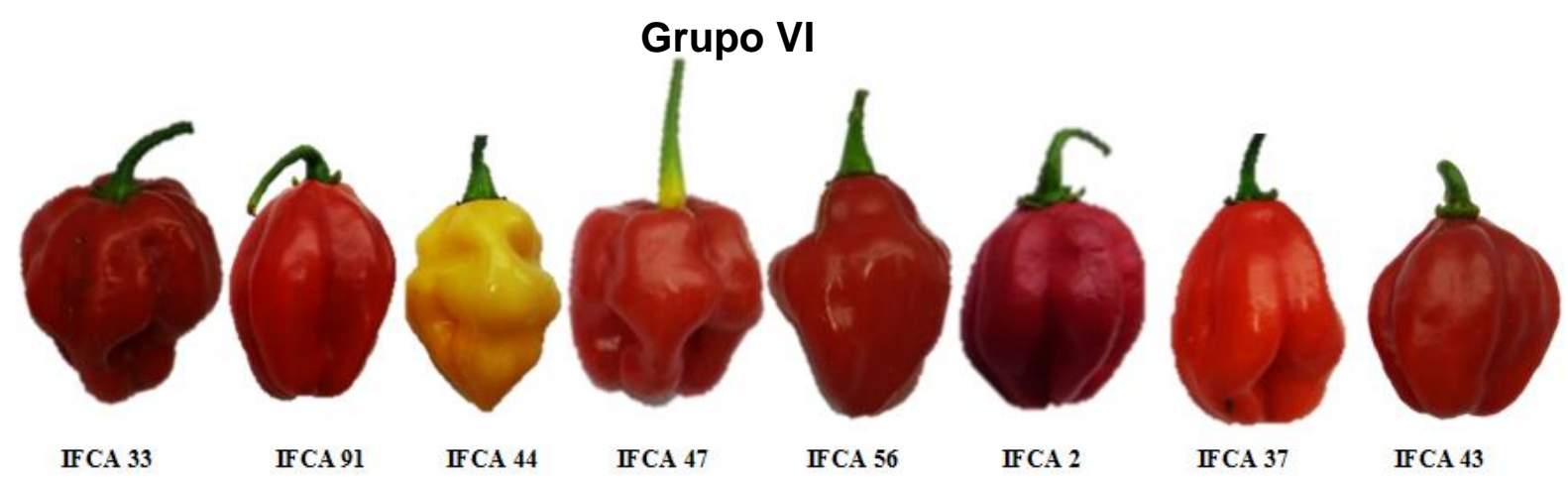

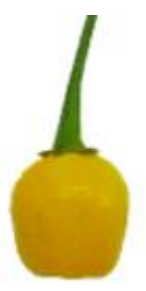

IF CA 23

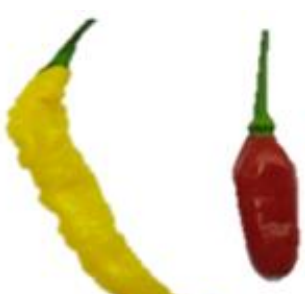

IFCA $26 \quad$ IFCA 57

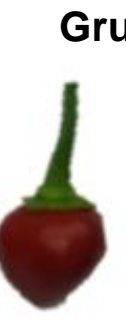

IF CA 53

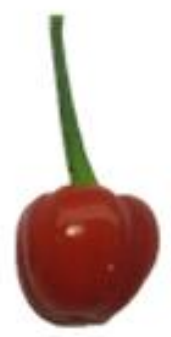

IF $\mathrm{CA} 7$

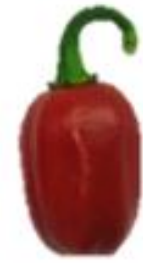

IF CA 36

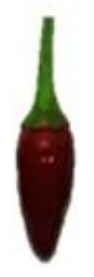

IFCA 40

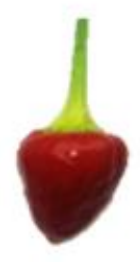

IFCA 61

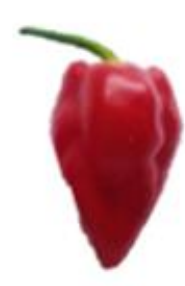

IFCA 34

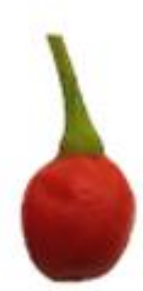

IFCA 22

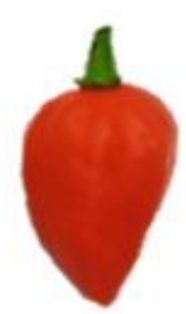

IFCA 32
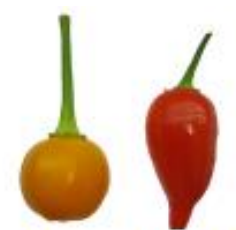

IF CA 25
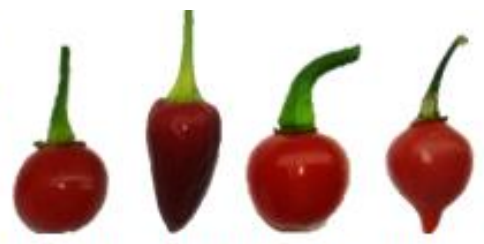

IFCA 4

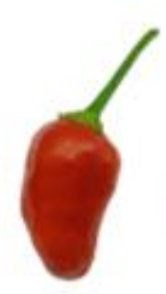

IF 4
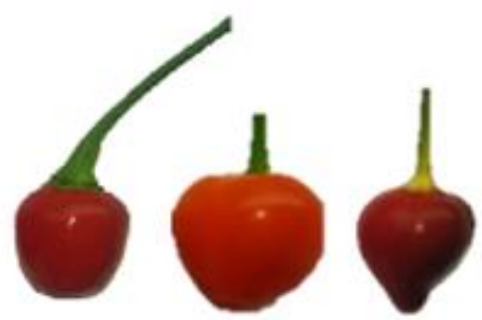

IFCA

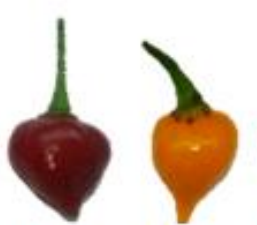

IFCA 49 IFCA 74

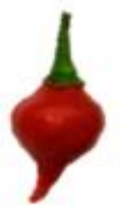

IFCA 41 IFCA 35

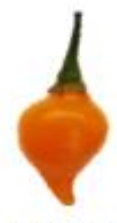

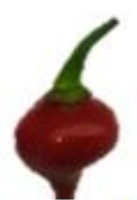

IFCA 39 IFCA 62

Figura 5. Agrupamento dos 69 acessos de Capsicum spp. obtido pelo método hierárquico de médias ponderadas (UPGMA), com base no algoritmo de Gower.

\section{Considerações finais}

O estudo da diversidade por meio de características morfoagronômicas permitiu a formação de sete grupos, mostrando a grande variabilidade entre os acessos do Banco de Germoplasma do Ifes - Campus de Alegre.

As características mais representantes e discriminativas foram aquelas inerentes ao fruto: massa fresca de fruto, diâmetro e comprimento do fruto. Isso aponta para a facilidade em novos estudos, vez que um pequeno número de características foi capaz de representar a variação entre os genótipos. 
Os acessos IFCA 31 e IFCA 40 são promissores para um programa de melhoramento de plantas para fins ornamentais, vez que possuem medidas de altura de planta e copa reduzidas. Os acessos IFCA 28, IFCA 40, IFCA 55, IFCA 57, IFCA 72, IFCA 93, IFCA 95 e IFCA 100 são os mais recomendados para o consumo dos frutos frescos em molhos e condimentos, uma vez que seu tamanho reduzido e pericarpo menos espesso são os principais requisitos para esse nicho.

\section{Agradecimentos}

Ao Instituto Federal do Espírito Santo - Campus de Alegre. À Universidade Federal do Espírito Santo - Centro de Ciências Agrárias e Engenharias. Ao Programa de PósGraduação em Agroecologia. Às agências de fomento Capes, Fapes e CNPq.

\section{Referências}

ABUD, H.; ARAUJO, R.; PINTO, C.; ARAÚJO, E.; ARAUJO, A.; SANTOS, J. Caraterização morfométrica dos frutos de pimentas malagueta e biquinho. Revista Brasileira de Agropecuária Sustentável, v. 8, n. 2, p. 29-39, 2018.

CARDOSO, R.; RUAS, C. F.; GIACOMIN, R. M.; RUAS, P. M.; RUAS, E. A.; BARBIERI, R. L.; RODRIGUES, R.; GONÇALVES, L. S. A. Genetic variability in brazilian Capsicum baccatum germplasm collection assessed by morphological fruit traits and AFLP markers. PloS one, v. 13, n. 5, e0196468, p. 1-15, 2018.

CARVALHO, S. I. C. de; BIANCHETTI, L. de B.; RIBEIRO, C. S. da C.; LOPES, C. A. Pimentas do gênero Capsicum no Brasil. Brasília: EMBRAPA hortaliças, 2006. 27p.

CARVALHO, S. I. C.; BIANCHETTI, L. B.; RAGASSI, C. F.; RIBEIRO, C. S. C.; REIFSCHNEIDER, F. J. B.; BUSO, G. S. C.; FALEIRO, F. G. Genetic variability of a brazilian Capsicum frutescens germplasm collection using morphological characteristics and SSR markers. Genetics and Molecular Research, v. 16, n. 3, p. 1-18, 2017.

CARVALHO, S. I.; BIANCHETTI, L. B. Botânica e recursos genéticos. In: RIBEIRO, C. S. C., LOPES, C. A.; CARVALHO, S. I. C., HENZ, G. P., REIFSCHNEIDER, F. J. B. Pimentas Capsicum. Brasília: EMBRAPA Hortaliças, 2008. p. 39-54.

COSTA, L. V.; LOPES, M. T. G.; LOPES, R.; ALVES, D. R. M. Polinização e fixação de frutos em Capsicum chinense Jacq. Acta Amazonica, v. 38, n. 2. p. 361-364, 2008.

CRUZ, C. D. Genes - software package for analysis in experimental statistics and quantitative genetics. Acta Scientiarum, v. 35, n. 3, p. 271-276, 2013.

Food and Agriculture Organization of the United Nations - FAO. Statistical databases. 2018.

FILGUEIRA, F. A. R. Novo manual de Olericultura: agrotecnologia moderna na produção e comercialização de hortaliças. Editora UFV. Viçosa, Minas Gerais, 2012. 421p. 
FONSECA, R. M.; LOPES, R.; BARROS, W.; LOPES, M.T.G.; FERREIRA, F. Morphologic characterization and genetic diversity of Capsicum chinense Jacq. accessions along the upper Rio Negro - Amazonas. Crop Breeding and Applied Biotechnology, v. 8, n. 3, p. 187-194, 2008.

GOWER, J. C. A general coefficient of similarity and some of its properties. Biometrics, v. 27, n. 4, p. 857-874, 1971.

HUNZIKER, A.T.; BARBOZA, G.E. Estudios sobre solanaceae XLV. Sobre la presencia de Exodeconus en Argentina y una novedad en Capsicum baccatum. Kurtziana, v. 26, p. 2331, 1998.

IPGRI. Catie descriptors for Capsicum (Capsicum spp.). International Plant Genetic Resources Institute, Rome, Italy, 1995. 114p.

LANNES, S. D.; FINGER, F. L.; SCHUELTER, A. R.; CASALI, V.W.D. Growth and quality of Brazilian accessions of Capsicum chinense fruits. Scientia Horticulturae, v. 112, n. 93, p. 266-270, 2007.

LEITE, P. S.; RODRIGUES, R.; SILVA, R. N.; PIMENTA, S.; MEDEIROS, A. M.; BENTO, C. S.; GONÇALVES, L. S. Molecular and agronomic analysis of intraspecific variability in Capsicum baccatum var. pendulum accessions. Genetics and Molecular Research, v. 15, n. 4, p.1-16, 2016.

LIMA, J. S. S.; SILVA, S. A.; OLIVEIRA, R. B.; CECÍLIO, R.A.; XAVIER, A.C. Variabilidade temporal da precipitação mensal em Alegre-ES. Revista Ciência Agronômica, v. 39, n. 2, p. 327-332, 2008.

MARTINEZ, A.; ARAÚJO, J.; RAGASSI, C. F.; BUSO, G.; REIFSCHNEIDER, F. Variability among Capsicum baccatum accessions from Goiás, Brazil, assessed by morphological traits and molecular markers. Genetics and Molecular Research, v. 16, n. 3, p. 1-13, 2017.

MOHAMMADI, R.; AMRI, A. Genotype $\times$ environment interaction and genetic improvement for yield and yield stability of rainfed durum wheat in Iran. Euphytica, v. 192, p. 227-249, 2013.

MELO, L. F.; GOMES, R. L. F.; SILVA, V. B.; MONTEIRO, E. R.; LOPES, A. C. A.; PERON, A. P. Potencial ornamental de acessos de pimenta. Ciência Rural, v. 44, n. 11, p. 20102015, 2014.

MOSCONE, E. A.; SCALDAFERRO, M. A.; GRABIELE, M.; CECCHINI, N. M.; GARCÍA, Y. S.; JARRET, R.; DAVIÑA, J. R.; DUCASSE, D. A.; BARBOZA, G. E.; EHRENDORFER, F. The evolution of chili peppers (Capsicum - Solanaceae): a cytogenetic perspective. Acta Horticulturae, n. 745, p. 137-169, 2007.

MOULIN, M. M.; RODRIGUES, R.; GONÇALVES, L. S. A.; SUDRÉ, C. P.; SANTOS, M. H; SILVA, J. R. P. Collection and morphological characterization ofsweet potato landraces in north of Rio de Janeiro state. Horticultura Brasileira, v. 30, p. 286-292, 2012.

NAHAK, S. C.; NANDI, A.; SAHU, G. S.; TRIPATHY, P.; DASH, S. K.; PATNAIK, A.; PRADHAN, S. R. Studies on variability, heritability and genetic advance for yield and yield contributing characters in Chilli (Capsicum annuum L.). Journal of Pharmacognosy and Phytochemistry, v. 7, n. 1, p. 2506-2510, 2018. 
NEITZKE, R. S.; FISCHER, S. Z.; VASCONCELOS, C.S.; BARBIERI, R.L.; TREPTOW, R.O. Pimentas ornamentais: aceitação e preferências do público consumidor. Horticultura Brasileira, n. 34, p.102-109, 2016.

OLIVEIRA, T. R. A. de.; GRAVINA, G. de. A.; OlIVEIRA, G. H. F. de.; ARAÚJO, K. C.; ARAÚJO, L. C. de.; DAHER, R. F.; VIVAS, M., GRAVINA, L. M.; CRUZ, D.P. The GT biplot analysis of green bean traits. Ciência Rural, v. 48, n. 6, p. 1-6, 2018.

R CORE TEAM. R: a language and environment for statistical computing. R Foundation for Statistical Computing, Vienna, Austria, 2020.

RIVA-SOUZA, E. M.; RODRIGUES, R.; SUDRÉ, C. P.; PEREIRA, M. G.; BENTO, C. dos S. MATTA, F. de P. Genetic parameters and selection for resistance to bacterial spot in recombinant F6 lines of Capsicum annuum. Crop Breeding and Applied Biotechnology, v. 9, n. 2, p. 108-115, 2020.

RODRIGUES, R.; BENTO, C. S.; PIMENTA, S.; SUDRE, C. P. Melhoramento de Pimentão e Pimentas. In: GOMES, C. N.; OLIVEIRA, A. B. de (Org.). Melhoramento de Hortaliças. 1.ed. Viçosa: UFV, v. 1, 2016. p. 1-464.

SOARES, R.; SILVA, E.; VIDAL, R.; CANDIDO, W.; FRANCO, C.; REIFSCHNEIDER, F.; BRAZ, L. Response of Capsicum annuum L. var. annuum genotypes to root-knot nematode infection. Chilean Journal of Agricultural Research, v. 78, p. 78-85, 2018.

SUDRÉ, C. P.; GONÇALVES, L. S. A.; RODRIGUES, R.; AMARAL JÚNIOR, A. T. DO.; RIVA-SOUZA, E. M.; BENTO, C. DOS S. Genetic variability in domesticated Capsicum spp as assessed by morphological and agronomic data in mixed statistical analysis. Genetics and Molecular Research, v. 9, n. 1, p. 283-294, 2010.

YAN, W. GGEbiplot a Windows application for graphical analysis of multi environment trial data and other types of two-way data. Agronomy Journal, v. 93, p. 1111-1118, 2001.

YAN, W.; FRÉGEAU-REID, J. Genotype by yield*trait (GYT) biplot: a novel approach for genotype selection based on multiple traits. Scientific Reports, v. 8, p. 8242, 2018.

YAN, W.; KANG, M. S.; MA, B.; WOODS, S.; CORNELIUS, P. L. GGE biplot vs. AMMI analysis of genotype-by-environment data. Crop Science, v. 47, p. 643-653, 2007.

YAN, W.; RAJCAN, I. Biplot analysis of test sites and trait relations of soybean in Ontario. Crop Science, v. 42, p. 11-20, 2001.

YAN, W.; TINKER, N. A. Biplot analysis of multi-environment trial data: principles and applications. Canadian Journal of Plant Science, v. 86, p. 623-645, 2006.

YANG, R. C.; CROSSA, J.; CORNELIUS, P.L.; BURGUEÑO, J. Biplot analysis of genotype $\times$ environment Interaction: proceed with caution. Crop Science, v. 49, n. 5, p. 1564-1576, 2009. 


\title{
Capítulo 7
}

\section{Estratégias de seleção de genótipos superiores para produção de grãos de milho sob seleção recorrente recíproca}

\author{
Fernanda Vargas Valadares ${ }^{1}$, Larícia Olária Emerick Silva², Rafael Nunes de Almeida ${ }^{1}$, \\ Lazaro Renilton Emerick Silva ${ }^{7}$, Leandro Heitor Rangel ${ }^{3}$, José Dias de Souza Neto ${ }^{4}$, Larissa \\ de Carvalho Nascimento ${ }^{4}$, Savio da Silva Berilli5 ${ }^{5}$, Paola Alfonsa Lo Mônaco ${ }^{6}$, Monique \\ Moreira Moulin ${ }^{5}$, Ana Paula Candido Gabriel Berilli ${ }^{5}$
}

\section{Introdução}

O milho (Zea mays L.) é consumido e cultivado e em todos os continentes, devido principalmente a sua importância na alimentação animal, humana e na utilização da matériaprima para a indústria (BARAVIERA et al., 2014).

Do ponto de vista econômico, por ser uma "commoditie", colabora para movimentar boa parte do capital do agronegócio a nível mundial e quanto a aspectos sociais, é um alimento de baixo custo, produzido nos mais variados sistemas de cultivo podendo ser empregado em diversos setores da cadeia produtiva. Esses fatores, somados a utilização do milho na composição de ração animal para os sistemas pecuários faz com que esteja entre os principais cereais cultivados em todo o mundo e o segundo grão mais cultivado no território brasileiro (CONAB, 2020).

Com toda essa versatilidade o milho desempenha também um papel fundamental para soberania alimentar de muitos países, uma vez que as lavouras podem ser conduzidas em sistemas agrícolas de baixo nível tecnológico e de base familiar, de modo que sua produção

\footnotetext{
1 Me. em Agroecologia pelo Programa de Pós-Graduação em Agroecologia do Instituto Federal do Espírito Santo - Campus de Alegre, Caixa Postal 47, CEP: 29500-000, Alegre-ES. E-mail: fernanda_valladares@hotmail.com; almeida.rna94@gmail.com

${ }^{2}$ Me. em Genética e Melhoramento pelo Programa de Pós-Graduação em Genética e Melhoramento da Universidade Federal do Espírito Santo, Caixa Postal 16, CEP: 29500-000, Alegre-ES. E-mail: lariciaemerick@gmail.com; lazaroemerick2@outlook.com

${ }^{3}$ Mestrando em Produção Vegetal pelo Programa de Pós-Graduação em Produção Vegetal da Universidade Norte Fluminense Darcy Ribeiro, CEP: 28013-600, Campos dos Goytacazes-RJ. E-mail: leandroheitor_18@hotmail.com

${ }^{4}$ Técnico do Laboratório de Genética e Biologia Molecular do Instituto Federal do Espírito Santo Campus de Alegre, Caixa Postal 47, CEP: 29500-000, Alegre-ES. E-mail: jdiassneto@gmail.com; larissacn1@hotmail.com

${ }^{5}$ Drs. Professores do Instituto Federal do Espírito Santo - Campus de Alegre, Caixa Postal 47, CEP: 29500-000, Alegre-ES. E-mail: savio.berilli@ifes.edu.br; mmmoulin@ifes.edu.br; ana.berilli@ifes.edu.br

${ }^{6}$ Dra. Professora do Instituto Federal do Espírito Santo - Campus Santa Teresa, CEP: 29660-000, Santa Teresa-ES. E-mail: paolalm@ifes.edu.br

7 Tecnólogo em Cafeicultura pelo Instituto Federal do Espírito Santo - Campus de Alegre, Caixa Postal 47, CEP: 29500-000, Alegre-ES. E-mail: lazaroemerick2@outlook.com
} 
garante a manutenção de criações animais e ainda renda extra aos produtores (CARVALHO, 2016).

No entanto, no Brasil percebe-se que há dois perfis de produção de milho, que juntas colaboram para uma produção nacional de cerca de 100 milhões de toneladas (CONAB, 2020). A produção mais tecnificada com alta produção e uso de sementes transgênicas e a produção com base na agricultura familiar, na qual se emprega sementes crioulas, na maioria das vezes, e lavouras com baixa ou nenhuma tecnificação.

Nesse sentido, de acordo com perfil da agricultura capixaba, em que $70 \%$ da agricultura é de base familiar (PEDEAG, 2007), vem sendo conduzido um programa de melhoramento genético de milho para atender aos anseios e necessidades dos produtores familiares, pois, ainda que sejam valiosas, as sementes de variedades tradicionais tem perdido espaço para sementes de híbridos comerciais. Isso porque o atual cenário de mudanças climáticas tem exigido cultivares cada vez mais adaptados, fazendo com que as variedades locais se tornem obsoletas frente a produtividade potencial dos híbridos comerciais.

Uma alternativa para motivar os produtores a manterem as práticas de cultivo das variedades tradicionais, sem a necessidade de elevados investimentos na incorporação de tecnologias de cultivo, é promover o melhoramento genético dessas variedades valorizando as particularidades de cada região e o grupo de produtores (MACHADO e AMARAL, 2014).

Ainda que visto de forma antagônica aos princípios da agroecologia, o melhoramento genético vegetal possui ferramentas e métodos capazes de melhorar populações de plantas garantindo a manutenção da variabilidade genética (ALMEIDA et al., 2018). Métodos de seleção recorrente, por exemplo, tem como princípio garantir o aumento médio em produtividade sem que haja perda de variabilidade genética (SOUZA JUNIOR, 2018).

Assim, vem-se desenvolvendo um programa de melhoramento de milho por meio da seleção recorrente recíproca para que sejam elevadas a proporção de alelos favoráveis nas populações estudadas, bem como seja, possível a obtenção de híbridos interpopulacionais e populações de polinização aberta para serem disponibilizados aos produtores da região. Esse capítulo, portanto, retrata estratégias utilizadas para potencializar a seleção de genótipos superiores para acelerar o processo de ganhos genéticos após a obtenção do primeiro ciclo de seleção.

\section{Seleção Recorrente Recíproca}

Os melhoristas têm a sua disposição diferentes métodos de melhoramento, desde os mais simples e rápidos, como a seleção massal, até métodos mais elaborados e trabalhosos, mas que garantem maior chance de sucesso nos programas de melhoramento, como o método de 
seleção recorrente, em que os genótipos com melhor desempenho são selecionados e recombinados dentro sua respectiva população (BERILLI et al., 2013). Desta forma, mantémse a identidade das populações per se, e melhora-se o desempenho dos híbridos. A seleção recorrente permite o aumento gradual da frequência dos alelos favoráveis sem, com isso, reduzir a variabilidade genética da população (REIS et al., 2011).

O sucesso de um programa de melhoramento depende, em grande parte, de três fatores: 1- selecionar e desenvolver novas populações geneticamente promissoras, usando progenitores de qualidade e com características superiores; 2- avaliar em campo essas populações, suas linhagens e seus híbridos experimentais e 3-desenvolver tecnologia de ponta para aumentar a eficiência do processo de seleção, reduzindo assim tempo. A seleção recorrente recíproca, proposta por Comstock e Robinson (1948), visa à melhoria simultânea de duas populações. Estas populações devem ser geneticamente distantes e de elevado potencial agronômico.

Dentre os métodos de melhoramento aplicáveis à cultura do milho, merece destaque o procedimento denominado seleção recorrente recíproca de famílias de irmãos completos, proposto por Hallauer e Ebehart (1970). Esta metodologia permite, ao mesmo tempo, assegurar ganhos genéticos diretos (nas populações per si) e indiretos (nas populações em cruzamento). Tal método consiste em se cruzar plantas $S_{0}$ aos pares (plantas da população A com plantas da população B), autofecundando-se simultaneamente os indivíduos selecionados. Para tanto há necessidade de que as plantas selecionadas sejam prolíficas.

Em milho, usualmente procede-se a autofecundação da segunda espiga de cada uma das plantas. A primeira espiga (superior) de cada planta é fecundada com pólen de outra planta (PATERNIANI e CAMPOS, 1999). As sementes dessas espigas correspondem às progênies de irmãos completos $(A \times B)$, que são avaliados em ensaios de produção, os quais permitem identificar as combinações (progênies) mais promissoras. Cada ciclo se completa quando as progênies $S_{1}$ de cada população, correspondentes aos melhores cruzamentos, são recombinadas em lote isolado, produzindo assim as populações melhoradas $A_{1}$ e $B_{1}$.

Assim depois de avaliadas as progênies de irmãos completos, as sementes $S_{1}$ correspondentes às melhores progênies são plantadas, efetuando-se a autofecundação das plantas envolvidas nos cruzamentos, gerando, após algumas gerações de autofecundação, linhagens potenciais para híbridos de alta produção.

Dentro de cada uma das categorias de SR mencionadas, existem diferenças e, estão relacionadas aos tipos de progênies utilizadas nas unidades de avaliação e recombinação, tamanho efetivo da população, pressão de seleção, dentre outros (SOUZA JUNIOR, 2018).

É fundamental que se escolham populações divergentes e preferencialmente de grupos heteróticos distintos. No caso do milho, existem dois grupos heteróticos, os denominados 'DENT' (Piranão) e 'FLINT' (CIMMYT), a maioria dos híbridos de milho pertence a tais grupos 
heteróticos. Pois a identificação de genótipos superiores, que atendam aos interesses do mercado em relação a uma série de atributos agronômicos, é um ponto de partida para a constituição da população base (FREITAS et al., 2012).

\section{Obtenção e avaliação de famílias de irmãos completos de milho na região sul capixaba}

Uma etapa importante na seleção recorrente é a escolha de populações de elevado potencial agronômico. Neste sentido, em se tratando de melhoramento interpopulacional, duas populações de polinização aberta pertencentes a grupos heteróticos distintos foram definidas para utilização conforme apresentadas a seguir:

Cimmyt: População oriunda do Centro Internacional de Melhoramento de Milho e Trigo (CIMMYT) e posteriormente melhorada na Universidade Federal de Viçosa; pertence ao grupo heterótico tipo 'FLINT'.

Piranão: População também oriunda da Universidade Federal de Viçosa, pertencente ao grupo heterótico tipo "DENT".

Ambas populações são descritas como portadoras de genes braquíticos, os quais conferem menor porte às plantas, caráter este que facilita a colheita e diminui as perdas por quebra e tombamento de plantas.

A seleção recorrente recíproca consiste no cruzamento de plantas de duas populações contrastantes, obtendo-se as famílias de irmãos completos, em concomitância é realizada também a autofecundação das mesmas, com a finalidade de obter sementes puras para ao final do ciclo realizar a recombinação.

O método consiste em: a primeira espiga (superior) de cada planta é fecundada com pólen de outra planta. As sementes dessas espigas correspondem às famílias de irmãos completos, estas são avaliados em ensaios de competição para identificar as combinações mais promissoras. Cada ciclo se completa quando as progênies de cada população, correspondentes aos melhores cruzamentos, são recombinadas em lote isolado, produzindo assim as populações melhoradas.

A avaliação das famílias de irmãos completos foi realizada no lfes - Campus de Alegre, no município de Alegre, ES, Brasil, nas coordenadas geográficas de $20^{\circ} 45^{\prime} 30^{\prime \prime} \mathrm{S}$ e de $41^{\circ} 27^{\prime}$ 23" W (sistema de referência SIRGAS 2000). Foram avaliadas 120 famílias de irmãos completos em delineamento em blocos ao acaso, com duas repetições. O plantio aconteceu em novembro de 2015.

Dado o grande número de tratamentos, os mesmos foram agrupados em "sets", sendo que cada "set" continha 30 famílias, totalizando 04 "sets". Cada unidade experimental foi 
constituída de uma fileira de 5 metros de comprimento, espaçadas de $1 \mathrm{~m}$ entre fileiras, e 0,2 $\mathrm{m}$ entre covas. No plantio foram semeadas três sementes por cova, e após 30 dias da semeadura foi efetuado o desbaste, deixando 1 planta por cova, no intuito de se deixar um 'stand' de 25 plantas por parcela o que equivale a 50.000 plantas ha-1. Foram feitas adubações de acordo com a análise de solo e exigências nutricionais da cultura, realizou-se também os tratos culturais usuais recomendados para a cultura.

Os seguintes caracteres agronômicos foram avaliados:

a) Altura de Planta: altura média de seis plantas competitivas, medidas do nível do solo até o nó de inserção da folha-bandeira em metros;

b) Altura de Espiga: altura média das mesmas seis plantas competitivas, medidas do nível do solo até o nó de inserção da espiga superior no colmo, em metros;

c) Plantas Quebradas: número de plantas que se apresentarem quebradas, abaixo da espiga superior, no momento da colheita;

d) Número de plantas: número de plantas sadias.

Após colheita ainda serão obtidos dados das seguintes características:

e) Número de Espigas: número total de espigas colhidas;

f) Número de Espigas Atacadas por Pragas: número de espigas brocadas;

g) Peso de Espigas: peso, em quilogramas, das espigas despalhadas, com precisão de centésimos de quilograma;

h) Peso de Grãos: peso, em quilogramas, dos grãos debulhados, com precisão de centésimos de quilograma;

i) Peso de 100 grãos: peso, em gramas, de uma amostra de 100 grãos sadios, com precisão de centésimos de grama.

As características mensuradas foram submetidas a análise de variância pelo teste $F$, respeitando o modelo estatístico de análise em blocos casualizados:

$$
Y_{i j k}=\mu+B_{k}+S_{j}+F / S_{i(j)}+\varepsilon_{i j k}
$$

Onde $Y_{\mathrm{ijk}}$ é o valor observado na parcela ijk; $\mu$ é a constante geral; $B_{k}$ é o efeito do k-ésimo bloco; $S_{j}$ é o efeito do j-ésimo set; $F / S_{i(j)}$ é o efeito da i-ésima família dentro do j-ésimo set, e; $\varepsilon_{\mathrm{ijk}}$ é o erro aleatório associado à observação $Y_{\mathrm{ijk}}$.

\section{Estratégias de seleção de genótipos superiores de milho com base na produtividade de grãos}

A partir dos valores médios, foram selecionadas 40 famílias de irmãos completos, referente a uma pressão de seleção de $33 \%$, as quais serviram como indicativo dos genitores a serem recombinados para formação da população do ciclo 1 . De modo a monitorar a 
variabilidade genética, a divergência genética entre as famílias, para os caracteres agronômicos avaliados, foi verificada pela análise de agrupamento com base na distância de Mahalanobis, seguido de agrupamento das famílias de acordo com o método de ligação média entre grupos (UPGMA).

As análises estatísticas e construção de gráficos foram realizadas com auxílio do programa Genes (CRUZ, 2016) e do programa R, a partir das funções dos pacotes básicos.

\section{Resultados de desempenho agronômico das famílias}

A análise de variância revelou efeitos significativos entre genótipos para 10 dentre os 13 caracteres avaliados (Tabela 1).

Tabela 1. Quadrados médios para as características analisadas nas famílias de irmãos completos.

\begin{tabular}{lcccc}
\hline Caract. ${ }^{1 /}$ & \multicolumn{3}{c}{ QM } \\
\cline { 2 - 5 } & 'Set'(S) & Genótipo/S & Resíduo & CV(\%) \\
\hline Prod & $0,38352167^{\text {ns }}$ & $0,82782894^{* *}$ & 0,2053898 & 20,43 \\
Alp & $0,38352167^{\text {ns }}$ & $0,04592897^{* *}$ & 0,02352874 & 6,94 \\
Ale & $0,15563333^{\text {ns }}$ & $0,02312408^{\text {ns }}$ & 0,01146753 & 8,60 \\
Npl & $397,40417^{\star *}$ & $175,77802^{\star *}$ & 177,52917 & 62,29 \\
Npq & $998,605556^{\text {ns }}$ & $21,442816^{* *}$ & 21,970402 & 46,21 \\
Nes & $308,911111^{\text {ns }}$ & $52,060345^{* *}$ & 34,98218 & 22,08 \\
Neap & $153,881944^{\star *}$ & $45,832040^{\text {ns }}$ & 43,07629 & 54,52 \\
Pes & $3,22899478^{\text {ns }}$ & $0,37065797^{* *}$ & 0,06284313 & 16,59 \\
P100 & $209,933865^{\text {ns }}$ & $18,685728^{* *}$ & 10,511727 & 14,96
\end{tabular}

1/ Prod = produção; $\mathrm{Alp}=$ altura de plantas; $\mathrm{Ale}=$ altura de espiga; $\mathrm{Npl}=$ número de plantas; $\mathrm{Npq}=$ número de plantas quebradas; Nes = número de espigas; Neap = número de espigas atacadas por pragas; Pes = peso de espiga; $\mathrm{p} 100=$ peso de 100 grãos.

${ }^{*} ;{ }^{* *}$ Significativo a $1 \%$ e $5 \%$ de probabilidade pelo teste $F$, respectivamente.

ns = Não significativo.

Fonte: Os Autores.

Foram constatadas diferenças significativas pelo teste $\mathrm{F}$ a $5 \%$ de probabilidade entre os genótipos para as características mais importantes, indicando a presença de variabilidade genética entre os genótipos, o que é de fundamental importância para obtenção de ganhos genéticos em programas de melhoramento.

Apenas Ale e Neap não apresentaram significância, indicando, portanto, uma reduzida variabilidade genética para essas características. 
De acordo com a classificação proposta por Scapim et al. (1995), a qual foi elaborada levando-se em consideração a cultura do milho, e a natureza das características avaliadas, os coeficientes de variação da maioria dos caracteres foram considerados médios e altos.

Esses valores elevados se justificam pelo fato de as famílias serem advindas de populações de ampla base genética e pelo fato dos ensaios terem sido conduzidos com apenas duas repetições. O maior número de repetições contribui para menores desvios entorno das médias, no entanto, devido ao baixo número de sementes obtidos para cada família quando se trabalha com seleção recorrente, não garante a possibilidade de se utilizar elevados números de repetições. Assim, é comum nesse tipo de método que sejam encontrados valores de CV mais elevados para alguns caracteres (BERILLI et al., 2013; GALVÃO et al., 2015). Ainda, é relevante destacar que apesar do baixo número de repetições, os valores de CV para o principal caráter que é a produtividade de grãos, apresentou valores satisfatórios.

Na tabela 2 estão apresentadas as estimativas dos componentes genéticos da população.

Tabela 2. Estimativas referentes às variâncias genotípica $\left(\sigma_{g}^{2}\right)$, fenotípica $\left(\sigma_{f}^{2}\right)$, coeficiente de herdabilidade $\left(h^{2}\right)$, coeficientes de variação genética $(\mathrm{CVg})$, índice de variação (IV) e as médias de cada característica.

\begin{tabular}{|c|c|c|c|c|c|}
\hline Carac $^{1}$ & & $\begin{array}{l}\text { Parâmetros } \\
\text { genéticos }\end{array}$ & $\mathrm{h}^{2}$ & $\mathrm{CV}_{g}(\%)$ & $I_{v}(\%)$ \\
\hline Prod & 0,31121957 & 0,41391447 & 75,19 & 21,09 & 1,03 \\
\hline Alp & 0,01912012 & 0,02221404 & 86,07 & 9,39 & 2,69 \\
\hline Ale & 0,00929016 & 0,01130489 & 82,18 & 10,52 & 2,09 \\
\hline Npl & 30298365,5 & 31294001,5 & 96,82 & 15,55 & 2,28 \\
\hline Npq & $-0,0048976$ & 0,19359600 & $-2,53$ & 38,73 & 0,81 \\
\hline Nes & 22193965,5 & 26388003,0 & 84,11 & 24,40 & 2,38 \\
\hline Neap & 0,03039195 & 0,49907335 & 6,09 & 57,18 & 2,04 \\
\hline Pes & 0,15390742 & 0,18532898 & 83,05 & 17,86 & 1,08 \\
\hline P100 & 4087000,5 & 9342864,0 & 43,74 & 7,45 & 0,50 \\
\hline
\end{tabular}

1/ Prod = produção; Alp = altura de plantas; Ale = altura de espiga; $\mathrm{Npl}=$ número de plantas; $\mathrm{Npq}=$ número de plantas quebradas; Nes = número de espigas; Neap = número de espigas atacadas por pragas; Pes $=$ peso de espiga e P100 = peso de 100 grãos.

Fonte: Os Autores.

Para a característica Npq a variância genotípica assumiu valor negativo e foi considerada nula neste trabalho, o que pode ter ocorrido devido a um elevado valor do quadrado médio do resíduo, juntamente com a baixa variabilidade genética encontrada para o caráter. 
Em relação à característica Prod considerada aquela de maior importância, verificou-se que existe alta possibilidade de identificação de genótipos superiores, pois apresentaram significância pela análise de variância $(p<0,01)$, alta herdabilidade $(75,19 \%)$, alto coeficiente de variação genético $(21,09)$ e índice de variação superior a um $(1,03)$. Uma vez que a herdabilidade é a parcela da variância observada a qual pode ser atribuída a variações da composição genética do material (CRUZ et al., 2012), valores de herdabilidade elevados apontam que o uso de estratégias de seleção mais simples, como a simples seleção massal por parte dos agricultores, podem contribuir ganhos efetivos (BORÉM e MIRANDA, 2005). É importante salientar, também, que quanto maior for a estimativa da herdabilidade, maior será a probabilidade de se realizar uma seleção eficaz.

Os valores elevados de herdabilidade encontrados neste estudo para Prod, Alp, Ale, Npl, Nes, e Pes indicam a confiança da transmissão dessas características a futuras gerações, implicando diretamente nos ganhos por seleção (HALLAUER et al., 2010).

Os valores das estimativas dos índices de variação foram satisfatórios para as características avaliadas. Tal parâmetro contribui para indicar presença de variabilidade genética suficiente na população em estudo e contribui para a tomada de decisão quanto ao método de melhoramento a ser utilizado no programa em questão (FERREIRA e BORÉM, 1999).

O CVg indica o ganho em relação à média no caso de seleção. Em milho, nas condições brasileiras, valores de $\mathrm{CVg}$ acima de $7 \%$ são considerados como bons indicadores do potencial genético do germoplasma para o melhoramento (RODRIGUES et al., 2011). Para tanto, os caracteres estudados obtiveram valores acima de 7\%, então foi possível detectar variação genética potencial para seleção.

É válido ainda ressaltar que as condições ótimas para estimação de parâmetros genéticos envolvem avaliações em múltiplos ambientes, no entanto, por se tratar de populações (variedades) de polinização aberta, a ampla variabilidade genética dessas variedades tendem a possibilitar grau de correlação elevado entre precisão da estimação dos parâmetros em um ou múltiplos ambientes de uma microrregião.

\section{Seleção de famílias de irmãos completos para recombinação}

A identificação das famílias mais produtivas constitui de uma etapa essencial no método de seleção recorrente. Isso porque, é a partir da performance média das famílias que o melhorista poderá inferir sobre o potencial dos genitores (plantas originalmente cruzadas) em gerar indivíduos com alelos favoráveis para o aumento médio da população. 
A variabilidade entre genética do material refletiu na produtividade média das famílias (Tabela 3) a qual apresentou amplitude em torno de $4190 \mathrm{Kg} \mathrm{ha}^{-1}$ (valores de $421 \mathrm{Kg} \mathrm{ha}^{-1} \mathrm{a}$ $\left.4610 \mathrm{Kg} \mathrm{ha}^{-1}\right)$.

Dentre as 120 famílias, 50 apresentaram produtividade acima da média geral de 2217,8 $\mathrm{Kg} \mathrm{ha}^{-1}$. Embora fatores ambientais adversos, como fortes ventos, tenham prejudicado 0 potencial produtivo das famílias de irmãos completos avaliadas, o elevado número de famílias que apresentaram valores inferiores à média geral, evidenciou que grande parte dos indivíduos que constituem as populações não contém alelos favoráveis para aumento da produtividade. Isso justifica ainda mais a necessidade e viabilidade de se trabalhar com métodos de melhoramento como a seleção recorrente.

Tabela 3. Média de produção, em $\mathrm{Kg} \mathrm{ha}^{-1}$, das famílias de irmãos completos em seus respectivos 'sets'.

\begin{tabular}{|c|c|c|c|c|c|c|c|}
\hline $\begin{array}{c}\text { Set } \\
1\end{array}$ & Prod & $\begin{array}{c}\text { Set } \\
2\end{array}$ & Prod & $\begin{array}{c}\text { Set } \\
3\end{array}$ & Prod & $\begin{array}{c}\text { Set } \\
4\end{array}$ & Prod \\
\hline 14 & 3340 & 42 & 3587 & 71 & 4610 & 117 & 2492 \\
\hline 23 & 3075 & 59 & 3151 & 66 & 4496 & 100 & 2410 \\
\hline 24 & 2785 & 44 & 3095 & 72 & 3752 & 114 & 2300 \\
\hline 20 & 2737 & 55 & 3084 & 74 & 3700 & 104 & 2280 \\
\hline 15 & 2645 & 58 & 2970 & 68 & 3407 & 108 & 2200 \\
\hline 19 & 2645 & 61 & 2860 & 75 & 3380 & 93 & 2195 \\
\hline 30 & 2500 & 40 & 2797 & 70 & 3360 & 92 & 2123 \\
\hline 16 & 2465 & 57 & 2765 & 85 & 3185 & 107 & 2075 \\
\hline 9 & 2400 & 60 & 2710 & 90 & 3170 & 119 & 2030 \\
\hline 10 & 2340 & 34 & 2535 & 69 & 3095 & 118 & 1995 \\
\hline 18 & 2322 & 41 & 2370 & 79 & 3055 & 103 & 1985 \\
\hline 11 & 2295 & 37 & 2355 & 91 & 2927 & 112 & 1970 \\
\hline 25 & 2245 & 43 & 2240 & 86 & 2795 & 109 & 1960 \\
\hline 17 & 2190 & 45 & 2240 & 65 & 2710 & 96 & 1957 \\
\hline 21 & 2155 & 32 & 2150 & 77 & 2710 & 115 & 1835 \\
\hline 12 & 2120 & 53 & 2085 & 63 & 2600 & 94 & 1832 \\
\hline 2 & 2112 & 54 & 2060 & 87 & 2500 & 113 & 1750 \\
\hline 22 & 2112 & 33 & 2045 & 82 & 2375 & 105 & 1700 \\
\hline 28 & 2090 & 49 & 2015 & 78 & 2357 & 97 & 1680 \\
\hline
\end{tabular}


Fernanda Vargas Valadares et al.

$\begin{array}{rrrrrrrr}29 & 2082 & 48 & 2004 & 67 & 2190 & 101 & 1657 \\ 26 & 2080 & 47 & 1957 & 89 & 2100 & 111 & 1645 \\ 4 & 1980 & 39 & 1955 & 81 & 2090 & 106 & 1610 \\ 13 & 1942 & 50 & 1950 & 64 & 2065 & 110 & 1595 \\ 27 & 1940 & 56 & 1880 & 62 & 2025 & 98 & 1520 \\ 5 & 1832 & 38 & 1875 & 83 & 1825 & 121 & 1442 \\ 8 & 1495 & 52 & 1860 & 76 & 1745 & 116 & 1417 \\ 6 & 1365 & 35 & 1720 & 80 & 1692 & 102 & 1390 \\ 7 & 827 & 51 & 1662 & 73 & 1415 & 120 & 1370 \\ 1 & 775 & 36 & 1495 & 84 & 1370 & 99 & 1190 \\ 3 & 650 & 46 & 1485 & 88 & 421 & 95 & 915\end{array}$

Fonte: Os Autores.

A partir das médias de produtividade, foram selecionadas as 40 famílias mais produtivas e que possuíssem uma menor média de características consideradas indesejáveis como número de plantas quebradas e atacadas por pragas. Assim, foram selecionadas as 10 famílias mais produtivas de cada set.

Pelo diferencial de seleção entre as todas as famílias e aquelas selecionadas (Figura 1) em função da herdabilidade média do caráter, a previsão é de que os ganhos de produtividade neste primeiro ciclo sejam em torno de $14,8 \%$.

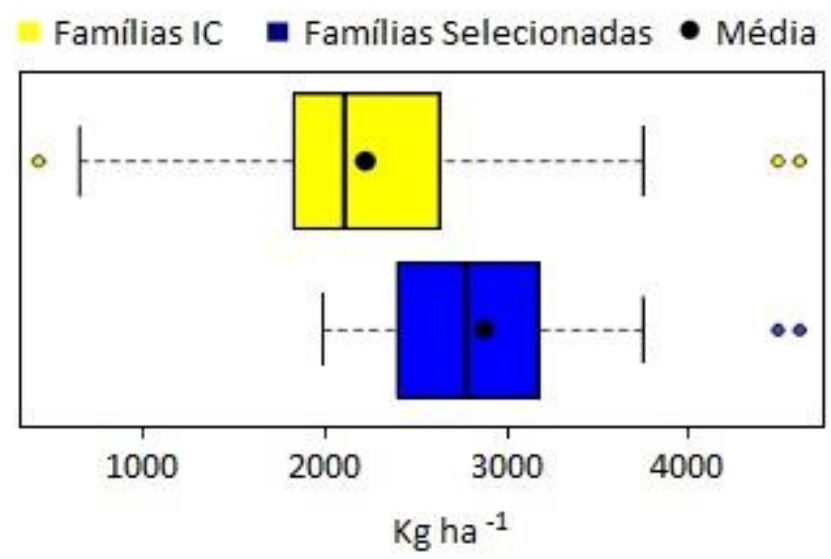

Figura 1. Variação na produtividade de grãos entre as 120 famílias de irmãos completos de milho avaliadas (caixa amarela) e aquelas 40 famílias selecionadas (caixa azul).

Fonte: Os Autores. 
Esse diferencial se deu pelo fato de que $90 \%$ das famílias selecionadas apresentaram valores acima do segundo quartil, dentre o montante de famílias avaliadas.

Com isso, o ganho esperado corresponde, na prática, a um aumento de $327,8 \mathrm{Kg} \mathrm{ha}^{-1}$ de grãos, cerca de 5.46 sacas $(60 \mathrm{Kg})$ a cada hectare plantado. Considerando o preço médio da saca de milho para o período atual, em torno de R\$51,00 (CEPEA, 2020), os ganhos neste primeiro ciclo representam aumento de $R \$ 278,66$ por hectare de milho plantado na região sul capixaba.

Embora os avanços em termos de produtividade já tenham indicado previsões promissoras para este e para os subsequentes ciclos de seleção recorrente a serem realizados, é importante monitorar a variabilidade genética dos indivíduos selecionados a fim de contribuir para manutenção da variabilidade genética das variedades e consequente soberania alimentar dos agricultores que manterão essas sementes.

Nesse sentido, a análise de divergência genética entre as famílias mostrou que houve considerável divergência para os caracteres agronômicos avaliados (Figura 2).

A variabilidade genética para os caracteres agronômicos resultou na formação de sete grupos distintos de famílias. O grupo I foi o que alocou maior quantidade de famílias, sendo maior parte delas com as maiores médias para as características estudadas. O grupo II foi composto por sete famílias que obtiveram maiores médias, exceto para número de plantas quebradas e peso de grãos.

No grupo III foram alocadas duas famílias, e estas obtiveram menor média para peso da espiga. Os grupos IV, V, VI e VII foram compostos apenas por uma família cada grupo, e estes apresentaram menores médias para número de plantas quebradas, peso de grãos, maiores médias em todos as características e peso de grãos e peso de cem grãos respectivamente.

Consequentemente, o maior número de famílias selecionadas foi dentre aquelas alocadas no grupo I. Os grupos IV, V e VI não tiveram suas famílias selecionadas, o que pode ser justificado pelo desempenho dessas famílias, conforme supracitado. Embora $87,5 \%$ das famílias selecionadas tenham sido alocadas no grupo I, as distâncias observadas estas famílias demonstram que a variabilidade genética a ser mantida para os próximos ciclos está dentro do desejável.

Como próximo passo, em cada população, os genitores das famílias selecionadas serão utilizados na etapa de recombinação para formação da população do Ciclo 1 de cada uma das variedades, as quais poderão ser disponibilizadas aos produtores locais. 


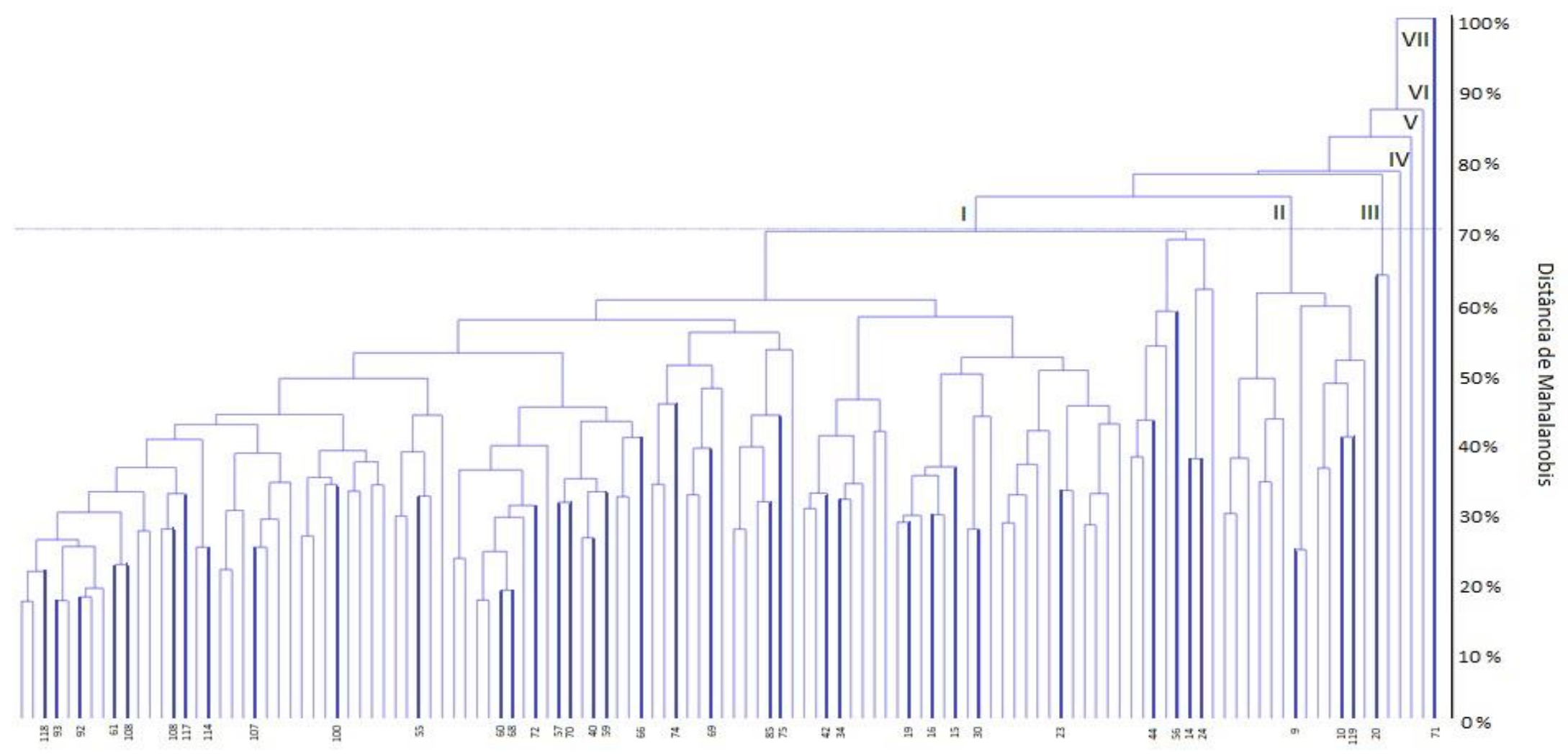

Figura 2. Dendrograma de dissimilaridade entre 120 famílias de irmãos completos, agrupadas de acordo com método de ligação média entre grupos (UPGMA) pela distância de Mahalanobis. Linhas em destaque correspondem às famílias selecionadas.

Fonte: Os Autores. 


\section{Considerações finais}

O melhoramento genético populacional mostrou-se eficiente na obtenção de ganhos genéticos para a produtividade para as condições sul capixaba. Para o primeiro ciclo de seleção recorrente houve um ganho de aproximadamente $327,8 \mathrm{Kg} \mathrm{ha}^{-1}$ no rendimento médio de grãos. O melhoramento via seleção recorrente demonstrou potencial para aumentar a renda de pequenos agricultores da região sul capixaba a partir da incorporação de tecnologia nos sistemas alimentares, sem perdas por erosão genética.

Espera-se que os resultados apresentados neste estudo possam somar aos esforços da agroecologia na conservação de recursos genéticos locais e desenvolvimento rural sustentável na região sul do estado do Espírito Santo.

\section{Referências}

ALMEIDA, R. N.; CHAGAS, J. T. B.; ROCHA, R. S.; OLIVEIRA, T. R. A.; GONÇALVES, G. R.; JORGE, T. S.; SALUCI, J. C. G.; CARLOS, M. C.; DUTRA, I. P.; MORAES, R. Melhoramento de plantas na agroecologia: Promoção da manutenção da diversidade das espécies cultivadas. XXII Encontro Latino Americano de Iniciação Científica, XVIII Encontro Latino Americano de Pós-Graduação e VIII Encontro de Iniciação à Docência - Universidade do Vale do Paraíba, 2018.

BARAVIERA, C. M. C.; CANEPELLE, C.; DOURADO, L. G. A.; AGUERO, N. F. Avaliação de propriedades físicas de grãos de híbridos de milho. Enciclopédia Biosfera, v. 10, n. 19, p. 291-297, 2014.

BERILLI, A. P. C. G.; PEREIRA, M. G.; TRINDADE, R. dos S.; DA COSTA, R. F.; CUNHA, K. $\mathrm{S}$. Response to the selection in the 11th cycle of reciprocal recurrent selection among full-sib families of maize. Acta Scientiarum, v. 35, n. 4, p. 435-441, 2013.

BORÉM, A.; MIRANDA, G. V. Melhoramento de plantas. 4. ed. Viçosa: UFV. 2005. 525p.

CENTRO DE ESTUDOS AVANÇADOS EM ECONOMIA APLICADA - CEPEA. Indicador do milho ESALQ/BM\&FBOVESPA. Disponível em: <https://www.cepea.esalq.usp.br/br/indicador/milho.aspx>. Acesso em: 06 ago. 2020.

CARVALHO, R. Manejo e qualidade de sementes crioulas em comunidades de várzea no médio Solimões, Amazônia. Amazônia, 2016. 59f. Dissertação (Mestrado) - Instituto Nacional de Pesquisas da Amazônia, 2016.

COMPANHIA NACIONAL DE ABASTECIMENTO - CONAB. Disponível em: <http://www.conab.gov.br/OlalaCMS/uploads/arquivos/16_06 99_16_49_15_boletim_graos_ junho_2016_-_final.pdf>. Acesso em: 11 jul. 2020.

COMSTOCK, R. E.; ROBINSON, H. F. The components of genetic variance in populations of biparental progenies and their use in estimating the average degree of dominance. Biometrics. v. 4, p. 254-266, 1948. 
CRUZ, C. D. Genes software - extended and integrated with the R, Matlab and Selegen. Acta Scientiarum. v. 38, n. 4, p. 547-552, 2016.

CRUZ, C. D.; REGAZZI, A. J.; CARNEIRO, P. C. S. Modelos biométricos aplicados ao melhoramento genético. 4 ed., v. 1. Viçosa: UFV. 2012. 514 p.

FERREIRA, G. A. D.; BORÉM, A. Predição de ganho genético em uma população de milho (Zea mays L.) Palha Roxa. Revista Ceres, Viçosa, v. 46, n. 263, p. 29-44, 1999.

FREITAS, J. P. X.; OLIVEIRA, E. J.; JESUS, O. N.; CRUZ NETO, A. J.; SANTOS, L. R. Formação de população base para seleção recorrente em maracujazeiro-amarelo com uso de índices de seleção. Pesquisa Agropecuária Brasileira, Brasília, v. 47, n. 3, p. 393-401, 2012.

GALVÃO, K. S. C.; RAMOS, H. C. C.; SANTOS, P. H. A. D.; ENTRINGER, G. C.; VETTORAZZI, J. C. F.; PEREIRA, M. G. Functional molecular markers (EST-SSR) in the fullsib reciprocal recurrent selection program of maize (Zea mays L.). Genetics and Molecular Research, v.14, p. 7344-7355, 2015.

HALLAUER, A. R.; CARENA, M. J.; MIRANDA FILHO, J. B. Quantitative genetic in maize breeding. 3.ed. lowa State University, 2010.

HALLAUER, A. R. Eberhart, S.A. Reciprocal full-sib selection. Crop Science, v. 10, p. 315316, 1970.

MACHADO, C. C.; AMARAL, M. B. Um pé de cultura e de milho, angico, mangaba e baobá. Textura, n. 30, p. 26-43, 2014.

PATERNIANI, E.; CAMPOS, M.S. Melhoramento do milho. In: BORÉM, A. (Ed.). Melhoramento de espécies cultivadas. Viçosa: UFV, 1999. p. 429-485.

PLANO ESTRATÉGICO DE DESENVOLVIMENTO DA AGRICULTURA CAPIXABA PEDEAG. Novo PEDEAG 2007 - 2025. Secretaria Estadual de Agricultura, Vitória, 2007. $281 p$.

REIS, R. V. D.; OLIVEIRA, E. J. D.; VIANA, A. P.; PEREIRA, T. N. S.; PEREIRA, M. G.; SILVA, M. G. D. M. Diversidade genética em seleção recorrente de maracujazeiro-amarelo detectada por marcadores microssatélites. Pesquisa Agropecuária Brasileira, Brasília, v. 46, p. 51-57, 2011.

RODRIGUES, F.; VON PINHO, R. G.; ALBUQUERQUE, C. J. B.; VON PINHO, E. V. R. Índice de seleção e estimativa de parâmetros genéticos e fenotípicos para características relacionadas com a produção de milho-verde. Ciência e Agrotecnologia, Lavras, v. 35, n. 2, p. 278-286, 2011.

SCAPIM, C. A.; CARVALHO, C. G. P.; CRUZ, C. D. Uma proposta de classificação dos coeficientes de variação para a cultura do milho. Pesquisa Agropecuária Brasileira, Brasília, v.30, p. 683-686, 1995.

SOUZA JUNIOR, C. L. Seleção recorrente. In: LIMA, R.O., BORÉM, A. (Eds.). Melhoramento de milho. Viçosa: UFV, p.73-101, 2018. 


\title{
Capítulo 8
}

\section{Caracterização morfológica e bromatológica de genótipos de pimenta (Capsicum spp.) coletados no Estado do Espírito Santo}

\author{
Yuri Ferreira Quirido Veiga ${ }^{1}$, Talles de Oliveira Santos ${ }^{2}$, Raissa Olmo Lacerda Pirovani', \\ Rafael de Almeida ${ }^{3}$, Larissa de Carvalho Nascimento ${ }^{4}$, José Dias de Souza Neto ${ }^{4}$, Alexandre \\ Cristiano Santos Júnior ${ }^{5}$, Monique Moreira Moulin ${ }^{5}$
}

\section{Introdução}

O Brasil é um dos países que possui maior variabilidade genética para as espécies do gênero Capsicum, sendo encontrada no país grande diversidade de espécies domesticadas, semi-domesticadas e silvestres (NASCIMENTO et al., 2012; SANTOS et al., 2019). As pimentas de Capsicum possuem alta variabilidade quanto aos seus caracteres morfológicos, como formato, tamanho, cor de folhas e frutos, posição de flores e frutos, bem como sua pungência característica (VASCONCELOS et al., 2012).

As pimentas e pimentões possuem grande papel sociocultural no Brasil, pois possuem diversas utilidades que variam de seu uso na culinária, indústria farmacêutica e de cosméticos (BIANCHI et al., 2020). As pimenteiras também se destacam no ramo do comércio de plantas ornamentais em razão da folhagem variegada, do porte anão e dos frutos com diferentes cores (MOREIRA, 2006). Além destes atributos, também são de fácil cultivo, de grande durabilidade e com ampla capacidade de crescer em recipientes pequenos (NEITZKE et al., 2010).

A diversidade encontrada no gênero Capsicum é muito importante para programas de melhoramento de plantas e para a sociedade, uma vez que o desenvolvimento de novas cultivares que atendam o interesse regional depende da disponibilidade dos recursos genéticos. No Brasil, a agricultura familiar tem assegurado o uso de práticas de conservação de diversas variedades locais, como as de pimentas e pimentões. Comunidades locais

\footnotetext{
${ }^{1}$ Graduado em Ciências Biológicas pelo Instituto Federal do Espírito Santo, CEP: 29500-000, AlegreES. E-mail: yfqv@hotmail.com; raissaolmo@hotmail.com

${ }_{2}^{2}$ Me. em Genética e Melhoramento de Plantas pela Universidade Estadual do Norte Fluminense Darcy Ribeiro, CEP: 28013-600, Campos dos Goytacazes-RJ. E-mail: tallesdeoliveeira@live.com ${ }^{3}$ Mestrando em Agroecologia pelo Instituto Federal do Espírito Santo, CEP: 29500-000, Alegre-ES. Email: rafael.t.dealmeida@gmail.com

${ }^{4}$ Técnico do Laboratório de Genética e Biologia Molecular do Instituto Federal do Espírito Santo Campus de Alegre, Caixa Postal 47, CEP: 29500-000, Alegre-ES. E-mail: jdiassneto@gmail.com; larissacn1@hotmail.com

${ }^{5}$ Drs. Professores do Instituto Federal do Espírito Santo - Campus de Alegre, Caixa Postal 47, CEP: 29500-000, Alegre-ES. E-mail: alexandre.cristiano@ifes.edu.br, mmmoulin@ifes.edu.br
} 
podem contribuir para o uso e conservação de germoplasma adaptado aos agroecossistemas das comunidades agrícolas (ALMEKINDERS e ELINGS, 2001).

O conhecimento sobre a biodiversidade e distribuição dos genótipos entre as populações locais é necessário tanto para o manejo quanto para a conservação dos recursos genéticos de pimentas (RODRIGUES et al., 2012).

Considerando que a agrobiodiversidade é base para a agroecologia, nesse sentido a caracterização e avaliação de acessos de pimentas são fundamentais para seu uso pelos agricultores familiares. Nesse aspecto, a caracterização da divergência morfológica e a análise da composição físico-química dos frutos de pimentas compõem uma importante etapa no trabalho de manutenção de coleções e bancos de germoplasma, sendo de grande relevância para o melhoramento genético da cultura (TAVARES, 2013).

Neste contexto, o objetivo deste trabalho foi caracterizar e estimar a diversidade genética entre 19 acessos de pimenta do Banco Ativo de Germoplasma do Ifes - Campus de Alegre, com base em descritores morfoagronômicos e físico-químicos.

\section{Metodologia}

\section{Material vegetal, condições de cultivo e delineamento experimental}

Para a caracterização morfoagronômica e físico-química foram utilizados 19 acessos de pimenta que fazem parte do acervo do Banco Ativo de Germoplasma de Capsicum do Ifes Campus de Alegre (Tabela 1).

O experimento foi conduzido na Fazenda Experimental "Caixa D'água" do Ifes - Campus

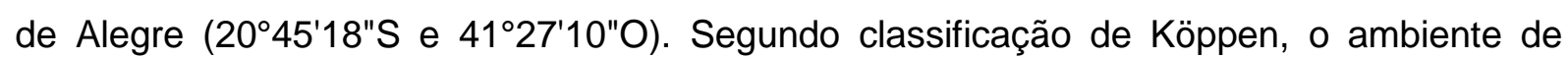
estudo é caracterizado como clima subtropical úmido (Cwa), apresentando temperatura e precipitação médias anuais de $23,1^{\circ} \mathrm{C}$ e $1.341 \mathrm{~mm}$, respectivamente (LIMA et al., 2008).

A obtenção das mudas foi desenvolvida em casa de vegetação com irrigação por aspersão, para possibilitar maior uniformidade no desenvolvimento dos acessos. Para isso, a semeadura foi realizada em bandejas de poliestireno com 128 células, contendo substrato para a produção de mudas.

O transplantio foi efetuado após dois meses para as condições de campo, no Setor de Olericultura do Ifes-Campus de Alegre, em solo preparado com esterco de vaca curtido. Todos os tratos culturais utilizados foram aqueles recomendados por Filgueira (2012) para a cultura. O experimento foi conduzido em um delineamento em blocos casualizados com 19 tratamentos e seis repetições, totalizando 114 parcelas experimentais. 
Tabela 1. Dados de passaporte dos 19 acessos de Capsicum estudados pertencentes ao Banco Ativo de Germoplasma do Ifes - Campus de Alegre.

\begin{tabular}{ccc}
\hline Acesso & Local de coleta & Procedência \\
\hline IFES 02 & Propriedade rural & Alegre \\
IFES 04 & Propriedade rural & Alegre \\
IFES 05 & Propriedade rural & Alegre \\
IFES 06 & Propriedade rural & Alegre \\
IFES 07 & Propriedade rural & Alegre \\
IFES 08 & Propriedade rural & Alegre \\
IFES 10 & Propriedade rural & Alegre \\
IFES 11 & Propriedade rural & Venda Nova do Imigrante \\
IFES 15 & Estabelecimento comercial & Cachoeiro de Itapemirim \\
IFES 16 & Estabelecimento comercial & Cachoeiro de Itapemirim \\
IFES 17 & Estabelecimento comercial & Cachoeiro de Itapemirim \\
IFES 23 & Estabelecimento comercial & Venda Nova do Imigrante \\
IFES 25 & Estabelecimento comercial & Venda Nova do Imigrante \\
IFES 26 & Propriedade rural & Venda Nova do Imigrante \\
IFES 34 & Estabelecimento comercial & Jerônimo Monteiro \\
IFES 36 & Propriedade rural & Guaçuí \\
IFES 37 & Propriedade rural & Guaçuí \\
IFES 39 & Estabelecimento comercial & Guaçuí \\
IFES 40 & Estabelecimento comercial & Guaçuí \\
\hline
\end{tabular}

Fonte: Os Autores.

\section{Caracterização morfoagronômica}

Os acessos foram caracterizados por descritores morfoagronômicos altamente discriminantes, essenciais específicos para pimenta da Bioversity International (IPGRI, 1995). Destes, foram utilizados 16 descritores, dentre eles sete qualitativos multicategóricos e nove quantitativos, a saber:

- Forma do fruto: observada no fruto maduro (1= alongado, $2=$ redondo, $3=$ triangular, 4= campanulado, $5=$ quadrado, $6=$ pitanga, $7=$ oval e $8=\operatorname{sino}$ );

- Cor do fruto no estádio intermediário: frutos classificados pela última gradação de cor antes da fase madura ( 1 = verde, variando entre 1.1 = verde claro, $1.2=$ verde intermediário, $1.3=$ verde escuro, e 1.4 = verde com manchas púrpuras; 2 = amarelo claro 3 = roxo e $4=$ laranja);

- Cor do fruto no estádio maduro - Observada quando o fruto estiver completamente maduro $(1=$ vermelho, variando entre $1.1=$ vermelho escuro, $1.2=$ vermelho intermediário, $1.3=$ vermelho claro; 2 = laranja, $3=$ roxo, $4=$ amarelo, $5=$ verde e $6=$ creme);

- Hábito de crescimento da planta: Analisado de acordo com escala de notas: $1=$ prostrado; 2 = compacto; 3 = ereto; 4 = outro;

- Forma da folha: Analisada de acordo com escala de notas: 1 = deltoide; 2 = ovalada; 3 = lanceolada; 
- Densidade de folhas: analisada de acordo com escala de notas: 1 = esparsa; $2=$ intermediária; 3 = densa;

- Cor da folha: Analisada de acordo com uma escala de notas: 1 = amarelo; 2 = verde claro; $3=$ verde; $4=$ verde escuro; $5=$ violeta claro; $6=$ violeta; $7=$ variegada; $8=$ verde com antocianina;

- Altura da planta: mensurada com trena metálica a maior altura da planta em cm;

- Diâmetro da copa: mensurado com trena metálica o maior diâmetro da copa em cm;

- Comprimento da folha: mensurado com trena metálica o maior comprimento da folha em cm;

- Largura da folha: Mensurada com trena metálica a maior largura da folha em cm;

- Comprimento do fruto: mensurado o maior comprimento, em $\mathrm{cm}$, utilizando paquímetro digital;

- Largura do fruto: mensurado a maior largura, em $\mathrm{cm}$, utilizando paquímetro digital;

- Número de sementes por fruto: obtido pela contagem do número total de sementes por fruto;

- Número de lóculos por fruto: observado cortando-se transversalmente o fruto; $\mathrm{e}$

- Número de frutos por planta: somatório do número de frutos obtidos em todas as colheitas realizadas por acesso.

\section{Caracterização físico-química}

Para a avaliação das características físico-químicas, foram coletados seis frutos por acesso completamente maduros e firmes. A caracterização físico-química foi efetuada no Laboratório de Química Aplicada do Ifes - Campus de Alegre. Foram realizadas as determinações de $\mathrm{pH}$, acidez total titulável, sólidos solúveis totais, umidade e teor de cinzas.

Os acessos IFES 10, IFES 11 e IFES 37 não apresentaram frutos maduros durante o período de análises e os acessos IFES 15, IFES 16 e IFES 17 não apresentaram teores de cinzas mensuráveis, sendo estes seis acessos não utilizados na análise estatística físicoquímica.

$\mathrm{O} \mathrm{pH}$ dos frutos foi determinado utilizando-se um medidor de $\mathrm{pH}$ da marca MS Tecnopon, que foi calibrado com solução de $\mathrm{pH} 7$ e depois de $\mathrm{pH}$ 4. Dos frutos, foram utilizadas $2 \mathrm{~g}$ após maceração e diluídos em $30 \mathrm{~mL}$ de água destilada em um béquer. A análise foi feita em triplicata, com o eletrodo do medidor de pH mergulhado na solução conforme a metodologia de Vilas Boas et al. (2008). 
Para a determinação da acidez total titulável foi realizada a titulação da amostra com solução de $\mathrm{NaOH}$ (hidróxido de sódio) a $0,01 \mathrm{~N}$, inserindo-se o medidor de $\mathrm{pH}$ na solução e a titulação efetuada com o auxílio de uma bureta de $10 \mathrm{~mL}$ contendo $\mathrm{NaOH}$ até a solução atingir um pH próximo a 8,2 conforme metodologia de Moretti (2006).

Após este procedimento, foi realizado o cálculo para obtenção da acidez total titulável (\% ATT) utilizando a seguinte fórmula:

$$
\% A T T=\frac{\left(V_{\mathrm{NaOH}} \times M_{\mathrm{NaOH}} \times f \times E q_{\text {ácido }}\right) \times 100}{1000 \times V_{\text {amostra }}} \text { onde: }
$$

$V_{\mathrm{NaOH}}$ é o volume da solução de hidróxido de sódio gasto na titulação; $M_{\mathrm{NaOH}}$ é a concentração molar da solução de hidróxido de sódio; $f$ é fator de correção da solução de hidróxido de sódio (1,0639); Eqácido é o equivalente-grama do ácido cítrico; e $V_{\text {amostra }}$ é o volume em $\mathrm{mL}$ da amostra utilizada na titulação.

Os sólidos solúveis totais foram determinados por refratometria, em refratômetro digital de mão e expressos em ${ }^{\circ}$ Brix. Para esta avaliação, o fruto de pimenta foi macerado e coado, e adicionadas duas gotas no refratômetro para leitura.

Para a determinação da umidade foi utilizado o método gravimétrico com emprego de calor, com o auxílio de uma estufa regulada a $105^{\circ} \mathrm{C}$. De acordo com as normas do Instituto Adolfo Lutz (1985), pesando-se de 2 a $10 \mathrm{~g}$ da amostra de pimenta em cápsulas de porcelana. As cápsulas foram submetidas, antecipadamente, à estufa para retirada de toda umidade e levadas para o dessecador com uma umidade relativa interior em torno de $0 \%$. As cápsulas com as amostras devidamente pesadas foram submetidas à estufa a $105^{\circ} \mathrm{C}$ até peso constante (aproximadamente 24 horas). Após este procedimento, a umidade em porcentagem (\% U) foi obtida utilizando a seguinte fórmula:

$$
\% U=\frac{[(\text { Cápsula }+ \text { Amostra Integral })-(\text { Cápsula }+ \text { Amostra Dessecada })] \times 100}{\text { Amostra Integral }}
$$

A determinação do teor de cinzas foi pela incineração da amostra em mufla a $550^{\circ} \mathrm{C}$ POR cinco horas, até obtenção de cinzas claras. Posteriormente, as cápsulas e as amostras foram colocadas em um dessecador para esfriar e posterior pesagem. O cálculo para determinação do teor de cinzas utilizou a seguinte fórmula:

$$
\% C=\frac{[(\text { Cápsula }+ \text { Cinza })-\text { Cápsula }] \times 100}{\text { Amostra Seca }}
$$

Obtido o teor de cinzas da amostra seca, procedeu-se à obtenção da quantidade de cinzas da amostra integral. Para tal determinação, somou-se a amostra seca à \% U. 


\section{Análises estatísticas genéticas}

As estimativas dos coeficientes de correlação de Pearson foram obtidas com base na média de repetições entre os caracteres combinados dois a dois. As análises estatísticas foram realizadas com o software RStudio (R CORE TEAM, 2020) com auxílio do pacote corrplot. A estimativa da divergência genética foi obtida por meio da matriz da distância de Mahalanobis e o agrupamento dos acessos foi realizado através do método UPGMA com auxílio do programa Genes (CRUZ, 2013).

\section{Resultados e discussão}

Foi observada alta variabilidade fenotípica entre os acessos (Figura 1) avaliados, o que evidencia a diversidade genética entre os acessos de pimenta coletados no Sul do Estado do Espírito Santo.

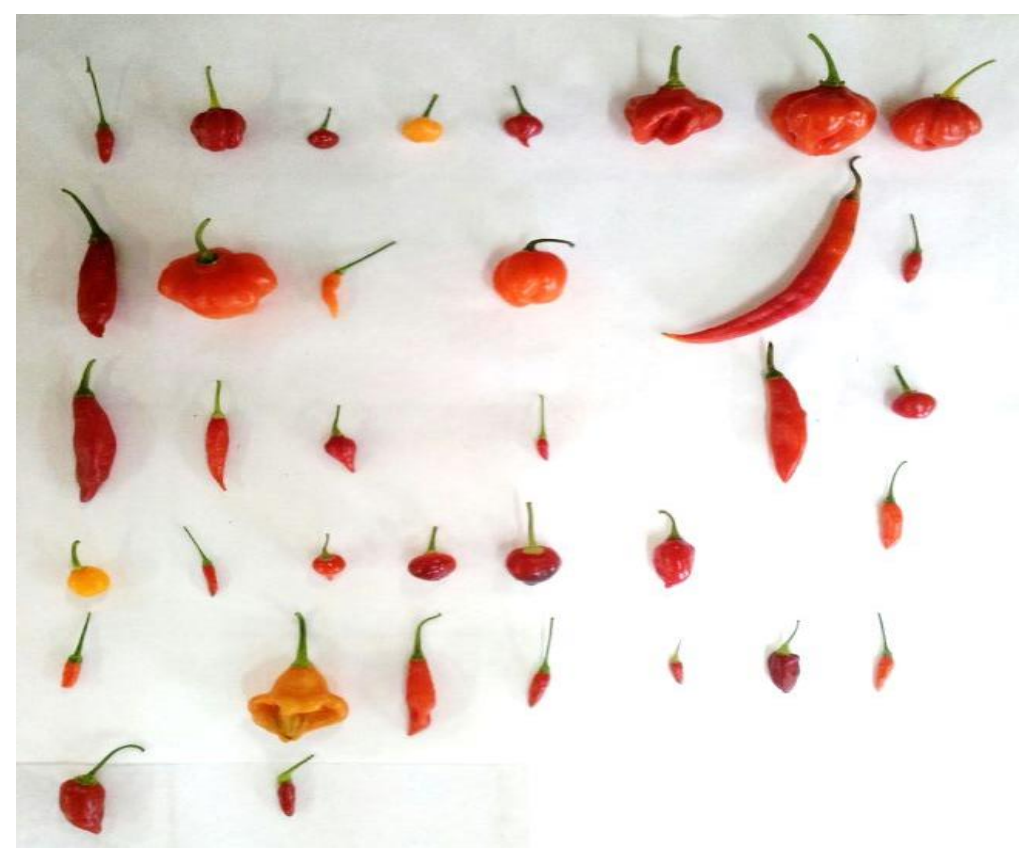

Figura 1. Variabilidade fenotípica dos frutos de Capsicum, coletados no Sul do Estado do Espírito Santo.

Fonte: Os Autores.

Para o formato dos frutos, foi constatada uma grande variabilidade, com um total de oito variações: alongado $(47,22 \%)$, redondo $(11,11 \%)$, triangular $(2,77 \%)$, campanulado $(8,33 \%)$, quadrado $(2,77 \%)$, pitanga $(5,55 \%)$, oval $(13,88 \%)$ e sino $(8,33)$. De forma similar, Domenico et al. (2012) encontraram formatos alongados, redondos, triangulares, campanulados e quadrados. Jarret e Berke (2008) observaram que $92 \%$ dos frutos de pimentas estudados 
apresentaram formato alongado que, por sua vez, são os mais procurados no comércio de pimentas in natura. Para o descritor coloração do fruto imaturo foi detectada uma predominância da cor verde $(83,31 \%)$ - com variações entre verde escuro $(13,88 \%)$, verde intermediário $(19,44 \%)$, verde claro $(44,44 \%)$, e verde com manchas púrpuras $(5,55 \%)$ além de amarelo claro (5,55\%), roxo (8,33\%) e laranja (2,77\%).

Vermelho foi a cor predominante do fruto no estágio maduro, tendo $94,42 \%$ dos acessos classificados com essa característica, que apresentou variações para vermelho escuro $(38,88 \%)$, vermelho intermediário $(38,88 \%)$ e vermelho claro $(16,66 \%)$. O restante dos acessos apresentou a coloração laranja (5,56\%). Rufino e Penteado (2006) também observaram predominância da coloração vermelho escuro $(41,2 \%)$, e a segunda maior frequência foi para a coloração vermelho intermediário, representada por $28,6 \%$ dos acessos estudados. Lannes et al. (2007) atribuíram a cor vermelha uma das características mais importantes e desejadas para produção de páprica em pó, além de ser a cor preferida pelo mercado consumidor. $O$ descritor cor dos frutos é também de grande importância para o mercado de plantas de pimentas ornamentais, em função de promoverem contraste com as folhas da planta no arranjo (CARVALHO et al., 2006).

A ocorrência das variadas classes fenotípicas observadas para os descritores associados ao fruto se dá pela presença da variabilidade genética existente entre os acessos, intra e interespécies. A variação na coloração dos frutos também foi reportada por Sudré et al. (2010), estudando acessos de Capsicum. Observações similares, relacionadas à coloração dos frutos, também foram realizadas por Cardoso et al. (2018), Santos et al. (2019) e Bianchi et al. (2020)

A cor predominante encontrada entre as folhas foi verde intermediário $(52,77 \%)$, seguida de verde escuro $(27,77 \%)$ e verde claro $(19,44 \%)$. A forma de folha predominante entre os acessos foi lanceolada $(83,33 \%)$, seguida da ovalada $(16,66 \%)$. Quanto à característica densidade da folha foram observados que $47,22 \%$ apresentaram densidade intermediária, $47,22 \%$ densa e 5,55\% esparsa. Andrade (2012) ao caracterizar a morfologia de 200 acessos de Capsicum encontrou o predomínio da cor verde para folha (83\%), formato da folha ovalada $(71 \%)$ e densidade da folha densa $(81 \%)$. Para o descritor cor da folha, Silva et al. (2013) destacam que esse caráter é determinado pela expressão de um gene com dominância incompleta que apresenta alta herdabilidade, e por esse motivo, em geral, as folhas são verdes.

O hábito de crescimento ereto $(47,36 \%)$ predominou dentre os acessos estudados, seguido de compacto $(36,84 \%)$ e prostrado (15,78\%). Melo et al. (2014) também encontraram o hábito de crescimento do tipo ereto predominante ao estudar acessos de Capsicum, que possui importância considerável no manejo do cultivo de pimentas, uma vez 
que plantas prostradas dificultam os tratos culturais. Com relação aos descritores qualitativos analisados, Silva et al. (2011) relatam que a forma da folha e hábito de crescimento, juntamente com o formato e coloração dos frutos, são bastante significativos no comércio de pimenteiras ornamentais, uma vez que influenciam na harmonia da copa e do vaso, chamando a atenção do consumidor.

Quanto às características quantitativas, para a característica altura da planta (AP), houve os resultados variaram de $36 \mathrm{~cm}$ a $81,33 \mathrm{~cm}$, e em relação ao caráter diâmetro da copa (DC) foi observada medidas que variaram de $37,5 \mathrm{~cm}$ a $80 \mathrm{~cm}$ (Tabela 2).

Tabela 2. Médias das variáveis morfoagronômicas quantitativas de pimentas do Banco de Germoplasma do Ifes - Campus de Alegre.

\begin{tabular}{lcccccccc}
\hline Acesso & AP & DC & CFR & DFR & CFO & LFO & NSF & NFP \\
\hline IFES 02 & 42,75 & 65,25 & 13,76 & 5,05 & 2,50 & 2,57 & 47,00 & 10,50 \\
IFES 04 & 58,75 & 62,50 & 12,75 & 4,67 & 0,88 & 1,65 & 24,50 & 87,00 \\
IFES 05 & 42,00 & 51,33 & 8,20 & 3,63 & 2,03 & 1,50 & 26,00 & 66,66 \\
IFES 06 & 36,00 & 37,50 & 13,60 & 4,95 & 3,70 & 4,85 & 38,00 & 19,00 \\
IFES 07 & 36,60 & 60,00 & 12,26 & 5,28 & 3,74 & 4,02 & 32,60 & 5,60 \\
IFES 08 & 37,80 & 54,00 & 11,00 & 4,58 & 5,14 & 4,00 & 32,40 & 13,00 \\
IFES10 & 37,00 & 56,66 & 11,76 & 5,46 & 4,33 & 4,30 & 83,66 & 7,00 \\
IFES 11 & 72,80 & 64,20 & 19,06 & 8,70 & 2,54 & 0,62 & 14,80 & 93,00 \\
IFES 15 & 40,00 & 42,50 & 12,40 & 4,65 & 12,35 & 1,40 & 40,00 & 3,00 \\
IFES 16 & 70,25 & 52,00 & 15,55 & 6,75 & 2,45 & 0,90 & 12,25 & 32,75 \\
IFES 17 & 54,00 & 59,50 & 8,30 & 4,05 & 5,80 & 1,75 & 46,00 & 20,50 \\
IFES 23 & 45,00 & 43,33 & 11,23 & 4,33 & 6,73 & 1,56 & 47,00 & 15,66 \\
IFES 25 & 52,50 & 42,00 & 9,15 & 3,85 & 1,65 & 1,60 & 27,00 & 19,00 \\
IFES 26 & 58,66 & 45,33 & 13,80 & 6,10 & 2,50 & 0,83 & 27,66 & 34,33 \\
IFES 34 & 81,33 & 74,33 & 16,86 & 7,40 & 2,76 & 0,90 & 31,66 & 195,00 \\
IFES 36 & 38,50 & 48,00 & 12,00 & 4,57 & 6,32 & 1,50 & 62,25 & 38,75 \\
IFES 37 & 49,00 & 53,66 & 12,50 & 4,66 & 2,60 & 0,73 & 32,00 & 74,00 \\
IFES 39 & 66,00 & 80,00 & 16,45 & 6,70 & 2,35 & 1,45 & 30,00 & 179,00 \\
IFES 40 & 63,00 & 79,50 & 16,60 & 6,30 & 3,70 & 2,05 & 63,00 & 111,00 \\
\hline
\end{tabular}

Fonte: Os Autores.

Silva Neto et al. (2014) observaram valores mais baixos para essas características ao descrever acessos de $C$. annuum no semiárido, com uma variação média de $14 \mathrm{~cm}$ a $31 \mathrm{~cm}$ para altura da planta e de $20 \mathrm{~cm}$ a $34 \mathrm{~cm}$ para diâmetro da copa. As mensurações para altura e diâmetro da copa foram bem inferiores ao observado neste estudo, o que pode estar relacionado às condições climáticas do semiárido.

Para o descritor comprimento do fruto (CFR) foram encontrados valores médios entre 8,2 cm e 19,06 cm, e para diâmetro do fruto (DFR) de 3,63cm a 8,7cm. Jarret e Berke (2008) ao estudarem as características morfológicas de frutos de $C$. chinense encontraram resultados 
divergentes, onde o comprimento do fruto variou de $0,7 \mathrm{~cm}$ a $11,3 \mathrm{~cm}$ e o diâmetro do fruto de $0,6 \mathrm{~cm}$ a $4,0 \mathrm{~cm}$, o que pode estar associada à avaliação de acessos de espécie diferente da deste estudo. É relatado que determinadas características morfológicas como maior comprimento dos frutos tem grande importância em função da sua alta correlação com outros caracteres de interesse como a produtividade (RÊGO et al., 2001; SANTOS et al., 2019).

Para a caracterização foliar também foi observada uma grande dispersão dos valores, o comprimento da folha (CFO) variou de $0,87 \mathrm{~cm}$ a $12,35 \mathrm{~cm}$. E em relação à largura da folha (LFO) os valores variaram entre 0,62 cm e 4,85 cm. Segundo Pereira et al. (1997), a área da superfície foliar de uma planta de pimenta é a base do rendimento potencial da cultura, o que indica que folhas de maiores extensões são favoráveis à produção.

Em relação ao número de sementes por fruto (NSF), os valores variaram de 10 a 98 sementes. Pereira et al. (2004) constataram uma variação de 11 a 279 sementes por fruto em um estudo de diversidade genética de Capsicum spp, entretanto o número de genótipos estudados foi bastante superior ao do presente trabalho.

O número de frutos por plantas (NFP) teve uma variação média de 3 a 195 frutos. Vasconcelos et al. (2012) relatam que o descritor número de frutos por planta é considerado o de maior relevância para o melhoramento de plantas, correspondendo diretamente à produtividade da cultura. Neste sentido, os acessos IFES 34, IFES 39 e IFES 40 destacamse quanto à produtividade.

A presença de correlação entre as variáveis foi analisada pelo coeficiente de correlação de Pearson, que é uma medida de associação linear entre duas variáveis quantitativas, na qual uma característica pode ser selecionada com base em outra (Figura 2). Elevados valores de correlação positiva foram encontrados entre as características de comprimento e diâmetro do fruto (93\%), altura de planta e número de frutos por planta $(75 \%)$, altura de planta e diâmetro do fruto (74\%), diâmetro da copa e número de frutos por planta $(74 \%)$. Correlação positiva moderada foi encontrada entre os caracteres altura de planta e comprimento do fruto (66\%), altura de planta e diâmetro da copa (57\%), diâmetro da copa com comprimento e diâmetro do fruto - ambos com $5 \%$ - e diâmetro do fruto e número de frutos por planta (57\%). As características de altura de planta e largura de folha apresentaram correlação negativa moderada (66\%), assim como altura de planta e comprimento da folha $(42 \%)$, altura de planta e número de sementes por fruto $(46 \%)$ e largura de folha e número de frutos por planta (45\%) (Figura 2). 


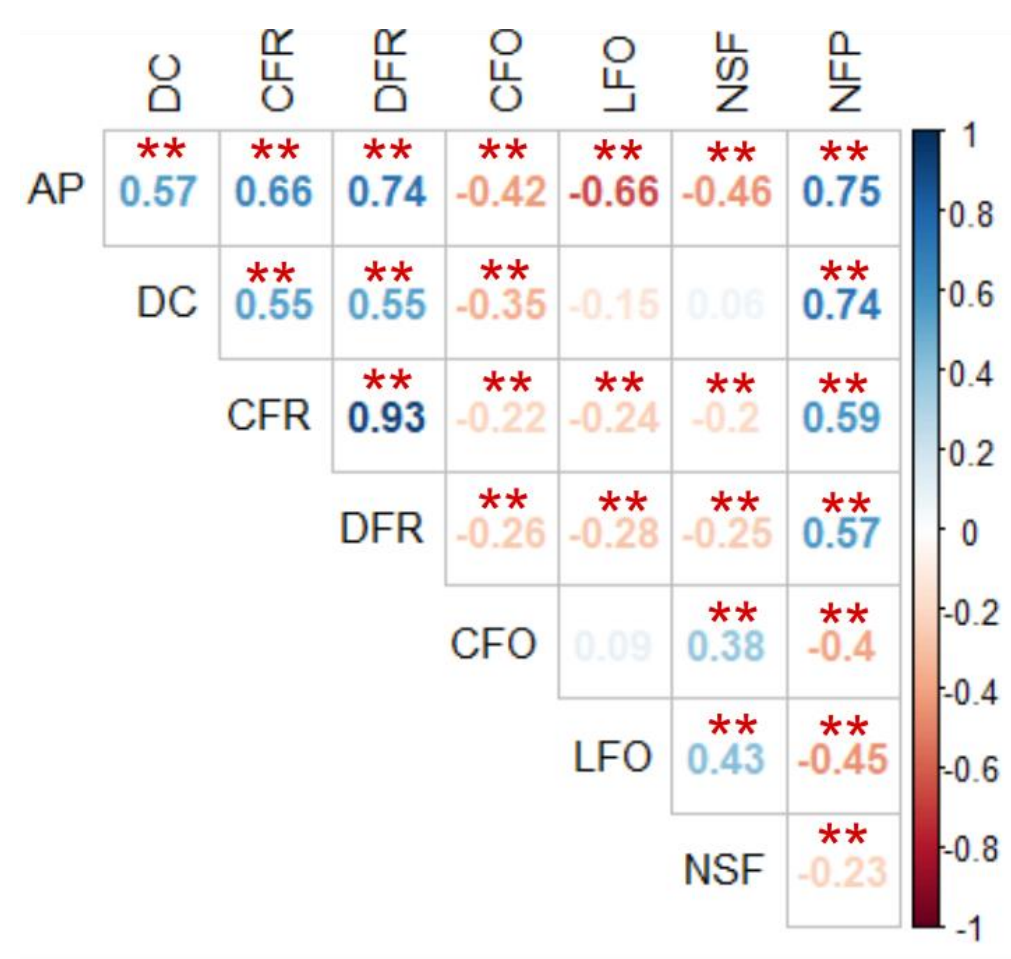

Figura 2. Coeficientes de correlação de Pearson dos caracteres quantitativos dos acessos de Capsicum coletados no Sul do Estado do Espírito Santo. AP: altura de planta; DC: diâmetro da copa; CFR: comprimento do fruto; DFR: diâmetro do fruto; CFO: comprimento da folha; LFO: largura da folha; NSF: número de sementes por fruto; e NFP: número de frutos por planta. ${ }^{* *}$ : $p$-valor $\leq 0,01$.

Fonte: Os Autores.

Similar aos resultados desse estudo, Soares et al. (2017) avaliando 22 acessos de Capsicum chinense encontraram elevados valores de correlação positiva entre os caracteres de altura de planta e diâmetro da copa, produtividade e número de frutos por planta. Santos et al. (2019), ao estudarem 33 acessos de Capsicum encontraram forte correlação positiva entre as características de comprimento e diâmetro dos frutos e número de frutos por plantas, indicando que a seleção de genótipos com base em qualquer uma dessas características implica em ganhos concomitantes na outra. Esses resultados apontam para maior eficácia na seleção de genótipos mais promissores para a produtividade, além do fato de que os descritores com associação positiva elevada com aqueles de fácil mensuração permitem reduzir o número de características estudadas, tornando o processo de seleção menos oneroso e menos demorado (SILVA et al., 2015; OLIVEIRA et al., 2018; SANTOS et al., 2019).

O dendrograma obtido por meio da matriz de dissimilaridade com base nas características qualitativas e quantitativas estudadas permitiu a geração de seis grupos distintos (Figura 3). O grupo I reuniu os acessos IFES 02 e IFES 06, IFES 07, IFES 08 e IFES 10, sendo caracterizados por forma da folha lanceolada, densidade intermediária e cor 
verde claro para as folhas. Neste grupo foi detectada a presença de duplicatas, tendo os acessos IFES 07 e IFES 08 considerados iguais para os descritores que foram avaliados.

Por isso, destaca-se a caracterização de um germoplasma como ferramenta importante para resolver o grave problema enfrentado por diversos bancos de germoplasma, que se refere à duplicação de acessos (ROBICHAUD et al., 2006). Como a constante troca de materiais genéticos ocorre livremente, em muitas situações, materiais originários de uma região são comumente encontrados em outras regiões com outros nomes, assim como também é encontrado um mesmo nome dado a diferentes acessos (MOURA et al., 2013). Essas duplicatas oneram a manutenção dos bancos de germoplasma e precisam ser identificadas para se garantir uma maior e mais representativa diversidade genética da espécie, além de otimizar a conservação e o manejo do germoplasma (ALBURQUERQUE, 2017).

O grupo II foi composto pelos acessos IFES 05, IFES 15 e IFES 25, que apresentam hábito de crescimento compacto e formato de folha ovalado. O grupo III foi formado apenas pelo acesso IFES 40, que apresentou cor do fruto no estágio intermediário verde com manchas púrpuras, diferente dos demais. Isso aponta para a alta divergência presente entre esse genótipo e os demais (VIEIRA et al., 2005). Grupos formados por poucos indivíduos tornam-se importantes em um banco de germoplasma uma vez que são importantes fontes de variabilidade genética.

O grupo IV reuniu os acessos IFES 17, IFES 23 e IFES 36, que apresentam fruto verde escuro no estágio intermediário e vermelho quando maduro, assim como formato do fruto alongado. $\mathrm{O}$ grupo $\mathrm{V}$ foi constituído pelos acessos IFES 11, IFES 16, IFES 26, IFES 34 , IFES 37 e IFES 39, que compartilharam formato do fruto alongado e crescimento foliar denso. O grupo $\mathrm{VI}$ foi constituído apenas pelo acesso IFES 04, que apresenta fruto roxo no estágio intermediário e laranja quando maduro. Segundo Pino et al. (2007), variedades que produzem frutos de cores laranja e marrom apresentaram melhor composição química relacionada ao aroma do que variedades de frutos vermelhos, sendo importantes para o comércio dessas pimentas em forma de condimentos em pó, como a páprica. 


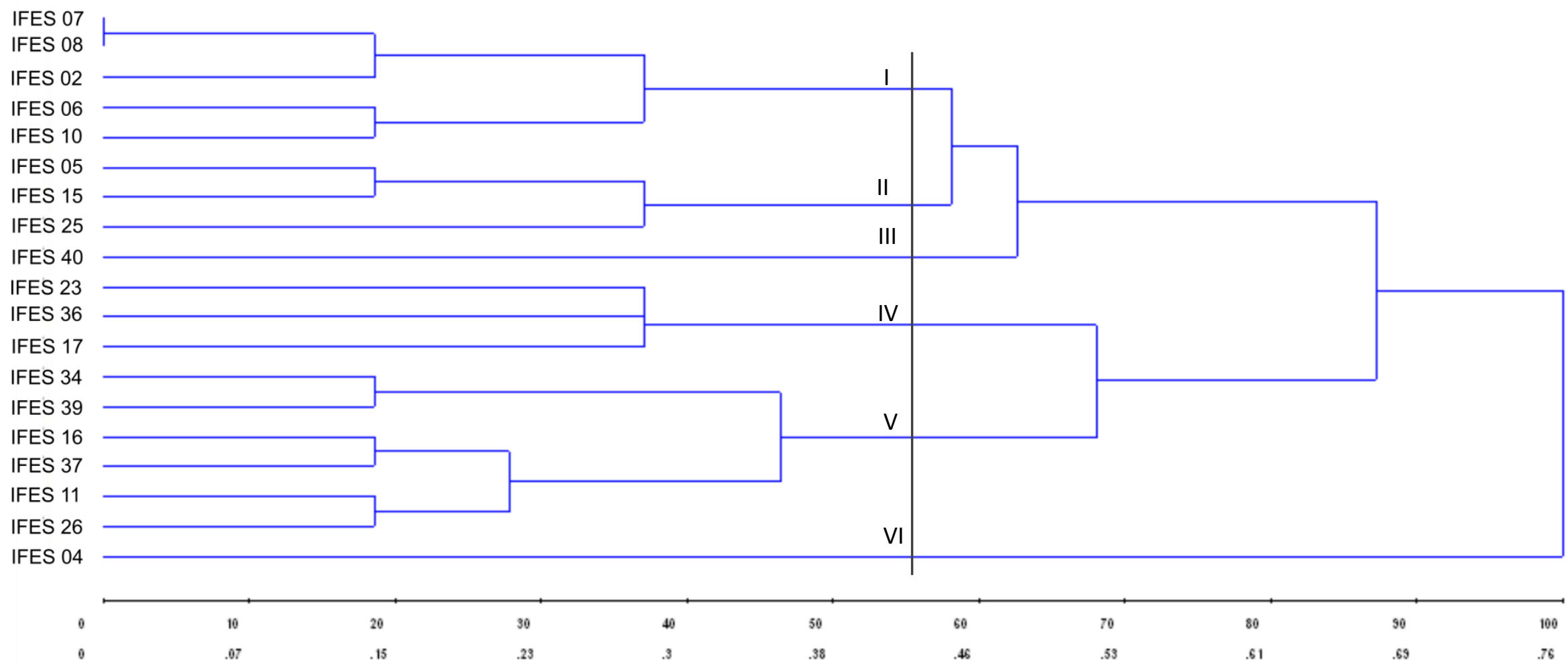

Figura 3. Dendrograma obtido pelo método UPGMA a partir da matriz de dissimilaridade genética, com base em descritores qualitativos e quantitativos.

Fonte: Os Autores. 
A análise dos componentes principais (CP) indicou as contribuições significativas das oito características que sustentam sua relevância na determinação da variabilidade entre os 19 genótipos de Capsicum estudados. Os dois componentes principais explicam $69,70 \%$ do total de variações de dados, valor considerado satisfatório para a correta interpretação dos resultados. Esses componentes foram considerados significativos de acordo com o critério da raiz latente que retém componentes com valores próprios superiores a 1,0. (Tabela 3).

Tabela 3. Cargas, autovalores, variância e variância acumuladas nos três componentes principais (PCs) nos genótipos de Capsicum estudados.

\begin{tabular}{cccc}
\hline \multirow{2}{*}{ Descritor } & \multicolumn{3}{c}{ Componente } \\
\cline { 2 - 4 } & 1 & 2 & 3 \\
\hline AP & $0.929^{\mathrm{a}}$ & -0.174 & 0.099 \\
DC & $0.715^{\mathrm{a}}$ & 0.486 & -0.197 \\
CFR & $0.818^{\mathrm{a}}$ & 0.304 & 0.206 \\
DFR & $0.845^{\mathrm{a}}$ & 0.239 & 0.186 \\
CFO & -0.496 & 0.198 & $0.800^{\mathrm{a}}$ \\
LFO & -0.549 & $0.556^{\mathrm{a}}$ & -0.420 \\
NSF & -0.428 & $0.766^{\mathrm{a}}$ & 0.116 \\
NFP & $0.852^{\mathrm{a}}$ & 0.110 & -0.072 \\
\hline Autovalores & $4.213^{\mathrm{b}}$ & $1.362^{\mathrm{b}}$ & 0.961 \\
\% de variância & 52.67 & 17.03 & 12.01 \\
Variância acumulada (\%) & 52.67 & 69.70 & 81.70 \\
\hline
\end{tabular}

AP: altura de planta; DC: diâmetro da copa; CFR: comprimento do fruto; DFR: diâmetro do fruto; CFO: comprimento da folha; LFO: largura da folha; NSF: número de sementes por fruto; e NFP: número de frutos por planta. ${ }^{a}$ Cargas $>0,55$ são significativas; ${ }^{b}$ Autovalores $>1$ são significativos. Fonte: Os Autores.

As características com maiores cargas $(>0,56)$ foram as mais relevantes para os respectivos componentes. Portanto, os descritores de altura de planta, diâmetro da copa, comprimento e diâmetro do fruto se destacaram no CP1, o que significa que estas características foram responsáveis pela maior parte da variação dos dados estudados. No CP2 destacaram-se as características de largura de folha e número de sementes por frutos.

Apesar de AP possuir a maior contribuição, a obtenção desse dado para discriminação de genótipos se torna menos viável visto que demanda maior mão de obra e tempo. Por outro lado, estudos de germoplasma de Capsicum revelam que caracteres associados ao fruto são promissores para o estudo a variabilidade entre acessos e seleção de genótipos superiores (MOSES et al., 2014; BABA et al., 2016; BIANCHI et al., 2016; SANTOS et al., 2019, BIANCHI et al., 2020). A linha tracejada vermelha indica a média da contribuição dos caracteres para a variância acumulada nos PC1 e PC2 fruto (Figura 4). Nesse sentido, caracteres de destaque apresentam valores acima dessa linha no gráfico. Portanto, a 
contribuição significativa dos descritores associados ao apontam o que vem sido relatado na literatura.

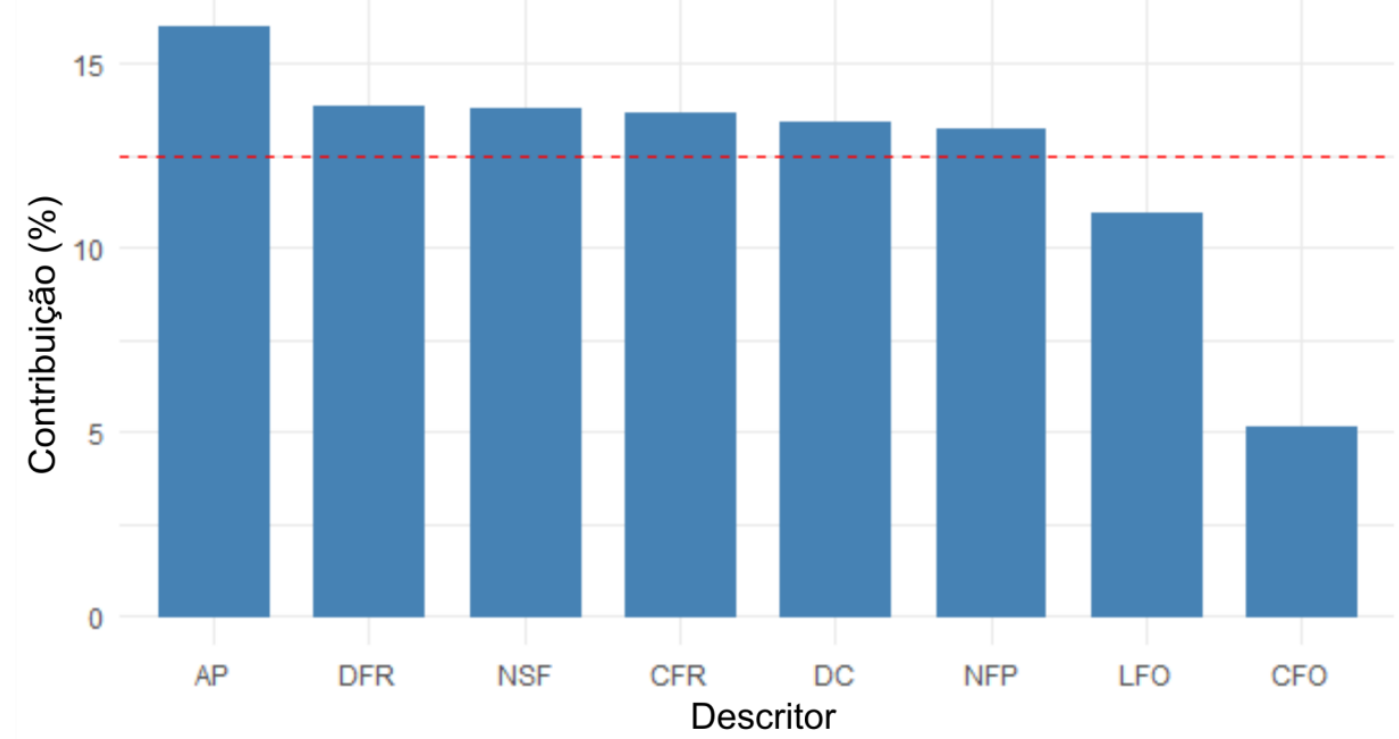

Figura 4. Percentual de contribuições (\%) de oito caracteres nos dois primeiros componentes na análise de componentes principais.

Fonte: Os Autores.

No que tange à análise físico-química dos acessos estudados, constatou-se alta variação para os caracteres avaliados (Tabela 4). Para a análise de $\mathrm{pH}$ foram obtidos resultados entre 5,07 e 6,21. Segundo Braga et al. (2013), valores de $\mathrm{pH}$ mais baixos ajudam na conservação do fruto após a colheita, sendo uma importante característica para o mercado por promover uma melhor durabilidade do fruto. Nesse aspecto, destaca-se o acesso IFES 36, com o menor valor de $\mathrm{pH}$ encontrado. Para acidez total titulável foram obtidos valores entre $0,02 \%$ e $0,11 \%$.

A acidez total titulável indica a quantidade de ácidos orgânicos presentes e a adstringência do produto (SAMPAIO e FONTES, 1998) sendo a principal influência no sabor dos frutos. Quanto menor o teor de acidez titulável no fruto melhor seu estado de conservação, o que reflete diretamente na qualidade de um produto final para o consumo (REIS et al., 2015). Nesse estudo, foram encontrados valores entre 0,02 (IFES 06 e IFES 07) e 0,11 (IFES 16 e IFES 23). Amplitude diferente foi descrita por Braga et al. (2013) que, ao estudarem espécies de Capsicum constataram uma variação de 0,22 \% a 0,48 \% para a essa característica.

Os sólidos solúveis totais (SST) apresentaram valores médios de $3,0^{\circ}$ a $12,0^{\circ}$ Brix. Segundo Ferreira et al. (2013), o teor de sólidos solúveis totais tem importância fundamental na formação do sabor, o que influencia diretamente a preferência e a aceitação do consumidor. Do ponto de vista comercial, tanto para consumo in natura quanto para o processamento industrial, são preferidos os frutos com teores de sólidos solúveis totais mais 
elevados. Para a indústria, maiores teores implicam maior rendimento e menor custo operacional (CAMILO et al., 2014).

Tabela 4. Médias das variáveis físico-químicas de pimentas do Banco de Germoplasma do Ifes - Campus de Alegre.

\begin{tabular}{cccccc}
\hline Acesso & $\mathbf{p H}$ & $\begin{array}{c}\text { Acidez Total } \\
\text { Titulável }\end{array}$ & $\begin{array}{c}\text { Sólidos } \\
\text { Solúveis } \\
\text { Totais }\end{array}$ & Umidade (\%) & $\begin{array}{c}\text { Teor de } \\
\text { Cinzas (\%) }\end{array}$ \\
\hline IFES 02 & $5,75 \pm 0,11$ & $0,04 \pm 0,00$ & 6,75 & $89,36 \pm 0,14$ & $1,81 \pm 0,30$ \\
IFES 04 & $5,47 \pm 0,17$ & $0,04 \pm 0,00$ & 10,0 & $84,57 \pm 1,76$ & $1,31 \pm 0,20$ \\
IFES 05 & $5,32 \pm 0,06$ & $0,07 \pm 0,02$ & 7,5 & $86,59 \pm 0,49$ & $1,30 \pm 0,03$ \\
IFES 06 & $6,21 \pm 0,10$ & $0,06 \pm 0,00$ & 7,5 & $88,01 \pm 0,64$ & $0,69 \pm 0,05$ \\
IFES 07 & $5,66 \pm 0,01$ & $0,02 \pm 0,00$ & 6,0 & $90,41 \pm 0,16$ & $0,91 \pm 0,19$ \\
IFES 08 & $5,74 \pm 0,18$ & $0,02 \pm 0,00$ & 7,0 & $93,35 \pm 4,39$ & $0,98 \pm 0,11$ \\
IFES 10 & - & - & - & - & - \\
IFES 11 & - & - & - & - & - \\
IFES 15 & $5,53 \pm 0,18$ & $0,07 \pm 0,01$ & 12,0 & $98,87 \pm 0,13$ & - \\
IFES 16 & $5,65 \pm 0,06$ & $0,11 \pm 0,01$ & 6,0 & $71,51 \pm 0,20$ & - \\
IFES 17 & $5,68 \pm 0,16$ & $0,08 \pm 0,01$ & 7,5 & $98,67 \pm 0,25$ & - \\
IFES 23 & $5,47 \pm 0,18$ & $0,11 \pm 0,01$ & 8,25 & $83,97 \pm 1,87$ & $1,35 \pm 0,24$ \\
IFES 25 & $5,61 \pm 0,17$ & $0,05 \pm 0,01$ & 8,1 & $84,24 \pm 0,81$ & $0,99 \pm 0,06$ \\
IFES 26 & $6,10 \pm 0,48$ & $0,09 \pm 0,02$ & 8,5 & $64,16 \pm 0,12$ & $1,58 \pm 0,20$ \\
IFES 34 & $5,82 \pm 0,05$ & $0,06 \pm 0,01$ & 5,2 & $73,50 \pm 1,16$ & $1,83 \pm 0,06$ \\
IFES 36 & $5,07 \pm 0,06$ & $0,04 \pm 0,01$ & 6,4 & $83,94 \pm 0,39$ & $1,58 \pm 0,07$ \\
IFES 37 & - & - & - & - & - \\
IFES 39 & $5,36 \pm 0,06$ & $0,06 \pm 0,01$ & 3,0 & $82,77 \pm 0,45$ & $1,69 \pm 0,31$ \\
IFES 40 & $5,46 \pm 0,01$ & $0,04 \pm 0,00$ & 6,0 & $87,04 \pm 1,95$ & $0,83 \pm 0,11$ \\
\hline FoE
\end{tabular}

Fonte: Os Autores.

Nesse sentido, o acesso IFES 15 apresentou o maior valor de sólidos solúveis (12,0Brix) e o IFES 39 o menor (3,0Brix). Além de ser uma característica genética, Nascimento et al. (2013) ressaltam que o teor de sólidos solúveis nos frutos, sofre influência da adubação, irrigação e temperatura. Para o comércio de alimentos naturais, variedades mais doces ou mais ácidas podem ter preferências, o que varia de acordo com o hábito alimentar de cada consumidor e dos parâmetros regionais (BRAGA et al., 2013). Logo, é necessário disponibilizar ao mercado variedades com diferentes padrões sensoriais e físico-químicos.

A umidade dos frutos teve uma variação de $64,16 \%$ a $98,87 \%$ apresentada pelos acessos IFES 26 e IFES 15 respectivamente. Já o teor de cinzas das amostras integrais variou de 0,69\% (IFES 06) a 1,83\% (IFES 34). Para o consumo natural dos frutos é mais satisfatório que a umidade seja elevada e o teor de cinzas reduzido, pois confere aos frutos maior suculência, o que o torna mais apreciável pelo consumidor. Porém para a agroindústria, frutos com maior teor de matéria seca são desejados, o que aumenta o seu rendimento (FAGUNDES et al., 2005). 


\section{Considerações finais}

O estudo das correlações mostrou que características de comprimento e diâmetro dos frutos estão correlacionadas positivamente com o número de frutos por plantas, mostrando que a seleção com base em qualquer uma dessas características acarretará em ganhos na produtividade dos acessos.

Os descritores associados ao fruto se destacam para o estudo da divergência entre os acessos, dada sua facilidade de mensuração.

A análise da divergência genética por meio de características morfoagronômicas permitiu a formação de seis grupos, evidenciando a variabilidade existente entre os acessos do Banco de Germoplasma do Ifes - Campus de Alegre.

Quanto aos atributos físico-químicos estudados, foram obtidas importantes informações para aceitação do produto pelo mercado consumidor, permitindo destacar os acessos IFES 15 e IFES 04 por apresentarem maior teor de sólidos solúveis totais e o IFES 36 a maior acidez.

\section{Agradecimentos}

Ao Instituto Federal do Espírito Santo - Campus de Alegre e à Fundação de Amparo à Pesquisa e Inovação do Espírito Santo (FAPES) pelo aporte financeiro que oportunizou a realização desse trabalho.

\section{Referências}

ALBUQUERQUE, H. Y. G. Diversidade genética e identificação de duplicatas de Manihot esculenta Crantz com base em marcadores Single-Nucleotide Polymorphism (SNP). Cruz das Almas, 2017. Dissertação (Mestrado em Recursos Genéticos Vegetais) Universidade Federal do Recôncavo da Bahia Embrapa Mandioca e Fruticultura, Cruz das Almas, 2017.

ALMEKINDERS, C. J. M.; ELINGS, A. Collaboration of farmers and breeders: participatory crop improvement in perspective. Euphytica. v. 122, p. 425-438, 2001.

BABA, V. Y.; ROCHA, K. R.; GOMES, G. P.; RUAS, C. F.; RUAS, P. M.; RODRIGUES, R.; GONÇALVES, L.S.A. Genetic diversity of Capsicum chinense accessions based on fruit morphological characterization and AFLP markers. Genetic Resouces and Crop Evolution, v. 63, p. 1371-1381, 2016.

BIANCHI, P. A.; SILVA, LÍGIA RENATA ALMEIDA DA; ALENCAR, A. A. S.; 547 SANTOS, P.H.A.D.; PIMENTA, S.; SUDRÉ, C.P.; CORTE, L. E.; GONÇALVES, 548 L.S.A.; RODRIGUES, R. Biomorphological characterization of brazilian capsicum 549 chinense jacq. germplasm. Agronomy-Basel, v. 10, p. 1-17, 2020. 
BIANCHI, P. A.; DUTRA, I. P.; MOULIN, M. M.; SANTOS, J. O.; JÚNIOR, A. C. S. Morphological characterization and analysis of genetic variability among pepper accessions. Ciência Rural, v. 46, n. 7, p. 1151-1157, 2016.

BRAGA, T. R.; PEREIRA, R. C. A.; SILVEIRA, M. R. S.; SILVA, L. R., SILVA, A. R.; OLIVEIRA, M. M. T. Caracterização físico-química de progênies de pimentas cultivadas em Paraipaba-CE. Scientia Plena, v. 9, n. 5, p. 1-6, 2013.

CAMILO, Y. M. V.; SOUZA, E. R. B.; VERA, R.; NAVES, R. V. Caracterização de frutos e seleção de progênies de cagaiteiras (Eugenia dysenterica DC.). Científica, v. 42, n. 1, p. 110, 2014.

CARVALHO, S. I. C.; BIANCHETTI, L. B.; RIBEIRO, C. S. C.; LOPES, C. A. Pimentas do gênero Capsicum no Brasil. Brasília: EMBRAPA Hortaliças, 2006. 27p. (Documentos, 94)

CRUZ, C. D. Genes - software package for analysis in experimental statistics and quantitative genetics. Acta Scientiarum, v. 35, n. 3, p. 271-276, 2013.

FAGUNDES, A. F.; ABREU, R. S.; LUCCA, A. C. Influência do grau de umidade na textura do tomate seco refrigerado ou envasado em óleo. Ciências Exatas e da Terra, v. 2, p. 2841, 2005.

FERREIRA, L. L.; OLIVEIRA, F. S.; ALMEIDA, A. E. D. S.; LOIOLA, A. T.; SANTOS, E. C. D.; PORTO, V. C. N. Caracterização físico-química de frutos de pimentão em diferentes acessos mercadológico. Agropecuária Científica no Semiárido, v. 9, n. 1, p. 99-103, 2013.

FILGUEIRA, F. A. R. Novo manual de olericultura: agrotecnologia moderna na produção e comercialização de hortaliças. Viçosa: UFV, 2005. 412p.

JARRET, R. L.; BERKE, T. Variation for fruit morphological characteristics in a Capsicum chinense Jacq. germplasm collection. HortScience, v. 43, p. 1694-1697, 2008.

LANNES, S. D.; FINGER, F. L; SCHUELTER, A. R.; CASALI, V. W. D. Growth and quality of Brazilian accessions of Capsicum chinense fruits. Scientia Horticulturae, v. 112, p. 266270, 2007.

LIMA, J. S. S.; SILVA, S. A.; OLIVEIRA, R. B.; CECÍLIO, R.A.; XAVIER, A.C. Variabilidade temporal da precipitação mensal em Alegre-ES. Revista Ciência Agronômica, v. 39, n. 2, p. 327-332, 2008.

MELO, L.F.; GOMES, R. L. F.; SILVA, V. B.; MONTEIRO, E. R.; LOPES, Â. C. A.; PERON, A. P. Potencial ornamental de acessos de pimenta. Ciência Rural, v. 44, n. 11, p. 2010-2015, 2014.

MOSES, M.; UMAHARAN, P.; DAYANANDAN, S. Microsatellite based analysis of the genetic structure and diversity of Capsicum chinense in the Neotropics. Genetic Resouces and Crop Evolution, v. 61, p. 741-755, 2014.

MOULIN, M. M.; RODRIGUES, R.; BENTO, C. S.; GONCALVES, L. S. A.; SANTOS, J. O.; SUDRE, C. P.; VIANA, A. P. Genetic dissection of agronomic traits in Capsicum baccatum var. pendulum. Genetics and Molecular Research, v. 14, p. 2122-2132, 2015.

MOURA, F. E.; FARIAS NETO, T. J.; SAMPAIO, E. J.; SILVA, T. D.; 20 RAMALHO, F. G. Identification of duplicates of cassava accessions sampled on the North Region of Brazil using microsatellite markers. Acta Amazonica, v. 43, p. 461-468, 2013. 
NASCIMENTO, A. R.; MANOEL S SOARES JÚNIOR; CALIARI, M.; FERNANDES, P. M.; RODRIGUES, J. P. M.; CARVALHO, W. T. Qualidade de tomates de mesa cultivados em sistema orgânico e convencional no estado de Goiás. Horticultura Brasileira, v. 31, p. 628635. 2013.

NEITZKE, R. S.; BARBIERI, R. L.; RODRIGUES, W. F.; CORREAA, I. V.; CARVALHO, F. I. F. Dissimilaridade genética entre acessos de pimenta com potencial ornamental. Horticultura Brasileira, v. 28, n. 4, p. 47-53, 2010.

PEREIRA, A. R.; VILLA NOVA, N. A.; SEDIYAMA, G. C. Evapotranspiração. Piracicaba: FEALQ, 1997. 183 p.

PINO, J.; GONZÁLEZ, M.; CEBALLOS, L.; CENTURIÓN-YAH, A. R.; TRUJILLO AGUIRRE, J.; LATOURNERIE-MORENO, L.; SAURI-DUCH, E. Characterization of total capsaicinoids, color and volatile compounds of habanero chilli pepper (Capsicum chinense Jacq.) cultivars in Yucatan. Food Chemistry, v. 104, p. 1682-1686, 2007.

R CORE TEAM. R: a language and environment for statistical computing. R Foundation for Statistical Computing, Vienna, Austria, 2020.

RÊGO ER; RÊGO MM; CRUZ CD; FINGER FL. 2001. Correlações entre caracteres morfoagronômicos e produção de Capsicum baccatum. In: CONGRESSO BRASILEIRO DE MELHORAMENTO DE PLANTAS, 1 Anais...Goiânia: SBMP(CD-ROM).

REIS, D. R. D.; DANTAS, C. M. B.; SILVA, F. S.; PORTO, A. G.; SOARES, E. J. O. Caracterização biométrica e físico-química de pimenta variedade biquinho. Enciclopédia Biosfera, v. 11, n. 21, p. 454, 2015.

ROBICHAUD, R.; GLAUBITZ, J. C.; RHODES J. R. O. E.; WOESTE, K. A robust set of black walnut microsatellites for parentage and clonal identification. New Forests, v. 32, p. 179196, 2006.

RUFINO, J. L. S.; PENTEADO, D. C. S. Importância econômica, perspectivas e potencialidades do mercado para pimenta. Informe Agropecuário, v. 27, n. 235, p. 7-15, 2006.

SAMPAIO, R. A.; FONTES, P. C. R. Qualidade de frutos de tomateiro fertirrigado com potássio em solo coberto com polietileno preto. Horticultura Brasileira, v. 16, n. 1, p. 136139, 1998.

SANTOS, T. O.; MOULIN, M. M.; RANGEL, L. H.; PRIOVANI, R. O. L.; VALADARES, F. V.; ALMEIDA, R. N.; SILVA, L. O. E. Characterization and diversity of peppers (Capsicum spp.) genotypes based on morphological traits using 680 multivariate analysis. Journal of Experimental Agriculture International, v. 39, n. 681 1, p. 1-10, 2019.

SILVA NETO, J. J.; RÊGO, E. R.; NASCIMENTO, M. F.; SILVA FILHO, V. A. L.; ALMEIDA NETO, J. X.; RÊGO M. M. Variabilidade em população base de pimenteiras ornamentais (Capsicum annuum L.). Revista Ceres, v. 61, n. 1, p. 084-089, 2014.

SILVA, A. R.; RÊGO, E. R.; CECON, P. R. Tamanho de amostra para caracterização morfológica de frutos de pimenteira. Horticultura Brasileira, v. 29, n. 2, p. 125-129, 2011.

SILVA, C. A.; OLIVEIRA, R. L.; MOURA, W. M.; LIMA, P. C.; CARVALHO, V. C. F. M.; JACOOB, L. L.; FREITAS, M. A. VIII Simpósio de Pesquisa dos Cafés do Brasil, 2013. 
TAVARES, I. B.; CRIZEL, R. L.; ACUNHA, T. S.; BARBIERI, R. L.; CHAVES, F. C.; ROMBALDI, C. V. Potencial físico-quimico e bioativo de 50 acessos de pimentas (Capsicum spp). XXII Congresso de Iniciação Científica da Universidade Federal de Pelotas. 2013.

VASCONCELOS, C. S.; BARBIERI, R. L.; NEITZKE, R. N.; PRIORI, D.; FISCHER, S. Z.; MISTURA, C. C. Determinação da dissimilaridade genética entre acessos de Capsicum chinense com base em características de flores. Revista Ceres, v. 59, n. 4, p. 493-498, 2012. 


\title{
Capítulo 9
}

\section{Estudo da diversidade genética de variedades de milho-pipoca em ambiente com déficit hídrico com base em descritores morfológicos, fisiológicos e radiculares}

\author{
Talles de Oliveira Santos ${ }^{1}$, Antônio Teixeira do Amaral Júnior ${ }^{2}$, Rosimeire Barboza Bispo ${ }^{3}$, \\ Valter Jário de Lima ${ }^{1}$, Samuel Henrique Kamphorst ${ }^{4}$, Monique Moreira Moulin ${ }^{5}$
}

\section{Introdução}

O déficit hídrico é um estresse abiótico comum nas regiões tropicais e subtropicais, incluindo o Brasil (DIAS et al., 2018), e os períodos de seca têm se tornado cada vez mais frequentes devido aos efeitos globais de mudança climática (EL-SABAGH et al., 2018). Além disso, somado ao cenário de escassez de chuvas, aponta-se que, de toda a água destinada às atividades humanas, a agricultura é responsável por usar 70\% desse uso (SHENET al., 2008). O Brasil está entre os dez países com maior área irrigada do planeta (ANA, 2017). Até 2050, estima-se que 2,3 bilhões de pessoas sofram com a falta de água (IPCC, 2013).

Os estresses abióticos causam impactos negativos no crescimento e desenvolvimento das plantas, impedindo a expressão do potencial genético das culturas agrícolas (DALAL et al., 2017). Inúmeras restrições aos processos metabólicos das plantas ocorrem durante o período de déficit hídrico, que é causado pela elevada demanda evaporativa e pelo suprimento limitado de água no solo que, por sua vez, restringe a atividade fotossintética, afetando o crescimento e o desenvolvimento vegetal (DEJONGE et al., 2015). O estresse hídrico é apontado como o maior causador de perdas de produtividade nos cultivos agrícolas (AVRAMOVA et al., 2015; MAGETO et al., 2017) e, dentre eles o milho-pipoca (Zea mays var. everta) (KAMPHORST et al., 2018a).

Em se tratando do milho-pipoca, uma cultura altamente apreciada e economicamente atrativa, pesquisas visando à seleção de genótipos tolerantes à seca ainda são incipientes (KAMPHORST et al., 2018b). No Brasil, o Estado do Mato Grosso é o maior produtor desse

\footnotetext{
${ }^{1}$ Me. e Doutorando em Genética e Melhoramento de Plantas pelo programa de Pós-Graduação em Genética e Melhoramento de Plantas da Universidade Estadual do Norte Fluminense Darcy Ribeiro, Campos dos Goytacazes, RJ. E-mail: tallesdeoliveira@live.com; valter_jario@hotmail.com

${ }^{2}$ Dr. Professor Associado do Laboratório de Melhoramento Genético Vegetal da Universidade Estadual do Norte Fluminense Darcy Ribeiro, Campos dos Goytacazes, RJ. E-mail: amaraluenf@gmail.com

${ }^{3}$ Me. e Doutoranda do Programa de Pós-Graduação em Genética e Melhoramento de Plantas da UENF, Campos dos Goytacazes, RJ. E-mail: rosimeirebarboza1@hotmail.com

${ }^{4}$ Dr. em Genética e Melhoramento de Plantas e Pós-Doutorando da Universidade Estadual do Norte Fluminense Darcy Ribeiro, Campos dos Goytacazes, RJ. E-mail: samuelkampho@hotmail.com

${ }^{5}$ Dra. Professora do Instituto Federal do Espírito Santo - Campus de Alegre, Caixa Postal 47, CEP: 29500-000, Alegre-ES. E-mail: autor E-mail: moniquemoulin@gmail.com
} 
cereal, tendo atingido a marca recorde de 268,402 mil toneladas produzidas em área cultivada de 60.017 hectares no ano agrícola de 2018. A área para produção para o ano de 2019 expandiu para 66.986 hectares, o que representa um aumento de $11,61 \%$ (KIST, 2019).

A seleção de genótipos superiores para as condições de déficit hídrico é a estratégia mais viável, economicamente, para minimizar os efeitos da seca (OLIVEIRA et al., 2015; CHALLINOR et al., 2016). Porém, devido à baixa herdabilidade das características quantitativas, aliado ao fato de que as principais características de produção expressam ocorrência de interação genótipo × ambiente, sendo assim, esse intento não é fácil de ser alcançado (ALMEIDA et al., 2014; KONDWAKWENDA et al., 2019). Portanto, é importante refletir que o estudo de variáveis secundárias de maior herdabilidade e que produzam menor interação dos genótipos com o ambiente é opção ainda moderna e extremamente factível para alcançar eficiência da seleção em ambientes com baixo teor de água no solo.

Nesse aspecto, caracteres secundários com elevada correlação com a produtividade de grãos podem ser usados para seleção indireta ou composição de índices de seleção, buscando tornar o processo de melhoramento para a tolerância ao déficit hídrico mais eficaz (ALI et al., 2017). Como exemplos, podem-se citar o intervalo entre florescimento masculino e feminino, a altura de planta, o rendimento de grãos, a massa de cem grãos e o comprimento médio da espiga (LI et al., 2016),bem como a matéria seca (MS) (ALI et al., 2017), em milho comum, e o índice clorofila (SPAD) em milho-pipoca (KAMPHORST et al., 2018a), como variáveis secundárias identificadas como de interesse para a seleção indireta.

Com vistas ao desenvolvimento da agricultura sustentável no uso da água, a Universidade Estadual do Norte Fluminense Darcy Ribeiro (UENF), incorporou ao Programa de Melhoramento de Plantas, a linha de pesquisa do melhoramento de milho-pipoca para tolerância à seca (KAMPHORST et al., 2018a,b). O Norte do Estado do Rio de Janeiro destaca-se pelo seu elevado consumo de pipoca (XAVIER et al., 2019) e enfrenta longos períodos de escassez de recursos hídricos, o que afeta o desenvolvimento da agricultura familiar existente na região (XAVIER et al., 2019).

Para esse nicho de agricultura, não apenas no Norte Fluminense, a indicação de Variedades de Polinização Aberta (VPAs) é a melhor alternativa, visto que garante menor dependência do produtor para com o consumo de sementes, além de gerar menor demanda de insumos tecnológicos para a lavoura. Tendo em vista que a agrobiodiversidade é base para a agroecologia, a caracterização e avaliação de germoplasma de milho são fundamentais para seu uso pelos agricultores familiares.

Considerando que a UENF detém um Banco de Germoplasma com VPAs de milhopipoca oriundas de países de climas temperado e tropical, além de que há raros estudos 
com a cultura para a seleção de genótipos superiores para a condição de seca, sobretudo envolvendo abordagens estatísticas de maior alcance, como procedimentos multivariados, julgou-se oportuno o desenvolvimento desse estudo, que teve como objetivos: estimar a diversidade genética de genótipos de milho-pipoca para tolerância à seca com base em caracteres morfoagronômicos, fisiológicos e radiculares; e selecionar genótipos de milhopipoca para ambientes com estresse hídrico.

\section{Metodologia}

\section{Material vegetal}

Quinze variedades de polinização aberta (VPAs) de milho-pipoca pertencentes ao Banco de Germoplasma da Universidade Estadual do Norte Fluminense Darcy Ribeiro (UENF) foram avaliadas em dois ambientes com distinta disponibilidade hídrica (Tabela 1).

Tabela 1. Variedades de polinização aberta utilizadas na composição do experimento.

\begin{tabular}{rcccc}
\hline & Genótipo & Origem & Instituição & Adaptação Climática \\
\hline 1 & 288POP & Guaraciaba-SC & - & Subtropical \\
2 & 574POP & Guaraciaba-SC & - & Subtropical \\
3 & 880POP & Guaraciaba-SC & - & Subtropical \\
4 & ARZM13050 & Argentina & CIMMYT & Temperada/Tropical \\
5 & BARÃOUFV & Viçosa/MG & UFV & Temperada/Tropical \\
6 & BOYA462 & Colômbia & CIMMYT & Temperada/Tropical \\
7 & BOZM260 & Bolívia & CIMMYT & Temperada/Tropical \\
8 & BRS Angela & Sete Lagoas/MG & Embrapa & Tropical \\
9 & CHZM13134 & Chile & CIMMYT & Temperada/Tropical \\
10 & ISLA & Paraná & ISLA S/A & Temperada/Tropical \\
11 & PARA172 & Paraguai & CIMMYT & Temperada/Tropical \\
12 & UNB-2C0 & Campos/RJ & UENF & Tropical \\
13 & UNB-2C6 & Campos/RJ & UENF & Tropical \\
14 & UNB-2C8 & Campos/RJ & UENF & Tropical \\
15 & URUG298A & Uruguai & CIMMYT & Temperada/Tropical \\
\hline
\end{tabular}

Fonte: Os Autores. 


\section{Desenho experimental, tratos culturais e condições experimentais}

O experimento foi realizado no período de menores precipitações para a região Norte Fluminense, de maio a setembro, na Estação Experimental do Colégio Estadual Agrícola

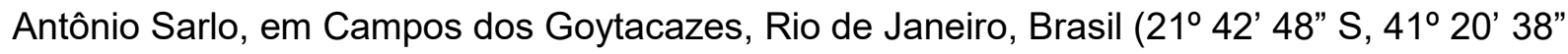
O). $O$ experimento foi em delineamento de blocos casualizados, com três repetições e sob condições hídricas: plena (WW - condições de irrigação à capacidade de campo do solo) e estresse hídrico (WS - quando o solo se aproximou do ponto de murcha permanente -1,5 Mpa). Cada parcela foi constituída de uma linha de 4,80 m, espaçadas em 0,20 m entre plantas e 0,80 m entre linhas, com um total de 23 plantas por linha (62500 plantas ha-1).

O plantio foi realizado em maio, no ano de 2018. A adubação de base do experimento foi realizada com $30 \mathrm{~kg} \mathrm{ha}^{-1}$ de $\mathrm{N}$ (na forma de uréia), $60 \mathrm{~kg} \mathrm{ha}^{-1}$ de $\mathrm{P}_{2} \mathrm{O}_{5}$ (na forma de superfosfato triplo) e $60 \mathrm{~kg} \mathrm{ha}^{-1}$ de $\mathrm{K}_{2} \mathrm{O}$ (na forma de cloreto de potássio). A adubação de cobertura ocorreu 30 dias após semeadura, disponibilizando-se $100 \mathrm{~kg} \mathrm{ha}^{-1}$ de $\mathrm{N}$ (na forma de uréia).

A irrigação foi aplicada por meio de um sistema de gotejamento, no qual foi instalado um gotejador por planta, respeitando o espaçamento utilizado. Para garantir a imposição do estresse hídrico, a irrigação foi suspensa 15 dias antes do florescimento masculino no ambiente WS e mantida até que o solo atingisse o ponto de murcha permanente. $O$ sistema de irrigação foi equipado com hidrômetros, garantindo precisão no volume de água aplicado a cada ambiente.

Uma estação automática do Instituto Nacional de Meteorologia (INMET) localizada a 100 $\mathrm{m}$ do experimento registrou uma precipitação de $148,20 \mathrm{~mm}$ durante todo o período experimental. As condições experimentais durante todo o período do crescimento e desenvolvimento da cultura foram mensuradas, tendo sido registradas as variações de temperatura $\left(15,90-25,40^{\circ} \mathrm{C}\right)$, de umidade relativa do $\operatorname{ar}(66,50-92,0 \%)$ e da radiação fotossinteticamente ativa média $\left(1.190 \mu \mathrm{mol} \mathrm{m}^{-2} \mathrm{~s}^{-1}\right)$ (Figura 1). 
— Temperatura $\left({ }^{\circ} \mathrm{C}\right) \quad$ Umidade Relativa do $\operatorname{Ar}(\%) \quad$ Fluxo de Fótons Fotossintéticos
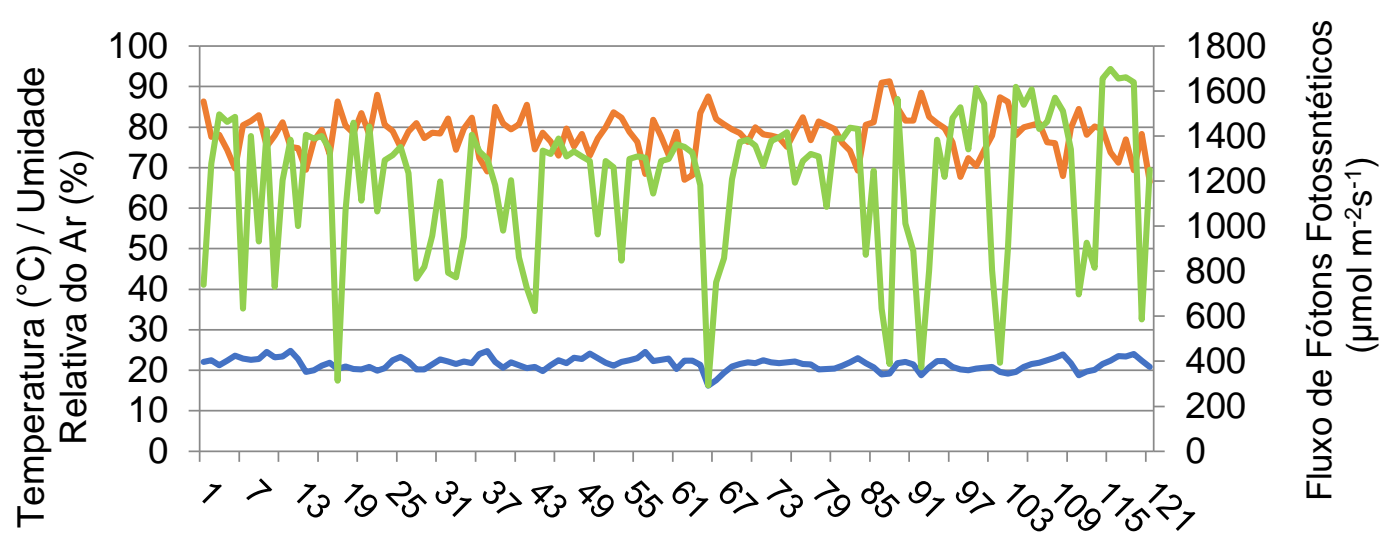

Dias após semeadura

Figura 1. Condições climáticas de temperatura $\left({ }^{\circ} \mathrm{C}\right)$, umidade relativa do ar $(\%)$ e fluxo de fótons fotossintéticos $\left(\mu \mathrm{mol} \mathrm{m} \mathrm{m}^{-2} \mathrm{~s}^{-1}\right)$ registrados pela estação automática do Instituto Brasileiro de Meteorologia (INMET) no período de abril a setembro de 2018.

Fonte: Os Autores.

Quanto à disponibilidade de água nos ambientes, o ambiente WW recebeu 186,90 mm, enquanto no ambiente WS foi fornecida a quantidade de $69,30 \mathrm{~mm}$, além da precipitação de $148,20 \mathrm{~mm}$ registrada durante o período (Tabela 2 ).

\section{Caracteres avaliados}

Os caracteres avaliados na planta foram: altura de planta (AP), teor relativo de clorofila (SPAD), comprimento do pendão (CP) e número de ramificações do pendão (NRP). A AP foi medida com base na distância da inserção da planta no solo até a folha bandeira, com auxílio de fita métrica ao fim do período de florescimento. O valor de SPAD foi coletado durante o período de enchimento de grãos (107 DAS), visto que esse é o período mais nocivo do déficit nas plantas (DARYANTO et al., 2016).

As medidas de SPAD foram obtidas em frequência semanal, em ambos os experimentos WW e WS, com o uso de medidor de clorofila (SPAD 502, MinoltaCoLtd, Osaka, Japan). Para tanto, foram identificadas três localizações na folha bandeira (base, meio e ápice) (AVRAMOVA et al., 2016), para as quais foram obtidas as estimativas. Para minimizar as variações nos valores obtidos devido às flutuações da intensidade luminosa, adotou-se como padronização a obtenção dessas medidas entre 10 e $12 \mathrm{~h}$ durante todo o período de avaliação. 
O CP foi mensurado no fim do período de florescimento desde a inserção na folha bandeira até o ápice da ramificação principal, com o auxílio de uma régua graduada. Já o NRP foi mensurado com base na contagem dessas estruturas.

A colheita ocorreu cerca de 120 dias após a semeadura. Após a colheita, a matéria seca da parte aérea (MS) foi obtida com base na coleta de duas plantas por parcela, levadas a estufa com circulação por $72 \mathrm{~h}$ a $80^{\circ} \mathrm{C}$. Após a secagem, as amostras foram pesadas e, por fim, considerado o valor médio das medidas.

O comprimento médio de espigas (CME) foi mensurado com base em cinco amostras de espigas por parcela experimental, expresso em $\mathrm{cm}$ e obtido por meio de um paquímetro digital. O número médio de fileiras de grãos (NFG) e de grãos por fileira (NGF) foi determinado por meio de sua contagem. A massa de cem grãos (MCG) foi determinada a partir da pesagem (g) de duas amostras por parcela de 100 grãos cada uma.

O caractere rendimento de grãos (RG) foi corrigido para 13\% de umidade e expresso em $\mathrm{kg} \cdot \mathrm{ha}^{-1}$. A capacidade de expansão (CE) aferida para a massa de $30 \mathrm{~g}$ de grãos, irradiada em microondas, em saco de papel especial para pipocamento, na potência de $1000 \mathrm{~W}$, por tempo determinado de dois minutos e quinze segundos. O volume de pipoca foi quantificado em proveta de $2000 \mathrm{~mL}$. A CE foi determinada pela razão do volume obtido de pipoca e massa de grãos, expressa em $\mathrm{mL} \mathrm{g}^{-1}$.

Os caracteres de arquitetura de raízes mensurados foram: ângulo de raízes de suporte (ARS) e ângulo de raízes da coroa (ARC), os quais foram obtidos com o auxílio de transferidor de graus e em expresso em graus $\left(^{\circ}\right)$ em relação ao solo; número de raízes de suporte (NRS) e número de raízes da coroa (NRC) e densidade de raízes da coroa (DRC). Para tanto, utilizou-se da metodologia proposta por Trachsel et al. (2011). A priori, adotou-se o procedimento de que, após a colheita, o solo dos ambientes de estresse hídrico e controle, recebessem irrigação de $50 \mathrm{~mm}$ de água, facilitando a remoção das plantas. A seguir, o sistema radicular de duas plantas por parcela nos dois ambientes foi removido em cilindros de solo de $40 \mathrm{~cm}$ de diâmetro e $25 \mathrm{~cm}$ de profundidade. Imediatamente após a remoção, esses cilindros foram lavados para a completa remoção do solo e, assim, aferidas as características ARS, ARC, NRS, NRC e DRC. 
Tabela 2. Precipitação e irrigação $(\mathrm{mm})$ aplicada na condição irrigada normal (WW) e sob estresse hídrico (WS), em dias após a semeadura.

\begin{tabular}{cccccc}
\hline \multirow{2}{*}{$\begin{array}{c}\text { Dias após a } \\
\text { semeadura }\end{array}$} & Chuva & \multicolumn{4}{c}{ Quantidade de água (mm) } \\
\cline { 3 - 6 } & & Irrigação plena & \multicolumn{2}{c}{ Estresse hídrico } \\
& 0,00 & 2,60 & 2,60 & 2,67 & 2,67 \\
7 & 17,00 & 3,60 & 20,60 & 3,50 & 20,50 \\
14 & 6,00 & 10,97 & 16,97 & 10,24 & 16,24 \\
21 & 0,00 & 10,13 & 10,13 & 9,86 & 9,86 \\
28 & 10,60 & 10,72 & 21,32 & 10,27 & 20,87 \\
35 & 5,20 & 8,35 & 13,55 & 8,43 & 13,63 \\
42 & 2,00 & 11,60 & 13,60 & 12,18 & 14,18 \\
49 & 0,00 & 12,94 & 12,94 & 12,12 & 12,12 \\
56 & 0,00 & 10,86 & 10,86 & 0,00 & 0,00 \\
63 & 0,00 & 18,79 & 18,79 & 0,00 & 0,00 \\
70 & 0,00 & 18,95 & 18,95 & 0,00 & 0,00 \\
77 & 30,80 & 1,14 & 31,94 & 0,00 & 30,80 \\
84 & 0,00 & 16,73 & 16,73 & 0,00 & 0,00 \\
91 & 0,00 & 14,00 & 14,00 & 0,00 & 0,00 \\
98 & 65,00 & 2,00 & 67,00 & 0,00 & 65,00 \\
105 & 0,00 & 13,50 & 13,50 & 0,00 & 0,00 \\
112 & 9,20 & 10,00 & 19,20 & 0,00 & 9,20 \\
119 & 2,40 & 10,00 & 12,40 & 0,00 & 2,40 \\
Total final & 148,20 & 186,88 & 335,08 & 69,27 & 217,47 \\
\hline
\end{tabular}

Fonte: Os Autores.

\section{Análises estatísticas}

Realizou-se a análise de variância individual de acordo com o seguinte modelo:

$$
Y_{i j}=\mu+g_{i}+b_{j}+\varepsilon_{i j}
$$

onde: $Y_{\mathrm{ij}}$ : valor observado do i-ésimo genótipo no j-ésimo bloco; $\mu$ : constante geral; $g_{\mathrm{i}}$ efeito fixo atribuído ao i-ésimo genótipo; $b_{\mathrm{j}}$ : efeito do bloco j; e $\varepsilon_{\mathrm{ij}}$ : erro aleatório associado à observação $Y_{\mathrm{ij}}$.

Posteriormente, realizou-se a análise de variância conjunta com base no seguinte modelo estatístico:

$$
Y_{i j k}=\mu+G_{i}+B / A_{j k}+A_{j}+G A_{i j}+\varepsilon_{i j k}
$$

onde: $Y_{i j k}$ : observação do i-ésimo genótipo no j-ésimo ambiente no k-ésimo bloco; $\mu$ : constante geral; $G_{i}$ : efeito fixo do i-ésimo genótipo; $B / A_{j k}$ : efeito do k-ésimo bloco dentro do ambiente $\mathrm{j} ; A_{j}$ : efeito fixo do j-ésimo ambiente; $G A_{i j}$ : efeito fixo da interação entre o i-ésimo 
genótipo com o j-ésimo ambiente; e $\varepsilon_{i j k}$ : erro aleatório experimental médio associado à observação $Y_{i j k}$.

O coeficiente de variação experimental foi obtido por $C V_{e}=(\sqrt{Q M R} / \mu) \times 100$. As análises estatísticas foram realizadas com auxílio do programa Genes (CRUZ, 2003).

Para a escolha do método mais apropriado para o agrupamento dos acessos, foram determinadas as matrizes de distância euclidiana média padronizada (D) e de distância generalizada de Mahalanobis (D2) entre os genótipos. Essas matrizes de distâncias foram utilizadas como medida de dissimilaridade para a análise de agrupamento pelo método hierárquico da ligação média dentro de grupo (UPGMA). Posteriormente foi feita a análise de correlação entre matrizes pelo teste de Mantel com 1000 simulações, conforme metodologia proposta por Cruz (2014).

Para isso, as estimativas das médias das características avaliadas foram padronizadas e as análises, então, realizadas com auxílio do programa Genes e RStudio (R CORE TEAM, 2017) - pacotes gplot e heatmaply.

\section{Resultados e discussão}

Existe variabilidade genética entre os genótipos nos ambientes WW e WS para os caracteres estudados, estatisticamente comprovados pelo Teste $F(p \leq 0,01)$ exceto para SPAD e ARC em WW. Em ambas as condições hídricas, os coeficientes de variação experimental não superaram o valor de $20 \%$, apontando para um nível satisfatório de acurácia experimental (Tabela 3). 
Tabela 3. Resumo da análise de variância individual e conjunta, médias gerais, desviospadrões, coeficientes de variação experimental (CVe \%), de caracteres morfoagronômicos, fisiológicos e radiculares de 15 variedades de polinização aberta de milho-pipoca avaliadas em condições de estresse hídrico (WS) e de irrigação plena (WW).

\section{Quadrados Médios}

\begin{tabular}{|c|c|c|c|c|c|}
\hline \multirow[b]{2}{*}{ Caráter } & \multirow[b]{2}{*}{$\begin{array}{l}\text { Ambiente } \\
\text { (A) }\end{array}$} & & \multirow[b]{2}{*}{ Média \pm DP } & \multirow[b]{2}{*}{$\mathrm{CV}_{\mathrm{e}}(\%)$} \\
\hline & & $\begin{array}{c}\text { Genótipo (G) } \\
\text { (GL=14) }\end{array}$ & $\begin{array}{c}G \times A \\
(G L=14)\end{array}$ & & \\
\hline \multirow{2}{*}{ SPAD } & WW & $73,84^{\text {ns }}$ & \multirow{2}{*}{$109,19^{* *}$} & $33,25 \pm 6,44$ & 19,35 \\
\hline & WS & $159,92^{* *}$ & & $28,02 \pm 5,49$ & 19,60 \\
\hline \multirow{2}{*}{ AP } & WW & $1074,06^{* *}$ & \multirow{2}{*}{$192,25^{\text {ns }}$} & $181,55 \pm 12,43$ & 6,85 \\
\hline & WS & $888,84^{\star \star}$ & & $163,48 \pm 9,32$ & 5,70 \\
\hline \multirow{2}{*}{$\mathrm{CP}$} & WW & $7,63^{* *}$ & \multirow{2}{*}{$4,58^{* *}$} & $12,04 \pm 0,42$ & 3,51 \\
\hline & WS & $8,20^{* *}$ & & $11,95 \pm 0,58$ & 4,88 \\
\hline \multirow{2}{*}{ NRP } & WW & $14,26^{\star \star}$ & \multirow{2}{*}{$7,33^{* *}$} & $19,31 \pm 2,06$ & 5,97 \\
\hline & WS & $9,74^{\star \star}$ & & $16,02 \pm 1,15$ & 12,85 \\
\hline \multirow{2}{*}{ CME } & WW & $4,56^{\star *}$ & \multirow{2}{*}{$2,55^{\star \star}$} & $12,79 \pm 0,86$ & 6,73 \\
\hline & WS & $5,62^{* *}$ & & $11,30 \pm 1,02$ & 8,99 \\
\hline \multirow{2}{*}{ NFG } & WW & $4,28^{\star \star}$ & \multirow{2}{*}{$1,43^{\text {ns }}$} & $13,24 \pm 0,94$ & 7,07 \\
\hline & WS & $4,79^{\text {ns }}$ & & $12,64 \pm 1,59$ & 12,58 \\
\hline \multirow{2}{*}{ NGF } & WW & $22,16^{\star \star}$ & \multirow{2}{*}{$28,22^{*}$} & $27,41 \pm 2,84$ & 10,36 \\
\hline & WS & $60,97^{\star *}$ & & $23,24 \pm 4,10$ & 17,63 \\
\hline \multirow{2}{*}{ MCG } & WW & $12,33^{\star *}$ & \multirow{2}{*}{$2,01^{\mathrm{ns}}$} & $15,99 \pm 1,33$ & 8,29 \\
\hline & WS & $25,49^{* *}$ & & $15,07 \pm 1,15$ & 7,65 \\
\hline \multirow{2}{*}{$R G$} & WW & $1776800,80^{\star *}$ & \multirow{2}{*}{$288045,29^{* *}$} & $2684,28 \pm 349,06$ & 13,00 \\
\hline & WS & $760443,71^{* *}$ & & $1862,62 \pm 254,88$ & 13,68 \\
\hline \multirow{2}{*}{ CE } & WW & $207,50^{\star *}$ & \multirow{2}{*}{$5,48^{\text {ns }}$} & $20,87 \pm 2,04$ & 9,77 \\
\hline & WS & $166,59^{* *}$ & & $20,14 \pm 1,63$ & 8,08 \\
\hline \multirow{2}{*}{ MS } & WW & $8706,63^{\star *}$ & \multirow{2}{*}{$3392,40^{\star *}$} & $201,69 \pm 32,48$ & 16,11 \\
\hline & WS & $6384,97^{* *}$ & & $191,49 \pm 32,07$ & 16,75 \\
\hline \multirow{2}{*}{ ARS } & WW & $147,95^{\star *}$ & \multirow{2}{*}{$1,12^{\text {ns }}$} & $61,24 \pm 2,64$ & 4,32 \\
\hline & WS & $139,86^{\star *}$ & & $60,87 \pm 2,38$ & 3,90 \\
\hline $\mathrm{ARC}$ & WW & $49,34^{\text {ns }}$ & & $68,76 \pm 6,69$ & 9,73 \\
\hline ARU & WS & $93,51^{* *}$ & $10,13^{10}$ & $67,71 \pm 2,44$ & 3,60 \\
\hline & WW & $16,47^{\star *}$ & & $12,96 \pm 0,99$ & 7,62 \\
\hline NRS & WS & $14,80^{* *}$ & $1,10^{13}$ & $13,20 \pm 1,93$ & 14,65 \\
\hline NRC & WW & $60,90^{* *}$ & $253^{\mathrm{ns}}$ & $20,16 \pm 0,78$ & 3,88 \\
\hline IVחU & WS & $55,45^{\star *}$ & $<, \infty 0$ & $19,91 \pm 1,50$ & 7,51 \\
\hline & WW & $0,93^{* *}$ & $154^{\star *}$ & $4,32 \pm 0,27$ & 6,25 \\
\hline URC & WS & $2,34^{* *}$ & 1,54 & $5,20 \pm 0,31$ & 5,87 \\
\hline
\end{tabular}

WS: Estresse hídrico; WW: Bem irrigado; SPAD: Teor relativo de clorofila; AP: Altura de planta $(\mathrm{cm})$; CP: comprimento do pendão (cm); NRP: número de ramificações do pendão; CME: comprimento médio de espiga (cm); NGF: número de fileiras de grãos (un); NGF: Número de grãos por fileira (un); 
MCG: massa de cem grãos (g); RG: Rendimento de grãos (kg ha-1); CE: capacidade de expansão (g $\mathrm{mL}^{-1}$ ); MS: Matéria seca da parte aérea (g); ARS: ângulo de raízes de suporte; ARC: ângulo de raízes da coroa; NRS: número de raízes de suporte; NRC: número de raízes da coroa; e DRC: densidade de raiz da coroa. Os símbolos *, ${ }^{* *}$ indicam significância em 5 e $1 \%$ de probabilidade, respectivamente, pelo Teste $F .{ }^{\text {ns }}=$ não significativo, pelo Teste $F$, em 1 e $5 \%$ de probabilidade.

Fonte: Autores.

Para SPAD, a redução causada pelo déficit hídrico foi de 15,80\%. Em WW, o valor médio dessa característica foi de $33,25 \%$ enquanto em WS foi de $28,02 \%$. Em um estudo em linhagens e híbridos de milho comum, ao avaliar o conteúdo de clorofila foliar em condições de estresse hídrico, Cairns et al. (2012) encontraram reduções de 32,43 e 17,49\%, para essa característica. A redução em maiores proporções das linhagens era esperada vez que há grande depressão por endogamia em plantas com essa estrutura genética, já nos híbridos a redução percentual é menor, considerando o efeito positivo da heterose. Todavia, cabe ressaltar que a menor diminuição de SPAD no presente trabalho pode estar relacionada com a base genética dos genótipos estudados, tendo em vista que trabalhos nessas condições para variedades de polinização aberta ainda são escassos.

A redução de SPAD se dá quando, em condições de baixa disponibilidade de água, ocorre o fechamento estomático e, por conseguinte, a indução da formação de espécies reativas de oxigênio (EROs) que inibem enzimas do ciclo de Calvin (ZAEFYZADEH et al., 2009; AVRAMOVA et al., 2015) e degradam estruturas celulares fundamentais, bem como os compostos fotossintéticos importantes, como a clorofila (CAVERZAN et al., 2016; LAXA et al., 2019).

A altura das plantas teve pouco efeito da limitação hídrica, da ordem de 9,95\%. A imposição do déficit hídrico no período de pré-florescimento pode estar relacionada à baixa redução dessa característica, visto que plantas nesse período estão próximas ao fim do desenvolvimento vegetativo sendo pouco afetadas pelas condições limitantes de água (DURÃES et al., 2007; KAMPHORST et al., 2018b).

O comprimento do pendão apresentou redução de 0,72\%. Em condição WW, essa característica apresentou valor médio de $12,04 \mathrm{~cm}$, enquanto em condição WS o valor médio foi de $11,95 \mathrm{~cm}$. Já o número de ramificações do pendão apresentou redução significativa. No ambiente WW, os pendões apresentavam a média de 19 ramificações, enquanto no WS esse valor foi em média 16, o que significa uma redução de $20 \%$.

É relatada na literatura a existência de uma dominância em relação ao desenvolvimento das espigas e pendões e que a diferença dessa dominância nas plantas varia entre genótipos (BECHOUXET al., 2000; MONNEVEUX et al., 2006). No milho, essa diferença está relacionada à monoicia e protrandria, que favorece o desenvolvimento da inflorescência masculina em detrimento à feminina, assegurando a produção de pólen antes do completo 
amadurecimento dos órgãos reprodutivos femininos (BOLAÑOS E EDMEADES, 1993; MONNEVEUX et al., 2006). A despeito dessa diferença em condições de déficit hídrico, alguns estudos reportam a importante relação entre o menor tamanho e número de ramificações no pendão.

Alguns autores sustentam a hipótese de que a associação entre o despendoamento e incremento na produtividade pode estar relacionada à competição entre espigas e pendão por recursos hídricos (HUNTER et al., 1969; MAGALHÃES et al., 1999). Já alguns estudos associam os ganhos de produtividade em plantas com pendões reduzidos à baixa competividade por luz entre essa estrutura e as folhas primárias, que garantem fotoassimilados para o processo de enchimento de grãos (MICKELSON et al., 2002). A exemplo disso, Monneveux et al. (2006) apontam para um incremento na produtividade de híbridos de milho em condições de déficit hídrico quando as plantas apresentavam menores números dessas estruturas.

Os componentes de rendimento CME, NFG, NGF e MCG, em condições WS, foram reduzidos em $11,67 \%, 4,51 \%, 15,24 \%$ e 5,76\%, respectivamente. No ambiente WW, os valores médios para essas características foram de 12,79 cm (CME), 13,24 (NFG), 27,41 (NGF) e 15,99 g (MCG), em comparação a 11,30 cm, 12,64, 23,24 e 15,07 g, nessa ordem, em WS. A redução em $R G$ devido à limitação hídrica foi de $30,61 \%$, dada a média de $1.862,62 \mathrm{~kg} \mathrm{ha}^{-1}$ em WS e de 2.684,28 kg ha-1 no ambiente com WW. Pode-se inferir, portanto, que o estresse hídrico reduziu, sobretudo, o número de grãos por fileira e o comprimento médio da espiga, afetando, portanto, o rendimento de grãos.

Períodos de condições de seca no solo podem comprometer até $60 \%$ da produtividade de grãos, em milho comum, quando o estresse coincide com as fases de pré-florescimento e enchimento de grãos, período crítico para a cultura (DARYANTO et al., 2016; JIANG et al., 2018). A redução desses caracteres é resultante do estresse imposto, visto que a escassez de água retarda o crescimento do pendão e em maior proporção, o da espiga, causando um grande intervalo entre o amadurecimento das anteras e a recepção do pólen pelos estigmas, provocando diminuição na formação e enchimento de grãos (MARTINS et al., 2017). Kamphorst et al. (2018b) aplicando estresse hídrico nos estádios fenológicos citados, em linhagens endogâmicas de milho-pipoca, observaram reduções de 55,29\% para produtividade de grãos.

A CE sofreu redução de 3,50\%, tendo apresentado valor médio de $20,14 \mathrm{~mL} \mathrm{~g}^{-1}$ em condição WS e de $20,87 \mathrm{~mL} \mathrm{~g}^{-1}$ no ambiente WW. Uma hipótese para o baixo efeito do déficit hídrico em CE é a base genética ampla de variedades de polinização aberta, que sofrem menos com estresses ambientais, garantindo-lhes maior estabilidade fenotípica. Resultados semelhantes podem ser evidenciados nos trabalhos com milho-pipoca realizados por 
Kamphorst et al. (2018b, 2019) e Lima et al. (2019), em que a CE apresentou redução de $8,76 \%$ e 9,08\%, respectivamente, entre os ambientes WW e WS.

Os caracteres associados à arquitetura de raízes - ARS, ARC e NRC- sofreram reduções em WS da ordem de 0,60\%, 1,50\% e 1,20\%, respectivamente. Já para NRS e DRC o déficit hídrico proporcionou incrementos de 1,90\% e 20,30\%, respectivamente. Destes, o maior efeito do estresse foi sobre DRC.

A adaptação morfológica do ângulo de raízes (ARS e ARC) já foi descrita por Lynch (2013) que, ao analisar o sistema radicular de genótipos de milho em condições de estresse hídrico, propôs o ideótipo radicular Steep, Cheap and Deep (íngreme, barato e profundo) para condições de seca. Isso porque genótipos com sistema radicular íngreme conseguem buscar água em perfis mais longínquos do solo. Fenótipos radiculares com menor número e maior tamanho de células corticais reduzem o custo metabólico de exploração do solo.

Mais recentemente, Gao e Lynch (2016) acrescentaram como elemento deste ideótipo, o número reduzido de raízes da coroa (NRC), visto que com base em estudos complementares, essa característica é que permite o maior aprofundamento do sistema radicular. As raízes da coroa são responsáveis pela aquisição de boa parte dos recursos hídricos e minerais durante o crescimento vegetativo e se mostra importante durante 0 desenvolvimento reprodutivo, período em que o estresse hídrico é mais crítico (HOCHHOLDINGER et al., 2004; YU et al., 2014; GAO E LYNCH et al., 2016). No presente estudo, a redução de NRC sugere uma adaptação radicular das variedades estudadas. Além disso, o incremento em DRC - 20,30 \% - pode estar associado à maior presença de pelos radiculares, o que garante maior superfície para absorção de água em eventual condição de seca.

O estudo da variabilidade entre acessos é essencial em etapas iniciais de um programa de melhoramento, vez que é o procedimento mais rápido e viável para conhecimento da diversidade genética de um banco de germoplasma disponível para o melhorista. As variações fenotípicas representam uma oportunidade ideal para este fim, por demandarem pouco tempo e menor custo (FRANCO et al., 2001; ACl et al., 2018).

O teste de Mantel mostrou haver correlação linear significativa $(p<0,01)$ entre as estimativas das distâncias euclidiana média padronizada (D) e generalizada de Mahalanobis (D2), nos ambientes WS e WW, o que evidencia boa concordância entre as medidas (Figura $2 \mathrm{~A}$ e B), possibilitando a formação de grupos semelhantes em análises subsequentes. 

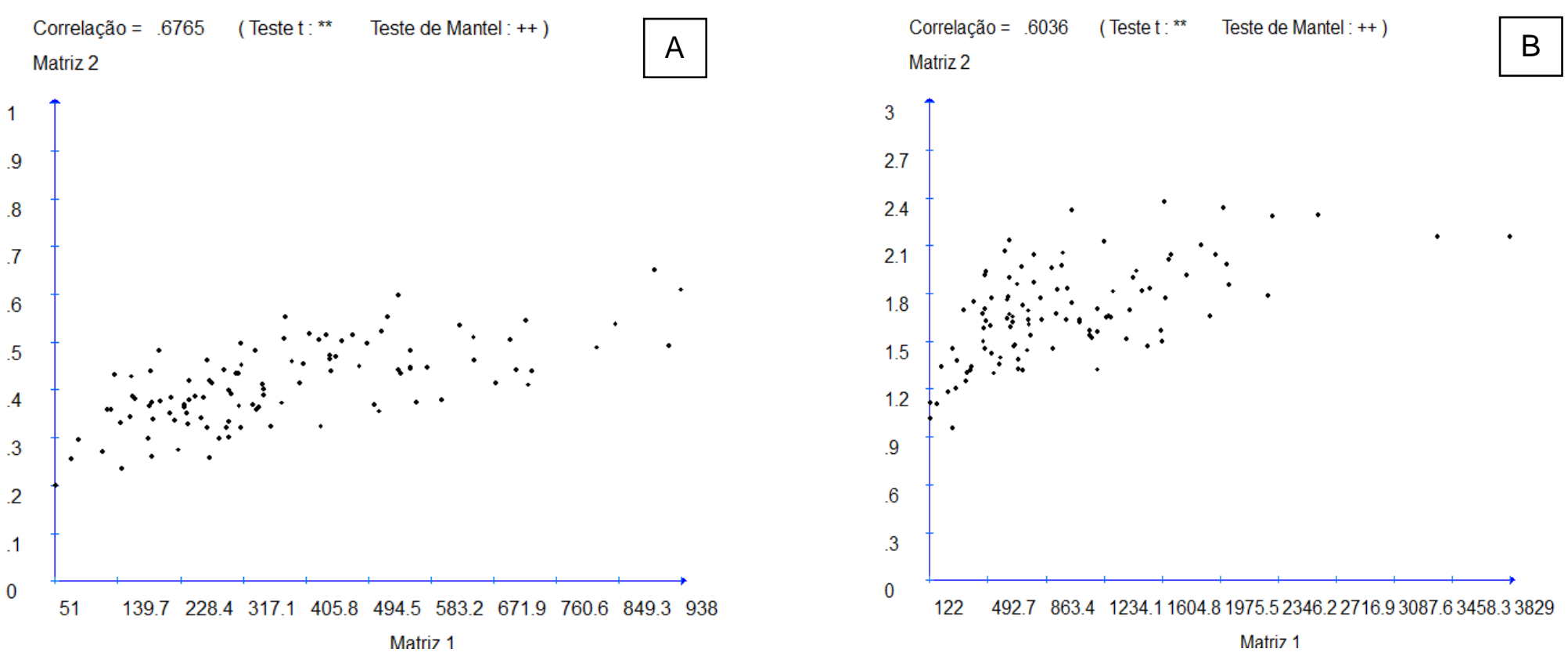

Figura 2. Análise de Mantel para as estimativas da distância euclidiana média padronizada (D) e generalizada de Mahalanobis (D2), no ambiente WS (A) e WW (B) para 15 genótipos de milho-pipoca. ${ }^{*} \mathrm{e}^{* *}$ indicam significância a 5 e $1 \%$ pelo teste $t ;+\mathrm{e}++$ indicam significância a 5 e $1 \%$ pelo teste de Mantel com base em 1.000 simulações.

Fonte: Os Autores. 
Para milho-pipoca em condições de déficit hídrico ainda não há relatos do de métodos mais apropriados de obtenção de medidas de dissimilaridade para o estudo de diversidade genética. Porém, é relatado para outras culturas correlação linear significativa e de alta magnitude entre as estimativas das distâncias euclidiana média padronizada e generalizada de Mahalanobis. Aguiar et al. (2008), em um estudo de diversidade de 16 linhagens S5 oriundas de nove variedades de milho-pipoca, encontraram correlação linear igual a 0,88 entre as duas matrizes de dissimilaridade. Cargnelutti Filho et al. (2008), estudando 14 genótipos de feijão em nove experimentos, em Santa Maria/RS, encontraram correlação linear de 0,92 entre as estimativas de D e D2.

Desse modo, com base na distância euclidiana média, a análise de dissimilaridade genética entre as 15 variedades de polinização aberta estudadas nos dois ambientes (WW e WS) permitiu a formação de quatro grupos distintos (Figuras 5 e 6), condizentes com o esperado baseado nas informações previamente conhecida das variedades.

No ambiente WS, o primeiro grupo conteve apenas a variedade $\mathrm{CHZM13134}$ por possuir menores médias para RG, MS, AP, ARS, NRC e DRS. O segundo grupo foi formado pelos genótipos BOYA 462, ARZM13050, PARA 172 e BOZM 260, que possuíam maiores médias de RG, MCG e os menores valores para CE e DRC. O terceiro grupo reuniu os genótipos URUG298-A, 880POP, UNB2-C8, 574POP, 288POP, BRS Angela, UNB2-C0, BARÃO-UFV e UNB2-C6, que possuíram as maiores médias de CE. O grupo quatro foi formado apenas pela variedade ISLA, por possuir o menor valor de SPAD (Figura 3).

No ambiente WW, o primeiro grupo foi formado pelas variedades 574POP, UNB2-C8 e 880POP, que possuem menores valores de ARC e ARS. Já no grupo dois, foram agrupadas as variedades 288POP, BRS Angela, URUG298A, UNB2-C6, ISLA, BARÃO-UFV e UNB2CO por possuírem maiores valores de CME e NRS. O grupo três foi formado apenas por CHZM13134 e ARZM13050, com menores valores de SPAD, DRC, NRC e MS. O grupo quatro reuniu as variedades BOYA 462, BOZM 260 e PARA 172, com maiores valores de MCG e menores valores de CE (Figura 4).

A formação de quatro grupos mostra a variabilidade existente entre as variedades estudadas com base nos caracteres fisiológicos, radiculares e morfoagronômicos. Em um estudo realizado por Aci et al. (2018), dentre 27 variedades de milho estudadas, houve a formação de três grupos com base em 24 descritores morfoagronômicos. 


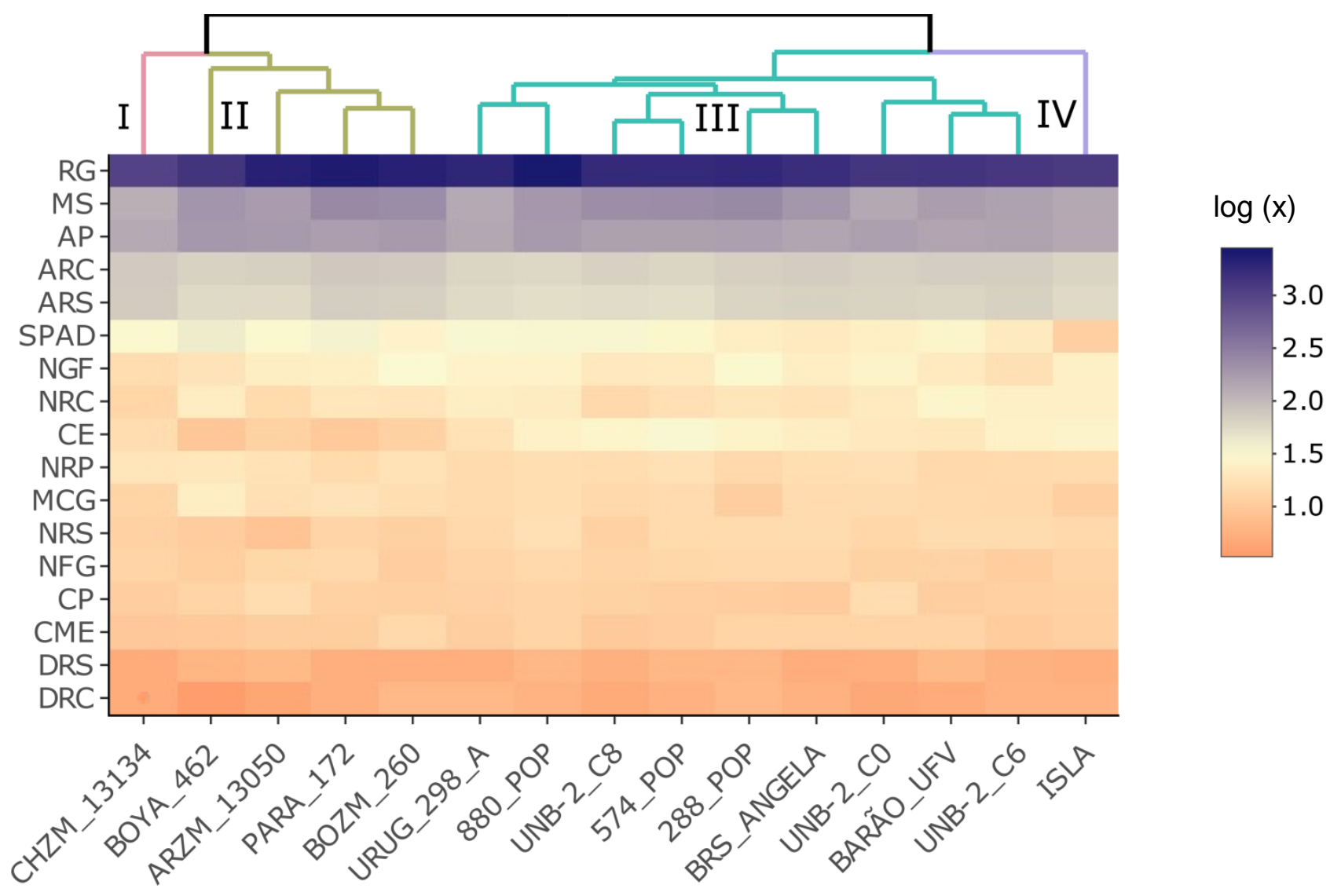

Figura 3. Heatmap da Distância Euclidiana Média, pelo método UPGMA, entre 15 variedades de polinização aberta de milho-pipoca com base nas médias dos caracteres morfoagronômicos, fisiológicos e radiculares em condições de irrigação plena (WS) em escala logarítmica. SPAD: Teor relativo de clorofila; AP: Altura de planta $(\mathrm{cm})$; $\mathrm{CP}$ : comprimento do pendão $(\mathrm{cm})$; NRP: número de ramificações do pendão; CME: comprimento médio de espiga (cm); NFG: número de fileiras de grãos (un); NGF: Número de grãos por fileira (un); MCG: massa de cem grãos (g); RG: Rendimento de grãos $\left(\mathrm{kg} \cdot \mathrm{ha}^{-1}\right)$; CE: capacidade de expansão (g. $\mathrm{mL}^{-1}$ ); MS: Matéria seca da parte aérea (g); ARS: ângulo de raiz de suporte; ARC: ângulo de raiz da coroa; NRS: número de raízes de suporte; NRC: número de raízes da coroa; e DRC: densidade de raiz da coroa. Fonte: Os Autores. 
Esses resultados ressaltam a grande importância das variedades de polinização aberta para a manutenção da variabilidade genética em um programa de melhoramento de plantas (WARBURTON et al., 2008) visto que somente $5 \%$ de toda variabilidade existente na cultura do milho é explorada no uso comercial (CARENA et al., 2019) e que muitas variedades são descartadas por conta de características indesejadas.

Em milho, as variedades de polinização aberta apresentam menores valores para atributos de importância comercial se comparadas aos híbridos, por exemplo. Entretanto, é a variabilidade presente nessas variedades que garantem a adaptação da cultura a ambientes sujeitos a estresses abióticos no cenário atual de mudanças climáticas (IGNJATOVIC-MICIC et al., 2015; ACl et al., 2018).

Com base nisso, as variedades agrupadas por possuírem menores valores para produtividade ou capacidade de expansão não são descartadas como fonte importante de variabilidade para outros atributos, como é o caso de CHZM13134 (menor valor de RG) e BOYA 462, ARZM13050, PARA 172 e BOZM 260 (menores valores de CE). Além disso, por RG e CE serem características correlacionadas negativamente (LARISH E BREWBACKER, 1999; PEREIRA E AMARAL JÚNIOR, 2001), é comum que se agrupem genótipos com diferentes desempenhos para RG e CE em alocações distintas. Nesse sentido, e considerando-se ainda a ausência de cultivar de milho-pipoca no mercado com adaptação ao estresse hídrico, em um programa de melhoramento de milho-pipoca com essa conotação, há que se ter destaque para as variedades de polinização aberta como fontes promissoras para a extração de linhagens e, consequente, formação de híbridos superiores. 


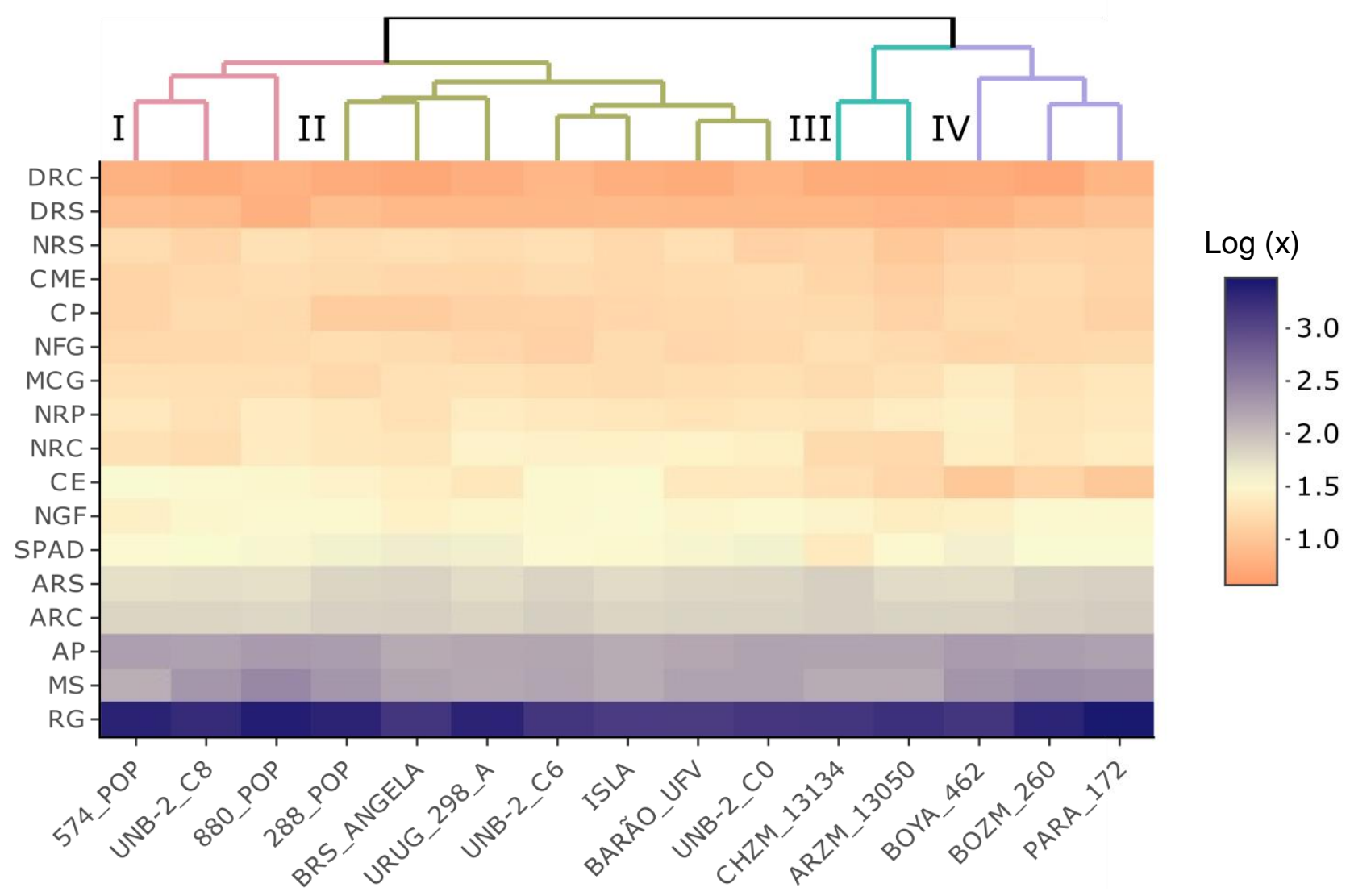

Figura 4. Heatmap da Distância Euclidiana Média, pelo método UPGMA, entre 15 variedades de polinização aberta de milho-pipoca com base nas médias dos caracteres morfoagronômicos, fisiológicos e radiculares em condições de irrigação plena (WW) em escala logarítmica. SPAD: Teor relativo de clorofila; AP: Altura de planta $(\mathrm{cm})$; CP: comprimento do pendão $(\mathrm{cm})$; NRP: número de ramificações do pendão; CME: comprimento médio de espiga (cm); NFG: número de fileiras de grãos (un); NGF: Número de grãos por fileira (un); MCG: massa de cem grãos (g); RG: Rendimento de grãos $\left(\mathrm{kg} \cdot \mathrm{ha}^{-1}\right)$; CE: capacidade de expansão (g. $\left.\mathrm{mL}^{-1}\right)$; MS: Matéria seca da parte aérea $(\mathrm{g})$; ARS: ângulo de raiz de suporte; ARC: ângulo de raiz da coroa; NRS: número de raízes de suporte; NRC: número de raízes da coroa; e DRC: densidade de raiz da coroa. Fonte: Os Autores. 


\section{Considerações finais}

Existe variabilidade genética entre as 15 variedades de polinização aberta avaliadas para os caracteres agronômicos, morfofisiológicos e radiculares nos ambientes com déficit hídrico (WS) e com oferta de água (WW), revelando diversidade na coleção de germoplasma da UENF, de interesse para a obtenção de genótipos superiores para tolerância à seca e, ou eficiência no uso da água.

O genótipo 880POP se destaca para a condição de limitação hídrica tanto para RG quanto para CE, tornando-se promissor para o avanço do programa de melhoramento de milho-pipoca.

Sugere-se a formação de composto constituído por 574POP, 880POP, BOZM260 e ISLA, para a extração de linhagens e obtenção de híbridos e, ou implantação de programa de seleção recorrente intrapopulacional.

\section{Agradecimentos}

À Universidade Estadual do Norte Fluminense Darcy Ribeiro pelo conhecimento adquirido e aporte físico. Ao Instituto Federal do Espírito Santo - Campus de Alegre pelo empréstimo dos equipamentos. À Coordenação de Aperfeiçoamento de Pessoal de Nível Superior (CAPES - Código de Financiamento 001) e à Fundação de Amparo à Pesquisa do Estado do Rio de Janeiro (FAPERJ) pelo aporte financeiro.

\section{Referências}

ACI, M. M.; LUPINI, A., MAUCERI, A.; MORSLI, A.; KHELIF, L.; SUNSERI, F. Genetic variation and structure of maize populations from Saoura and Gourara oasis in Algerian Sahara. BMC Genetics, v. 19, n. 51, p. 1-10, 2018.

AGÊNCIA NACIONAL DE ÁGUAS - ANA. Atlas irrigação: uso da água na agricultura irrigada. Agência Nacional de Águas: Brasília, Brasil, 2017. 86 p.

AGUIAR, C. G.; SCHUSTER, I.; AMARAL JÚNIOR, A. T.; SCAPIM, C. A.; VIEIRA, E. S. N. Heterotic groups in tropical maize germplasm by test crosses and simple sequence repeat markers. Genetics and Molecular Research, v. 7, n. 4, p. 1233-1244, 2008.

ALI, F.; AHSAN, M.; ALI, Q.; KANWAL, N. Phenotypic stability of Zea mays grain yield and its attributing traits under drought stress. Frontiers and Plant Science, v. 8, p. 1397, 2017.

ALMEIDA, G. D.; NAIR, S.; BORÉM, A.; CAIRNS, J.; TRACHSEL, S.; RIBAUT, J. M.; BÄNZIGER, M.; PRASANNA, B. M.; CROSSA, J.; BABU, R. Molecular mapping across three 
populations reveals a QTL hotspot region on chromosome 3 for secondary traits associated with drought tolerance in tropical maize. Molecular Breeding, v. 34, p. 701-715, 2014.

AVRAMOVA, V.; NAGEL, K. A.; ABDELGAWAD, H.; BUSTOS, D.; DUPLESSIS, M.; FIORANI, F.; BEEMSTER, G. T. S. Screening for drought tolerance of maize hybrids by multi-scale analysis of root and shoot traits at the seedling stage. Journal of Experimental Botany, v. 67, p. 2453-2466, 2016.

AVRAMOVA, V.; ABDELGAWAD, H.; ZHANG, Z.F.; FOTSCHKI, B.; CASADEVALL, R.; VERGAUWEN, L.; KNAPEN, D.; TALEISNIK, E.; GUISEZ, Y.; ASARD, H.; BEEMSTER, G.T.S. Drought induces distinct growth response, protection, and recovery mechanisms in the maize leaf growth zone. Plant Physiology, v. 169, p. 1382-1396, 2015.

BECHOUX, N.; BERNIER, G.; LEJEUNE, P. Environmental effects on the early stages of tassel morphogenesis in maize (Zea mays L.). Plant, Cell \& Environmental, v. 23, p. 91-98, 2000.

BOLAÑOS, J.; EDMEADES, G. O. Eight cycles of selection for drought tolerance in tropical maize: Responses in grain yield, biomass, and radiation utilization. Field Crops Research, v. 31, p. 233-252, 1993.

CARGNELUTTI FILHO, A.; RIBEIRO, N. D.; REIS, R. C. P.; SOUZA, J. R.; JOST, E. Comparação de métodos de agrupamento para o estudo da divergência genética em cultivares de feijão. Ciência Rural, v. 38, n. 8, p. 2138-2145, 2008.

CAVERZAN, A.; CASASSOLA, A.; BRAMMER, S. P. Antioxidant responses of wheat plants under stress. Genetics and Molecular Biology, v. 39, n. 1, p. 1-6, 2016.

CHALLINOR, A. J.; KOEHLER, A. K.; RAMIREZ-VILLEGAS, J.; WHITFIELD, S.; DAS, B. Current warming will reduce yields unless maize breeding and seed systems adapt immediately. Nature Climate Change, v. 6, p. 954-958, 2016.

CRUZ, C. D. GENES - a software package for analysis in experimental statistics and quantitative genetics. Acta Scientiarum.Agronomy, v. 35, p. 271-276, 2003.

CRUZ, C. D., CARNEIRO, P. C. S., REGAZZI, A. J. Modelos biométricos aplicados ao melhoramento genético. Viçosa: UFV, 2012. 668p.

DALAL, M.; SHARMA, T. R. Biotechnological Applications for Improvement of Drought Tolerance. In: Abiotic Stress Management for Resilient Agriculture; Springer: Singapore, 2017. p. 299-312.

DARYANTO, S.; WANG, L.; JACINTHE, P. A. Global synthesis of drought effects on maize and wheat production. PLoS ONE, v. 11, n. 5, p. 1-15, 2016.

DEJONGE, K. C.; TAGHVAEIAN, S.; TROUT, T. J.; COMAS, L. H. Comparison of canopy temperature based water stress indices for maize. Agricultural Water Management, v. 156, p. 51-62, 2015.

DIAS, K. O. G.; GEZAN, S. A.; GUIMARÃES, C. T.; et al. Improving accuracies of genomic predictions for drought tolerance in maize by joint modeling of additive and dominance effects in multi-environment trials. Heredity, v. 121, p. 24-37, 2018. 
DURÃES, F. O. M.; SANTOS, M. X.; GAMA, E. E. G.; MAGALHÃES, P. C.; ALBUQUERQUE, P. E. P.; GUIMARÃES, C. T. Fenotipagem associada a tolerância à seca em milho para uso em melhoramento, estudos genômicos e seleção assistida por marcadores. Embrapa Milho e Sorgo: Sete Lagoas, 2004. 17p.

EL-SABAGH, A.; HOSSAIN, A. K.; BARUTÇULAR, C.; et al. Sustainable maize (Zea mays L.) production under drought stress by understanding its adverse effect, survival mechanism and drought tolerance indices. Journal of Experimental Biology and Agricultural Sciences, v. 6, n. 2, p. 282-295, 2018.

FRANCO, J.; CROSSA, J.; RIBAUT, J. M.; BETRAN, J.; WARBURTON, M. L.; KHAIRALLAH, M. A method for combining molecular markers and phenotypic attributes for classifying plant genotypes. Theoretical and Applied Genetics, v. 103, p. 944-952, 2011.

GAO, Y.; LYNCH, J. P. Reduced crown root number improves water acquisition under water deficit stress in maize (Zea mays L.). Journal of Experimental Botany, v. 67, n. 15, p. 4545-4557, 2016.

HOCHHOLDINGER, F.; WOLL, K.; SAUER, M.; DEMBINSKY, D. Genetic dissection of root formation in maize (Zea mays) reveals root-type specific developmental programmers. Annals of Botany, v. 93, p. 359-368, 2004.

HUNTER, R. B.; DAYNARD, P. B.; HUME, D. J.; TANNER, J. W.; CURTIS, J. D.; KANNENBURG, L. W. Effect of tassel removal on grain yield of corn (Zea mays). Crop Scence, v. 9, p. 405-406, 1989.

IGNJATOVIC-MICIC, D.; RISTIC, D.; BABIC, V.; ANDJELKOVIC, V.; VANCETOVIC, J. A simple SSR analysis for genetic diversity estimation of maize landraces. Genetika, v. 47, p. 53-62, 2015.

IPCC. SUMMARY FOR POLICYMAKERS. In: Climate Change 2013: The Physical Science Basis. Contribution of working Group I to the fifth assessment report of the intergovernmental panel on climate change. STOCKER., T.F.D.; QIN, G.-K.; PLATTNER, M.; TIGNOR, S. K.; ALLEN, J.; BOSCHUNG, A.; NAUELS, Y.; XIA, V.; BEX P.M. M. (Eds.). Cambridge University Press, Cambridge, United Kingdom and New York, NY, USA, 2013.

JIANG, P.; CAI, F.; ZHAO, Z. Q.; MENG, Y.; GAO, L. Y.; ZHAO, T. H. Physiological and dry matter characteristics of spring maize in northeast China under drought stress. Water, v. 10, n. 11, p. 1561, 2018.

KAMPHORST, S. H.; LIMA, V. J.; AMARAL JÚNIOR, A. T.; SCHIMITT, K. F. M.; LEITE, J. T.; CARVALHO, C. M.; SILVA, R. R. M.; XAVIER, K. B.; FERREIRA, F. R. A.; SANTOS, P. H. A. D.; CAMPOSTRINI, E. Popcorn breeding for water-stress tolerance or for agronomic water-use efficiency? Genetics and Molecular Research, v. 17, n. 4, p. 1-18, 2018 a.

KAMPHORST, S.H.; DE LIMA, V.J.; SCHIMITT, K.F.M.; LEITE, J.T.; AZEREDO, V.C.; PENA, G.F.; SANTOS, P.H.D.; SANTOS JÚNIOR, D.R.; SILVA JÚNIOR, S.B DA.; BISPO, R.B.; SANTOS, T.O.; KHAN, S.; AMARAL JÚNIOR, A.T. Water stress adaptation of popcorn roots and association with agronomic traits. Genetics and Molecular Research, v. 17, n. 3, p. 1-14, 2018b.

KIST, B.B. Anuário brasileiro do milho. Santa Cruz: Editora Gazeta , Brasil, 2019. 72p. 
KONDWAKWENDA, A.; SIBIYA, J.; ZENGENI, R.; MUSVOSVI, C.; TESFAY, S. Screening of provitamin-A maize inbred lines for drought tolerance: beta-carotene content and secondary traits. Agronomy, v. 9, n. 692, p. 1-17, 2019.

LARISH, L. B.; BREWBAKER, J. L. Diallel analyses of temperate and tropical popcorn, Maydica, v. 44, p. 279-284, 1999.

LAXA, M.; LIEBTHAL, M.; TELMAN, W.; CHIBANI, K.; DIETZ, K. The role of the plant antioxidant system in drought tolerance. Antioxidants, v. 8, n. 4, p. 94, 2019.

LI, C.; SUN, B.; LI, Y.; LIU, C.; WU, X.; ZHANG, D.; SHI, Y.; SONG, Y.; BUCKLER, E. S.; ZHANG, Z.; WANG, T.; LI, Y. Numerous genetic loci identified for drought tolerance in the maize nested association mapping populations. BMC Genomics, v. 17, n. 894, p. 2-11, 2016.

LIMA, V. J.; AMARAL JÚNIOR, A. T.; KAMPHORST, S. H.; BISPO, R. B.; LEITE, J. T.; SANTOS, T. O.; SCHMITT, K. F. M.; CHAVES, M. M.; OLIVEIRA, U. A.; SANTOS, P. H. A. D.; GONÇALVES, G. M. B.; KHAN, S.; GUIMARÃES, L. J. M. Combined dominance and additive gene effects in trait inheritance of drought-stressed and full irrigated popcorn. Agronomy, v. 9, n. 782, p. 1-17, 2019.

LYNCH, J. P. Steep, cheap and deep: an ideotype to optimize water and $\mathrm{N}$ acquisition by maize root systems. Annals of Botany, v. 112, p. 347-357, 2013.

MAGETO, E. K.; MAKUMBI, D.; NJOROGW, K.; NYANKANGA, R. Genetic analysis of earlymaturing maize (Zea mays L.) inbred lines under stress and nonstress conditions. Journal of Crop Improvement, v. 31, p. 560-588, 2017.

MARTINS, E. S.; DAVIDE, L. M. C.; MIRANDA, G. J.; BARIZON, J. O.; SOUZA JUNIOR, F. A.; CARVALHO, R. P.; GONÇALVES, M. C. In vitro pollen viability of maize cultivars at different times of collection. Ciência Rural, v. 47, n. 2, p. 2-8, 2017.

MICKELSON, S. M.; STUBER, C. S.; SENIOR, L.; KAEPPLER, S. M. Quantitative trait loci controlling leaf and tassel traits in a B73 $\times$ Mo17 population of maize. Crop Science, v. 42, p. 1902-1989, 2002.

MONNEVEUX, P.; SANCHEZ, C.; BECK, D.; EDMEADES, G.O. Drought tolerance improvement in tropical maize source populations: evidence of progress. Crop Science, v. 46, p. 180-191, 2006.

OLIVEIRA, E. J.; AIDAR, S. T.; MNORGANTE, C. V.; CHAVES, A. R. M.; CRUZ, J. L.; COELHO FILHO, M. A. Genetic parameters for drought-tolerance in cassava. Pesquisa Agropecuária Brasileira, v. 50, n. 3, p. 233-241, 2015.

PEREIRA, M. G.; AMARAL JÚNIOR, A. T. Estimation of genetic components in popcorn based on the nested design. Crop Breeding and Applied Biotechnology, v. 1, n. 1, p. 310, 2001.

R CORE TEAM. R: a language and environment for statistical computing, 2020.

TRACHSEL, S.; KAEPPLER, S. M.; BROWN, K. M.; LYNCH, J. P. Shovelomics: high throughput phenotyping of maize (Zea mays L.) root architecture in the field. Plant and Soil, v. 341 , v. 12 , p. $75-87,2011$. 
XAVIER, K. B.; KAMPHORST, S. H.; CARVALHO, C. M.; SILVA, R. M. R.; SILVA JÚNIOR, S. B.; DE LIMA, V. J. Comércio de milho-pipoca no Norte Fluminense e características apreciadas no produto. Revista de Extensão UENF, v. 3, n. 1, p. 22-35, 2019.

YU, P.; WHITE, P. J.; HOCHHOLDINGER, F.; LI, C. Phenotypic plasticity of the maize root system in response to heterogeneous nitrogen availability. Planta, v. 240, p. 667-678, 2014. 


\title{
Capítulo 10
}

\section{Produção sustentável da cultura da banana: estratégias de manejo alternativo da broca-do-rizoma Cosmopolites sordidus (Germar) (Coleoptera: Curculionidae)}

\author{
Alciro Lamao Lazzarini ${ }^{1}$, José Salazar Zanuncio Junior ${ }^{2}$, Rogério Carvalho Guarçoni ${ }^{2}$ \\ Lorenzo Montovaneli Lazzarini ${ }^{3}$, Claudio Martins de Almeida ${ }^{3}$, Maurício José Fornazier ${ }^{2}$, \\ Andréa Ferreira da Costa ${ }^{4}$
}

\section{Introdução}

O avanço tecnológico atingiu o espaço agrário do Brasil na produção agrícola com os crescentes processos industriais no campo na segunda metade do século $X X$, a partir da década de 60. Desde o fortalecimento do processo de modernização das atividades agrícolas ocorrido no final da década de 1990, se tornou intenso com base no paradigma da Revolução Verde que constitui o conjunto de esforços realizados para incrementar a produção agrícola no mundo através de novas variedades e uso de técnicas agrícolas modernas como fertilizantes, agrotóxicos e irrigação, com a intenção de aumentar a produção e a produtividade (NAVARRO, 2001).

O uso de tecnologias no campo sem ter como base a proteção ao ambiente tem, rotineiramente, trazido inúmeros reflexos negativos. São nítidos os problemas socioambientais oriundos da simplificação e artificialização dos agroecosistemas. Dentre os aspectos que merecem destaque estão a erosão do solo, a poluição por agrotóxicos e, em muitos casos, a perda de agrobiodiversidade local, resultados estes contrários a práticas sistêmicas defendidas pela agroecologia (CAPORAL, 2003).

\footnotetext{
${ }^{1}$ Me. em Agroecologia pelo Programa de Pós-Graduação em Agroecologia do Instituto Federal do Espírito Santo - Campus de Alegre, Coordenador do CRDR Litoral Sul do Instituto Capixaba de Pesquisa Assistência Técnica e Extensão Rural Fazenda Experimental do Incaper, CEP 29240-000, Alfredo Chaves - ES. Email: lazzarinial@incaper.es.gov.br

${ }^{2}$ Drs. Pesquisadores do Centro de Pesquisa e Desenvolvimento Incaper Espírito Santo - Fazenda do Estado, Rodovia BR 262, CEP: 29000-000, Domingos Martins - ES. E-mail: jose.zanuncio@incaper.es.gov.br; rogerio.guarconi@incaper.es.gov.br; mauriciofornazier@gmail.com ${ }^{4}$ Graduando em Agronomia pela Universidade Estadual do Norte Fluminense Darcy Ribeiro, CEP: 28013-602, Campos dos Goytacazes-RJ. E-mail: I.lazzarini14@gmail.com; claudio@pq.uenf.br ${ }^{4}$ Dra. Pesquisadora do Centro de Pesquisa e Desenvolvimento Incaper Espírito Santo - Fazenda do Estado, Rodovia BR 262, CEP: 29000-000, Domingos Martins - ES. E-mail: andrea.costa.uenf@gmail.com
} 
A agroecologia, como ciência num enfoque sistêmico, vem sendo construída a partir da atual matriz tecnológica e da forma de organização da produção na agricultura. Esta crise se mostra sob múltiplas dimensões da atividade humana e sua superação é dependente da produção de novos conhecimentos (CAPORAL e COSTABEBER, 2000).

Uma das principais dificuldades da agricultura sustentável diz respeito ao controle de pragas e doenças. Antes da difusão dos agrotóxicos, os agricultores usavam recursos oferecidos pela natureza, encontrando condições de sobrevivência e melhor adaptação ao meio em que vivem (EMBRAPA MEIO AMBIENTE, 2015). A agroecologia, compreendida como um conjunto de conhecimentos, vem contribuir tanto para a realização de análises críticas sobre a agricultura produtivista como para orientar o correto redesenho e o manejo de agroecossistemas, buscando a sustentabilidade dos sistemas produtivos (CAPORAL e COSTABEBER, 2004).

Nesse contexto, é de extrema importância estudar métodos alternativos de controle de pragas, que sejam eficientes, que produzam alimentos nutritivos e saudáveis, com menor impacto ao meio ambiente, trazendo maior autonomia para os agricultores e atendendo as demandas crescentes dos consumidores por produtos mais saudáveis e com menos resíduos de agrotóxicos (DALZOTO e UHR, 2009).

O novo consumidor, cada vez mais preocupado com questões socioambientais acabou por modificar o mercado, que passou a ser exigido na adoção em seus sistemas de produção premissas de sustentabilidade socioambiental em relação às questões sociais do trabalho e uso de tecnologias com reduzido impacto ao meio ambiente e à saúde (MOURA et al., 2015). Visando esse mercado, a banana, uma das frutas que possuem grande importância socioeconômica para região produtora do Espírito Santo, pode ser beneficiada pois, com uma área plantada de 28.191 hectares e produção de 408.740 toneladas, é responsável pela geração de 17.000 empregos e renda para uma maioria de agricultores de base familiar envolvidos nos processos de produção e comercialização com 30.000 postos de trabalho. (IBGE/LSPA, 2019). No entanto, a cultura da banana vem apresentando problemas de resíduo de agroquímicos, com elevado percentual de resíduos de agrotóxicos não autorizados sendo o maior quantitativo de amostras insatisfatórias identificadas nas análises de resíduos (ANVISA, 2016).

Com a finalidade de evitar o uso de agrotóxicos não registrados e disponibilizar alternativas aos agricultores, muitas pesquisas têm realizado estudos de bioinsumos como alternativa ao controle de pragas, doenças e plantas daninhas, como óleos essenciais, extratos vegetais, urina de vaca, soro de leite, bactérias, vírus e fungos entomopatogênicos (BATISTA FILHO et al., 2016). 
Observa-se um grande número de trabalhos sobre o estudo de óleos essenciais que apresentam comprovada atividade fungicida, inseticida e controle de plantas espontâneas. Podendo citar como exemplos os óleos essências de Capim limão (Cymbopogom citratus), Pimenta de macaco (Piper aduncum L.), Eucalipto comum (Eucaliptus globulus Labill), Copaíba (Copaifera sp.) e de frutos de anis-estrelado (Illicium verum L.) para controle de insetos (LIMA et al., 2008; SANTANA et. al, 2015; MELO et al., 2015).

\section{A cultura da banana no Espírito Santo}

Após anos de elevada produção e valor de comercialização, o café atravessou um período de crise no Brasil na década de 1960, provocada pelo excedente na produção e da qualidade do produto, que resultou na redução da área plantada de café. Diversificar a produção agrícola foi uma alternativa encontrada pelos pequenos produtores capixabas em meio a essa crise. Foi nessa época, que as regiões centro-sul, centro-serrana e sul do Espírito Santo iniciaram os primeiros plantios da bananeira. A atividade foi promissora nos municípios que apresentavam solos férteis e condições hídricas favoráveis, como Cariacica, Viana, Alfredo Chaves, Iconha, Rio Novo do Sul, Santa Leopoldina e Domingos Martins. Era uma alternativa que surgia e o mercado consumidor se mostrou promissor, principalmente no Rio de Janeiro (SILVA e VENTURA, 2016).

A introdução da cultura da banana prata no Município de Alfredo Chaves, teve início no ano de 1968, onde até então, as principais fontes de renda das famílias vinham da cafeicultura e da agricultura de subsistência. Com a redução da área de cafés arábica bourbon, houve a introdução dessa fruta a nível comercial no estado do Espírito Santo. Cerca de $80 \%$ da população vivia no campo, a maioria de agricultores de base familiar (IBGE, 1975). Para o atendimento do consumo familiar e alimentação animal, a banana prata comum já era explorada de forma tradicional na região, apresentando de 20 a 30 rebentos por touceira, pois não haviam técnicas de condução. Essas touceiras encontravam-se nas encostas "grotas", que tinham condições de clima mais favorável ao desenvolvimento dessa cultura.

No final da década de 60, um agricultor da região de Quarto Território Sr. Osvaldo Magnago reuniu-se com outros cinco agricultores, os senhores Antonio Rigotti, Angelo Bertholde, Ademar Bertholde, Jair Partelli e João Partelli, e juntos fizeram a primeira carga de banana para comercialização no Rio de Janeiro. As bananas foram transportadas em cachos no caminhão modelo Mercedes Bens 1111 de propriedade do Sr. Osvaldo Magnago. O mercado consumidor se mostrou promissor e assim começou a expandir o cultivo da banana na região de Quarto Território e adjacência, depois seguida pelos municípios de Iconha, Anchieta, 
Guarapari, Cariacica, Viana e Rio Novo do Sul que iniciaram os primeiros plantios comerciais de banana prata.

Com a alta demanda do produto e a expansão da cultura, a Associação de Credito e Assistência Técnica Rural do Espírito Santo ACARES, no início dos anos 70, iniciou um trabalho de pesquisa em novas variedades e tecnologia de espaçamento, desbrota, desfolha, calagem e adubação dos bananais.

O cultivo da banana prata no Estado teve o seu auge no final da década de 80 quando foi responsável pela exportação de $75 \%$ da demanda do Estado do Rio de Janeiro além de ocupar posição de destaque no fornecimento do produto para Minas Gerais e Distrito Federal. Entretanto, em razão da suscetibilidade às doenças, à baixa produtividade, qualidade e a frágil estrutura de comercialização, ocorreu um desestímulo da atividade agravada com a expansão da cultura na Região Norte do Estado de Minas Gerais, no Vale do Jaíba, que passou a ofertar banana com padrão superior dominando no mercado do Rio de Janeiro, Minas Gerais e Distrito Federal. A participação de outros estados que produzem a banana na cadeia produtiva da banana 'Prata' acarretou em uma concorrência acirrada com impactos negativos na estrutura produtiva, econômica e social das regiões tradicionalmente produtoras no Estado do Espírito Santo (COSTA et al., 2006).

Atualmente, sabe-se que o Brasil é o quarto maior produtor mundial de banana, sendo superado pela Índia, China e a Indonésia, que possuem os postos de primeiro, segundo e terceiro maiores produtores globais desta cultura, respectivamente. Estes quatro países foram os responsáveis pela metade de produção mundial de banana em 2017 (FAO, 2017).

\section{Origem e classificação botânica}

O centro de origem da maioria das cultivares de banana é o continente asiático, apesar de serem reconhecidos também outros centros de origem secundários na África e Ilhas do Pacífico (NELSON et al., 2006).

Segundo Moura et al. (2015) é provável que em época anterior à expansão de seu cultivo, as bananeiras tenham sido distribuídas da Malásia para as orlas ocidentais do Pacífico, chegando à ilha de Madagascar, de onde comerciantes árabes a teriam espalhado até as costas ocidentais. Sua chegada ao continente americano teria se dado em São Domingos, em 1516, procedente das Ilhas Canárias, para onde teria sido levada por navegadores portugueses. A banana foi constatada no Brasil desde 1500, havendo relatos sobre uma bananeira nativa denominada pelos indígenas de "pacoba". 
A bananeira produtora de frutos comerciais, segundo a sistemática botânica de classificação hierárquica pertence à classe das Monocotyledoneae, ordem Scitaminales, família Musaceae, subfamília Musoideae, gênero Musa (ALVES, 1999).

A banana comestível originou-se a partir de dois progenitores diplóides selvagens, a Musa acuminata Colla e Musa balbisiana Colla, podendo conter combinações variadas de genomas destas espécies, denominados pelas letras $A(M$. acuminata) e B ( $M$. balbisiana), cujas combinações resultam em grupos diplóides ( $A A, B B$ e $A B$ ), triplóides ( $A A A, A A B$ e $A B B$ ) e tetraplóides (AAAA, AAAB, AABB, ABBB) (FIGUEIREDO e BRIOSO, 2007).

\section{Importância socioeconômica da banana}

A banana destaca-se como a principal fruteira tropical, e é uma das frutas mais consumidas mundialmente devido suas características alimentares, como sabor, atrativos nutricionais de estímulo ao seu consumo, pois é rica em vitaminas $\mathrm{A}$ e $\mathrm{C}$, fibras e potássio, carboidratos, além de conter pouco sódio (GHAG e GANAPATHI, 2018).

Um único fruto de banana é capaz de suprir, segundo Alves (1999), 25\% da quantidade total de vitamina $\mathrm{C}$ recomendada diariamente para crianças, além de conter niacina, riboflavina e tiamina.

A bananicultura é explorada em quase todo o território nacional, permitindo o desenvolvimento econômico e a inclusão social das localidades ligadas ao seu cultivo. Atualmente mais de 125 países dedicam-se ao cultivo da bananeira, incluindo diferentes continentes como a Ásia, as Américas e a África, que produzem 55,8\%, 24,7\% e 17,9\% respectivamente da produção de banana no mundo (FAO, 2018).

Em 20 anos, aumentou em aproximadamente duas vezes o volume mundial de banana produzida, saindo de 47,10 milhões de toneladas na safra 1990 para 105,50 milhões de toneladas na safra 2010. Na safra 2011 houve um crescimento de 1,6\% no volume de frutas produzidas em comparação com a safra passada, resultado decorrente da expansão nas áreas de plantio e ganho de produtividade (FAO, 2014).

Os países com as maiores produções são a Índia responsável por 29,1\% da produção, seguida pela China, com 9,6\%; Filipinas, com 8,9\%; Equador, com 7,7\% e Brasil, com 6,8\%. Entretanto, os maiores produtores não possuem as maiores produtividades, que são

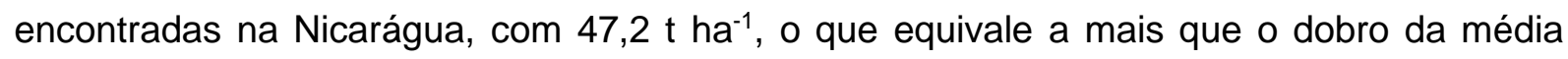
mundial, que é de 20,3 t ha-1 (FAO, 2014).

No Brasil, a área colhida em 2019 foi de 457,7 mil hectares, com produção de aproximadamente $7.113,6 \mathrm{t}$ de cachos, atingindo produtividade média de $15,5 \mathrm{t} \mathrm{ha}^{1}$ (LEVANTAMENTO SISTEMÁTICO DE PRODUÇÃO AGRÍCOLA, 2019). 
Apesar de não ser nativa do Brasil, a produção de banana se dá em todos os Estados brasileiros. O Estado da Bahia, com 1.004 .000 t, lidera o ranking de produção seguido por São Paulo (985.332 t), Minas Gerais (772.845 t), Santa Catarina (708.000 t) e Pará (519.348 t). Pernambuco ocupa a sexta posição com uma produção anual de 393.215 toneladas e rendimento de 10,324 t/ha (IBGE, 2017).

O Espirito Santo é o $7^{\circ}$ maior produtor de banana no país. Desenvolveu um agronegócio expressivo e marcado pela agricultura familiar, com uma área plantada de 28.191 hectares, com produção de 392 toneladas, sendo responsável pela geração de 17.000 empregos diretos e 30.000 postos de trabalho, envolvidos nos processos de produção e comercialização (IBGE/LSPA, 2018).

Os principais municípios produtores são: Alfredo Chaves, Iconha, Guarapari, Anchieta, Rio Novo do Sul, Santa Leopoldina, Domingos Martins, Ibiraçú, Linhares, Fundão, Viana, Cariacica e Mimoso do Sul (IBGE, 2017). Predominando o cultivo de banana do subgrupo Prata, com aproximadamente $80 \%$ da área cultivada, seguida pela banana do subgrupo Terra ('Terra' e 'Terrinha'), com 15\% e pela banana do subgrupo Cavendish ('Nanicão', 'Grande Naine' e 'Nanica'), com 5\% (VENTURA e GOMES, 2005).

\section{Problemas fitossanitários}

As doenças da cultura da banana descritas como de ocorrência no Brasil até o período da colheita são as seguintes: Sigatoka-amarela (Mycosphaerella musicola). Sigatoka-negra (Mycosphaerella fijiensis), mancha de cordana (Neocordana musae), mancha de cloridium (Cloridium musae), pinta de deightoniella (Deightoniella torulosa), mancha de cladosporium (Cladosporium musae), mal do panamá (Fusarium oxysporum $f$. sp. cubense, raças 1, 2 e 4, podridão-mole ou podridão de Erwinia (Erwinia musae), mosaico da bananeira (Cucumber mosaic virus - CMV), estrias da bananeira (Banana Streak Virus - BSV) (CORDEIRO et al., 2017).

Quanto as pragas, são descritos no Brasil a ocorrência dos seguintes insetos: Broca-dorizoma (Cosmopolites sordidus), tripes-da-erupção dos frutos (Frankliniella spp.), tripes-daferrugem dos frutos (Chaetanaphothrips spp., Caliothrips sp., Bradinothrips musae), lagartasdesfolhadoras (Caligo spp., Opsiphanes spp. e Antichloris spp.), lagartas-desfolhadoras (Brassolis sp.), broca-gigante (Castnia licus), ácaros-de-teia (Tetranychus spp.), traça-dabananeira (Opogona sacchari), abelha-arapuá (Trigona spinipes), gafanhotos (Chromacris speciosa; Tropidacris collaris), broca-rajada (Metamasius hemipterus) (CORDEIRO et al., 2017). 
Dentre os problemas fitossanitários, destaca-se mais recentemente, a esperança da banana Meroncidius intermedius (Orthoptera: Tettigoniidae) (ZANUNCIO-JUNIOR et al., 2017). O aumento no nível populacional das pragas, faz com que seja atingido nível de dano econômico, causando prejuízos ao agricultor.

\section{Broca do rizoma Cosmopolites sordidus (Germar, 1824) (Coleoptera: Curculionidae)}

A praga broca do rizoma, também conhecida como broca da bananeira ou moleque da bananeira foi descrita pela primeira vez em 1824 na Indo-Malásia, centro de origem da cultura da banana. No Brasil, sua primeira manifestação foi notificada no ano de 1885 (MESQUITA, 2003).

A broca do rizoma é uma das pragas chaves da cultura, considerada cosmopolita, pois encontra-se distribuída geograficamente em quase todos os países que produzem a banana (DANTAS et al., 2011). Quando a sua taxonomia, a broca do rizoma é classificada em: Reino Animalia, filo Arthopoda, classe insecta, ordem Coleoptera, família Curculionidae, gênero Cosmopolites e espécie Cosmopolites sordidus (Germar, 1824) (GALLO et al., 2002).

Não há espécies e variedades de bananeiras que se possa considerar verdadeiramente resistente ao ataque desta praga, mas há, contudo, diferenças consideráveis quanto a suscetibilidade ao ataque. No Brasil, foi observado que os cultivares "Maçã" e "Terra" são as mais atacadas que a "Prata", "Nanica" e "Nanicão" (BATISTA FILHO; TAKADA; CARVALHO, 2002).

\section{Prejuízos}

Os danos causados pelas larvas do C. sordidus se dá pela produção de galerias no interior do rizoma, deixando a planta vulnerável a organismos patogênicos, entre os quais se destaca o Fusarium oxysporum, f. cubense, responsável pela doença conhecida como "Mal do Panamá" (MESQUITA, 2003; ALVES, 2016).

Em muitos casos também afetando o pseudocaule. Dessa forma, as plantas diminuem a capacidade de absorção de água e nutrientes, consequentemente ficando mais susceptíveis a entrada de doenças e também se tornam mais vulneráveis aos ventos, principalmente quando as plantas estão em fase reprodutiva, devido ao peso dos cachos (BATISTA FILHO et al., 2002; MICHEREFF FILHO et al., 2010). Em algumas regiões, as altas populações de brocas encontradas nos bananais podem reduzir a produção em até $80 \%$ (BATISTA FILHO et al., 2016). 


\section{Monitoramento e métodos de controle}

O controle natural da broca do rizoma é grandemente favorecido pela diversidade do habitat no qual está inserido o cultivo da banana, favorecendo os inimigos naturais e reduzindo a população e os danos causados pela broca do rizoma (HASYIM et al., 2009). No entanto, na maioria dos cultivos, torna-se necessário utilizar método de controle da praga, sendo os principais métodos: químico, biológico, cultural e comportamental, sendo este último uma alternativa para reduzir os gastos e danos tóxicos ao meio ambiente.

Segundo Alves (2016), é preciso monitorar a população desse inseto no bananal antes de utilizar qualquer método de controle. Raga (2005) recomenda de 20 a 30 iscas por hectare para monitoramento da praga. As iscas utilizadas podem ser do tipo "telha" ou "queijo". A isca do tipo "telha" é confeccionada a partir de pedaços do pseudocaule, de aproximadamente 60 $\mathrm{cm}$, cortados novamente ao meio, no sentido longitudinal, sendo colocada a parte cortada voltada para o solo e próxima à touceira. A isca "queijo" é preparada através da secção transversal do pseudocaule a uma altura de 40 a $60 \mathrm{~cm}$ do solo, colocando-a próxima à touceira. O nível de controle se dá com a contagem de 5 adultos/isca/mês (FANCELLI et al., 2016). Um novo modelo de isca, chamada de isca tipo cunha, tem se destacado com maior atração para adultos da broca do rizoma, sendo recomendada no monitoramento (QUEIROZ et al, 2017), com potencial de uso na captura massal da broca do rizoma.

Dessa forma, quatro dos principais métodos alternativos de controle serão melhor explicados, que são: Método comportamental, Controle cultural e Controle biológico, além do uso de compostos extraídos de plantas com propriedades inseticidas que podem ser usados, isoladamente ou em conjunto com outros métodos de controle.

\section{Controle comportamental}

O desenvolvimento de novos métodos de manejo integrado de pragas se deve ao estudo comportamental dos insetos, principalmente o uso de feromônios, que têm se tornado uma forte ferramenta para implementar alternativas, como por exemplo monitoramento e controle de pragas (MOREIRA et al., 2005).

Para a utilização deste método de controle é necessário utilizar feromônios sintéticos em armadilhas para atrair e capturar este inseto (MESQUITA, 2003).

O propósito dessa armadilha no campo é reduzir a infestação da praga, já que é atraída até as armadilhas com os atrativos (feromônios) ao invés de procurar o pseudocaule ou rizoma das plantas (FIGUEIREDO et al., 2008). 
Contudo, os resultados obtidos até o momento são ainda insuficientes para se tirar conclusões sobre o efeito do controle comportamental na redução de danos no rizoma, aumento de vigor das plantas e da produção e melhoria da qualidade dos frutos obtidos (MESQUITA, 2003).

Para captura massal da broca do rizoma recomenda-se a utilização de 50 a 100 iscas/ha, sendo que as mesmas devem ser destruídas após a coleta (FANCELLI et al., 2015).

\section{Controle cultural}

O controle cultural tem sido amplamente recomendado, principalmente por evitar a infestação em lavouras recém instaladas. A utilização das mudas deve ser de lavouras idôneas de modo a evitar o contato com outras para evitar a infestação, já que a parte que foi cortada, são atrativos para a pragas. Também verificar a existência de mudas broqueadas durante o preparo das mudas, e eliminar as mesmas. Existem mudas produzidas por meio de cultura de tecidos, que conferem maior segurança fitossanitária (FANCELLI e MESQUITA, 2000).

Para controle da broca da banana, opções de manejo de habitat incluem o uso de material de plantio limpo, seleção de sistemas de cultivo, melhores práticas agronômicas para promover o vigor da planta, manejo de resíduos da colheita (ou seja, saneamento) e armadilhas (GOLD et al., 2001). Outras medidas de controle também são adotadas como por exemplo utilização de irrigações nos períodos seco; eliminar restos culturais das plantas, cortando em pedaços menores os pseudocaules, e espalhar ente as fileiras. (VENTURA e GOMES, 2005).

\section{Controle biológico}

Gravena (1992), define controle biológico como uma ação de inimigos naturais sobre uma população de pragas, a fim de equilibrar essa população. A utilização do fungo B. bassiana, como agente biológico de controle da praga, apresentou boas perspectivas de aplicação prática (PRANDO, 2006; FANCELLI et al., 2015). Em laboratório, os níveis de controle atingiram $100 \%$ de eficiência e, em campo, chegou a alcançar níveis de até $40 \%$ de mortalidade dos adultos, através da suspensão do inóculo pulverizado ou pincelado $(20 \mathrm{~g}$ de Boveril/isca) sobre iscas tipo telha ou queijo (MESQUITA, 2003).

Tinzaara et al. (2007) acrescentaram que o uso dos fungos entomopatogênicos, como $B$. bassiana que infectam larvas e adultos de coleópteros têm apresentado resultados positivos, desde que utilizados juntamente com armadilhas de feromônio. 
Aplicações de inseticidas orgânicos naturais, como extrato de neem, ou biológicos como nematóides em alta densidade de iscas, têm ocasionado reduções nas populações do besouro, todavia as altas taxas de aplicação têm encarecido muito esta técnica (ALPÍZAR et al., 2012). Inseticidas botânicos a base de neem tem mostrado ação inseticida e pode ser usado no controle da broca do rizoma da bananeira (SAHAYARAJ e KOMBIAH, 2010).

\section{Compostos naturais com propriedades inseticidas sobre a broca do rizoma da banana}

A torta de mamona pode representar uma alternativa interessante para fertilização e também para manejo da broca-do-rizoma, pois não deixa resíduos tóxicos nos frutos, além de apresentar propriedades fertilizantes e nematicidas (FERMINO e KAMPF, 2003). Lins et al. (2013) observaram que houve tendência de aumento do número de adultos mortos com o aumento da dose de torta de mamona, assim como o número de larvas e pupas, com tendência de redução no número de larvas na medida em que se aumentou a dosagem da torta de mamona aplicada. Assim, a aplicação da torta de mamona proporcionou redução das galerias feitas pelas larvas, na medida em que se aumentou a dosagem fornecida da torta de mamona, e resultante do aumento da mortalidade dos insetos e consequente redução de sua progênie (LINS et al., 2013).

Estudos de compostos oriundos de plantas com propriedades inseticidas tem surgido como alternativa no manejo de pragas, mostrando seu potencial no manejo integrado de broca do rizoma, com destaque para o gênero Piper, reduzindo a viabilidade de ovos e causando repelência em adultos da broca do rizoma (BAKAZE et al., 2020). Com relação a espécie de Piper aduncum, o óleo essencial extraído de folhas e ramos mostrou ação inseticida sobre a formiga lava-pé Solenopsis saevissima (Hymenoptera: Formicidae) e o pulgão do morango Cerosipha forbesi (Hemiptera: Aphididae) (SANTOS, 2018).

Trabalho realizado por Lazzarini (2020), investigando a propriedade inseticida do óleo essencial da pimenta de macado Piper aduncum, mostrou ação inseticida sobre a broca do rizoma em bananeiras, constatando-se diferenças na mortalidade das brocas do rizoma em relação ao tempo de ação do óleo com ambos os emulsificantes Polissorbato Tween80® e detergente neutro. Observou-se que o óleo essencial de $P$. aduncum diluídas em detergente neutro, apresentou ação inseticida sobre a broca do rizoma, ocorrendo mortalidade em menor tempo de ação quando comparadas as diluições com Polissorbato. O tratamento controle, que utilizou apenas água destilada e detergente, nas mesmas quantidades utilizadas nos demais tratamentos, não apresentou mortalidade das brocas do rizoma. As concentrações letais do óleo essencial de pimenta de macaco $\left(\mathrm{CL}_{50}\right.$ e $\left.\mathrm{CL}_{90}\right)$ utilizando o polissorbatoTween $80 \AA \mathrm{e}$ 
detergente neutro como emulsificantes foram, respectivamente, 9,29/59,42 e 7,66/28,53 $\mathrm{mL} / \mathrm{L}$, sendo a concentração letal estimada para ocasionar mortalidade de $50 \%$ dos indivíduos (CL 50) considerada satisfatória, apresentando potencial para o manejo da broca da bananeira em sistemas agroecológicos.

\section{Considerações finais}

A banana é uma das culturas de maior importância sócio-econômica para o Brasil, uma vez que seu cultivo está associado a agricultura familiar. O maior desafio na sua produção é o manejo fitossanitário, incluindo a broca do rizoma como a principal praga associada a cultura, causando grandes perdas. A principal forma de controle desta praga é o método químico, sendo muitas vezes utilizado inseticidas não registrados para a cultura, causando problemas de inconformidades nos programas de análise de resíduos. Assim, o desenvolvimento de estratégias de manejo, como o controle biológico, o uso de plantas com propriedades inseticidas e armadilhas despontam como alternativas ao uso do método químico, mostrando eficiência compatível, sem problemas de contaminação e sem restrição de uso, sendo recomendados, inclusive na produção orgânica. Dentre estes métodos, o controle biológico com o fungo entomopatogênico Beauveria bassiana, nematoides e compostos de plantas com atividade inseticida despontam como mais promissores no manejo da broca do rizoma, visando a produção da banana em sistemas agroecológicos.

\section{Referências}

ALPÍZAR, D.; FALLAS, M.; OEHLSCHLAGER, A. C.; GONZALEZ, L. M. Management of Cosmopolites sordidus and Metamasius hemipterus in banana by pheromone-based mass trapping. Journal of Chemical Ecology, v. 38, n. 4, p. 245-252, 2012.

ALVES, E. J. (Org.). A cultura da banana: aspectos técnicos, sócio-econômicos e agroindustriais. 2. ed. rev. Brasília DF: Serviço de Produção de Informação - SPI, 1999. 585p.

ALVES, T. P. Avaliação da incidência e severidade de Sigatoka-amarela (Mycosphaerella musicola Leach) e infestação do Moleque-da-bananeira (Cosmopolites sordidus) em variedades de banana da Fazenda Água Limpa, Distrito Federal. 2016. Brasília, 2016. 43 f. Monografia (Graduação em Agronomia) - Universidade de Brasília - UnB, Brasília, 2016.

AGÊNCIA NACIONAL DE VIGILÂNCIA SANITÁRIS - ANVISA. Programa de Análise de Resíduos de Agrotóxicos em Alimentos (PARA) - Relatórios de atividades de 2013 e 2015. Gerência Geral de Toxicologia. Anvisa: Brasília, 2016. 246p

BAKAZE, E.; KOFLER, J. DZOMEKU, B. M.; WÜNSCHE, J. Natural compounds with potential insecticidal properties against banana weevil Cosmopolites sordidus. American Journal of Sciences and Engineering Research, v. 3, n. 4, p. 11-22, 2020. 
BATISTA FILHO, A.; HOJO, H.; LEITE, L. G.; RAGA, A.; SATO, M. E.; ALMEIDA, J. E. M.; TAKADA, H. M. Tecnologia Sustentável: Controle biológico de brocas da bananeira. [S. I.], [2016]. Disponível

em: $<$ http://www.biologico.sp.gov.br/uploads/files/pdf/tecnologia_sustentavel/broca_bananeira.pd f>. Acesso em: 10 dez. 2019.

BATISTA FILHO, A.; TAKADA, H. M.; CARVALHO, A G. Brocas da bananeira. In: Reunião Itinerante de Fitossanidade do Instituto Biológico, 6, 2002, São Bento do Sapucaí-SP. Anais... São Paulo: Arquivos do Instituto Biológico, 2002. v.1. p.1-16.

CAPORAL, F. R. Superando a revolução verde: a transição agroecológica no estado do Rio Grande do Sul, Brasil. EMATER/RS-ASCAR. 2003.

CAPORAL, F. R.; COSTABEBER, J. A. Agroecologia: alguns conceitos e princípios. Brasilia. 2004. 24p.

CAPORAL, F. R.; COSTABEBER, J. A. Agroecologia e desenvolvimento rural sustentável: perspectivas para uma nova Extensão Rural. Agroecologia e Desenvolvimento Rural Sustentável, v.1, n.1, p.16-37, 2000.

CORDEIRO, Z. J. M.; FANCELI, M.; RITZINGER, C. H. S. P.; FERREIRA, M. V.; HADDAD, $F$. Manual de identificação de doenças, nematoides e pragas na cultura da bananeira. Brasília: EMBRAPA, 2017. 59p.

COSTA, A. N.; COSTA, A. F. S.; ARAÚJO, J. B. S.; MANGARAVITE, J. C. S.; VENTURA, J. A.; MIRANDA, V. Recomendações técnicas para o cultivo da banana orgânica. Vitória: INCAPER, 2006. 48 p. (Documentos, 144).

DALZOTO, P. R.; UHRY, K. F. Controle biológico de pragas no Brasil por meio de Beauveria bassiana (Bals.) Vuill. Biológico, São Paulo, v. 71, n. 1, p. 37- 41, 2009.

DANTAS, D. J.; MEDEIROS, A. C; NUNES, G. H. S.; MENDOÇA, V.; MOREIRA, M. A. B. Reação de cultivares de bananeira ao Cosmopolites sordidus no Vale do Açu - RN. Revista Verde, v. 6, n. 3, p.152-155, 2011.

EMBRAPA MEIO AMBIENTE. Manejo de Pragas, Doenças e Plantas Invasoras. [S. I.], $2015 . \quad$ Disponível em: <http://www.cnpma.embrapa.br/unidade/index.php3?id=239\&func=pesq>. Acesso em: 10 dez. 2019.

FANCELLI, M.; MESQUITA, A. L. M. Pragas. In: CORDEIRO, Z-J.M. (Org.). Banana: fitossanidade. Brasília: EMBRAPA Comunicação para Transferência de Tecnologia, p. 21-35, 2000.

FANCELLI, M.; MESQUITA, A. L. M.; QUEIROZ, J. S. Monitoramento e controle da brocado-rizoma-da-bananeira pelo uso de armadilhas atrativas de pseudocaule. EMBRAPA Mandioca e Fruticultura Bahia-Folder/Folheto/Cartilha (INFOTECA-E), 2016. 6p.

FANCELLI, M.; MILANEZ, J. M.; MESQUITA, A. L. M.; COSTA, A. C. F.; COSTA, J. N. M.; PAVARINI, R.; PAVARINI, G. P. P. Artrópodes: pragas da bananeira e controle. Informe Agropecuário, v. 36, n. 288, p. 7-18, 2015. 
FOOD AND AGRICULTURE ORGANIZATION OF THE UNITED NATIONS - FAO. 2018. Disponível em: <http://fao.org/FAO/en\#datanload/Q/QC/E\%5Cnhttp://foastat3.fao.org/>. Acesso em: 21 jan. 2020.

FOOD AND AGRICULTURE ORGANIZATION OF THE UNITED NATIONS - FAO. Roma: FAO, 2017. Disponível em: http://FAO.fao.org/site/567/defaul.aspx\#ancor. Acesso em: 20 mai. 2020.

FOOD AND AGRICULTURE ORGANIZATION OF THE UNITED NATIONS - FAO. 2014. Disponível em: <http://FAO.fao.org/site/567/defaul.aspx\#ancor>. Acesso em: 20 mai. 2020.

FERMINO, M. H.; KAMPF, A. N. Uso do solo Bom Jesus com condicionadores orgânicos como alternativa de substrato para plantas. Pesquisa Agropecuária Gaúcha, Porto Alegre, v. 9, n. 1/2, p. 33-41, 2003.

FIGUEIREDO, A. D.; ÁZERA, S.; MARTINS, J. T.; LOPES, D. J. Eficácia de diferentes tipos de armadilhas na captura Cosmopolites sordidus (Coleoptera: Curculionidae) Boletim do Museu Municipal do Funchal, v. sup., n. 14, p. 49-54, 2008.

FIGUEIREDO, D. V.; BRIOSO, P. S. T.; PCR multiplex para a detecção de BSV e CMV em bananeiras micropropagadas. Summa Phytopathologica, v. 33, n. 3, p. 229-232, 2007.

GALLO, D.; NAKANO, O.; SILVEIRA NETO, S.; CARVALHO, R.P.L.; BAPTISTA, G. C.; BERTI FILHO, E.; PARRA, J. R. P.; ZUCCHI, R. A.; ALVES, S. B.; VENDRAMIM, J. D.; MARCHINI, L. C.; LOPES, J. S.; OMOTO, C. Entomologia Agrícola. 3. ed. Piracicaba: Fealq, 2002. 920p.

GHAG, S. B.; GANAPATHI, T. R. Banana and plantains: improvement, nutrition, and health. In: MÉRILLON J. M., RAMAWAT K. (Eds.). Bioactive Molecules in Food. Reference Series in Phytochemistry: Springer, v. 1, p. 1-20, 2018.

GOLD, C. S.; PENA, J. E.; KARAMURA, E. B. Biology and integrated pest management for the banana weevil Cosmopolites sordidus (Germar) (Coleoptera: Curculionidae). Integrated Pest Management Reviews, v. 6, p. 79-155, 2001.

HASYIM, A.; AZWANA, A.; SYAFRIL, S. Evaluation of natural enemies in conrolling of the banana weevil borer Cosmopolites sordidus Germar in West Sumatra. Indonesian Journal of Agricultural Science, v. 10, n. 2, p. 43-53, 2009.

INSTITUTO BRASILEIRO DE GEOGRAFIA E ESTATíSTICA - IBGE. Levantamento sistemático de produção agrícola. Censo agropecuário. 2019. Disponível em:< https://www.ibge.gov.br/estatisticas/economicas/agricultura-e-pecuaria/9201-levantamentosistematico-da-producao-agricola.html?edicao=25987\&t=resultados $>$. Acesso em: 24 jan. 2019.

INSTITUTO BRASILEIRO DE GEOGRAFIA E ESTATÍSTICA - IBGE. Censo agropecuário. Disponível em: <http://www.ibge.gov.br/home/estatistica/indicadores/agropecuaria/spa/>. Acesso em: 24 jan. 2019.

INSTITUTO BRASILEIRO DE GEOGRAFIA E ESTATÍSTICA - IBGE. Sistema IBGE de Recuperação Automática: Levantamento Sistemático Da Produção Agrícola, Brasília: Instituto Brasileiro de Geografia e Estatística, v. 30, p. 115, 2017. 
INSTITUTO BRASILEIRO DE GEOGRAFIA E ESTATÍSTICA - IBGE. Levantamento sistemático de produção agrícola. Censo agropecuário. 1975. Disponível em: <http://www.ibge.gov.br/home/estatistica/indicadores/agropecuaria/lspa/>. Acesso em: 24 jan. 2019.

LAZZARINI, A. L. Óleo essencial de Piper aduncum L. no controle da broca-do-rizoma Cosmopolites sordidus (Germar) (Coleoptera: Curculionidae) na cultura da banana. Alegre, 2020. 86p. Dissertação (Mestrado em Agroecologia). Programa de Pós-graduação em Agroecologia. Instituto Federal de Educação, Ciência e Tecnologia do Espírito Santo, campus de Alegre. Alegre, 2020.

LIMA, R. K.; CARDOSO, M. G.; MORAES, J.; VIEIRA, S.; MELO, B.; FIGUEIRAS, C. Composição dos óleos essenciais de anis-estrelado Illicium verum L. e de capim-limão Cymbopogon citratus (DC.) Stapf; Avaliação do Efeito Repelente sobre Brevicoryne brasicae (L.) (Hemiptera: Aphidae). Bioassay, v. 3, p. 1-6, 2008.

LINS, L. C. R.; FANCELLI, M.; RITZINGER, C. S. P.; FILHO, M. A. C.; LEDO, C. A. S. Torta de mamona no controle da broca-do-rizoma (Cosmopolites sordidus) em bananeira-terra. Revista Brasileira de Fruticultura, v. 35, n. 2, p. 499, 2013.

MESQUITA, A. L. M. Importância e métodos de controle do "moleque" ou broca-dorizoma-da-bananeira. Fortaleza: EMBRAPA Agroindústria Tropical, v.1, 6p., 2003.

MICHEREFF FILHO, M.; FANCELLI, M.; NEVES, P. M. O. J.; TIGANO, M. S.; LOPES, R. B.; OLIVEIRA, S. O. D.; OLIVEIRA, M. W. M. Metodologia de inoculação de Beauveria bassiana para avaliação da virulência em adultos de Cosmopolites sordidus (Coleoptera: Curculionidea). (Boletim de Pesquisa e Desenvolvimento, 47). 2010, 24p.

MOREIRA, M. A. B.; ZARBIN, P. H. G.; CORACINI, M. D. A. Feromônios associados aos coleópteros-praga de produtos armazenados. Química Nova, v. 28, n. 3, p. 472-477, 2005.

MOURA, N. A.; SILVA, A. F.; BORGES, V. E.; VILLAR, M. L. P. Avaliação do controle biológico da broca de rizoma da bananeira (Cosmopolites sordidus Germ., 1824) utilizando o fungo entomopatogênico Beauveria bassiana (Bals.) Vuill. REB. v. 8, n.2, p. 249-266, 2015.

NAVARRO, Z. S. Desenvolvimento rural no Brasil: os limites do passado e os caminhos do futuro. Estudos Avançados, USP, v. 15, n. 43, p. 83-100, 2001.

NELSON, S.; PLOETZ, R. C.; KEPLER, A. K. Musa Species (Banana and Plantain). Species Profiles for Pacific Island Agroforestry. 2006. 33 p. Disponível em: $<\mathrm{http}$ ://agroforestry.net/images/pdfs/Musa-banana-plantain.pdf>. Acesso em: 21 jan. 2020.

PRANDO, H. F. Controle da broca do rizoma da bananeira com Beauveria bassiana em Santa Catarina. In: REUNIÃO INTERNACIONAL DA ASSOCIAÇÃO PARA COOPERAÇÃO NAS PESQUISAS SOBRE BANANA NO CARIBE E NA AMÉRICA TROPICAL, 17., 2006, Joinvile. Anais... Bananicultura: um negócio sustentável. Joinvile: ACORBAT, v. 2, p. 794-797, 2006.

QUEIROZ, J. S.; FANCELLI, M.; COELHO FILHO, M. A.; LEDO, C. A. S.; SÁNCHES, C. G. New type of trap for monitoring banana weevil population. African Journal of Agricultural Research, v. 12, n. 10, p. 764-770, 2017. 
SAHAYARAJ, K.; KOMBIAH, P. Insecticidal activities of neem gold on banana rhizome weevil (BRW), Cosmopolites sordidus (Germar) (Coleoptera: Curculionidae). Journal of Biopesticides, v. 3, p. 304-308, 2010.

SANTOS, A. T. B. Caracterização química e atividade inseticida de óleos essenciais de Tephrosia vogelii e Piper aduncum no manejo de Solenopsis saevissima (Hymenoptera: Formicidade) e Cerosipha forbesi (Hemiptera: Aphididae). Alegre, 2018. 84 f. Dissertação (Mestrado em Agroecologia). Programa de Pós-Graduação Stricto Sensu em Agroecologia. Instituto Federal de Educação, Ciência e Tecnologia do Espírito Santo, Alegre, 2018.

SILVA, D. N; VENTURA, J. A. Transformações da agricultura capixaba: 50 anos, editores técnicos - Vitória, ES: CEDAGRO; INCAPER; SEAG, 2016. 42p.

TINZAARA, W.; GOLD, C. S.; DICKE, M.; VAN HUIS, A.; NANKINGA, C. M.; KAGEZI, G. H. e RAGAMA, P. E. The use of aggregation pheromone to enhance dissemination of Beauveria bassiana for the control of the banana weevil in Uganda. Biocontrol Science and Technology, v. 17, n. 2, p. 111-124, 2007.

VENTURA, J. A.; GOMES, J. A. Recomendações técnicas para o cultivo da bananeira no Estado do Estado do Espírito Santo. Vitória: INCAPER, 2005. 42p.

ZANUNCIO-JUNIOR, J. S.; FORNAZIER, M. J.; MARTINS, D. S.; CHAMORRO-RENGIFO, J.; QUEIRÓZ, R. B.; LAZZARINI, A. L.; FERREIRA, P. S. Meroncidius intermedius (Orthoptera: Tettigoniidae): a threat to brazilian banana. Florida Entomologist, v. 100, n. 3, p. 669-671, 2017. 


\section{Capítulo 11}

\section{Aplicações tecnológicas para subprodutos do processamento da graviola}

Jaqueline Rodrigues Cindra de Lima Souza ${ }^{1}$, Luciano Menini², Tércio da Silva de Souza², Luciana Alves Parreira ${ }^{3}$

\section{Introdução}

A graviola (Annona muricata L.), conhecida popularmente pelos nomes de graviola, guanabara, araticum, coração-de-rainha, jaca-do-pará, coração-de-boi, condessa, jaca-depobre, araticum-manso, entre outras denominações (BADRIE e SCHAUSS, 2010), é uma fruta tropical, pertencente ao gênero Annona, família Annonaceae. Essa espécie, originária das Antilhas, é amplamente cultivada em regiões de clima tropical e subtropical, como América do Sul, América Central, África e Ásia (CORRÊA, 1984; SÃO JOSÉ et al., 2014). É uma cultura de exploração comercial recente e as informações disponíveis sobre produtividade e área cultivada com gravioleira no Brasil são bastante escassas, sendo os estados de Pernambuco, Bahia e Ceará os maiores produtores (IBGE, 2009).

A fruta graviola é uma importante fonte alimentícia para o homem devido ao seu conteúdo de vitaminas, minerais e substâncias aromáticas excitantes ao paladar e olfato (SCHMIDTHEBBEL, 1973). Pode ser consumida in natura, além de ser empregada na fabricação sucos, doces e sorvetes (DE CASTRO, 1984). Quando processada na indústria de alimentos, a graviola produz em torno de $30 \%$ do seu peso em resíduos, sendo este constituído, principalmente, por casca, miolo e sementes (NAZARÉ, 2000).

Estes resíduos, apesar de seu potencial nutritivo e medicinal, têm seu destino limitado a aterros sanitários devido à falta de alternativas viáveis para seu uso local e in natura, o que desperta a necessidade de investigar maneiras praticáveis de aproveitamento. Os resíduos das indústrias de alimentos podem conter substâncias de alto valor que, a partir do emprego de tecnologia adequada, podem ser convertidas em subprodutos comerciais, tais como, matérias primas para o uso em processos secundários (LAUFENBERG et al., 2003).

A obtenção de coprodutos a partir de resíduos pode se apresentar como alternativa para a redução da produção de rejeitos nas indústrias alimentícias, uma vez que resíduos não aproveitados se caracterizam como potenciais poluidores do meio ambiente (PELIZER et al.,

\footnotetext{
${ }^{1}$ Me. pelo Programa de Pós-Graduação em Agroecologia do Instituto Federal do Espírito Santo Campus de Alegre, Caixa Postal 47, CEP: 29500-000, Alegre-ES. E-mail: jrsouza@ifes.edu.br.

2 Drs. Professores do Instituto Federal do Espírito Santo - Campus de Alegre, Caixa Postal 47, CEP: 29500-000, Alegre-ES. E-mail: Imenini@ifes.edu.br; tssouzai@ifes.edu.br

${ }^{3}$ Dra. Professora da Universidade Federal do Espírito Santo - Campus de Alegre, Caixa Postal 16, CEP: 29500-000, Alegre-ES. E-mail: lucianap.ufes@gmail.com
} 
2007).

Neste contexto, este trabalho visa investigar potenciais aplicações para utilização de resíduos agroindustriais de graviola, visando valorizar a cadeia produtiva da fruta e minimizar os impactos ambientais gerados pelo descarte inadequado destes resíduos.

\section{Potencialidades de aplicação para os resíduos do processamento da graviola}

A graviola é uma baga geralmente verde, de casca flexível, ouriçada de pseudos espinhos carnosos, curtos e moles. A polpa é branca, de odor forte e acre, quando verde, tornando-se suave, agradável, sucosa, refrigerante, doce, ligeiramente ácida e um tanto cotonosa ao amadurecer. Na polpa está encerrado um considerável número de sementes escuras, de forma ovoide e com cerca de $2 \mathrm{~cm}$ de largura (BRAGA, 1960; GOMES, 1977).

Tanto no consumo in natura como no processamento da graviola pela indústria algumas de suas partes não são aproveitadas e acabam sendo rejeitadas, como é o caso das cascas, fibras e sementes rejeitadas pela agroindústria de processamento da graviola para extração da polpa (Figura 1).

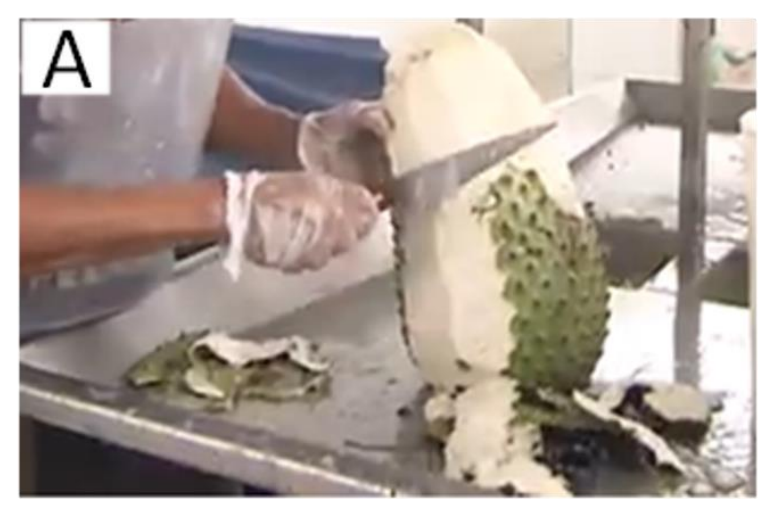

Fonte: Google imagens

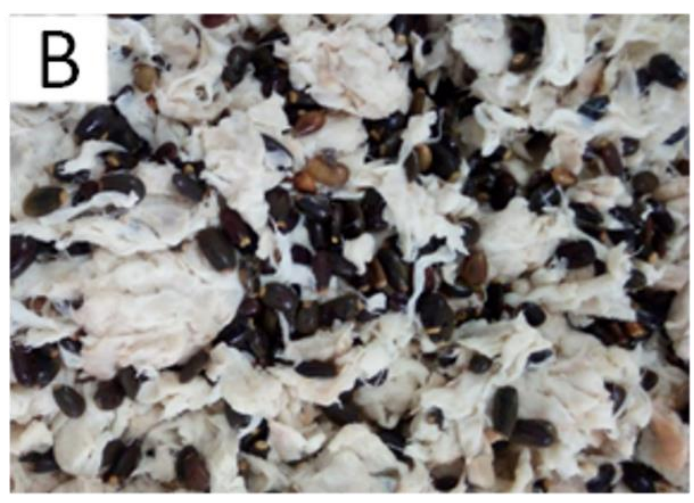

Fonte: Os Autores

Figura 1. Resíduos gerados no processamento da graviola para produção de polpa de fruta: A - Cascas; B - Bagaço e sementes.

Os resíduos do processamento da graviola vem despertando interesse de pesquisadores em várias áreas de aplicação, como por exemplo: alimentação humana; tratamento de água e efluentes; indústria oleoquímica; extração de compostos bioativos com uma ampla gama de aplicação (larvicida, ovicida, acaricida, antioxidante, antidiabético, antitumoral), entre outras aplicações (Tabela 1, Figura 2).

Foram pesquisados cerca 50 artigos relacionados a potencialidades de aplicação para o resíduo agroindustrial de graviola e selecionados 32 para estudo, tendo como critério o caráter inovador, relevância, viabilidade e publicação mais recente. Dos artigos em estudo, dois abordaram potencialidades nutricionais, dois potencialidade para remoção de contaminantes, 
três como fonte alternativa para extração de óleo vegetal fixo, dois para produção de biodiesel, três medicinais, seis como fonte de compostos bioativos e quatorze no combate de pragas agrícolas. Foram ao todo nove publicações nacionais e 23 internacionais (Tabela 1 e Figura 2).

Tabela 1. Potencialidades de aplicação para o resíduo agroindustrial de graviola.

\begin{tabular}{|c|c|c|}
\hline Aplicação & Autor, Ano & Revista, País (autor) \\
\hline Panificação & $\begin{array}{l}\text { Santos e Boêno (2016) } \\
\text { Lima et al. (2020) }\end{array}$ & $\begin{array}{l}\text { Revista de Agricultura Neotropical, Brasil } \\
\text { Research, Society and Development, Brasil }\end{array}$ \\
\hline $\begin{array}{l}\text { Remoção de } \\
\text { contaminantes }\end{array}$ & $\begin{array}{l}\text { Ndamitso et al. (2016) } \\
\text { Dos Reis et al. (2016) }\end{array}$ & $\begin{array}{l}\text { Science Journal of Analytical Chemistry, Nigéria } \\
\text { Interfaces Científicas-Saúde e Ambiente, Brasil }\end{array}$ \\
\hline $\begin{array}{l}\text { Extração de } \\
\text { óleo vegetal } \\
\text { fixo }\end{array}$ & $\begin{array}{l}\text { Da Silva e Jorge (2014) } \\
\text { Elagbar et al. (2016) } \\
\text { Pinto et al. (2018b) }\end{array}$ & $\begin{array}{c}\text { Food Research International, Brasil } \\
\text { Journal of Chemistry, Jordânia } \\
\text { Grasas y aceites, Brasil }\end{array}$ \\
\hline Biodiesel & $\begin{array}{c}\text { Su et al. (2018) } \\
\text { Dharmawan et al. (2016) }\end{array}$ & $\begin{array}{c}\text { Energies, Taiwan } \\
\text { Mechanova, Indonésia } \\
\end{array}$ \\
\hline $\begin{array}{l}\text { Medicinal } \\
\text { (Antidiabético } \\
\text { e Antitumural) }\end{array}$ & $\begin{array}{c}\text { Pinto et al. (2018a) } \\
\text { Arifianti et al. (2014) } \\
\text { Raybaudi-Massilia et al. (2015) }\end{array}$ & $\begin{array}{c}\text { PharmaNutrition, Brasil } \\
\text { Jurnal Farmasi dan Ilmu Kefarmasian Indonesia, } \\
\text { Indonésia } \\
\text { Current Journal of Applied Science and } \\
\text { Technology, Venezuela }\end{array}$ \\
\hline $\begin{array}{l}\text { Fonte de } \\
\text { compostos } \\
\text { bioativos }\end{array}$ & $\begin{array}{l}\text { Menezes et al. (2019) } \\
\text { Nguyen et al. (2020) } \\
\text { Elagbar et al. (2016) } \\
\text { Siswarni et al. (2016) } \\
\text { Orak et al. (2019) } \\
\text { Dorado et al. (2016) }\end{array}$ & $\begin{array}{c}\text { Food Science and Technology, Brasil } \\
\text { Management Science and Engineering, Vietnâ } \\
\text { Journal of Chemistry, Jordânia } \\
\text { Jurnal Teknik Kimia USU, Indonésia } \\
\text { Polish Journal of Food and Nutrition Sciences, } \\
\text { Turquia } \\
\text { Información tecnológica, Colômbia }\end{array}$ \\
\hline Acaricida & $\begin{array}{l}\text { Lima et al. (2014) } \\
\text { Saputra et al. (2015) }\end{array}$ & $\begin{array}{l}\text { Research, Society and Development, Brasil } \\
\text { Jurnal Hama dan Penyakit Tumbuhan, } \\
\text { Indonésia }\end{array}$ \\
\hline Larvicida & $\begin{array}{l}\text { Nombe e Binawati (2017) } \\
\text { Mila Sari (2019) } \\
\text { Setiawan et al. (2017) } \\
\text { Widyastuti et al. (2019) } \\
\text { Parra-Rodríguez et al. (2017) } \\
\text { Bobadilla, et al. (2005) } \\
\text { Gomes et al. (2016) }\end{array}$ & $\begin{array}{c}\text { Jurnal Matematika dan IImu Pengetahuan Alam } \\
\text { Unipa, Indonésia } \\
\text { Menara llmu, Indonésia } \\
\text { Jurnal Ilmiah Mahasiswa Kesehatan } \\
\text { Masyarakat, Indonésia } \\
\text { Bioeksperimen: Jurnal Penelitian Biologi, } \\
\text { Indonésia } \\
\text { Intropica, Colombia } \\
\text { Revista peruana de Biología, Peru } \\
\text { Ciência Rural, Brasil }\end{array}$ \\
\hline Inseticida & $\begin{array}{l}\text { Baideng (2017) } \\
\text { Blandino et al. (2020) } \\
\text { Fitri et al. (2019) } \\
\text { Manullang et al. (2020) } \\
\text { Gilang et al. (2018) }\end{array}$ & $\begin{array}{c}\text { Jurnal Ilmiah Sains, Indonésia } \\
\text { Revista Torreón Universitario, Nicarágua } \\
\text { Media Kesehatan Politeknik Kesehatan } \\
\text { Makassar, Indonésia } \\
\text { AGRILAND Jurnal Ilmu Pertanian, Indonésia } \\
\text { CROPSAVER-Journal of Plant Protection, } \\
\text { Indonésia }\end{array}$ \\
\hline
\end{tabular}

Fonte: Os Autores. 


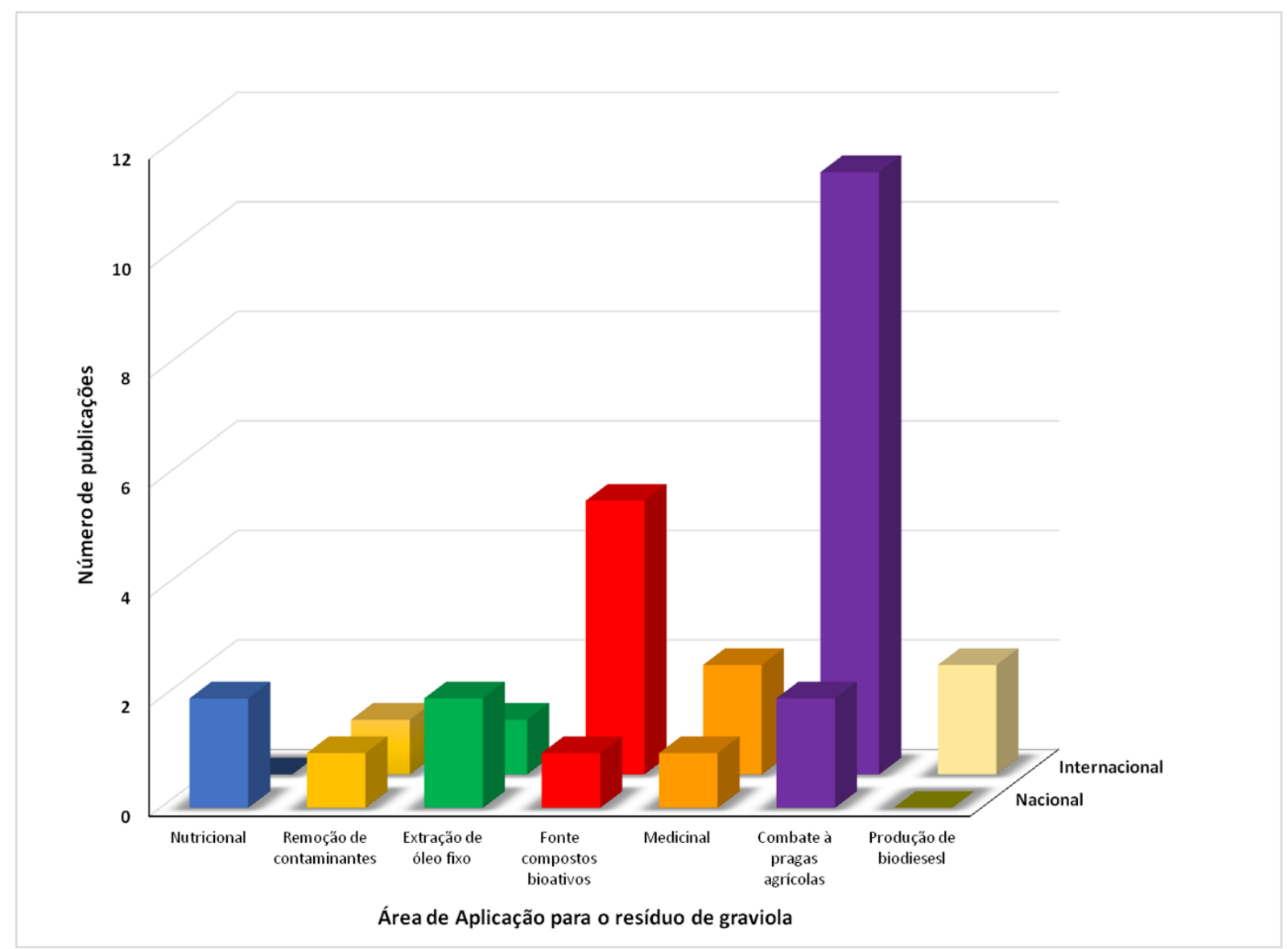

Figura 2. Principais temas abordados em publicações nacionais e internacionais para potencialidade de uso do resíduo agroindustrial de graviola.

Fonte: Os Autores.

Para alimentação humana, por exemplo, Lima et al. (2020) utilizou a casca da graviola para elaboração de pão de forma em substituição a farinha de trigo e comprovou que a casca pode ser utilizada na proporção de até $10 \%\left(\mathrm{~m} \mathrm{~m}^{-1}\right)$ sem interferir na aceitabilidade. Já em estudos realizados por Santos e Boêno (2016), mostraram ser possível a preparação de muffins utilizando o bagaço da graviola em substituição de até $30 \%\left(\mathrm{~m} \mathrm{~m}^{-1}\right)$ da farinha de arroz.

Outro potencial de aplicação para os resíduos do processamento da graviola é sua utilização como adsorvente na remoção de contaminantes. Ndamitso et al. (2016) mostraram que a casca de graviola é um potencial biossorvente para a remoção de íons $\mathrm{Pb}$ (II), Cd (II) e Co (II) da água do derramamento de petróleo. Há relatos também da utilização das sementes de graviola tratada para auxiliar na floculação do tratamento de água, as quais apresentaram eficiência na remoção de $90 \%$ da cor e da turbidez e 50\% de remoção de ferro da água (DOS REIS et al., 2016).

As sementes obtidas do resíduo de graviola apresentam-se também como uma fonte alternativa de óleo vegetal para a indústria, pois apresentam elevado teor de óleo, cerca de 30\% (DA SILVA e JORGE, 2014), sendo este óleo composto por importantes ácidos graxos como oleico (cerca de 40\%), linoleico (cerca de 35\%) e palmítico (cerca de $20 \%$ ). Além disso, 
dependendo do método de extração, esse óleo fixo pode apresentar teores consideráveis de compostos bioativos o que o torna atrativo para os setores farmacêutico e cosmético (ELAGBAR et al., 2016; PINTO et al., 2018b).

Uma das possíveis aplicações para o óleo obtido das sementes de graviola é para produção de biodiesel. Em ensaios realizados por Su et al. (2018) foi obtida taxa de conversão de $95 \%$ na produção de ésteres metílicos a partir do óleo extraído das sementes de graviola com solvente hexano, via transesterificação por catálise básica. O elevado teor de éster no biodiesel, suas propriedades físicos químicas, teor de enxofre $(0,04 \%)$, teor de éster $(98,6 \%)$, viscosidade $\left(5,5 \mathrm{~mm}^{2} \mathrm{~s}^{-1}\right)$, conteúdo de água (300 $\left.\mathrm{mg} \mathrm{kg}^{-1}\right)$, número de cetano (53), densidade (868 $\left.\mathrm{kg} \mathrm{m}^{-3}\right)$, ponto de inflamação $\left(123^{\circ} \mathrm{C}\right)$ e acidez $<0,8 \mathrm{mg} \mathrm{KOH} \mathrm{g}^{-1}$ sugerem que o óleo de graviola é uma matéria prima em potencial para produção desse combustível (SU et al.,2018).

Dharmawan et al. (2016) testaram o desempenho em motores a diesel do éster metílico produzido por transesterificação metílica com catalise alcalina do óleo extraído das sementes de graviola com hexano. A mistura B-10 gerou valores máximos de potência $=40,11 \mathrm{hp}$, Torque $=141,20 \mathrm{~N} \mathrm{~m}$, BMEP $=70014,55 \mathrm{~kg} \mathrm{~m}^{-2}, \mathrm{SFC}=0,20 \mathrm{~kg} \mathrm{hp}^{-1} \mathrm{~h}^{-1}$ de combustível e eficiência térmica $=31,37 \%$.

Estudos promissores vem sendo realizados na medicina com compostos isolados das sementes de Annona muricata L. Dentre estes estudos, pode-se citar o potencial de citoxicidade seletiva contra linhas celulares tumorais humanas (ARIFIANTI et al., 2014; RAYBAUDI-MASSILIA et al., 2015) e a melhora nos parâmetros de diabetes tipo 1 in vivo e in vitro (PINTO et al., 2018a).

Cascas e sementes de graviola podem ser úteis para extração de compostos antioxidantes, devendo se levar em conta o solvente utilizado para a extração. Nguyen et al. (2020), ao analisar extratos de sementes de graviola extraídas com diferentes solventes (água destilada, etanol, acetato de etila e clorofórmio) constataram atividade antioxidante em todos os extratos, com valores variando de 86 a $382 \mathrm{mg}$ ácido ascórbico/100g. Nesse estudo o etanol se revelou o solvente mais eficiente, com resultados de atividade antioxidante cerca de 3-4 vezes maior do que os outros solventes investigados. Já em estudos realizados por Orak et al. (2019), ao investigar o potencial antioxidante de extrato da casca e das sementes de graviola, extraídas com hexano, diclorometano, acetato de etila e metanol, indicou que o metanol foi o solvente mais eficiente, apresentando no extrato da casca $465 \mu \mathrm{mol} \mathrm{Fe}{ }^{2+} / \mathrm{g}$ e no da semente $1101 \mu \mathrm{mol}$ $\mathrm{Fe}^{2+} / \mathrm{g}$.

Dentre os principais compostos bioativos investigados nas sementes de graviola pode-se citar os compostos fenólicos, flavonoides, carotenoides, tocoferois, alcalóides, estetóis, acetogeninas, entre outros. Menezes et al. (2019) obtiveram no extrato das sementes de graviola com metanol/água (1:1) os seguintes compostos fenólicos: catequina (169 mg kg-1), ácido trans cinâmico $\left(290 \mathrm{mg} \mathrm{kg}^{-1}\right.$ ), rutina $\left(891 \mathrm{mg} \mathrm{kg}^{-1}\right.$ ) e antocianinas (3 mg cianidina-3- 
glucosidio $\mathrm{kg}^{-1}$ ). A presença de flavonoides foi investigada por Nguyen et al. (2020), que obtiveram no extrato etanólico das sementes $86,6 \mathrm{mg}$ Quercetina/100g. Os carotenoides foram estudados por Menezes et al. (2019), que obtiveram no extrato acetônico das sementes de graviola $770 \mu \mathrm{g}$ de $\beta$-caroteno $\mathrm{kg}^{-1}$. A existência de tocoferois foi pesquisada por Elagbar et al. (2016), que obtiveram no extrato hexânico das sementes de graviola 12,5 mg $\alpha$-tocoferol $\mathrm{kg}^{-1}$. No trabalho de Dorado et al. (2016) as sementes de graviola passaram pelo método de extração por dióxido de carbono supercrítico sob diferentes condições de temperatura, pressão e tempo de extração e foram quantificados os esteroides no óleo: $0,70-1,36 \mathrm{mg} \mathrm{mL}^{-1}$ de $\beta$-sitosterol, 0,52-0,88 $\mathrm{mg} \mathrm{mL}^{-1}$ de estigmasterol e 0,19-0,50 $\mathrm{mg} \mathrm{mL}^{-1}$ de campesterol. Foram investigados também por Siswarni et al. (2016) a presença de acetogenina no extrato acetônico das sementes de graviola e alcaloides do tipo indol em extrato metanólico.

Dentre as potencialidades investigadas para o resíduo da graviola, a mais explorada foi a utilização de extrato das sementes no combate a pragas agrícolas, sendo a Indonésia o país com maior quantidade de publicações nesta área. Lima et al. (2014) constataram que o extrato hexânico das sementes de $A$. muricata apresenta efeito acaricida sobre Tetranychus evansi tanto em protoninfas quanto em fêmeas adultas, com eficiência média de $98 \%$ da mortalidade dos ácaros após $24 \mathrm{~h}$ da aplicação na concentração 5,0\% $\left(\mathrm{m} \mathrm{m}^{-1}\right)$ e, após $48 \mathrm{~h}, 100 \%$ de mortalidade. $O$ efeito acaricida do extrato bruto da semente de graviola também foi investigado por Saputra et al. (2015) no combate ao ácaro da soja (Nezara viridula L.), com resultados satisfatórios em sinergismo com vírus JSI SINPV-JTM 97C, no combate a larvas com inibição de $100 \%$ na concentração de $200 \mathrm{~g} \mathrm{~L}^{-1}$.

Bobadilla et al. (2005) avaliaram a toxicidade larvicida de suspensões aquosas de extratos etanólicos das sementes, flores, folhas, casca de galhos e casca de raízes de Annona muricata L. em larvas no quarto estágio de Aedes aegypti. O maior efeito tóxico correspondeu à suspensão de sementes na concentração $0,5 \mathrm{mg} \mathrm{mL}^{-1} \mathrm{com} 100 \%$ de mortalidade em $24 \mathrm{~h}$. Resultados satisfatórios também foram obtidos por outros autores para potencialidade de utilização do extrato etanólico das sementes de graviola no combate as larvas dos mosquitos Aedes aegypti (MILA SARI, 2019; SETIAWAN et al., 2017), Culex quinquefasciatus (NOMBE e BINAWATI 2017; PARRA-RODRÍGUEZ et al., 2017) e; Aedes albopictus (WIDYASTUTI et al., 2019).

A potencialidade larvicida do extrato da semente de graviola também foi constatada por Gomes et al. (2016) no combate a traça-das-crucíferas (Plutella xylostella L.), com toxicidade aguda ( $C L 50=258 \mathrm{mg} \mathrm{L}^{-1}$ ) e efeitos crônicos, especialmente na redução da viabilidade larval e aumento da duração do estágio larval. Baideng (2017) verificaram também o potencial inseticida no controle da população de $P$. xylostella com extrato aquoso de semente de graviola.

Vários autores verificaram efeito inseticida em diferentes extratos de sementes de graviola. 
Blandino et al., (2020) utilizaram extrato etanólico no combate a lagarta do exército (Spodoptera frugiperda); Fitri et al., (2019) utilizaram extrato acetônico no combate ao piolho de arroz (Sitophylus oryzae L.); Gilang et al. (2018) avaliaram o extrato metanólico contra o caruncho do feijão (Callosobruchus maculatus F) e; Manullang et al. (2020) investigaram o extrato bruto da semente de graviola no combate a joaninha verde (Nezara viridula) de vagens de soja.

\section{Considerações finais}

Pode-se verificar algumas potencialidades de aproveitamento para o resíduo agroindustrial de graviola: para nutrição humana, como auxiliar no tratamento de efluentes, como fonte de matéria prima alternativa para extração de óleo e também para extração de compostos bioativos como uma ampla gama de aplicação (antitumoral, antidiabético, larvicida, ovicida, acaricida e antioxidante). Nota-se, porém, de acordo com as publicações estudadas, que esse resíduo ainda é pouco explorado em sua totalidade e existe uma gama de aplicações bem limitada. A maioria das publicações explora apenas as sementes, sendo as cascas e o bagaço pouco exploradas e os estudos publicados para uso da semente em sua maioria destinam-se ao combate a pragas agrícolas. Entretanto, existe uma infinidade de potencialidades de utilização destes resíduos que ainda não foram exploradas ou que necessitam de mais estudos para sua comprovação e viabilidade.

\section{Agradecimentos}

Os autores agradecem ao Programa de Pós-Graduação em Agroecologia (PPGA), à Coordenação Aperfeiçoamento de Pessoal do Ensino Superior (CAPES), ao Conselho Nacional para o Desenvolvimento Científico e Tecnológico (CNPq), a Fundação de Apoio à Pesquisa e Inovação do Espírito Santo (FAPES) e a Agroindústria Papa Fruta ${ }^{\circledR}$.

\section{Referências}

ARIFIANTI, L.; SUKARDIMAN, H.; STUDIAWAN; RAKHMAWATI, L. M. Uji aktivitas ekstrak biji sirsak (Annona muricata L.) terhadap sel kanker mamalia secara in vitro. Jurnal Farmasi dan IImu Kefarmasian Indonesia, v. 1, n. 2, p. 63-66, 2014.

BADRIE, N.; SCHAUSS, A. G. Soursop (Annona muricata L.): composition, nutritional value, medicinal uses, and toxicology. In: WATSON, R. R.; PREEDY, V. R. Bioactive foods in promoting health, 2010. p. 621-643. 
BAIDENG, E. L. Uji Daya Bunuh Ekstrak Biji Sirsak (Annona muricata) terhadap Larva Kubis plutella xylostella (Linn.) (Lepidoptera: Plutellidae). Jurnal IImiah Sains, v. 16, n. 2, p. 98-103, 2017.

BLANDINO, M. G.; SUÁREZ, J. P.; CALERO, S. M.; CARCACHE, E. R.; URBINA, J. R.; ROMERO, M. L.; ORTEGA, F. B.; CHAMORRO, H. P. Análisis de la composición proximal y potencial insecticida de la semilla de guanábana (Annona muricata L.) para el control del gusano cogollero del maíz (Spodoptera frugiperda JE Smith). Revista Torreón Universitario, v. 9 , n. 24, p. 27-44, 2020.

BOBADILLA, M.; ZAVALA, F.; SISNIEGAS, M.; ZAVALETA, G.; MOSTACERO, J.; TARAMONA, L. Evaluación larvicida de suspensiones acuosas de Annona muricata Linnaeus "guanábana» sobre Aedes aegypti Linnaeus (Diptera, Culicidae). Revista Peruana de Biología, v. 12, n. 1, p. 145-152, 2005.

BRAGA, R. Plantas do nordeste, especialmente do Ceará. 2. ed. Fortaleza: Imprensa Oficial, 1960. 274p.

CORRÊA, M. P. Dicionário de plantas medicinais do Brasil e das exóticas cultivadas. Rio de Janeiro: Instituto Brasileiro de Desenvolvimento Florestal, v. 6, n. 3, p. 646. Graviola do Norte, 1984.

DA SILVA, A. C.; JORGE, N. Bioactive compounds of the lipid fractions of agroindustrial waste. Food Research International, v. 66, p. 493-500, 2014.

DE CASTRO, F. A.; MAIA, G. A.; HOLANDA, L. F. F.; GUEDES, Z. B. L.; FÉ, J. D. A. M. Características físicas e químicas da graviola. Pesquisa Agropecuária Brasileira, v. 19, n. 3, p. 361-365, 1984.

DHARMAWAN, J. J.; ANGGONO, W.; SUTRISNO, T. Pengaruh penambahan Minyak Biji sirsak terhadap unjuk kerja mesin diesel. Mechanova, v. 5, p. 1-6, 2016.

DORADO, D. J.; HURTADO-BENAVIDES, A. M.; MARTÍNEZ-CORREA, H. A. Extracción con $\mathrm{CO}_{2}$ supercritico de aceite de semillas de guanábana (Annona muricata): cinetica, perfil de acidos grasos y esteroles. Información tecnológica, v. 27, n. 5, p. 37-48, 2016.

DOS REIS, E. N.; SILVA, A. S.; DE JESUS, E. Avaliação do potencial de utilização de resíduos de sementes de frutas como auxiliar de floculação no tratamento de água. Interfaces Científicas-Saúde e Ambiente, v. 5, n. 1, p. 145-152, 2016.

ELAGBAR, Z. A.; NAIK, R. R.; SHAKYA, A. K.; BARDAWEEL, S. K. Fatty acids analysis, antioxidant and biological activity of fixed oil of Annona muricata L. seeds. Journal of Chemistry, v. 2016, p. 1-6, 2016.

FITRI, A.; SARI, Y.; NURJANNA, A.; ASTUTI A. Qualitative and activities tests of acetogenin compound from soursop seeds extract (Annona muricata $L$ ) as rice weevil insecticide (Sitophylus oryzae L). Media Kesehatan Politeknik Kesehatan Makassar, v. 14, n. 2, p. 158162, 2019.

GILANG, R. G.; SUSNIAHTI, N.; DONO, D. The effectiveness of soursop seed (Annona muricata L.) agains Callosobruchus maculatus F. (Coleoptera: Bruchidae). CROPSAVERJournal of Plant Protection, v. 1, n. 1, p. 15-19, 2018. 
GOMES, I. B.; TRINDADE, R. C. P.; SANT'ANA, A. E. G.; LEMOS, E. E. P. D.; JÚNIOR, B., E DINIZ, I. Bioactivity of microencapsulated soursop seeds extract on Plutella xylostella. Ciência Rural, v. 46, n. 5, p. 771-775, 2016.

GOMES, R.P. Fruticultura brasileira. 3. ed. São Paulo, Nobel, 1977. p. 254 '9.

IBGE - Instituto Brasileiro de Geografia e Estatística. Tabela SIDRA - 2009. Tabela 1179/2006 - Produção, Valor da produção, Venda, Valor da venda, Colheita, Área plantada e Efetivos das plantações da lavoura permanente nos estabelecimentos agropecuários com mais de 50 pés existentes por produtos da lavoura permanente, uso de irrigação, uso de agrotóxicos, uso de adubação e principal mês da colheita. Atualização em 30/09/2009. Disponível em: <https://sidra.ibge.gov.br/tabela/1179>. Acesso em: fev. 2019.

LAUFENBERG, G.; KUNZ, B.; NYSTROEM, M. Transformation of vegetable waste into value added products: (A) the upgrading concept; (B) practical implementations. Bioresource technology, v. 87, n. 2, p. 167-198, 2003.

LIMA, D. V.; DA COSTA AZEVEDO, O. O.; SILVA, N. S.; SILVA, G. S.; PONTES, E. D. S.; DE ARAUJO, M. G. G.; PEREIRA, D. E.; PIOVESAN, N.; MEDEIROS, R. G.; SOARES, J. K. B.; VIERA, V. B. Development and sensory evaluation of added bread from soursop residue flour. Research, Society and Development, v. 9, n. 1, p. 172911857, 2020.

LIMA, H. M. A.; DE MELO RODRIGUES, V.; VALENTE, E. C. N.; DOS SANTOS, M. D.; DUARTE, A. G.; TRINDADE, R. C. P. Toxicidade do extrato orgânico de sementes de Annona muricata L.(Annonaceae) sobre Tetranychus evansi (Baker \& Pritchard, 1960) (Acari: Tetranychidae) em tomateiro. Revista Brasileira de Biociências, v. 12, n. 4, p. 201-205, 2014.

MANUlLANG, A. A.; ASMANIZAR, A.; SIREGAR, D. Pengaruh ekstrak kasar biji sirsak (Annona muricata Linn) terhadap hama kepik penghisap polong (Nezara viridula Linnaeus) (Hemiptera; Pentatomidae) pada tanaman kedelai (Glycine max L. Merr.). AGRILAND Jurnal IImu Pertanian, v. 8, n. 1, p. 84-88, 2020.

MENEZES, E. G. T.; OLIVEIRA, E. R.; CARVALHO, G. R.; GUIMARÃES, I. C.; QUEIROZ, F. Assessment of chemical, nutritional and bioactive properties of Annona crassiflora and Annona muricata wastes. Food Science and Technology, v. 39, p. 662-672, 2019.

MILA SARI, M. Pengendalian Vektor Larva Aedes aegypti Dengan Menggunakan Biji Sirsak (Annona muricata Linn). Menara IImu, v. 13, n. 6, p. 137- 145, 2019.

NAZARÉ, R.F.R. de. Produtos agroindustriais de bacuri, cupuaçu, graviola e açai, desenvolvidos pela Embrapa Amazônia Oriental. Belém: EMBRAPA Amazônia Oriental, 2000. $27 \mathrm{p}$.

NDAMITSO, M. M.; MUSTAPHA, S.; ETSUYANKPA, M. B.; JACOB, J. O.; ADESHINA, I. O.; EKOR, L. Removal of lead, cadmium and cobalt from oil spill water onto soursop (Annona muricata) Peel. Science, v. 4, n. 1, p. 7-11, 2016.

NGUYEN, V. T.; NGUYEN, M. T.; TRAN, Q. T.; THINH, P. V.; BUI, L. M. LE, T. H. N.; LE, V. M.; LINH, H. T. K. Effect of extraction solvent on total polyphenol content, total flavonoid content, and antioxidant activity of soursop seeds (Annona muricata L.). MS\&E, v. 736, n. 2, p. 022063, 2020. 
NOMBE, S.; BINAWATI, D. K. Pemberian ekstrak biji alpukat (Persea americana Mill.) dan biji sirsak (Annona muricata L.) terhadap mortalitas larva Nyamuk culex sp. STIGMA: Jurnal Matematika dan IImu Pengetahuan Alam Unipa, v. 10, n. 02, p. 1-15, 2017.

ORAK, H. H.; BAHRISEFIT, I. S.; SABUDAK, T. Antioxidant activity of extracts of soursop (Annona muricata L.) leaves, fruit pulps, peels and seeds. Polish Journal of Food and Nutrition Sciences, v. 69, n. 4, p. 359-366, 2019.

PARRA-RODRÍGUEZ, G. L.; CORTES-DAZA, K.; CORRADINE-MORA, D. T. Efecto del extracto etanólico de semillas de Annona muricata (Guanábana) para el control de larvas de mosquitos Culex quinquefasciatus. Intropica, v. 12, n.1, p. 23-30, 2017.

PELIZER, L. H.; PONTIERI, M. H.; DE OLIVEIRA M. I. Utilização de resíduos agroindustriais em processos biotecnológicos como perspectiva de redução do impacto ambiental. Journal of Technology Management \& Innovation, v. 2, n. 1, p. 118-127, 2007.

PINTO, L. C.; CERQUEIRA-LIMA, A. T. SUZARTH, S. S.; DE SOUZA, R.; TOSTA, B. R.; DA SILVA, H. B.; PIRES, A. O.; QUEIROZ, G. A.; TEIXEIRA, T. O.; DOURADO, K. M. C.; COSTA, V. O.; BAQUEIRO, V.; OLIVEIRA, D. P.; BRANDÃO, H. R.; SOUZA, C. O.; DRUZIAN, J. I.; MEDEIROS, K. C. P.; ALVES, C. A. D. FIGUEIREDO, C. A. V. Anonna muricata L.(soursop) seed oil improves type 1 diabetes parameters in vivo and in vitro. PharmaNutrition, v. 6, n. 1, p. 1-8, 2018.

PINTO, L. C.; DE SOUZA, C. O.; DE SOUZA, S. A.; DA SILVA, H. B.; DA SILVA, R. R.; CERQUEIRA-LIMA, A. T.; TEIXEIRA, T. O.; SILVA, T. M. S.; MEDEIROSE, K. C. P.; BITTENCOURTF M.; BRANDÃO, H. R.; DRUZIANB, J.I.; CONCEIÇÃO, A. S.; LOPESH M.V.; FIGUEIREDO, C. A. Potential of Annona muricata L. seed oil: phytochemical and nutritional characterization associated with non-toxicity. Grasas y aceites. v. 69, n. 1, p. 234, 2018.

RAYBAUDI-MASSILIA, R.; SUÁREZ, A. I.; ARVELO, F.; MOSQUEDA-MELGAR, J.; ZAMBRANO, A.; CALDERÓN-GABALDÓN, M. I. An analysis in vitro of the cytotoxic, antioxidant and antimicrobial activity of aqueous and alcoholic extracts of Annona muricata L. seed and pulp. Current Journal of Applied Science and Technology, v. 5, n. 4, p. 333-341, 2015.

SANTOS, J. R.; BOÊNO, J. A. Muffins isentos de glúten e lactose desenvolvidos com resíduo de polpa de graviola (Annona muricata). Revista de Agricultura Neotropical, v. 3, n. 3, p. 42-51, 2016.

SÃO JOSÉ, A. R.; PIRES, M. D. M.; FREITAS, A.; RIBEIRO, D. P. e PEREZ, L. A. A. Atualidades e perspectivas das Anonáceas no mundo. Revista Brasileira de Fruticultura, Jaboticabal-SP, v. 36, p. 86-93, 2014.

SAPUTRA, R. D.; HADIASTONO T.; AMINUDIN AFANDHI A.; BEDJO. Sinergisme Spodoptera litura nuclear polyhedrosis virus JTM 97C (SINPV-JTM 97C) Dengan Ekstrak Biji Sirsak (Annona muricata L.) Dalam Pengendalian Helicoverpa armigera Hubner (Lepidoptera: Noctuidae) Pada Tanaman Kedelai (Glycine max L.) Di Laborator. Jurnal Hama dan Penyakit Tumbuhan, v. 3, n. 3, p. 26-33, 2016.

SCHMIDT-HEBBEL, H. Qencia y tecnologia de los alimentos. Santiago, Ed. Universitaria, 1973. p.I 19. 
SETIAWAN, E.; KARIMUNA, S. R.; JAFRIATI, J. Efektifitas ekstrak biji sirsak (Annona muricata $\mathrm{L}$ ) sebagai insektisida alami terhadap nyamuk Aedes aegypti Sebagai Vektor Dbd. Jurnal IImiah Mahasiswa Kesehatan Masyarakat, v. 1, n. 3, p. 1-8, 2017.

SISWARNI, M. Z.; NURHAYANI; SINAGA, S. D. Ekstraksi acetogenin dari daun dan biji sirsak (Annona muricata L) dengan pelarut aseton. Jurnal Teknik Kimia USU, v. 5, n. 2, p. 38-42, 2016.

SU, C. H.; NGUYEN, H. C.; PHAM, U. K.; NGUYEN, M. L.; JUAN, H. Y. Biodiesel production from a novel nonedible feedstock, soursop (Annona muricata L.) seed oil. Energies, v. 11, n. 10, p. 2562, 2018.

WIDYASTUTI, D. A.; RAHAYU, P.; DEWI, L. R. Potensi ekstrak sirsak (Annona muricata) sebagai larvasida pengendali populasi Aedes albopictus. Bioeksperimen: Jurnal Penelitian Biologi, v. 5, n. 1, p. 48-54, 2019. 


\title{
Capítulo 12
}

\section{Manejo agroecológico do ácaro rajado -Tetranychus urticae}

\author{
Kíssila França Lima1, Luciano Menini ${ }^{2}$, Victor Dias Pirovani ${ }^{2}$, Luciana Alves Parreira ${ }^{3}$
}

\section{Introdução}

Nas últimas décadas, a preocupação com o desenvolvimento sustentável tomou conta da sociedade em decorrência do declínio da qualidade de vida no meio rural e urbano e de problemas ambientais, associados a fatores como a intensa degradação dos recursos naturais, atrelada à modernização da agricultura (MENDONÇA et al., 2014).

Devido a isso, tem crescido o mercado de produtos oriundos da produção em sistema orgânico e agroecológico, ganhando espaço com abrangência mundial. Os consumidores desses produtos têm buscado pela segurança alimentar associada também a preocupações sociais e ambientais relativas aos sistemas de produção. Dessa forma, é importante que a cadeia produtiva se atualize com alternativas sustentáveis de manejo que atendam essa demanda de mercado (VEDANA et al., 2016; VENZON et al., 2016).

Alguns dos grandes problemas enfrentados pelos produtores agrícolas nos processos produtivos são de ordem fitossanitária. Dentre a diversidade de pragas e doenças que as lavouras são acometidas, destacam-se os ácaros fitófagos, dentre eles o Tetranychus urticae (Koch, 1836) (Acari: Tetranychidae), praga que tem causado inúmeros prejuízos, pois alimenta-se de diversos cultivos agrícolas e ornamentais no Brasil e no mundo (SATO et al., 2009).

A adoção de práticas ecológicas, baseadas em tecnologias alternativas ao método químico sintético por meio de calendários de aplicações, para o controle de pragas agrícolas necessitam ser difundidas pela assistência técnica e extensão rural, conciliando os saberes tradicionais e científicos, de forma que esses conhecimentos sejam adotados e adaptados de acordo com a realidade de cada agricultor.

Nesse contexto, a proposta deste capítulo é apresentar, de modo geral, as alternativas agroecológicas para o manejo de ácaros fitófagos, com ênfase no ácaro rajado Tetranychus urticae, pois este tem ocasionado enormes danos econômicos a diversos cultivos e, dessa

${ }^{1}$ Me. em Agroecologia pelo Programa de Pós-Graduação em Agroecologia do Instituto Federal do Espírito Santo - Campus de Alegre, Caixa Postal 47, CEP: 29500-000, Alegre-ES. E-mail: kissilalima03@gmail.com

${ }^{2}$ Dr. Professor do Instituto Federal do Espírito Santo - Campus de Alegre, Caixa Postal 47, CEP: 29500000, Alegre-ES. E-mail: Imenini@ifes.edu.br; victor.pirovani@ifes.edu.br

${ }^{3}$ D. Professor da Universidade Federal do Espírito Santo, Caixa Postal 16, CEP: 29500-000, AlegreES. E-mail: lucianap.ufes@gmail.com 
forma, mostrar as possibilidades de controle dessa praga com uso sustentável do agroecossistema e a produção de alimentos seguros.

\section{Ácaro rajado e danos causados à agricultura}

Tetranychus urticae (Koch, 1836) é conhecido como ácaro-rajado. Pertencente à família Tetranychidae, é encontrado em locais de clima tropical e temperado, infestando cultivos em ambientes protegidos e em campo (ARAÚJO JUNIOR et al., 2010; MIGEON et al., 2019).

É uma espécie polífaga e cosmopolita, sendo considerada praga chave de muitos cultivos agrícolas e ornamentais (CABEDO-LÓPEZ et al., 2019). Possuindo uma extensa variedade de plantas hospedeiras, essa praga alimenta-se de mais de 1.100 espécies botânicas (GRBIC et al., 2011). Dentre as diversas plantas atacadas por esse ácaro, destacam-se as culturas de cultivo protegido, principalmente solanáceas (tomate, berinjela, pimentão), cucurbitáceas (pepino, abobrinha), plantas ornamentais (rosas, crisântemo, cravos), culturas anuais de campo (milho, algodão, soja) e culturas perenes (alfafa, morangos, uvas, cítricos e ameixas (CAZAUX et al., 2014).

Os danos provocados pelo ácaro rajado na agricultura vão desde perdas no rendimento dos cultivos ou na qualidade das culturas a prejuízos avaliados indiretamente, devido ao alto custo para o produtor com pesticidas para o controle da praga (VAN LEEUWEN et al., 2014).

Para se alimentar, esses ácaros fazem a raspagem e a sucção do conteúdo citoplasmático das células dos vegetais. Para tanto, possuem quelíceras modificadas em forma de estiletes, as quais são utilizadas para perfurarem diferentes partes da planta, promovendo a clorose e a necrose do órgão afetado, reduzindo a fotossíntese tendo consequentemente, perda acentuada da produção e da qualidade do produto colhido (BERTOLO et al., 2011; CARDOSO et al., 2012; AGUT et al., 2018).

O ácaro rajado é conhecido pela capacidade de produzir teias, utilizadas para estabelecer um micro-habitat colonial para proteção contra agentes abióticos, abrigo contra predadores, para comunicação através de feromônios e como veículo para sua dispersão (GRBIC et al., 2011). Possui curto ciclo de vida e alta fecundidade, o que tem dificultado seu controle. $\mathrm{Na}$ agricultura convencional (não agroecológica), aplicações frequentes de acaricidas sintéticos tem sido utilizadas, o que tem causado problemas pois tem levado ao desenvolvimento de resistência, tendo relatos de 93 ingredientes ativos diferentes que deixaram de ser eficientes contra essa praga e 417 casos registrados (VAN LEEUWEN et al., 2014).

Devido à dificuldade de controle desse ácaro e pela necessidade de buscar estratégias para fortalecer a segurança alimentar, serão apresentadas propostas de manejo com técnicas 
menos agressivas ao agroecossistema e a saúde dos produtores e consumidores visando o controle alternativo dessa praga.

\section{Métodos de manejo agroecológico do ácaro rajado}

Os artrópodes são organismos muito importantes do ponto de vista ecológico, pois assumem diferentes papéis no agroecossistema. A agricultura convencional (pós revolução verde) com a simplificação da vegetação, tem trazido grande desequilíbrio ao meio ambiente, como a redução da biodiversidade vegetal e animal original favorecendo o crescimento populacional de poucas espécies que tornam-se pragas, comprometendo as produções agrícolas (MEDEIROS et al., 2011).

O sistema de produção de alimentos de forma agroecológica orienta-se para a exploração dos variados produtos e serviços gerados pela biodiversidade nos agroecossistemas (PETERSEN et al., 2019), utilizando-se tecnologias de base ecológica.

Dessa forma, existem diversas estratégias de manejo de pragas, utilizando produtos de baixo custo e que não afetam a saúde do homem e nem causam desequilíbrio na natureza (PENTEADO, 2001). Na agroecologia essas alternativas geralmente são utilizadas de forma integrada e interligada, contribuindo para o controle dessas pragas da lavoura com mais efetividade.

Vale ressaltar que o controle do ácaro rajado em sistemas agroecológicos é um desafio para o agricultor, principalmente devido ao alto potencial reprodutivo dessa praga (SOTO, 2013). Porém, não é impossível se essas alternativas forem disponibilizadas e oferecidas ao produtor para diminuir os riscos de insegurança alimentar e ambiental.

É importante destacar também que o conhecimento do agricultor familiar sobre os agroecossistemas é fundamental na prática de ações sustentáveis e produtivas, devendo -se promover o sinergismo entre os conhecimentos tradicional e científico, procurando metodologias que promovam ações integradoras desses conhecimentos visando o manejo adequado dos agroecossistemas, oferta de alimentos de qualidade e serviços ambientais (MENDONÇA et al., 2014).

Assim sendo, apresenta-se aqui as três principais alternativas de controle do ácaro rajado para cultivos agroecológicos de produção de alimentos e que tem mostrado viabilidade.

- Controle Biológico;

- Controle Cultural;

- Controle Químico para uso na agroecologia. 


\section{Controle biológico}

O papel dos artrópodes na cadeia alimentar é variado, podendo ser tanto prejudicial quanto benéfico. Por essa razão, é importante que o agricultor saiba reconhecer sua função ecológica dentro do agroecossistema, pois há uma diversidade de organismos benéficos que atuam como inimigos naturais no controle biológico de pragas (MEDEIROS et al., 2011).

Define-se controle biológico como um fenômeno natural em que populações da praga que se pretende controlar são reguladas pela ação de seus inimigos naturais, deixando a densidade destas espécies em um nível inferior àquela que ocorreria na ausência desses reguladores (BARBOSA et al., 2017). O grupo dos inimigos naturais que atuam como agentes de controle biológico são formados por patógenos, predadores e parasitóides (ZANUNCIO JUNIOR et al., 2018). O controle biológico pode ocorrer naturalmente no agroecossistema, contribuindo para a manutenção do nível de equilíbrio das pragas na lavoura, ou de forma aplicada, onde criações massais são produzidas em condições laboratoriais e, posteriormente, liberadas no campo (ZANUNCIO JUNIOR et al., 2018).

O ácaro rajado e os outros ácaros fitófagos possuem diversos inimigos naturais que ocorrem naturalmente no agroecossistema. Dentre eles, os ácaros predadores da família Phytoseiidae (fitoseídeos), destacam-se no controle do Tetranychus urticae, além de outros artrópodes como aranhas e insetos. De acordo com Aguiar-Menezes et al. (2007), há uma diversidade de inimigos naturais que regulam populações de ácaros fitófagos.

Os ácaros predadores que pertencem às famílias Stigmaeidae, Bdellidae,
Cunaxidae, Anystidae, Cheyletidae, Tarsonemidae e Tydeidae. As famílias
Therididae e Linyphiidae, destacam-se por serem as mais abundantes e
principais aranhas predadoras de ácaros. Entre os insetos, destacam-se os
besouros da família Coccinellidae, principalmente do gênero Stethorus e da
família Staphylinidae, como espécies do gênero Oligota, os insetos da família
Chrysopidae e Conyopterigidae (Ordem Neuroptera), os percevejos da
família Miridae e Anthocoridae (Ordem Hemiptera), as moscas
Cecidomyiidae (Diptera), e os tripes (Ordem Thysanoptera) (AGUIAR-
MENEZES et al., 2007).

No Brasil, dentre os ácaros predadores fitoseídeos (Acari: Phytoseiidae), o Phytoseiulus macropilis (BANKS, 1905) e o Neoseiulus californicus (MCGREGOR,1954) têm sido utilizados como agentes de controle biológico do ácaro rajado em diferentes culturas, em cultivos extensivos, frutíferas, ornamentais e hortaliças. O Phytoseiulus macropilis é um especialista no controle dessa espécie devido ao seu ao hábito alimentar seletivo, pois consome exclusivamente ácaros pertencentes ao gênero Tetranychus. Já o $N$. californicus, alimenta-se preferencialmente do ácaro rajado, mas na ausência deste, pode se alimentar e desenvolverse com diferentes alimentos como outros ácaros, pequenos insetos ou pólen (BARBOSA et al., 2017). 
Outra possibilidade de controle biológico de ácaros fitófagos, e que tem demonstrado eficiência sobre o ácaro rajado, são os fungos entomopatogênicos. Os fungos Beauveria bassiana e Metarhizium anisopliae têm sido promissores no manejo de ácaros em diversas lavouras, por serem facilmente produzidos em meios de cultura sob condições laboratoriais e possibilitar a aplicação através de pulverizadores (CAVALCANTI et al., 2008; SANTOS et al., 2016). Os sintomas nos ácaros infectados são a perda da mobilidade e apresentar o corpo recoberto por micélio e, posteriormente, a morte por ação do patógeno (CAVALCANTI et al., 2008).

É importante destacar que tanto os predadores quanto os entomopatógenos supracitados são disponibilizados no mercado, podendo ser adquiridos comercialmente de empresas produtoras e, posteriormente, serem aplicados na lavoura. Informações detalhadas a respeito dos fabricantes, formulações, dosagens e modo de aplicação podem ser encontradas no Agrofit, sítio eletrônico do Ministério da Agricultura (MAPA) ${ }^{1}$ (VENZON et al., 2016), sendo recomendados para serem utilizados nos cultivos agroecológicos e orgânicos de produção de alimentos (BRASIL, 2014).

A manutenção de populações de inimigos naturais no campo é fundamental para o controle de ácaros, devendo-se fornecer condições e recursos suficientes para essa permanência. Deste modo, o controle biológico deve estar associado a um manejo cultural para obter maiores chances de sucesso (FADINI et al., 2004). Nesse sentido, destaca-se a importância da produção agroecológica, pois coopera para o aumento e para a manutenção de inimigos naturais dentro do agroecossistema, trazendo grandes contribuições no controle de pragas indesejáveis.

\section{Controle cultural}

O controle cultural de ácaros consiste em tornar as condições do ambiente menos favoráveis para as populações de fitófagos, reduzindo seu potencial reprodutivo e aumentando a taxa de mortalidade, favorecendo as populações de inimigos naturais (FADINI et al., 2004). De acordo com Medeiros et al. (2011), algumas medidas de controle cultural que são essenciais para manter e melhorar a atividade dos inimigos naturais na propriedade estão descritas neste trecho de seu trabalho:

manter nas áreas de cultivo as espécies arbóreas (nativas ou não); manter faixas de plantas arbustivas e arbóreas (bordaduras) em volta da área cultivada, servindo também como quebra-vento; dividir a área cultivada em talhões para otimizar o uso da terra; realizar plantio em consórcio ou policultivos com as espécies pertencendo a diferentes famílias, diferentes

1 Disponível em: http://agrofit.agricultura.gov.br/agrofit cons/principal agrofit cons. Acessado em: 22/09/2020. 
alturas e tempos de vida; manter espécies de plantas espontâneas em locais onde a terra não está sendo usada; realizar plantios com o mínimo de perturbação no ambiente; fazer a rotação de cultivos (MEDEIROS et al., 2011).

Nenhum outro aspecto dos sistemas agrícolas proporciona os serviços ecológicos necessários para assegurar a proteção de plantas contra as pragas tão bem como a diversidade da vegetação (AGUIAR-MENEZES e SILVA, 2011). A diversificação vegetal tende a favorecer o controle biológico, pois estão presentes inúmeras plantas com propriedades inseticidas, repelentes e atrativas que favorecem as populações dos inimigos naturais estabilizando as populações de insetos nocivos à plantação (ARAÚJO et al., 2018), além de atuarem como quebra ventos que auxiliam no controle de pragas atuando como barreiras e dificultando sua disseminação (TIVELLI, 2013). Um agroecossistema diverso e saudável se autorregula, não havendo necessidade de insumos externos, significando menos risco à saúde de pessoas e do ambiente, maior qualidade no trabalho, menor custo de produção e, além disso, a garantia de diversidade alimentar (MENDONÇA et al., 2014).

Outras medidas de controle cultural seriam a retirada de partes atacadas da planta para evitar a disseminação dentro da lavoura, a realização de podas em frutíferas, o ensacamento de frutos e o uso de feromônios em armadilhas (VENZON et al., 2016). O uso de sementes ou propágulos livres de pragas, adubação equilibrada e adequada, catação manual de algumas pragas, além de uso ferramentas limpas dentro da lavoura (ZANUNCIO JUNIOR et al., 2018), contribuem como medidas de controle cultural, dificultando a entrada de pragas na área de cultivo.

A irrigação por aspersão contribui para redução de pragas devido ao impacto das gotas de água sobre os artrópodes fitófagos (VIEIRA et al., 2004). A escolha da época correta de plantio de cada cultura, respeitando suas exigências climáticas, contribui para as plantas serem mais resistentes às pragas e doenças. A adoção de práticas que promovam a conservação do solo e seu uso sustentável, como o aporte de resíduos e a manutenção da cobertura do solo, contribuem para o aumento da matéria orgânica e, consequentemente, para o aumento da fauna edáfica, melhorando a sua qualidade biológica (TIVELLI, 2013).

O cultivo protegido em estufas com telado também é uma opção de controle, pois dificulta a entrada de fitófagos (MICHEREFF FILHO et al., 2012).

\section{Controle químico para uso na agroecologia}

Há uma diversidade de substâncias e práticas permitidas para uso em sistemas orgânicos/agroecológicos de produção, sendo divulgadas e regulamentadas pela Instrução 
Normativa (IN) № 17, de 18 de junho de 2014, e que encontram-se disponibilizadas nos anexos VII e VIII desta (BRASIL, 2014).

Dentre elas destacam-se os materiais repelentes, uso de semioquímicos (feromônios e aleloquímicos) em armadilhas, calda bordalesa e sulfocálcica, extratos de plantas, outros preparados fitoterápicos, óleos essenciais, dentre outros (BRASIL, 2014).

Para o controle do ácaro rajado, inúmeras plantas têm demonstrado potencialidade e atividade acaricida através da utilização de seus óleos essenciais e extratos, provenientes do seu metabolismo secundário. Pesquisas tem demonstrado a atividade sobre o T. urticae, dos óleos essenciais de folhas de Piper macedoi e Piper arboreum, de folhas de erva -de -santamaria, de folhas de eucalipto, de gengibre, de folhas de manjericão, de tomilho, alecrim, tangerina, dentre outros (BORN, 2012; PAES et al., 2015; SOUZA et. al., 2016; LIMA, 2020). Além disso, os extratos de folhas de eucalipto ( $E$. citriodora), de erva cidreira, de hortelã pimenta, de hortelã comum, capítulos florais de calêndula, bulbos de alho, folhas de agave, sementes de moringa, dentre outros, também tem demonstrado efeito sobre essa praga (VIEIRA et al., 2006; VERONEZ et al., 2012; HOLTZ et al., 2016).

O MAPA disponibiliza fichas agroecológicas, onde são divulgadas diversas alternativas (preparados ou receitas) para o controle de pragas agrícolas em sistemas agroecológicos de produção (MAPA, 2020). No que concerne ao controle de ácaros, estão disponibilizadas as fichas "controle de ácaros", "calda sulfocálcica", "uso de cavalinha", "extrato de alho e cebola", dentre outras (MEIRA et al., [s.d]a), (MEIRA et al., [s.d]b), (MOREIRA, [s.d]a), ( LEITE, et al.,[s.d]). Além dessas, existem outros tipos de caldas e preparados que são disponibilizados pela Embrapa e outras instituições, explicitando seus modos de preparo e usos (ANDRADE e NUNES, 2001; AYRES et al., 2020). As referências citadas mencionam atividade acaricida da "calda de pimenta do reino, alho e sabão", os "extratos de folhas e sementes de Nim", os "extratos de folhas de cravo de defunto", "calda de fumo", "soro de leite", "extratos de folha de arruda", dentre outros.

Há também diversos tipos de biofertilizantes que são divulgados para cultivos agroecológicos e que contribuem para o fortalecimento da resistência de plantas contra ácaros e outras pragas, atuam também como adubação para nutrição das plantas (MOREIRA, [s.d]b), sendo também divulgados pelo MAPA por meio de fichas agroecológicas (MAPA, 2020). Os biofertilizantes possuem concentrações variadas de macronutrientes ( $N, P, K, C a$, $\mathrm{S}, \mathrm{Mg}$ ) e micronutrientes ( $\mathrm{B}, \mathrm{Zn}, \mathrm{Cu}, \mathrm{Cl}, \mathrm{Mo}, \mathrm{Fe}, \mathrm{Mn}$ ), além da presença de algumas moléculas orgânicas como proteínas, enzimas, vitaminas, antibióticos naturais e bactérias benéficas, sendo considerados defensivos naturais, pois aumentam o vigor e a resistência das plantas (AYRES et al., 2020). 
É importante ressaltar que produtores orgânicos e agroecológicos certificados devem consultar a organização de controle social (OCS) ou ao organismo de avaliação da conformidade orgânica $(\mathrm{OAC})$ no qual estão vinculados, para que essas práticas sejam utilizadas caso não esteja no plano de manejo da propriedade (BRASIL, 2014).

Como podemos observar, diversas são as possibilidades de manejo para o controle do ácaro rajado e de outros ácaros em cultivos agroecológicos de alimentos. Essas tecnologias são oriundas do conhecimento de produtores, técnicos e pesquisadores, sendo importante ressaltar a necessidade dessas práticas serem cada vez mais divulgadas, aumentando a produção e o acesso a alimentos produzidos pelo manejo agroecológico a um maior número de consumidores.

\section{Considerações finais}

Esta revisão de literatura apresentou diversas formas de controles alternativos recomendados e regulamentados para serem utilizadas em sistemas agroecológicos de produção de alimentos para o manejo de ácaros fitófagos, incluindo o ácaro rajado.

Dentre as possíveis alternativas de controle do ácaro rajado em cultivos agroecológicos estão o controle biológico, o controle cultural e o controle químico para uso na agroecologia.

Entendendo que o conhecimento deve ser compartilhado e que os avanços científicos ocorrem a partir do diálogo de pesquisadores em conjunto com a sociedade, esse texto é um convite para que novas técnicas sejam pesquisadas e divulgadas e, conjugadas com os saberes tradicionais da agricultura familiar, possam contribuir com o desenvolvimento de práticas sustentáveis, economicamente viáveis e eticamente responsáveis.

\section{Agradecimentos}

Ao Programa de Pós-Graduação em Agroecologia (PPGA) do Instituto Federal do Espírito Santo - Campus de Alegre, pela oportunidade de estarmos publicando esse capítulo com um tema tão relevante, compartilhando conhecimentos agroecológicos para agricultores, técnicos, estudantes e sociedade em geral.

\section{Referências}

AGUIAR-MENEZES, E. L.; SILVA, A. C. Plantas atrativas para inimigos naturais e sua contribuição para o controle de pragas agrícolas. Seropédica: EMBRAPA Agrobiologia, 2011. 60p. 
AGUIAR-MENEZES, E. L; AQUINO, A. M.; CORREIA, M. E. F.; MENEZES, E. B. Ácaros: taxonomia, bioecologia e sua importância agrícola. Seropédica: EMBRAPA Agrobiologia, 2007. 24p.

AGUT, B.; PASTOR, V.; FLORS, V. Can plant defense mechanisms provide new approaches for the sustainable control of the two-spotted spider mite Tetranychus urticae? Review. Internacional Journal of Molecular Sciences, v. 19, n. 614, 20 p. 2018.

ANDRADE, L. N. T.; NUNES, M. U. C. Produtos alternativos para controle de doenças e pragas em agricultura orgânica. Aracajú: EMBRAPA Tabuleiros Costeiros, 2001. 20p.

ARAÚJO JÚNIOR, C. P.; CAMARA, C. A. G.; NEVES, I. A.; RIBEIRO, N. C; GOMES, C. A.; MORAES, M. M.; BOTELHO, P. S. Acaricidal activity against Tetranychus urticae and chemical composition of peel essential oils of three citrus species cultivated in NE Brazil. Natural Product Communications, v. 5, n. 3, p. 471-476, 2010.

ARAÚJO, E. A. S. G. O.; FERNANDES, S. D. C.; ROQUE, F.; DELGADO, M. N. Levantamento de plantas fitossanitárias utilizadas no manejo de pragas agrícolas. Revista Brasileira de Agroecologia, v. 13, n. 4, p. 164, 2018.

AYRES, M. I. C.; PUENTE, R. J. A.; NETO, J. G. F.; UGUEN, K.; ALFAIA, S. S. Defensivos naturais: manejo alternativo para pragas e doenças. Cartilha para produtores familiares. Manaus: Editora INPA, 2020. 32p.

BARBOSA, M. F. C.; DEMITE, P. R.; MORAES, G. J.; POLETTI, M. Controle biológico com ácaros predadores e seu papel no manejo integrado de pragas. PROMIP - Manejo Integrado de Pragas, 1. ed., São Paulo, 2017. 71p.

BERTOLO, F. O. A.; OTT, A. P.; FERIA, N. J. Ácaros em videira no Rio Grande do Sul. Boletim técnico da fundação estadual de pesquisa agropecuária. Rio Grande do Sul: Secretaria da Agricultura, Pecuária e Agronegócio, 2011. 26p.

BORN, F. S. Atividade de óleos essenciais das famílias Burseraceae, Lamiáceae, Rutaceae e Verbenaceae em Tetranychus urticae $\mathrm{KOCH}$, Neoseiulus californicus (MCGREGOR). Recife, PE, 2012, 101f.Tese (Doutor em Entomologia Agrícola). Universidade Federal Rural de Pernambuco, Recife, PE. 2012.

BRASIL. Ministério da Agricultura, Pecuária e Abastecimento. Instrução Normativa № 17, de 18 de Junho de 2014. Disponível em: <https://www.gov.br/agricultura/ptbr/assuntos/sustentabilidade/organicos/legislacao/portugues/instrucao-normativa-no-17-de18-de-junho-de-2014.pdf/view>. Acesso em: 09 ago. 2020.

CABEDO-LÓPEZ, M.; CRUZ-MIRALLES, J.; VACAS, S.; NAVARRO-LLOPIS, V.; PÉREZHEDO, M.; FLORS, V.; JAQUES, J. A. The olfactive responses of Tetranychus urticae natural enemies in citrus depend on plant genotype, prey presence, and their diet specialization. Journal of Pest Science, v. 92, p. 1165-1177, 2019.

CARDOSO, M. O.; MICHEREFF FILHO, M.; PAMPLONA, A. M. S. R. Recomendações técnicas para o manejo de insetos sugadores e ácaros fitófagos prejudiciais à melancia no Amazonas. Embrapa Amazônia Ocidental, Manaus, AM, 2012. 48p. 
CAVALCANTI, R. S.; REIS, P. R.; MOINO JUNIOR, A.; ALTOÉ, B. F.; FRANCO, R. A.; CARVALHO, T. M. B. Patogenicidade de fungos entomopatogênicos a três espécies de ácaros em cafeeiro. Coffee Science, Lavras, v. 3, n. 1, p. 68-75, 2008.

CAZAUX, M.; NAVARRO, M.; BRUINSMA, K. A.; ZHUROV, V.; NEGRAVE, T.; VAN LEEUWEN, T.; GRBIC, V., GRBIC, M. Application of two-spotted spider mite Tetranychus urticae for plant-pest interaction studies. Journal of Visualized Experiments, v. 89, p. 1-7, 2014.

FADINI, M. A. M.; PALLINI, A.; VENZON, M. Controle de ácaros em sistema de produção integrada de morango. Ciência Rural, Santa Maria, v. 34, n. 4, p. 1271-1277, jul-ago, 2004.

GRBIC, M.; VAN LEEUWEN, T.; PEER, Y. V. The genome of Tetranychus urticae reveals herbivorous pest adaptations. Nature, v. 479, p. 487-492, 2011.

HOLTZ, A. M.; CARVALHO, J. R.; FRANZIN, M. L.; PIRES, A. A.; COFFLER, T.; MARCHIORI, J. J. P. Toxicidade de extratos de Moringa oleífera para Tetranychus urticae. Revista Ifes Ciência, v. 2, n.1, 2016.

LEITE, C. D.; MEIRA, A. L.; MOREIRA, V. R. R. Extrato de alho e cebola no controle de insetos. Fichas agroecológicas, tecnologias apropriadas para a agricultura orgânica. Sanidade Vegetal 25. Disponivel em: <https://www.gov.br/agricultura/ptbr/assuntos/sustentabilidade/organicos/fichas-agroecologicas/arquivos-sanidade-vegetal/25extrato-de-alho-e-cebola-no-controle-de-insetos.pdf>. Acesso em: 10 ago. 2020.

LIMA, K. F. Caracterização química e atividade acaricida dos óleos essenciais de Piper macedoie Piper arboreum sobre Tetranychus urticae (Koch, 1836). Alegre, ES. 2020. 56f. Dissertação (Mestrado em Agroecologia), Instituto Federal do Espírito Santo, Alegre, 2020.

MAPA. Ministério da Agricultura, Pecuária e Abastecimento. Fichas Agroecológicas. Disponível em: <https://www.gov.br/agricultura/ptbr/assuntos/sustentabilidade/organicos/fichas-agroecologicas>. Acesso em: 16 ago. 2020.

MEDEIROS, M. A.; HARTERREITEN-SOUZA, E. S.; TOGNI, P. H. B.; MILANE, P. V. G. N.; PIRES, C. S. S.; CARNEIRO, R. G.; SUJII, E. R. Princípios e práticas ecológicas para o manejo de insetos-praga na agricultura. Brasília: EMATER - DF, 2011. 44p.

MEIRA, A. L.; LEITE, C. D; MOREIRA, V. R. R. Calda sulfocálcica. Fichas agroecológicas, tecnologias apropriadas para a agricultura orgânica. Sanidade Vegetal 5. Disponível em: $<$ https://www.gov.br/agricultura/pt-br/assuntos/sustentabilidade/organicos/fichas-

agroecologicas/arquivos-sanidade-vegetal/5-calda-sulfocalcica.pdf>. Acesso em: 10 ago. 2020.

MEIRA, A. L.; LEITE, C. D; MOREIRA, V. R. R. Uso de cavalinha no controle de doenças e insetos nocivos. Fichas agroecológicas, tecnologias apropriadas para a agricultura orgânica. Sanidade Vegetal 10. Disponível em: <https://www.gov.br/agricultura/ptbr/assuntos/sustentabilidade/organicos/fichas-agroecologicas/arquivos-sanidade-vegetal/10uso-de-cavalinha-no-controle-de-doenca-e-insetos-nocivos.pdf>. Acesso em: 10 ago. 2020.

MENDONÇA, E. S.; CARDOSO, I. M.; BOTELHO, M. I. V.; FERNANDES, R. B. A. Agroecologia, conservação do solo e da água e produção de alimentos na agricultura familiar. In: LEITE, L. F. C.; MACIEL, G. A.; ARAÚJO, A. S. F de. Agricultura conservacionista no Brasil. Brasília: EMBRAPA, 2014. p.411-424. 
MICHEREFF FILHO, M.; MOURA, A. P.; GUIMARÃES, J. A.; REYES, C. P.; CARVALHO, A. D. F.; AMARO, G. B.; LOPES, J. F.; LIZ, R. S. Recomendações técnicas para o controle de pragas do pepino. Brasília: EMBRAPA, 2012. 15p. (Circular Técnica 109)

MIGEON, A; TIXIER, M.S.; NAVAJAS, M.; LITSKAS, V. D.; STAVRINIDES, M. C. A predatorprey system: Phytoseiulus persimilis (Acari: Phytoseiidae) and Tetranychus urticae (Acari: Tetranychidae): worldwide occurrence datasets. Acarologia, v. 59, n. 3, p. 301-307, 2019.

MOREIRA, V. R. R. Controle de ácaros. Fichas agroecológicas, tecnologias apropriadas para a agricultura orgânica. Sanidade Vegetal 22. Disponível em: <https://www.gov.br/agricultura/pt-br/assuntos/sustentabilidade/organicos/fichas-

agroecologicas/arquivos-sanidade-vegetal/22-controle-de-acaros.pdf>. Acesso em: 10 ago. 2020.

MOREIRA, V. R. R. Biofertilizante. Fichas agroecológicas, tecnologias apropriadas para a agricultura orgânica. Fertilidade do Solo e Nutrição de Plantas 4. Disponível em: <https://www.gov.br/agricultura/pt-br/assuntos/sustentabilidade/organicos/fichas-

agroecologicas/arquivos-fertilidade-do-solo/4-biofertilizante.pdf>. Acesso em: 16 ago. 2020.

PAES, J. P. P.; RONDELLI, V. M.; COSTA, A. V.; VIANNA, U. R.; QUEIROZ, V. T. Caracterização química e efeito do óleo essencial de erva-de-santa-maria sobre 0 ácarorajado de morangueiro. Revista Brasileira de Fruticultura, Jaboticabal, SP, v. 37, n. 2, p. 346-354, 2015.

PENTEADO, S. R. Agricultura orgânica. Série Produtor Rural, edição especial, Piracicaba: ESALQ - Divisão de Biblioteca e Documentação, 2001. 41 p.

PETERSEN, P. F.; WEID, J. M. V. D.; FERNANDES, G. B. Agroecologia: reconciliando agricultura e natureza. In: SOUZA, M. M. O.; FOLGADO, C. A. R. (Eds.). Agrotóxicos e agroecologia: enfrentamentos científicos, jurídicos, políticos e socioambientais. Anápolis: UEG, 2019. 384p.

SANTOS, M. D.; DUARTE, M. E.; VALENTE, E. C. N.; BARBOSA, T. J. A.; SILVA, E. S. Eficiência de isolados comerciais de Beauveria bassiana (Bals.) Vuillemin e Metarhizium anisopliae (Metsch.) Sorok (Hypocreales: Cordycipitaceae, Clavicipitaceae) sobre o ácaro rajado Tetranychus urticae Koch (Acari: Tetranychidae). Revista Brasileira de Biociências, Porto Alegre, v. 14, n. 2, p. 76-79, 2016.

SATO, M. E.; SILVA, M. Z. da; SILVA, R. B. da; SOUZA FILHO, M. F. de; RAGA, A. Monitoramento da resistência de Tetranychus urticae Koch (acari: Tetranychidae) a abamectin e fenpyroximate em diversas culturas no estado de São Paulo. Arquivos do Instituto Biológico, São Paulo, v. 76, n. 2, p. 217-223, abr./jun., 2009.

SOTO, A.G. Manejo alternativo de ácaros plagas. Revista de Ciências Agrícolas, v. 30, n. 2, p. 34-44, 2013.

SOUZA, L. P.; ZAGO, H. B.; PINHEIRO, P. F.; VALBON, W. R.; ZUIM, V.; PRATISSOLI, D. Composição química e toxicidade do óleo essencial de eucalipto sobre o ácaro rajado. Comunicata Scientiae, v. 7, n. 4, p. 486-493, 2016.

TIVELLI, S. W. Como controlar pragas e doenças no cultivo orgânico? Pesquisa \& Tecnologia, v. 10, n. 1, p. 1-5, 2013. 
VAN LEEUWEN, T.; TIRRY, L.; YAMAMOTO, A.; NAUEN, R.; DERMAUW, W. The economic importance of acaricides in the control of phytophagous mites and an update on recent acaricide mode of action research. Pesticide Biochemistry and Physiology, v. 121, p. 12$21,2014$.

VEDANA, M. B.; VIEIRA, E. T. V.; ITAVO, L. C. V. Produção integrada: possibilidade de alimentos seguros e de qualidade. Revista FSA, Teresina, v. 13, n. 4, art.7, p. 115-133, jul./ago. 2016.

VENZON, M.; DIEZ-RODRIGUES, G. I.; FERRAZ, C. S.; LEMOS, F.; NAVA, D. E.; PALLINI, A. Manejo agroecológico das pragas das fruteiras. Informe Agropecuário, Belo Horizonte, v. 37, n. 293, p. 94-103, 2016.

VERONEZ, B.; SATO, M. E.; NICASTRO, R. L. Toxicidade de compostos sintéticos e naturais sobre Tetranychus urticae e o predador Phytoseiulus macropilis. Pesquisa Agropecuária Brasileira, Brasília, v. 47, n. 4, p. 511-518, 2012.

VIEIRA, M. R.; CORREA, L. S.; CASTRO, T. M. M. G.; SILVA, L. F. S.; MONTEVERDE, M. S. Efeito do cultivo do mamoeiro (Carica papaya L.) em ambiente protegido sobre a ocorrência de ácaros fitófagos e moscas-brancas. Revista Brasileira de Fruticultura, Jaboticabal, v. 26, n. 3, p. 441-445, 2004.

VIEIRA, M. R.; SACRAMENTO, L. V. S.; FURLAN, L. O.; FIGUEIRA, J. C.; ROCHA, A. B. O. Efeito acaricidade de extratos vegetais sobre fêmeas de Tetranychus urticae Koch (Acari: Tetranychidae). Revista Brasileira de Plantas Medicinais, Botucatu, v. 8, n. 4, p. 210-217, 2006.

ZANUNCIO JUNIOR, J. S.; LAZZARINI, A. L.; OLIVEIRA, A. A.; RODRIGUES, L. A.; SOUZA, I. I. M.; ANDRIKOPOULOS, F. B.; FORNAZIER, M. J.; COSTA, A. F. Manejo agroecológico de pragas: alternativas para uma agricultura sustentável. Revista Científica Intelleto, Venda Nova do Imigrante, ES, v. 3, n. 3, p. 18-34, 2018. 


\title{
Capítulo 13
}

\section{Produção de cafés especiais e sua relação com as condições edafoclimáticas: uma abordagem introdutória ao tema}

\author{
Lucas Louzada Pereira ${ }^{1}$, Aldemar Polonini Moreli ${ }^{1}$, Evandro de Andrade Siqueira ${ }^{2}$, Rogério \\ Carvalho Guarçoni ${ }^{3}$, Alexandre Rosa dos Santos ${ }^{4}$, Tais Rizzo Moreira ${ }^{5}$
}

\section{Introdução}

A lenda sobre a descoberta do chave ou café remonta a um pastor de ovelhas conhecido como Kaldi, descrita em diversos manuscritos no lêmen, no ano de 575 d.C, tendo como figura alusiva o pastor como o descobridor do café, em virtude das observações sobre seu rebanho após a ingestão de tais frutos, uma vez que os animais ficavam acordados além do normal.

A expansão da cultura do café no mundo é considerada complexa, não existindo um consenso literário a respeito do volume de produção nas zonas produtivas até o século XV e XVI. De forma resumida, os holandeses introduziram o café no Suriname em 1718, no Brasil a rubiácea chegou em 1727, por volta de 1730 os Ingleses levaram as plantas para a Jamaica e, em 1740, missionários da Espanha introduziram o café nas Filipinas, em Java. Em 1748, Don José Antonio Gelabert introduziu o café em Cuba, com sementes trazidas de Santo Domingo e por volta de 1750-60 o café atingiu o plantio na Guatemala (UKERS, 1922).

O café é uma bebida com sabores e aromas complexos, mundialmente consumida e sendo superada apenas pelo consumo da água. A composição de nuances de um café, são oriundas de diversos fatores que interagem entre vários estágios da produção, que se coadunam desde a escolha das mudas para produção, a escolha da forma de cultivo e manejo, técnicas de nutrição e adubação, perfazendo diversos estágios produtivos, passando pela colheita, pelo processamento, pela secagem e pelo armazenagem, findando com os processos de

\footnotetext{
1Drs. Professores do Instituto Federal do Espírito Santo - Campus Venda Nova do Imigrante, Rua Elizabeth Minete Perim, 500, Bairro São Rafael, CEP: 29375-000, Venda Nova do Imigrante - ES. Email: lucas.pereira@ifes.edu.br; aldemar.moreli@ifes.edu.br.

${ }^{2}$ Me. Professor do Instituto Federal do Espírito Santo - Campus Venda Nova do Imigrante, Rua Elizabeth Minete Perim, 500, Bairro São Rafael, CEP: 29375-000, Venda Nova do Imigrante - ES. Email: evandro.siqueira@ifes.edu.br.

${ }^{3}$ Dr. Pesquisador do Instituto Capixaba de Pesquisa, Assistência Técnica e Extensão Rural, Departamento de Estatística, Rua Afonso Sarlo, 160, Bento Ferreira, CEP: 29052-010, Vitória, Espírito Santo, Brasil. E-mail: rogerio.guarconi@incaper.es.gov.br.

${ }^{4}$ Dr. Professor da Universidade Federal do Espírito Santo, Centro de Ciências Agrárias e Engenharias, Alto Universitário; s/n 29500-000, Alegre - ES. E-mail: alexandre.santos@pq.cnpq.br.

${ }^{5}$ Doutoranda pela Universidade Federal do Espírito Santo, Centro de Ciências Agrárias e Engenharias, Av. Gov. Lindemberg, 316, 29550-000, Jerônimo Monteiro - ES. E-mail: taisr.moreira@hotmail.com
} 
industrialização. Sendo que no caso do café, a qualidade final é sempre expressa pela análise sensorial, por meio de provadores que fazem o controle de qualidade.

Até onde se sabe e se defende, à qualidade intrínseca do fruto é estabelecida ao nível da propriedade e das técnicas de processamento adotadas, sendo nas fazendas as operações mais importantes, e que irão determinar a qualidade da bebida final (VELMOUROUGANE, 2011).

Entretanto, os frutos do cafeeiro podem sofrer diversas reações biológicas e químicas durante a fase de formação dos frutos, impactando diretamente a colheita, o processamento, a secagem, o armazenamento e a torrefação. Sendo o processo de fermentação uma etapa quase que concomitante com a colheita, de acordo com Evangelista et al. (2014), os frutos de café ao serem processados permitem o surgimento de uma fermentação espontânea ou selvagem. Sendo assim, a compreensão dos fatores de ordem ecológica é primordial na condição de produção de café sustentável.

A função da fermentação é relativizada, muitas vezes, com o objetivo de degradação da mucilagem (apenas para a remoção dos açúcares presentes no pergaminho para facilitar a secagem do café), seja a fermentação em estado líquido, quando o café é processado por via-úmida (em tanques), seja por via seca, quando os frutos vão para a secagem natural.

Além disso, o efeito e ação dos microrganismos presentes nos frutos do café e no póscolheita, como Debaryomyces, Pichia, Candida, Saccharomyces Kluyveri e S. Ceverisiae (SILVA, 2008; PEREIRA et al., 2014a); de fungos filamentosos, como Aspergillus, Penicillium, Fusarium e Trichoderma; bem como as bactérias, por exemplo Lactobacillus, Bacillus, Arthrobacter, Acinetobacter, Klebsiella e Weissella (VELMOUROUGANE, 2013; EVANGELISTA et al., 2014) e a sua capacidade de fermentação no café vêm sendo estudados ao longo das últimas décadas, como uma oportunidade de otimização no processamento do café. Porém, pouco se sabe efetivamente a respeito dos reais impactos das populações microbianas na qualidade e como os fatores de ordem climática podem afetar estas populações.

Além destes fatores descritos, sabe-se que, normalmente os cafés de regiões mais elevadas recebem notas mais altas referentes ao sabor, ao aroma, à doçura e ao corpo, do que os cafés de regiões mais quentes (VAAST et al., 2006; JOËT et al., 2010).

Esse fator tem sido associado ao fato das altas temperaturas impedirem a translocação de alguns compostos químicos para os frutos (GUYOT et al., 1996; BERTRAND et al., 2006; 
BOSSELMANN et al., 2009), podendo assim constituir em um terroir ${ }^{1}$ natural destas microrregiões.

Outro fator a ser considerado é a produção de café no sistema de base agroecológica, especialmente com relação ao plantio sob a sombra de árvores, no qual é considerado como uma das alternativas daquele sistema na manutenção e restauração dos nutrientes do solo, bem como o sombreamento contribui na diminuição dos impactos severos do microclima, no qual o café está submetido (MOURA et al., 2019).

Embora o sombreamento e a altitude sejam empiricamente conhecidos por terem efeitos benéficos sobre a qualidade do café, apenas alguns estudos científicos realmente documentaram esses efeitos (JOËT et al., 2010).

De acordo com Botero et al. (2006), existe uma grande controvérsia sobre a produção de café sombreado e a pleno sol; para Somporn et al. (2012), pouco se tem discutido a respeito do efeito do sombreamento na qualidade final do café arábica. Muito desta controvérsia está associada a qual altitude e perfil de solo as lavouras podem receber ou não, quando se opta pelo sombreamento.

Para os autores, estudos nesta linha precisam considerar o nível de radiação solar, a luminosidade das lavouras, bem como a temperatura média, bem como as mudanças de câmbio climático. Nesta linha de raciocínio, alguns estudos tentam evidenciar o efeito do sombreamento, da altitude e da incidência de radiação solar sobre a qualidade do café. Dentre estes estudos relativos à altitude e sombreamento, destacam-se as contribuições de Guyot et al. (1996) e Bertrand et al. (2006) e mais recentemente (PEREIRA et al., 2018), indicando que o sombreamento e a altitude podem promover melhoria de qualidade do café arábica.

Assim, este capítulo tem por objetivo apresentar ao leitor um breve recorte a respeito de possíveis impactos na qualidade do café arábica, quando considerado os seguintes fatores: fatores determinantes da qualidade, aplicação de microrganismos na fermentação, e relação da altitude, clima e sombreamento sobre a qualidade final do café.

\section{Fatores determinantes da qualidade do café}

A qualidade natural do café é determinada por uma combinação complexa de sabores e aromas. O sabor possui apenas quatro classificações (doce, salgado, amargo e azedo), mas o aroma é mais complexo, com mais de 44 grupos básico de classificação (DE SOUZA ROLIM et al., 2020). Normalmente, existem dois meios de se processar o café após a colheita;

\footnotetext{
1 Referências que identifiquem um bem como originário do território de um país ou uma região, ou localidade nesse território, onde uma determinada qualidade, reputação ou outra característica do bem é essencialmente atribuível à sua origem geográfica (BARHAM, 2003).
} 
mantendo-se o fruto intacto, comumente denominado café natural (via seca ou Dry), ou processando-o por via-úmida (wet process), que pode ser entendida e desdobrada sob três formas: removendo-se apenas a casca e parte da mucilagem, denominado cereja descascado (CD); removendo-se a casca e a mucilagem mecanicamente (desmucilado); ou removendo-se a casca mecanicamente e a mucilagem por meio de fermentação (despolpado) (REINATO et al., 2012).

Aproximadamente 300 compostos químicos, presentes no café beneficiado grão cru, originam cerca de 850 compostos após o processo de torra (FLAMENT, 2001) e, estes determinam o sabor e aroma da bebida do café (GIOMO e BORÉM, 2011), ou seja, sua qualidade. Porém, a presença desses precursores depende de diversos fatores, dentre eles, os microrganismos presentes no grão (FARAH et al., 2006).

Os procedimentos de processamento e secagem do café (BORÉM et al., 2008; ISQUIERDO et al., 2011; CORADI e BORÉM, 2015), bem como, o armazenamento (CORADI et al.,2008; SAATH, 2010) também interferem na qualidade do produto, que é determinada pelas condições ambientais e de manejo da cultura ( FAVARIN et al., 2004; CUSTÓDIO et al., 2015).

Um fruto de café bem formado pode produzir uma boa bebida, mas um fruto cultivado sob qualquer estresse ambiental, provavelmente, não produzirá qualidade, independentemente de qualquer tratamento pós-colheita (BORÉM et al., 2008).

A cereja do café é composta por um exocarpo que é uma película externa, o mesocarpo que compreende a polpa mucilaginosa conhecida como polpa e mucilagem e o endosperma que consiste em dois grãos que contêm o embrião. Cada grão é coberto por um espermatozoide e é cercado pelo pergaminho (endocarpo).

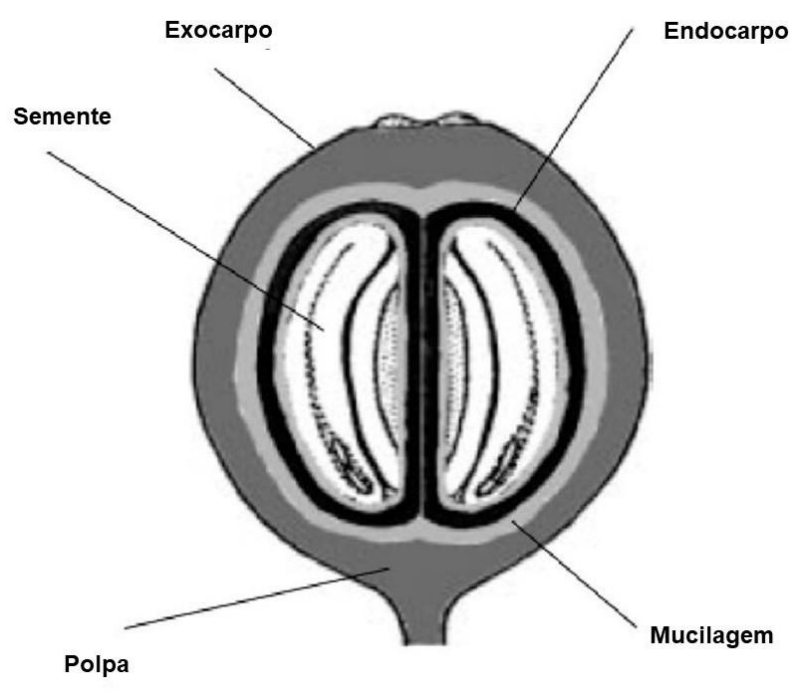

Figura 1. Secção longitudinal do fruto de café.

Fonte: Adaptado de Avallone et al. (2000). 
Assim, o processamento tem sido amplamente relativizado como uma etapa determinante da qualidade para a composição final da bebida do café, sendo que os fatores de ordem edafoclimáticas, muitas vezes são negligenciados se comparados aos processos que são aplicados nas fazendas produtoras de café.

Ao longo de séculos de produção de café no mundo, diversas técnicas e rotinas foram desenvolvidas, disseminadas, revisadas e aprimoradas. Estima-se que $40 \%$ das características físicas, químicas e sensoriais dos grãos são definidas por fatores de précolheita e que os $60 \%$ restantes dos índices de qualidade são determinados pelo método de processamento que é empregado no pós-colheita (MUSEBE et al., 2007).

Ou seja, deve existir um equilíbrio entre as condições de produção, manejo da lavoura, nutrição do solo e da planta, escolha adequada das variedades genéticas, para que os frutos cheguem saudáveis a etapa de processamento, para que o máximo da qualidade seja extraído. A fermentação espontânea aplicada na via-úmida ${ }^{2}$ é o processo fermentativo mais antigo que se tem conhecimento. $O$ processo consiste em colocar o café recém despolpado em tanques, geralmente de alvenaria, com água. O principal objetivo é promover a retirada da camada mucilaginosa que envolve a semente do café, rica em açucares simples e pectina (UKERS, 1922).

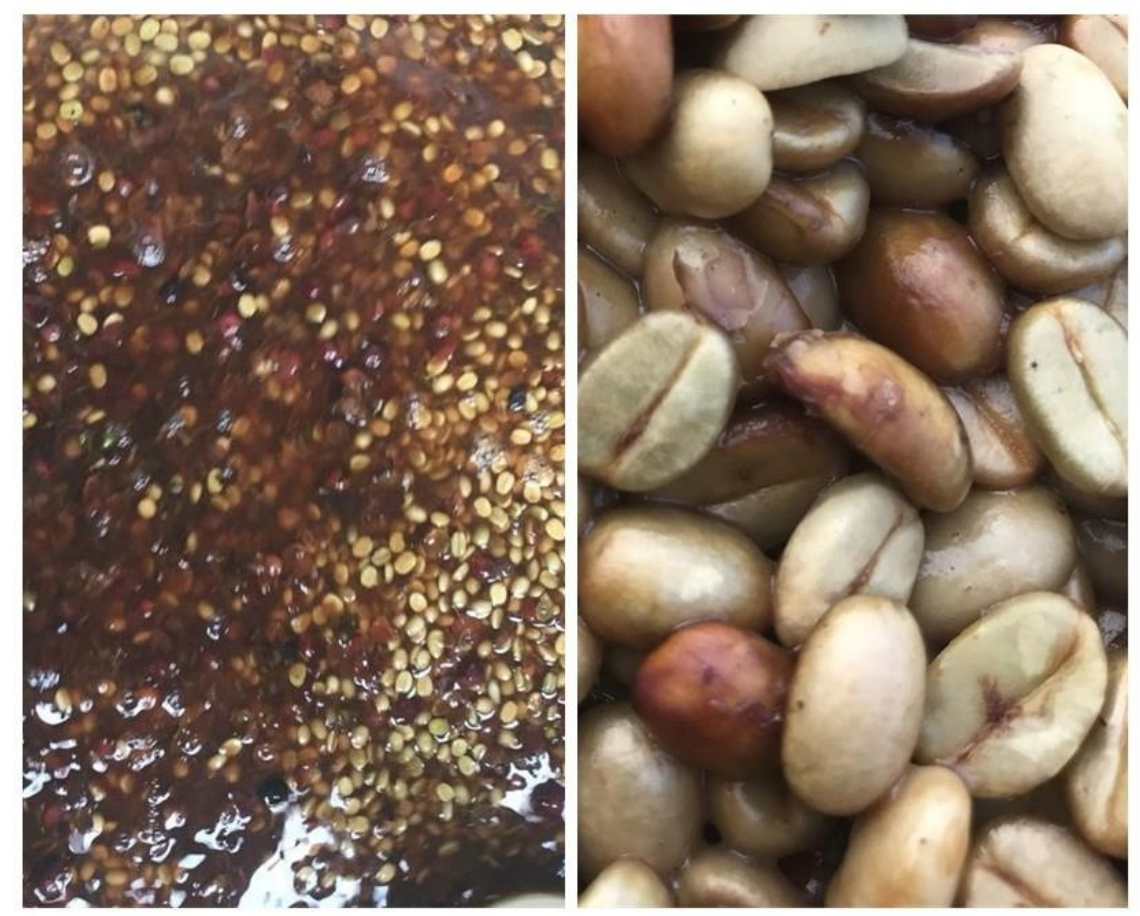

Figura 2. Processo de fermentação espontânea com o método washed. Fonte: Os Autores.

2 Etapa do processamento que aplica o uso da água para separação de frutos boias, e retirada da casca (mesocarpo), visando um processo de fermentação espontânea, com a finalidade de remoção da mucilagem e simplificação da secagem. 
A função da fermentação é relativizada muitas vezes, com o objetivo de degradação da mucilagem (apenas para a remoção dos açúcares presentes no pergaminho para facilitar a secagem do café), seja a fermentação em estado líquido, quando o café é processado por via-úmida (em tanques), seja por via seca, quando os frutos vão para a secagem natural.

Na fermentação com água (washed), também chamada de espontânea ou indígena, ocorre à fermentação natural do café, diferentes processos bioquímicos ocorrem, nos quais as enzimas produzidas pelas leveduras e bactérias presentes na mesma mucilagem fermentam e degradam seus açúcares, lipídios, proteínas e ácidos, e os convertem em álcoois, ácidos, ésteres e cetonas (QUINTERO e MOLINA, 2015).

Produtores optam por esse processamento devido ao baixo investimento em infraestrutura, pois eles utilizam uma caixa para retenção dos frutos, onde o café descascado é colocado e submergido por água. De modo convencionado, gerou-se um senso comum de que esse processo seria mais recomendado em zonas com alto indíce de humidade relativa do ar, com a finalidade de evitar fermentações nocivas a qualidade dos cafés, resultando assim, em um processo amplamente difundido na América Central e na América do Sul.

Já o processo via seco é o mais antigo e corresponde à maneira mais simples e natural de processar os frutos de café recém-colhidos. Nesse método, os frutos de café são secos com todas as partes que os constituem, dando origem aos cafés denominados coco, de terreiro ou natural (SILVA et al., 2013).

Em caso de condições ambientais favoráveis, tem sido relatado que esse método de processamento envolve uma maior probabilidade de exposição as micotoxinas. Isso acontece porque a casca do café tende a ser a maior fonte de micotoxinas para o grão. Para evitar o desenvolvimento de fungos patogênicos na casca do grão, recomenda-se que a secagem do café natural seja realizada sob rigorosos cuidados.

Autores têm discutido que as fermentações espontâneas ocorrem durante 0 processamento via-úmida e via seca, em razão de uma gama de microrganismos presentes nos frutos, como as bactérias, as leveduras e fungos filamentosos (PEREIRA et al., 2014; EVANGELISTA et al., 2014).

Para que o processamento de café alcance este nível de refinamento, seja por via-úmida ou via seca, é necessário estudar detalhadamente os processos internos à fermentação, tanto no aspecto do processamento em si quanto nas mudanças de ordem química e biológicas que possam ocorrer neste decurso. 

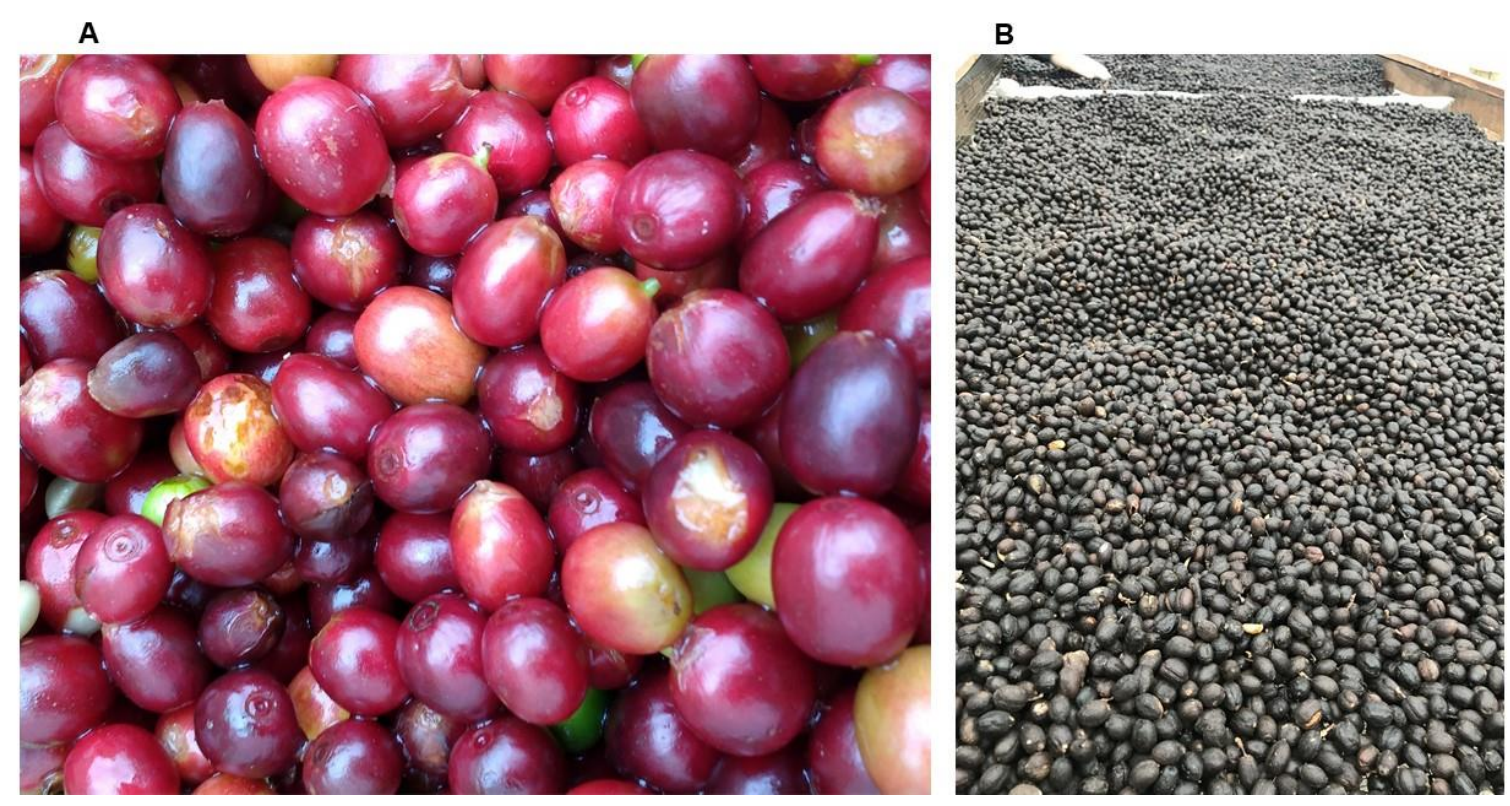

Figura 3. Frutos de café cereja processados pela via-seca em estágio maduro no sistema de secagem $(A)$ e frutos secos de forma natural $(B)$.

Fonte: Lucas Louzada Pereira.

A partir destas proposições é possível verificar que existe uma lacuna de oportunidades para maiores investigações, consequentemente, aumentar o conhecimento sobre a ecologia dos microrganismos e a bioquímica dentro do processamento/fermentação do café e como esse conhecimento científico pode contribuir para o desenvolvimento das características da bebida de café (KLEINWÄCHTER e SELMAR, 2010; PEREIRA et al., 2014). Para Masoud et al. (2004), as informações, quanto à comunidade de leveduras durante a fermentação do café, ainda são limitadas, principalmente, sobre suas ações no decurso do processamento.

Embora ainda não exista um acordo ou consenso, evidências recentes sugerem que os mecanismos pelos quais os microrganismos podem exercer impacto sobre o processamento de café passam pelos seguintes estágios: a degradação de materiais de celulose e mucilagem; gerando contribuições positivas e negativas para o sabor e aroma do café; a produção de micotoxinas que afetam a segurança alimentar do café; e o biocontrole de qualidade (SCHWAN e FLEET, 2015).

Os produtores que optam pelo processo de fermentação via-úmida geralmente adotam um período relativamente curto de fermentação (24 a 48h), onde a lavagem com água é usada para remover a camada de mucilagem final. Os cafés são, em seguida, levados para secagem até atingirem 12\% de umidade (UKERS, 1922; CORREA et al., 2014; TASCÓN et al., 2014).

Neste momento do processo, ocorrem ações microbianas que atuam com a fermentação no processamento via-úmida, sendo que no início da fase de fermentação, a população de bactérias é maior do que a população de levedura, independentemente do processo. Os gêneros mais comuns de bactérias presentes durante a fermentação de café são: 
Lactobacillus, Bacillus, Arthrobacter, Acinetobacter, Klebsiella e Weissella. As leveduras tendem a aumentar durante a fermentação/secagem e podem chegar a valores maiores do que a população bacteriana. Dentre as leveduras, cita-se: Saccharomyces, Pichia, Cândida, Rhodotorula, Hanseniaspora e Kluyveromyces, sendo a maioria dos gêneros de leveduras comumente encontradas (EVANGELISTA et al., 2014).

É evidente que a fermentação é um processo complexo, que envolve diversos fatores, com a ação de diferentes microrganismos, que podem atuar tanto na melhoria, quanto na perda da qualidade. Daí a importância em se conhecer melhor a ação da microbiota e dos processos de fermentação no decurso da produção de cafés especiais, tendo em vista a oportunidade de criação de processos mais padronizados, que considerem os fatores descritos, com vias de se promover melhorias de qualidade ao produto final, bem como segurança alimentar ao consumidor.

\section{Condições edáficas, climáticas e topográficas: possíveis impactos na qualidade sensorial do café}

O café arábica no Brasil é normalmente produzido a pleno sol, em zonas que variam de 600 a 1.400 metros de altitude, criando assim estratos e diferentes percepções sensoriais associadas aos sabores que cada café pode ter em virtude das condições edafoclimáticas e topográficas.

Até então, o que se sabe é que, normalmente, no Brasil, o café de região mais fria (altitude mais elevada) recebe maiores notas referentes ao sabor, ao aroma, à doçura e ao corpo, que as amostras de regiões mais quentes (ANDROCIOLI et al., 2003). Para Damatta (2004), este fator está associado ao fato de as altas temperaturas impedirem a translocação de compostos químicos para os frutos.

Para Neto et al. (2014), as constatações das alterações climáticas do planeta fazem com que novas técnicas de manejo sejam desenvolvidas, visando melhores adaptações da lavoura ao novo cenário climático mundial. Bertrand et al. (2006) discutem que depois de várias décadas promovendo intensivamente sistemas de plantio de café em pleno sol, há um renovado interesse na gestão do café arábica sob condições de sombra, principalmente, na América Central.

Associado ao fornecimento de água, a radiação solar e a temperatura condicionam a energia para a realização da fotossíntese, de grande importância para os processos de transpiração e metabolização da cultura (ANGELOCCI et al., 2008). Assim, devem-se considerar novas formas de manejo e cultivo do café em um sistema de sombreamento, uma vez que uma das benesses deste sistema é diminuir a severidade do microclima contribuindo 
para o aumento da produção (MOURA et al., 2019).

Isso ocorre porque a qualidade natural do fruto depende do acúmulo de carboidratos, compostos fenólicos e aldeídos durante o seu desenvolvimento (FAGAN et al., 2011), que depende principalmente da temperatura do ar e da disponibilidade de água (DAMATTA e RAMALHO, 2006).

A alta temperatura do ar, comum em altitudes mais baixas, acelera o enchimento e a maturação dos grãos (PIMENTA e VILELA, 2003), o que impede um acúmulo adequado de compostos aromáticos e, consequentemente, diminui a qualidade da bebida (CUSTÓDIO et al., 2015).

Da mesma forma, a baixa disponibilidade de água causa má formação do fruto, diminuindo sua qualidade natural (FAGAN et al., 2011). A qualidade dos frutos também pode ser influenciada pelo sombreamento. Neste sentido, Damatta; Ramalho (2006) observaram uma elevada porcentagem de grãos chochos em cafezais a pleno sol, devido à má formação dos grãos em função de estresses fisiológicos provocados na cultura.
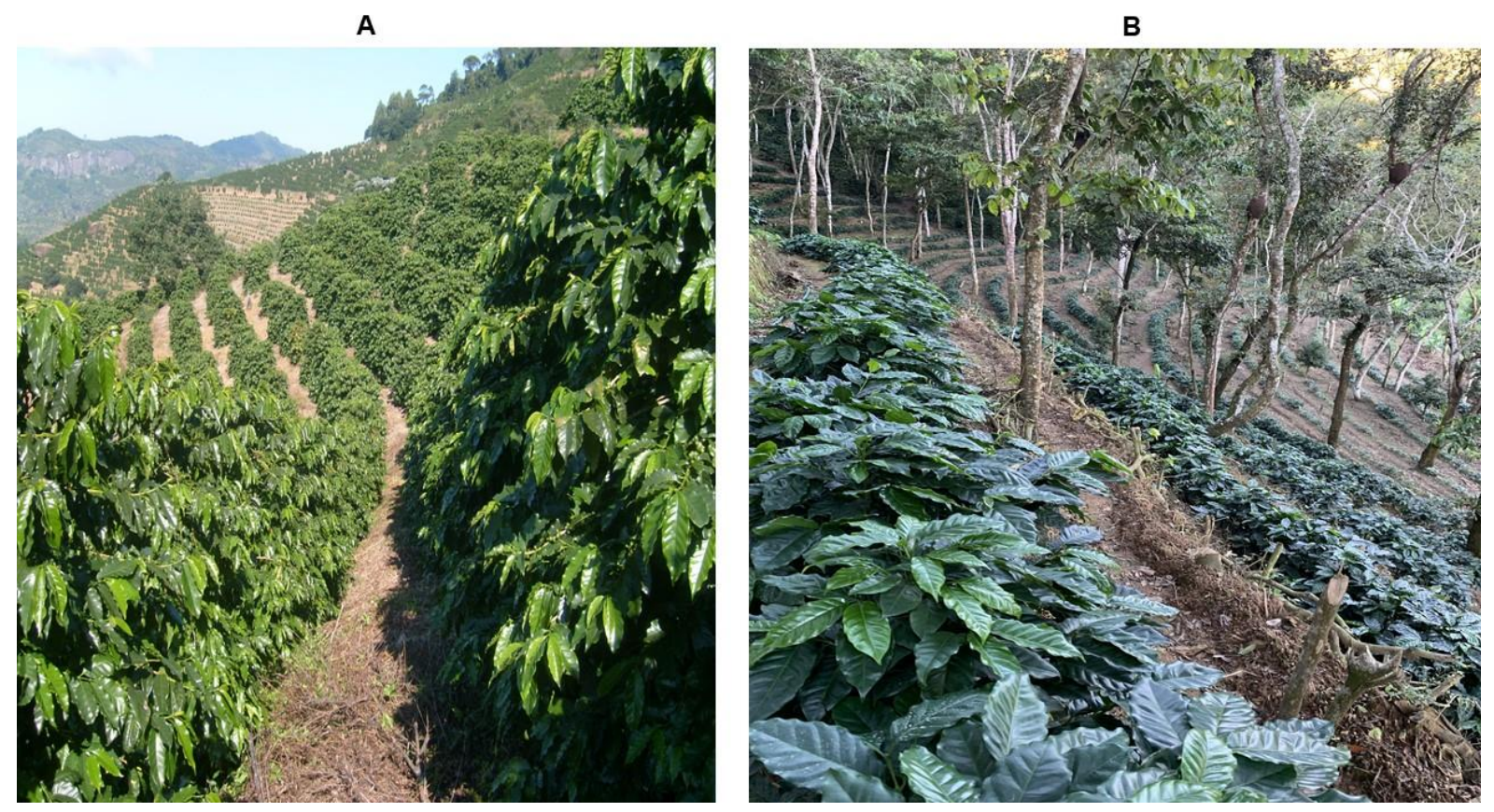

Figura 4. Sistema de cultivo do café arábica a pleno sol $(A)$ e sombreado (B). Fonte: Os Autores.

Acredita-se que os desafios impostos pelas alterações climáticas à produção agrícola, em geral, são cada vez mais intensos. Decorrentes de fenômenos, como El Niño e La Niña, resultantes de alterações atmosféricas, as atividades antrópicas, como desertificações, salinização de solos e escassez de água foram mais comuns, e as práticas de mitigação de seus efeitos devem ser incorporadas às práticas agropecuárias (INNOCENTINI, 2015).

As condições climáticas desfavoráveis podem diminuir o acúmulo de fotoassimilados, 
afetando a qualidade natural do grão de café (FAGAN et al., 2011). Brando e Staut (2012) relataram que a produção de café arábica de alta qualidade é tão difícil quanto a produção de vinho fino, pois depende tanto da experiência dos agricultores quanto das características climáticas dominantes da região. Chuvas excessivas e alta umidade durante a maturação, causam a proliferação de microrganismos que podem promover a fermentação da polpa de grãos e, portanto, reduzir drasticamente a qualidade natural do café (ABRAHÃO et al., 2009).

Por outro lado, a ausência de água no período crítico de desenvolvimento dos grãos, bem como altas temperaturas, reduzem a qualidade natural da bebida. Medidas como irrigação e sombreamento surgem para mitigar o impacto dessas variáveis climáticas sobre os cultivos, condicionando uma produtividade de qualidade e em quantidade economicamente rentável para os produtores.

Os fatores ambientais mais correlacionados à qualidade do café são: altitude, sombreamento e precipitação (com efeitos positivos e negativos). Outros fatores importantes associados à qualidade são a face de exposição do solo e a inclinação em que os cafeeiros são cultivados. Os efeitos dessas condições sobre algumas plantas (uvas -vinhos, ervas chás etc.) são conhecidos há muito tempo; porém, para a cultura do café, a influência desses fatores não estão claros (AVELINO et al., 2005).

O cultivo a pleno sol, no Brasil, é uma prática muito comum, em quase todas as regiões produtoras de café arábica e conilon. No entanto, o sistema de cultivo de café a pleno sol e o manejo intensivo não são recomendados na ausência de condições favoráveis ao desenvolvimento da cultura. Esses sistemas possuem uma riqueza ecológica inferior aos cultivos consorciados, pois a presença de árvores auxiliam no sombreamento e na melhoria dos teores de matéria orgânica do solo, além de, auxiliar no bloqueio da radiação solar direta, reduzindo a amplitude da variação térmica que, consequentemente, poderiam afetar o cafeeiro (VAAST et al., 2006).

É comum o emprego de dois termos específicos para denominar a orientação da encosta da montanha em relação à radiação solar incidente. Um deles é a "Encosta" ou "Face Noruega", que faz referência à encosta da montanha orientada em direção ao quadrante Sudeste, no qual se encontram as lavouras de café que recebem menor incidência de radiação solar direta, o outro é a face de solo Soalheira, onde as lavouras recebem maior carga de incidência solar (ZAIDAN et al., 2017).

Para Sediyama et al. (2001), as encostas de face Sul e Sudoeste podem estar sob a influência de ventos moderados a fortes, com temperaturas baixas. Por outro lado, as regiões norte, noroeste e nordeste mostram-se mais inaptas ao plantio por deficiência hídrica, ocorre com maior expressão nas regiões conhecidas como soalheiras. 
A partir dos relatos científicos, de que o clima pode ser um aliado da qualidade, existem esforços para tentar demonstrar que terrenos mais sombreados naturalmente produzem cafés de melhor qualidade do que terrenos soalheiros. Neste sentido, é necessário que as boas práticas de manejo, produção, processamento e industrialização sejam aplicadas para atender à demanda do mercado consumidor, que exige alta qualidade, a indústria cafeeira deve apoiar pesquisas que busquem identificar, rastrear e prever as condições climáticas que afetam a qualidade da bebida (FAGAN et al., 2011).

\section{Considerações finais}

O café é uma bebida que apresenta variação física e sensorial em função de sua proveniência, ou seja, impactada pelos fatores edafoclimáticos e pela forma como é cultivado e processado. Assim, é essencialmente um produto de terroir, sendo influenciado diretamente pelos aspectos ambientais, o que converge, por exemplo, com a produção do café no sistema de base agroecológica.

Os diferentes métodos de cultivo, as diferentes técnicas de colheita e de secagem, e as condições particulares de clima, solo e relevo, associados às características genéticas das diferentes variedades, criam a identidade da bebida e implicam na não repetição das safras, seja no aspecto qualitativo ou quantitativo (ALVES et al., 2011).

Desta forma, os fatores edafoclimáticos exercem papel fundamental nos processos fisiológicos e bioquímicos do cafeeiro, influenciando no excesso ou déficit hídrico do sistema solo-planta-atmosfera, e na absorção de nutrientes pela planta, interferindo na qualidade e produtividade do café (AGRIOS, 2005).

Ressalta-se que o café arábica é uma planta característica de clima tropical úmido, com temperaturas amenas, cultivado em regiões com altitude acima de $500 \mathrm{~m}$, sendo mais sensível às mudanças do clima, não suportando temperaturas elevadas e períodos prolongados de estiagem. As temperaturas médias anuais para o seu desenvolvimento estão na faixa de 19 a $22{ }^{\circ} \mathrm{C}$, com precipitações pluviométricas anuais acima de $1.200 \mathrm{~mm}$ e deficiência hídrica anual menor que $100 \mathrm{~mm}$ (MATIELLO et al., 2002; SANTINATO et al., 2008; PEZZOPANE et al., 2012; OMENA, 2014; SANTOS, et al., 2015).

Temperaturas abaixo de $18^{\circ} \mathrm{C}$, inaptas para o desenvolvimento do café Arábica, ocasionam danos aos tecidos foliares e no tronco, principalmente devido a formação de geadas. Já, temperaturas acima de $22{ }^{\circ} \mathrm{C}$, consideradas também inaptas, podem ocasionar prejuízos no florescimento, comprometendo a produção de frutos (TOMAZ et al., 2012). 
Deste modo, as características e condições edáficas para o plantio do café também devem ser consideradas (RENA et al., 1986). Ao realizar a seleção dos solos, deve-se observar com prioridade as condições físicas (cor, textura, estrutura, densidade, porosidade e profundidade), pois estas não podem ser modificadas. Entretanto, as propriedades químicas (superfície específica, cargas elétricas, adsorção e troca de íons, acidez do solo e teor de nutrientes) podem ser manejadas, objetivando a melhoria das características do solo, com destaque para as práticas de calagem e adubação.

Além disso, a escolha dos locais para o plantio do café deve-se dar preferência para o relevo que possa favorecer a mecanização, conservação do solo e manejo da cultura. De acordo com Bragança (2012), Luppi (2014), Matiello (1991), Omena (2014), Rena et al. (1986), Santos (1999) e Thomaziello et al. (1997) os solos adequados ao cultivo do cafeeiro devem apresentar as seguintes características: a) profundidade efetiva variando de $1 \mathrm{~m}$ (áreas sem carência hídrica) a 1,5 m (áreas com carência hídrica), b) serem bem drenados e porosos, c) teor de argila variando de 20 a $50 \%$ e d) suprimento de água, ar e nutrientes disponíveis às plantas.

Logo, fica evidente que a qualidade final é resultante de uma série de fatores que interagem no percurso da produção, dependendo assim de uma combinação adequada de fatores climáticos, edáficos, ecológicos e principalmente da forma de manejo a ser empregada, ou seja, o tipo de cultivo que o produtor adota pode ser um determinante da qualidade.

Assim, se a qualidade é afetada pelo sistema produtivo, e pelas condições edafoclimáticas, é primordial que tenhamos um cuidado de estudar, descrever e caracterizar sistemas de produção eficientes que aliem a produtividade, a qualidade e a sustentabilidade dos recursos naturais em zonas de produção.

\section{Agradecimentos}

Os autores agradecem à Cooperativa de Crédito de Livre Admissão Sul Serrana do Espírito Santo - Sicoob (23186000886201801), à Coordenação de Aperfeiçoamento de Pessoal de Nível Superior - CAPES e ao Conselho Nacional de Desenvolvimento Científico e Tecnológico - CNPq, ao Instituto Federal do Espírito Santo, pela apoio a pesquisa, por meio do edital PRPPG no. 10/2019 - Programa Produtividade Pesquisador - PPP, ao Programa de PósGraduação em Agroecologia (PPGA) do Ifes - Campus de Alegre, bem como o Instituto Capixaba de Assistência Técnica e Extensão Rural - INCAPER, e a Universidade Federal do Espírito Santo pela colaboração na pesquisa. 


\section{Referências}

ABRAHÃO, A. A.; PEREIRA, R. G. F. A.; BORÉM, F. M.; REZENDE, J. C.; BARBOSA, J. C. Physical analyses and quimical composition of coffee submitted to different fungicidal treatments. Coffee Science, v. 4, n. 2, p. 100-109, 2009.

AGRIOS, G. N. Plant Pathology. 5.ed. San Diego, CA: Academic Press, 2005.

ALVES, H. M. R; VOLPATO, M. M. L; VIEIRA, T. G. C; BORÉM, F. M.; BARBOSA, J. N. Características ambientais e qualidade da bebida dos cafés do estado de Minas Gerais. Informe Agropecuário, v. 32, n. 261, p. 1-12, 2011.

ANDROCIOLI, A; LIMA, F. B.; TRENTO, E. J.; CARNEIRO, F.; CARAMORI, P. H.; SCHOLZ, M. B. D. S. Caracterização da qualidade de bebida dos cafés produzidos em diversas regiões do Paraná. In: SIMPÓSIO DA PESQUISA DE CAFÉS DO BRASIL, 3., 2003, Porto Seguro. Anais... Brasília, DF: Embrapa Café, p. 256-257.2003.

ANGELOCCI, L. R.; MARIN, F. R.; PILAU, F. G.; RIGHI, E. Z.; FAVARIN, J. L. Radiation balance of coffee hedgerows. Revista Brasileira de Engenharia Agrícola e Ambiental, v. 12, n. 3, p. 274-281, 2008.

AVALLONE, S.; GUYOT, B.; BRILLOUET, J. M.; OLGUIN, E.; GUIRAUD, J. P. Microbiological and biochemical study of coffee fermentation current microbiology an international journal. Current Microbiology, v. 42, p. 252-256, 2001.

AVELINO, J.; BARBOZA, B.; ARAYA, J. C.; FONSECA, C.; DAVRIEUX, F.; GUYOT, B.; CILAS, C. Effects of slope exposure, altitude and yield on coffee quality in two altitude terroirs of Costa Rica, Orosi and Santa María de Dota. Journal of the Science of Food and Agriculture, v. 85, p. 1869-1876, 2005.

BERTRAND, B.; VAAST, P.; ALZIPAR, E.; ETIENNE, H.; DAVRIEUX, F.; CHARMETANT, P. Comparison of bean biochemical composition and beverage quality of arabica hybrids involving Sudanese-Ethiopian origins with traditional varieties at various elevations in Central America. Tree Physiology, Victoria, Canada: Heron Publishing, v. 26, p. 1239-1248, 2006.

BORÉM, F. M. Pós-colheita do café. Lavras: UFLA, 2008.

BOSSELMANN, A. S.; DONS, K.; OBERTHUR, T.; OLSEN, C. S.; RAEBILD, A.; USMA, H. The influence of shade trees on coffee quality in small holder coffee agroforestry systems in Southern Colombia. Agriculture, Ecosystems and Environment, v. 129, p. 253-260, 2009.

BOTERO, C. J.; MARTINEZ, H. E. P.; SANTOS, R. H. S. Característica do café (Coffea arabica L.) sombreado no note da América Latina e no Brasil. Coffee Science, Lavras, v. 1, n. 2, p. 94-102, jul./dez. 2006.

BRAGANÇA, R. Mapeamento da área plantada e impactos das mudanças climáticas no zoneamento agroclimatológico para as culturas do café conilon (Coffea canephora Pierre ex Froehner) e arábica (Coffea arabica L.) no estado do Espírito Santo. 2012. Thesis (Doctorate in Plant Production) - Federal University of Norte Fluminense, 2012. 
BRANDO, C. H. J.; STAUT, J. B. A. The revival of natural coffees. P \& A international marketing, v. 55, p. 4, 2012.

CORREA, E. C.; JIMÉNEZ-ARIZA, T.; DÍAZ-BARCOS, V.; BARREIRO, P.; DIEZMA, B.; OTEROS, R.; ECHEVERRI, C.; ARRANZ, F. J.; RUIZ-ALTISENT, M. Advanced characterization of a coffee fermenting tank by multi-distributed wireless sensors: spatial interpolation and phase space graphs. Food Bioprocess Technology, v. 7, p. 3166-3174, 2014.

CUSTÓDIO, A. A. DE P.; LEMOS, L. B.; MINGOTTE, F. L. C.; POLLO, G. Z.; FIORENTIN, C. F.; ALVES, G. S. P. Quality of coffee under different irrigation management, side of solar exposure and positions in the plant. IRRIGA, v. 20, n. 1, p. 177-192, 10 fev. 2015.

DAMATTA, F. M. Exploring drought tolerance in coffee: a physiological approach with some insights for plant breeding. Brazilian Journal Plant Physiology, v. 16, n. 1, p. 1-6, 2004.

DAMATTA, F. M.; RAMALHO, J. D. C. Impacts of drought and temperature stress on coffee physiology and production: A review. Brazilian Journal of Plant Physiology, v. 18, n. 1, p. 55-81, 2006.

DE SOUZA ROLIM, G.; APARECIDO, L. E. O; SOUZA, P. S.; LAMPARELLI, R. A. C.; SANTOS, E. R. Climate and natural quality of Coffea arabica L. drink. Theoretical and Applied Climatology, p. 87-98, 2020.

EVANGELISTA, S. R.; SILVA, C. F.; DA CRUZ MIGUEL, M. G. P.; CORDEIRO, C. S.; PINHEIRO, A.C. M.; DUARTE, W. F.; SCHWAN, R. F. Improvement of coffee beverage quality by using selected yeasts strains during the fermentation in dry process. Food Research International. v. 61, p. 183-195, 2014.

FAGAN, E. B.; SOUZA, C. H. E. de; PEREIRA, N. M. B.; MACHADO, V. J. Effect of time on coffe bean (Coffea sp.) grouth in cup quality. Bioscience Journal, v. 27, n. 5, p. 729-738, 2011.

FARAH, A.; MONTEIRO, M. C.; CALADO, V.; FRANCA, A. S.; TRUGO, L. C. Correlation between cup quality and chemical attributes of brazilian coffee. Food Chemistry, v. 98, n. 2, p. 373-380, 2006.

FLAMENT, I. Coffee flavor chemistry. [s.I.] Wiley, 2001, 424p.

GIOMO, G. S.; BORÉM, F. M. Cafés especiais no Brasil: opção pela qualidade. In: Produção de cafés: opção pela qualidade. Belo Horizonte: EPAMIG, p. 128. 2011.

GUYOT, B.; GUEULE, D.; MANEZ, J. C.; PERRIOT, J. J.; GIRON, J. ; VILLAIN, L. Influence de l'altitude et de l'ombrage sur la qualité des cafés arabica. Plantations, recherche, développement, p. 272-283, Juillet, Août 1996.

INNOCENTINI, M. Política brasileira do agronegócio do café: desafios e propostas. Revista Política Agrícola, ano 24, n. 52, p. 5-16, abr./jun. 2015.

JOËT, T.; LAFFARGUE, A.; DESCROIX, F.; DOULBEAU, S.; BERTRAND, B.; KOCHKO, A. de; DUSSERT, S. Influence of environmental factors, wet processing and their interactions on the biochemical composition of green Arabica coffee beans. Food Chemistry. v. 118, p. 693701, 2010. 
KLEINWÄCHTER, M.; SELMAR, D. Influence of drying on the content of sugars in wet processed green Arabica coffees. Food Chemistry. v. 119, p. 500-504, 2010.

LUPPI, A. S. L. Potencial agroclimático para o desenvolvimento da cultura do cafeeiro no estado do Espírito Santo. Viçosa, 2014. 131 f. Dissertação (Mestrado em Meteorologia Agrícola) - Universidade Federal de Viçosa, Viçosa, MG., 2014.

MASOUD. W.; CESAR, L. B.; JESPERSEN, L.; JAKOBSEN, M. et al. Yeast involved in fermentation of Coffea arabica in East Africa determined by genotyping and by direct desaturating gradient gel electrophoresis. Yeast. V. 21, p. 549-556, 2004.

MATIELLO, J.B.; SANTINATO, R; GARCIA, A.W.R.; ALMEIDA; S.R.; FERNANDES, D.R. Cultura do café no Brasil: novo manual de recomendações. Rio de Janeiro/ Varginha: Mapa - Sarc/Procafé; Fundação Procafé, 2002. 387p.

MATIELLO, J. B. O café: do cultivo ao consumo. São Paulo: Globo, 1991, 320p.

MOURA, W.M., LOPES, V.S., SILVA, A.S.L. Sistemas de base agroecológica: cultivo orgânico de café arábica e conilon. In: CARMO, D.L., PEREIRA, D.S., MIGUEL, E.S., LOPES, S.O., PRIORE, S.E. (Eds.). Pesquisa em Agroecologia: conquistas e perspectivas. Viçosa: Furnabe, 2019. p.123-143.

MUSEBE, R., AGWANDA, C., MEKONEN, M. No Title. Primary coffee processing in Ethiopia: patterns, constrains and determinants, p. 1417-1421, 2007. Disponível em: $<$ https://www.researchgate.net/publication/228470404\%0APrimary>.

NETO, J. N. P.; ALVARENGA, M. I. N.; CORREAA, M. de P.; OLIVEIRA, C. C. de. Efeito das variáveis ambientais na produção de café. Coffee Science, Lavras, v. 9, n. 2, p. 187-195, abr./jun. 2014.

OMENA, M. S. Conjunto de ferramentas computacionais para análises agroclimáticas. 2014. $106 \mathrm{f}$. Thesis (Master in Plant Production) - North Fluminense State University, 2014. Disponível em: <http://uenf.br/pos-graduacao/producao-vegetal/files/2015/02/CompletaDissertacao-Moises-Omena_ComFichaCatalografica_Color_Min.pdf >.

PEREIRA, L.L.; GUARÇONI, R.C.; CARDOSO, W.S.; TAQUES, R. C.; MOREIRA, T.R.; SILVA, S.F., TEN CATEN, C.S. Influence of Solar Radiation and Wet Processing on the Final Quality of Arabica Coffee. Journal of Food Quality., Article ID 6408571, 9 pages https://doi.org/10.1155/2018/6408571.

PEREIRA. G. V. M.; SOCCOL, V. T.; PANDEY, A.; MEDEIROS, A. B. P.; LARA, J. M. R. A., GOLLO, A. L.; SOCCOL, A. R. Isolation, selection and evaluation of yeasts for use in fermentation of coffee beans by the wet process. International Journal of Food Microbiology. v. 188, p. 60-66, 2014.

PEZZOPANE, J. E. M. et al. Zoneamento agroclimático. In: Agrometeorologia: aplicações para o Espírito Santo. Alegre: CAUFES, p. 99-134. 2012.

PIMENTA, C. J.; VILELA, E. R. Effect of type and harvest period on coffee quality (Coffea arabica L.). Acta Scientiarum-Agronomy, v. 25, n. 1, p. 131-136, 2003.

QUINTERO, G. I. P.; MOLINA, J. G. E. Fermentación controlada del café: tecnología para agregar valor a la calidad. Cenicafé, p. 1-12, 2015. 
REINATO, C. H. R.; BOREM, F. M.; CIRILLO, M. A.; OLIVEIRA, E. C. Qualidade do café secado em terreiros com diferentes pavimentações e espessuras de camadas. Coffee Science, Lavras, v. 7, n. 3, p. 223-237, set./dez. 2012.

RENA, A. B.; MALAVOLTA, E.; ROCHA, M.; YAMADA, T. Cultura do cafeeiro: fatores que afetam a produtividade. Piracicaba, SP: Associação Brasileira para Pesquisa da Potassa e do Fosfato, 1986, $447 \mathrm{p}$.

SAATH, R. Qualidade do café natural e despolpado em diferentes condições de secagem e tempos de armazenamento. Tese (Doutorado em Agronomia) - Universidade Estadual Paulista "Júlio de Mesquita Filho", Botucatu., 2010.

SANTINATO, R.; FERNANDES, A. L. T.; FERNANDES, D. R. Irrigação na cultura do café. 2. ed. Uberaba, MG: O Lutador, 2008.

SANTOS, A. R.; RIBEIRO, C. A. A. S.; SEDIYAMA, G. C.; PELUZIO, J. B. E.; PEZZOPANE, J. E. M.; BRAGANÇA, R. Zoneamento agroclimático no ArcGIS 10.3.1 passo a passo. Alegre: CAUFES, 2015, $58 \mathrm{p}$.

SANTOS, Alexandre Rosa. Zoneamento agroclimatológico para a cultura do café conilon (Coffea canephora L.) e arábica (Coffea arabica L.), na bacia do rio Itapemirim, ES. 1999. 125 f. Dissertação. (Mestrado em Meteorologia Agrícola), Viçosa, MG., 1999.

SCHWAN, R. F.; FLEET, G. H. Cocoa and coffee fermentation. By Taylor \& Francis Group, LLC. CRC Press, 2015.

SEDIYAMA, G. C.; MELO JUNIOR, J. C. F.; SANTOS, A. R. dos; RIBEIRO, A.; COSTA, M. H; HAMAKAWA, P. J.; COSTA, J. M. N. da; COSTA, L. C. Zoneamento agroclimático do cafeeiro (Coffea arabica L.) para o estado de Minas Gerais. Revista Brasileira de Agrometeorologia, Passo Fundo, v. 9, n. 3, Ed. Especial: Zoneamento Agrícola, p. 501-509, 2001.

SILVA, C. F.; BATISTA, L. R.; ABREU, L. M.; DIAS, E. S.; SCHWAN, R. F. Succession of bacterial and fungal communities during natural coffee (Coffea arabica L.) fermentation. Food Microbiology. v. 25, p. 951-957, 2008.

SILVA, C. F., VILELA, D.M., CORDEIRO, C.S., DUARTE, W.F., DIAS, D.R., SCHWAN, R.F. Evaluation of a potential starter culture for enhance quality of coffee fermentation. World Journal of Microbiology and Biotechnology, 2013.

SOMPORN, C.; KAMTUO, A.; THEERAKULPISUT, P.; SIRIAMORNPUN. Effect of shading on yield, sugar content, phenolic acids and antioxidant property of coffee beans (Coffea arabica L. cv. Catimor) harvested from north-eastern Thailand. Journal of Science and Food Agriculture, v. 92, p. 1956-1963, 2012.

TASCÓN, C. E. O.; VIANCHÁ, C. A. T.; RESTREPO, E. C. M.; URIBE, J. R. S.; GÓMEZ, C. A. R. Tecnología de bajo impacto ambiental para el lavado del café en proceso com fermentación natural. Cenicafé, v. 65, n. 1, p. 44-56, 2014.

TOMAZ, M. A.; AMARAL, J. F. T. do.; JESUS JUNIOR, W. C. de.; FONSECA, A. F. A. da.; FERRÃO, R. G.; FERRÃO, M. A. G.; MARTINS, L. D.; RODRIGUES, W. N. (Org.). Inovação, difusão e integração: bases para a sustentabilidade da cafeicultura. Alegre: CAUFES, 2012, 270 p. 
THOMAZIELLO, R.A.; OLIVEIRA, E.G.; TOLEDO FILHO, J.A.; COSTA, T.E. Cultura do Café. 3.ed. Campinas: Coordenadoria de Assistência Técnica Integral CATI, 1997, 75p. (Boletim Técnico, 193).

UKERS, W. H. All about coffee. Inter-American Copyright Union. By Burr Pirnting House. First Edition, 1922.

VAAST, P.; BERTRAND, B.; PERRIOT, J. J.; GUYOT, B.; GÉNARD, M. Fruit thinning and shade improve bean characteristics and beverage quality of coffee (Coffea arabica L.) under optimal conditions. Journal of the Science of Food and Agriculture, v. 86, p. 197-204, 2006. DOI: 10.1002/jsfa.2338.

VELMOUROUGANE, K.; BHAT, R.; GOPINANDHAN, T. N.; PANNEERSELVAM, P. Impact of delay in processing on mold development, ochratoxin-A and cup quality in arabica and robusta coffee. World Journal Microbiol Biotechnology, v. 27, p. 1809-1816, 2011.

VELMOUROUGANE, K. Impact of natural fermentation on physicochemical, microbiological and cup quality characteristics of arabica and robusta coffee. Proceedings of the National Academy of Science, India, v. 83, n. 2, p. 233-239, 2013.

ZAIDAN, U. R.; CORRÊA, P. C.; FERREIRA, W. P. M.; CECON, P. R. Ambiente e variedades influenciam a qualidade de cafés das matas de Minas. Coffee Science, Lavras, v. 12, n. 2, p. 240-247, abr.jun. 2017. 


\title{
Capítulo 14
}

\section{Implantação de sistema agroflorestal sucessional como alternativa para recuperação de áreas degradadas}

\author{
Lorenza Bandeira de Paula1 ${ }^{1}$, Otacílio José Passos Rangel², Lorena Abdalla de Oliveira Prata \\ Guimarães $^{3}$, Renato Ribeiro Passos ${ }^{4}$, André Oliveira Souza ${ }^{5}$, Júlio Cezar Machado \\ Baptestini $^{2}$
}

\section{Introdução}

O modelo de produção agrícola atual, baseado nos princípios da Revolução Verde, é caracterizado pela demanda intensiva de recursos naturais, insumos de síntese química e seleção de plantas e animais com potencial de resposta a estes insumos. Inegavelmente estes sistemas produtivos aumentaram a oferta de alimentos, combustíveis e fibras, contudo essas práticas da agricultura moderna têm desencadeado riscos potenciais ao meio ambiente (ROCHA et al., 2016). Esses riscos são causados principalmente por práticas inadequadas de manejo do solo. Uma das consequências dessas práticas foi o aumento das áreas degradadas no mundo. No Brasil, estima-se que há cerca de 140 milhões de hectares de áreas degradadas, o que corresponde a $16,5 \%$ do território nacional (CGEE, 2016). O Espírito Santo possui 393 mil hectares de solos degradados, o que corresponde a 8,5\% da área estadual e $16,7 \%$ da área agrícola total, destacando-se áreas cultivadas com pastagens e café (BARRETO e SARTORI, 2012).

A necessidade de colocar em prática sistemas sustentáveis de produção agrícola vêm sendo fundamentada há décadas pela ciência agroecológica, definida como a aplicação de conceitos e princípios ecológicos no desenho e manejo de agroecossistemas sustentáveis (ARANTES et al., 2017). Os sistemas agroflorestais (SAF's) têm grande relevância para os sistemas de produção mais eficientes e ambientalmente mais adequados. A consorciação de culturas traz uma série de benefícios, tanto produtivos (ex.: diversificação dos produtos)

${ }^{1}$ Me. em Agroecologia pelo Programa de Pós-Graduação em Agroecologia do Instituto Federal do Espírito Santo - Campus de Alegre, Caixa Postal 47, CEP: 29500-000, Alegre-ES. E-mail: lorenzabandeira@hotmail.com

${ }^{2}$ Drs. Professores do Instituto Federal do Espírito Santo - Campus de Alegre, Caixa Postal 47, CEP: 29500-000, Alegre-ES. E-mail: ojprangel@ifes.edu.br, julio.baptestini@ifes.edu.br

${ }^{3}$ Dra. Professora do Instituto Federal do Espírito Santo - Campus Centro-Serrano, CEP: 29645-000, Caramuru, Santa Maria do Jetibá-ES. E-mail: Iorena.guimaraes@ifes.edu.br

${ }^{4}$ Dr. Professor da Universidade Federal do Espírito Santo, Caixa Postal 16, CEP: 29500-000, AlegreES. Bolsista de Produtividade em Pesquisa do CNPq. E-mail: renatoribeiropassos@hotmail.com

${ }_{5} \mathrm{Me}$. Professor do Instituto Federal do Espírito Santo - Campus de Alegre, Caixa Postal 47, CEP: 29500000, Alegre-ES. E-mail: andreolisouza@gmail.com 
quanto ambientais (ex.: regulação do microclima e da umidade nos ambientes de produção) (MÜLLER et al., 2014).

A agrofloresta sucessional, proposta por Ernst Götsch, tem sido disseminada pelo Brasil e é um sistema biodiverso de produção agrícola, que visa a produção de alimentos de forma harmônica com o meio ambiente. Os SAF's sucessionais são operados de forma complexa e multiestratificada, implantados e manejados de modo a imitar a dinâmica da sucessão ecológica de uma floresta nativa. Diferente da agricultura convencional ou das agroflorestas tradicionais, o enfoque da agricultura sucessional são os processos de vida e biogeoquímicos, e não os insumos (GUIMARÃES e MENDONÇA, 2019).

Há quatro princípios que regem os sistemas agroflorestais sucessionais (GUIMARÃES e MENDONÇA, 2019): i) a alta biodiversidade, onde os consórcios, assim como na natureza, devem ser o mais variado possível, com espécies de todas as etapas sucessionais aproximando-se do clímax da vegetação natural local; ii) estratificação das espécies, que é a ocupação do espaço vertical da agrofloresta, sendo utilizada para reduzir a competição por luz entre as plantas e otimizar o uso do espaço agroflorestal.; iii) sucessão das espécies, que se resume no estabelecimento de consórcios sucessivos, em que cada consórcio cria condições melhores para outro que virá posteriormente e; iv) o abundante, contínuo e permanente aporte de resíduos orgânicos ao solo através das podas.

O local que cada espécie ocupa no redesenho agroflorestal dependerá de suas características ecofisiológicas e morfológicas na fase adulta - como exigência por luz, altura e ciclo de vida. Assim, as espécies são classificadas em estratos baixo, médio, alto e emergente, sendo este último o topo da agroflorestal, e é possível também aproveitar o espaço abaixo das espécies de estrato baixo - chamado de estrato rasteiro (GUIMARÃES e MENDONÇA, 2019).

A sucessão de espécies é o processo natural de acumulação quantitativa e qualitativa de fertilidade do solo, diversidade, complexidade, energia e vitalidade, em que o redesenho inicial transforma gradualmente o ambiente para receber consórcios mais complexos e exigentes (ARANTES et al., 2017).

As podas contínuas cumprem duas importantes funções: a abertura de clareiras para a renovação do sistema e o aporte abundante de resíduos vegetais ao solo. O input de matéria orgânica que ocorre através da decomposição dos resíduos vegetais, além da cobertura do solo, potencializa a ciclagem de nutrientes, gerando alterações físicas, químicas e biológicas, fatores fundamentais na manutenção da qualidade das funções da pedosfera (THOMAZINI et al., 2015; MU et al., 2016; Da SILVA et al., 2018).

O uso dos princípios da agrofloresta sucessional permite transformar áreas abandonadas e solos degradados em agroflorestas altamente produtivas e, simultaneamente, aumenta a 
biodiversidade e melhora a fertilidade do solo (GÖTSCH, 1996). A intervenção antrópica promove a melhoria do ambiente em um espaço de tempo consideravelmente reduzido em comparação com a regeneração que ocorre durante o pousio; como subproduto, tem-se a produção de alimentos (ANDRADE e PASINI, 2014).

Assim, utilizando-se a área experimental na Fazenda Experimental Bananal do Norte (FEBN), pertencente ao Instituto Capixaba de Pesquisa Assistência Técnica e Extensão Rural (INCAPER), o presente trabalho visa demonstrar a implantação e manejo do sistema agroflorestal sucessional para recuperação de áreas degradadas.

\section{Metodologia}

\section{Localização e descrição da área de estudo}

O estudo foi realizado na Fazenda Experimental Bananal do Norte (FEBN) pertencente ao Instituto Capixaba de Pesquisa Assistência Técnica e Extensão Rural (INCAPER), no município de Cachoeiro de Itapemirim, distrito de Pacotuba, sul do estado do Espírito Santo (Figura 1).

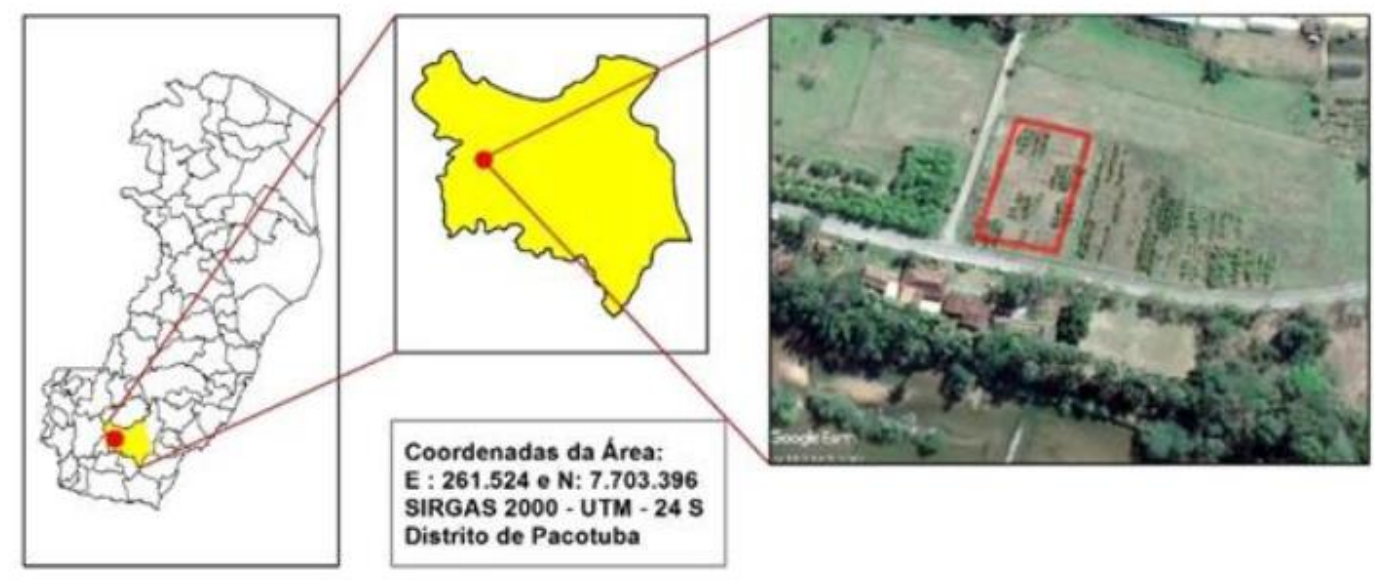

Figura 1. Mapa de localização da área experimental, em Cachoeiro de Itapemirim, Sul do estado do Espírito Santo. No polígono vermelho encontra-se a área do experimento.

Fonte: Os Autores.

A área experimental está a $81 \mathrm{~m}$ de altitude, nas coordenadas 2045'15"S (latitude) e $41^{\circ} 17^{\prime 2} 21^{\prime \prime O}$ (longitude). Segundo a Classificação de Köppen, o clima da região é do tipo Cwa, com verão chuvoso e inverno seco. A temperatura média anual é de $23^{\circ} \mathrm{C}$ e a precipitação média anual é de $1.200 \mathrm{~mm}$ (MENDONÇA et al., 2018). O solo da área é classificado como Neossolo Flúvico, situado em relevo suave ondulado (SOUZA et al., 2016), de textura argilosa apresentando $22 \%$ de areia, $22 \%$ de silte e $56 \%$ de argila. A caracterização química do solo, 
realizada conforme metodologia descrita em Teixeira et al. (2017), na profundidade de 0,00$0,20 \mathrm{~m}$, é apresentada na tabela 1.

Tabela 1. Caracterização química do solo antes da implantação do experimento.

\begin{tabular}{|c|c|c|c|c|c|c|c|c|c|c|c|c|c|}
\hline $\mathrm{pH}$ & $\mathrm{P}$ & $\mathrm{K}$ & $\mathrm{Na}$ & $\mathrm{Ca}$ & $\mathrm{Mg}$ & Al & $\mathrm{H}+\mathrm{Al}$ & SB & CTC & V & $\mathrm{m}$ & COT & $\mathrm{MO}$ \\
\hline $\mathrm{H}_{2} \mathrm{O}$ & \multicolumn{3}{|c|}{$-----\mathrm{mg} \mathrm{dm}^{-3}-----$} & \multicolumn{6}{|c|}{${ }_{-1}$} & \multicolumn{2}{|c|}{-----\%----- } & \multicolumn{2}{|c|}{--dag/kg-- } \\
\hline 5,02 & 8,99 & 151,25 & 3,5 & 2,5 & 0,8 & 0,63 & 5,35 & 3,72 & 9,7 & 41,6 & 15,5 & 1,06 & 1,83 \\
\hline
\end{tabular}

SB: soma de bases, T: capacidade de troca catiônica a pH 7,0, V: saturação por bases, m: saturação por Al, COT: carbono orgânico total, MO: mat. orgânica - Oxidação: $\mathrm{Na}_{2} \mathrm{Cr}_{2} \mathrm{O}_{7} 4 \mathrm{~N}+\mathrm{H}_{2} \mathrm{SO}_{4} 10 \mathrm{~N}$ Fonte: Os Autores.

Os dados climatológicos da área de estudo foram oriundos do banco de dados agroclimatológicos da Estação Meteorológica automática situada na FEBN, localizada a 146 m de altitude (Figura 2).

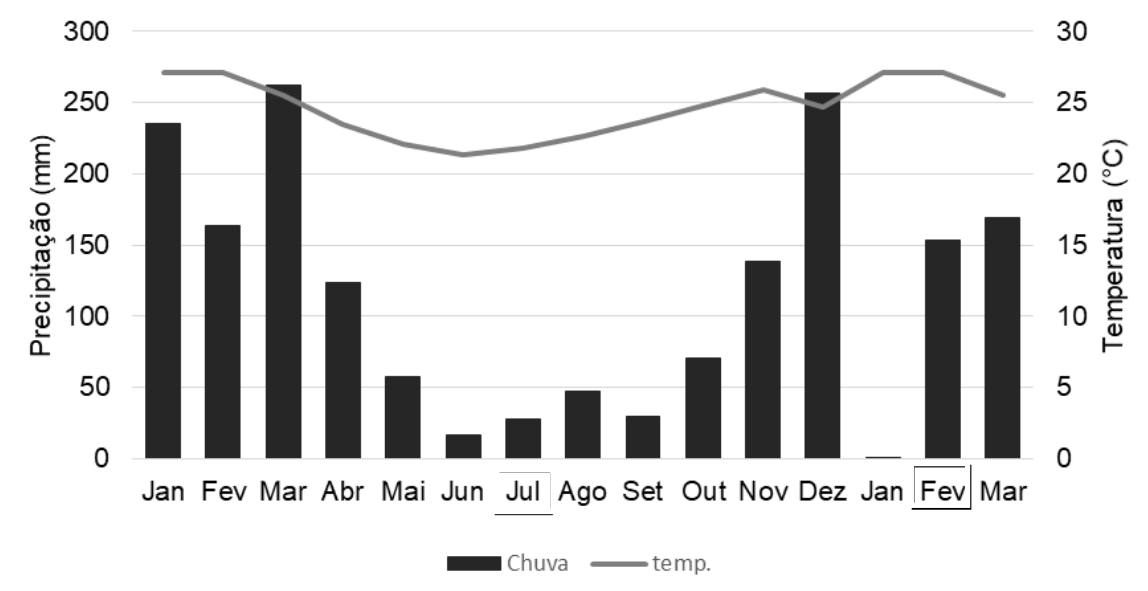

Figura 2. Climograma da região de Pacotuba, Espírito Santo, durante o período de janeiro de 2018 a março de 2019 (destaque para as épocas de avaliação do experimento, julho de 2018 e fevereiro de 2019).

Fonte: INCAPER, adaptado pelos autores.

Antes da implantação, a área foi utilizada por quase 20 anos num consórcio de café conilon (Coffea canephora Pierre ex. Froenher cv. Conilon) com pupunha (Bactris gasipaes kunth) (Figura 3). 


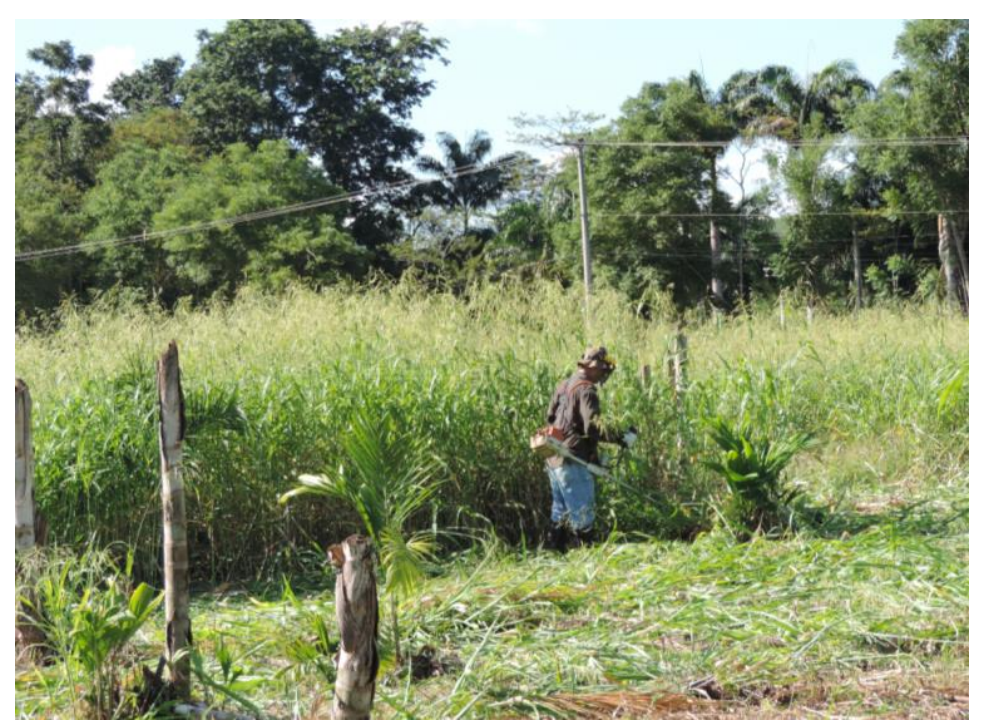

Figura 3. Área do experimento antes da implantação dos sistemas agroflorestais sucessionais. Fonte: Os Autores.

O café foi plantado no espaçamento $3,0 \times 1,5 \mathrm{~m}$, com a pupunheira plantada nas entrelinhas do café, em espaçamentos variados. Não havia irrigação na área em questão e as adubações eram realizadas de acordo com a análise de solo e demanda nutricional das culturas.

\section{Instalação e condução dos sistemas agroflorestais sucessionais}

Foram implantados dois sistemas agroflorestais sucessionais biodiversos (SAF's): SAF com frutíferas (SAF-F) e SAF com cafeeiro conilon (SAF-C). No SAF-F foram plantadas culturas anuais e frutíferas. No SAF-C, além do café foram cultivadas culturas anuais. Os SAF's foram baseados no manejo intensivo de podas e plantio em consórcio (GÖTSCH, 1996). Nos SAF-F e SAF-C foram plantadas as mesmas culturas anuais, divididas em dois ciclos de cultivo: o primeiro ano com culturas alimentares e o segundo com hortaliças. Os plantios foram realizados na mesma época (maio de 2017).

\section{Preparo inicial da área}

Antes da implantação do experimento, em março de 2017, realizou-se a calagem da área do experimento, com o objetivo de elevar a saturação por base do solo a $70 \%$, valor indicado para a maioria das hortaliças, frutíferas e café $O$ calcário foi aplicado a lanço e incorporado com a aração e gradagem até $0,30 \mathrm{~m}$ de profundidade. A necessidade de calagem foi calculada de acordo com os resultado da análise de solo (3,4 t/ha). Após 30 dias da calagem, os sistemas agroflorestais (SAF-C e SAF-F), receberam 30 tha de esterco de frango 
compostado, incorporados com enxada rotativa acoplada a microtrator. Em seguida, o solo foi coberto com resíduos de poda urbana triturados, tendo essa cobertura aproximadamente 4 $\mathrm{cm}$ de altura.

Como tratava-se de um trabalho experimental, os SAF's foram implantados em áreas reduzidas, com as parcelas apresentado uma área de $90 \mathrm{~m}^{2}$ (Figura 4).

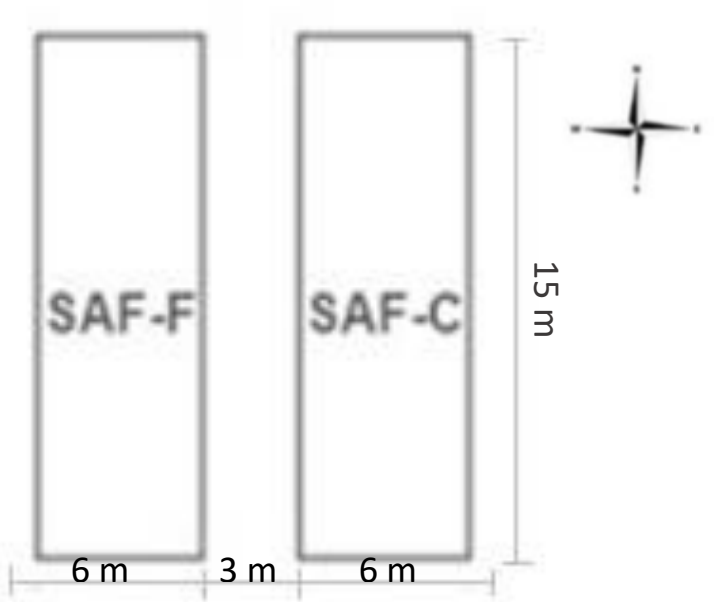

Figura 4. Croqui das parcelas experimentais.

Fonte: Os Autores.

\section{Plantio e condução dos tratamentos com sistemas agroflorestais (SAF's)}

Após o preparo das parcelas com calagem, incorporação do esterco de frango compostado e cobertura com resíduos vegetais, foram realizados os plantios.

A parcela experimental era constituída por cinco canteiros. Nos canteiros das bordas (linha das árvores ou linha das frutas) foram plantadas as frutíferas/cafeeiro conilon e as espécies arbóreas e nos outros três canteiros centrais, as culturas anuais (Figura 5). Após a delimitação dos canteiros, toda a superfície das parcelas foi coberta com uma camada de resíduos vegetais triturados (proveniente de podas urbanas), com $4 \mathrm{~cm}$ de altura. 


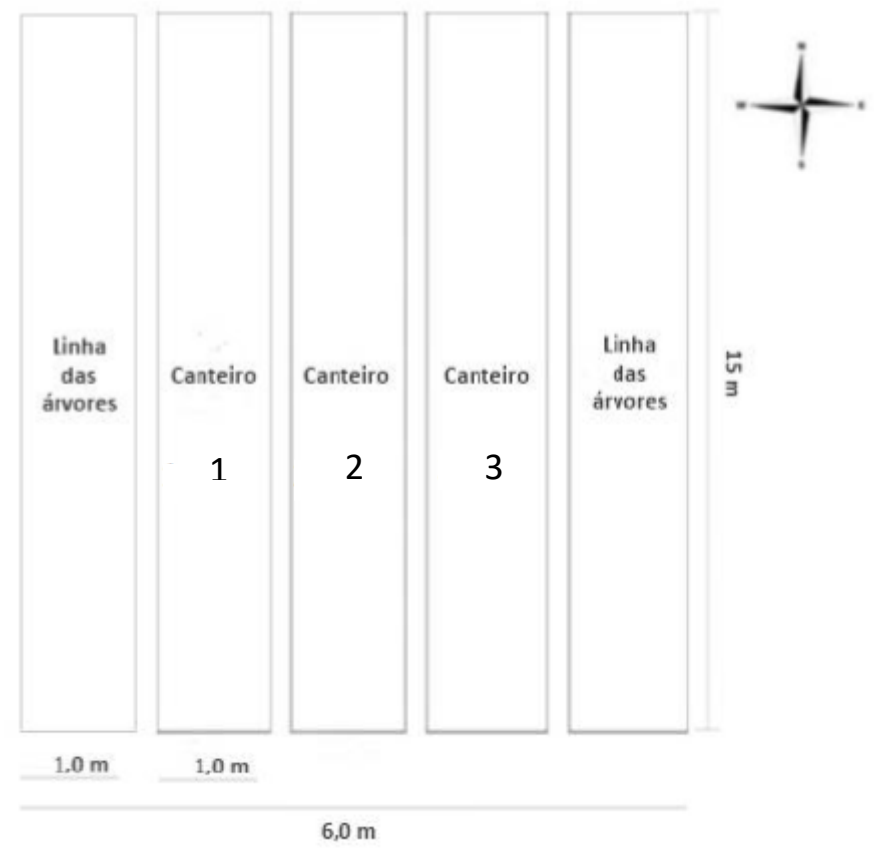

Figura 5. Croqui das parcelas experimental dos SAF's.

Fonte: Os Autores.

Os SAF's foram preparados e conduzidos da mesma forma, porém no SAF-F a cultura perene principal é a laranja (Citrus sinensis) e no SAF-C o café conilon (Coffea canephora). No primeiro ano de cultivo, na linha das árvores, foram plantadas as espécies perenes: laranja (SAF-F) ou café (SAF-C), bananeira (Musa sp.) e eucalipto (Eucalyptus urograndis). As duas últimas espécies foram escolhidas para as podas periódicas devido à elevada produção de biomassa, rápida rebrota, rusticidade, baixo custo e facilidade de aquisição (GUIMARÃES e MENDONÇA, 2019), onde os resíduos gerados foram utilizados para a cobertura do solo. Também foram plantadas mudas de mandioca (Manihot esculenta) e inhame (Dioscorea spp.) e semeadas sementes de milho (Zea mays) e feijão (Phaseolus vulgaris) (Figuras 6 e 7).

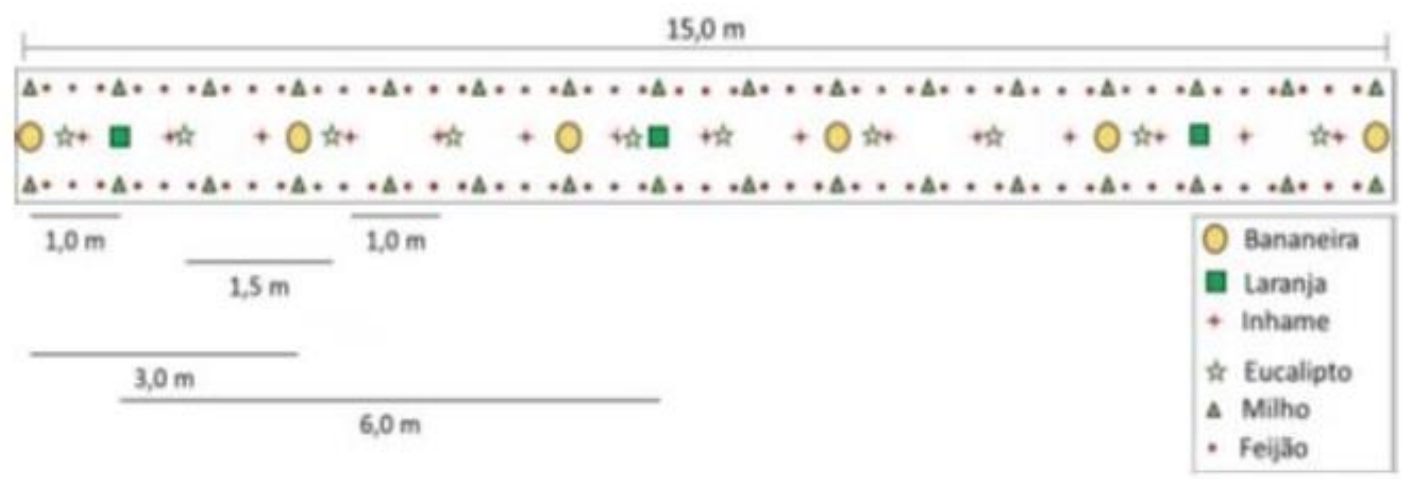

Figura 6. Croqui da linha das árvores no primeiro ano das culturas anuais do SAF-F. Fonte: Os Autores. 


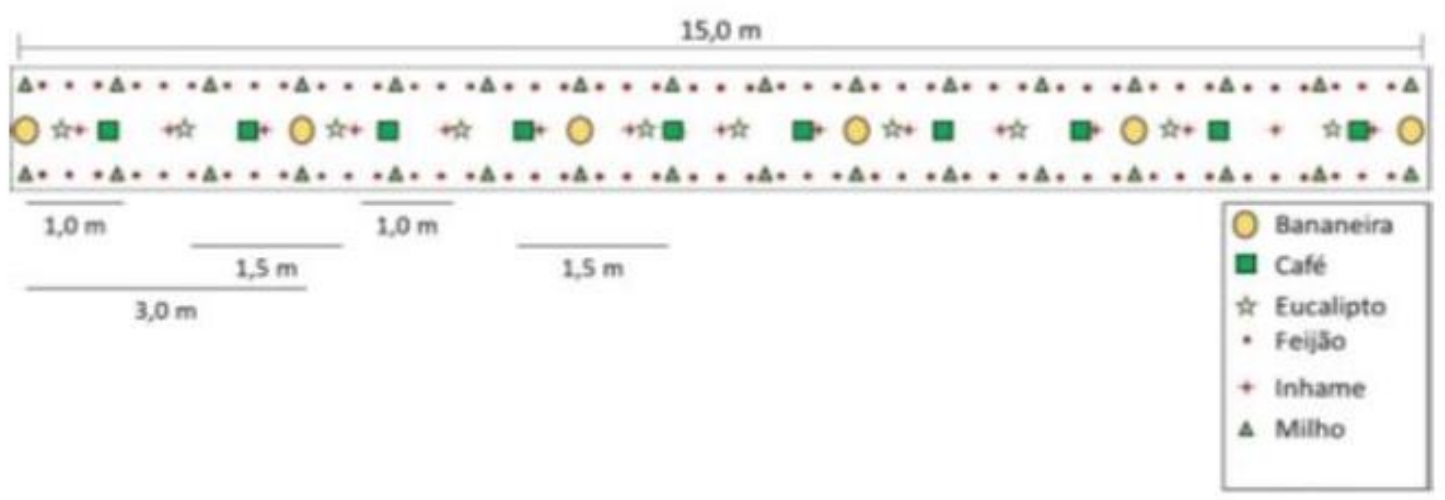

Figura 7. Croqui da linha das árvores no primeiro ano das culturas anuais do SAF-C. Fonte: Os Autores.

Na figura 8, observa-se a linha das árvores durante o primeiro ano das culturas anuais nos SAF's.
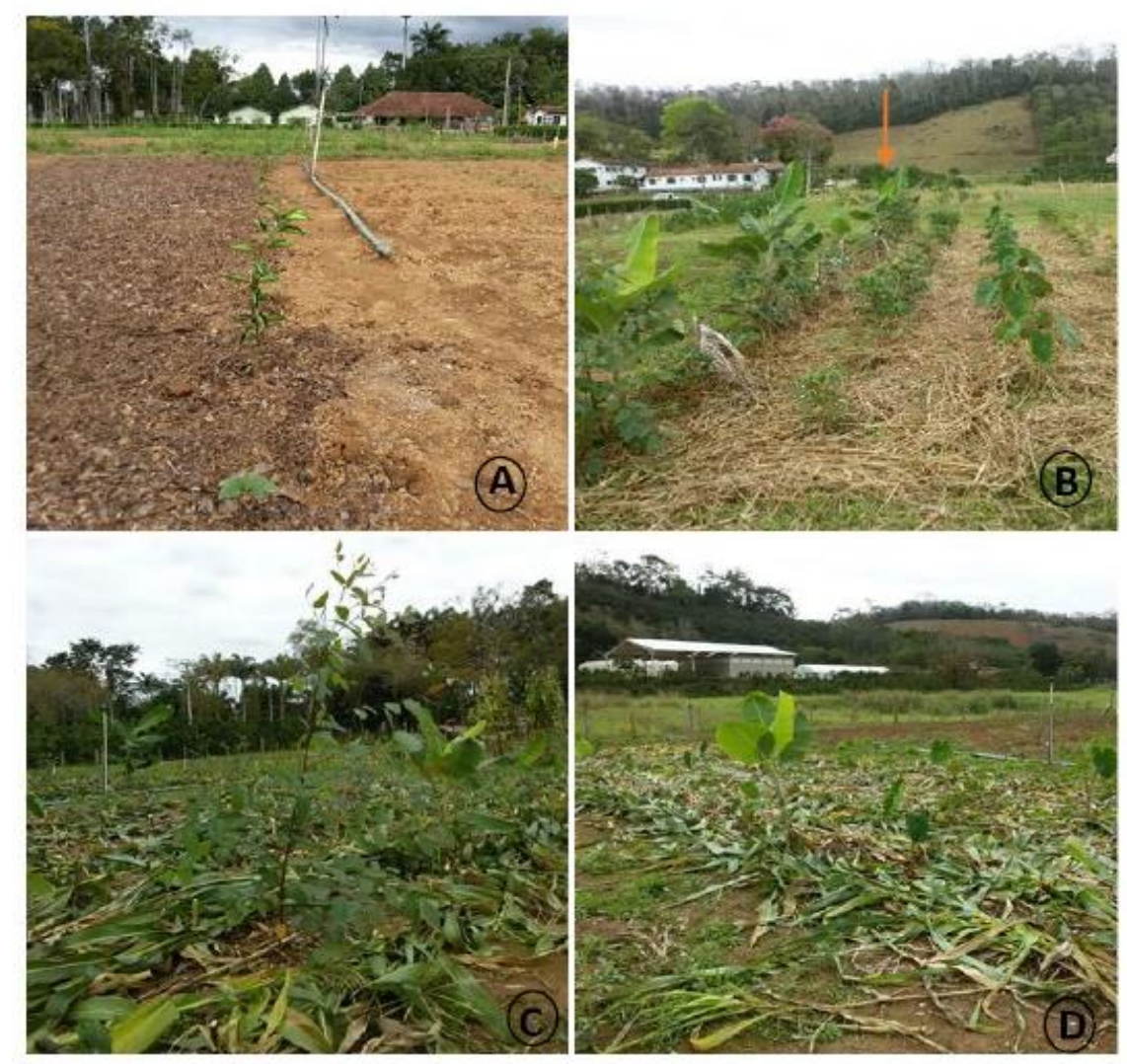

$A=$ Linha das árvores do SAF-F com um mês de implantação (maio, 2017); $B$ = Linha das árvores do SAF-C com cinco meses de implantação (outubro, 2017); C e D = Linha do SAF-F, após manejo do milho com três meses de implantação (agosto, 2017).

Figura 8. Imagens das linhas das árvores nos SAF’s no primeiro ano de implantação. Fonte: Os Autores.

Nos canteiros centrais dos SAF's, foram plantadas mudas de mandioca e inhame, ambas com espaçamento de 1,0 metro entre plantas, sendo alternado com o milho (Zea mays), semeado com espaçamento $1,5 \mathrm{~m}$ entre plantas. Nas bordas dos canteiros foram semeadas 
sementes de feijão (Phaseolus vulgaris) espaçadas $0,15 \mathrm{~m}$ entre si. Em cada parcela, um canteiro (canteiro 2) recebeu as mudas de inhame e dois (canteiros 1 e 3 ) receberam as manivas de mandioca (Figura 9).

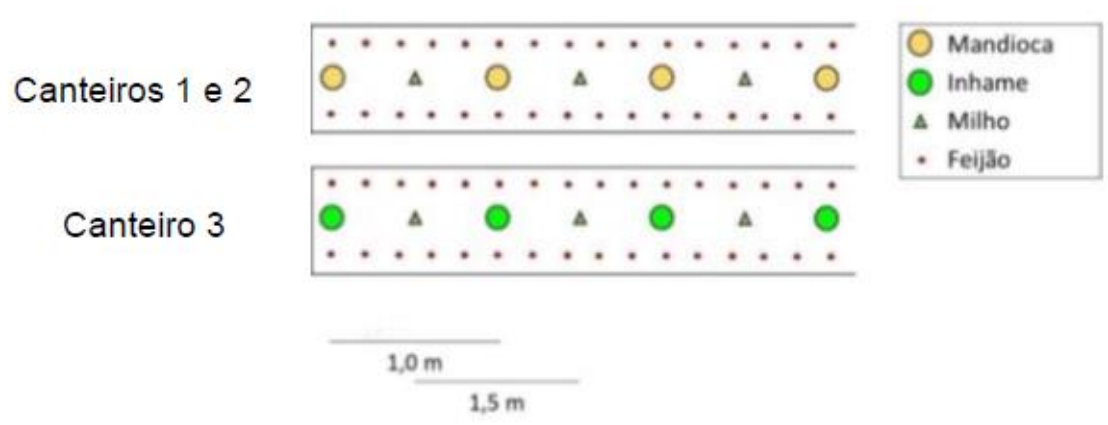

Figura 9. Croqui dos canteiros dos SAF's no primeiro ano das culturas anuais.

Fonte: Os Autores.

Na figura 10, observa-se os canteiros dos sistemas agroflorestais sucessionais no primeiro ano de produção.

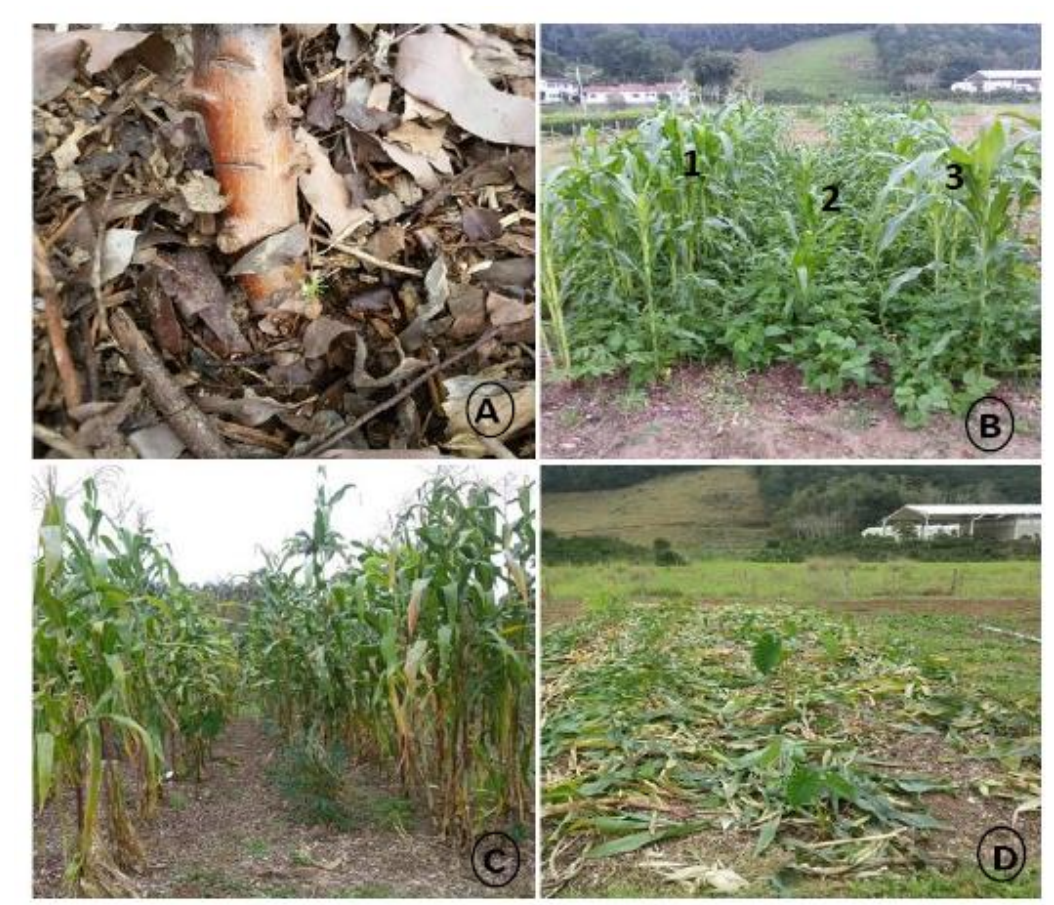

$A=$ Manivas de mandioca plantadas nos canteiros (canteiro 1 e 3 ) em maio de 2017; $B=$ Canteiros 1 , 2 e 3 dos SAF's com um mês de implantação (junho, 2017); C = Canteiros dos SAF's após a colheita do feijão com três meses de implantação (agosto, 2017) $D=$ Canteiros 1, 2 e 3 após a colheita do milho e o manejo da palhada com três meses de implantação (agosto, 2017).

Figura 10. Imagens dos canteiros nos SAF's no primeiro ano de implantação.

Fonte: Os Autores. 
Após a colheita das culturas anuais (inhame em fevereiro de 2018 e mandioca em março de 2018) em abril do mesmo ano, foram coletadas dez sub-amostras de solo na profundidade de 0,00-0,20 m nos canteiros centrais dos SAF's para compor uma amostra composta para realização de uma nova análise química do solo nas parcelas experimentais, afim de averiguar a necessidade de nova calagem e adubação para o próximo ciclo de cultivo das culturas anuais. Na tabela 2, estão discriminadas as culturas utilizadas nos sistemas agroflorestais, bem como as formas de plantio e suas adubações no primeiro ano do experimento.

Tabela 2. Discriminação e manejo de adubação das culturas utilizadas no primeiro ano de cultivo nos sistemas agroflorestais.

\begin{tabular}{|c|c|c|c|}
\hline \multicolumn{4}{|c|}{ Sistemas Agroflorestais } \\
\hline Cultura & Plantio & Adubação de plantio & $\begin{array}{c}\text { Adubação de } \\
\text { cobertura }\end{array}$ \\
\hline $\begin{array}{c}\text { Laranja } \\
\text { (SAF-F) } \\
\text { Espaçamento: } \\
5 \times 1 \mathrm{~m}\end{array}$ & Cova & $\begin{array}{l}\text { - } 300 \mathrm{~g} / \text { cova de } \\
\text { SS } \\
\text { - } 100 \mathrm{~g} / \text { cova de } \\
\text { calcário } \\
\text { - } 20 \text { g/cova de } \\
\text { FTE } \\
\text { - } 2 \text { L/cova esterco } \\
\text { de frango } \\
\end{array}$ & $\begin{array}{l}\text { - } 30 \text { d.a.p: } 50 \\
\text { g/cova de nitrabor } \\
\text { - } 80 \text { d.a.p: } 80 \\
\text { g/cova nitrabor } \\
\text { - } 130 \text { d.a.p: } 100 \\
\text { g/cova nitrabor }\end{array}$ \\
\hline $\begin{array}{c}\text { Café } \\
\text { (SAF-C) } \\
\text { Espaçamento: } \\
1,5 \times 1 \mathrm{~m}\end{array}$ & Cova & $\begin{array}{llr}\text { - } & 300 \mathrm{~g} / \text { cova } & \text { de } \\
& \mathrm{SS} & \\
\text { - } & 100 \mathrm{~g} / \text { cova } & \text { de } \\
& \text { calcário } & \\
\text { - } & 20 \mathrm{~g} / \text { cova } & \text { de } \\
& \text { FTE } & \\
\text { - } & 1,5 & \mathrm{~L} / \text { cova } \\
& \text { esterco } & \text { de } \\
& \text { frango }\end{array}$ & $\begin{array}{l}\text { - } 30 \text { d.a.p: } 40 \\
\text { g/cova de nitrabor } \\
\text { - } 60 \text { d.a.p: } 40 \\
\text { g/cova nitrabor } \\
\text { - } 90 \text { d.a.p: } 50 \\
\text { g/cova de nitrabor } \\
\text { - }\end{array}$ \\
\hline
\end{tabular}

- $300 \mathrm{~g} / \mathrm{cova}$ de

Banana

Espaçamento:

$3 \times 1 \mathrm{~m}$
Cova

Canteiro
Inhame

Espaçamento:

1X1 m
SS

- $20 \mathrm{~g} / \mathrm{cova}$ de

FTE

- $5 \mathrm{~L} /$ cova esterco de frango
- $26 \mathrm{~g} /$ cova de SS

- $2 \mathrm{~g} /$ cova de FTE

$\mathrm{SS}=$ Superfosfato Simples; FTE $=$ Micronutrientes $\mathrm{Mo}+\mathrm{B}+\mathrm{Zn}+\mathrm{Cu}+\mathrm{Mn}$.

Fonte: Os Autores.

De posse da análise do solo, constatou-se que não era necessário a realização da calagem para a implantação das culturas do segundo ano. Assim, apenas os canteiros centrais 
voltaram a serem preparados (maio de 2018), uma vez que as linhas das árvores já estavam consolidadas em ambos os SAF's.

No segundo ano das culturas anuais, na porção central dos canteiros foram semeadas sementes de quiabo (Abelmoschus esculentus) e jiló (Solanum aethiopicum). Nas laterais, foram plantadas mudas de alface (Lactuca sativa), rúcula (Eruca sativa L.) e couve (Brassica oleracea) (Figura 11). Com exceção do quiabo e do jiló, que foram plantados com espaçamento de $1 \mathrm{~m}$ entre plantas, todas as outras olerícolas foram semeadas com 0,6 m em consórcio.

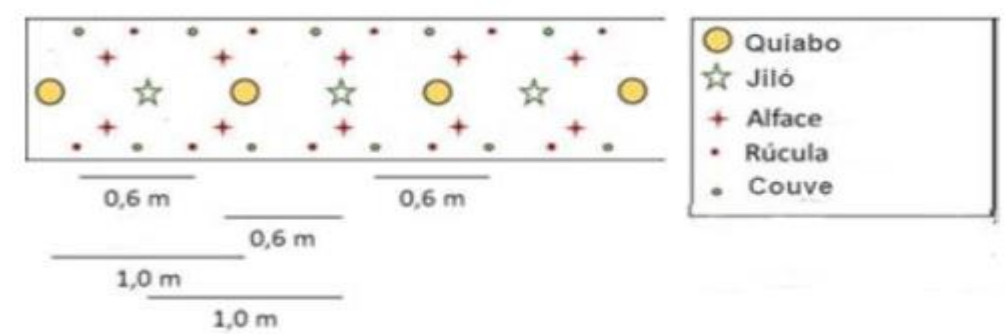

Figura 11. Canteiro dos SAF's no segundo ano das culturas anuais.

Fonte: Os Autores.

Na figura 12, observa-se que as linhas das árvores não foram preparadas após a colheita das culturas do primeiro ano. Foi realizado apenas a limpeza e poda das árvores (bananeira e eucalipto).

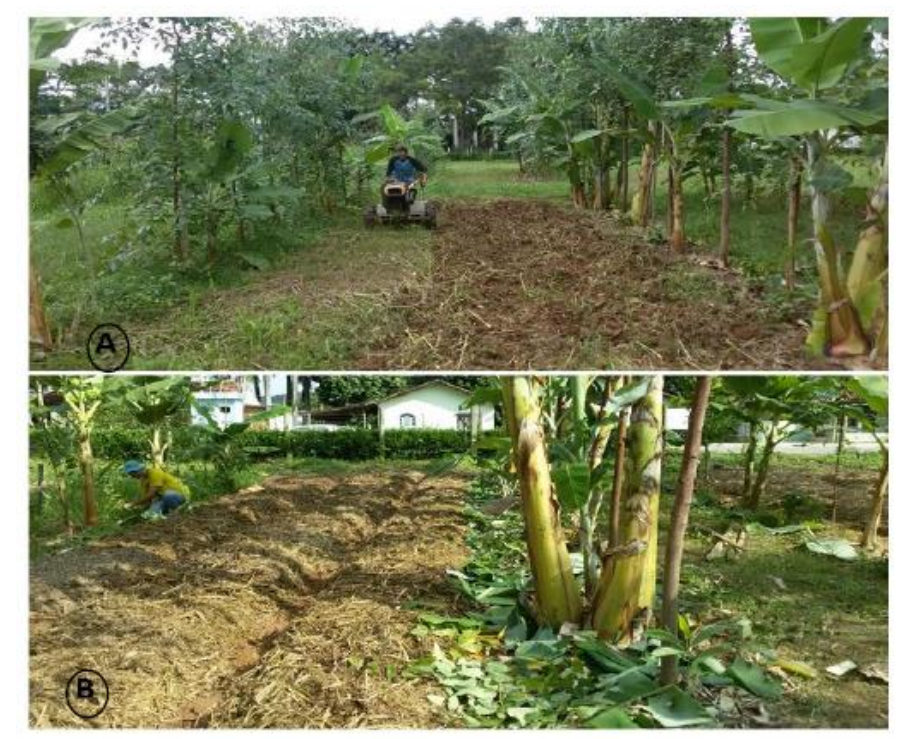

$A=$ Preparo do solo para implantação das hortaliças após 12 meses de experimento apenas nos canteiros dos SAFs; B = Preparo dos canteiros e realização da poda na linha das árvores (maio, 2018). Figura 12 Canteiros centrais dos SAF's sendo preparados para o segundo ano de plantio das culturas anuais.

Fonte: Os Autores. 
A adubação aplicada no segundo ano de cultivo encontra-se na tabela 3. Devido ao consórcio com várias espécies, foi utilizada a adubação da cultura com maior demanda nutricional (alface) nos canteiros centrais do SAF-C e SAF-F.

Tabela 3. Discriminação e manejo de adubação das culturas utilizadas no segundo ano de cultivo nos sistemas agroflorestais.

\begin{tabular}{|c|c|c|c|}
\hline \multicolumn{4}{|c|}{$\begin{array}{c}\text { Sistemas Agroflorestais } \\
\text { SAF-C }\end{array}$} \\
\hline Cultura & Plantio & Adubação de plantio & $\begin{array}{l}\text { Adubação de } \\
\text { cobertura }\end{array}$ \\
\hline Hortaliças & Canteiro & $\begin{array}{l}\text { - } 150 \text { L/canteiro } \\
\text { de esterco de } \\
\text { frango } \\
\text { - Canteiro 1 e 3: } \\
3 \text { kg de SS e } 210 \\
\text { g de FTE } \\
\text { - Canteiro 2: } 4,5 \\
\text { kg de SS e } 240 \mathrm{~g} \\
\text { de FTE }\end{array}$ & $\begin{array}{l}20 \mathrm{~g} / \mathrm{canteiro} \mathrm{de} \\
\text { nitrabor em três } \\
\text { parcelas: } 15,30 \mathrm{e} \\
45 \text { dias após o } \\
\text { semeio. }\end{array}$ \\
\hline
\end{tabular}

\begin{tabular}{|c|c|c|c|}
\hline \multicolumn{4}{|c|}{ SAF - F } \\
\hline Cultura & Plantio & Adubação de plantio & $\begin{array}{l}\text { Adubação de } \\
\text { cobertura }\end{array}$ \\
\hline Hortaliças & Canteiro & $\begin{array}{l}\text { - } 150 \text { L/canteiro } \\
\text { de esterco de } \\
\text { frango } \\
\text { - Canteiro } 1 \mathrm{e} \mathrm{3:} \\
4,5 \mathrm{~kg} \text { de SS e } \\
240 \mathrm{~g} \text { de FTE } \\
\text { - Canteiro 2: } 3 \mathrm{~kg} \\
\text { de SS e 210 g de } \\
\text { FTE }\end{array}$ & $\begin{array}{l}-20 \mathrm{~g} / \mathrm{canteiro} \mathrm{de} \\
\text { nitrabor em três } \\
\text { parcelas: } 15,30 \mathrm{e} \\
45 \text { dias após o } \\
\text { semeio. }\end{array}$ \\
\hline
\end{tabular}

$\mathrm{SS}=$ Superfosfato simples; FTE $=$ Micronutrientes $\mathrm{Mo}+\mathrm{B}+\mathrm{Zn}+\mathrm{Cu}+\mathrm{Mn}$.

Fonte: Os Autores.

\section{O impacto socioambiental dos sistemas agroflorestais sucessionais}

Embora ainda não esteja amplamente difundida, a agricultura sucessional tem sido disseminada pelo Brasil e já possui casos de sucesso de produção agrícola em áreas abandonadas e degradadas como no sul da Bahia (DAMANT e VILLELA, 2018) e São Paulo (MARÇAL, 2018).

O SAF contribui para a melhoria da alimentação e das condições de trabalho do produtor rural (ARANTES et al., 2017) e para a redução da demanda por água (irrigação) e insumos 
externos (GUIMARÃES e MENDONÇA, 2018), além de propiciar segurança alimentar e qualidade ambiental. Além disso, contribui para diversificar a atividade agrícola, diminuindo a dependência do agricultor às oscilações dos preços de mercado tornando-o mais independente.

Os SAFs, quando comparados aos monocultivos, aumentam a rentabilidade líquida da propriedade pela possibilidade de elevar a produtividade e reduzir os custos de produção, por meio da menor necessidade de tratos, como controle fitossanitário, adubação e irrigação (ARANTES et al., 2017). Ademais, vale ressaltar que novas fontes de renda e novos postos de trabalho são oportunidades de desenvolvimento e permanência da população do meio rural.

\section{Considerações finais}

Já foram realizados alguns trabalhos científicos relatando os benefícios dos sistemas conservacionistas no melhoramento das propriedades do solo (PEZARICO et al., 2013). Logo, os SAF's podem atuar como protagonistas na recuperação de áreas degradadas em propriedades rurais (áreas de preservação permanente ou reserva legal), principalmente na agricultura familiar, além de estimular o aumento e a diversificação de produtos, contribuindo para maior fonte de renda familiar, o que pode contribuir para a permanência dos agricultores no campo.

Em De Paula (2020) são descritos os resultados de produtividade dos SAF's mencionados nesse capítulo, bem como a avaliação da qualidade do solo nos diferentes sistemas de manejo estudados.

\section{Agradecimentos}

Ao Instituto Capixaba de Pesquisa, Assistência Técnica e Extensão Rural (INCAPER), pelo apoio e disponibilidade da área para a implantação do experimento.

À Fundação de Amparo à Pesquisa e Inovação do Espírito Santo (FAPES), pela concessão da bolsa e auxílio financeiro para condução e realização do experimento. 


\section{Referências}

AGENDA GÖTSCH. Disponível em: <http://agendagotsch.com>. Acesso em: 23 jul. 2019. n.p

ANDRADE, D. V. P.; PASINI, F. S. Implantação e manejo de agroecossistema segundo os métodos da agricultura sintrópica de Ernst Götsch. Cadernos de Agroecologia, v. 9, n. 4, nov. 2014.

ARANTES P.B.; RIGHI, C.A.; BOSI, C.; DOMENICO, C.I.; GALVEZ, V.A.R. Agroflorestas familiares no Vale do Ribeira: diagnóstico produtivo, estratégias e desafios. REDD - Revista Espaço de Diálogo e Desconexão, v. 9, n. 1, 2017

BARRETO, P.; SARTORI, M. Levantamento das áreas agrícolas degradadas no Estado do Espírito Santo. Vitória: CEDAGRO, 2012. 63p.

CENTRO DE GESTÃO E ESTUDOS ESTRATÉGICOS - CGEE. Degradação neutra de terra: o que significa para o Brasil? Brasília, DF: 2016. 28p.

DA SILVA, D. M. N.; VENTURIM, C. H. P.; CAPUCHO, M. E. O. V.; DE OLIVEIRA, F. L.; DE SÁ MENDONÇA, E. Impact of soil cover systems on soil quality and organic production of yacon. Scientia horticulturae, v. 235, p. 407-412, 2018.

DAMANT, G; VILLELA, F. Can agroforestry improve soil water and temperature dynamics in agriculture? A case study with syntropic farming in Bahia, Brazil. In: European Agroforestry Conference-Agroforestry as Sustainable Land Use, 4th. EURAF, p. 161-164, 2018.

DE PAULA, L.B. Qualidade do solo em agroflorestas sucessionais. Alegre, 2020. 117p. Dissertação (Mestrado em Agroecologia) - Instituto Federal do Espírito Santo, Alegre ES, 2020.

GÖTSCH, E. O renascer da agricultura. 2.ed. Rio de Janeiro: AS-PTA, 1996. 24p. (Cadernos de T.A.)

GUIMARÃES, L.A.O.P.G; MENDONÇA, G.C. Agricultura sintrópica (agrofloresta sucessional): fundamentos e técnicas para uma agricultura efetivamente sustentável. Incaper em revista, Vitória, v. 10, p. 6-21, 2019. Disponível em: <https://incaper.es.gov.br/Not\%C3\%ADcia/sustentabilidade-na-agropecuaria-e-o-enfoquedo-incaper-em-revista>. Acesso em 20 abr. 2020.

MARÇAL, M. F. M. Qualidade do solo em sistemas agroflorestais desenvolvidos para produção em larga escala. 2018. 98p. Dissertação (Mestrado em Engenharia Agrícola) Universidade Estadual de Campinas, Faculdade de Engenharia Agrícola, Campinas, SP, 2018.

MENDONÇA, E. S.; CANDIDO, A. D. O.; MORAES, B. S. A. D.; CURTY, G. C. N. D. S.; SILVA, D. M. N. D.; SOUZA, G. S. D. Estoque de carbono e nitrogênio em sistemas agroflorestais de café conilon. Cadernos de Agroecologia, v. 13, n. 1, 2018.

MU, L.; FANG, L.; LIANG, Y. Temporal and spatial variation of soil respiration under mulching in a greenhouse cucumber cultivation. Pesquisa Agropecuária Brasileira, v. 51, n. 7, p. 869879, 2016. 
MÜLLER, M. D.; PACIULLO, D. S. C.; MARTINS, C. E.; ROCHA, W. S. D.; CASTRO, C. R. T. Desenvolvimento vegetativo de pinhão-manso em diferentes arranjos de plantio em sistemas agrossilvipastoris. Pesquisa Agropecuária Brasileira, v. 49, n.7, p. 506-514, 2014.

PEZARICO, C. R.; VITORINO, A. C. T.; MERCANTE, F. M.; DANIEL, O. Indicadores de qualidade do solo em sistemas agroflorestais. Revista de Ciências Agrárias, v. 56, n.1, p. 40-47, 2013.

ROCHA, C. H.; WEIRICH NETO, P. H. MAZER, G. P.; EURICH, J. Agricultura familiar: base para o desenvolvimento sustentável. In: ROCHA, C. H.; WEIRICH NETO, P. H.; SOUZA, N. M. (Orgs.). Sustentabilidade: a transformação vem da agricultura familiar. 1.ed., v. 1, p. 27$38,2016$.

SOUZA, G. S.; DAN, M. L.; ARAÚJO, J. B. S. Qualidade física do solo sob cafeeiro conilon consorciado e em monocultivo. Coffee Science, v. 11, n. 2, p. 180 - 186, 2016.

TEIXEIRA, P. C.; DONAGEMMA, G. K.; FONTANA, A.; TEIXEIRA, W. G. Manual de métodos de análise de solo. Brasília: EMBRAPA Solos, v.4, p. 573, 2017.

THOMAZINI, A.; MENDONÇA, E.S.; SOUZA, J.L.; CARDOSO, I.M.; GARBIN, M.L. Impact of organic no-till vegetables systems on soil organic matter in the Atlantic Forest biome. Scientia Horticulturae, v. 182, p. 145-155, 2015. 


\section{Capítulo 15}

\section{Dinâmica e degradação dos pesticidas no solo: uma ameaça eminente a sustentabilidade dos sistemas agrícolas}

Dalila da Costa Gonçalves ${ }^{1}$, Wilian Rodrigues Ribeiro², Alex Justino Zacarias ${ }^{1}$, Geisa Corrêa Louback ${ }^{1}$, Rafael de Almeida ${ }^{1}$, Vanessa Sessa Dian ${ }^{1}$, Otacílio José Passos Rangel ${ }^{3}$

\section{Introdução}

A partir da Revolução Verde, e a necessidade de aumentar a produção de alimentos para atender as necessidades alimentícias da população mundial, projetada para mais de 9 bilhões de pessoas em 2050, o setor agrícola tem intensificado e inovado seus pacotes tecnológicos, que visam aumentar a produtividade dos alimentos (SAATH e FACHINELLE, 2018).

Dentro das tecnologias propostas pelo modelo agrícola atual, o desenvolvimento e a otimização de uso dos pesticidas, nas últimas décadas, foram responsáveis por poupar muitas perdas econômicas em termos de produção agrícola. Entretanto, sua utilização tem sido associada a uma série de riscos: i) ambientais, contribuindo para a contaminação dos recursos hídrico e do solo; ii) saúde pública, afligindo diretamente quem manuseia esses produtos e indiretamente com que consome estes produtos; iii) segurança e a soberania Alimentar, por meio da introdução no mercado de sementes e, ou, alimentos altamente dependentes de aporte de insumos externos e químicos. Segundo Oberemok et al. (2015), em 2050, o uso de pesticidas na agricultura será 2,7 vezes maior que em 2000, o que provavelmente aumentara a pressão sob os agroecossistemas e impactará a segurança ambiental e alimentar.

Segundo Cuenca et al., (2019), os pesticidas tem sido amplamente utilizados no controle de pragas, doenças e controle de vegetação inerente a cultura de interesse econômico. $O$ mesmo autor relata que o uso intenso e prolongado sem orientações técnicas, podem causar prejuízos aos ecossistemas, acarretando em problemas de ordem socioambiental e econômica.

Os pesticidas, direta ou indiretamente, tem como destino final o solo, e este atua como um receptáculo de micropartículas que podem ou não, ao longo do tempo, se tornarem vital a

\footnotetext{
${ }^{1}$ Mestrandos pelo Programa de Pós-Graduação em Agroecologia do Instituto Federal do Espírito Santo - Campus de Alegre, Caixa Postal 47, CEP: 29500-000, Alegre-ES. Email: dalilant@hotmail.com; alexjustino12@gmail.com; geisa.louback1980@gmail.com; rafael.t.dealmeida@gmail.com; vanessasessa2@gmail.com

2Doutorando pelo Programa de Pós-Graduação em Produção Vegetal da Universidade Federal do Espírito Santo, Caixa Postal 16, CEP: 29500-000, Alegre-ES. E-mail: wilianrodrigues@msn.com

${ }^{3}$ Dr. Professor do Instituto Federal do Espírito Santo - Campus de Alegre, Caixa Postal 47, CEP: 29500 000, Alegre-ES. E-mail: ojprangel@ifes.edu.br
} 
vida microbiológica do solo, comprometendo a qualidade do solo pois os microrganismos desempenham funções essenciais no ecossistema e na produtividade das culturas.

O solo é composto por partículas minerais e orgânicas, que possuem a capacidade de reter vários poluentes, podendo atuar como um absorvedor de substancias nocivas. Sua natureza físico-química o caracteriza ainda como um reservatório de água e nutrientes, que são necessários para o desenvolvimento de microrganismos e de proporcionar o desenvolvimento de plantas e culturas agrícolas, proporcionando o desenvolvimento radicular e sua nutrição. Em função de suas propriedades físico - químicas, as partículas coloidais são capazes de reter as moléculas quimicamente ativas presentes nos pesticidas, que ao longo do tempo podem interferir nos processos de biodegração no solo, nas suas atividades enzimáticas, estimulando ou inibindo a microbiota edáfica que atua diretamente sobre a ciclagem de materiais, na matéria orgânica do solo, na capacidade de troca catiônica (CTC) e, consequentemente, na capacidade produtividade do solo ao longo do tempo (ARORA et al., 2019; SATAPUTE et al., 2019; ZHANG et al., 2019).

Devido a sua persistência, toxicidade e bioacumulação, alguns compostos presentes nos pesticidas podem permanecer quimicamente ativos no solo passando por transformações biológicas e físico-químicas, influenciando o crescimento microbiano e as atividades enzimáticas, podendo ainda atingir o lençol freático (FARENHORST, 2006; WOŁEJKO et al., 2019). Além da influência sobre os microrganismos, o acúmulo de pesticidas afeta significativamente as enzimas do solo, que são catalisadores essenciais que influenciam o habitat dos microrganismos no solo (ŁOZOWICKA et al., 2017)

Para minimizar os impactos ambientais e socioeconômicos da agricultura têm-se buscado compreender o comportamento dos pesticidas no solo, que podem ser influenciados pelas propriedades físico-químicas dos pesticidas, pelas propriedades físicas, químicas e biológicas do solo, pelos sistemas de produção, pela presença de resíduos de cobertura morta e pelas condições agrometeorológicas (ASLAM et al., 2015, 2018; KARAS et al., 2018; KHALID et al., 2020).

Podemos definir como comportamento dos pesticidas, a forma como suas moléculas agem em determinado ambiente. Ao entrarem em contato com as partículas coloidais do solo, estas ficam sujeitas a processos físico-químicos que regulam seu destino no ambiente. Como exemplo de processos físico-químicos podemos destacar a retenção, a lixiviação, a volatilização, a fotodegradação, a decomposição química e microbiológica, o escorrimento superficial e a absorção pelas plantas (BAILEY e WHITE, 1970; LAVORENTI et al., 2003; KUMAR et al., 2017; APARICIO et al., 2018; YE et al., 2018).

A dinâmica de pesticida no solo é muito complexa, e seu estudo é baseado em estimativas dos três principais processos envolvidos: 1) retenção; 2) transformação e 3) transporte que 
determinam respectivamente a sua disponibilidade na solução, persistência e o seu local de depósito no ambiente (OLIVEIRA JR e REGITANO, 2009; KUMAR et al., 2017).

Os estudos buscam definir e quantificar os efeitos nocivos dos pesticidas em todo sistema, além de selecionar tecnologias agrícolas que cumpram os requisitos agronômicos propostos e, ao mesmo tempo, causem menos danos ao meio ambiente e a sociedade (YAVARI et al., 2019).

O objetivo deste capítulo é realizar um levantamento teórico acerca da dinâmica dos pesticidas no solo, destacando as principais interferências acerca da sua aplicabilidade dentro do contexto agroecológico.

\section{Os pesticidas}

A partir da década de 60 os pesticidas se tornaram grandes aliados dos sistemas de produção, reduzindo as perdas de produção e intensificando a produtividade. No entanto, sua utilização na agricultura vem sendo discutida. O seu uso tem se tornado irracional devido a falta de orientação sobre as técnicas de aplicação, utilização acima dos limites recomendados, pela ação sobre organismos não-alvo e falta de responsabilidade sobre a segurança residual de suas moléculas. Estas moléculas mesmo em baixas concentrações podem ser bioacumulativas devido a contínua exposição do organismo-alvo, causando efeitos a longo prazo ao meio solo, águas subterrâneas e à saúde humana, além do desenvolvimento de populações de competidores resistentes (YAVARI et al., 2019).

Os pesticidas são descritos como substância ou mistura de substâncias exógenas ao meio, compostos por moléculas orgânicas e hidrofóbicas formuladas a partir de ingredientes ativos que possuem características físico-químicas e biológicas específicas com propriedades curativa e preventiva, que podem ser utilizados para erradicar, repelir, reduzir ou controlar um organismo vivo, que venha colocar em risco a produção (KUMAR et al., 2015; LAMICHHANE et al., 2016).

Dependendo do método de prevenção e controle, os pesticidas podem ser classificados como: acaricidas (para o controle ácaros), bactericidas (para o controle de bactérias), nematicidas (para o controle de nematóides), fungicidas (para o controle de fungos) e inseticidas (para controlar insetos). O pesticida considerado ideal seria aquele capaz de exercer $100 \%$ de sua eficiência e logo após desaparecer sem causar danos ao ambiente e ao solo (LAVORENTI et al., 2003; OLIVEIRA JR e REGITANO, 2009).

A dinâmica dos pesticidas em regiões de clima tropical ainda é escassamente abordada, o que pode estar relacionado às condições edafoclimáticas nos trópicos. A dinâmica dos pesticidas no solo tem sido avaliada através de modelos de simulação, porém, devido à 
complexidade das reações envolvidas, modelos que incluem maior número de fatores resultem em melhor simulação da realidade (HERMAN e SCHERER, 2003). Entretanto, é um grande desafio para ciência estudar os efeitos residuais destas moléculas bioacumulativas no solo.

Devido a sua complexidade e diversidade estrutural, uma variedade de vias de decomposição estão envolvidas em sua dinâmica no solo. A sorção, a degradação, o escoamento superficial e a lixiviação são os principais processos envolvidos no destino final destes pesticidas no solo (OLIVEIRA JR e REGITANO, 2009). Os processos de adsorção / dessorção (sorção) se destacam como o principais processos que determinam a distribuição de pesticidas entre as fases sólida, líquida e gasosa e, portanto, controlam sua disponibilidade para outros processos de distribuição e transformação que ocorrem nos solos (MOORMAN et al., 2001; MOSQUERA-VIVAS et al., 2016; PEÑA et al., 2020).

Os resíduos de pesticidas encontrados nos solos são derivados principalmente de sua aplicação direta e algumas moléculas podem permanecer estáveis, resultando em maior acúmulo nas camadas superficiais e persistir no ambiente. A longo prazo essas características podem agravar o processo resiliente do solo. A quantidade de água que se move na superfície e no perfil do solo é muito importante para a movimentação das moléculas, pois para que o pesticida seja degradado é necessário que o mesmo esteja adsorvido ou na solução do solo (APARICIO et al., 2018; WOŁEJKO et al., 2019). Os fatores edáficos influenciam muito no comportamento e no destino dos pesticidas no ambiente.

Quando a molécula de um pesticida chega ao solo, ela pode sofrer os processos de degradação e sorção, podendo estar solúvel ou disponível na solução do solo; adsorvida e em equilíbrio dinâmico com a solução do solo ou fortemente ligada e não disponível (OECD, 2000). Os resultados destes processos podem ser: a absorção da molécula pelas plantas ou a lixiviação das mesmas para camadas subsuperficiais do solo, podendo até mesmo atingir os cursos de água subterrâneos, ou a formação de resíduos. Um dos fatores agravantes neste processo deve-se ao fato de que os metabólitos oriundos da degradação podem se tornar inativos, ativos e até mesmo mais ativos que as moléculas originais.

A dinâmica dos pesticidas no ambiente é governada por suas propriedades físicoquímicas, conformação da estrutura molecular e do seu princípio bioativo; pelas propriedades do solo (granulometria das partículas do solo, processo erudito do solo, atividade microbiana, aeração, presença de cargas dependentes de $\mathrm{pH}$, a predominância de minerais de argila 1:1, 2:1 e óxidos de ferro e alumínio, matéria orgânica e CTC); fatores edafoclimáticos e tipo de manejo. Dentre as condições ambientais destacam-se a temperatura, a umidade, a luminosidade, a classe de solo e a declividade (OLIVEIRA JR e REGITANO, 2009; APARICIO et al., 2018). 
Segundo Appleby e Dawson (1994) as moléculas dos pesticidas podem ser retidas pelos colóides minerais e orgânicos, podendo ser transformadas em outras, absorvidas pelas raízes, lixiviadas, sofrer escoamento superficial ou ser volatilizada. A capacidade de serem biotransformadas em outras, é ainda mais preocupante para o sistema água, solo e planta, por se tratar de uma molécula desconhecida.

O movimento dos pesticidas no ambiente acontece via processos físicos, químicos e biológicos. Dentre os físicos destacam-se o escorrimento superficial, a lixiviação, a translocação pelas plantas e a volatilização. Os processos químicos acontecem preferencialmente no ar e na água (oxidação, redução, hidrólise e fotólise). Já em contato com o solo, os pesticidas podem sofrer processos de sorção (adsorção/dessorção); transformação ou degradação microbiológica e, por fim, transportados (APPLEBY e DAWSON, 1994).

A sorção dos pesticidas a partículas do solo refere-se à habilidade do solo em reter ou não uma molécula por meio de processos que envolvem interações hidrofóbicas (afinidade de compostos orgânicos pela matéria orgânica), processos físicos (forças de Van der Waals e ligações iônicas) e químicos (pontes de hidrogênio e ligações covalentes), em que o composto passa da solução do solo para superfícies externas e internas dos colóides minerais e orgânicos (OLIVEIRA et al., 2005; OLIVEIRA JR e REGITANO, 2009). Dentre os colóides do solo, as substâncias húmicas são consideradas as mais importantes no processo de sorção. Quanto menor a sorção da molécula do pesticida pelos colóides do solo maior será seu potencial de perda por lixiviação (PIASAROLO et al., 2008). Os fatores que governam estes processos são extremamente complexos, o que dificulta respostas mais assertivas no comportamento das moléculas dos pesticidas nas interfases do solo, ao longo do tempo.

A atividade microbiológica do solo é determinante para a eficiência do pesticida no solo, pois são os organismos vivos os responsáveis pela biodegradação (oxidação, redução, hidrólise e suas conjugações) (FARENHORST, 2006; APARICIO et al., 2018). Alguns grupos de organismos presentes no solo são capazes não apenas de metabolizar e degradar as moléculas de pesticidas (transformação biológica em produtos menos tóxicos, como por exemplo $\mathrm{CO}_{2}, \mathrm{H}_{2} \mathrm{O}$ e sais, mas também de sobreviver no ambiente contaminado e desfavorável (EL FANTROUSSI e AGATHOR, 2005).

Vale ressaltar que o processo de degradação dos pesticidas pode resultar na transformação biológica em moléculas que exibem um comportamento diferenciado do composto original, tornando-se fitotóxicas às plantas ou a outros organismos vivos. Percebese que a dinâmica dos pesticidas no solo é muito complexa. Não existe uma degradação puramente física e química destas moléculas, e sim uma integração mediante a ação enzimática da biota presente e as propriedades do solo. Quando moléculas ativas dos pesticidas não são degradadas, ocorre acumulo e persistência no solo por um longo tempo, 
poluindo o ambiente do solo, afetando a fauna edáfica. Assim, os pesticidas também podem interferir na sequência correta de vias bioquímicas nos ciclos biogeoquímicos do solo produzindo metabólitos diferentes (BAILEY e WHITE, 1970; LAVORENTI et al., 2003).

Os compostos mais perigosos ao meio ambiente e a saúde humana pertencem ao grupo de pesticidas organoclorados que, devido ao seu maior tempo de degradação e efeitos deletérios à saúde humana, muitos já foram banidos do mercado pelas organizações internacionais. Estes pesticidas são semi-voláteis e podem volatilizar do solo para a atmosfera, onde são transportados pela corrente aérea para outros locais. Dado a essa característica, esses pesticidas são considerados muito perigosos, por serem capazes de gerar um novo local de contaminação, como a água e o solo, e afetar o metabolismo dos organismos que ali habitam (LEÓN-SANTIESTEBAN e RODRÍGUEZ-VÁZQUEZ; 2017; WU et al.,2020).

\section{Propriedades físicas e químicas dos pesticidas que influenciam seu destino no ambiente}

Algumas das principais propriedades físico-químicas dos pesticidas que afetam sua dinâmica no solo são descritas a seguir.

Coeficiente de partição no solo ou coeficiente de sorção (Kd e Kf): é o mais aplicado e considerado o mais eficiente para estimar a mobilidade dos pesticidas no solo. Este coeficiente indica a distribuição relativa do pesticida entre o sorvente (argila e matéria orgânica do solo - MOS) e o solvente (água), podendo ser determinado em laboratório a partir de misturas solo/solução aquosa do pesticida, submetidas à agitação por determinado tempo e subsequente centrifugação. Quanto menor o valor de Kd e Kf, maior a proporção de pesticida disponível na solução do solo e maior sua mobilidade e disponibilidade às plantas e aos microrganismos. Vale destacar que em solos tropicais onde as variáveis agroclimatológicas não são constantes, estes parâmetros se tornam pouco assertivos. Entretanto quanto maior sua disponibilidade na solução do solo maior probabilidade de ser lixiviado, e sob condições naturais, muitos fatores podem interferir nesse processo. A degradação dos pesticidas consiste na mistura de muitas substâncias e moléculas quimicamente e biologicamente ativas, as quais não são analisadas em conjunto. Nos testes laboratoriais as análises muitas vezes são de uma única substância ativa, fato que pode vir a mascarar muitos resultados.

O coeficiente de sorção padronizado para o carbono orgânico (Koc): é considerado o melhor parâmetro para predição da sorção dos pesticidas à fração orgânica do solo devido a 
sua natureza orgânica hidrofóbica e sua alta afinidade pela MOS. É calculado a partir do Kd, levando-se em consideração a porcentagem de carbono orgânico do solo. O Koc é obtido pela seguinte equação:

$$
K_{o c}=\frac{K_{d .100}}{\% C O}
$$

Quando a molécula de um pesticida se encontra adsorvida ela não está prontamente disponível para a planta, no entanto, ela pode sofrer uma dessorção e retornar a solução do solo, ou seja as moléculas podem ser continuamente transferidas entre a solução e a superfície do solo tornando-se disponível (LAVORENTI et al., 2003). Estes processos de sorção e dessorção são dinâmicos e controlados por diferentes mecanismos (ligações hidrofóbicas, pontes de hidrogênio, forças de van der Waals, ligações iônicas e covalentes) (BAILEY e WHITE, 1970).

O grau de adsorção no solo aumenta à medida que aumenta o teor de MOS, CTC, superfície específica, teor de argila e de hidróxidos de ferro e alumínio presentes (CLAUSEN e FABRICIUS, 2002; INOUE et al., 2010). Entretanto, é a fração orgânica que rege a adsorção das moléculas dos pesticidas. A parte humificada da MOS representa a fração mais ativa na adsorção de pesticidas no solo, devido principalmente a sua hidrofobicidade, formando frações "não-extraíveis", não disponibilizando-as em solução (LAVORENTI et al., 2003; FARENHORST, 2006).

A MOS atua diretamente sobre as melhorias das propriedades físicas do solo (porosidade, densidade permeabilidade e retenção de água), além de condicionar a disponibilidade de compostos orgânicos para as plantas (a partir do processo de decomposição realizado pela microfauna do solo) contribui para manutenção da qualidade química, física e biológica do solo, incrementando a sua fertilidade. A MOS representa o equilíbrio sinergético entre os componentes do solo, contribuindo para degradação dos pesticidas, sendo, portanto, determinante para os mecanismos de mitigação das substâncias poluentes. A MOS é a base fundamental para o desenvolvimento de sistemas agrícolas mais ecologicamente sustentáveis.

Solubilidade em água: definida como a quantidade máxima da molécula pura que pode ser dissolvida em água, é um dos mais importantes parâmetros que influenciam no destino final e transporte do pesticida no perfil do solo. De forma geral, quanto maior a solubilidade da molécula maior a tendência da mesma ser degrada e, ou, lixiviada junto com a água, e menor sua afinidade com a MOS (LAVORENTI et al., 2003). A solubilidade em água pode variar de 
acordo com o pH da solução. Pesticidas que possuem grupos funcionais ionizáveis em sua estrutura podem apresentar-se protonados (forma molecular) ou desprotonados (forma ionizada). Assim, em valores de $\mathrm{pH}$ superiores ao seu $\mathrm{pKa}$, as moléculas encontram-se ionizadas (mais polar) portanto, com maior solubilidade em solventes polares, como a água, podendo ser mais facilmente lixiviadas (OLIVEIRA JR., 2001). Ao contrário, em valores de pH inferiores ao seu pKa, os pesticidas encontram-se na forma molecular, apresentando maior afinidade por solventes de natureza apolar (PROCÓPIO et al., 2003; OLIVEIRA JR. e BRIGHENTI, 2011). A lixiviação dos pesticidas pode levar a um aumento no seu potencial de fitotóxico para a cultura, por reduzir a seletividade das partículas do solo principalmente em solos arenosos. Para tanto é de extrema importante levar em consideração a textura do solo no momento da definição do tipo e dose do pesticida. Para pesticidas que apresentam alta solubilidade e baixa adsorção, existe uma grande possibilidade de que estes possam vir a contaminar águas subterrâneas.

Contudo, estas moléculas estão mais suscetíveis à degradação microbiana, podendo ser dissipadas rapidamente do ambiente, pois a sorção de um pesticida tende a ser inversamente proporcional à sua solubilidade em água (OLIVEIRA JR., 2001).

Pressão de vapor (PV): é a medida de saturação em termos de concentração ou pressão de um soluto na fase gasosa responsável pelas perdas através da volatilização.

$\mathrm{Na}$ tabela 1 observar-se que quanto maior a PV de um pesticida maior seu poder de volatização, consequentemente, maiores as perdas e menor sua eficiência (MACKAY et al., 1997). Esta classificação contribui para aplicações mais assertivas no campo e menos nocivas ao meio ambiente.

Tabela 1. Classificação dos pesticidas em relação à pressão de vapor (PV).

\begin{tabular}{lll}
\hline Classe & Categoria & PV $(\mathbf{m m H g})$ \\
\hline 1 & Não Volátil & $<10-8$ \\
2 & Pouco Volátil & $10^{-7}-10^{-5}$ \\
3 & Mediamente Volátil & $10^{-4}-10^{-3}$ \\
4 & Muito Volátil & $>10^{-2}$ \\
\hline
\end{tabular}

Fonte: Alves (2008).

Coeficiente de partição n-octanolágua (Kow): mede o caráter hidrofóbico ou hidrofílico de uma molécula. Pesticidas lipofílicos (log Kow > 4,0), tendem a ser acumulados (adsorvidos) em materiais lipídicos, como a matéria orgânica do solo, apresentando baixa mobilidade, favorecendo assim a ocorrência do efeito residual. Por outro lado, pesticidas hidrofílicos (log 
Kow < 1,0) são mais solúveis em água e, de forma geral, apresentam baixo potencial de adsorção, apresentando maior mobilidade com tendência à bioacumulação, principalmente nos ecossistemas aquáticos. Na tabela 2 Vidal (2002) apresenta os valores de Kow e sua lipofilicidade.

Tabela 2. Valores de coeficiente de partição n-octanolágua (Kow) e lipofilicidade.

\begin{tabular}{lll}
\hline Log Kow & Kow & Lipofilicidade \\
\hline$<0,1$ & $<1$ & $\begin{array}{l}\text { Hidrofílico } \\
\text { Medianamente }\end{array}$ \\
0,1 a 1 & 1 a 10 & Lipossolúvel \\
1 a 2 & 10 a 100 & Lipofílico \\
2 a 3 & 100 a 1000 & Muito Lipofílico \\
$>3$ & $>1000$ & Extremamente Lipofílico
\end{tabular}

Fonte: Vidal (2002).

Constante de equilíbrio de ionização (pKa/pKb): ligada a possibilidade de ionização das moléculas em soluções. De acordo com diferentes valores de $\mathrm{pH}$, as formas ionizadas de pesticidas se comportam diferentemente das não ionizadas (neutras) (PRATA e LAVORENTI, 2000; OLIVEIRA, et al., 2001; OLIVEIRA JR. e BRIGHENTI, 2011). O comportamento das moléculas dos pesticidas varia de acordo com a sua natureza iônica (ácida ou básica) e o pH da solução.

Constante da Lei de Henry (KH): é obtida pela relação entre a pressão parcial e a concentração na interface ar/água, levando em consideração o peso molecular, a solubilidade e a pressão de vapor (LAVORENTI et al., 2003). Quanto maior o valor de $\mathrm{KH}$, maior é o potencial de volatilização (PROCÓPIO et al., 2001), definida pela equação:

$$
H=P i / C i
$$

Fotodegradação ou degradação fotoquímica: varia em função da absorção de luz pelo pesticida, resultando na excitação de seus elétrons e, por consequência, no rompimento de determinadas ligações moleculares (RADOSEVICH et al., 1997). Este processo afeta principalmente moléculas que apresentam alto grau de volatilidade (GEBLER e SPADOTTO, 2004). Portanto, a degradação fotoquímica de determinado pesticida ocorrerá somente se houver presença de luz, sendo específica para cada pesticida (OLIVEIRA JR. e BRIGHENTI, 2011). 
Meia vida (T1/2): o tempo necessário para que ocorra a dissipação de $50 \%$ da quantidade inicial aplicada do pesticida, ou seja, sua passagem para formas não ativas. Na prática indica o período de eficácia do produto (PROCÓPIO et al., 2001). O conhecimento da T1/2 dos pesticidas no solo é fundamental para evitar fitointoxicação de cultivos subsequentes ("carryover"), pois eles podem formar metabólicos tão ou mais tóxicos que suas moléculas originais. A combinação mobilidade/persistência é que determina se o composto será degradado durante seu tempo de permanência na zona não saturada do solo (SPADOTTO et al., 2001). Este fator é o mais conhecido entre os produtores e também enfatizado pelas empresas de agroquímicos.

\section{Atributos do solo e a sorção dos pesticidas}

Na solução do solo, as moléculas dos pesticidas tendem a atingir o equilíbrio entre a fase adsorvida e a que permanece em solução, diminuindo na maioria das vezes sua eficiência e mobilidade à medida que aumenta a adsorção aos coloides do solo (OLIVEIRA et al., 2005).

A tabela 3 apresenta algumas propriedades do solo que interferem na sua capacidade adsortiva. A superfície específica da matéria sólida do solo é um sítio importante para o processo de adsorção, principalmente para os pesticidas polares em solos com baixo conteúdo volumétrico de matéria orgânica.

Quanto maior o teor de argila do solo, maior a sorção dos pesticidas e menor sua disponibilidade para exercer sua atividade biológica. Os óxidos de Fe e Al, por exemplo, são considerados sítios primários de alguns pesticidas aniônicos. Em pH entre 4 e 6 estes minerais apresentam carga elétrica positiva, que atraem eletrostaticamente formas aniônicas dos pesticidas de caráter ácido (HELLING et al., 1971).

Tabela 3. Colóides do solo com capacidade de adsorção de pesticidas.

\begin{tabular}{lcc}
\hline Constituintes do solo & $\begin{array}{c}\text { CTC } \\
\left(\mathbf{c m o l} \mathbf{~} \mathbf{~ g g}^{-\mathbf{1}}\right)\end{array}$ & $\begin{array}{c}\text { Superfície Específica (SE) } \\
\left(\mathbf{m}^{\mathbf{2}} \mathbf{g}^{-\mathbf{1}} \mathbf{)}\right.\end{array}$ \\
\hline Materia Orgânica & $200-400$ & $500-800$ \\
Vermiculita & $100-150$ & $600-800$ \\
Montmorilonita & $80-150$ & $600-800$ \\
Ilita & $10-40$ & $65-100$ \\
Clorita & $10-40$ & $25-40$ \\
Caulinita & $3-15$ & $7-30$ \\
Óxidos e Hidróxidos & $2-6$ & $100-800$ \\
\hline
\end{tabular}

Fonte: Bailey e White (1970).

Tópicos em Agroecologia, volume II 
Em alguns casos o pH e a mineralogia podem influenciar de forma significativa na adsorção. Solos altamente intemperizados como os tropicais, as cargas de atração podem ser geradas nas bordas do mineral pela dissociação de prótons $\mathrm{H}^{+}$, permitindo a adsorção de moléculas de pesticidas catiônicos. O pH também influencia indiretamente na biodegradação de pesticidas no solo, pois ele vai interferir na seleção de microrganismos, por exemplo em solos onde há predominância de $\mathrm{pH}$ abaixo que 5,0, os microrganismos fúngicos prevalecem em relação às bactérias.

Solos com predominância de argilas expansíveis 2:1 como a montmorilonita e a vermiculita apresentam maior CTC e ASE e, consequentemente, maior capacidade de adsorção devido à formação de forças de atração de grande intensidade. A contribuição relativa de superfícies orgânicas e inorgânicas para adsorção dependerá da extensão da camada de argila em contato com as substâncias húmicas. Já considerando solos tropicais, os processos que mais se correlacionam com a adsorção são a capacidade de troca catiônica e o teor de MOS, pois a maior parte da CTC nesses solos está relacionada à matéria orgânica.

A MOS é fundamental para o solo, pois representa o estádio de equilíbrio sinérgico entre os componentes ali presente. É composta principalmente por compostos orgânicos $(C, H, O$, $\mathrm{N}, \mathrm{S}$ e P), que estarão disponíveis para as plantas a partir do processo de decomposição realizado pela microfauna do solo, tem papel fundamental na retenção de água no sistema agrícola, podendo ser atribuída a ela a função do desenvolvimento de um sistema agrícola mais fértil e sustentável.

A fração orgânica do solo é muito heterogênea e possui uma variedade de compostos polares ou grupos aromáticos de estrutura complexa, com vários sítios funcionais ativos, que favorecem a interação entre cátions para formação de diferentes complexos estruturais que podem contribuir para a mobilidade de moléculas na solução e na deposição destas na superfície do solo. As substâncias húmicas também influenciam na retenção de calor e umidade no solo, podendo influenciar na dissipação dos pesticidas através dos processos químicos e biológicos, servindo também de ligação entre as partículas do solo, formando agregados mais estáveis (BAILEY e WHITE, 1970; LAVORENTI et al., 2003). Com isso podemos dizer que solos com altos teores de MOS tendem a reduzir perdas por lixiviação, ficando mais adsorvidos nos complexos organominerais do solo. A MOS é a principal fonte nutricional e enérgica para os microrganismos que atuam nos processos de biodegradação das moléculas dos pesticidas no solo, agindo diretamente na sua retenção e estabilização no solo, ou seja, quanto maior o número de microrganismos maior a degradação dos pesticidas. Por outro lado, o elevado teor de MOS pode aumentar a persistência dos pesticidas e de seus metabólitos no ambiente, uma vez que adsorvidos estes estão indisponíveis ao processo de biodegradação (LANGENBACH et al., 2001). 


\section{Considerações finais}

Na agricultura moderna, a utilização de pesticidas é uma prática comum em todo o mundo. As recentes demandas produtivas, tornará cada vez mais intensiva a sua utilização, com consequente incremento de moléculas bioativas no solo e nas águas subterrâneas. Por isso é importante estudar a mobilidade e degradação dos pesticidas nos solos, bem os riscos ambientais, econômicos e sociais, além de estudar tecnologias inovadoras que cumpram os requisitos agronômicos propostos e que causem menos danos ao meio ambiente, a saúde animal e humana.

O pesticida ideal é aquele que permanece ativo no ambiente por tempo suficientemente longo para o controle de determinada praga ou doença, porém não tão longo que cause injúria às culturas susceptíveis que venham em rotação/sucessão. Compreender os processos envolvidos e os fatores que influenciam a retenção e a liberação dos pesticidas é essencial para a tomada racional de decisões em relação à sua autorização e, mais ainda, sua aplicação, reduzindo o nível de resíduo dos mesmos no solo.

A persistência de um pesticida não degradado ou de metabólitos prejudiciais ao solo constitui um risco sempre presente e cumulativo tanto para o meio ambiente como para saúde humana. É necessária uma abordagem multidisciplinar das pesquisas cientificas para o desenvolvimento de ferramentas e técnicas que permitam uma tomada de decisão ambiental eficaz. Mais que nunca, são necessárias estratégias para a agricultura sustentável, principalmente para os pequenos produtores, como forma de aumentar a confiança e segurança do usuário final, bem como a segurança alimentar dos consumidores.

\section{Referências}

ALVES, S.N.R. Efeito residual de herbicidas aplicados em pré-emergência em diferentes períodos de seca na soqueira de cana-de-açúcar. Piracicaba, 2008. 126p. Dissertação (Mestrado em Fitotecnia) - Curso de Pós-graduação em Fitotecnia, Escola Superior de Agricultura Luiz de Queiroz (ESALQ), Piracicaba, 2008.

APARICIO, V. C.; AIMAR, S.; DE GERÓNIMO, E.; MENDEZ, M. J.; COSTA, J. L. Glyphosate and AMPA concentrations in wind-blown material under field conditions. Land Degradation \& Development, v. 29, n. 5, p. 1317-1326, 2018.

APPLEBY, A. P.; DAWSON, J. H. Microbial and non-microbial breakdown of herbicides in soil: intensive course on the activity, selectivity, behavior, and fate of herbicides in plants and soils. West Lafayette, USA: Purdue University, Departments of Horticulture, Agronomy, Botany and Plant Pathology, and Forest and Natural Resources, p. 446, 1994.

ARORA, S.; ARORA, S.; SAHNI, D.; SEHGAL, M.; SRIVASTAVA, D. S.; SINGH, A. Pesticides use and its effect on soil bacterial and fungal populations, microbial biomass carbon and enzymatic activity. Current Science, v. 116, n. 4, p. 643-649, 2019. 
ASLAM, S.; IQBAL, A.; DESCHAMPS, M.; RECOUS, S.; GARNIER, P.; BENOIT, P. Effect of rainfall regimes and mulch decomposition on the dissipation and leaching of $S$-metolachlor and glyphosate: a soil column experiment. Pest Management Science, v. 71, n. 2, p. 278-291, 2015.

ASLAM, S.; IQBAL, A.; LAFOLIE, F.; RECOUS, S.; BENOIT, P.; GARNIER, P. Mulch of plant residues at the soil surface impact the leaching and persistence of pesticides: a modelling study from soil columns. Journal of Contaminant Hydrology, v. 214, p. 54-64, 2018.

BAILEY, G.W.; WHITE, J.L., Factors in fencing the adsorption, desorption and movement of pesticides in soil. In: Residue review: the triazines herbicides. New York, USA: Springer Verlag, v. 32, p. 29 92, 1970

CUENCA, J. B.; TIRADO, N.; BARRAL, J.; ALI, I.; LEVI, M.; STENIUS, U.; BERGLUND, M.; DREIJ, K. Increased levels of genotoxic damage in a Bolivian agricultural population exposed to mixtures of pesticides. Science of The Total Environment, v. 695, p. 133942, 2019.

EL BILALI, H.; CALLENIUS, C.; STRASSNER, C.; PROBST, L. Food and nutrition security and sustainability transitions in food systems. Food Energy Security. v. 8, p. 1-20, 2018.

EL FANTROUSSI, S.; AGATHOS, S. N. Is bioaugmentation a feasible strategy for pollutant removal and site remediation? Current Opinion in Microbiology, v. 8, n. 3, p. 268-275, 2005.

FARENHORST, A. Importance of soil organic matter fractions in soil-landscape and regional assessments of pesticide sorption and leaching in soil. Soil Science Society American Journal., v. 70, n. 3, p. 1005-1012, 2006.

GEBLER, L.; SPADOTTO, C.A. Comportamento ambiental dos herbicidas. In: VARGAS, L.; ROMAN, E.S. (Eds.). Manual de manejo e controle de plantas daninhas. Bento Gonçalves: EMBRAPA Uva e Vinho, 2004. p.57-87.

INOUE, M.H.; SANTANA, D.C.; OLIVEIRA JR., R.S.; CLEMENTE, R.A.; DALLACORT, R.; POSSAMAI, A.C.S.; SANTANA, C.T.C.; PEREIRA, K.M. Potencial de lixiviação de herbicidas utilizados na cultura do algodão em colunas de solo. Planta Daninha, v. 28, n. 4, p. 825-833, 2010.

HELLING, C.S.; KEARNEY, P.C.; ALEXANDER, M. Behavior of pesticide in soils. Advances in Agronomy, v.23, p.147-239, 1971.

HERMAN, R.A.; SCHERER, P.N. Comparison of linear and nonlinear regression for modeling the first-order degradation of pest control substances in soil. Journal of Agricultural and Food Chemistry, v. 51, n. 16, p. 4722-4726, 2003.

KARAS, P. A.; BAGUELIN, C.; PERTILE, G.; PAPADOPOULOU, E. S.; NIKOLAKI, S.; STORCK, V.; FERRARI, F.; TREVISAN M.; FERRARINI, A.; FORNASIER, F.; VASILEIADIS,S.; TSIAMIS, G.; MARTIN-LAURENT, F.; KARPOUZAS, D.G. Assessment of the impact of three pesticides on microbial dynamics and functions in a lab-to-field experimental approach. Science of the Total Environment, v. 637, p. 636-646, 2018.

KHALID, S.; SHAHID, M.; MURTAZA, B.; BIBI, I.; NAEEM, M. A.; NIAZI, N. K. A critical review of different factors governing the fate of pesticides in soil under biochar application. Science of The Total Environment, v. 711, p. 134645, 2020. 
KUMAR, P.; KIM, K.H.; DEEP, A. Recent advancements in sensing techniques based on functional materials for organophosphate pesticides. Biosensors and Bioelectronics v. 70, p. 469-481, 2015.

KUMAR, N.; MUKHERJEE, I.; SARKAR, B.; PAUL, R. K. Degradation of tricyclazole: effect of moisture, soil type, elevated carbon dioxide and Blue Green Algae (BGA). Journal of Hazardous Materials, v. 321, p. 517-527, 2017.

LAMICHHANE, J.R.; DACHBRODT-SAAYDEH, S.; KUDSK, P.; MESSÉAN, A. Conventional pesticides in agriculture: benefits versus risks. Plant Disease, v. 100, n. 1, p. 10-24, 2016.

LANGENBACH, T.; SCHROLL, R.; SCHEUNERT, I. Fate of the herbicide ${ }^{14} \mathrm{C}$ terbuthylazine in Brazilian soils under various climatic conditions. Chemosphere, v. 45, p. 87-398, 2001.

LAVORENTI, A.; PRATA, F.; REGITANO, J.B. Comportamento de pesticidas em solos: fundamentos. In: CURI, N.; MARQUES, J.J.; GUILHERME, L.R.G.; LIMA, J.M.; LOPES, A.S.; ALVAREZ V., V.H. (Eds.). Tópicos em Ciência do Solo. Viçosa: Sociedade Brasileira de Ciência do Solo, 2003. v.3. p.291-33

LEÓN-SANTIESTEBAN H.H.; RODRÍGUEZ-VÁZQUEZ R. Fungal Degradation of Organochlorine Pesticides. In: SINGH, S. (Ed.). Microbe-Induced degradation of pesticides. Environmental Science and Engineering. Springer, Cham, 2017.

ŁOZOWICKA, B.; MOJSAK, P.; KACZYŃSKI, P.; KONECKI, R. BORUSIEWICZ, A. The fate of spirotetramat and dissipation metabolites in Apiaceae and Brassicaceae leaf-root and soil system under greenhouse conditions estimated by modified QuEChERS/LC-MS/MS. Science of The Total Environment, v. 603, p. 178-184, 2017.

MACKY, D.; SHIU, W.; MA, K. Illustrated handbook of physical-chemical properties and environmental fate for organic chemicals. Boca Raton: CRC Press, 1997. 795p.

MOORMAN, T.B.; JAYACHANDRAN, K.; REUNGSANG, A. Adsorption and desorption of atrazine in soils and subsurface sediments. Soil Science, v.166, n. 12, p. 921-929, 2001.

MOSQUERA-VIVAS, C. S.; HANSEN, E. W.; GARCÍA-SANTOS, G.; OBREGÓN-NEIRA, N.; CELIS-OSSA, R. E.; GONZÁLEZ-MURILLO, C. A.; JURASKE, R.; HELLWEG, S.; GUERRERO-DALLOS, J. A. The effect of the soil properties on adsorption, single-point desorption, and degradation of chlorpyrifos in two agricultural soil profiles from Colombia. Soil Science, v. 181, n. (9/10), p. 446-456, 2016.

OBEREMOK, V. V.; LAIKOVA, K. V.; GNINENKO, Y. I.; ZAITSEV, A. S.; NYADAR, P. M.; ADEYEMI, T. A. The need for the application of modern chemical insecticides and environmental consequences of their use: a mini review. Journal of Plant Protection Research, v. 55, n. 3, p.221-226, 2015.

OECD guidelines for the testing of chemicals. Adsorption/desorption using a batch equilibrium method OECE Test Guideline. v. 106. Paris, 2000.

OLIVEIRA JR, R. S.; KOSKINEN, W. C.; FERREIRA, F. A. Sorption and leaching potential of herbicides on Brazilian soils. Weed Research, v. 41, n. 2, p. 97-110, 2001. 
OLIVEIRA JR, R.S. Conceitos importantes no estudo do comportamento de herbicidas no solo. Sociedade Brasileira de Ciência do Solo, v.27, n. 2, p.9- 13, 2001. (Boletim Informativo).

OLIVEIRA JR., R.S.; REGITANO, J.B. Dinâmica de pesticidas no solo. In: Química e mineralogia do Solo. In: MELO, V.F.; ALLEONI, L.R.F. (Eds.). Viçosa: Sociedade Brasileira de Ciência do Solo, 187-248; 2009.

OLIVEIRA, M.F.; PRATES, H.T.; SANS, L.M.A. Sorção e hidrólise do herbicida flazasulfuron. Planta daninha, Viçosa, v. 23, n. 1, p. 101-113, 2005.

PEÑA, ARÁNZAZU; DELGADO-MORENO, LAURA; RODRÍGUEZ-LIÉBANA, JOSÉ ANTONIO. A review of the impact of wastewater on the fate of pesticides in soils: effect of some soil and solution properties. Science of The Total Environment, p. 134468, 2020.

PIASAROLO, L.; RIGITANO, R. L.O.; GUERREIRO, M. C. Influência da polaridade de pesticidas não-iônicos sobre sua sorção em um Latossolo. Ciência \& Agrotecnologia, v. 32, n. 6, p.1802-1809; 2008.

PRATA, F.; LAVORENTI, A. Comportamento de herbicidas no solo: influência da matéria orgânica. Revista Biociências, v. 6, n. 2, p.17-22, 2000.

PROCÓPIO, S. O.; PIRES, F. R.; WERLANG, R. C.; SILVA, A. A.; QUEIROZ, M. E. L. R.; NEVES, A. A.; MENDONÇA, E. S.; SANTOS, J. B.; EGREJA FILHO, F. B. Sorção do herbicida atrazin em complexos organominerais. Planta Daninha, v.19, n.3, p.391-400, 2001.

SAATH, K. C. O.; FACHINELLO, A. L. Crescimento da demanda mundial de alimentos e restrições do fator terra no Brasil. Revista de Economia e Sociologia Rural, v.56, p.195212, 2018.

SATAPUTE, P.; KAMBLE, M.V.; ADHIKARI, S.S.; JOGAIAH, S. Influence of triazole pesticides on tillage soil microbial populations and metabolic changes. Science of the Total Environment, v. 651, p. 2334-2344, 2019.

YAVARI, S.; SAPARI, N. B.; MALAKAHMAD, A.; YAVARI, S. Degradation of imazapic and imazapyr herbicides in the presence of optimized oil palm empty fruit bunch and rice husk biochars in soil. Journal of Hazardous Materials, v. 366, p. 636-642, 2019.

YE, X.; DONG, F.; LEI, X. Microbial resources and ecology-microbial degradation of pesticides. Natural Resources Conservation and Research, v. 1, n. 1, 2018.

ZHANG, Q.; SALEEM, M.; WANG, C. Effects of biochar on the earthworm (Eisenia foetida) in soil contaminated with and/or without pesticide mesotrione. Science of The Total Environment, v. 671, p. 52-58, 2019.

WOŁEJKO, E.; JABŁOŃSKA-TRYPUĆ, A.; WYDRO, U.; BUTAREWICZ, A.; ŁOZOWICKA, B. Soil biological activity as an indicator of soil pollution with pesticides: A review. Applied Soil Ecology, v. 147, p. 103356, 2020.

WU, Z., LIN, T.; HU, L.; GUO, T.; GUO, Z. Atmospheric legacy organochlorine pesticides and their recent exchange dynamics in the Northwest Pacific Ocean. Science of The Total Environment, p. 138408, 2020. 


\title{
Capítulo 16
}

\section{Umidade e temperatura do solo: efeitos da cobertura morta e do tipo de preparo}

\author{
Gustavo Haddad Souza Vieira1, Arildo Sebastião Silva², Lusinerio Prezotti ${ }^{3}$, Paola Alfonsa \\ Vieira Lo Monaco ${ }^{3}$, Ana Paula Candido Gabriel Berilli ${ }^{4}$, Savio da Silva Berilli ${ }^{4}$, Arun \\ Dilipkumar Jani ${ }^{5}$
}

\section{Introdução}

O solo é um importante recurso natural disponível para exploração racional da humanidade, quando em equilíbrio, o solo desempenha um papel fundamental para promover a vida de milhares de seres vivos ocupantes deste universo. Um solo vivo atua de forma harmoniosa com outros elementos naturais essenciais para o desenvolvimento das plantas, dos animais e do homem.

O solo é o principal componente para a produção de alimentos e também atua como o principal reservatório para o armazenamento de água disponível, alimentando rios, córregos e lençóis freáticos (LEPSCH, 2010). Desta forma, para o pleno crescimento das plantas e sua produção, o solo deve ser bem estruturado, permitir um bom desenvolvimento da raiz, ter nutrientes suficientes para a planta, ser arejado e conservar a maior quantidade de água disponível (PRIMAVESI, 2002; WENDLING et al., 2012).

Práticas de manejo do solo intensivas e não adaptadas às condições edafoclimáticas locais acarretam o aumento da degradação física, química e biológica do mesmo, refletindo na queda de produtividade e na elevação dos custos econômicos e ambientais.

A expansão da monocultura, o aumento do uso da mecanização agrícola e o preparo convencional do solo contribuem para a degradação e o aparecimento de problemas de erosão, compactação e a contaminação das águas subterrâneas e superficiais (EMBRAPA, 2014).

\footnotetext{
${ }^{1}$ Dr. Professor do Instituto Federal do Espírito Santo - Campus Santa Teresa. Rod ES 080, km 93, São João de Petrópolis, CEP: 29650-000, Santa Teresa-ES. E-mail: ghsv@ifes.edu.br

${ }^{2}$ Me. em Agroecologia pelo Programa de Pós-Graduação em Agroecologia do Instituto Federal do Espírito Santo - Campus de Alegre, Caixa Postal 16, CEP: 29500-000, Alegre-ES. E-mail: arildos.silva@gmail.com

${ }^{3}$ Drs. Professores do Instituto Federal do Espírito Santo - Campus Santa Teresa. Rod ES 080, km 93, São João de Petrópolis, CEP: 29650-000, Santa Teresa-ES. E-mail: lusineriop@ifes.edu.br; paolalomonaco2004@yahoo.com.br

${ }^{4}$ Drs. Professores do Instituto Federal do Espírito Santo - Campus de Alegre, Caixa Postal 16, CEP: 29500-000, Alegre-ES. E-mail: anapaulacg@gmail.com; savio.berilli@ifes.edu.br

${ }^{5} \mathrm{PhD}$. State Agronomist, USDA-Natural Resources Conservation Service, Ecological Sciences Division, Portland, Oregon, USA. Zip Code 97232. E-mail: arun.jani@usda.gov
} 
Estudos da Organização das Nações Unidas para Alimentação e a Agricultura - FAO (2015) apontam que 33\% dos solos do mundo estão degradados. Somente a erosão elimina 25 a 40 bilhões de toneladas de solo por ano, reduzindo significativamente a produtividade das culturas e a capacidade de armazenar nutrientes e água. A perda de solos produtivos prejudica gravemente a produção de alimentos e a segurança alimentar, e amplifica a volatilidade dos preços dos alimentos. O Brasil precisa avançar na adoção de práticas sustentáveis na produção de alimentos em que o uso da água e solo seja o mais eficiente possível.

A agroecologia, como instrumento de desenvolvimento sustentável para a agricultura familiar, orienta para a construção de uma agricultura socialmente justa, economicamente viável e ecologicamente correta, objetivando integrar os agricultores ao meio rural, para solucionar os problemas deixados pela modernização da agricultura, que é excludente do ponto de vista social e causadora da dependência econômica (FIEIRA e BATISTA, 2009).

Para isso, lança mão, dentre outras ações, do uso de tecnologias com baixo impacto sobre os recursos naturais, com uso racional do solo e da água, através da adoção de técnicas e práticas conservacionistas e de baixa emissão de carbono. Dentre estas práticas conservacionistas, destaca-se o uso da cobertura do solo com resíduos vegetais, integrado ao revolvimento mínimo do solo (PRIMAVESI, 2002).

Estas ações além de contribuírem para a melhoria dos atributos químicos, físicos e biológicos do solo, contribuem para maior retenção e armazenamento de água no sistema. O uso de cobertura morta atua na manutenção e incremento do teor de matéria orgânica, além de promover a descompactação dos solos e a supressão de plantas infestantes. Solos sem cobertura vegetal apresentam, geralmente, maior amplitude térmica diária do que solos protegidos (STEFANOSKI et al., 2013).

Conservar solo e água é fundamental para as propriedades rurais e outras atividades econômicas, garantindo a subsistência humana e melhorando a qualidade de vida das populações. Para tanto, são necessárias pesquisas sobre a utilização das coberturas e seus diferentes manejos, na retenção e armazenamento de água no solo. Compreender e quantificar o impacto do uso e manejo do solo é fundamental para o desenvolvimento de sistemas agrícolas sustentáveis (MESCHEDE et al., 2007).

O Espírito Santo enfrentou a mais grave crise hídrica de sua história, que começou em 2014. A redução das chuvas provocou a diminuição recorde das vazões dos rios, onde os efeitos afetaram boa parte da população rural e urbana, principalmente na região Norte do Estado. Em face dessa situação, a Agência Estadual de Recursos Hídricos (AGERH) editou as Resoluções 05 e 06/2015, que caracterizam o cenário de alerta frente à prolongada escassez hídrica e priorizam o abastecimento humano e a dessedentação animal (CESAN, 2016). 
A agricultura é reconhecidamente a atividade humana que mais consome água, em média $70 \%$ de todo o volume captado, destacando-se a irrigação a atividade de maior demanda (PESSOA, 2016). Como explanado acima, o uso da água para irrigação não se constitui prioridade. Essa realidade demanda que sejam utilizadas técnicas que permitam o aproveitamento mais eficiente possível da água na agricultura. Diante do exposto, objetivouse avaliar a temperatura, capacidade de retenção e armazenamento de água do solo sob diferentes manejos e coberturas mortas.

\section{Cobertura do solo}

A cobertura do solo é uma prática conservacionista e exerce influência marcante nas características físicas, químicas e biológicas do mesmo. Em relação ao tipo de cobertura, este pode ser inorgânico ou orgânico. Plantas de cobertura (cobertura viva), resíduos orgânicos (cobertura morta) e coberturas plásticas proporcionam excelentes benefícios ao agricultor e ao ambiente (CAPUCHO, 2016).

A cobertura morta é uma prática agrícola que consiste em cobrir a superfície do solo, com uma camada de material orgânico, geralmente com sobras de culturas como a palha ou cascas. A cobertura morta é formada principalmente por gramíneas, consorciadas ou não com leguminosas, com alta capacidade de produção de matéria seca, semeadas para este fim na própria área onde se deseja ter a cobertura ou com uso de materiais ou palhadas transportadas de outros locais (VARGAS e OLIVEIRA, 2005).

A presença desses resíduos vegetais na superfície do solo diminui as perdas de água por evaporação e a amplitude térmica no solo, propiciando a manutenção da umidade do solo por maior período de tempo (FABRIZZI et al., 2005). A utilização de cobertura também exerce influência sobre a estrutura do solo na camada superficial, promovendo melhoria das características físicas, reduzindo a compactação e favorecendo a infiltração da água através do aumento da porosidade (EMBRAPA, 1987).

Santos et al. (2011), ao investigarem a variabilidade temporal do conteúdo superficial da água no solo sob diferentes coberturas, concluíram que a cobertura morta se destaca como a prática conservacionista mais adequada para manutenção da umidade do solo nas condições do estudo. Teófilo et al. (2012) ao avaliarem sistemas de plantio e estratégias de manejo de plantas daninhas na economia de água de irrigação, verificaram que a cobertura do solo com palha no plantio direto reduziu a perda de água em $13 \%$, em relação ao tratamento com capinas no plantio convencional, aumentando a eficiência no uso da água.

A cobertura morta também protege o solo contra o impacto direto das gotas de chuva, reduzindo as perdas de água e solo. Com a incorporação lenta e gradativa no solo, promove 
o aumento de matéria orgânica e é fonte de energia para os microrganismos. Assim, proporciona o aumento da atividade microbiana que, aliada à mineralização, torna disponível nutrientes às plantas, induzindo melhoria na produtividade. Sua presença também promove o controle de plantas daninhas (FERREIRA et al., 2013).

Nogueira et al. (2012) destacaram a eficiência do uso de espécies leguminosas como plantas de cobertura viva ou morta sobre o solo, e destacaram ainda a sua eficiência como prática de conservação do solo evitando sua degradação. O bom desempenho da cobertura do solo a partir de resíduos vegetais depende basicamente de dois fatores, a biomassa deixada sobre o solo para formar a cobertura e a taxa de decomposição do resíduo.

\section{Porcentagem de cobertura do solo}

A quantidade de material residual gerada para proteger o solo é um fator importante quando seu objetivo é evitar a degradação do solo por meio da erosão hídrica, principalmente quando se trata dos efeitos causados pelas gotas da chuva (FABIAN, 2009). O desafio do trabalho com plantas de cobertura é fazer com que o solo permaneça o maior tempo possível protegido com resíduos vegetais.

Sodré Filho et al. (2004) observaram a redução gradual da cobertura do solo ao trabalharem com resíduos vegetais de milheto e crotalária no Distrito Federal. As duas espécies vegetais foram plantadas no mês de abril e os cortes foram realizados respectivamente com 67 e 95 dias. Após 30 dias do corte, os resíduos vegetais de milheto cobriam $83 \%$ do solo, enquanto que os resíduos de crotalária cobriam $87 \%$ do solo. Estes valores apresentaram uma queda aos 90 dias após o corte, onde os resíduos de milheto cobriam $31 \%$ do solo e os resíduos de crotalária cobriam $50 \%$ do solo.

Soares (2006), avaliando a cobertura do solo utilizando resíduo vegetal de braquiária, milheto e crotalária, observou logo após o corte, realizado em pleno florescimento, que os resíduos das espécies cobriam o solo em $100 \%, 75 \%$ e $85 \%$, respectivamente. O autor observou que após 21 dias do corte, as coberturas reduziram respectivamente para 99\%, $62 \%$ e $30 \%$ e após 84 dias verificou que os resíduos da braquiária ainda mantinham $97 \%$ do solo coberto, enquanto que os resíduos do milheto cobriam $50 \%$ do solo e os resíduos da crotalária apenas $15 \%$. A rápida decomposição da crotalária foi atribuída à relação $\mathrm{C} / \mathrm{N}$ mais baixa e aos menores teores de lignina quando comparados à braquiária e ao milheto. 


\section{Sistemas de preparo do solo}

O sistema de preparo do solo influencia diretamente nas características do solo, alterando a dinâmica do ar e da água e a disponibilidade de nutrientes. Em geral, o objetivo do preparo do solo é oferecer condições físicas adequadas para um ótimo crescimento, desenvolvimento e produtividade das culturas (TORMENA et al., 2004).

Os sistemas de preparo mecanizados do solo são empregados com o objetivo de movimentar suas camadas superficiais e favorecer o desenvolvimento das plantas, porém, o emprego excessivo de máquinas e implementos agrícolas é uma das causas da degradação das propriedades físicas do solo (STEFANOSKI et al., 2013).

Segundo Aratani et al. (2009), o preparo convencional acelera a decomposição da matéria orgânica, rompe os agregados e reduz sua estabilidade nas camadas manejadas, além de favorecer o aumento da densidade do solo e a resistência do solo à penetração de raízes em subsuperfície.

O plantio direto pode ser uma alternativa ao sistema convencional de preparo do solo, pois contribui para a sustentabilidade de sistemas agrícolas intensivos, por manter o solo coberto por restos culturais ou por plantas vivas, minimizando os efeitos da erosão.

A semeadura direta é um tipo de manejo conservacionista, que permite a redução na intensidade de preparo do solo, nesse sistema é menor a decomposição da cobertura vegetal, acumulando a matéria orgânica e aumentando o teor de $\mathrm{C}$ orgânico total, que estabiliza a estrutura do solo, pelo efeito cimentante na formação e manutenção dos agregados (BARRETO et al., 2009).

\section{Armazenamento de água no solo}

Para um correto manejo da irrigação é necessário conhecer a quantidade de água armazenada no perfil do solo, para assim definir a quantidade da lâmina a ser aplicada e o intervalo de tempo para a próxima irrigação. A quantidade de água armazenada é representada pela sua umidade, que pode ser expressa relacionando a massa de água com a massa de sólidos, denominada umidade gravimétrica (REICHARDT, 1990).

A retenção de água no solo é característica específica de cada solo, sendo resultado da ação conjunta e complexa de vários fatores, como o teor e mineralogia da fração argila, teor de matéria orgânica, estrutura, densidade do solo, dentre outros. Numa segunda consideração, o uso e manejo do solo afetam diretamente a densidade e porosidade, consequentemente o armazenamento de água ao longo do perfil (STONE e MOREIRA, 2000). 
No solo, a água ocupa os espaços porosos formados do arranjo físico das partículas da fase sólida. A água do solo é altamente dinâmica, exibindo variação no tempo e no espaço, sobretudo perto da superfície do solo, devido à evaporação e atividade das raízes das plantas (PAZ GONZÁLES e ALVES, 2005).

O incremento de matéria orgânica no solo contribui para a retenção de água, e, associado à menor intensidade de revolvimento, melhora substancialmente a estrutura do solo, o que favorece o desenvolvimento radicular e assim aumenta o tamanho do reservatório de água disponível (KLEIN e KLEIN, 2015).

Muitas técnicas têm sido usadas na agricultura com o objetivo de reduzir as perdas de água do solo, porém são necessárias mais pesquisas, visto que os comportamentos dos diferentes solos e climas não traduzem resultados semelhantes (PAZ GONZÁLES e ALVES, 2005).

Em estudo realizado por Silva (2018) em um Latossolo Vermelho-Amarelo, com textura média, avaliaram-se dois tipos de manejo do solo e três tipos de materiais de cobertura do solo, mais a testemunha (Figura 1).

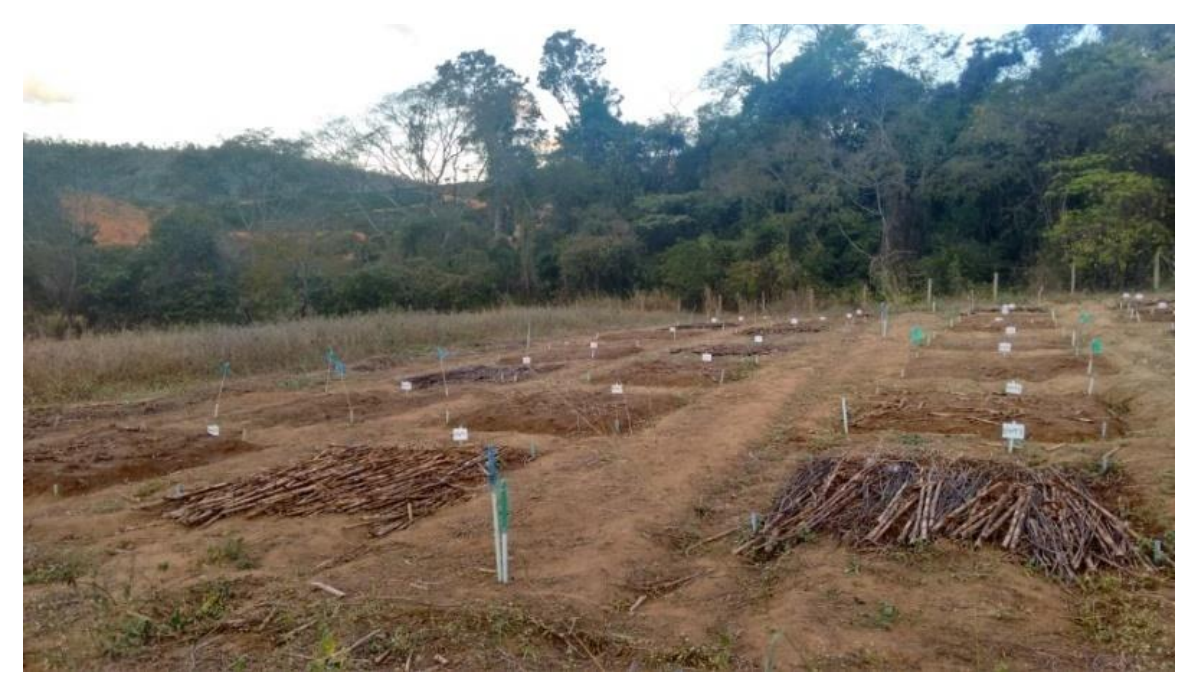

Figura 1. Vista parcial do estudo de diferentes tipos de manejo do solo e de materiais de cobertura do solo.

Fonte: Silva (2018).

Os sistemas de manejo de solo utilizados foram solo com preparo (CP), ou seja, incorporação da biomassa utilizando enxada rotativa acoplada a um micro trator. O segundo sistema foi o solo sem preparo (SP), ou seja, a biomassa permaneceu sobre o solo formando uma cobertura vegetal ou camada de proteção. Os tipos de materiais utilizados para formar cobertura foram milho (Zea mays), crotalária juncea ( $C$. juncea) e uma mistura de milho mais $C$. juncea (Tabela 1 ). 
Tabela 1. Descrição dos diferentes tipos de manejo do solo e de materiais de cobertura do solo.

\begin{tabular}{ccc}
\hline Tipos de materiais & \multicolumn{2}{c}{ Tipos de manejo } \\
\cline { 2 - 3 } de cobertura & Sem preparo (SP) & Com preparo (CP) \\
\hline Milho & $\mathrm{T} 1$ & $\mathrm{~T} 5$ \\
C. juncea & $\mathrm{T} 2$ & $\mathrm{~T} 6$ \\
Milho + C. juncea & $\mathrm{T} 3$ & $\mathrm{~T} 7$ \\
Testemunha & $\mathrm{T} 4$ & $\mathrm{~T} 8$ \\
\hline
\end{tabular}

Fonte: Silva (2018).

Neste estudo, avaliou-se a umidade do solo, pelo método gravimétrico (BERNARDO et al. 2019), em função do tipo de preparo e da cobertura morta, tanto na camada 0 a $0,05 \mathrm{~m}$ quanto na camada 0,10 a $0,15 \mathrm{~m}$ de profundidade (Figura 2).
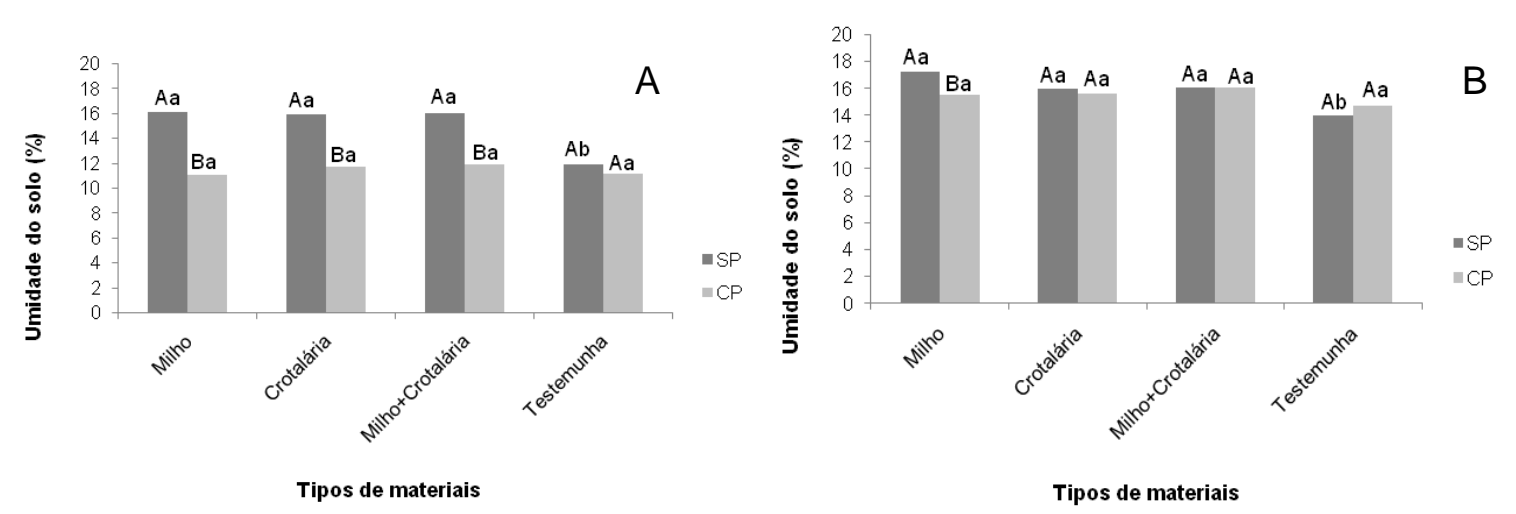

Figura 2. Umidade do solo nas profundidades de 0,0 a $0,05 \mathrm{~m}(\mathrm{~A})$ e de 0,10 a $0,15 \mathrm{~m}(\mathrm{~B}) \mathrm{em}$ função do tipo de preparo do solo e do tipo de cobertura morta utilizada.

Letras iguais, minúsculas para tipos de materiais e maiúsculas para tipos de preparo do solo não diferem entre si pelo teste Tukey $(p \leq 0,05)$. SP: solo sem preparo; CP: solo com preparo.

Fonte: Silva (2018).

Os maiores valores de umidade obtidos na profundidade de 0,00 a $0,05 \mathrm{~m}$ ocorreram nas unidades experimentais sem preparo de solo, especificamente nas coberturas de milho, $C$. juncea e milho mais C. juncea, sendo 16,07, 15,88 e 16,05\%, respectivamente, todos estatisticamente iguais. Apenas a testemunha diferiu, onde o valor da variável analisada foi consideravelmente inferior e estatisticamente semelhante ao encontrado para a testemunha com preparo do solo.

Dentre as unidades experimentais sem preparo do solo, o maior valor foi obtido na cobertura com milho, sendo $16,07 \%$, já o menor valor foi para a testemunha1(1,88\%), apresentando uma redução de $26,07 \%$ no valor de umidade. Sendo assim, a cobertura com 
milho, $C$. juncea e milho mais $C$. juncea, sem o preparo do solo, são igualmente eficientes para um maior armazenamento de água no mesmo.

As unidades experimentais com preparo do solo apresentaram os menores valores de umidade e não diferiram estatisticamente. Comparando-se o maior valor de umidade obtido (milho/sem preparo), sendo 16,07\%, com o menor valor (milho/com preparo), 11,03\%, observa-se uma redução de $31,36 \%$ da variável analisada.

O revolvimento do solo causa degradação da estrutura do mesmo, fracionando os agregados em unidades menores, aumentando os microporos, diminuindo a infiltração e o armazenamento de água no solo. Segundo Klein e Klein (2015), o não revolvimento do solo, aliado aos resíduos vegetais em cobertura promovem benefícios na física do solo, como estabilidade estrutural, redução da compactação, aumento da infiltração e percolação de água e capacidade de armazenamento de água no solo.

A cobertura em superfície contribui para uma maior eficiência no uso da água, já que ocorre maior armazenamento de água no solo, pela redução das perdas por evaporação. Segundo Allen et al. (2011), a prática do uso de cobertura morta forma uma espécie de bloqueio ao fluxo da água do solo para a atmosfera. Para Carvalho et al. (2011a) isso permite conservá-la por um maior período de tempo no solo, promovendo assim, o aumento da eficiência do uso da água.

Segundo Silva et al. (2012), a cobertura morta reduz a evapotranspiração das culturas. Stanghelline (1993) observou em seus estudos que solos submetidos à proteção têm uma redução de até 30\% da taxa de evapotranspiração, quando comparado ao solo descoberto. Neto et al. (2011), estudando o efeito da cobertura morta no cultivo de beterraba orgânica, concluíram que o uso da cobertura com leguminosa ou gramínea contribuiu para a redução da demanda de água ao alcançarem uma redução de 53\% da taxa de evapotranspiração quando comparado com um solo sem cobertura.

Sendo assim, constatou-se neste experimento, que a cobertura vegetal aliada ao não revolvimento do solo, melhorou as condições de conservação da umidade do mesmo, sendo uma alternativa para minimizar os efeitos adversos decorrentes do déficit hídrico, podendo influenciar diretamente no crescimento e desenvolvimento de plantas. Ribeiro et al. (2016), avaliando a produtividade de cebola em sistema de cultivo agroecológico sob distintas lâminas de irrigação e coberturas de solo, observaram aumento da produtividade total de bulbos e o incremento na eficiência do uso da água.

Com base nos cálculos da lâmina armazenada foi possível observar uma diferença de umidade entre o tratamento utilizando o milho sem preparo e a testemunha sem preparo. $A$ diferença de umidade foi de $2,54 \mathrm{~mm}$ ou $2,54 \mathrm{~L} \mathrm{~m}^{-2}$. Em um hectare este resultado representa uma economia de 25.400 litros de água aplicados durante uma irrigação. Tomando por base uma média entre os produtores orgânicos no município de Santa Maria 
de Jetibá/ES que utilizam uma frequência de irrigação de três vezes por semana, essa economia semanal alcançaria um volume de $76.200 \mathrm{~L} \mathrm{ha}^{-1}$, o que ao final de um mês, representaria uma economia de $304.800 \mathrm{~L} \mathrm{ha}^{-1}$.

Esta economia seria ainda superior se compararmos os dois tipos de manejo entre o milho sem preparo formando cobertura morta, e milho com preparo, com incorporação da biomassa. Como a diferença de umidade foi de $3,05 \mathrm{~mm}$ ou $3,05 \mathrm{~L} \mathrm{~m}^{-2}$, em um hectare este resultado representaria uma economia de 30.500 litros de água aplicados durante uma irrigação. Considerando-se as mesmas condições da estimativa anterior, essa economia semanal alcançaria um volume de $91.500 \mathrm{~L} \mathrm{ha}^{-1}$, o que ao final de um mês, representaria uma economia de $366.000 \mathrm{~L} \mathrm{ha}^{-1}$.

Em relação aos resultados apresentados referentes ao tipo de preparo de solo na profundidade de 0,10 a $0,15 \mathrm{~m}$, todos os tratamentos apresentaram valores de umidade estatisticamente iguais, com exceção da cobertura com milho, onde o solo sem preparo apresentou valor superior aos demais (17,25\%). Comparando-se com o valor obtido para a cobertura de milho com preparo (15,51\%), observa-se um incremento na variável analisada em $10,08 \%$.

Referente ao tipo de material utilizado na cobertura, nas unidades experimentais sem preparo do solo, apenas a testemunha diferiu estatisticamente dos demais, apresentando o menor valor para a umidade do solo. Comparando-se o maior valor obtido para a variável analisada (cobertura com milho), cerca de 17,25\%, com o menor valor (Testemunha), 13,93\%, percebe-se uma redução de $19,24 \%$ no teor de umidade do solo. Já para as unidades experimentais com preparo do solo, não se observou diferença entre os valores de umidade obtidos.

\section{Temperatura do solo}

A temperatura do solo é de fundamental importância pelo papel que desempenha nos processos de interações solo-planta. O solo, além de armazenar e permitir os processos de transferência de água, solutos e gases, também armazena e transfere calor, através de suas propriedades térmicas e pelas condições meteorológicas que, por sua vez, influenciam todos os processos químicos, físicos e biológicos do solo. É a partir do balanço de radiação na superfície que o solo se aquece e se resfria no decurso do dia e do ano, provocando variações térmicas nas camadas subjacentes (GASPARIM et al., 2005).

A temperatura do solo tem efeitos diretos no desenvolvimento da planta, já que temperaturas extremas podem causar sérios danos ao desenvolvimento das culturas. A germinação ocorre dentro de certos limites de temperatura, cuja amplitude e valores 
absolutos dependem de cada espécie. Dentro da faixa de temperatura em que as sementes de uma espécie germinam, há geralmente uma temperatura ótima, acima e abaixo da qual a taxa de germinação diminui, assim como existe uma temperatura média ideal para o desenvolvimento fenológico de cada espécie vegetal (SILVA et al., 2002).

A temperatura do solo também influencia a taxa de liberação de nutrientes da matéria orgânica, a absorção pelas raízes e a subsequente translocação e utilização em várias partes da planta (FAGERIA, 1998). A atividade microbiológica poderá ser interrompida, as sementes poderão não germinar e as plantas não se desenvolverem caso o solo não se apresente dentro de uma faixa de temperatura adequada para a manutenção dos processos fisiológicos envolvidos (GASPARIM et al., 2005).

O ambiente de cultivo, a cobertura do solo e os níveis de irrigação exercem influência na temperatura do solo, sendo que esta diminui na medida em que aumenta o potencial de água no solo (CARVALHO et al., 2011b). Carneiro et al. (2014), ao determinarem a temperatura do solo, com cobertura vegetal ou não, verificaram que a presença de água afeta o fluxo de calor no solo, a umidade é capaz de modificar a temperatura ao nível de superfície por ocasião da evaporação.

Oliveira et al. (2005), ao avaliarem as flutuações de temperatura e umidade do solo em resposta à cobertura vegetal, constataram que a ausência de cobertura vegetal propicia maior amplitude de variação da temperatura, observando também que nessas condições ocorrem os menores valores de umidade e os maiores valores de temperatura.

No mesmo estudo citado no tópico de umidade do solo, realizado por Silva (2018), avaliou-se o comportamento da temperatura, com medidas realizadas a partir das 12:00 horas, semanalmente, utilizando um termômetro de solo (Soloterm 1200), tipo K, da marca Solotest. Em cada unidade foram aferidas três leituras, sendo a primeira na superfície do solo e as outras duas a $0,03 \mathrm{~m}$ e a $0,13 \mathrm{~m}$ de profundidade.

Nas tabelas 2 e 3 estão apresentados os resultados desta variável em função do tipo de preparo do solo e do material utilizado para cobertura morta.

Tabela 2. Temperatura $\left({ }^{\circ} \mathrm{C}\right)$ para o solo sem preparo (SP).

\begin{tabular}{cccc}
\hline Cobertura morta & Superficial & $\mathbf{0 , 0 3} \mathbf{~ m}$ & $\mathbf{0 , 1 3} \mathbf{~ m}$ \\
\hline Milho & $28,37 \mathrm{Ab}$ & $27,00 \mathrm{Ab}$ & $25,66 \mathrm{Bb}$ \\
Crotalária & $28,37 \mathrm{Ab}$ & $27,26 \mathrm{Ab}$ & $25,46 \mathrm{Bb}$ \\
M+C & $29,05 \mathrm{Ab}$ & $26,89 \mathrm{Bb}$ & $25,54 \mathrm{Bb}$ \\
Testemunha & $36,97 \mathrm{Aa}$ & $32,95 \mathrm{Ba}$ & $28,12 \mathrm{Ca}$ \\
\hline
\end{tabular}

Médias seguidas pela mesma letra maiúscula na linha e minúscula na coluna não diferem entre si pelo teste Tukey $(p \leq 0,05)$.

Fonte: Silva (2018). 
Tabela 3. Temperatura $\left({ }^{\circ} \mathrm{C}\right)$ para o solo com preparo $(\mathrm{CP})$.

\begin{tabular}{cccc}
\hline Cobertura morta & Superficial & $\mathbf{0 , 0 3} \mathbf{~}$ & $\mathbf{0 , 1 3} \mathbf{~}$ \\
\hline Milho & $38,09 \mathrm{Aa}$ & $33,48 \mathrm{Ba}$ & $27,36 \mathrm{Ca}$ \\
Crotalária & $37,58 \mathrm{Aa}$ & $33,58 \mathrm{Ba}$ & $27,86 \mathrm{Ca}$ \\
M+C & $37,57 \mathrm{Aa}$ & $33,33 \mathrm{Ba}$ & $27,72 \mathrm{Ca}$ \\
Testemunha & $37,89 \mathrm{Aa}$ & $34,13 \mathrm{Ba}$ & $28,32 \mathrm{Ca}$ \\
\hline
\end{tabular}

Médias seguidas pela mesma letra maiúscula na linha e minúscula na coluna não diferem entre si pelo teste Tukey $(p \leq 0,05)$.

Fonte: Silva (2018).

\section{Temperatura do solo na superfície}

Em relação aos tipos de preparo, observa-se que os menores valores de temperatura na superfície do solo ocorreram nas unidades experimentais sem preparo do solo, especificamente nas coberturas de milho, $C$. juncea e milho mais $C$. juncea, sendo 28,37; 28,37 e $29,05^{\circ} \mathrm{C}$, respectivamente, sendo estes estaticamente iguais. Apenas a testemunha diferiu, onde o valor da variável analisada foi consideravelmente superior, e estatisticamente semelhante ao encontrado para a testemunha com preparo do solo.

Nas unidades experimentais sem preparo de solo, ao comparamos o menor valor obtido, $28,37^{\circ} \mathrm{C}$, com o maior valor, $36,97^{\circ} \mathrm{C}$, observa-se uma diferença de $8,60^{\circ} \mathrm{C}$, cerca de $23,26 \%$ a mais. Os maiores valores de temperatura na superfície do solo ocorreram nas unidades experimentais com preparo, sendo todos os materiais estaticamente iguais.

Comparando-se o maior valor encontrado para temperatura do solo na superfície $\left(38,09^{\circ} \mathrm{C}\right)$ (milho/com preparo), com o menor valor $\left(28,37^{\circ} \mathrm{C}\right)$ (milho/sem preparo), observase um incremento de $9,72^{\circ} \mathrm{C}(25,51 \%)$.

A temperatura e o regime térmico do solo dependem da sua cobertura superficial, com vegetação ou resíduos, e do conteúdo de água, além da intensidade e duração da radiação solar (BELAN et al., 2013; BEZERRA et al., 2016), Os materiais vegetais refletem a radiação solar, agindo como um atenuador de ondas térmicas, diminuindo a temperatura do solo. $A$ menor temperatura do solo (milho/sem preparo), pode ser consequência, além da cobertura dos resíduos vegetais, à maior umidade volumétrica na camada superficial.

A cobertura morta propiciou a redução da temperatura em $25,51 \%$ na camada superficial do solo e promoveu a alteração do clima abaixo da camada de resíduo vegetal. Oliveira et al. (2005) observaram a oscilação da térmica do solo a partir da interceptação dos raios solares pela camada cobertura do solo, criando um microclima sob a superfície.

A cobertura morta também atuou como uma camada de proteção do solo contra a exposição direta do sol. A maioria dos animais edáficos são antifototrópicos e um solo 
desnudo não promove uma barreira de proteção ou zona de refúgio para estes animais que morrem ao não suportarem a insolação direta devido ao seu estado despigmentado (PRIMAVESI, 2002).

Segundo Primavesi (2002), altas temperaturas do solo contribuem para a morte da maioria dos componentes da meso e macrofauna do solo. Esta mesma autora destaca o papel importante destes componentes do solo na mobilização de nutrientes e na estrutura do solo. No experimento, em especial nas unidades com resíduo vegetal sem preparo, observou a presença de aracnídeos, minhocas, larvas de insetos, pequenos coleópteros e formigas.

\section{Temperatura do solo a $0,03 \mathrm{~m}$ de profundidade}

Em relação aos tipos de preparo, observa-se que os menores valores de temperatura a 0,03 m de profundidade, ocorreram nas unidades experimentais sem preparo do solo, sendo estes estaticamente iguais. Apenas a testemunha diferiu, onde o valor da variável analisada foi consideravelmente superior, e estatisticamente semelhante ao encontrado para a testemunha com preparo do solo.

Nas unidades experimentais sem preparo de solo, ao comparamos o menor valor obtido, $26,89^{\circ} \mathrm{C}$, com o maior valor $\left(32,95^{\circ} \mathrm{C}\right)$ observa-se uma diferença de $6,06^{\circ} \mathrm{C}$, cerca de $18,39 \%$ a mais. Os maiores valores de temperatura do solo a $0,03 \mathrm{~m}$ de profundidade ocorreram nas unidades experimentais com preparo, sendo todos os materiais estaticamente iguais.

O maior valor de temperatura do solo ocorreu na unidade experimental testemunha, com preparo de solo $\left(34,13^{\circ} \mathrm{C}\right)$, já o menor valor foi obtido na cobertura com milho mais $C$. juncea, sem preparo do solo $\left(26,89^{\circ} \mathrm{C}\right)$, constatando-se uma diferença de $7,24^{\circ} \mathrm{C}(21,21 \%)$.

\section{Temperatura do solo a $0,13 \mathrm{~m}$ de profundidade}

A temperatura do solo a $0,13 \mathrm{~m}$ de profundidade seguiu o mesmo comportamento das demais profundidades avaliadas. Os menores valores obtidos ocorreram nas unidades experimentais sem preparo, com exceção da testemunha, a qual foi estatisticamente semelhante às unidades com preparo do solo.

Nas unidades experimentais sem preparo de solo, ao compararmos o menor valor obtido, $25,46^{\circ} \mathrm{C}$, com o maior valor $\left(28,12^{\circ} \mathrm{C}\right)$, observa-se uma diferença de $2,66^{\circ} \mathrm{C}(9,45 \%)$ a mais. Os maiores valores de temperatura na superfície do solo ocorreram nas unidades experimentais com preparo, sendo todos os materiais estaticamente iguais. 
Conforme observado nas tabelas 2 e 3 , em que foram apresentados os valores de temperaturas para todas as profundidades. Percebe-se que a variação da temperatura é menor com o aumento do volume de água armazenada no solo, tanto a temperatura, quanto a amplitude térmica em superfície, a 0,03 e a 0,13 m de profundidade foi menor nos solos sem preparo, com cobertura vegetal. Na testemunha, onde a quantidade de água armazenada foi menor, tanto a temperatura, quanto a amplitude térmica foram maiores, indicando um aumento da difusidade térmica da superfície para o interior do perfil.

Resultados semelhantes foram descritos por Resende et al. (2005), que ao estudarem o efeito de diferentes coberturas mortas no cultivo de cenoura concluíram que os materiais utilizados foram igualmente eficientes e com resultados significativamente diferentes da ausência de cobertura na manutenção das características de umidade e temperatura do solo.

Esses autores também destacam que em média, esses materiais mantiveram o solo com um gradiente de temperatura de aproximadamente $3,5^{\circ} \mathrm{C}$ inferior ao tratamento sem cobertura e a umidade manteve-se 2,0\% superior ao solo descoberto. Valores superiores foram obtidos neste experimento, sendo o gradiente de temperatura de aproximadamente $6,06^{\circ} \mathrm{C}$ inferior ao tratamento sem cobertura, para a mesma profundidade avaliada. Em relação à umidade, o solo com cobertura vegetal manteve-se $26,07 \%$ superior ao solo descoberto e sem preparo.

Neste experimento, observou uma redução no gradiente entre a maior temperatura e a menor temperatura obtida nas unidades experimentais sem preparo. O gradiente de temperatura reduziu com o aumento da profundidade $\left(8,60^{\circ} \mathrm{C}\right.$ na superfície, $6,06^{\circ} \mathrm{C}$ na profundidade $0,03 \mathrm{~m}$ e $2,66^{\circ} \mathrm{C}$ na profundidade $0,13 \mathrm{~m}$; respectivamente $23,26 \%, 18,39 \%$ e $9,45 \%$ ), comportamento semelhante foi observado por Faria (1996).

\section{Considerações finais}

Solos sem preparo ou não revolvidos retêm a maior quantidade de água e proporcionam as menores temperaturas se comparados a solos com preparo. As coberturas mortas de milho, crotalária e milho mais crotalária são eficientes e retêm a maior quantidade de água se comparado com solos desnudos e solos com preparo. As coberturas mortas de milho, crotalária e milho mais crotalária são eficientes e propiciaram as temperaturas mais baixas se comparadas com solos desnudos e solos com preparo. 


\section{Agradecimentos}

Ao Instituto Federal do Espírito Santo - Campus Santa Teresa, por disponibilizar a área experimental e laboratórios de apoio e ao Programa de Pós-Graduação em Agroecologia (PPGA), por terem proporcionado os meios para a realização deste trabalho.

\section{Referências}

ALLEN, R. G.; HOWELL, T. A.; SNYDER, R. L. Irrigation water requirements. In: STETSON, L. E.; MECHAM, B. Q. Falls Church - Irrigation Association, 2011. 1.045 p.

ARATANI, R. G.; FREDDI, O. S.; CENTURION, J. F.; ANDRIOLI, I. Qualidade física de um Latossolo vermelho acriférrico sob diferentes sistemas de uso e manejo. Revista Brasileira de Ciência do Solo, v. 33, p. 677-687, 2009.

BARRETO, R. C.; MADARI, B. E.; MADDOCK, J. E. L.; MACHADO, P. L. O. A.; TORRES, E.; FRANCHINI, J.; COSTA, A. C. The impact of soil management on aggregation, carbon stabilization and carbon loss as $\mathrm{CO}_{2}$ in the surface layer of a Rhodic Ferralsol in Southern Brazil. Agriculture, Ecosystems and Environment, v. 132, p. 243- 251, 2009.

BELAN, L. L.; XAVIER, T. M. T.; TORRES, H.; TOLEDO, J. V.; PEZZOPANE, J. E. M. Dinâmica entre temperaturas do ar e do solo sob duas condições de cobertura. Revista Acadêmica Ciência Animal, v. 11, p. 147-154, 2013.

BeZerRA, A. C.; MONTENEGRO, A. A. A.; PANDORFI, H.; SILVA, W. P.; ANDRADE, C. W. L.; SILVA, W. P. Variabilidade espaço temporal da temperatura do solo sob diferentes coberturas no semiárido pernambucano. Water Resources and Irrigation Management, v. 5, n. 3, p. 75-85, 2016.

BERNARDO, S.; MANTOVANI, E. C.; SILVA, D. D.; SOARES, A. A. Manual de irrigação. 9. ed. Viçosa: UFV, 2019. 545 p.

CAPUCHO, M. E. O. V. Emissão de $\mathbf{C O}_{2}$, temperatura e umidade do solo sob diferentes sistemas de cobertura de solo no cultivo de Yacon. Alegre-ES, 2016. 26f. Monografia (Graduação em Engenharia Florestal) - Departamento de Ciências Florestais e da Madeira, Universidade Federal do Espírito Santo, Alegre, 2016.

CARNEIRO, R. G.; MOURA, M. A. L.; SILVA, V. P. R.; SILVA JÚNIOR, R. S.; ANDRADE, A. M. D.; SANTOS, A. B. Variabilidade da temperatura do solo em função da liteira em fragmento remanescente da Mata Atlântica. Revista Brasileira Engenharia Agrícola e Ambiental, v. 1, p. 99-108, 2014.

CARVALHO, D. F.; OLIVEIRA NETO, D. H.; RIBEIRO, R. L. D.; GUERRA, J. G. M.; ROUWS, J. R. C. Manejo da irrigação associada a coberturas mortas vegetais no cultivo orgânico da beterraba. Engenharia Agrícola, v. 31, n. 2, p. 269-277, 2011a.

CARVALHO, J. F.; MONTENEGRO, A. A. A.; SOARES, T. M.; SILVA, E. F. F.; MONTENEGRO, S. M. G. L. Produtividade do repolho utilizando cobertura morta e 
diferentes intervalos de irrigação com água moderadamente salina. Revista Brasileira de Engenharia Agrícola e Ambiental, Campina Grande, v. 15, p. 256-263, 2011 b.

COMPANHIA ESPÍRITO SANETENSE DE ABASTECIMENTO - CESAN. Como o Espírito Santo atravessa a pior crise hídrica de sua história, 2016. Disponível em: $<$ TTPS://www.cesan.com.br/noticia/como-o-espirito-santo-atravessa-a-pior-crise-hidrica-dasua-historia/>. Acesso em: 19 de abril de 2018.

EMPRESA BRASILEIRA DE PESQUISA AGROPECUÁRIA - EMBRAPA. Agricultura conservacionista no Brasil. Brasília: EMBRAPA, 2014. 598 p.

EMPRESA BRASILEIRA DE PESQUISA AGROPECUÁRIA. Utilização de cobertura morta do solo para a produção de hortaliças no Estado de Rondônia. EMBRAPA-UEPAE, Porto Velho, 1987. 11 p. (Circular Técnica, 10).

FABIAN, A. J. Plantas de cobertura: efeito nos atributos do solo e na produtividade de milho e soja em rotação. Jaboticabal, SP, 2009. 99 f. Tese (Doutorado em Agronomia Produção Vegetal) - Faculdade de Ciência Agrárias e Veterinária - Unesp, 2009.

FABRIZZI, K. P.; GARCÍA, F. O.; COSTA, J. L.; PICONE, L. I. Soil water dynamics, physical properties and corn and wheat responses to minimum and no-tillage systems in the southern Pampas of Argentina. Soil \& Tillage Research, v. 81, p. 57-69, 2005.

FAGERIA, N. K. Otimização da eficiência nutricional na produção das culturas. Revista Brasileira de Engenharia Agrícola e Ambiental, Campina Grande, v. 2, p. 6-16, 1998.

FARIA, J. C. Dinâmica de água, comportamento térmico e selamento de um Podzólico vermelho-amarelo, em relação ao controle de plantas invasoras. Viçosa, MG, 1996. 104p. Tese (Mestrado) - Universidade Federal de Viçosa - UFV, 1996.

FERREIRA, I. C. P. V.; ARAUJO, A. V.; NASCIMENTO, A. L.; CAVALCANTI, T. F. M.; SANTOS, L. D. T. Cobertura morta e adubação orgânica na produção de alface e supressão de plantas daninhas. Revista Ceres, v. 60, n. 4, p. 582-588, 2013.

FIEIRA, C.; BATISTA, K. A. Agroecologia e o manejo ecológico do solo. Synergismus scyentifica, v. 4, n. 1, 2009.

GASPARIM, E.; RICIERI, R. P.; SILVA, S. DE L.; DALLACORT, R.; GNOATTO, E. Temperatura no perfil do solo utilizando duas densidades de cobertura e solo nu. Acta Scientiarum Agronomy, Maringá, v. 27, n. 1, p. 107-115, 2005.

KLEIN, C.; KLEIN, V. A. Estratégias para potencializar a retenção e disponibilidade de água no solo. Revista Eletrônica em Gestão, Educação e Tecnologia Ambiental, v. 19, n. 1, p. 21-29, 2015.

LEPSCH, I. F. Formação e conservação dos solos. 2. ed. São Paulo: Oficina de Textos, 2010. 216 p.

MESCHEDE, D. K.; FERREIRA, A. B.; RIBEIRO JUNIOR, C. C. Avalição de diferentes coberturas na supressão de plantas daninhas no Cerrado. Planta Daninha, Viçosa, v. 25, n. 3, p. 465-471, 2007. 
NETO, D. H. O.; CARVALHO, D. H.; SILVA, L. D. B.; GUERRA, J. G. M.; CEDDIA M. B. Evapotranspiração e coeficientes de cultivo da beterraba orgânica sob cobertura morta de leguminosa e gramínea. Horticultura Brasileira, v. 29, n. 3, p. 330-334, 2011.

NOGUEIRA, N. O.; OLIVEIRA, O. M.; MARTINS, C. A. S.; BERNARDES, C. O. Utilização de leguminosas para recuperação de áreas degradadas. Enciclopédia Biosfera, v. 8, n. 14, p. 2121, 2012.

OLIVEIRA, M. L. D.; RUIZ, H. A.; COSTA, L. M.; SCHAEFER, C. E. Flutuações de temperatura e umidade do solo em resposta à cobertura vegetal. Revista Brasileira de Engenharia Agrícola e Ambiental, v. 9, n. 4, p. 535-539, 2005.

ORGANIZAÇÃO DAS NAÇÕES UNIDAS PARA ALIMENTAÇÃO E A AGRICULTURAFAO. Status of the world's soil resources, 2015. Disponivel em: <http://www.fao.org/3/ai5199e.pdf>. Acesso em: 19 de abril de 2018.

PAZ GONZÁLES, A.; ALVES, M. C. Armazenamento de água e densidade do solo sob três condições de superfície, em um Cambissol gleico de Lugo, Espanha. Revista Brasileira de Engenharia Agrícola e Ambiental, v. 9, n. 1, p. 45-50, 2005.

PESSOA, M. F.; ASSIS, L. F.; VIEIRA, A. S. Planejamento ótimo da água na agricultura irrigada: um estudo de caso em um perímetro paraibano. Revista Ibero Americana de ciências ambientais, v. 7, n. 1, p. 221-234, 2016.

PRIMAVESI, A. M. Manejo ecológico do solo: a agricultura em regiões tropicais. NBL Editora, 2002. 549p.

REICHARDT, K. A água em sistemas agrícolas. São Paulo: Manole, 1990. 188p.

RESENDE, F. V.; SOUZA, L. S.; OLIVEIRA, P. S. R.; GUALBERTO, R. Efficiently of mulching on soil moisture and temperature, weed control and yield of carrot in summer season. Ciência e Agrotecnologia, v. 29, n. 1, p. 100-105, 2005.

RIBEIRO, E. C.; CARVALHO, D. F.; SANTOS, L. A. F.; GUERRA, J. G. M. Onion yield under agroecological farming system using distinct irrigation depths and soil covers. Ciência Rural, v. 46, n. 5 , p. $783-789,2016$.

SILVA, A. S. Efeito da cobertura morta e do preparo do solo sobre a umidade e temperatura do solo. Alegre, 2018. 45 f. Dissertação (Mestrado em Agroecologia) - Instituto Federal do Espírito Santo - Ifes, Alegre, 2018.

SILVA, L. M. D. M.; RODRIGUES, T. D. J. D.; Aguiar, I. B. D. The effect of light and temperature on the germination of Myracrodruon urundeuva Allemão. Revista Árvore, v. 26, n. 6, p. 691-697, 2002.

SILVA, R. M.; VANZELA, L. S.; VAZQUEZ, G. H.; SANCHES, A. C. Influência da irrigação e cobertura morta do solo sobre as características agronômicas e produtividade de milho. Irriga, Edição especial, v. 1, n. 1, p. 170-180, 2012.

SANTOS, T. E. M.; MONTENEGRO, A. A. A.; SILVA, D. D. Umidade do solo no semiárido pernambucano usando-se reflectometria no domínio do tempo (TDR). Revista Brasileira de Engenharia Agrícola e Ambiental, v. 15, n. 7, p. 670-679, 2011. 
SOARES, T. G. Produção de palhada e reciclagem de nutrientes de leguminosas e gramíneas para implantação do sistema plantio direto no Nordeste paraense. Belém, 2006. Dissertação (Mestrado em Agronomia - Solos e Nutrição de Plantas) - Universidade Federal Rural da Amazônia, 2006.

SODRÉ FILHO, J. Fitomassa e cobertura do solo de culturas de sucessão ao milho na Região do Cerrado. Pesquisa Agropecuária Brasileira, v. 39, n. 4, p. 327-334, 2004.

STANGHELLINE, C. Evapotranspiration in greenhouse with special reference to Mediterranean conditions. Acta Horticulturae, v. 335, p. 296-304, 1993.

STEFANOSKI, D. C.; SANTOS, G. G.; MARCHÃO, R. L.; PETTER, F. A.; PACHECO, L. P. Uso e manejo do solo e seus impactos sobre a qualidade física. Revista Brasileira de Engenharia Agrícola e Ambiental, v. 17, n. 12, p. 1301-1309, 2013.

STONE, L. F.; MOREIRA, J. A. A. Efeitos de sistemas de preparo do solo no uso da água e na produtividade do feijoeiro. Pesquisa Agropecuária Brasileira, v. 35, n. 4, p. 835-841, 2000.

TORMENA, C. A.; FILHO, P. S. V.; GONÇALVES, A. C. A.; ARAÚJO, M. A. PINTRO, J. C. Influência de diferentes sistemas de preparo do solo nas propriedades físicas de um Latossolo Vermelho distrófico. Revista Brasileira de Engenharia Agrícola e Ambiental, v. 8, n. 1, p. 65-71, 2004.

TEÓFILO, T. D. S.; FREITAS, F. C. L.; MEDEIROS, J. D.; SILVA, D. D.; GRANGEIRO, L. C.; TOMAZ, H. D. Q. Eficiência no uso da água e interferência de plantas daninhas no meloeiro cultivado nos sistemas de plantio direto e convencional. Planta Daninha, v. 30, n. 3, p. 547556, 2012.

VARGAS, L.; OLIVEIRA, O. L. P. de. Embrapa Uva e Vinho. Sistema de Produção, 9. ISSN 1678-8761. Versão Eletrônica. Dez./2005. Disponível em: <TTPS://sistemasdeproducao.cnptia.embrapa.br/FontesHTML/Uva/UvasRusticasParaProce ssamento/manejo.htm> Acesso em: 20 de abril de 2018.

WENDLING, B; VINHAL-FREITAS, I. C.; OLIVEIRA, R. C.; BABATA, M. M.; BORGES, E. N. Densidade, agregação e porosidade do solo em áreas de conversão do cerrado em floresta de pinus, pastagem e plantio direto. Bioscience Journal, v. 28, S. 1, p. 256-265, 2012. 


\title{
Capítulo 17
}

\section{Água residuária de suinocultura e sistema plantio direto: efeitos em propriedades do solo cultivado com milho}

\author{
Otacílio José Passos Rangel ${ }^{1}$, Gustavo Haddad Souza Vieira ${ }^{2}$, Marcus Vinícius Souza \\ Silva $^{3}$, Rebyson Bissaco Guidinelle ${ }^{3}$, Júlio Cezar Machado Baptestini ${ }^{1}$, Renato Ribeiro \\ Passos $^{4}$, André Oliveira Souza ${ }^{5}$, Thiago Lopes Rosado ${ }^{6}$, Paola Alfonsa Vieira Lo Monaco², \\ Ana Paula Candido Gabriel Berilli ${ }^{1}$, Sávio da Silva Berilli ${ }^{1}$
}

\section{Introdução}

De acordo com o relatório da Associação Brasileira de Proteína Animal (ABPA), o Brasil é detentor de um plantel de aproximadamente 1,7 milhão de matrizes industriais de suínos, com uma produção de mais 39 milhões de suínos para abate no ano de 2015, gerando cifra superior a $\mathrm{R} \$ 62$ bilhões no Produto Interno Bruto (PIB), o que corresponde em torno de $1 \%$ dos $R \$ 6$ trilhões do PIB nacional naquele ano (IBGE, 2018). A atividade também é responsável pela geração de 126 mil empregos diretos e mais de 900 mil indiretos.

Devido às implicações relacionadas à poluição ambiental, qualidade do solo e da água, é indispensável estabelecer os parâmetros que nortearão a disposição correta e não prejudicial ao meio ambiente dos dejetos de suínos, denominados também de biofertilizante ou água residuária de suinocultura (ARS). A ARS é definida como o efluente do biodigestor e/ou lagoa de estabilização, a qual tem carga patogênica amenizada pelo processo anaeróbico de tratamento, conservando as qualidades fertilizantes, contendo macro e micronutrientes.

Por apresentar potencial uso como biofertilizante, sua aplicação na agricultura é uma possibilidade ao despejo do efluente nos cursos hídricos naturais, o que atenua a poluição ambiental destes, principalmente devido às grandes quantidades de resíduos com alta carga

\footnotetext{
1 Drs. Professores do Instituto Federal do Espírito Santo - Campus de Alegre, Caixa Postal 47, CEP: 29500-000, Alegre-ES. E-mail: otaciliorangel@gmail.com; anapaulacg@gmail.com; savio.berilli@ifes.edu.br

${ }^{2}$ Drs. Professores do Instituto Federal do Espírito Santo - Campus Santa Teresa. Rod ES 080, km 93, São João de Petrópolis, CEP: 29650-000, Santa Teresa-ES. E-mail: ghsv@ifes.edu.br; paolalomonaco2004@yahoo.com.br

${ }_{3}$ Me. em Agroecologia pelo Programa de Pós-Graduação em Agroecologia do Instituto Federal do Espírito Santo - Campus de Alegre, Caixa Postal 16, CEP: 29500-000, Alegre-ES. E-mail: marcusvinicius.mvss@gmail.com; rebysonguidinelle@gmail.com

${ }^{4}$ Dr. Professor da Universidade Federal do Espírito Santo, Caixa Postal 16, CEP: 29500-000, AlegreES. Bolsista de Produtividade em Pesquisa do CNPq. E-mail: renatoribeiropassos@hotmail.com

${ }_{5}^{5}$. Professor do Instituto Federal do Espírito Santo - Campus de Alegre, Caixa Postal 47, CEP: 29500-000, Alegre-ES. E-mail: andreolisouza@gmail.com

${ }^{6}$ Me. Engenheiro Agrônomo do Instituto Federal do Espírito Santo - Campus de Santa Teresa. Rod ES 080, km 93, São João de Petrópolis, CEP: 29650-000, Santa Teresa-ES. E-mail: thiagolopesmil@gmail.com
} 
de nutrientes, como fósforo $(\mathrm{P})$, potássio $(\mathrm{K})$, sódio $(\mathrm{Na})$, cobre $(\mathrm{Cu})$ e zinco $(\mathrm{Zn})$. A ARS, quando mal manejada e sem tratamento, pode causar a contaminação do solo e de águas superficiais e subsuperficiais.

A presença de $\mathrm{Na}^{+}$pode causar a sodicidade do solo, o que reduz a disponibilidade de água para as plantas e pode tornar os solos inadequados ao cultivo (AYERS e WESTCOT, 1999). Nos estudos com o uso de ARS torna-se relevante sua caracterização, tanto para se verificar a composição química quanto para definir a quantidade a ser aplicada evitando, assim, alterações no solo, tais como a dispersão da argila, devido à presença de elementos dispersantes.

Aliado a isso, o sistema de manejo do solo contribui de modo relevante na lógica de produção ambientalmente correta e sustentável. O Sistema Plantio Direto (SPD), que se constitui de um sistema com rotação de cultura, manutenção da palha na superfície do solo e ausência de revolvimento do solo, tem se sobressaído por tratar-se de um sistema com potencial no controle da erosão, reduzindo as perdas de solo e água (CRUZ et al., 2006).

O SPD constitui uma importante prática agroecológica, uma vez que não promove o revolvimento do solo proporcionando decomposição mais lenta e gradual do material orgânico depositado no solo (CARVALHO et al., 2004), beneficiando as camadas do solo mais superficiais que apresentam propriedades químicas, físicas e biológicas superiores, quando comparadas ao Sistema Plantio Convencional (SPC), que tem como base o revolvimento do solo, pela aração e gradagem.

O SPD não visa somente alta produção, mas também assegurar a sustentabilidade do uso agrícola dos solos (SCHERER et al., 2010), alinhado aos preceitos da agroecologia. Entre os efeitos da associação do sistema plantio direto com o uso agrícola da ARS, destaca-se a possibilidade de aumentar a matéria orgânica $(\mathrm{MO})$ e carbono orgânico $(\mathrm{CO})$ do solo ao longo dos anos (BERNARDES, 2017). A literatura mostra que a adubação com dejetos de animais é mais eficaz no incremento dos teores de $\mathrm{CO}$ do que a fertilização mineral (YANG et al., 2005). Neste sentido, Scherer et al. (2010) verificaram, após aplicações sucessivas de dejetos de suínos entre 15 a 25 anos em sistema plantio direto, aumento do teor de CO do solo.

\section{Efeitos da água residuária de suinocultura na salinidade do solo}

Um dos fatores de grande preocupação na agricultura atual é a salinidade do solo, especialmente na agricultura irrigada. O manejo incorreto da irrigação e dos adubos químicos utilizados na atividade agrícola são um dos principais causadores da elevação da quantidade de solos degradados com este problema (EPSTEIN e BLOOM, 2006). 
Tal como outras características químicas e físicas do solo, a salinidade apresenta oscilação temporal e espacial natural conforme a profundidade do lençol freático, das práticas culturais utilizadas, da taxa de evapotranspiração, da salinidade da água, da pluviosidade e de outros fatores hidrogeológicos (D'ALMEIDA et al., 2005). Neste sentido, altas taxas de evaporação e baixa precipitação pluviométrica, aliados ao manejo inadequado da água de irrigação, são os principais fatores de causa do problema de salinidade (OLIVEIRA et al., 2002).

A salinidade pode ser definida como o fenômeno de excesso de sais solúveis, sódio trocável ou ambos em horizontes superficiais, prejudicando o desenvolvimento vegetal (D'ALMEIDA et al., 2005). No entanto, o problema da salinidade nos solos agricultáveis está relacionado às respostas dos vegetais, tanto na fisiologia quanto no metabolismo, interferindo desde a germinação, no desenvolvimento das plantas, provocando déficit na produtividade e, em casos mais graves, podendo causar até a morte (TAIZ et al., 2017).

O problema está atrelado também às características físico-químicas do solo em seu estado natural e das técnicas de manejo a ele aplicadas, uma vez que é comum a ocorrência da salinidade em áreas irrigadas cujas técnicas de manejo não visam a conservação da capacidade produtiva dos solos, bem como onde há uso excessivo de fertilizantes (D'ALMEIDA et al., 2005).

Os solos afetados por sais podem ser classificados como salinos (apresentam altas concentrações de sais solúveis), sódicos (com altas concentrações de sódio trocável) e salino-sódicos (apresentam altas concentrações de sais e sódio trocável).

A caracterização dos solos afetados por sais é realizada de acordo com algumas propriedades químicas indicativas de suas características salina e/ou sódicas, proposta pelo Laboratório de Salinidade do Departamento de Agricultura dos Estados Unidos (RICHARDS, 1962). Os principais critérios usados são a condutividade elétrica do extrato de saturação, o pH do solo, a porcentagem de saturação de sódio trocável (PST), a relação de adsorção de sódio (RAS) e a capacidade de troca de cátions potencial do solo (CTC pH 7).

No solo, os efeitos da salinidade no desenvolvimento vegetal provem de alterações nas suas propriedades químicas e físicas. Em relação às propriedades químicas, o aumento das concentrações de sais e sódio trocável ocasiona a redução de sua fertilidade e, em longo prazo, pode levar a desertificação (D'ALMEIDA et al., 2005).

A alta condutividade elétrica observada em solos salinos é ocasionada pelas altas concentrações de sais, podendo prejudicar a absorção de nutrientes, interferir no desenvolvimento das plantas e restringir a produção em níveis econômicos, por causa da elevação do potencial osmótico (AYERS e WESTCOT, 1999). A implicação prática da salinidade sobre o solo é a perda da fertilidade e a susceptibilidade à erosão, além da contaminação de aquíferos subterrâneos. 
Além disto, a salinidade influência as propriedades físicas do solo, provocando desestruturação, aumento da densidade e redução das taxas de infiltração de água no solo pelo excesso de $\mathrm{Na}^{+}$(RHOADES et al., 2000). O sódio eleva a espessura da dupla camada iônica. A principal característica desse efeito é a expansão da argila quando umedecida e a contração quando seca. $\mathrm{O}$ excesso de $\mathrm{Na}^{+}$na solução do solo provoca a dispersão da argila e, desta forma, ocasiona uma camada adensada que dificulta o crescimento, respiração, crescimento radicular, além da absorção de água e fixação de $\mathrm{CO}_{2}$ pela planta (TAIZ et al., 2017).

\section{Dispersão e floculação da argila do solo}

De acordo a composição mineralógica do solo, este pode conter, ao mesmo tempo, cargas elétricas positivas e cargas elétricas negativas. Há um certo valor de $\mathrm{pH}$ do solo em que a porção de cargas elétricas positivas é igual à porção de cargas negativas. Esse valor de $\mathrm{pH}$, que é próprio para cada solo, é denominado de Ponto de Carga Zero (PCZ) (MEURER, 2006). Quando o pH do solo estiver abaixo do PCZ, há predomínio de cargas elétricas positivas, em função da atividade do cátion $\mathrm{H}^{+} \mathrm{e}$, quando $\mathrm{o} \mathrm{pH}$ do solo estiver acima do PCZ, predominam cargas negativas, em função do ânion $\mathrm{OH}^{-}$, nas superfícies das partículas do solo (MEURER, 2006).

Nos solos que apresentam carga dependente de $\mathrm{pH}$, é possível fazer uma estimativa da predominância de cargas positivas ou negativas. Isto é feito através de um índice denominado de $\Delta \mathrm{pH}$, que se refere à diferença entre o $\mathrm{pH}$ em $\mathrm{KCl}$ e o $\mathrm{pH}$ em $\mathrm{H}_{2} \mathrm{O}$. Se o valor do $\Delta \mathrm{pH}$ for positivo, a carga líquida será positiva; ao contrário, se o valor de $\Delta \mathrm{pH}$ for negativo, a carga líquida das partículas será negativa.

O PCZ afeta significativamente o processo de floculação-dispersão de argila. A dispersão das argilas ocorre quando o $\mathrm{pH}$ é muito mais elevado que o $\mathrm{pH}$ em que ocorre o $\mathrm{PCZ}$, predominando complexos de esfera-externa e baixos teores de óxidos (MEURER, 2006). Nesses casos, a argila dispersa em água pode eluviar no perfil do solo e produzir horizontes mais ricos em argila, como também pode entupir os macroporos, diminuindo a aeração e a infiltração de água. Quando o pH do meio coincide com o PCZ, a argila flocula-se totalmente.

A tendência de dispersão da fração coloidal, colocando-se em suspensão na água, é um fenômeno que pode ocorrer naturalmente ou por ação antrópica. Deste modo, a análise de determinados atributos, como a argila dispersa em água (ADA), que reflete diretamente sobre a formação da compactação nos solos e também o grau de floculação das argilas 
(GFA), que afeta na agregação das partículas do solo, são importantes para os estudos de conservação e salinização dos solos (SANTOS et al., 2010).

A ADA é a parcela da argila do solo que se dispersa espontaneamente em água e, assim, a que possui, potencialmente, maior mobilidade. $O$ aumento da ADA está diretamente atrelado com a redução da infiltração de água nos Latossolos brasileiros. A ADA é um importante parâmetro utilizado para avaliar a susceptibilidade do solo à erosão hídrica (LIMA et al., 1990).

A dispersão ocorre em decorrência da combinação de pequena concentração eletrolítica e/ou valência dos contra-íons, a energia de repulsão domina sobre a energia de atração. Azevedo e Bonumá (2004) afirmam que as partículas podem aproximar-se umas das outras devido a vários mecanismos de atração e ao movimento Browniano, mas a força de repulsão aumenta à medida que a distância entre partículas diminui. As partículas não contêm energia para romper a barreira energética que as separa, chamada de mínimo primário, e se mantêm dispersas.

Floculação, entretanto, é ocasionada por forças de atração de van der Waals que são oriundas de variações nos campos eletromagnéticos dos átomos dos minerais. As forças de van der Waals são fracas e de pequeno alcance. Mas, a teoria DLVO mostra que uma resultante significativamente maior é alcançada quando o número de pares atômicos é abundante e está alinhado, como no caso das estruturas dos argilominerais (AZEVEDO e BONUMÁ, 2004).

Assim, a floculação é resultado de uma grande concentração eletrolítica e/ou alta valência de contra-íons, que promove a dominância de forças de atração sobre forças de repulsão. Portanto, a dupla camada e o mínimo primário diminuem, e consequentemente, as partículas podem se aproximar e flocular.

A literatura constata a ocorrência de dispersão de argilas em consequência da aplicação de dejetos de suínos. Homem et al. (2012) observaram, analisando a ocorrência de dispersão de argila pela aplicação de águas residuárias de criatórios de bovinos, suínos e coelhos, em um Latossolo Vermelho amarelo, 61\% de dispersão aplicando, durante 20 dias, doses de $72 \mathrm{~mm}$ das águas residuárias.

\section{Potencial de uso agrícola da água residuária de suinocultura}

A potencial poluente dos dejetos suínos, em termos comparativos, é mais elevado que de outras espécies. Fazendo-se uso do conceito de equivalente populacional, Silva et al. (2015) destacam que uma granja com 600 animais possui potencial poluente, semelhante ao de um conglomerado populacional de aproximadamente 2.100 pessoas. 
Deste modo, o tratamento dos dejetos suínos em biodigestores, gerando um biofertilizante denominado água residuária de suinocultura (ARS), e a consequente aplicação da ARS em solo agricultável, de acordo com Ceretta et al. (2005), é uma forma de ciclar e disponibilizar nutrientes às plantas, sendo sua ação biofertilizante eficaz quando realizada de forma adequada.

A utilização de águas residuárias tratadas ou parcialmente tratadas na agricultura, ao invés de lançá-las em cursos de água, tem-se tornado uma oportuna alternativa, com rápida e recente expansão. O conhecimento que possibilite a utilização das águas residuárias geradas nos processos produtivos em áreas agrícolas, reduzindo o impacto ambiental e aumentando a produtividade, é de fundamental importância.

Este resíduo, além de conter nutrientes e matéria orgânica, favorece a melhoria das características químicas, físicas e biológicas do solo tendo potencial, ainda, para melhorar a produtividade das culturas (FACTOR et al., 2008).

Pesquisas vêm sendo realizadas a fim de avaliar o potencial de uso da ARS na agricultura, em culturas como soja (ROSA et al., 2017), pastagens (SILVA et al., 2015), e sobretudo na cultura do milho (PRIOR et al., 2016; PEREIRA et al., 2016; ROSA et al., 2017).

Porém, devido a seu potencial poluidor, esta aplicação demanda conhecimento prévio das variáveis solo, planta e clima, conforme afirmam Barros et al. (2005), que destacaram que as quantidades e as frequências com que os dejetos animais podem ser aplicados ao solo devem estar associadas com o tipo de solo, com a natureza e a composição dos resíduos, com as condições climáticas e com a espécie vegetal cultivada.

Os efeitos da aplicação de águas residuárias nas propriedades físicas e químicas do solo se manifestam após um período da aplicação e dependem das características do solo e do clima. Em solos irrigados com ARS, têm sido observadas alterações das quais se destacam os efeitos sobre o cálcio e magnésio trocáveis, salinidade, sodicidade e dispersão de argilas (FONSECA et al., 2007).

Estudando o efeito da ARS no solo, Silva et al. (2011) verificaram que doses crescentes aplicadas em Latossolos Vermelho-Amarelos distróficos de textura argilosa com adição de adubo químico tendem a aumentar a estabilidade de agregados do solo. Por outro lado, o diâmetro médio ponderado - DMP tende a aumentar quando os agregados do solo recebem a adição de efluentes sem adubo, contudo os agregados são menos estáveis.

Em um estudo sobre o uso da ARS, Condé et al. (2013) verificaram tendência de aumento do percentual de ADA na camada mais profunda. Também Homem et al. (2014) observaram aumento da porcentagem de ADA com a aplicação deste dejeto. Os autores atribuíram o aumento da ADA ao acúmulo de sódio na solução do solo com a aplicação do resíduo, causando o fenômeno de dispersão da argila. 
Sistemas de manejo que favorecem a adição de resíduos vegetais e a retenção de carbono no solo representam importantes estratégias para a exploração sustentável do solo. Estudos demonstram que a palhada na superfície do solo em plantio direto pode promover inúmeros benefícios, tais como: (i) aumento da infiltração e do armazenamento de água no solo; (ii) diminuição da temperatura superficial; (iii) redução do impacto das gotas de chuva; (iv) aumento da atividade microbiana e; (v) acúmulo superficial de nutrientes e de matéria orgânica (PANACHUKI et al., 2011; DONEDA et al., 2012; GUEDES et al., 2013).

Portanto, o emprego combinado da ARS com sistemas conservacionistas de uso do solo, como o sistema plantio direto, necessitam ser avaliadas a campo, em trabalhos de médio a longo prazo. A validação do efeito combinado dessas duas práticas é importante para a consolidação de uma nova tecnologia em sistemas agroecológicos. Ressalta-se também o viés ambiental de pesquisas dessa natureza, que culminarão em menor dano ambiental de importantes recursos naturais, como água e solo.

Este capítulo traz alguns resultados de estudo de campo, conduzido no período de janeiro a julho de 2018, em um Latossolo Vermelho-Amarelo, com textura média. Avaliou-se o potencial de uso agrícola da água residuária de suinocultura (ARS) na irrigação da cultura do milho (Zea mays L.) cultivado em dois ciclos sucessivos sob diferentes sistemas de manejo do solo e os efeitos nos atributos químicos e físicos do solo. Informações detalhadas do estudo são obtidas em Guidinelle (2019) e Silva (2019).

Os sistemas de manejo de solo utilizados foram Sistema Plantio Convencional - SPC e Sistema Plantio Direto - SPD. Adotou-se cinco lâminas de irrigação com água residuária de suinocultura - ARS (L1=50\%, L2=75\%, L3=100\%, L4=125\% e $\quad L 5=150 \%$ da evapotranspiração real, ETc, da cultura do milho).

O sistema de irrigação empregado na área foi o de aspersão convencional semifixo, instalado no meio de cada parcela. Integrado ao sistema encontrava-se um conjunto motobomba, responsável pelo bombeamento da ARS, proveniente da lagoa de estabilização.

Constatou ausência de interação significativa entre as lâminas de irrigação com ARS, dentro de sistema de manejo do solo, nos valores de estoque de COT, nas profundidades de 0-10 e 10-20 cm, nos dois ciclos de cultivo de milho, e na profundidade de 20-40 cm, no segundo ciclo de cultivo (Tabelas 1, 2 e 3), bem como no somatório na profundidade (0-40 $\mathrm{cm}$ ), nos dois ciclos de cultivo. Contudo, na profundidade de $20-40 \mathrm{~cm}$, no $1^{\circ}$ ciclo de cultivo, verificou-se interação significativa, porém, essa interação não manteve um padrão, apresentando oscilação entres os sistemas de manejo nas diferentes lâminas de irrigação.

A oscilação nos estoques de COT podem estar relacionadas ao processo de estabilização do SPD, quando se observa maior equilíbrio entre o processo de imobilização e mineralização da matéria orgânica do solo (CALONEGO et al., 2012). Segundo Franchini et al. (2012), que trabalharam com diferentes sistemas de manejo do solo, dentre eles o 
SPD, durante 23 anos na região sul do Brasil, o SPD possui uma fase de estabilização que dura cerca de seis anos.

Não foi constatado efeito significativo dos sistemas de manejo sobre o estoque de COT na maioria das profundidades de solo avaliadas, muito em função do pouco tempo de implantação do SPD. Respostas semelhantes foram obtidas por Ceretta et al. (2003) os quais, trabalhando com dejetos líquidos em pastagens também não constataram incremento no teor de COT no solo, mesmo após 48 meses de aplicações sucessivas. Resultado similar foi apresentado por Ellerbrock et al. (1999).

Esses resultados podem estar associados aos baixos teores de matéria seca dos dejetos ou pelas próprias características do carbono dos dejetos líquidos de suínos, ricos em polissacarídeos, proteína, lipídeos e outros compostos que podem ser considerados de fácil degradação no solo (CABRAL et al., 2011).

Dependendo da lâmina de irrigação com ARS adotada, houve incrementos significativos no estoque de COT do solo ( $1^{\circ}$ ciclo, $\left.20-40 \mathrm{~cm}\right)$ no SPD, sendo de 51,5\% (23,1 $\left.\mathrm{t} \mathrm{ha}^{-1}\right)$ na lâmina de $50 \%$ e 30,6\% (14 t ha $\left.{ }^{-1}\right)$ na lâmina de irrigação com ARS de $75 \%$ da ETc, em comparação ao SPC.

Verificou-se maior incremento no estoque de COT no SPC nas lâminas de 50, 75 e 100\% (Tabela 1). Entretanto, é possível verificar novamente valores superiores, ainda que não significativos, no SPD nas lâminas de 125 e 150\%, sendo os incrementos de 14,6\% (3,6 t $\left.\mathrm{ha}^{-1}\right)$ e $37,7 \%\left(12,1 \mathrm{t} \mathrm{ha}^{-1}\right)$, respectivamente. Souza e Melo (2003), estudando o impacto de diferentes sistemas de produção do milho sobre a dinâmica do carbono do solo, observaram menores valores de estoque de COT no solo cultivado no SPC, comparativamente aos valores obtidos nos sistemas onde os restos culturais eram mantidos na superfície.

Quando se observa o estoque de COT no $1^{\circ}$ ciclo de cultivo de milho, na profundidade de 20-40 cm, com aplicação de lâmina de 100\% (Tabela 1), nota-se no SPC acúmulo superior em comparação ao SPD. A área experimental possui um histórico de décadas de cultivo sob SPC e um período relativamente curto de adoção do SPD. Tal oscilação no estoque de COT, mediante variação da lâmina aplicada, pode estar atrelada a fase de estabilização do SPD, que dura em torno de seis anos (FRANCHINI et al., 2012). Além disso, no SPC o solo é revolvido e a matéria orgânica é distribuída por toda a camada arável. Com isso, os teores de COT em profundidades maiores podem ser semelhantes ou até superiores aos do sistema SPD (USSIRI e LAL, 2009).

Comparando os valores absolutos de estoque de COT em todas as profundidades aos respectivos valores das testemunhas, é possível estimar se houve incremento ou redução do estoque de COT do solo. No $1^{\circ}$ ciclo de cultivo de milho, as variações nos estoques de COT apresentaram valores superiores às testemunhas nas profundidades de solo de 0-10 cm, nas lâminas de $75 \%$ (29,86\%), 125\% (8,11\%) e 150\% (17,32\%) aplicadas no SPC, ao 
passo que, apenas na lâmina $75 \%(3,67 \%)$ aplicada no SPD, foi constado valor superior às testemunhas. Ainda no $1^{\circ}$ ciclo de cultivo, na profundidade de solo de $10-20 \mathrm{~cm}$, tal resultado foi encontrado nas lâminas de 75 (28,65\%), 100 (8,78\%), 125 (5,71\%) e 150\% $(16,70 \%)$ aplicadas no SPC e, nas lâminas de irrigação com ARS de 50 (11,38\%) e 75\% (31,57\%) aplicadas no SPD.

No $1^{\circ}$ ciclo, na profundidade do solo de $20-40 \mathrm{~cm}$ (Tabela 1), acréscimo no estoque de COT foi constatado apenas na lâmina de 125\% aplicada no SPC e, nas lâminas de 50, 75, 125 e 150\% aplicadas no SPD. Nas demais profundidades, no $2^{\circ}$ ciclo de cultivo, todos os sistemas de plantio e as lâminas de irrigação resultaram em incremento nos estoques de COT.

Os resultados de incrementos nos estoques de COT foram superiores aos encontrado por Rangel et al. (2007) estudando estoques de COT em Latossolo Vermelho submetido a diferentes sistemas de uso e manejo, que verificaram valores similares ou inferiores ao percentual de $40 \%$.

Tabela 1. Estoques de COT avaliados em três profundidades do solo sob diferentes sistemas de manejo do solo (Sistema Plantio Convencional - SPC e Sistema Plantio Direto SPD), dentro de cada lâmina de irrigação com ARS, ao término do $1^{\circ}$ ciclo de cultivo do milho.

\begin{tabular}{|c|c|c|c|c|c|c|}
\hline \multirow{2}{*}{$\begin{array}{l}\text { Sistemas de } \\
\text { manejo }\end{array}$} & \multicolumn{6}{|c|}{ Lâminas de Irrigação com ARS } \\
\hline & Test. $^{1 /}$ & $50 \%$ & $75 \%$ & $100 \%$ & $125 \%$ & $150 \%$ \\
\hline & \multicolumn{6}{|c|}{$0-10 \mathrm{~cm}$} \\
\hline & \multicolumn{6}{|c|}{ Estoque de COT $\left(\mathrm{t} \mathrm{ha}^{-1}\right)$} \\
\hline SPC & 15,53 & $15,05 \mathrm{a}$ & $22,14 a$ & $13,60 \mathrm{a}$ & $16,90 \mathrm{a}$ & $18,22 \mathrm{a}$ \\
\hline \multirow[t]{3}{*}{ SPD } & 19,32 & $16,34 a$ & $20,03 \mathrm{a}$ & $17,03 \mathrm{a}$ & $17,65 \mathrm{a}$ & $15,21 \mathrm{a}$ \\
\hline & \multicolumn{6}{|c|}{$10-20 \mathrm{~cm}$} \\
\hline & \multicolumn{6}{|c|}{ Estoque de COT $\left(\mathrm{t} \mathrm{ha}^{-1}\right)$} \\
\hline SPC & 16,51 & $16,42 \mathrm{a}$ & $23,14 a$ & $18,10 \mathrm{a}$ & $17,51 \mathrm{a}$ & $19,82 \mathrm{a}$ \\
\hline \multirow[t]{3}{*}{ SPD } & 16,67 & $18,81 \mathrm{a}$ & $24,36 \mathrm{a}$ & $14,05 \mathrm{a}$ & $15,48 \mathrm{a}$ & $14,17 \mathrm{a}$ \\
\hline & \multicolumn{6}{|c|}{$20-40 \mathrm{~cm}$} \\
\hline & \multicolumn{6}{|c|}{ Estoque de COT $\left(\mathrm{t} \mathrm{ha}^{-1}\right)$} \\
\hline SPC & 31,85 & $21,80 \mathrm{~b}$ & $31,82 b$ & $32,80 \mathrm{a}$ & $21,46 a$ & $20,10 a$ \\
\hline SPD & 22,47 & $44,92 \mathrm{a}$ & $45,86 a$ & $16,17 b$ & $25,14 a$ & $32,18 a$ \\
\hline
\end{tabular}

*Letras minúsculas iguais na coluna não diferem a $5 \%$ de probabilidade pelo teste $\mathrm{F} ;{ }^{1 /}$ Testemunha irrigado com $100 \%$ da lâmina com água bruta, utilizado somente como efeito de comparação.

Fonte: Silva (2019). 
Tabela 2. Estoques de COT avaliados em três profundidades do solo sob diferentes sistemas de manejo do solo (Sistema Plantio Convencional - SPC e Sistema Plantio Direto SPD), dentro de cada lâmina de irrigação com ARS, ao término do $2^{\circ}$ ciclo de cultivo do milho.

\begin{tabular}{|c|c|c|c|c|c|c|}
\hline \multirow{2}{*}{$\begin{array}{l}\text { Sistemas de } \\
\text { manejo }\end{array}$} & \multicolumn{6}{|c|}{ Lâminas de Irrigação com ARS } \\
\hline & Test. $^{1 /}$ & $50 \%$ & $75 \%$ & $100 \%$ & $125 \%$ & $150 \%$ \\
\hline & \multicolumn{6}{|c|}{$0-10 \mathrm{~cm}$} \\
\hline & \multicolumn{6}{|c|}{ Estoque de COT $\left(\mathrm{t} \mathrm{ha}^{-1}\right)$} \\
\hline SPC & 7,66 & $19,02 \mathrm{a}$ & $19,58 \mathrm{a}$ & 19,49 a & $15,45 \mathrm{a}$ & $17,33 \mathrm{a}$ \\
\hline \multirow[t]{3}{*}{ SPD } & 7,98 & $21,22 \mathrm{a}$ & $20,60 \mathrm{a}$ & $16,37 \mathrm{a}$ & $15,24 \mathrm{a}$ & $17,38 \mathrm{a}$ \\
\hline & \multicolumn{6}{|c|}{$10-20 \mathrm{~cm}$} \\
\hline & \multicolumn{6}{|c|}{ Estoque de COT $\left(\mathrm{t} \mathrm{ha}^{-1}\right)$} \\
\hline SPC & 8,21 & $15,34 \mathrm{a}$ & $18,36 \mathrm{a}$ & $17,70 \mathrm{a}$ & $19,16 \mathrm{a}$ & $17,41 \mathrm{a}$ \\
\hline \multirow[t]{3}{*}{ SPD } & 7,81 & $16,89 \mathrm{a}$ & $20,71 \mathrm{a}$ & $15,64 \mathrm{a}$ & $14,89 \mathrm{a}$ & $16,77 \mathrm{a}$ \\
\hline & \multicolumn{6}{|c|}{$20-40 \mathrm{~cm}$} \\
\hline & \multicolumn{6}{|c|}{ Estoque de COT $\left(\mathrm{t} \mathrm{ha}^{-1}\right)$} \\
\hline SPC & 16,39 & $27,28 \mathrm{a}$ & $38,01 \mathrm{a}$ & $22,93 \mathrm{a}$ & $29,12 \mathrm{a}$ & $20,52 \mathrm{a}$ \\
\hline SPD & 16,23 & $26,72 \mathrm{a}$ & $37,55 \mathrm{a}$ & $24,78 \mathrm{a}$ & $16,64 \mathrm{a}$ & $36,45 \mathrm{a}$ \\
\hline
\end{tabular}

*Letras minúsculas iguais na coluna não diferem a $5 \%$ de probabilidade pelo teste $\mathrm{F} ;{ }^{1 /}$ Testemunha irrigado com $100 \%$ da lâmina com água bruta, utilizado somente como efeito de comparação.

Fonte: Silva (2019).

Tabela 3. Estoques totais de carbono do solo $(0-40 \mathrm{~cm})$ nos diferentes sistemas de manejo do solo (Sistema Plantio Convencional - SPC e Sistema Plantio Direto - SPD), dentro de cada lâmina de irrigação com ARS, ao término do $2^{\circ}$ ciclo de cultivo do milho.

\begin{tabular}{lcccccc}
\hline $\begin{array}{l}\text { Sistemas de } \\
\text { manejo }\end{array}$ & \multicolumn{5}{c}{ Lâminas de Irrigação com ARS } \\
\cline { 2 - 7 } & Test. $^{\mathbf{1}}$ & $\mathbf{5 0 \%}$ & $\mathbf{7 5 \%}$ & $\mathbf{1 0 0 \%}$ & $\mathbf{1 2 5 \%}$ & $\mathbf{1 5 0 \%}$ \\
\hline SPC & 15,36 & $61,65 \mathrm{a}$ & 75,94 a & $60,12 \mathrm{a}$ & $63,73 \mathrm{a}$ & $55,27 \mathrm{a}$ \\
SPD & 15,29 & $64,82 \mathrm{a}$ & $78,86 \mathrm{a}$ & $56,78 \mathrm{a}$ & $46,77 \mathrm{a}$ & $70,60 \mathrm{a}$ \\
\hline
\end{tabular}

*Letras minúsculas iguais na coluna não diferem a $5 \%$ de probabilidade pelo teste $\mathrm{F} ;{ }^{1 /}$ Testemunha irrigado com $100 \%$ da lâmina com água bruta, utilizado somente como efeito de comparação.

Fonte: Silva (2019).

Nas tabelas 4 e 5 estão apresentados os resultados de diferentes sistemas de manejo do solo (Sistema Plantio Convencional - SPC e Sistema Plantio Direto - SPD), dentro de cada lâmina de irrigação com ARS, nos valores de condutividade elétrica - $C E$, relação de adsorção de sódio - RAS, percentual de sódio trocável - PST nas profundidades de 0-10, 1020 e $20-40 \mathrm{~cm}$, ao término do $1^{\circ}$ e $2^{\circ}$ ciclos de cultivo do milho. 
Tabela 4. Condutividade elétrica - CE, relação de adsorção de sódio - RAS e percentual de sódio trocável - PST em três profundidades do solo sob diferentes sistemas de manejo do solo (Sistema Plantio Convencional - SPC e Sistema Plantio Direto - SPD), dentro de cada lâmina de irrigação com ARS, ao término do $1^{\circ}$ ciclo de cultivo do milho.

\begin{tabular}{|c|c|c|c|c|c|c|}
\hline \multirow{2}{*}{$\begin{array}{l}\text { Sistemas de } \\
\text { manejo }\end{array}$} & \multicolumn{6}{|c|}{ Lâminas de Irrigação com ARS } \\
\hline & Test. $^{1 /}$ & $50 \%$ & $75 \%$ & $100 \%$ & $125 \%$ & $150 \%$ \\
\hline & \multicolumn{6}{|c|}{$0-10 \mathrm{~cm}$} \\
\hline & \multicolumn{6}{|c|}{$\mathrm{CE}\left(\mathrm{dS} \mathrm{m} \mathrm{m}^{-1}\right)$} \\
\hline SPC & 0,15 & $0,10 \mathrm{a}$ & $0,12 a$ & $0,14 a$ & $0,10 \mathrm{a}$ & $0,12 \mathrm{a}$ \\
\hline \multirow[t]{2}{*}{ SPD } & 0,12 & $0,10 \mathrm{a}$ & $0,10 a$ & $0,09 \mathrm{a}$ & $0,11 \mathrm{a}$ & $0,11 \mathrm{a}$ \\
\hline & \multicolumn{6}{|c|}{ RAS } \\
\hline SPC & 0 & $0,02 \mathrm{a}$ & $0,02 \mathrm{a}$ & $0,02 \mathrm{a}$ & $0,01 \mathrm{a}$ & $0,03 a$ \\
\hline \multirow[t]{2}{*}{ SPD } & 0 & $0,02 \mathrm{a}$ & $0,01 \mathrm{a}$ & $0,00 \mathrm{~b}$ & $0,01 \mathrm{a}$ & $0,00 \mathrm{~b}$ \\
\hline & \multicolumn{6}{|c|}{ PST $(\%)$} \\
\hline SPC & 0 & $0,32 \mathrm{a}$ & $0,43 a$ & $0,26 \mathrm{a}$ & $0,21 \mathrm{a}$ & $0,57 \mathrm{a}$ \\
\hline \multirow[t]{3}{*}{ SPD } & 0 & $0,30 \mathrm{a}$ & $0,23 a$ & $0,00 \mathrm{~b}$ & $0,15 a$ & $0,04 \mathrm{~b}$ \\
\hline & \multicolumn{6}{|c|}{$10-20 \mathrm{~cm}$} \\
\hline & \multicolumn{6}{|c|}{$\mathrm{CE}\left(\mathrm{dS} \mathrm{m^{-1 } )}\right.$} \\
\hline SPC & 0,06 & $0,09 \mathrm{a}$ & $0,11 \mathrm{a}$ & $0,08 \mathrm{a}$ & $0,10 \mathrm{a}$ & $0,10 a$ \\
\hline \multirow[t]{2}{*}{ SPD } & 0,06 & $0,09 \mathrm{a}$ & $0,08 \mathrm{a}$ & $0,08 \mathrm{a}$ & $012 \mathrm{a}$ & $0,10 a$ \\
\hline & \multicolumn{6}{|c|}{ RAS } \\
\hline SPC & 0 & $0,02 \mathrm{a}$ & $0,03 a$ & $0,02 \mathrm{a}$ & $0,03 \mathrm{a}$ & $0,03 a$ \\
\hline \multirow[t]{2}{*}{ SPD } & 0 & $0,03 \mathrm{a}$ & $0,01 \mathrm{a}$ & $0,00 \mathrm{a}$ & $0,05 \mathrm{a}$ & $0,01 \mathrm{a}$ \\
\hline & \multicolumn{6}{|c|}{ PST $(\%)$} \\
\hline SPC & 0 & $0,05 \mathrm{a}$ & $0,54 \mathrm{a}$ & $0,42 \mathrm{a}$ & $0,57 \mathrm{a}$ & $0,74 \mathrm{a}$ \\
\hline \multirow[t]{3}{*}{ SPD } & 0 & $0,66 \mathrm{a}$ & $0,19 a$ & $0,00 \mathrm{~b}$ & $0,94 \mathrm{a}$ & $0,20 \mathrm{~b}$ \\
\hline & \multicolumn{6}{|c|}{$20-40 \mathrm{~cm}$} \\
\hline & \multicolumn{6}{|c|}{$\mathrm{CE}\left(\mathrm{dS} \mathrm{\textrm {m } ^ { - 1 } )}\right.$} \\
\hline SPC & 0,07 & $0,09 a$ & $0,09 a$ & $0,08 \mathrm{a}$ & $0,09 \mathrm{~b}$ & $0,11 \mathrm{a}$ \\
\hline \multirow[t]{2}{*}{ SPD } & 0,05 & $0,08 \mathrm{a}$ & $0,05 \mathrm{~b}$ & $0,08 \mathrm{a}$ & $0,13 a$ & $0,09 a$ \\
\hline & \multicolumn{6}{|c|}{ RAS } \\
\hline SPC & 0 & $0,02 \mathrm{a}$ & $0,01 \mathrm{a}$ & $0,03 a$ & $0,04 \mathrm{a}$ & $0,03 a$ \\
\hline \multirow[t]{2}{*}{ SPD } & 0 & $0,04 \mathrm{a}$ & $0,01 \mathrm{a}$ & $0,01 \mathrm{a}$ & $0,07 \mathrm{a}$ & $0,03 a$ \\
\hline & \multicolumn{6}{|c|}{ PST $(\%)$} \\
\hline SPC & 0 & $0,52 \mathrm{a}$ & $0,26 a$ & $0,57 \mathrm{a}$ & $0,81 \mathrm{a}$ & $0,73 a$ \\
\hline SPD & 0 & $0,96 \mathrm{a}$ & $0,13 a$ & $0,26 a$ & $0,77 \mathrm{a}$ & $0,55 a$ \\
\hline
\end{tabular}

${ }^{*}$ Letras minúsculas iguais na coluna não diferem a $5 \%$ de probabilidade pelo teste $\mathrm{F} ;{ }^{1 /}$ Testemunha irrigado com $100 \%$ da lâmina com água bruta, utilizado somente como efeito de comparação.

Fonte: Silva (2019). 
Tabela 5. Condutividade elétrica - CE, relação de adsorção de sódio - RAS e percentual de sódio trocável - PST em três profundidades do solo sob diferentes sistemas de manejo do solo (Sistema Plantio Convencional - SPC e Sistema Plantio Direto - SPD), dentro de cada lâmina de irrigação com ARS, ao término do $2^{\circ}$ ciclo de cultivo do milho.

\begin{tabular}{|c|c|c|c|c|c|c|}
\hline \multirow{2}{*}{$\begin{array}{l}\text { Sistemas de } \\
\text { manejo }\end{array}$} & \multicolumn{6}{|c|}{ Lâminas de Irrigação com ARS } \\
\hline & Test. $^{1 /}$ & $50 \%$ & $75 \%$ & $100 \%$ & $125 \%$ & $150 \%$ \\
\hline & \multicolumn{6}{|c|}{$0-10 \mathrm{~cm}$} \\
\hline & \multicolumn{6}{|c|}{$\mathrm{CE}\left(\mathrm{dS} \mathrm{m} \mathrm{m}^{-1}\right)$} \\
\hline SPC & 0,16 & $0,25 \mathrm{a}$ & $0,29 a$ & $0,28 \mathrm{a}$ & $0,35 a$ & $0,36 \mathrm{a}$ \\
\hline \multirow[t]{2}{*}{ SPD } & 0,13 & $0,26 a$ & $0,37 \mathrm{a}$ & $0,26 a$ & $0,27 a$ & $0,27 \mathrm{a}$ \\
\hline & \multicolumn{6}{|c|}{ RAS } \\
\hline SPC & 0,91 & $0,09 a$ & $0,09 a$ & $0,13 a$ & $0,11 \mathrm{a}$ & $0,10 \mathrm{a}$ \\
\hline \multirow[t]{2}{*}{ SPD } & 0 & $0,07 \mathrm{a}$ & $0,15 a$ & $0,14 a$ & $0,09 a$ & $0,12 \mathrm{a}$ \\
\hline & \multicolumn{6}{|c|}{ PST (\%) } \\
\hline SPC & 1,10 & $1,40 \mathrm{a}$ & $1,63 \mathrm{a}$ & $1,94 a$ & $1,63 \mathrm{a}$ & $1,49 a$ \\
\hline \multirow[t]{3}{*}{ SPD } & 0 & $1,24 \mathrm{a}$ & $2,01 \mathrm{a}$ & $1,79 a$ & $1,27 \mathrm{a}$ & $1,66 \mathrm{a}$ \\
\hline & \multicolumn{6}{|c|}{$10-20 \mathrm{~cm}$} \\
\hline & \multicolumn{6}{|c|}{$\mathrm{CE}\left(\mathrm{dS} \mathrm{m}^{-1}\right)$} \\
\hline SPC & 0,10 & $0,14 \mathrm{a}$ & $0,22 \mathrm{a}$ & $0,20 a$ & $0,22 a$ & $0,26 a$ \\
\hline \multirow[t]{2}{*}{ SPD } & 0,08 & $0,13 \mathrm{a}$ & $0,18 \mathrm{a}$ & $0,23 \mathrm{a}$ & $0,16 \mathrm{~b}$ & $0,16 \mathrm{~b}$ \\
\hline & \multicolumn{6}{|c|}{ RAS } \\
\hline SPC & 0 & $0,04 \mathrm{a}$ & $0,06 \mathrm{a}$ & $0,07 \mathrm{a}$ & $0,07 \mathrm{a}$ & $0,08 \mathrm{a}$ \\
\hline \multirow[t]{2}{*}{ SPD } & 0 & $0,04 \mathrm{a}$ & $0,09 \mathrm{a}$ & $0,10 a$ & $0,07 \mathrm{a}$ & $0,06 \mathrm{a}$ \\
\hline & \multicolumn{6}{|c|}{ PST $(\%)$} \\
\hline SPC & 0 & $0,73 \mathrm{a}$ & $1,08 \mathrm{a}$ & $1,20 a$ & $1,26 \mathrm{a}$ & $1,48 \mathrm{a}$ \\
\hline \multirow[t]{3}{*}{ SPD } & 0 & $0,79 a$ & $1,42 a$ & $1,27 a$ & $1,26 a$ & $0,94 \mathrm{a}$ \\
\hline & \multicolumn{6}{|c|}{$20-40 \mathrm{~cm}$} \\
\hline & \multicolumn{6}{|c|}{$\mathrm{CE}\left(\mathrm{dS} \mathrm{m^{-1 } )}\right.$} \\
\hline SPC & 0,03 & $0,09 \mathrm{a}$ & $0,14 \mathrm{a}$ & $0,11 \mathrm{a}$ & $0,12 a$ & $0,15 \mathrm{a}$ \\
\hline \multirow[t]{2}{*}{ SPD } & 0,05 & $0,10 a$ & $0,08 \mathrm{a}$ & $0,13 a$ & $0,12 a$ & $0,09 a$ \\
\hline & \multicolumn{6}{|c|}{ RAS } \\
\hline SPC & 0 & $0,02 \mathrm{a}$ & $0,04 \mathrm{a}$ & $0,05 a$ & $0,05 a$ & $0,05 \mathrm{a}$ \\
\hline \multirow[t]{2}{*}{ SPD } & 0 & $0,03 \mathrm{a}$ & $0,03 a$ & $0,06 a$ & $0,05 a$ & $0,02 \mathrm{a}$ \\
\hline & \multicolumn{6}{|c|}{ PST (\%) } \\
\hline SPC & 0 & $0,43 a$ & $0,80 a$ & $0,99 a$ & $1,02 \mathrm{a}$ & $1,05 \mathrm{a}$ \\
\hline SPD & 0 & $0,76 \mathrm{a}$ & $0,56 a$ & $0,93 a$ & $1,15 a$ & $0,45 a$ \\
\hline
\end{tabular}

${ }^{*}$ Letras minúsculas iguais na coluna não diferem a $5 \%$ de probabilidade pelo teste $\mathrm{F} ;{ }^{1 /}$ Testemunha irrigado com $100 \%$ da lâmina com água bruta, utilizado somente como efeito de comparação.

Fonte: Silva (2019).

No geral, os valores de CE não foram influenciados pelos sistemas de manejo do solo em todas as profundidades amostradas e nos dois ciclos de cultivo do milho, com exceção apenas para as lâminas de ARS de $125 \%$ e 150\%, na profundidade de $10-20 \mathrm{~cm}$, no $2^{\circ}$ ciclo (Tabela 5), onde os valores de CE foram significativamente maiores no solo no SPC (lâmina de $75 \%$ ) e no SPD (lâmina de 125\%), contudo, como se nota, esta interação não manteve um padrão, apresentando oscilação entres os sistemas de plantio e as lâminas de irrigação. 
Considerando os dois sistemas de manejo do solo e todas as lâminas de irrigação com ARS aplicadas, a CE variou de 0,05 a 0,37 dS $\mathrm{m}^{-1}$. Segundo a Allen et al. (2011), a cultura do milho mantém níveis de produção aceitáveis em presença de sais. Porém ultrapassando o valor de 1,7 dS m $\mathrm{m}^{-1}$, a perda de produção ocorre de modo proporcional aos incrementos de salinidade (comportamento linear), sendo que para cada $\mathrm{dS} \mathrm{m}^{-1}$ de acréscimo da condutividade elétrica do extrato de saturação, há uma perda de $12 \%$ da produção.

O PST avaliado sofreu moderada influência pelos sistemas de manejo do solo, sendo observadas pontuais diferenças significativas nos tratamentos, nas profundidades de 0-10 e 10-20 cm, nas lâminas de 100\% e 150\%. Nessas duas lâminas de irrigação, os maiores valores de PST foram medidos nas parcelas sob o SPC, com incrementos de $260 \%$ e $92,98 \%(0-10 \mathrm{~cm})$ e $420 \%$ e $73 \%(10-20 \mathrm{~cm})$, respectivamente.

Guidinelle (2019), em desdobramento deste experimento, relatou aumento do valor de $\mathrm{pH}$ em relação às parcelas testemunha, nos dois sistemas de manejo do solo empregados (SPC e SPD), devido à elevada concentração de bicarbonato de sódio na ARS. Porém, as variações dos valores de $\mathrm{pH}$ ficaram muito abaixo do relatado na literatura. Deste modo, o parâmetro de $\mathrm{pH}$ está dentro da faixa que classifica o solo da área experimental como normal.

Avaliando as concentrações de $\mathrm{Na}^{+}$, Guidinelle (2019) constatou que os teores foram influenciados pelos sistemas de manejo do solo apenas para a lâmina de ARS de $150 \%$, na profundidade de 10-20 cm, no $2^{\circ}$ ciclo, onde o teor de $\mathrm{Na}^{+}$foi maior no solo sob SPC. $\mathrm{O}$ autor ainda verificou que apesar da ausência de influência dos sistemas de manejo, houve um incremento elevado nos teores de $\mathrm{Na}^{+}$no solo. Utilizando como referência as parcelastestemunha (onde os teores de $\mathrm{Na}^{+}$variaram de 0,0 a $1,0 \mathrm{mg} \mathrm{dm}^{-3}$ ), observou-se incrementos percentuais nos teores de $\mathrm{Na}+$ no $1^{\text {o }}$ ciclo de: $567 \%(0-10 \mathrm{~cm}, \mathrm{SPC}), 467 \%(0-$ $10 \mathrm{~cm}, \mathrm{SPD}), 800 \%$ (10-20 cm, SPC), 540\% (10-20 cm, SPD), 750\% (20-40 cm, SPC) e $850 \%\left(20-40 \mathrm{~cm}\right.$, SPD). No $2^{\circ}$ ciclo de cultivo, os incrementos foram de: $3.043 \%(0-10 \mathrm{~cm}$, SPC), $2.550 \%$ (0-10 cm, SPD), $1.980 \%$ (10-20 cm, SPC), $1.520 \%(10-20 \mathrm{~cm}, \mathrm{SPD}), 1.250 \%$ (20-40 cm, SPC) e $973 \%(20-40 \mathrm{~cm}$, SPD). Tais resultados corroboram com as conclusões de Leal et al. (2009), que comprovaram a ocorrência de acúmulo de $\mathrm{Na}^{+}$ao longo do tempo nos tratamentos em Latossolo cultivado com cana de açúcar irrigados com efluente de esgoto.

Apesar dos elevados incrementos de $\mathrm{Na}^{+}$no solo, constatou-se que a RAS foi pouco influenciada pelos sistemas de manejo em todas as profundidades amostradas, à exceção no $1^{\circ}$ ciclo para as lâminas de $100 \%$ e $150 \%$, na profundidade de 0-10 cm. De modo geral, as ARS contêm grandes teores de $\mathrm{Na}$ em comparação ao $\mathrm{Ca}$ e ao $\mathrm{Mg}$, o que pode causar deterioração da estrutura do solo pela dispersão das partículas coloidais. A dimensão deste efeito varia com as precipitações e aplicações de ARS, de modo a promover a lixiviação do 
$\mathrm{Na}^{+}$(ERTHAL et al., 2010). Apesar de constatar elevados incrementos no teor de $\mathrm{Na}^{+}$, Guidinelle (2019) não verificou altos teores de $\mathrm{Ca}^{2+}$ no solo, mesmo com a aplicação da lâmina de irrigação com ARS 50\% acima da ETc do milho. Entretanto, para $\mathrm{Mg}^{2+}$, observaram incrementos significativos nos teores deste nutriente no solo, variando na faixa de classificação entre médio e alto.

Houve diferenças de dispersão da argila do solo apenas no $1^{\circ}$ ciclo de cultivo, em pelo menos duas lâminas de irrigação em cada profundidade avaliada (Tabela 6). As constatações de incremento na ADA do solo, entre os sistemas de manejo, na profundidade de 0-10 cm, foram: 30,4\% (lâmina de 100\%, SPC) e 32,5\% (lâmina de 150\%, SPC). Na profundidade de 10-20 cm, foram: 4,5\% (lâmina de 75\%, SPD), 13,6\% (lâmina de 100\%, SPC), 22,0\% (lâmina de 125\%, SPC) e 31,0\% (lâmina de 150\%, SPC). Por fim, na profundidade de $20-40 \mathrm{~cm}$, foram: 30,2\% (lâmina de 100\%, SPC) e 35,0\% (lâmina de 150\%, SPC). Para o $2^{\circ}$ ciclo de cultivo, não houve diferenças para ADA e GL (Tabela 7).

Tabela 6. Argila dispersa em água - ADA e grau de floculação - GF em três profundidades do solo sob diferentes sistemas de manejo (Sistema Plantio Convencional - SPC e Sistema Plantio Direto - SPD), dentro de cada lâmina de irrigação com ARS, ao término do 1ํㅜㄷㅇo de cultivo do milho.

\begin{tabular}{|c|c|c|c|c|c|c|}
\hline \multirow{2}{*}{$\begin{array}{l}\text { Sistemas de } \\
\text { manejo }\end{array}$} & \multicolumn{6}{|c|}{ Lâminas de Irrigação com ARS } \\
\hline & Test. ${ }^{11}$ & $50 \%$ & $75 \%$ & $100 \%$ & $125 \%$ & $150 \%$ \\
\hline & \multicolumn{6}{|c|}{$0-10 \mathrm{~cm}$} \\
\hline & \multicolumn{6}{|c|}{ ADA $\left(\mathrm{g} \mathrm{kg}^{-1}\right)$} \\
\hline SPC & 93,02 & $124,33 \mathrm{a}$ & $140,56 \mathrm{a}$ & $161,70 \mathrm{a}$ & $102,23 \mathrm{a}$ & $156,93 \mathrm{a}$ \\
\hline \multirow[t]{2}{*}{ SPD } & 108,71 & $134,15 a$ & $153,22 \mathrm{a}$ & $112,53 b$ & $112,04 \mathrm{a}$ & $105,95 b$ \\
\hline & \multicolumn{6}{|c|}{ GF $(\%)$} \\
\hline SPC & 64,22 & $52,18 \mathrm{a}$ & $45,94 \mathrm{a}$ & $37,81 \mathrm{~b}$ & 60,68 a & $39,64 \mathrm{~b}$ \\
\hline \multirow[t]{3}{*}{ SPD } & 58,19 & $48,41 \mathrm{a}$ & $41,07 \mathrm{a}$ & $56,72 \mathrm{a}$ & $56,91 \mathrm{a}$ & $59,25 \mathrm{a}$ \\
\hline & \multicolumn{6}{|c|}{$10-20 \mathrm{~cm}$} \\
\hline & \multicolumn{6}{|c|}{ ADA $\left(\mathrm{g} \mathrm{kg}^{-1}\right)$} \\
\hline SPC & 118,80 & $147,43 \mathrm{a}$ & $147,04 \mathrm{~b}$ & $147,88 \mathrm{a}$ & $159,75 \mathrm{a}$ & $167,94 \mathrm{a}$ \\
\hline \multirow[t]{2}{*}{ SPD } & 127,96 & $151,06 \mathrm{a}$ & $154,03 \mathrm{a}$ & $127,82 \mathrm{~b}$ & $124,56 \mathrm{~b}$ & $116,03 \mathrm{~b}$ \\
\hline & \multicolumn{6}{|c|}{ GF (\%) } \\
\hline SPC & 56,00 & $45,40 \mathrm{a}$ & $45,54 \mathrm{a}$ & $45,23 b$ & $40,83 \mathrm{~b}$ & $37,80 \mathrm{~b}$ \\
\hline \multirow[t]{3}{*}{ SPD } & 52,61 & $44,05 \mathrm{a}$ & $42,95 \mathrm{~b}$ & $52,66 \mathrm{a}$ & 53,87 a & 57,03 a \\
\hline & \multicolumn{6}{|c|}{$20-40 \mathrm{~cm}$} \\
\hline & \multicolumn{6}{|c|}{ ADA $\left(g^{k g}{ }^{-1}\right)$} \\
\hline SPC & 96,37 & $158,82 \mathrm{a}$ & $173,55 \mathrm{a}$ & $178,47 \mathrm{a}$ & $144,55 \mathrm{a}$ & $172,13 \mathrm{a}$ \\
\hline \multirow[t]{2}{*}{ SPD } & 9,63 & $166,51 \mathrm{a}$ & $165,23 \mathrm{a}$ & $124,50 \mathrm{~b}$ & $137,75 \mathrm{a}$ & $92,60 \mathrm{~b}$ \\
\hline & \multicolumn{6}{|c|}{ GF $(\%)$} \\
\hline SPC & 69,89 & $50,37 a$ & 45,77 a & $44,23 \mathrm{~b}$ & $54,83 a$ & $46,21 \mathrm{~b}$ \\
\hline SPD & 96,99 & $47,97 \mathrm{a}$ & $48,37 \mathrm{a}$ & $61,09 \mathrm{a}$ & $56,95 \mathrm{a}$ & $71,06 \mathrm{a}$ \\
\hline
\end{tabular}

*Letras minúsculas iguais na coluna não diferem a $5 \%$ de probabilidade pelo teste $\mathrm{F} ;{ }^{1 /}$ Testemunha irrigado com $100 \%$ da lâmina com água bruta, utilizado somente como efeito de comparação.

Fonte: Silva (2019). 
Tabela 7. Argila dispersa em água - ADA e grau de floculação - GF em três profundidades do solo sob diferentes sistemas de manejo do solo (Sistema Plantio Convencional - SPC e Sistema Plantio Direto - SPD), dentro de cada lâmina de irrigação com ARS, ao término do $2^{\circ}$ ciclo de cultivo do milho.

\begin{tabular}{|c|c|c|c|c|c|c|}
\hline \multirow{2}{*}{$\begin{array}{l}\text { Sistemas de } \\
\text { manejo }\end{array}$} & \multicolumn{6}{|c|}{ Lâminas de Irrigação com ARS } \\
\hline & Test. ${ }^{1 /}$ & $50 \%$ & $75 \%$ & $100 \%$ & $125 \%$ & $150 \%$ \\
\hline & \multicolumn{6}{|c|}{$0-10 \mathrm{~cm}$} \\
\hline & \multicolumn{6}{|c|}{ ADA $\left(\mathrm{g} \mathrm{kg}^{-1}\right)$} \\
\hline SPC & 113,37 & $112,40 \mathrm{a}$ & $167,88 \mathrm{a}$ & $122,85 a$ & $116,84 \mathrm{a}$ & $107,62 \mathrm{a}$ \\
\hline \multirow[t]{2}{*}{ SPD } & 95,83 & $113,01 \mathrm{a}$ & $162,35 \mathrm{a}$ & $114,18 \mathrm{a}$ & $126,03 \mathrm{a}$ & $108,89 \mathrm{a}$ \\
\hline & \multicolumn{6}{|c|}{$\mathrm{GF}(\%)$} \\
\hline SPC & 56,39 & $56,77 \mathrm{a}$ & 35,43 a & $52,75 a$ & $55,06 \mathrm{a}$ & $58,61 \mathrm{a}$ \\
\hline \multirow[t]{3}{*}{ SPD } & 63,14 & $56,54 \mathrm{a}$ & $37,56 \mathrm{a}$ & 56,09 a & $51,53 \mathrm{a}$ & $58,12 \mathrm{a}$ \\
\hline & \multicolumn{6}{|c|}{$10-20 \mathrm{~cm}$} \\
\hline & \multicolumn{6}{|c|}{ ADA $\left(\mathrm{g} \mathrm{kg}^{-1}\right)$} \\
\hline SPC & 96,04 & 135,83 a & $143,48 \mathrm{a}$ & 110,06 a & 99,07 a & 94,85 a \\
\hline \multirow[t]{2}{*}{ SPD } & 106,31 & $137,17 \mathrm{a}$ & $139,20 \mathrm{a}$ & $101,88 \mathrm{a}$ & $101,77 \mathrm{a}$ & $105,14 \mathrm{a}$ \\
\hline & \multicolumn{6}{|c|}{ GF (\%) } \\
\hline SPC & 64,43 & 49,69 a & 46,86 a & 59,24 a & $63,31 \mathrm{a}$ & $64,87 \mathrm{a}$ \\
\hline \multirow[t]{3}{*}{ SPD } & 60,42 & $49,20 \mathrm{a}$ & $48,44 \mathrm{a}$ & $62,27 \mathrm{a}$ & $62,31 \mathrm{a}$ & $61,06 \mathrm{a}$ \\
\hline & \multicolumn{6}{|c|}{$20-40 \mathrm{~cm}$} \\
\hline & \multicolumn{6}{|c|}{ ADA $\left(g^{k g}{ }^{-1}\right)$} \\
\hline SPC & 46,28 & $118,69 a$ & $158,67 \mathrm{a}$ & $143,27 \mathrm{a}$ & $128,96 \mathrm{a}$ & $126,17 \mathrm{a}$ \\
\hline \multirow[t]{2}{*}{ SPD } & 7,23 & $141,73 \mathrm{a}$ & $143,83 a$ & 99,83 a & $67,45 \mathrm{a}$ & $118,69 a$ \\
\hline & \multicolumn{6}{|c|}{ GF (\%) } \\
\hline SPC & 85,54 & $62,91 \mathrm{a}$ & $50,42 \mathrm{a}$ & $55,23 \mathrm{a}$ & 59,70 a & $60,57 \mathrm{a}$ \\
\hline SPD & 97,74 & $55,71 \mathrm{a}$ & 55,05 a & $68,80 \mathrm{a}$ & $78,92 \mathrm{a}$ & $62,91 \mathrm{a}$ \\
\hline
\end{tabular}

*Letras minúsculas iguais na coluna não diferem a $5 \%$ de probabilidade pelo teste $\mathrm{F} ;{ }^{1 /}$ Testemunha irrigado com $100 \%$ da lâmina com água bruta, utilizado somente como efeito de comparação.

Fonte: Silva (2019).

A explicação para o fenômeno de dispersão das argilas está na elevada concentração de sódio da ARS, que somada a saturação do solo neste experimento com lâminas de irrigação com ARS, pode ter promovido o acúmulo de sódio na solução do solo (HOMEM et al., 2012). O sódio aumenta a espessura da dupla camada iônica (AZEVEDO e BONUMÁ, 2004). Assim, o excesso de $\mathrm{Na}+$ na solução do solo provoca a dispersão da argila e, desta forma, acarreta em uma camada adensada que dificulta o crescimento, respiração, expansão radicular, além da absorção de água e fixação de $\mathrm{CO}_{2}$ pela planta (TAIZ et al., 2017).

Speir et al. (1999) afirmam que a dimensão dos impactos, principalmente do sódio, sobre as propriedades do solo é atrelada às quantidades e frequências das precipitações ou aplicações, de modo a promover a lixiviação deste nutriente, para que não se acumule na solução do solo e posteriormente possa causar o fenômeno de dispersão de argila.

O grau de floculação (GF) do solo nas parcelas irrigadas com ARS também foi similar ao verificado na ADA, sendo constatadas diferenças apenas no $1^{\circ}$ ciclo de cultivo. As 
constatações de incremento no GF do solo, entre os sistemas de manejo, na profundidade de $0-10 \mathrm{~cm}$ variaram de 44,0\% (lâmina de 100\%, SPD) a 33,1\% (lâmina de 150\%, SPD). Na faixa de solo de 10-20 cm, esses percentuais foram: 5,7\% (lâmina de 75\%, SPC), 14,1\% (lâmina de 100\%, SPD), 24,2\% (lâmina de 125\%, SPD) e 33,7\% (lâmina de 150\%, SPD). Por fim, na profundidade de 20-40 cm, foram: 27,6\% (lâmina de 100\%, SPD) e 35,0\% (lâmina de 150\%, SPD).

Os resultados corroboram parcialmente aos obtidos por Freire (2001), que trabalhando com nove solos do estado de Pernambuco, verificou que, de forma geral, a ADA aumentou com o incremento da RAS, com ausência de diferenças marcantes com relação à $C E$. Homem et al. (2012) observaram ADA em torno de 30 a $40 \%$ em solo irrigado com águas residuárias.

\section{Considerações finais}

A combinação das diferentes lâminas de irrigação com ARS e sistemas de manejo do solo promoveu aumento dos valores de PST nas diferentes profundidades avaliadas em relação às parcelas-testemunha e ao solo no período anterior à instalação do experimento. As diferentes lâminas de ARS associadas com os sistemas de manejo do solo promoveram valores adequados de CE, influenciando pouco a RAS. A aplicação de variadas lâminas de ARS combinada aos sistemas de manejo do solo proporcionaram poucas alterações nos estoques de COT do solo. Os valores de ADA foram influenciados apenas no primeiro ciclo de cultivo, com incremento de ADA no SPC, em pelo menos duas lâminas de irrigação em cada profundidade avaliada.

\section{Agradecimentos}

Ao Instituto Federal do Espírito Santo - Campus de Alegre, por disponibilizar a área experimental e laboratórios de apoio e ao Programa de Pós-Graduação em Agroecologia (PPGA), por terem proporcionado os meios para a realização deste trabalho. À Fundação de Amparo à Pesquisa e Inovação do Espírito Santo (FAPES), pela concessão da bolsa e auxílio financeiro para condução e realização do experimento. 


\section{Referências}

ALLEN, R. G.; HOWELL, T. A.; SNYDER, R. L. Irrigation water requirements. In: STETSON, L. E.; MECHAM, B. Q. Falls Church - Irrigation Association, 2011. 1.045 p.

AYERS, R. S.; WESTCOT, D. W. A qualidade de água na agricultura. 2.ed. Campina Grande: UFPB/FAO, 1999. 153p.

AZEVEDO, A. C. de S.; BONUMÁ, A. Partículas coloidais, dispersão e agregação em Latossolos. Ciência Rural, v. 34, n. 2, p. 609-617, 2004.

BARROS, F. M.; MARTINEZ, M. A.; NEVES, J. C. L.; MATOS, A. T.; SILVA, D. D. Características químicas do solo influenciadas pela adição de água residuária da suinocultura. Revista Brasileira de Engenharia Agrícola e Ambiental, v. 9, (Suplemento), p. 47-51, 2005.

BERNARDES, R. F. B. Água residuária de suínos em um sistema agroflorestal: atributos químicos e translocação de nutrientes no solo. Uberlândia, 2017. 88 f. Dissertação (Mestrado em Agronomia) - Universidade Federal de Uberlândia, Uberlândia, 2017.

CABRAL, J. R.; FREITAS, P. S.; REZENDE, R.; MUNIZ, A. S.; BERTONHA, A. Impacto da água residuária de suinocultura no solo e na produção de capim-elefante. Revista Brasileira de Engenharia Agrícola e Ambiental, v. 15, n. 8, p. 823-831, 2011.

CALONEGO, J. C.; SANTOS, C. H.; TIRITAN, C. S.; JÚNIOR, J. R. C. Estoques de carbono e propriedades físicas de solos submetidos a diferentes sistemas de manejo. Revista Caatinga, v. 25, n. 2, p. 128-135, 2012.

CARVAlHO, M. A. C. D.; SORATtO, R. P.; ATHAYDE, M. L. F.; ARF, O.; SÁ, M. E. D. Produtividade do milho em sucessão a adubos verdes no sistema de plantio direto e convencional. Pesquisa Agropecuária Brasileira, v. 39, n. 1, p. 47-53, 2004.

CERETTA, C. A.; BASSO, C. J.; VIEIRA, F. C. B.; HERBES, M. G.; MOREIRA, I. C. L.; BERWANGER, A. L. Dejeto líquido de suínos: I - perdas de nitrogênio e fósforo na solução escoada na superfície do solo, sob plantio direto. Ciência Rural, v. 35, n. 6, p. 1296-1304, 2005.

CERETTA, C. A.; DURIGON, R.; BASSO, C. J.; BARCELLOS, L. A. R.; VIEIRA, F. C. B. Características químicas de solo sob aplicação de esterco líquido de suínos em pastagem natural. Pesquisa Agropecuária Brasileira, v. 38, n. 6, p. 729-735, 2003.

CONDÉ, M. S.; ALMEIDA, N. O. B.; HOMEM, B. G. C.; FERREIRA, I. M.; SILVA, M. D. Impacto da fertirrigação com água residuária da suinocultura em um Latossolo vermelhoamarelo. Vértices, v. 15, n. 2, p. 161-178, 2013.

CRUZ, J. C.; PEREIRA FILHO, I. A.; ALVARENGA, R.; GONTIJO NETO, M. M.; VIANA, J. H. M.; DE OLIVEIRA, M. F.; SANTANA, D. P. Manejo da Cultura do milho em sistema de plantio direto. Informe agropecuário, v. 27, n. 233, p. 42-53, 2006. 
D'ALMEIDA, D. M.; ANDRADE, E. M.; MEIRELES, A.; NESS, R. L. Importância relativa dos íons na salinidade de um Cambissolo na Chapada do Apodi, Ceará. Engenharia Agrícola, v. 25, n. 3, p. 615-621, 2005.

DONEDA, A.; AITA, C.; GIACOMINI, S. J.; MIOLA, E. C. C.; GIACOMINI, D. A.; SCHIRMANN, J.; GONZATTO, R. Fitomassa e decomposição de resíduos de plantas de cobertura puras e consorciadas. Revista Brasileira Ciência do Solo, v. 36, n. 6, p. 17141723, 2012.

ELLERBROCK, R. H.; HÖHN, A.; ROGASIC, J. Functional analysis of soil organic matter as affected by long-term manorial treatment. European Journal of Soil Science, v. 50, n. 1, p. 65-71, 1999.

EPSTEIN, E.; BLOOM, A. J. Nutrição mineral das plantas: princípios e perspectivas. São Paulo: Planta, 2006. 403p.

ERTHAL, V. J. T.; FERREIRA, P. A.; MATOS, A. T.; PEREIRA, O. G. Alterações físicas e químicas de um Argissolo pela aplicação de água residuária de bovinocultura. Revista Brasileira de Engenharia Agrícola e Ambiental, v. 14, n. 5, p. 467-477, 2010.

FACTOR, T. L.; ARAÚJO, J. A. C. de; VILELLA JUNIOR, L. V. E. Produção de pimentão em substratos e fertirrigação com efluente de biodigestor. Revista Brasileira de Engenharia Agrícola e Ambiental, v. 12, n. 2, p. 143-149, 2008.

FONSECA, A. F.; HERPIM, U.; PAULA, A. M. Agricultural use of treated sewage effluents: Agronomic and environmental implications and perspectives for Brazil. Scientia Agricola, v. 64, n. 2, p. 194-209, 2007.

FRANCHINI, J. C.; DEBIASI, H.; JUNIOR, A. A. B.; TONON, B. C.; FARIAS, J. R. B.; DE OLIVEIRA, M. C. N.; TORRES, E. Evolution of crop yields in different tillage and cropping systems over two decades in southern Brazil. Field Crops Research, v. 137, p. 178-185, 2012.

FREIRE, M. B. G. S. Saturação por sódio e qualidade da água de irrigação na degradação de propriedades físicas de solos do Estado de Pernambuco. Viçosa, 2001. 66 f. Tese (Doutorado em Agronomia) - Universidade Federal de Viçosa, Viçosa, 2001.

GUEDES, F. O.; SILVA, A. P.; GIAROLA, N. F. B.; TORMENA, C. A. Structural properties of the soil seedbed submitted to mechanical and biological chiseling under no-tillage. Geoderma, v. 204-205, p. 94-101, 2013.

GUIDINELLE, R. B. Água residuária de suinocultura e sistema plantio direto no desenvolvimento do milho para produção de silagem. Alegre, 2019. 125 f. Dissertação (Mestrado em Agroecologia) - Instituto Federal do Espírito Santo, Alegre, 2019.

HOMEM, B. G. C.; ALMEIDA, N. O. B.; CONDÉ, M. S.; SILVA, M. D.; FERREIRA, I. M. Efeito do uso prolongado de água residuária da suinocultura sobre as propriedades químicas e físicas de um Latossolo Vermelho-Amarelo. Científica, v. 42, n. 3, p. 299-309, 2014.

HOMEM, B. G. C.; ALMEIDA NETO, O. B.; SANTIAGO, A. M. F.; DE SOUZA, G. H. Dispersão da argila provocada pela fertirrigação com águas residuárias de criatórios de animais. Revista Brasileira de Agropecuária Sustentável, v. 2, n. 1, p. 89-98, 2012. 
INSTITUTO BRASILEIRO DE GEOGRAFIA E ESTATÍSTICA - IBGE. Estatística da produção pecuária. Rio de Janeiro: IBGE, 2018. 52p.

LEAL, R. M. P.; FIRME, L. P.; MONTES, C. R.; MELFI, A. J.; PIEDADE, S. M. D. S. Soil exchangeable cations, sugarcane production and nutrient uptake after wastewater irrigation. Scientia Agricola, v. 66, n. 2, p. 242-249, 2009.

LIMA, J. M.; CURI, N.; RESENDE, M.; SANTANA, D. P. Dispersão do material de solo em água para avaliação indireta da erodibilidade de Latossolos. Revista Brasileira de Ciência do Solo, v.14, p. 85-90, 1990.

MEURER, E. J. Fundamentos da química do solo. 3. ed. Porto Alegre: Evangraf, 2006. $285 p$.

OLIVEIRA, L. B. D.; RIBEIRO, M. R.; FERREIRA, M. D. G. D. V.; LIMA, J. F. W. F. D.; MARQUES, F. A. Inferências pedológicas aplicadas ao perímetro irrigado de Custódia, PE. Pesquisa Agropecuária Brasileira, v. 37, n. 10, p. 1477-1486, 2002.

PANACHUKI, E.; BERTOL, I.; ALVES, S. T.; OLIVEIRA, P. T. S.; RODRIGUES, D. B. B. Perdas de solo e de água e infiltração de água em Latossolo Vermelho sob sistemas de manejo. Revista Brasileira de Ciências do Solo, v. 35, n. 5, p. 1777-86, 2011.

PEREIRA, P. A.; SAMPAIO, S. C.; REIS, R. R. D.; ROSA, D. M.; CORREA, M. M. Swine farm wastewater and mineral fertilization in corn cultivation. Revista Brasileira de Engenharia Agrícola e Ambiental, v. 20, n. 1, p. 49-54, 2016.

PRIOR, M.; SAMPAIO, S. C.; NÓBREGA, L. H.; DIETER, J.; COSTA, M. S. D. M. Efeitos na cultura do milho e no solo devido a aplicação água residuária de suinocultura associada com adubação química. Engenharia Agrícola, v. 35, n. 4, p. 744-755, 2016.

RANGEL, O. J. P.; SILVA, C. A.; GUIMARÃES, P. T. G. Estoque e frações da matéria orgânica de Latossolo cultivado com cafeeiro em diferentes espaçamentos de plantio.

Revista Brasileira de Ciência do Solo, v. 31, n. 6, p. 1341-1353, 2007.

RHOADES, J.; KANDIAH, A.; MASHALI, A. M. Uso de águas salinas para produção agrícola. Campina Grande: UFPB, 2000. 117p.

RICHARDS, L. A. Diagnóstico y reabilitacíon de suelos salinos y sódicos. Los Angeles: Department of Agriculture, 1962. $172 \mathrm{p}$.

ROSA, D. M.; SAMPAIO, S. C.; PEREIRA, P.A.M.; REIS, R.R.; SBIZZARO, M. Corn fertilization using swine wastewater and soil-water environmental quality. Engenharia Agrícola, v. 37, n. 4, p. 801-810, 2017.

SANTOS, L. N. S.; PASSOS, R. R.; SILVA, L. V. M.; OLIVEIRA, P. P.; OLIVEIRA GARCIA, G.; CECÍLIO, R. A. Avaliação de alguns atributos físicos de um Latossolo Vermelho-amarelo sob diferentes coberturas vegetais. Bioscience Journal, v. 26, n. 6, p. 940-947, 2010.

SCHERER, E. E.; NESI, C. N.; MASSOTTI, Z. Atributos químicos do solo influenciados por sucessivas aplicações de dejetos suínos em áreas agrícolas de Santa Catarina. Revista Brasileira de Ciência do Solo, v. 34, n. 4, p. 1375-1383, 2010. 
SILVA, A. D. A.; LANA, A. M.; LANA, R. M.; COSTA, A. M. Fertilization with swine waste manure: the influence of chemical characteristics in Brachiaria decumbens and changes in the soil. Engenharia Agrícola, v. 35, n. 2, p. 254-265, 2015.

SILVA, C. M.; FRANÇA, M. T. de; OYAMADA, G. C. Características da suinocultura e os dejetos causados ao ambiente. Connection Line, n. 12, p. 44-59, 2015.

SILVA, J. B.; BIANCHINI, A.; WEBER, O. L. S.; SCARAMUZZA, W. L. M. P.; SILVA, J. B.; MAAS, K.D.B. Atributos físicos de um Latossolo fertirrigado com efluentes de suínos. In: Simpósio internacional sobre gerenciamento de resíduos agropecuários e agroindustriais, 2., 2011, Foz do Iguaçu. Anais... Foz do Iguaçu: Sigera, 2011.

SILVA, M. V. S. Água residuária de suinocultura e sistema plantio direto: efeitos em propriedades do solo cultivado com milho. Alegre, 2019. $80 \mathrm{f}$. Dissertação (Mestrado em Agroecologia) - Instituto Federal do Espírito Santo, Alegre, 2019.

SOUZA, W. J. O.; MELO, W. J. Matéria orgânica de um Latossolo submetido a diferentes sistemas de produção de milho. Revista Brasileira de Ciência do Solo, v. 27, n. 6, p. 11131122, 2003.

SPEIR, T. W.; SCHAIK, A. P. V.; KETTLES, H. A. Soil and stream-water impacts of sewage effluent irrigation onto steeply sloping land. Journal of Environmental Quality, v. 28, n. 4, p. 1105-1114, 1999.

TAIZ, L.; ZEIGER, E.; MOLLER, I. M.; MURPHY, A. Fisiologia e desenvolvimento vegetal. 6. ed. Porto Alegre: Artmed, 2017. 858p.

USSIRI, D. A. N.; LAL, R. Long-term tillage effects on soil carbon storage and carbon dioxide emissions in continuous corn cropping system from an Alfisol in Ohio. Soil and Tillage Research, v. 104, p. 39-47, 2009.

YANG, C. M.; YANG, L. Z.; ZHU, O. Y. Organic carbon and its fractions in paddy soil as effected by different nutrient and water regimes. Geoderma, v. 124, p. 133-142. 2005. 


\title{
Capítulo 18
}

\section{Cafeeiro conilon em sistema agroflorestal: qualidade física do solo e carbono orgânico}

\author{
Davi Salgado de Senna ${ }^{1}$, Renato Ribeiro Passos², Otacílio José Passos Rangel ${ }^{3}$, João \\ Batista Silva Araújo ${ }^{4}$, Alex Justino Zacarias ${ }^{5}$, Jéferson Luiz Ferrari ${ }^{3}$, André Oliveira Souza ${ }^{6}$
}

\section{Introdução}

A perspectiva de desenvolvimento rural do atual modelo convencional de produção agropecuária parte da premissa de que as terras devem ser desocupadas de sua vegetação natural antes de se iniciar o plantio dos cultivos econômicos ou a introdução das pastagens (CAPORAL, 2011). Isto elevou as taxas de desmatamento em todos os biomas brasileiros. No caso da Mata Atlântica, por exemplo, originalmente o bioma cobria aproximadamente 90\% da extensão territorial do Estado do Espírito Santo e atualmente sua extensão é de 10,5\% (ATLÂNTICA, 2019).

A implantação de sistemas agropecuários em substituição da vegetação nativa dos ecossistemas naturais pode provocar alterações relevantes em propriedades de ordem física, química e biológica do solo (ARCOVERDE et al., 2015). Essas alterações podem causar melhoria ou podem acelerar a degradação, dependendo principalmente da natureza do solo, das espécies vegetais, do sistema de manejo usado e do tempo de exploração da área (COSTA et al., 2008).

Atualmente, estudos científicos têm evidenciado a necessidade de se buscar novos caminhos para o desenvolvimento rural, apoiando ações que valorizam os "serviços ecossistêmicos". Estes serviços são caracterizados como processos naturais que tem a capacidade de prover bens e serviços ecossistêmicos que satisfaçam as necessidades humanas direta ou indiretamente (GUEDES e SEEHUSEN, 2011) e são proporcionados

${ }^{1}$ Me. em Agroecologia pelo Programa de Pós-Graduação em Agroecologia do Instituto Federal do Espírito Santo - Campus de Alegre, Caixa Postal 47, CEP: 29500-000, Alegre-ES. E-mail: davi_ssenna@yahoo.com

${ }^{2}$ Dr. Professor da Universidade Federal do Espírito Santo - Campus de Alegre, Caixa Postal 16, CEP: 29500-000, Alegre-ES. Bolsista de Produtividade em Pesquisa do CNPq. renatoribeiropassos@hotmail.com

${ }^{3}$ Drs. Professores do Instituto Federal do Espírito Santo - Campus de Alegre, Caixa Postal 47, CEP: 29500-000, Alegre-ES. E-mail: otaciliorangel@gmail.com; ferrarijl@ifes.edu.br

${ }^{4}$ Dr. Pesquisador do Instituto Capixaba de Pesquisa, Assistência Técnica e Extensão Rural, CEP: 29323-000, Pacotuba, Cachoeiro de Itapemirim-ES. E-mail: joaoaraujovni@gmail.com

${ }^{5}$ Mestrando em Agroecologia pelo Programa de Pós-Graduação em Agroecologia do Instituto Federal do Espírito Santo - Campus de Alegre. Caixa Postal 47, CEP: 29500-000, Alegre-ES. E-mail: alexjustino12@gmail.com

${ }^{6}$ Me. Professor do Instituto Federal do Espírito Santo - Campus de Alegre, Caixa Postal 47, CEP: 29500-000, Alegre-ES. E-mail: andreolisouza@gmail.com 
tanto pelos ecossistemas naturais quanto pelos ecossistemas manejados pelo homem (CARDOSO et al., 2010).

Estes serviços ecossistêmicos são encontrados em diferentes níveis nos sistemas agroecológicos de produção que emergem como adequados à promoção da sustentabilidade e fortalecimento da agricultura familiar (PERFECTO e VANDERMEER, 2008). A agroecologia, enquanto ciência proporciona as bases científicas do processo de transição do modelo de agricultura convencional para estilos de agricultura ecológica ou sustentável (CAPORAL e RAMOS, 2006).

A agricultura de base agroecológica tem sido apontada como capaz de aliar preservação ambiental e produtividade em diversos países do mundo, inclusive no Brasil (PERFECTO et al., 2008). Entretanto, a agroecologia não é reconhecida apenas como ciência, mas como um movimento e como prática agrícola (WEZEL et al., 2009).

A produção de café no estado do Espírito Santo ocorre em 96\% dos municípios capixabas (GODINHO et al., 2018). No Estado são cultivadas as espécies Coffea arabica nas microrregiões do Caparaó, Sudoeste Serrana e Central Sul, ocupando 150.000 hectares de área colhida e Coffea canephora nas regiões do Sudoeste, Centro-Oeste, Nordeste, Rio Doce e Noroeste, ocupando 256.000 hectares de área colhida na safra de 2016/2017 (IBGE, 2017). O Espírito Santo é o segundo produtor nacional de café, com 9,3 milhões de sacas anuais, sendo responsável por 20,1\% da produção nacional em 2017 (GODINHO et al., 2018).

As lavouras de café conilon no estado do Espírito Santo estão localizadas principalmente em propriedades rurais pequenas e de base familiar, com predomínio de lavouras em monocultivo, com uso de adubação mineral, agrotóxicos e alto uso de irrigação no norte do ES, e baixo uso de irrigação na região sul. Segundo Lopes et al. (2014), a ausência de práticas conservacionistas de solo em lavouras cafeeiras possibilita o seu empobrecimento e contribui com a má nutrição das plantas, o que aumenta a susceptibilidade às pragas e doenças, promovendo desequilíbrios ecológicos.

Dentre as práticas agroecológicas com o potencial de aliar conservação e produtividade nas lavouras de café conilon, destacam-se o manejo orgânico e os consórcios agroflorestais com espécies frutíferas e madeireiras, principalmente para os pequenos produtores (VANDERMEER e PERFECTO, 2007).

A presença de árvores e outras culturas associadas nas lavouras de café aumentam o aporte de resíduos orgânicos em virtude da queda de material vegetal. Mendonça et al. (2010) estudando o cafeeiro cultivado em associação com espécies arbóreas, relatam que o maior aporte orgânico desse sistema resulta em ganhos em termos de carbono orgânico e 
substâncias húmicas no solo, as quais geram cargas e contribuem para a retenção de água, capacidade de troca de cátions e estabilidade dos agregados do solo.

A fração orgânica do solo quando se associa à fração mineral, atua como componente importante na formação dos agregados e estruturação do solo (TISDALL e OADES, 1982; OADES, 1984). Segundo Betioli Júnior et al. (2012), uma das formas de se incrementar a qualidade estrutural do solo é por meio da conservação e adição de matéria orgânica. $A$ adição de compostos orgânicos em diferentes sistemas de manejo pode trazer benefícios químicos e melhoria na qualidade física e biológica do solo.

Considerando a matéria orgânica como um dos principais agentes de agregação das partículas do solo, é de se esperar, em solos tropicais, que parte da variação do tamanho dos agregados e, por consequência, dos índices de agregação seja atribuída à variação do conteúdo de matéria orgânica do solo e à constância no aporte de resíduos ao solo. Portanto, diante do exposto, espera-se que solos sob lavouras de café conilon consorciadas possuam melhor qualidade física e orgânica do que lavouras em monocultivo (pleno sol).

O objetivo geral deste capítulo é abordar a relação da matéria orgânica e os atributos físicos dos solos, com ênfase na agregação do solo em lavouras de café conilon consorciado, comparativamente ao café conilon em monocultivo.

\section{Cafeeiro conilon em sistemas agroflorestais}

O café é originário de florestas caducifólias da Etiópia e Sudão (BOULAY et al., 2000) e, portanto, é uma espécie adaptada à sombra. Nos países da América Latina (México, Nicarágua, El Salvador, Peru, Panamá e Guatemala) e alguns países da África (Etiópia, Sumatra, Nova Guiné e Timor), o cafeeiro é cultivado sob sombra, já no Brasil, é predominante o cultivo a pleno sol, onde houve melhoramento genético para a adaptação das plantas a essa condição (MOREIRA, 2009).

O cafeeiro conilon (Coffea canephora Pierre) pertence ao gênero Coffea da família Rubiaceae. É uma espécie rústica, com tolerância a pragas e doenças e adaptada a uma ampla faixa de condições edafoclimáticas tropicais, de baixas altitudes e temperaturas elevadas (FERRÃO et al., 2000).

A principal região produtora de café conilon no Brasil se concentra no norte do Espírito Santo. Em grande área da região, há expressivo déficit hídrico anual, que, aliado à distribuição irregular de chuvas, promove um período seco, que se estende por aproximadamente cinco meses, coincidindo com a estação fria (SIAG, 2006).

Estes e outros fatores têm tornado o plantio de café conilon em consórcios, prática cada vez mais comum em todo o estado. Consórcios de café conilon com fruteiras (mamoeiro e 
coqueiro), com espécies florestais de alto valor econômico de sua madeira (cedro australiano e teca) e com seringueira têm sido praticados desde a década de 80 (DA MATTA et al., 2015).

A lavoura cafeeira consorciada com espécies e espaçamentos adequados pode apresentar resultados satisfatórios, quando comparado ao cultivo do café a pleno sol (FERNANDES, 1986). Segundo Rodrigues (2009), o sombreamento do cafeeiro deve atingir cerca de 30 a $50 \%$ da cobertura da área plantada. O sombreamento não afeta somente a disponibilidade de luz ao longo da copa do cafeeiro, mas também melhora as condições microclimáticas via redução dos extremos de temperatura do ar e do solo, reduz a velocidade dos ventos, mantém a umidade relativa do ar e a disponibilidade hídrica do solo (BEER et al., 1998). A proposta de cultivos arborizados, por meio do sombreamento moderado, visa atenuar os efeitos de condições climáticas extremas, além de proporcionar maior sustentabilidade aos sistemas (PEZZOPANE et al., 2005).

Os cultivos consorciados aumentam a biodiversidade das lavouras. Essa biodiversidade torna o sistema mais vigoroso, reduzindo ou até mesmo dispensando o uso de agrotóxicos e fertilizantes sintéticos (BERTALOT et al., 2004). Esse sistema de cultivo reduz a pressão de pragas e doenças (MOREIRA, 2009) e promove o aumento de inimigos naturais das pragas do cafeeiro (LIMA et al., 2010).

Os sistemas agroflorestais (SAF's) podem ser considerados como sistemas de manejo que conservam as características do solo as mais próximas das condições naturais, havendo um melhor aproveitamento dos componentes do agroecossistema, no tempo e no espaço (NAIR, 1993). Segundo o mesmo autor, nos SAF's com cafeeiro ocorrem interações ecológicas e econômicas entre as árvores e as outras culturas, que resultam em vantagens em relação aos sistemas em monoculturas.

Os SAF`s possuem sistemas radiculares diversos que propiciam um contínuo aporte de matéria orgânica e condicionam favoravelmente o meio físico do solo, melhorando as condições de infiltração e retenção de água (FAO, 1995). O aporte de resíduos pode reduzir as perdas de $\mathrm{N}$, aumentar a capacidade de absorção e infiltração de água e reduzir o risco de erosão e emergência de plantas invasoras (BARBERA-CASTILLO, 2001). Os SAF's podem melhorar a qualidade dos solos cultivados, principalmente devido ao aporte de material vegetal senescente e material oriundo das podas, além da fixação biológica de nitrogênio (FBN) por microrganismos associados às árvores.

Em cafezais sombreados com leguminosas, quantidades apreciáveis de nitrogênio ( 60 $\mathrm{kg} \mathrm{N} \mathrm{ha}^{-1} \mathrm{ano}^{-1}$ ) podem ser fixadas, segundo dados obtidos na Costa Rica (BEER et al., 1998), reduzindo ainda mais a necessidade de adubação nitrogenada. 
Lavouras cafeeiras cultivadas com práticas conservacionistas e na forma de sistemas agroflorestais promovem maior conservação que em cultivo convencional, diminuindo perda de solo e nutrientes por processos erosivos (FRANCO et al., 2002; THOMAZINI et al., 2012). No Estado do Espírito Santo, o cultivo do café conilon com espécies arbóreas e frutíferas é considerado uma importante alternativa utilizada pelos agricultores visando à diversificação da produção agrícola (SALES et al., 2013).

Segundo Alves (2017), no Brasil, diversas plantas têm sido estudadas para o cultivo consorciado com café, como o ingazeiro (Inga sessilis), a leucena (Leucaena leucocephala), o cedro australiano [Toona ciliata var. australis (F. Muell.) Bahadur] (GUIMARÃES et al., 2014 a,b), a seringueira (Hevea brasiliensis Mull.) (SANTOS et al., 2015; SALES et al., 2013), a gliricídia [Gliricidia sepium (Jacq.) Steud], o mamoeiro (Carica papaya L.) (SALES et al., 2013), a teca (Tectona grandis L.f.) (MACEDO et al., 2004), a macadâmia (Macadamia integrifólia Maidene Betche) (PEZZOPANE et al., 2010), a eritrina (Erythrina verna Vell.) (RICCI et al., 2011), a grevílea (Grevillea robusta A. Cunn.) (SALGADO et al., 2005), a bananeira (Musa spp.) (ARAÚJO et al., 2015; RICCI et al., 2011; THOMAZINI et al., 2013) e o coqueiro (Cocos nucifera L.) (PEZZOPANE et al., 2011; SALES et al., 2013).

A associação de cafeeiros com outras árvores pode ser entendida como um consórcio de culturas perenes, mas recebe denominações diferentes, como sistema agroflorestal. Os SAF's são formas de uso e manejo dos recursos naturais, nas quais espécies perenes (arvores, arbustos, palmáceas) são utilizadas em associação com cultivos agrícolas ou com animais no mesmo terreno, de maneira simultânea ou numa sequência temporal (MONTAGNINI, 1992).

Os SAF`s apresentam duas características principais: a estratificação vertical, possuindo dois ou mais estratos e a presença de no mínimo uma espécie arbórea (nativa ou exótica) e uma espécie arbustiva e/ou herbácea de importância agrícola, que possuem diferentes épocas de produção (ALTIERI, 2004). Rezende et al. (2006) consideram o cultivo consorciado um sistema intermediário entre o monocultivo e a vegetação natural, onde duas ou mais culturas desenvolvem-se em uma mesma área por determinado período de tempo.

Estes sistemas diversificados podem atenuar os efeitos da fragmentação florestal contribuindo para a conexão entre os remanescentes da Mata Atlântica, representados pelas áreas de Reserva Legal, pelas Áreas de Preservação Permanente (APPs), pequenos fragmentos florestais conservados e capoeira em regeneração natural, funcionando como corredores ecológicos (SEOANE et al., 2010).

Nos SAF's, o uso de espécies que se associam com microrganismos fixadores de nitrogênio, é recomendado, o que favorece a mineralização e disponibilização de nutrientes para as culturas. Além da relação $\mathrm{C} / \mathrm{N}$, que seria a principal controladora da taxa de 
decomposição de resíduos vegetais, exercem também influencia os teores de polifenóis e lignina nos materiais. O teor de polifenóis e a capacidade destes de complexarem com as proteínas afetam diretamente os processos de decomposição e mineralização dos resíduos (PALM, 1995). Conhecer, portanto, a composição dos materiais vegetais torna-se importante para inferir sobre a velocidade de decomposição e mineralização dos nutrientes.

\section{Matéria orgânica do solo}

A matéria orgânica do solo (MOS) é tida como componente principal para garantir qualidade ao solo, atuando nos mecanismos que permitem a manutenção da capacidade produtiva dos mesmos. A MOS representa um dos principais reservatórios de carbono (C) no ciclo global deste elemento.

O solo retém duas vezes mais $C$ orgânico do que a vegetação e até três vezes a quantidade presente na atmosfera, deforma que mudanças no índice de carbono do solo podem ter grande efeito no balanço global do carbono (BELLAMY et al., 2005). A MOS não é um componente simples e homogêneo (ROSCOE e MACHADO, 2002), mas sim um conjunto heterogêneo de materiais orgânicos que diferem em composição, grau de disponibilidade para a microbiota e função no ambiente (CARTER, 2001).

Segundo Theng et al. (1989), a MOS é constituída por componentes vivos e não- vivos. Os componentes vivos são representados por raízes de plantas, micro e macrorganismos que correspondem em média $4 \%$ do $\mathrm{C}$ do solo. Os componentes não-vivos correspondem a 96\% do C do solo e incluem a matéria macrorgânica, constituída por resíduos vegetais em estágio de decomposição variado, as substâncias húmicas e as não húmicas. As substâncias húmicas são divididas em três categorias: ácidos fúlvicos, ácidos húmicos e humina. As substâncias não- húmicas compreendem os carboidratos, lipídeos, aminoácidos, proteínas, ligninas, ácidos nucléicos, pigmentos e uma variedade de ácidos orgânicos.

A MOS também pode ser dividida em constituintes lábeis e estáveis, que se referem à taxa de decomposição (THENG et al.1989). A matéria orgânica lábil ou C orgânico lábil incluem a serapilheira de plantas, matéria macrorgânica ou fração leve, substâncias nãohúmicas não ligadas aos constituintes minerais, formas solúveis em água, macrorganismos (fauna) e biomassa microbiana, sendo que o processo de decomposição ocorre em poucas semanas ou meses. A matéria orgânica estável é representada por substâncias húmicas e outras macromoléculas, ambas resistentes ao ataque microbiano, devido à sua estrutura molecular ou por estarem fisicamente protegidos em complexos organominerais ou retidos no interior de agregados, podendo persistir no solo por centenas de anos (THENG et al.,1989). 
A fração lábil possui como principal característica o fornecimento de nutrientes às plantas pela mineralização, além de energia e C aos microrganismos do solo (SILVA e MENDONÇA, 2007). A fração de ácidos húmicos representa cerca de $2 / 3$ do $C$ orgânico e possui maior permanência no solo e sua principal função é atuar sobre as condições físicas e químicas do solo, além de ser importante no sequestro de $C$ atmosférico (SILVA e MENDONÇA, 2007).

A quantidade do compartimento lábil é controlada pela qualidade e quantidade de resíduos orgânicos adicionados ao solo e pelo clima. Outros fatores importantes incluem o estado físico dos resíduos e o tipo e a frequência de cultivo (DUXBURY et al., 1989). As substâncias húmicas representam a fração mais estável da matéria orgânica do solo. Possuem estrutura química complexa, associada à sua localização no interior dos agregados do solo e às suas interações com minerais de argilas e cátions metálicos. As substâncias húmicas são produtos da modificação e da degradação química e biológica dos resíduos vegetais, principalmente, e animais, assim como da atividade da microflora do solo (THENG et al., 1989).

Segundo Loss et al. (2009), as frações lábeis estão associadas à disponibilidade de nutrientes e à formação de macroagregados, enquanto que as frações recalcitrantes estão relacionadas a compostos de maior estabilidade química e massa molar, como a fração humina (SILVA et al., 2011), contribuindo, inclusive, para a estabilidade dos microagregados do solo (TISDALL e OADES, 1982).

O equilíbrio entre a entrada de resíduos orgânicos e a saída de $\mathrm{CO}_{2}$ representa o estoque de MOS. Segundo Mulvaney et al. (2010), a ciclagem da MOS é controlada por alguns fatores, como: taxas de deposição, decomposição e renovação dos resíduos, em um processo dinâmico. As taxas de entrada de resíduos ao solo em agroecossistemas podem ser controladas pelo homem, porém a determinação da taxa de decomposição desses materiais é controlada por uma complexa interação entre fatores climáticos, população microbiana do solo e a composição química do material vegetal (COSTA e SANGAKKARA, 2006). A umidade e a temperatura do solo são fatores climáticos que influenciam a taxa de decomposição. Em geral, as taxas de decomposição são maiores com o aumento da umidade e da temperatura (COSTA e SANGAKKARA, 2006).

As práticas convencionais de preparo do solo como aração e, ou, gradagem, aumentam o potencial de perda de MOS por erosão hídrica e decomposição microbiana, sendo a última a principal forma de perda de MOS afetada pela utilização de máquinas agrícolas (BAYER et al., 1999). Ações voltadas para conservação do solo podem resultar na manutenção ou incremento da MOS (CARIDE et al., 2012). 
As alterações na MOS têm consequências sobre as propriedades químicas, físicas e biológicas do solo e se mostram dependentes das condições do solo, do clima e das práticas culturais adotadas (CARIDE et al., 2012). A manutenção de resíduos na superfície do solo reduz a evaporação e a temperatura do solo, aumentando a infiltração de água no mesmo e diminuindo o escoamento superficial (UNGERA et al., 1991).

\section{Atributos físicos do solo}

\section{Textura do solo}

A textura do solo está relacionada com a proporção de tamanho das partículas minerais do solo. A análise granulométrica do solo permite classificar os componentes sólidos do solo em classes de acordo com os seus diâmetros, sendo divididos em areia, silte e argila. Segundo Prevedello (1996) e Oliveira (2005), a determinação das classes texturais presentes ao longo do perfil de um solo tem importante implicação no manejo dos solos agrícolas, interferindo na disponibilidade de água, aeração, condutividade térmica, drenagem e erodibilidade dos mesmos.

A textura é uma característica física que não se altera ao longo dos anos e é usada como fator determinante de manejo dos solos. As propriedades físicas relacionadas à qualidade do solo referem-se às condições que permitem a infiltração, a retenção e a disponibilização de água para as plantas, proporcionando as trocas de calor e de gases com a atmosfera e as raízes das plantas e possibilitando o crescimento das raízes (REICHERT et al., 2003).

\section{Densidade do solo}

A densidade de solo (Ds) é um dos fatores mais importantes na avaliação dos solos. Carvalho et. al. (2002) tratam a Ds como fator físico indicador de qualidade do solo. Essa propriedade está associada à estrutura, à densidade de partículas e à porosidade do solo, podendo ser usada como um indicador de processos de degradação da estrutura do solo, que pode mudar em função do uso e do manejo do solo (EMBRAPA, 1999).

Segundo Chioderoli et al. (2012), com o aumento da Ds há uma redução da porosidade total e da macroporosidade e aumento da microporosidade e da resistência à penetração do solo. A matéria orgânica pode reduzir a Ds, elevar o volume de poros, favorecendo a infiltração e aeração para desenvolvimento das plantas (CUNHA et al., 2011). A Ds é afetada por diversos fatores, como: uso e manejo do solo, cobertura vegetal, teor de matéria orgânica, grau de compactação e profundidade do solo (SILVA et al., 2000).

Aguiar (2008), comparando o cultivo em sistema agroflorestal (SAF) e cultivo a pleno sol em um Latossolo, na zona da Mata de Minas Gerais, verificou que o SAF de café arábica 
com capim napier e árvores de uva do Japão (Hovenia dulcis. Thunb.) e no Brasil (Colubrina glandulosa Perkins) apresentou melhorias nos atributos físicos do solo, com redução da densidade do solo e da resistência à penetração do solo.

\section{Porosidade do solo}

O espaço do solo ocupado por água e ar compõe a porosidade do solo, definida como sendo a proporção entre o volume de poros e o volume total de um solo (ALMEIDA, 2017). O espaço poroso do solo é normalmente classificado, em função da distribuição de poros por tamanho, em micro e macroporos. Os microporos (Mip), depois de saturados em água, são responsáveis pela retenção e armazenamento de água no solo. Os macroporos (Map), depois de saturados em água são esvaziados pela ação da gravidade, sendo importante para a aeração e drenagem da água no solo (SEVERIANO, 2010). O tamanho, tipo, quantidade e continuidade dos poros, normalmente são determinados pela textura e estrutura do solo (REINERT e REICHERT, 2006).

A relação entre micro (Mip) e macroporos (Map) afeta o desenvolvimento das plantas, sendo que em solos com Map reduzida, ocorre a indução do crescimento lateral das raízes, e em solos excessivamente porosos há a redução da absorção de nutrientes e água pelo sistema radicular, devido ao menor contato solo-raiz. Com o uso do solo para atividades agrícolas, normalmente ocorre a redução dos macroporos devido à quebra de agregados e consequente entupimento de poros (AGUIAR, 2008).

A porosidade do solo condiciona importantes fenômenos e mecanismos na física do solo, tais como a retenção e movimento de água e ar, e as relações de massa e volume das fases do sistema solo (REINERT e REICHERT, 2006). A porosidade ainda influencia a resistência à penetração e ramificação de raízes no solo, a disponibilidade e o aproveitamento de nutrientes (RIBEIRO et al., 2007).

\section{Resistência do solo à penetração}

Algumas propriedades físicas do solo como a densidade, a porosidade, a taxa de infiltração de água e a resistência do solo à penetração têm sido largamente utilizadas para a avaliação da compactação dos solos em área agrícolas (FLORES et al., 2007). A compactação pode ocasionar a redução da taxa de infiltração de água no solo e o aumento do escoamento superficial, contribuindo para aumento das taxas de erosão do solo, assoreamento de cursos de água e poluição da água superficial.

As práticas agrícolas inadequadas de manejo convencional do solo geram a compactação e aumento da densidade do solo (PANDOLFI et al., 2007). Segundo Silva et al. (2005), a deposição de argila nas paredes dos poros e sobre os grãos de quartzo 
ocasiona um arranjo mais compacto de partículas, aumentando o adensamento das camadas sub-superficiais. A compactação dos solos agrícolas é causada, principalmente, pela mecanização realizada com umidade do solo próxima ao limite de plasticidade, uma vez que água reduz a coesão e atua como lubrificante entre as partículas de solo, permitindo o deslizamento e o empacotamento das partículas, quando submetido a algum tipo de pressão (LUCIANO et al., 2012).

A susceptibilidade à compactação pode ser alterada pelo acúmulo de matéria orgânica, porém, a textura do solo e seus efeitos associados à retenção de água, coesão e densidade do solo determinarão a magnitude e o tipo de efeito (BRAIDA et al., 2010). A compactação, devida à atividade agropecuária, também pode causar modificações na retenção de água do solo, decorrentes de alterações sofridas na distribuição do diâmetro de poros, principalmente na redução da macroporosidade (FIGUEIREDO et al., 2009).

A resistência do solo à penetração, utilizando um penetrômetro de impacto é um indicador secundário de compactação, pois esta poderá ser influenciada pela umidade do solo (MANTOVANI, 1987) e pela composição granulométrica do solo e sua mineralogia (MORAES et al., 2014).

\section{Agregação e estrutura do solo}

Os agregados do solo são definidos, segundo Martin et al. (1955), como grupos de partículas de solo, onde as forças que mantêm as partículas juntas são maiores do que as forças entre os agregados adjacentes. Esses grupos resistem às forças de destruição associadas aos ciclos de umedecimento e secagem e aos impactos das gotas de chuva (DEXTER, 1988).

A estabilidade dos agregados é uma das propriedades do solo mais sensíveis à remoção de resíduos de culturas, diminuindo significativamente com a diminuição da cobertura do solo. As superfícies dos agregados em solos sem cobertura por resíduos são prontamente dispersas sob as forças erosivas do impacto de gotas de chuva. Alguns estudos mostram que a estabilidade de agregados é positivamente correlacionada com a concentração de MOS (BLANCO-CANQUI e LAL, 2009).

A natureza química da matéria orgânica adicionada ao solo pode influenciar a persistência de mecanismos de ligação, promovendo ou não a formação de agregados estáveis. Tisdall e Oades (1982) propuseram três grupos de agentes ligantes orgânicos envolvidos na formação de agregados: transitórios, temporários e persistentes. O grupo de agentes transicionais é composto por polissacarídeos de rápida decomposição e está associado à estabilidade dos macroagregados $(\geq 0,25 \mathrm{~mm})$ pelos microrganismos (ANGERS e MEHUYS, 1989). O grupo de agentes temporários é composto pelas hifas de fungos e 
raízes, que permanecem no solo por poucas semanas ou até mesmo anos, e estão associados à macroagregação. Por último, o grupo dos agentes persistentes é composto pelos materiais orgânicos humificados, principalmente associados aos óxidos de $\mathrm{Fe}$ e $\mathrm{Al}$, constituindo, segundo Tisdall e Oades (1982), a parte mais importante na formação de microagregados $(<0,25 \mathrm{~mm})$ do solo.

De acordo com Brady e Weil (2012), os agregados são formados por dois processos distintos. A floculação, processo que define o grau de aproximação entre as partículas primárias do solo, e a cimentação, processo que define a capacidade de partículas resultantes da floculação não dispersar em água.

As raízes de espécies arbóreas estimulam a agregação do solo, tanto pela promoção da população microbiana na rizosfera e suprimento de resíduos orgânicos (SILVA e MIELNICZUK, 1997), quanto pela promoção à reorientação e aproximação dos microagregados pela sua expansão e remoção de água, fazendo com que ocorra coesão entre as partículas do solo (PALMEIRA et al., 1999),ocorrendo efeito diferente entre espécies, conforme comprovado por Perin et al. (2002) em trabalho com espécies herbáceas de fabáceas.

Fatores como textura e mineralogia têm influência na formação de agregados estáveis e no conteúdo de $C$ orgânico no solo (FELLER e BEARE, 1997). A taxa de decomposição de materiais orgânicos no solo é geralmente reduzida na presença de argila. As argilas e a matéria orgânica interagem para formar complexos e microagregados, tornando as substâncias orgânicas menos suscetíveis à biodegradação (TISDALL e OADES, 1982). Como resultado desse efeito estabilizador, solos argilosos geralmente contêm mais matéria orgânica do que solos de textura média ou arenosa, sob as mesmas quantidades de material orgânico, durante um período prolongado (JENKINSON, 1988).

A estrutura do solo é uma propriedade física que está relacionada com outras propriedades que são fundamentais nas relações solo planta e que determinam a qualidade do solo, tanto do ponto de vista agrícola quanto florestal (ROCHA et al., 2015). A estrutura é o principal atributo do solo que apresenta alterações, quando ocorre algum tipo de degradação (SILVA e CASTRO, 2014).

Avaliações quantitativas da estrutura do solo podem ser feitas por determinações indiretas, por meio da quantidade de agregados estáveis em água ou a seco ou pela resistência dos agregados ao impacto das gotas de chuva simulada, ou diretas, pela densidade do solo, da porosidade, dos índices de floculação e pela infiltração de água no solo (MENDES et al., 2006). A degradação da estrutura do solo afeta diretamente a qualidade física do solo, gerando alterações em propriedades como: estabilidade de agregados, retenção e infiltração de água, densidade e resistência do solo à penetração 
(HORN et al., 1995). Segundo Betioli Júnior et al. (2012), uma das formas de se incrementar a qualidade estrutural do solo é por meio da conservação e adição de matéria orgânica no solo. A adição de compostos orgânicos em diferentes sistemas de manejo pode trazer não só benefícios químicos, mas também melhoria na qualidade física do solo.

Senna (2019) realizou trabalho na Fazenda Experimental Bananal do Norte (FEBN), pertencente ao Instituto Capixaba de Pesquisa, Assistência Técnica e Extensão Rural (INCAPER), no município de Cachoeiro de Itapemirim-ES. A unidade de observação de café conilon em Sistema Agroflorestal (SAF) possui relevo plano, com $6.120 \mathrm{~m}^{2}$, dividida em cinco parcelas de $1.224 \mathrm{~m}^{2}$, sendo um com cafeeiro conilon (Coffea canephora) solteiro e quatro consórcios com as seguintes plantas: ingá (Inga edulis); gliricídia (Gliricidia sepium); banana (Musa spp.) e; palmito pupunha (Bactris gasipaes) (Figura 1). Os resultados experimentais demonstraram que as áreas de cafeeiro conilon consorciadas possuem melhores condições físicas, índices de agregação do solo e maiores teores de carbono orgânico total (COT), comparativamente ao cafeeiro em monocultivo. A camada superficial do solo (0-0-10 m) apresentou melhores condições físicas e orgânicas em relação à camada de 0,10-0-20 m. O manejo das lavouras de café conilon consorciadas com pupunha e com gliricídia proporcionou melhorias na qualidade física do solo, com menor valor de densidade, maiores valores de porosidade, maior umidade, menor temperatura e maior estabilidade de agregados do solo. Estes consórcios também apresentaram maiores valores de COT nos agregados do solo, evidenciando o efeito positivo da matéria orgânica na melhoria da qualidade estrutural do solo. 


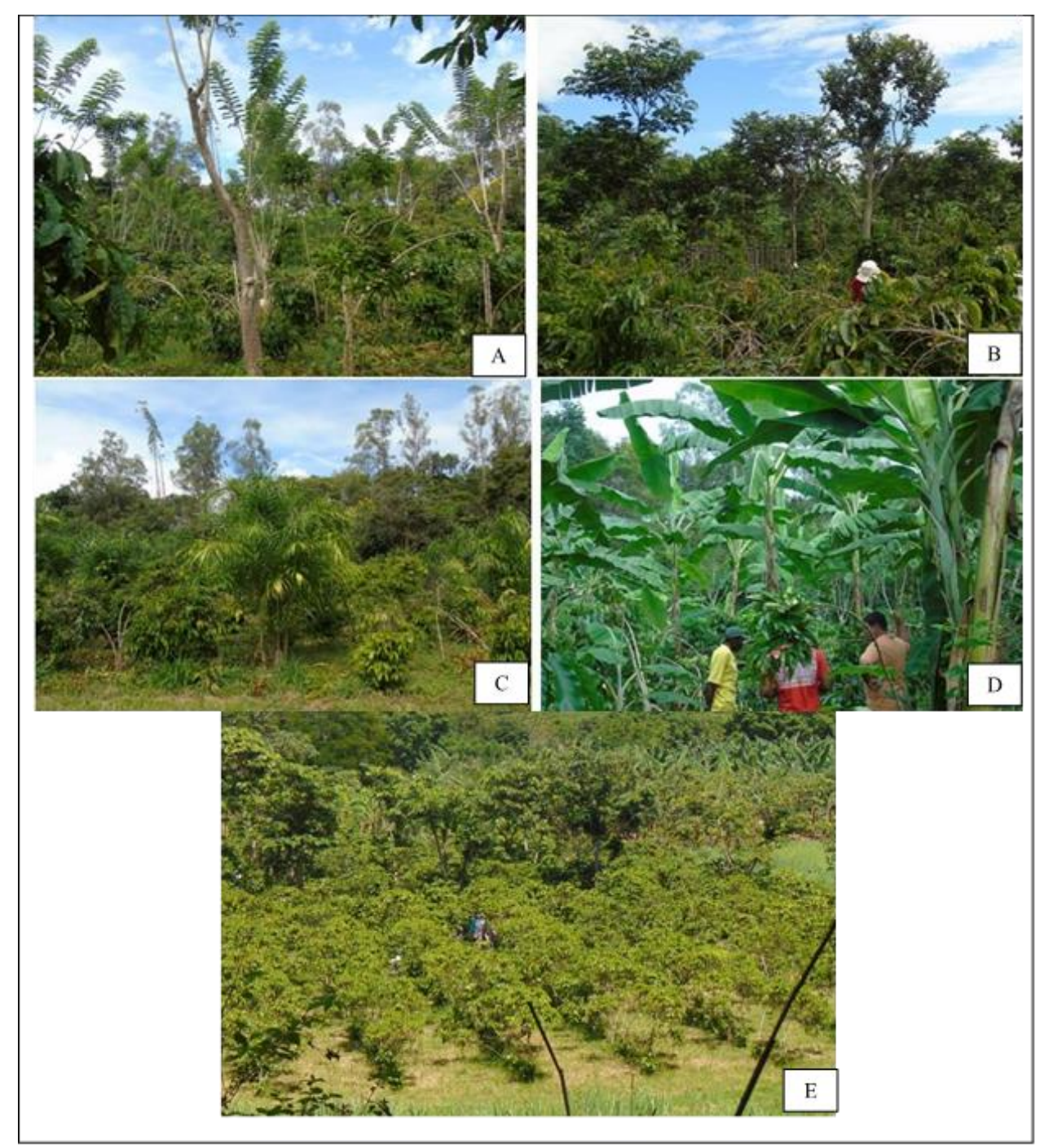

Figura 1. Fotografias da unidade de observação em café conilon em sistema agroflorestal. A) Café com gliricídia; B) Café com ingá; C) Café com Pupunha; D) Café com banana; E) Café solteiro

Fonte: Senna (2019).

\section{Considerações finais}

A matéria orgânica apresenta papel preponderante na agregação dos solos. Os solos sob lavouras de café conilon consorciadas (Sistemas Agroflorestais) possuem melhor qualidade física e orgânica do que lavouras em monocultivo (pleno sol). Práticas agroecológicas de conservação do solo, tais como: cultivos consorciados, eliminação da capina, adoção de roçada, adubação orgânica, adubação verde, cobertura do solo, podas e desbastes nas culturas consorciadas, contribuem para o acúmulo de resíduos orgânicos, favorecendo maiores teores de matéria orgânica sobretudo nas camadas mais superficiais do solo. As espécies utilizadas nos consórcios como cafeeiro conilon influenciam os atributos físicos do 
solo de forma distinta, sendo que sua escolha deve ser ajustada às características do local e aos objetivos do produtor.

\section{Agradecimentos}

Ao INCAPER, por ter possibilitado o desenvolvimento da pesquisa na unidade de observação de café conilon em Sistema Agroflorestal na Fazenda Experimental Bananal do Norte.

À Fundação de Amparo à Pesquisa e Inovação do Espírito Santo (FAPES), pela concessão da bolsa e auxílio financeiro para condução e realização do experimento.

\section{Referências}

AGUIAR, M. I. Qualidade física do solo em sistemas agroflorestais. Viçosa, 2008. Dissertação (Programa de Pós-Graduação e Solos e Nutrição de Plantas) - Universidade Federal de Viçosa, Viçosa, 2008.

ALMEIDA, B. G.; DE FREITAS, P. L.; TEIXEIRA, W. G.; VIANA, J. H. M.; DONAGEMMA, G. K. Manual de métodos de análise de solo / Paulo César Teixeira ... [et al.], editores técnicos. - 3. ed. rev. e ampl. - Brasília, DF: EMBRAPA, 2017.

ALTIERI, M. A. Agroecologia: a dinâmica produtiva da agricultura sustentável. Porto Alegre: Editora UFRGS, p. 1-110, 2004.

ALVES, D. I. Atributos físicos e químicos do solo em lavouras de café conilon consorciado. Alegre, 2017. 77 f. Dissertação de Mestrado (Programa de Pós-Graduação em Produção Vegetal) - Universidade Federal do Espírito Santo, Centro de Ciências Agrárias e Engenharias, Alegre, 2017.

ANGERS, D. A.; MEHUYS, G. R. Effects of cropping on carbohydrate content and water stable aggregation of a clay soil. Canadian Journal of Soil Science, v. 69, p. 373-380, 1989.

ARAÚJO, A. V.; PARTELLI, F. L.; OLIVEIRA, M. G.; PEZZOPANE, J. R. M.; FALQUETO, A. R.; CAVATTE, P. C. Microclima e crescimento vegetativo do café conilon consorciado com bananeiras. Coffee Science, v. 10, n. 2, p. 214-222, 2015.

ARCOVERDE, S. N. S.; SALVIANO, A. M.; OLSZEVSKI, N.; DE MELO, S. B.; CUNHA, T. J. F.; GIONGO, V.; e DE SOUZA PEREIRA, J. Qualidade física de solos em uso agrícola na região semiárida do estado da Bahia. Revista Brasileira de Ciência do Solo, v. 39, n. 5, p. 1473-1482, 2015.

ATLÂNTICA, SOS MATA. Fundação SOS Mata Atlântica e Instituto Nacional de Pesquisas Espaciais. Atlas dos remanescentes florestais da Mata Atlântica. Relatório Técnico, Período 2017-2018 São Paulo, 2019. 
BARBERA-CASTILLO, N. M. Diversidad de especies de hormigas en sistemas agroforestales contrastantes de café, em Turrialba, Costa Rica. Dissertação de Mestrado - Centro Agronômico Tropical de Investigación y Enseñanza, Turrialba, Costa Rica, 2001.

BAYER, C.; BERTOL, I. Características químicas de um Cambissolo húmico afetadas por sistemas de preparo, com ênfase à matéria orgânica. Revista Brasileira de Ciência do Solo, v.23, p.687-694, 1999.

BEER, J.; MUSCHLER, R.; KASS, D.; SOMARRIBA, E. Shade management in coffee and cacao plantations. Agroforestry Systems, v. 38, p. 139-164, 1998.

BELLAMY, P. H.; LOVELAND, P. J.; BRADLEY, R. I.; LARK, R. M.; KIRK, G. J. Carbon losses from all soils across England and Wales 1978-2003. Nature, v. 437, n. 7056, p. 245248, 2005.

BERTALOT, M. J. A.; GUERRINI, I. A.; MENDOZA, E.; DUBOC. E.; BARREIROS, R. M.; CORREA, F. M. Retorno de nutrientes ao solo via deposição de serapilheira de quatro espécies leguminosas arbóreas na região de Botucatu - São Paulo, Brasil. Scientia Forestalis, n. 65, p. 219-277, 2004.

BETIOLI JÚNIOR, E.; MOREIRA, W. H.; TORMENA, C. A.; FERREIRA, C. J. B.; SILVA, A. P.; GIAROLA, N. F. B. Intervalo hídrico ótimo e grau de compactação de um Latossolo vermelho após 30 anos sob plantio direto. Revista Brasileira de Ciência do Solo, v.36, p.971-982, 2012.

BLANCO-CANQUI, H.; LAL, R. Crop residue removal impacts on soil productivity and environmental quality. Critical Reviews in Plant Science, v.28, p.39-163, 2009.

BOULAY, M.; SOMARRIBA, E.; OLIVIER, A. Calidad de Coffea arabica bajo sombra de Erythrina poeppigiana a diferentes elevaciones en Costa Rica. Agroforestería em las Américas, v.7, p.40-42, 2000.

BRADY, N. C.; WEIL, R. R. Elementos da natureza e propriedades dos solos. 3.ed. Tradução técnica: Igo Fernando Lepsch. Porto Alegre: Bookman, 2012, 716p.

BRAIDA, J. A.; REICHERT, J. M.; REINERT, D. J.; VEIGA, M. Teor de carbono orgânico e a susceptibilidade à compactação de um Nitossolo e Argissolo. Revista Brasileira de Engenharia Agrícola e Ambiental, v.14, p.131-139, 2010.

CAPORAL, F. R.; RAMOS, L. F. Da extensão rural convencional à extensão rural para o desenvolvimento sustentável: enfrentar desafios para romper a inércia, Brasília, 2006.

CAPORAL, F.R. Lei de Ater: exclusão da Agroecologia e outras armadilhas. VII Congresso Brasileiro de Agroecologia, Fortaleza, 2011.

CARDOSO, I. M.; JUCKSCH, I.; MENDONÇA, E. S. Indicadores de sustentabilidade em sistemas de produção agrícola. Belo Horizonte: EPAMIG, p. 231-258, 2010.

CARIDE, C.; PIÑEIRO, G.; PARUELO, J. M. How does agricultural management modify ecosystem services in the argentine Pampas? The effects on soil $\mathrm{C}$ dynamics. Agriculture, Ecosystem and Environment, v. 154, p. 23-33, 2012. 
CARTER, M. R. Organic matter and sustainability. In: REES, R. M.; BALL, B. C.; CAMPBELL, C. D.; WATSON, C. A. Sustainable management of soil organic matter, New York: CABI Publishing, p. 9-22, 2001.

CARVALHO, M. P.; SORATO, R. P.; ONÃ, F. S. Variabilidade espacial de atributos físicos em um Latossolo vermelho distrófico sob preparo convencional em Selvíria, Estado de Mato Grosso do Sul. Acta Scientiarum Agronomy, v. 24, p. 1353-1361, 2002.

CHIODEROLI, C. A.; MELLO, L. M. M.; NORONHA, R. H. F.; PARIZ, C. M.; LIMA, R. C. Spatial and linear correlations between soil and corn. Revista Brasileira de Ciência do Solo, v. 36, n. 3, p. 765-774, 2012.

COSTA, F. S.; BAYER, C.; ZANATTA, J. A.; MIELNICZUK, J. Estoque de carbono orgânico no solo e emissões de dióxido de carbono influenciadas por sistemas de manejo no sul do Brasil. Revista Brasileira de Ciência do Solo, v. 32, p. 323-332, 2008.

COSTA, W. A. J. I. D.; SANGAKKARA, Y. O. U. R. Agronomic regeneration of soil fertility in tropical Asian small holderuplands for sustainable food production. Journal of Agricultural Science, v.144, N. 2, p. 111-133, 2006.

CUNHA, E. Q.; STONE, L. F.; MOREIRA, J. A. A.; FERREIRA, E. P. B.; DIDONET, A. D.; LEANDRO, W. M. Sistemas de preparo do solo e culturas de cobertura na produção orgânica de feijão e milho: atributos físicos do solo. Revista Brasileira de Ciência do Solo, v. 35, p. 589-602, 2011.

DEXTER, A. R. Advances in characterization of soil structure. Soil and Tillage Research, v. 11, p. 199-238, 1988.

DUXBURY, J. M.; SMITH, M. S.; DORAN, J. W. Soil organic matter as a source and a sink of plant nutrients. In: COLEMAN, S. C.; OADES, J. M.; UEHARA, G. (Eds.). Dynamics of soil organic matter in tropical ecosystems. Honolulu: Niftal Project, 1989. p. 33-67.

EMPRESA BRASILEIRA DE PESQUISA AGROPECUÁRIA - EMBRAPA. Diagnóstico rápido da estrutura do solo - DRES. Londrina, PR. 2017.

ORGANIZACION DE LAS NACIONES UNIDAS PARA LA AGRICULTURA Y LA ALIMENTACION - FAO. Consulta de espertos sobre la avance de la agrofloresteria em zonas áridas y semiáridas da américa latina ey caribe, Santiago, n. 1, p. 152, 1995.

FELLER, C.; BEARE, M. H. Physical control of soil organic matter dynamics in the tropics. Geoderma, v. 79, n. 1, p. 69-116, 1997.

FERNANDES, D. R. Manejo do cafezal, In: RENA, A. B.; MALAVOLTA, E.; ROCHA, M.; YAMADA, T. Cultura do café: fatores que afetam a produtividade. Piracicaba: Associação Brasileira para Pesquisa do Potássio e do Fosfato, p. 275-301,1986.

FERRÃO, R. G.; FONSECA, A. F. A.; FERRAO, M. A. G.; BRAGANÇA, S. M. Avaliação de clones de café conilon no Estado do Espírito Santo. In: Anais do Simpósio de Pesquisa dos Cafés do Brasil, Poços de Caldas, Embrapa Café, 2000.

FIGUEIREDO, C. C.; SANTOS, G. G.; PEREIRA, S.; NASCIMENTO, J. L.; ALVES JÚNIOR, J. Propriedades físico-hídricas em Latossolo do Cerrado sob diferentes sistemas de manejo. Revista Brasileira de Engenharia Agrícola e Ambiental, v. 13, n. 2, p. 146-151, 2009. 
FLORES, J. P. C.; ANGHINONI, I.; CASSOL, L. C.; CARVALHO, P. C. D. F.; LEITE, J. G. D. B.; FRAGA, T. I. Atributos físicos do solo e rendimento de soja em sistema plantio direto em integração lavoura pecuária com diferentes pressões de pastejo. Revista Brasileira de Ciência do Solo, v. 31, n. 4, p. 771-780, 2007.

FRANCO, F. S.; COUTO, L.; CARVALHO, A. F.; JUCKSCH, I.; FERNANDES FILHO, E. I.; SILVA, E.; NETO, J. A. A. M. Quantificação de erosão em sistemas agroflorestais e convencionais na Zona da Mata de Minas Gerais. Revista Árvore, v. 26, n. 6, p. 751-760, 2002.

GODINHO, T. D. O.; ROCHA, J.; FERRÃO, L.; SPERANDIO, F. D. M.; GALEANO, E.; CAETANO, L. Síntese da produção agropecuária do Espírito Santo 2016/2017, Vitória: INCAPER, p. 257, 2018.

GUEDES, F. B.; SEEHUSEN, S. E. Pagamento por serviços ecossistêmicos na Mata Atlântica: lições aprendidas e desafios. Brasília: MMA, 2011.

GUIMARÃES, G. P.; MENDONÇA, E. D. S.; PASSOS, R. R.; ANDRADE, F. V. Stocks and oxidizable fractions of soil organic matter under organic coffee agroforestry systems. Coffee Science, v. 9, n. 1, p. 132-141, 2014a.

GUIMARÃES, G. P.; MENDONÇA, E. D. S.; PASSOS, R. R.; ANDRADE, F. V. Soil aggregation and organic carbono of Oxisols under coffe in agroforestry systems. Revista Brasileira de Ciência do Solo, v. 38, n. 1, p. 278-287, 2014b.

HORN, R.; DOMIAL, H.; SLOWIHKA-JURKIEWICZ, A.; VAN OUWERKERK, C. Soil compaction processes and their effects on the structure of arable soils and the environment. Soil and Tillage Research, v. 35, n. 1, p. 23-36, 1995.

INSTITUTO BRASILEIRO DE GEOGRAFIA E ESTATÍSTICA - IBGE. Levantamento sistemático da produção agrícola. Pesquisa mensal de previsão e acompanhamento da safra agrícola do Espírito Santo, 2017.

JENKINSON, D.S. Determination of microbial biomass carbon and nitrogen in soil. In: WILSON, J.R. (Ed.), Advances in nitrogen cycling in agricultural ecossystems. Wallingford: C.A.B., 1988. p.368-386.

LIMA, S. S. D.; LEITE, L. F. C.; AQUINO, A. M. D.; OLIVEIRA, F. D. C.; CASTRO, A. A. J. F. Serapilheira e teores de nutrientes em Argissolo sob diferentes manejos no norte do Piauí. Revista Árvore, v. 34, n. 1, p.75-84, 2010.

LOPES, P. R.; ARAÚJO, K. C. S.; LOPES, I. M.; RANGEL, R. P.; DE FREITAS SANTOS, N. F.; KAGEYAMA, P. Y. Uma análise das consequências da cafeicultura convencional e das opções de modelos sustentáveis de produção: agricultura orgânica e agroflorestal. Revista Espaço de Diálogo e Desconexão, v. 8, n. 2, p.1- 38, 2014.

LOSS, A.; PEREIRA, M. G.; FERREIRA, E. P.; DOS SANTOS, L. L.; BEUTLER, S. J.; JÚNIOR, A. S. D. L. F. A. Frações oxidáveis do carbono orgânico do solo em sistema de aléias sob Argissolo vermelho-amarelo. Revista Brasileira de Ciência do Solo, v. 33, n. 4, p. 867-874, 2009. 
LUCIANO, R. V.; ALBUQUERQUE, J. A.; DA COSTA, A.; BATISTELLA, B.; WARMLING, M. $T$. Atributos físicos relacionados à compactação de solos sob vegetação nativa em região de altitude no sul do Brasil. Revista Brasileira de Ciência do Solo, v. 36, n.6, p. 1733-1744, 2012.

MACEDO, R. L. G.; VENTURIN, N.; MORAIS, V. M.; OLIVEIRA, T. K.; SALGADO, B. G.; VALE, R. S. Estabelecimento de Tectona grandis (Teca) em sistemas agroflorestais com Coffea arabica, em Lavras-MG. Agrossilvicultura, v. 1, n. 1, p. 71-80, 2004.

MANTOVANI, E. C. Compactação do solo. Sete Lagoas: EMBRAPA Milho e Sorgo Artigo em periódico indexado (ALICE), 1987.

MARTIN, J. P.; MARTIN, W. P.; PAGE, J. B.; RANEY, W. A.; DE MENT, J. D. Soil aggregation. Advances in Agronomy, v. 7, p. 1-37, 1955.

MATTA, F. M.; RONCHI, C. P.; SALLES, E. F.; ARAÚJO, J. B. S.: O café conilon em sistemas agroflorestais. In: FERRÃO, R. G.; FONSECA, A. F. A.; BRAGANÇA, S. M.; FERRÃO, M. A. G.; DE MUNER, L. H. (Eds.). Café conilon. Vitória: INCAPER, p. 375-390. 2015.

MENDES, F. G.; MELLONI, E. G. P.; MELLONI, R. Aplicações de atributos físicos do solo no estudo da qualidade de áreas impactadas, em Itajubá/MG. Revista Cerne, v. 12, n. 3, p. 211-220, 2006.

MENDONÇA, E. S.; CARDOSO, I. M.; JUCKSCH, I.; FERNANDES, R. B. A.; GARCIA, R. V. Fatores edáficos de cafezais arborizados: processo de aprendizado continuo com agricultores familiares. In: ZAMBOLIM, L. CAIXETA, E. T.; ZAMBOLIM, E. M. Estratégias para produção de café com qualidade e sustentabilidade. Viçosa: UFV, p. 63-84, 2010.

MONTAGNINI, F. Sistemas Agroflorestales: principios y aplicaciones en los trópicos, Organizacion para EstudiosTropicales, 2.ed., Costa Rica, p.622, 1992.

MORAES, M. T.; SILVA, V. R.; ZWIRTES, A. L.; CARLESSO, R. Use of penetrometers in agriculture: a review. Engenharia Agrícola, v. 34, p. 179-193, 2014.

MOREIRA, C. F. Sustentabilidade de sistemas de produção de café sombreado orgânico e convencional. Piracicaba, 2009. 145 p. Tese de doutorado (Programa de PósGraduação em Ecologia Aplicada) - Universidade de São Paulo, Escola Superior de Agronomia Luiz de Queiroz, ESALQ-USP 2009.

MULVANEY, M.J.; WOOD, C.W.; BALKCOM, K.S.; SHANNON, D.A.; KEMBLE, J.M. Carbon and nitrogen mineralization and persistence of organic residues under conservation and conventional tillage. Agronomy Journal, v.102, p.1425-1433, 2010.

NAIR, P. K. R. An introduction to agroforestry. Flórida: Kluwer Academic Publishers, p. 505, 1993.

OADES, J. M. Soil organic matter and structural stability: mechanisms and implications for management, Plant Soil, v. 76, p. 319-337, 1984.

OLIVEIRA, J. B. Pedologia aplicada. Piracicaba, ESALQ, p. 574, 2005. 
PALM, C. A. Contribution of agroforestry trees to nutrient requirements of intercropped plants. Agroforestry Systems, v. 30, n. 1, p. 105-124, 1995.

PALMEIRA, P. R. T.; PAULETTO, E. A.; TEIXEIRA, C. F. A.; GOMES, A. S.; SILVA, J. B. Agregação de um Planossolo submetido a diferentes sistemas de cultivo. Revista Brasileira de Ciência do Solo, v. 23, p.189-195, 1999.

PANDOLFI, F.; MENDONÇA, G. P.; MARTINS, C. A. S.; OLIVEIRA, C. M. R.; PASSOS, R. R.; REIS, E. F.; GRIFFO, E. Alterações na porosidade total do solo de um Latossolo Vermelho-Amarelo sob diferentes coberturas vegetais. In: Anais... Encontro Latino Americano de Iniciação Científica. São José dos Campos, SP, v. 11, p. 3412-3415, 2007.

PERFECTO, I.; VANDERMEER, J. Biodiversity conservation in tropical agroecossystems: a new conservation paradigm. New York Academico Sciences, v. 1, n. 134, p. 173-200, 2008.

PERIN, A.; GUERRA, J. G. M.; TEIXEIRA, M. G.; PEREIRA, M. G.; FONTANA, A. Efeito da cobertura viva com leguminosas herbáceas perenes na agregação de um Argissolo. Revista Brasileira de Ciência do Solo, v. 26, p. 713-720, 2002.

PEZZOPANE, J. R. M.; MARSETTI, M. M. S.; FERRARI, W. R.; PEZZOPANE, J. E. M. Alterações microclimáticas em cultivo de café conilon arborizado com coqueiro anão-verde. Revista Ciência Agronômica, v. 42, n. 4, p. 865-871, 2011.

PEZZOPANE, J. R. M.; MARSETTI, M. M. S.; SOUZA, J. M.; PEZZOPANE, J. E. M. Condições microclimáticas em cultivo de café conilon a pleno sol e arborizado com nogueira macadâmia, Ciência Rural, v. 40, n. 6, p. 1257-1263, 2010.

PEZZOPANE, J. R. M.; PEDRO JÚNIOR, M. j.; GALLO, P. B. Radiação solar e saldo de radiação em cultivo de café a pleno sol e consorciado com banana 'Prata Anã. Bragantia, v. 64, n. 3, p. 487- 499, 2005.

PREVEDELLO, C, L, Física do solo com problemas resolvidos. Curitiba: Sociedade Autônoma de Estudos Avançados em Física do Solo, p. 446, 1996.

REICHERT, J. M.; REINERT, D. J.; BRAIDA, J. A. Qualidade dos solos e sustentabilidade de sistemas agrícolas. Ciência Ambiental, v. 27, p. 29-48, 2003.

REINERT, D. J.; REICHERT, J. M. Propriedades físicas do solo. Santa Maria: UFSM, 2006.

REZENDE, B. L. A.; CECÍliO FILHO, A. B.; FELTRIM, A. L.; COSTA, C. C.; BARBOSA, J. C. Viabilidade da consorciação de pimentão com repolho, rúcula, alface e rabanete. Horticultura Brasileira, v. 24, n. 1, p. 36-41, 2006.

RIBEIRO, K. D.; MENEZES, S. M.; MESQUITA, M. D. G. B. D.; SAMPAIO, F. D. M. T. Propriedades físicas do solo, influenciadas pela distribuição de poros, de seis classes de solos da região de Lavras-MG. Ciência e Agrotecnologia, v. 31, n. 4, p. 1167-1175, 2007.

RICCI, M. S. F.; COSTA, J. R.; OLIVEIRA, N. G. Utilização de componentes principais para analisar o comportamento do cafeeiro a pleno sol e sombreado. Coffee Science, v. 6, n. 1, p. 44-54, 2011. 
ROCHA, S. P.; PREVEDELLO, J.; REINERT, D. J.; FLEIG, F. D.; VOGELMANN, E. S.; SOARES, J. C. W.; HEINZ, B. B. Propriedades físicas do solo e crescimento de eucalipto implantado em diferentes métodos de preparo do solo. Scientia Forestalis, v. 43, n. 108, p. 965-977, 2015.

RODRIGUES, V. G. S. Avaliação do desenvolvimento vegetativo de cafeeiros arborizados e a pleno sol, Embrapa Rondônia, p. 4, 2009 (Circular Técnica, 112).

ROSCOE, R.; MACHADO, P. L. O, A. Fracionamento físico do solo em estudos da matéria orgânica. Rio de Janeiro: Embrapa Solos, p.86, 2002.

SALES, E. F.; MÉNDEZ, V. E.; CAPORAL, F. R.; FARIA, J. C. Agroecological transition of conilon coffee (Coffea canephora) agroforestry systems in the State of Espirito Santo, Brazil. Agroecology and Sustainable Food, v. 37, n. 4, p. 405-429, 2013.

SALGADO, B. G.; MACEDO, R. L. G.; VENTURIN, N.; CARVALHO, V. L. Produtividade de cafeeiros arborizados com ingazeiros e com grevílea em Lavras, MG. Agrossilvicultura, v. 1, n. 2, p. 155-162, 2005.

SANTOS, E. O. J. S.; PINTO, F. B.; BARBOSA, M. A.; GONTIJO, I. Delineamento de zonas de manejo para macronutrientes em lavoura de café conilon consorciada com seringueira. Coffee Science, v. 10, n. 3, p. 309-319, 2015.

SENNA, D. S. Cafeeiro conilon em sistema agroflorestal: qualidade física do solo e carbono orgânico. Alegre, 2019. 90 p. Dissertação de Mestrado (Programa de PósGraduação em Agroecologia) - Instituto Federal do Espírito Santo. Alegre, 2019.

SEOANE, C. E. S.; DIAZ, V. S.; SANTOS, T. L.; FROUFE, L. C. M.; Corredores ecológicos como ferramenta para a desfragmentação de florestas tropicais. Pesquisa Florestal Brasileira, v. 30, n. 63, p. 207-206, 2010.

SEVERIANO, E. C. Alterações estruturais de Latossolos representativos da região do cerrado e potencial de uso de solos cultivados com cana-de-açúcar. Tese de Doutorado, Universidade Federal de Lavras, p. 148, 2010.

SISTEMA DE INFORMAÇÕES AGROMETEOROLÓGICAS - SIAG. Dados médios da série histórica da estação meteorológica localizada no município de Linhares-ES. Disponível em: <http://www.incaper.es.gov.br/clima/linhares_sh.htm>. Acesso em: 24 abr. 2006.

SILVA, A. A.; CASTRO, S. S. Indicadores macro e micromorfológicos da qualidade física de um Latossolo vermelho textura média cultivado com cana de açúcar na microrregião de Quirinópolis, Goiás. Boletim Goiano de Geografia, v. 34, n. 2, p. 233-251, 2014.

SILVA, A.J.N.; CABEDA, M.S.V.; LIMA, F.W.F. Efeito de sistemas de uso e manejo nas propriedades físico-hídricas de um Argissolo amarelo de tabuleiro costeiro. Revista Brasileira de Ciência do Solo, v.29, p.833-842, 2005.

SILVA, D. C.; SILVA, M. L. N.; CURI, N.; OLIVEIRA, A. H.; SOUZA, F. S.; MARTINS, S. G.; MACEDO, R. L. G. Atributos do solo em sistemas agroflorestais, cultivo convencional e floresta nativa. Revista de Estudos Ambientais, v. 13, p. 77-86, 2011. 
SILVA, I.F.; MIELNICZUK, J. Ação do sistema radicular de plantas na formação e estabilização de agregados do solo. Revista Brasileira de Ciência do Solo, v. 20, p,113117, 1997.

SILVA, I. R.; MENDONÇA, E. S. Matéria orgânica do solo. In: NOVAIS, R. F.; ALVAREZ V. V. H.; BARROS, N. F.; FONTES, R. L. F.; CANTARUTTI, R. B.; NEVES, J. C. L (Eds.). Fertilidade do solo. Viçosa: Sociedade Brasileira de Ciência do Solo, p. 1017, 2007.

SILVA, M. L. N.; CURI, N.; BLANCANEAUX, P. Sistemas de manejo e qualidade estrutural de Latossolo Roxo. Pesquisa Agropecuária Brasileira, v. 35, p. 2485- 2492, 2000.

THENG, B. K. G.; TATE, K. R.; SOLLINS, P. Constituents of organic matter in temperate and tropical soils, In: COLEMAN, D. C.; OADES, J. M.; UEHARA, G. (Eds.). Dynamics of soil organic matter in tropical ecosystems. University of Hawaii Press, Honolulu, HI. p. 5-32, 1989.

THOMAZINI, A.; AZEVEDO, H. C. A.; MENDONÇA, E. S. Perdas de solo, água e nutrientes em sistemas conservacionistas e convencionais de café no sul do estado do Espírito Santo. Revista Brasileira de Agroecologia, v. 7, n. 2, p. 150-159, 2012.

THOMAZINI, A.; AZEVEDO, H. C. A.; PINHEIRO, P. L.; MENDONÇA, E. S. Atributos físicos do solo em diferentes sistemas de manejo de café, na região sul do Espírito Santo. Coffee Science, v. 8, n. 4, p. 450-459, 2013.

TISDALL, J. M.; OADES, J. M. Organic matter and water stable aggregates in soils. Journal of Soil Science, v. 33, n. 2, p. 141-163, 1982.

UNGERA, P.W.; STEWARTA, B.A.; PARRB, J.F.; SINGHC, R.P. Crop residue management and tillage methods for conserving soil and water in semi-arid regions. Soil \& Tillage Research, v.20, p.219-240, 1991.

VANDERMEER, J.; PERFECTO, I. The agricultural matrix and a future paradigm for conservation. Conservation Biology 2007.

WEZEL, A.; BELLON, S.; DORÉ, T.; FRANCIS, C.; VALLOD, D.; DAVID, C. Agroecology as a science a movement and a practice: a review. Agronomy for Sustainable Development, v. 29, n. 4, p. 503-515, 2009. 


\title{
Capítulo 19
}

\section{Dinâmica do fósforo em solos tropicais e manejo da adubação organomineral fosfatada}

\author{
Ronaldo Willian da Silva ${ }^{1}$, Renato Ribeiro Passos ${ }^{2}$, Otacílio José Passos Rangel ${ }^{3}$, Felipe \\ Vaz Andrade ${ }^{2}$, Amanda Faé Sartori ${ }^{4}$
}

\section{Introdução}

A maioria dos solos sob cultivos agrícolas no Brasil são bastante intemperizados, ricos em oxidróxidos de ferro ( $\mathrm{Fe}$ ) e alumínio ( $\mathrm{Al}$ ) e pobres em nutrientes devido ao intenso processo de intemperismo (LOPES et al., 2012). Nessas condições, o fósforo (P) é um dos nutrientes mais limitantes à produção vegetal, dada a baixa disponibilidade de seus compostos e à sua forte interação com oxidróxidos de Fe e Al (NOVAIS et al., 2007). Assim, a eficiência de adubações fosfatadas é muito baixa (ASSUNÇÃO et al., 2016).

O processo de adsorção de $\mathrm{P}$ pelos oxidróxidos de ferro e alumínio é um dos principais fatores envolvidos na insolubilização desse nutriente, transformando o $P$ lábil em não lábil nos solos tropicais (NOVAIS et al., 2007; RAIJ, 2011). Nestas condições, o solo atua como dreno e não como fonte de P para as plantas (NOVAIS et al., 2007), sendo necessária a aplicação de quantidades de fertilizantes fosfatados acima da exigência das culturas (MENEZES-BLACKBURN et al., 2016).

Tendo em vista o requerimento de grandes quantidades de fosfatos na correção da fertilidade desses solos e a ausência de reservas abundantes de rochas fosfatadas de boa qualidade no país, associados ao elevado custo dos fertilizantes, torna-se essencial a busca por alternativas visando a otimização do uso das fontes de $\mathrm{P}$ (fontes não renováveis), seja reduzindo as perdas de $\mathrm{P}$ em sistemas agrícolas (SIMPSON et al., 2011), pelo desenvolvimento de fertilizantes fosfatados mais eficientes, uso complementar de fontes alternativas como os resíduos orgânicos (BRAOS et al., 2015), ou ainda, pela associação de

${ }^{1}$ Me. e Doutorando pelo Programa de Pós-Graduação em Produção Vegetal da Universidade Federal do Espírito Santo, Caixa Postal 16, CEP: 29500-000, Alegre-ES. E-mail: ronaldo_willian1@hotmail.com

${ }^{2}$ Drs. Professores da Universidade Federal do Espírito Santo, Caixa Postal 16, CEP: 29500-000, Alegre-ES. E-mail: renatoribeiropassos@hotmail.com, felipevazandrade@gmail.com

${ }^{3}$ Dr. Professor do Instituto Federal do Espírito Santo - Campus de Alegre, Caixa Postal 47, CEP: 29500-000, Alegre-ES. E-mail: otaciliorangel@gmail.com

${ }^{4}$ Mestranda pelo Programa de Pós-Graduação em Produção Vegetal da Universidade Federal do Espírito Santo, Caixa Postal 16, CEP: 29500-000, Alegre-ES. E-mail: amandafs@hotmail.com 
fertilizantes químicos e orgânicos formando fertilizantes organominerais (SÁ et al., 2017; FRAZÃO et al., 2019).

A associação de fontes minerais de $P$ com materiais orgânicos no fertilizante organomineral fosfatado reduz a adsorção de $\mathrm{P}$ pelos minerais do solo, uma vez que os compostos orgânicos interagem positivamente com P (SÁ et al., 2017; FRAZÃO et al., 2019), melhorando consequentemente a eficiência dos fertilizantes inorgânicos (FRAZÃO et al., 2019), o que pode ocasionar redução das doses de $P$ aplicadas e maior economia na agricultura (TEIXEIRA et al., 2014).

Dentre os efeitos positivos do uso de fertilizantes organominerais na redução da adsorção de $\mathrm{P}$, destaca-se o bloqueio de sítios de adsorção promovido por grupos funcionais carboxílicos e fenólicos de ácidos orgânicos liberados na mineralização da matéria orgânica (NOVAIS et al., 2007; SÁ et al., 2017). Há, também, geração de cargas negativas pela desprotonação de hidroxilas expostas nas argilas e matéria orgânica, ocorrendo repulsão entre o fosfato e a superfície adsorvente (NOVAIS et al., 2007; FRAZÃO et al., 2019), disponibilizando o $\mathrm{P}$ por mais tempo de forma lábil para as plantas.

Tendo em vista a melhoria do entendimento sobre a dinâmica do $P$ no solo e o aumento de eficiência da adubação fosfatada, esta revisão apresenta uma discussão sobre a influência da adubação organomineral fosfatada nos processos de transformação do $P$ lábil para não lábil, a eficiência de fertilizantes organominerais e seu manejo em solos tropicais.

\section{Fósforo em solos tropicais}

O fósforo $(\mathrm{P})$ é um elemento essencial para o crescimento das plantas, e sua deficiência em solos tropicais altamente intemperizados é frequentemente relatada reduzindo 0 rendimento das culturas (SANTOS et al., 2008; RODRIGUES et al., 2016). Os solos de regiões tropicais geralmente apresentam baixa fertilidade natural e baixo $\mathrm{pH}$. Além da baixa disponibilidade de $P$, a deficiência deste nutriente nestes solos também está associada à alta capacidade de fixação de fosfato (adsorção e precipitação) (ZHANG et al., 2016; FRAZÃO et al., 2019). Nesses solos altamente intemperizados predominam os minerais de argila 1:1, como a caulinita, e os óxidos de Fe (hematita e goethita) e Al (gibbsita) com alta capacidade de adsorção de P (SOUZA et al., 2006).

Para entender a sua dinâmica, o fósforo do solo é dividido em dois grandes grupos, fósforo inorgânico $(\mathrm{Pi})$ e fósforo orgânico $(\mathrm{Po})$, dependendo da natureza do composto a que está ligado. Este elemento pode variar de formas iônicas em solução a compostos altamente estáveis com a matéria orgânica do solo (MOS) e frações minerais (NOVAIS et al., 2007; SHEN et al., 2011). 
O fósforo inorgânico pode ser dividido em $\mathrm{P}$ ligado ao mineral primário (por exemplo, apatita), precipitados secundários de $\mathrm{Fe}, \mathrm{Al}$ e $\mathrm{Ca}$ amorfos e cristalinos (precipitação) e $\mathrm{P}$ adsorvido, predominantemente, a silicatos de argila 1:1 e oxi-hidróxidos de $\mathrm{Fe}$ e $\mathrm{Al}$ (adsorção) (NOVAIS et al., 2007; SANTOS et al., 2008).

A adsorção do fosfato aos oxidróxidos de ferro e alumínio se dá por ligação predominantemente covalente, onde os grupos $\mathrm{OH}^{-}$e $\mathrm{OH}_{2}{ }^{+}$ligados mono e tri coordenadamente ao metal (Fe ou Al) são trocados pelo fosfato, caracterizando o fenômeno de troca de ligantes (NOVAIS et al., 2007). O fosfato pode ligar-se em formas monodentadas, em que um oxigênio do fosfato é ligado ao e; bidentadas, em que dois oxigênios são ligados ao metal. A energia de ligação é crescente para os compostos monodentados e bidentados e a possibilidade de dessorção do fosfato aumenta na ordem inversa (NOVAIS et al., 2007). Com o passar do tempo, pode ocorrer o "envelhecimento" do fósforo adsorvido, cujas ligações tendem à especificidade, formando compostos bidentados ou ainda a penetração do fosfato nas imperfeições do mineral cristalizado. Isso resulta em maior estabilidade e menor possibilidade de dessorção do fosfato (NOVAIS et al., 2007; SANTOS et al., 2008).

Nas reações de adsorção, podem-se distinguir duas fases: uma mais rápida nos sítios ativos de superfície via atração eletrostática, seguida de outra mais lenta, quando ocorre troca de ligantes dos grupamentos $\mathrm{OH}^{-}$e $\mathrm{OH}_{2}{ }^{+}$pelos íons ortofosfatos (NOVAIS et al., 2007). Ocorrem, também, reações de precipitação do $P$ com formas iônicas de Al e Fe em solos ácidos e Ca em meio básico, formando compostos de baixa solubilidade (NOVAIS e SMYTH, 1999).

O fósforo orgânico pode constituir de 5 a $80 \%$ do fósforo total do solo e, nos solos tropicais, é fonte de fósforo às plantas e deve ser levada em consideração em estudos envolvendo a sua dinâmica e a biodisponibilidade (NOVAIS et al., 2007; DAMON et al 2014). O fósforo orgânico é originário dos resíduos vegetais adicionados ao solo, do tecido microbiano e dos produtos de sua decomposição (DAMON et al., 2014). As principais formas já identificadas são os fosfatos de inositol, os fosfolipídios, ácidos nucléicos e outros ésteres fosfatos (DAMON et al., 2014; NASH et al., 2014). O P orgânico pode ser liberado através de processos de mineralização mediados por organismos do solo e raízes de plantas em associação com a secreção de fosfatases (SHEN et al., 2011).

O grau de labilidade do $\mathrm{P}$ em solos tropicais está diretamente ligado ao intemperismo sofrido, mineralogia, $\mathrm{pH}$, balanço de cargas, conteúdo de matéria orgânica e a atividade microbiana do solo (NOVAIS et al., 2007). A fração lábil é representada pelo conjunto de compostos fosfatados capazes de repor rapidamente a solução do solo, quando ele é absorvido por plantas ou por microrganismos (NOVAIS et al., 2007; SANTOS et al., 2008). 
Solos altamente intemperizados, predominam os minerais de argila 1:1 e os oxidróxidos de Fe e Al com alta capacidade de adsorção de P (SOUZA et al., 2006). O processo de adsorção pode acontecer preferencialmente, segundo a seguinte ordem crescente de predomínio: minerais de argilas 2:1, argilas 1:1 e óxidos de Fe e Al (NOVAIS et al., 2007).

$\mathrm{O} \mathrm{pH}$ de solos tropicais é geralmente ácido $(\mathrm{pH}<6)$. A elevação do $\mathrm{pH}$ destes solos de carga variável, aumentando a concentração e atividade dos íons $\mathrm{OH}^{-}$em solução, promove a precipitação de Fe e Al, reduzindo a precipitação de P-Fe e P-Al de baixa solubilidade; há, também, geração de cargas negativas pela desprotonação de hidroxilas expostas nas argilas e matéria orgânica, ocorrendo repulsão entre o fosfato e a superfície adsorvente, 0 que reduz a intensidade da adsorção de P (NOVAIS et al., 2007; SHEN et al., 2011).

Fatores intensidade (I), quantidade (Q) e capacidade (Q/I) de P nos solos tropicais

A avaliação do fósforo disponível visa à quantificação de formas capazes de repô-lo à solução do solo após absorção pelas plantas (SANTOS et al., 2008). Os modelos de disponibilização consideram dois compartimentos interligados: a solução do solo, que constitui o fator intensidade (I), e a fase sólida, que armazena os fosfatos que abastecem a solução, lábeis ou moderadamente lábeis, denominado fator quantidade $(Q)$. A cinética de como o primeiro compartimento é abastecido pelo segundo, chamado fator capacidade (C) ou capacidade tampão de $\mathrm{P}(\mathrm{Q} / \mathrm{I})$, representa o poder tampão, ou a taxa de recomposição do I pelo $Q$, a qual é controlada pela energia de ligação do nutriente em $Q$ e pela difusividade para I, ou pelo grau de labilidade. No caso do fosfato, quanto maior o valor de Q, menor a energia de ligação aos colóides, pois os sítios de maior avidez já estão saturados. Por isso, os métodos de avaliação da fertilidade do solo procuram estimar a porção de $Q$ passível de repor I, para predizer a necessidade de suplementação do nutriente (GATIBONI et al., 2002; SANTOS et al., 2008).

Em solos com maior adsorção de $\mathrm{P}$, como os mais argilosos e, de modo particular os mais intemperizados, a relação $Q / I$ será maior que em solos com menor adsorção (NOVAIS et al., 2007). Quando fertilizantes fosfatados solúveis são adicionados ao solo, esses se dissolvem, migram para a solução do solo (I), mas em decorrência da baixa solubilidade dos compostos formados e da forte tendência de adsorção, a maior parte do $\mathrm{P}$ fica retida na fase sólida como $P$ lábil $(Q)$, passando gradativamente a $P$ não lábil, o qual não mais será disponibilizado para a solução do solo (I) (RAIJ, 2011).

À medida que o $\mathrm{P}$ da solução do solo (I) é absorvido pelas plantas, o $\mathrm{P}$ de formas menos lábeis $(Q)$ vai sendo disponibilizado. No entanto, quanto maior a força de interação do $P$ com os coloides do solo, menor é a velocidade de reposição do fósforo na solução ( $Q / I)$, o que 
evidencia o fato de que o $P$ não lábil presente nos solos não é suficiente para suprir a necessidade deste nutriente para as culturas (GATIBONI et al., 2007).

\section{Adubação fosfatada em solos tropicais}

\section{Adubação mineral}

Nos sistemas agrícolas, as adições anuais de fertilizantes inorgânicos tornam-se a principal fonte de $\mathrm{P}$, aumentando o conteúdo total de P no solo (RODRIGUES et al., 2016). A fim de atender às demandas de $P$ da planta, aproximadamente 15 milhões de toneladas de fertilizantes fosfatados são aplicados globalmente em terras agrícolas a cada ano (WANG et al., 2012). No entanto, apenas 5 a 30\% do P aplicado é absorvido pela cultura no ano seguinte à aplicação (SATTARI et al., 2012).

A adubação fosfatada mineral tem como base duas principais fontes, que variam de acordo com sua solubilidade: fosfatos naturais reativos e fosfatos acidulados, estes últimos considerados totalmente solúveis. As fontes solúveis correspondem à maior parte do total de $\mathrm{P}$ utilizados na agricultura brasileira devido a sua elevada quantidade de $\mathrm{P}$ disponibilizada para as plantas em um curto espaço de tempo (LOPES, 2004; RESENDE et al., 2006). Os fosfatos naturais apresentam, normalmente, menor eficiência, em especial no ano da aplicação e nas culturas anuais, as quais apresentam alta demanda de $\mathrm{P}$ num curto espaço de tempo (RESENDE et al., 2006; NOVAIS et al., 2007).

Dentre os fosfatos solúveis, os que são mais comumente utilizados são o superfosfato simples (SSP), superfosfato triplo (TSP), fosfato monoamônio (MAP) e fosfato diamônio (DAP) (NOVAIS et al., 2007; CHIEN et al., 2011). Esses materiais, por terem solubilização e liberação consideradas rápidas, reduzem uma possível deficiência de $\mathrm{P}$ no solo. No entanto, a rápida liberação de $\mathrm{P}$, por meio desses fertilizantes, pode favorecer o processo de adsorção e precipitação no solo (NOVAIS et al., 2007), o que reduz a disponibilidade de P para as plantas, ao longo do tempo, além de apresentar custo elevado (CARMO et al., 2014).

O baixo aproveitamento de $P$ de fontes solúveis é decorrente da rápida adsorção do $P$ solubilizado, o qual fica retido na fase sólida como $P$ lábil, passando gradativamente a $P$ não lábil (NOVAIS et al., 2007; RAIJ, 2011). Em razão disso, há necessidade de aplicações frequentes de $\mathrm{P}$ para proporcionar e manter alta produtividade das culturas (TEIXEIRA et al., 2014).

A magnitude e a velocidade do processo de formação de $P$ não-lábil em solos com grande fator $\mathrm{Q} / \mathrm{I}$ indicam que fazer uma fosfatagem corretiva nessas condições é 
questionável. A solução, para solos com esse perfil dreno seria minimizar o contato da fonte de $\mathrm{P}$, particularmente a solúvel, com o solo, pela aplicação localizada de $\mathrm{P}$, pela granulação do fertilizante, pela diminuição do tempo de contato do fertilizante com o solo em relação à época de plantio, ou até mesmo, pelo parcelamento da aplicação de P (NOVAIS et al., 2007).

Avaliando o modo de aplicação de fontes solúveis de fosfato na cultura do milho, Resende et al. (2006) encontraram melhores respostas conforme a sequência dos modos de aplicação: a lanço em área total < localizada no sulco < parcelada no sulco.

\section{Adubação orgânica}

Em ecossistemas naturais ou agrícolas com solos pobres de $\mathrm{P}$, a mineralização de $\mathrm{P}$ orgânico é a principal fonte de suprimento de $\mathrm{P}$ para plantas, especialmente em solos tropicais altamente intemperizados (VINCENT et al., 2010).

A adubação orgânica afeta a disponibilidade de $P$ direta e indiretamente. Os efeitos diretos incluem: liberação de Pi pela mineralização do composto orgânico (DAMON et al., 2014) ou imobilização microbiana Pi do solo (DAMON et al., 2014; BRAOS et al., 2015), dependendo da relação C/P; competição entre ânions de ácidos orgânicos e ânions de fosfatos por sítios de adsorção (NOVAIS et al., 2007); dissolução do composto Pi por ácidos orgânicos e complexação de metais, particularmente de $\mathrm{Al}^{3+}$ e $\mathrm{Fe}^{2+}$, com menores reações de precipitação de ânion fosfato (NOVAIS et al., 2007). Os efeitos indiretos da adubação orgânica sobre a disponibilidade de $\mathrm{P}$ são melhorias nas propriedades físicas do solo, resultando em melhor desenvolvimento radicular, aumento do $\mathrm{pH}$ e CTC de solos ácidos (NOVAIS et al., 2007; SHEN et al., 2011). A elevação do pH do solo pela calagem, aumentando a concentração e atividade dos íons $\mathrm{OH}^{-}$em solução promove a precipitação de Fe e Al, reduzindo a precipitação de P-Fe e P-Al de baixa solubilidade; há, também, geração de cargas negativas pela desprotonação de hidroxilas expostas nas argilas e matéria orgânica, ocorrendo repulsão entre o fosfato e a superfície adsorvente (SHEN et al., 2011).

Os efeitos da matéria orgânica na liberação e disponibilidade de $P$ no solo são decorrentes dos processos de mineralização, entretanto para que seus benefícios sejam duradouros, a biomassa deve ser reposta no solo com frequência (SANTOS et al., 2008; DAMON et al., 2014).

Um produto mais estável no solo, decorrente da pirólise de resíduos orgânicos é o biocarvão, o qual também tem potencial para alterar a sorção de $\mathrm{P}$ e, consequentemente, a biodisponibilidade de $\mathrm{P}$ no solo por diversos mecanismos: i) os efeitos do biocarvão no pH 
do solo podem afetar a adsorção/dessorção de íons $P$ e a precipitação/dissolução de minerais $P$ (BORNA et al., 2018); ii) o $P$ pode ser sorvido em compostos de biocarvão formados durante a pirólise contendo elementos específicos como $\mathrm{Ca}, \mathrm{Mg}$, Fe ou Al (SHEN et al., 2011), o que pode diminuir a adsorção de $\mathrm{P}$ no solo; iii) uma quantidade variável de $\mathrm{P}$ pode ser adicionada ao solo a partir do biocarvão. Gul et al. (2015) revisaram que o teor de $P$ do biochar produzido em diferentes condições de matérias-primas e pirólise variou entre 0,13 e 42,79 $\mathrm{g} \mathrm{kg}^{-1}$ em 38 biocarvões diferentes; iv) biocarvão pode liberar compostos orgânicos, como ácidos húmicos e matéria orgânica dissolvida, que competem com íons $P$ para locais de troca no solo (SCHNEIDER e HADERLEIN, 2016) e; v) alterações mediadas por biocarvão no ambiente do solo podem alterar a estrutura da comunidade microbiana e, portanto, afetar os processos de solubilização e mineralização de P (DEB et al., 2016).

Resíduos provenientes da agricultura, silvicultura e produção animal são materiais importantes para a reposição de matéria orgânica no solo (DAMON et al 2014; BRAOS et al., 2015). Os estercos bovino, suíno e de aves são alguns dos fertilizantes orgânicos mais promissores para a aplicação no solo (BRAOS et al., 2015; SÁ et al., 2017). No entanto, em grandes áreas de cultivo demanda-se grande quantidade de biomassa e a adição de fontes externas torna-se inviável. Nestas circunstâncias, a adoção de sistemas de manejo do solo, visando ao aumento de matéria orgânica, ocorre principalmente pela deposição de restos de culturas e adoção do sistema plantio direto (SANTOS et al., 2008; DAMON et al 2014; RODRIGUES et al., 2016).

\section{Adubação organomineral}

O fertilizante organomineral é definido como: "produto resultante da mistura física ou combinação de fertilizantes minerais e orgânicos". Segundo a Instrução Normativa (IN) № 25, de 23 de julho de 2009, os fertilizantes organominerais sólidos devem apresentar, no mínimo: 8\% de carbono orgânico; macronutrientes primários isolados $(N, P, K)$ ou em misturas (NP, NK, PK ou NPK) em 10\% e 30\% de umidade máxima. Estes fertilizantes têm como objetivo aumentar o teor de nutrientes dos materiais orgânicos e a eficiência dos fertilizantes minerais (NOVAIS et al., 2007).

No Brasil, a fabricação de fertilizantes organominerais iniciou-se após sua incorporação na legislação brasileira em 1982. A cada ano, o mercado de produção de fertilizantes organominerais cresce em torno de 16\% (POLIDORO et al., 2013) e cada vez mais esta categoria de fertilizante tem sido empregada na agricultura brasileira (FRAZÃO et al., 2019). A adição de fertilizantes minerais aos resíduos orgânicos reduz o impacto ambiental da 
atividade agropecuária, aumenta a fertilidade do solo e ainda reduz o uso de fertilizantes químicos (TEIXEIRA et al., 2014; FRAZÃO et al., 2019).

$A$ associação de fontes minerais de $P$ com materiais orgânicos reduz a adsorção de $P$ pelos minerais do solo, uma vez que os compostos orgânicos interagem positivamente com $P$, melhorando consequentemente a eficiência dos fertilizantes inorgânicos (FRAZÃO et al., 2019). A aplicação de fertilizantes organominerais pode reduzir os altos custos com adubação e permite o suprimento simultâneo de nutrientes minerais e matéria orgânica. Avaliando a produção de cana-de-açúcar, Teixeira et al. (2014) concluíram que aplicação do fertilizante organomineral na dose de $130 \mathrm{~kg} \mathrm{ha}^{-1}$ de $\mathrm{P}_{2} \mathrm{O}_{5}$ pode substituir a adubação mineral fosfatada (160 kg ha ${ }^{-1} \mathrm{P}_{2} \mathrm{O}_{5}$ ) e proporcionar economia de $18,8 \%$ no uso de fertilizantes.

Muitos estudos demonstram incrementos na produção de culturas com a utilização de adubos organominerais (FRAZÃO, 2013; CARMO et al., 2014; TEIXEIRA et al., 2014; FRAZÃO et al., 2019). Porém, a proporção destes incrementos é variável e depende principalmente da constituição do fertilizante, do tipo de solo utilizado e da cultura avaliada. No entanto, a maioria dos autores atribuiu a maior eficiência agronômica dos fertilizantes organominerais ao efeito benéfico que a matéria orgânica exerce sobre a diminuição da capacidade máxima de fixação do fósforo ao solo, em função da competição pelos sítios de adsorção do P no solo; que por sua vez, aumenta a disponibilidade de fósforo no solo e, consequentemente, o aproveitamento pelas culturas.

\section{Efeitos da adubação organomineral nos fatores intensidade (I), quantidade (Q) e capacidade tampão (Q/I) de $P$ nos solos tropicais}

Solos tropicais altamente intemperizados, dado as suas características oxídicas, podem adsorver grandes quantidades de $\mathrm{P}$, nestas condições o solo passa de fonte para dreno de P impondo forte competição com a planta pelo nutriente (NOVAIS et al., 2007).

Nestes solos a relação Q/I será alta. Quando fertilizantes fosfatados solúveis são adicionados ao solo, esses se dissolvem e o P migra para a solução do solo aumentando o fator I, no entanto, estes ânions são rapidamente atraídos eletrostaticamente para os sítios ativos de superfície de adsorção (aumentando $Q$ ), ocorrendo troca de ligantes dos grupamentos $\mathrm{OH}^{-}$e $\mathrm{OH}_{2}{ }^{+}$pelos íons ortofosfatos (NOVAIS et al., 2007). A ligação pode apresentar menor energia, caracterizada pela formação de complexos monodentados, ou maior energia, caracterizada pelos complexos bidentados que resultam na formação de $P$ não-lábil (NOVAIS et al., 2007; RAIJ, 2011). Devido à forte energia envolvendo a adsorção, 
maior fator $Q / /$ não implica que o $P$ do compartimento $Q$ seja reposto facilmente para o compartimento I quando este é reduzido (NOVAIS et al., 2007).

A maior eficiência de adubos organominerais em disponibilizar $\mathrm{P}$ no solo para as culturas é atribuída à matéria orgânica associada (CARMO et al., 2014; Teixeira et al., 2014; Frazão et al., 2019), a qual confere uma série de atributos que reduz ou retarda os processos de adsorção e/ou precipitação de P no solo (NOVAIS et al., 2007).

A quantidade de matéria orgânica aportada ao solo decorrente da adubação organomineral é baixa comparada à adubação orgânica, no entanto, os efeitos da matéria orgânica acompanhante são potencializados na região circundante ao granulo do fertilizante no solo (CASTRO et al., 2015; FRAZÃO et al., 2019).

Em solos ácidos, a matéria orgânica presente no fertilizante pode elevar $\mathrm{opH}$ nas proximidades do granulo, reduzindo a precipitação de $\mathrm{P}$ com formas iônicas de $\mathrm{Fe}$ e Al (NOVAIS et al., 2007). Com o aumento do pH, a carga superficial de partículas do solo torna-se cada vez mais negativa, aumentando a repulsão entre fosfatos e superfície adsorvente, diminuindo assim o potencial eletrostático do plano de adsorção (NOVAIS et al., 2007). O aumento da CTC promovido pela matéria orgânica também pode acentuar estas forças de repulsão reduzindo a intensidade da adsorção de P (NOVAIS et al., 2007; SCHNEIDER e HADERLEIN, 2016).

A acidez do solo também afeta a carga superficial de grupos orgânicos, como os carboxílicos, encontrados em grânulos de fertilizantes organominerais (FRAZÃO et al., 2019). Em pH mais baixo, os grupos orgânicos são protonados, resultando em maior afinidade por $\mathrm{P}$ pela matéria orgânica dos grânulos, a qual adsorve $\mathrm{P}$ por via de pontes de cátions como Fe, Al e Ca (NOVAIS et al, 2007). No entanto, a energia de ligação é mais fraca em comparação com os complexos de superfície interna formados na superfície dos óxidos de $\mathrm{Fe}$ e $\mathrm{Al}$, e podem não afetar a absorção de $\mathrm{P}$ pela planta (NOVAIS et al, 2007; FRAZÃO et al., 2019).

Estudando fertilizantes organominerais fosfatados a base de cama de frango, Frazão et al. (2019) encontraram aumentos significativos da biomassa microbiana do solo. Esta elevação foi atribuída à entrada de $C$ através do fertilizante organomineral. Outros autores também observaram maior $\mathrm{C}$ microbiano em solo tratado com adubos orgânicos ( $\mathrm{CHU}$ et al., 2007; SINGH et al., 2015). Entre os nutrientes, o C é o mais limitante para o crescimento microbiano, seguido por N e P (TORTORA et al., 2016). Atrelado ao aumento microbiano, Frazão et al. (2019) constataram aumento da atividade de fosfatases ácidas e alcalinas, enzimas catalizadoras no processo de transformação de $\mathrm{P}$ orgânico à inorgânico (NOVAIS et al., 2007) o que correlacionou diretamente com o aumento da disponibilidade de $\mathrm{P}$ no solo (FRAZÃO et al., 2019). 
O processo de mineralização da matéria orgânica contida nos fertilizantes organominerais pela microbiota libera ácidos orgânicos, os quais competem com o fosfato pelos sítios de adsorção (NOVAIS et al., 2007; SCHNEIDER e HADERLEIN, 2016). Estes ácidos bloqueiam os sítios de adsorção e, ou, solubilizam esses oxidróxidos, reduzindo sua superfície de adsorção. Essa competição por sítios de adsorção pode promover a dessorção de parte do $\mathrm{P}$ adsorvido na fração mineral do solo por menor energia de ligação (NOVAIS et al., 2007). O efeito do P-organomineral sobre a biomassa microbiana mostra a importância da matéria orgânica associada à adubação fosfatada, já que é possível, com essas fontes, a ocupação pelos ligantes orgânicos de sítios de adsorção de $\mathrm{P}$ no solo, menor reação do Porganomineral com os minerais de argila e oxidróxidos, o que se traduz em aumento da disponibilidade de $\mathrm{P}$ para as plantas (FRAZÃO et al., 2019).

Devido aos processos de redução da precipitação e adsorção, maior quantidade de $P$ ligado à matéria orgânica em formas mais lábeis, quantidades significativamente maiores de $P$ prontamente disponível são obtidas com o uso de fertilizantes organominerais em relação a fontes solúveis (FRAZÃO et al., 2019). Nestas condições, o fósforo armazenado no solo com menor energia de ligação (maior fator $Q$ ) é suprido com maior facilidade (aumento do fator capacidade) para solução do solo (aumento do fator I).

A menor fixação do $\mathrm{P}$ no solo por adsorção e precipitação, além da competição de ácidos orgânicos por sítios de adsorção e repulsão de $\mathrm{P}$ pelo aumento de cargas negativas do solo, aumentam a concentração e o fluxo difusivo deste íon em solução (CASTRO et al., 2015, FRAZÃO et al., 2019). Estudando adubos organominerais fosfatados, Castro et al. (2015) e Piccoli (2017), encontraram maior migração de $P$ no solo em relação a fontes solúveis, o que pode melhorar a interceptação e absorção radicular de $\mathrm{P}$, proporcionando maior produtividade e eficiência do uso de $\mathrm{P}$ em solos altamente intemperizados (CASTRO et al., 2015; FRAZÃO et al., 2019).

\section{Redução nas doses de $\mathrm{P}_{2} \mathrm{O}_{5}$ utilizando adubos organominerais}

Estudos recentes demonstram incrementos na produção de culturas com a utilização de adubos organominerais fosfatados (FRAZÃO, 2013; CARMO et al., 2014; TEIXEIRA et al., 2014; FRAZÃO et al., 2019). Teixeira et al. (2014) verificaram que a aplicação do fertilizante organomineral na dose de $130 \mathrm{~kg} \mathrm{ha}^{-1}$ de $\mathrm{P}_{2} \mathrm{O}_{5}$ pode substituir a adubação mineral fosfatada (MAP) (160 kg ha ${ }^{-1} \mathrm{P}_{2} \mathrm{O}_{5}$ ) e proporcionar economia de $18,8 \%$ no uso de fertilizantes.

Com o intuito de verificar o aumento da eficiência do uso de $P$ na produção agrícola com o uso de fontes organominerais fosfatadas em regiões tropicais, realizou-se um 
levantamento bibliográfico de pesquisas realizadas nestas condições. Os resultados são apresentados na tabela 1 .

Tabela 1. Efeito da adubação organomineral fosfatada comparada a adubação mineral na produção de culturas em regiões tropicais.

\begin{tabular}{lccc}
\multicolumn{1}{c}{ Autor } & Cultura & Solo & $\begin{array}{c}\text { Ganho de } \\
\text { produção \% }\end{array}$ \\
\hline Carmo et al., 2014 & Café & Latossolo Vermelho & 13,6 e 27,3 \\
Frazão et al., 2019 & Milho & Latossolo Vermelho & 6,4 \\
Frazão et al., 2019 & Milho & Neossolo Quartzarênico & 1,8 \\
Frazão, 2013 & Milheto & Latossolo Vermelho & 49,0 \\
Garcia et al., 2018 & Cana-de-açúcar & - & 3,7 \\
Lana et al., 2014a & Milho & Latossolo Vermelho & $-2,0$ \\
Lana et al., 2014b & Milho & Argissolo Vermelho- & $-16,0$ \\
Lana et al., 2014b & Milho & Amarelo & 4,9 \\
Magalhães, et al., & Eucalipto & - & 13,0 \\
2017 & Feijão & Latossolo Vermelho & 21,1 \\
Martins et al., 2017 & Milho & Latossolo Vermelho & 10,8 \\
Picoli, 2017 & Tomate & Nitossolo & 42,8 \\
Rabelo, 2015 & Milho & Latossolos Vermelho- & 15,7 e 30,2 \\
Sá et al., 2017 & Milho & Aatossolo Vermelho & $-35,0$ e 0 \\
Sakurada et al., 2016 & Cana-de-açúcar & Latossolo Vermelho & 18,8 \\
Teixeira et al., 2014 & - & - & 11,5 \\
\hline Ganho médio & & - &
\end{tabular}

Fonte: Os Autores.

A partir da avaliação de 18 fertilizantes organominerais comparados a fontes minerais, verifica-se uma grande variação de resposta destes fertilizantes. Estes resultados apontam variações que vão desde redução de eficiência de 35\% (SAKURADA et al.,2016), até incrementos de produção de 49\% (FRAZÃO, 2013). Entretanto, a adubação fosfatada organomineral apresenta um ganho médio de eficiência de 11,5\%. Estes resultados indicam que a eficiência de material orgânico enriquecido com fontes minerais de $\mathrm{P}$ é dependente do material orgânico utilizado e dos processos de produção. Estes fertilizantes podem aumentar a eficiência do uso de $P$ na agricultura, reduzir a dependência de utilização de fontes não renováveis deste mineral, além de dar uma destinação correta a resíduos orgânicos. 
Redução nas doses de $\mathrm{P}_{2} \mathrm{O}_{5}$ adicionadas ao solo para a cultura do café

O aumento da eficiência do uso de $\mathrm{P}$ por meio da adição ao solo de fontes organominerais é bastante variável e depende principalmente da constituição do fertilizante, do tipo de solo utilizado e cultura avaliada. Portanto, a recomendação destes fertilizantes deve ser cuidadosamente estudada. Entretanto, uma vez confirmada sua eficiência, as doses de $\mathrm{P}_{2} \mathrm{O}_{5}$ recomendadas para uma determinada cultura, devem ser reajustadas de acordo com a eficiência da fonte organomineral em questão.

Neste sentido, considerando um aumento médio de $11,5 \%$ na eficiência de utilização de $\mathrm{P}$ no solo, por meio de fontes organominerais e a cultura do café arábica, segundo recomendações de Ribeiro et al. (1999), as recomendações de adubação fosfatada organomineral para plantio (Tabela 2) e produção (Tabela 3) são ajustadas a seguir.

Tabela 2. Classes de fertilidade do fósforo para implantação da lavoura de café em função do teor de argila ou do valor de fósforo remanescente (P-rem), dose de $\mathrm{P}_{2} \mathrm{O}_{5}$ a ser aplicada na cova de plantio via fertilizantes minerais e correção para fontes organominerais.

\begin{tabular}{|c|c|c|c|c|c|}
\hline \multirow{2}{*}{ Característica } & \multicolumn{5}{|c|}{ Classes de Fertilidade } \\
\hline & Muito baixo & Baixo & Médio & Bom & Muito bom \\
\hline Argila & \multicolumn{5}{|c|}{ Teor de $\mathrm{P}$ no solo } \\
\hline$\%$ & \multicolumn{5}{|c|}{ 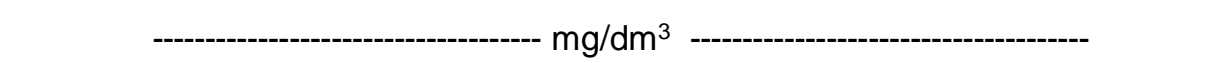 } \\
\hline $100-60$ & $<8,0$ & $8,1-16,0$ & $16,1-24,0$ & $24,1-36,0$ & $>36,0$ \\
\hline $60-35$ & $<12,0$ & $12,1-24,0$ & $24,1-36,0$ & $36,1-54,0$ & $>54,0$ \\
\hline $35-15$ & $<20,0$ & $20,1-36,0$ & $36,1-60,0$ & $60,1-90,0$ & $>90,0$ \\
\hline $15-0$ & $<30,0$ & $30,1-60,0$ & $60,1-90,0$ & $90,1-135,0$ & $>135,0$ \\
\hline \multicolumn{6}{|l|}{ P-rem (mg/L) } \\
\hline $0-4$ & $<9,0$ & $9,1-13,0$ & $13,1-18,0$ & $18,1-24,0$ & $>24,0$ \\
\hline $4-10$ & $<12,0$ & $12,1-18,0$ & $18,1-25,0$ & $25,1-37,5$ & $>37,5$ \\
\hline $10-19$ & $<18,0$ & $18,1-25,0$ & $25,1-34,2$ & $34,3-52,5$ & $>52,5$ \\
\hline $19-30$ & $<24,0$ & $24,1-34,2$ & $34,3-47,4$ & $47,5-72,0$ & $>72,0$ \\
\hline $30-44$ & $<33,0$ & $33,1-47,4$ & $47,5-65,4$ & $65,5-99,0$ & $>99,0$ \\
\hline $44-60$ & $<45,0$ & $45,1-65,4$ & $65,5-90,0$ & $90,1-135,0$ & $>135,0$ \\
\hline Dose plantio & \multicolumn{5}{|c|}{ Dose de $\mathrm{P}_{2} \mathrm{O}_{5}$} \\
\hline & \multirow{2}{*}{\multicolumn{5}{|c|}{ 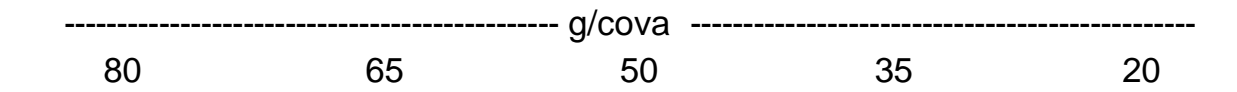 }} \\
\hline Mineral & & & & & \\
\hline Organomineral & 71 & 58 & 44 & 31 & 18 \\
\hline
\end{tabular}

Fonte: Os Autores, adaptado de Ribeiro et al. (1999).

Seguindo este ajuste, com redução de $11,5 \%$ nas doses de $\mathrm{P}_{2} \mathrm{O}_{5}$ via fertilizante organomineral utilizado nas covas de plantio para o café arábica. Considerando a área nacional plantada em 2018 de 252.786 ha (CONAB, 2018), a densidade tradicional de plantio de 2.500 covas/ha (RIBEIRO et al., 1999) e que a maioria dos solos tropicais tenham teor de $\mathrm{P}$ no solo baixo ou muito baixo (NOVAIS et al., 2007), e redução de $\mathrm{P}_{2} \mathrm{O}_{5}$ utilizado no 
plantio de café arábica em 2018 seria de 5.687,7 t e 4.423,8 t para as classes de fertilidade muito baixo e baixo, respectivamente.

Considerando 1.494.518,8 ha de área nacional em produção de café arábica em 2018, com uma produtividade média de $30,74 \mathrm{sc} \mathrm{ha}^{-1}$ (CONAB, 2018), e que a maioria dos solos tropicais tenham teor de P no solo baixo ou muito baixo (NOVAIS et al., 2007), a adubação fosfatada de produção do cafeeiro arábica, por meio de fontes organominerais traria uma redução de $8.467,1$ t e $7.472,6$ t de $\mathrm{P}_{2} \mathrm{O}_{5}$ para as classes de fertilidade muito baixo e baixo, respectivamente.

Tabela 3. Classes de fertilidade do fósforo para manutenção da lavoura de café em função do teor de argila ou do valor de fósforo remanescente (P-rem), doses de $\mathrm{P}_{2} \mathrm{O}_{5}$ via fertilizantes minerais a serem aplicadas de acordo com a produtividade e correção para fontes organominerais.

\begin{tabular}{|c|c|c|c|c|c|c|c|c|c|c|}
\hline \multirow{2}{*}{ Característica } & \multicolumn{10}{|c|}{ Classes de Fertilidade } \\
\hline & \multicolumn{2}{|c|}{ Muito baixo } & \multicolumn{2}{|c|}{ Baixo } & \multicolumn{2}{|c|}{ Médio } & \multicolumn{2}{|c|}{ Bom } & \multicolumn{2}{|c|}{ Muito bom } \\
\hline Argila & \multicolumn{10}{|c|}{ Teor de $\mathrm{P}$ no solo } \\
\hline$\%$ & \multicolumn{10}{|c|}{ - } \\
\hline $60-100$ & \multicolumn{2}{|c|}{$<1,9$} & \multicolumn{2}{|c|}{$2,0-4,0$} & \multicolumn{2}{|c|}{$4,1-6,0$} & \multicolumn{2}{|c|}{$6,1-9,0$} & \multicolumn{2}{|c|}{$>9,0$} \\
\hline $35-60$ & \multicolumn{2}{|c|}{$<3,0$} & \multicolumn{2}{|c|}{$3,1-6,0$} & \multicolumn{2}{|c|}{$6,1-9,0$} & \multicolumn{2}{|c|}{$9,1-13,5$} & \multicolumn{2}{|c|}{$>13,5$} \\
\hline $15-35$ & \multicolumn{2}{|c|}{$<5,0$} & \multicolumn{2}{|c|}{$5,1-9,0$} & \multicolumn{2}{|c|}{$9,1-15,0$} & \multicolumn{2}{|c|}{$15,1-22,5$} & \multicolumn{2}{|c|}{$>22,5$} \\
\hline $0-15$ & \multicolumn{2}{|c|}{$<7,5$} & \multicolumn{2}{|c|}{$7,5-15,0$} & \multicolumn{2}{|c|}{$15,1-22,5$} & \multicolumn{2}{|c|}{$22,6-33,8$} & \multicolumn{2}{|c|}{$>33,8$} \\
\hline \multicolumn{11}{|l|}{ P-rem (mg/L) } \\
\hline $0-4$ & \multicolumn{2}{|c|}{$<2,3$} & \multicolumn{2}{|c|}{$2,4-3,2$} & 3,3 & $-4,5$ & $4,6-$ & $-6,8$ & & 6,8 \\
\hline $4-10$ & & 3,0 & $3,1-$ & $-4,5$ & 4,6 & $-6,2$ & $6,3-$ & $-9,4$ & & 9,4 \\
\hline $10-19$ & & 4,5 & $4,6-$ & $-6,2$ & 6,3 & $-8,5$ & $8,6-$ & $-13,1$ & & 13,1 \\
\hline $19-30$ & & 6,0 & $6,1-$ & $-8,5$ & 8,6 & $-11,9$ & 12,0 & $-18,0$ & & 18,0 \\
\hline $30-44$ & & 8,3 & $8,4-$ & $-11,9$ & 12,0 & $-16,4$ & 16,5 & $-24,8$ & & 24,8 \\
\hline $44-60$ & $<1$ & 1,3 & $11,4-$ & $-16,4$ & 16,5 & $-22,5$ & $22,6-$ & $-33,8$ & & 33,8 \\
\hline Produtividade & & & & & ose de & $\mathrm{P}_{2} \mathrm{O}_{5}$ & & & & \\
\hline sc/ha & & & & 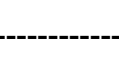 & $\mathrm{kg} / \mathrm{ha}$ & /ano ---- & --- & -------- & ---- & \\
\hline & Min & Org.M & Min & Org.M & Min & Org.M & Min & Org.M & Min & Org.M \\
\hline$<20$ & 30 & 27 & 20 & 18 & 10 & 9 & 0 & 0 & 0 & 0 \\
\hline $21-30$ & 40 & 35 & 30 & 27 & 20 & 18 & 0 & 0 & 0 & 0 \\
\hline $31-40$ & 50 & 44 & 40 & 35 & 25 & 22 & 0 & 0 & 0 & 0 \\
\hline $41-50$ & 60 & 53 & 50 & 44 & 30 & 27 & 15 & 13 & 0 & 0 \\
\hline $51-60$ & 70 & 62 & 55 & 49 & 35 & 31 & 18 & 16 & 0 & 0 \\
\hline$>60$ & 80 & 71 & 60 & 53 & 40 & 35 & 20 & 18 & 0 & 0 \\
\hline
\end{tabular}

Min = Mineral e Org. $M=$ Organomineral.

Fonte: Os Autores, adaptado de Ribeiro et al. (1999). 


\section{Manejo da adubação organomineral fosfatada em solos tropicais}

Solos tropicais altamente intemperizados, dado à suas características mineralógicas podem atuar como dreno forte de $\mathrm{P}$, chegando a fixar $9.200 \mathrm{~kg} \mathrm{ha}^{-1}$ de $\mathrm{P}_{2} \mathrm{O}_{5}$ (NOVAIS et al., 2007). Nestas condições, para o aumento da eficiência da adubação fosfatada, deve-se reduzir o tempo e a superfície de contato entre o fertilizante e o solo (RESENDE et al., 2006; NOVAIS et al., 2007), em culturas de ciclo mais longo, o parcelamento das doses de $\mathrm{P}$ pode ser uma opção para o melhor aproveitamento (NOVAIS et al., 2007).

Em culturas anuais o uso de fontes solúveis granuladas aplicadas em sulco na linha de plantio tem demonstrado os melhores resultados (RESENDE et al., 2006; SANTOS et al., 2008), no entanto o aproveitamento do fertilizante é baixo (5 a 30\%) (SATTARI et al., 2012). A maior parte do $\mathrm{P}$ aplicado visa saturar os sítios de adsorção do solo para que o restante chegue até a planta (NOVAIS et al., 2007).

A adição de fosfato na linha de plantio reduz a superfície de contato do fertilizante com o solo saturando mais facilmente os sítios de adsorção, o que disponibiliza maior quantidade de $P$ na linha aplicada (RESENDE et al., 2006). No entanto, a mobilidade do $P$ no solo, predominante por difusão, é baixa $(<1 \mathrm{~cm}$ ) (NOVAIS et al., 2007), o que limita a chegada do nutriente a uma maior área explorada pelo sistema radicular, dificultando a absorção deste pelas plantas (RESENDE et al., 2006).

São escassos os trabalhos abordando o manejo da adubação organomineral em solos tropicais. No entanto, os efeitos promovidos por estas fontes na redução dos processos de fixação de P no solo (CARMO et al., 2014; TEIXEIRA et al., 2014; FRAZÃO et al., 2019) aumentando seu fluxo difusivo (CASTRO et al., 2015; FRAZÃO et al., 2019), pode aumentar o acesso e disponibilidade de $\mathrm{P}$ ao sistema radicular com a aplicação localizada. A fixação reduzida de $P$ pode favorecer a aplicação de fontes organominerais em maiores áreas de exploração do sistema radicular, como em faixas ou a lanço em cobertura, promovendo mais opções para que o produtor possa escolher a mais viável ao seu sistema de produção.

Comparados aos fertilizantes minerais solúveis, os organominerais são menos solúveis no solo (aproximadamente $83 \%$ do $\mathrm{P}$ total no super triplo é solúvel em água, enquanto no organomineral é de apenas cerca de 50\%) (FRAZÃO et al., 2019). A liberação lenta de $P$ em solos com elevado poder tampão pode reduzir sua disponibilidade devido ao solo ser um dreno mais forte que a planta (NOVAIS et al., 2007). Porém, a solubilização gradual de fertilizantes organominerais associadas a suas características de menor fixação de $P$ confere uma propriedade lenta de liberação do P (SAKURADA et al., 2016), o que permite a 
aplicação do fertilizante na época do plantio e liberação de nutrientes mais uniforme durante o desenvolvimento de culturas anuais (FRAZÃO et al., 2019).

Em culturas perenes como o café, a adubação fosfatada de manutenção é indicada no inicio do período chuvoso coincidente com a época floração/granação (RIBEIRO et al., 1999; FERRÃO et al., 2017). A eficiência de absorção de $P$ pelo cafeeiro aumenta quando os adubos fosfatados são aplicados após a calagem, na forma granulada e de modo localizado, em filete, em volta da planta (FERRÃO et al., 2017). Segundo Ferrão et al. (2017), a maior parte do sistema radicular do cafeeiro encontra-se sob a copa. A utilização da adubação organomineral fosfatada nesta cultura, pode propiciar uma melhor distribuição do fertilizante sob a copa e em suas extremidades facilitando o aumento da absorção do nutriente e estimulando o crescimento radicular.

A solubilização gradual de fertilizantes organominerais permite sua aplicação no início do período chuvoso, propiciando uma liberação de nutrientes mais uniforme durante o desenvolvimento do cafeeiro, o que poderá melhorar a produtividade e a eficiência do uso de $\mathrm{P}$ em solos altamente intemperizados (FRAZÃO et al., 2019).

\section{Considerações finais}

A maioria dos solos encontrados em regiões tropicais são altamente intemperizados, com baixa concentração e/ou disponibilidade $\mathrm{P}$ e uma alta capacidade de adsorção deste nutriente. Nesse contexto, o desenvolvimento de novos fertilizantes, como os organominerais, com eficiência aumentada é importante para reduzir a dependência de recursos minerais fosfatados não renováveis, especialmente em países como o Brasil, onde a maioria dos fertilizantes fosfatados é importada. Assim, o uso de fertilizantes organominerais fosfatados nas culturas é uma estratégia importante para prolongar a vida útil das reservas minerais de $\mathrm{P}$, bem como para reduzir os problemas ambientais devido ao descarte inadequado de resíduos orgânicos no solo.

A maioria dos estudos avaliando os fertilizantes organominerais fosfatados foi realizada em condições de casa de vegetação. Considerando que fatores como manejo do solo, adubação e perdas de $P$ afetam a eficiência dos fertilizantes, estudos de campo, especialmente estudos de longo prazo para avaliar os efeitos residuais, são importantes para confirmar se estes fertilizantes possuem realmente maior eficiência agronômica que os fertilizantes minerais convencionais.

Embora a adsorção seja a principal forma de fixação de $\mathrm{P}$ em solos tropicais intemperizados, outras formas de perdas, como lixiviação e escoamento, também ocorrem, especialmente em solos arenosos. Como os fertilizantes organominerais possuem liberação 
lenta, seu uso poderia reduzir todas as formas de perda de $\mathrm{P}$ (adsorção, fixação, lixiviação e escoamento), atenuando sérios problemas ambientais, como a eutrofização dos corpos d’água. No entanto, essa hipótese ainda não foi investigada em condições tropicais.

São escassos os trabalhos investigando a forma de manejo da adubação organomineral fosfatada, assim como a avaliação de sua eficácia em relação a fontes convencionais. Portanto, uma linha de pesquisa está em aberto para investigar as formas, locais e épocas de aplicação em culturas anuais e perenes, bem como o efeito residual cumulativo durante vários anos de manejo, principalmente em condições de campo.

\section{Agradecimentos}

À Fundação de Amparo à Pesquisa e Inovação do Espírito Santo (FAPES), pelo financiamento do projeto de pesquisa (Processo $\left.\mathrm{N}^{\circ} 84336250\right)$ relacionado ao capítulo do livro.

\section{Referências}

ASSUNÇÃO, N. S.; CLEMENTE, J. M.; AQUINO, L. A.; DEZORDI, L. R.; SANTOS, L. P. D. Carrot yield and recovery efficiency of nitrogen, phosphorus and potassium. Revista Caatinga. v.29, p.859-865, 2016.

BORNA, M. L.; MÜLLER-STÖVERA, D. S.; LIU, F. Contrasting effects of biochar on phosphorus dynamics and bioavailability in different soil types. Science of The Total Environment. v.627, p.963-974, 2018.

BRAOS, L. B.; CRUZ, M. C. P.; FERREIRA, M. E.; KUHNEN, F. Organic phosphorus fractions in soil fertilized with cattle manure. Revista Brasileira de Ciência do Solo. v.39, p.140-150, 2015.

CARMO, D. L., TAKAHASHI, H. Y. U.; SILVA, C. A.; GUIMARÃES, P. T. G. Crescimento de mudas de cafeeiro recém-plantadas: efeito de fontes e doses de fósforo. Coffee Science. v.9, p.196-206, 2014.

CASTRO, R. C.; BENITES, V. M.; TEIXEIRA, P. C.; ANJOS, M. J.; OLIVEIRA, L.F. Phosphorus migration analysis using synchrotron radiation in soil treated with brazilian granular fertilizers. Applied Radiation and Isotopes, v.105, p.233-23, 2015.

CHIEN S. H.; PROCHNOW, L. I.; TU, S.; SNYDER, C. S. Agronomic and environmental aspects of phosphate fertilizers varying in source and solubility: an update review. Nutrient Cycling in Agroecosystems, v.89, p.229-255, 2011.

CHU, H.; LIN, X.; FUJII, T.; MORIMOTO, S.; YAGI, K.; HU, J.; ZHANG, J. Soil microbial biomass, dehydrogenase activity, bacterial community structure in response to long term fertilizer management. Soil Biology and Biochemistry. V.39, p.2971-2976, 2007. 
COMPANHIA NACIONAL DE ABASTECIMENTO - CONAB. Acompanhamento da safra brasileira: café. v.5 - Safra 2018 - N.3 - Terceiro levantamento, setembro 2018.

DAMON, P. M.; BOWDEN, B.; ROSE, T.; RENGEL, Z. Crop residue contributions to phosphorus pools in agricultural soils: a review. Soil Biology and Biochemistry. v.74, p.127-137, 2014.

DEB, D.; KLOFT, M.; LÄSSIG, J.; WALSH, S. Variable effects of biochar and P solubilizing microbes on crop productivity in different soil conditions. Agroecology and Sustainable Food Systems. v.40, p.145-168, 2016.

FERRÃO, R. G.; FONSECA, A. F. A.; FERRÃO, M. A. G.; MUNER, L. H (Eds.). Café conilon., 2. ed. atual. e ampl. $2^{a}$ reimpressão - Vitória: INCAPER, 784 p. 2017.

FRAZÃO, J. J. Eficiência agronômica de fertilizantes organominerais granulados à base de cama de frango e fontes de fósforo. Goiânia, 2013. 88f. Dissertação (Programa de Pós-Graduação em Agronomia) - Universidade Federal de Goiás, Goiânia, 2013.

FRAZÃO, J. J.; BENITESB, V. M.; RIBEIROC, J. V. S.; PIEROBONC, V. M.; LAVRESA, J. Agronomic effectiveness of a granular poultry litter-derived organomineral phosphate fertilizer in tropical soils: soil phosphorus fractionation and plant responses. Geoderma, v.337, p.582-593, 2019.

GARCIA, J. C.; MENDES, M. B.; BELUCI, L. R.; AZANIA, C. A. M.; SCARPARI, M. S. Fontes de fósforo mineral e organomineral no estado nutricional e no crescimento inicial da cana-de-açúcar. Nucleus. v.15, p.523-531, 2018.

GATIBONI, L. C.; KAMINSKI, J.; RHEINHEIMER, D. S.; FLORES, J. P. C. Biodisponibilidade de formas de fósforo acumuladas em solo sob sistema de plantio direto. Revista Brasileira de Ciência do Solo, v.31, p.691-699, 2007.

GATIBONI, L. C.; KAMINSKI, J.; RHEINHEIMER D. S.; SAGGIN A. Quantificação do fósforo disponível por extrações sucessivas com diferentes extratores em Latossolo vermelho distroférrico. Revista Brasileira de Ciência do Solo, v.26, p.1023-1029, 2002.

GUL, S.; WHALEN, J. K.; THOMAS, B. W.; SACHDEVA, V.; DENG, H. Physico-chemical properties and microbial responses in biochar-amended soils: mechanisms and future directions agriculture, Ecosystems \& Environment. v.206, p.46-59, 2015.

KOCH, M.; KRUSE, J.; EICHLER-LÖBERMANN, B.; ZIMMER, D.; WILLBOLD, S.; LEINWEBER, P.; SIEBERS, N. Phosphorus stocks and speciation in soil profiles of a longterm fertilizer experiment: evidence from sequential fractionation, $\mathrm{P}$ K-edge XANES, and ${ }^{31} \mathrm{P}$ NMR spectroscopy. Geoderma, v.316, p.115-126, 2018.

LANA, M. C.; RAMPIM, L.; VARGAS, G. Adubação fosfatada no milho com fertilizante organomineral em Latossolo Vermelho eutroférrico. Global Science and Technology. v.7, p.26-36, 2014a.

LANA, M. C.; RAMPIM, L.; SCHULZ, L. R.; KAEFER, J. E.; SCHMIDT, M. A. H.; RUPPENTHAL, V. Disponibilidade de fósforo para plantas de milho cultivadas com fertilizante organomineral e fosfato monoamônico. Scientia Agraria Paranaensis. v.13, p.198-209, 2014b. 
LOPES, A. S.; GUILERME, L. R. G.; RAMOS, S. J. The saga of the agricultural development of the brazilian cerrado. International Potash Institute, n. 32, 2012.

LOPES, A. S.; SILVA, C. A. P.; BASTOS, A. R. R. Reservas de fosfatos e produção de fertilizantes fosfatados no Brasil e no mundo. In: YAMADA, T.; ABDALLA, S. R. S. (Eds.). Fósforo na agricultura brasileira. Piracicaba: POTAFOS, p.13-34, 2004.

MAGALHÃES, C. A. S.; MORALES, M. M.; REZENDE, F. A.; LANGER, J. Eficiência de fertilizantes organominerais fosfatados em mudas de eucalipto. Revista Scientia Agraria. v.18, p.80-85, 2017.

MARTINS, D. C.; RESENDE, A. V.; GALVÃO, J. C. C.; SIMÃO, E. P.; FERREIRA, J. P. C.; ALMEIDA, G. O. Organomineral phosphorus fertilization in the production of corn, soybean and bean cultivated in succession. American Journal of Plant Sciences. v.8, p.2407-2421, 2017.

MENEZES-BLACKBURN, D.; GEORGE, T. S.; ZHANG, H.; STUTTER, M.; GILES, C.D.; DARCH, T.; COOPER, P.; WENDLER, R.; BROWN, L.; HAYGARTH, P. M. A Holistic approach to understanding the desorption of phosphorus in soils. Environmental Science \& Technology. v.50, p. 3371-3381, 2016.

NASH, D. M.; HAYGARTH, P. M.; TURNER, B. L.; CONDRON, L. M.; McDOWELL, R. W.; RICHARDSON, A. E.; WATKINS, M.; HEAVEN M. W. Using organic phosphorus to sustain pasture productivity: a perspective. Geoderma, v.221, p.11-19, 2014.

NOVAIS, R. F.; ALVAREZ, V. H.; BARROS, N. F.; FONTES, R. L. F.; CANTARUTTI, R. B.; NEVES, J. C (Eds.). Fertilidade do solo. Viçosa: SBCS, 2007. 1017p.

NOVAIS, R. F.; SMYTH, T. J. Fósforo em solo e planta em condições tropicais. Viçosa: UFV, 1999. 399 p.

PICCOLI, L. B. Disponibilidade de fósforo em função do revestimento do fertilizante por substâncias húmicas. Botucatu, 2017. 75p. Dissertação - Universidade Estadual Paulista "Júlio de Mesquita Filho. 2017.

POLIDORO, J. C. Fertilizantes organominerais: Aspectos tecnológicos, mercadológicos e legislação. In: Fórum Absolo. Ribeirão Preto-SP, 2013.

RABELO, K. C. C. Fertilizantes organomineral e mineral: aspectos fitotécnicos na cultura do tomate industrial. Goiânia, 2015. 69 f. Dissertação - Universidade Federal de Goiás, 2015.

RAIJ, B. V. Fertilidade do solo e manejo de nutrientes. Piracicaba: International Plant Nutrition Institute, 420p. 2011.

RESENDE, A. V.; FURTINI NETO, A. E.; AlVES, V. M. C.; MUNIZ, J. A.; CURI, N.; FAQUIN, V.; KIMPARA, D. I.; SANTOS, J. Z. L.; CARNEIRO, L. F. Fontes e modos de aplicação de fósforo para o milho em solo cultivado da região do cerrado. Revista Brasileira de Ciência do Solo. v.30, p.453-466, 2006.

RIBEIRO, A. C.; GUIMARÃES, P. T. G.; ALVAREZ, V. H. Recomendações para o uso de corretivos e fertilizantes em Minas Gerais - 5a Aproximação. Viçosa: Comissão de Fertilidade do Solo do Estado de Minas Gerais, 359p. 1999. 
RODRIGUES, M.; PAVINATO, P. S.; WITHERS, P. J. A.; TELES, A. P. B.; HERRERA, W. F. $B$. Legacy phosphorus and no tillage agriculture in tropical Oxisols of the brazilian savanna. Science Total Environment, v.542, p.1050-1061, 2016.

SÁ, J. M.; JANTALIA, C. P.; TEIXEIRA, P. C.; POLIDORO, J. C.; BENITES, V. M.; ARAÚJO, A. $P$. Agronomic and $P$ recovery efficiency of organomineral phosphate fertilizer from poultry litter in sandy and clayey soils. Pesquisa agropecuária Brasileira. v.52, p.786-793, 2017.

SAKURADA, R. L.; BATISTA, M. A.; INOUE, T. T.; MUNIZ, A. S.; PAGLIARI, P. H. Organomineral phosphate fertilizers: agronomic efficiency and residual effect on initial corn development. Agronomy Journal, v.108, p.2050-2059, 2016.

SANTOS, D. R.; GATIBONI, L. C.; KAMINSKII, J. Fatores que afetam a disponibilidade do fósforo e o manejo da adubação fosfatada em solos sob sistema plantio direto. Ciência Rural, v.38, p.576-586, 2008.

SATTARI, S. Z.; BOUWMAN, A. F.; GILLERA, K. E.; ITTERSUMA, M. K. V. Residual soil phosphorus as the missing piece in the global phosphorus crisis puzzle. PNAS. V.109, p.6348-6353, 2012.

SCHNEIDER, F.; HADERLEIN, S. B. Potential effects of biochar on the availability of phosphorus-mechanistic insights. Geoderma. v.277, p.83-90, 2016.

SHEN, J.; YUAN, L.; ZHANG, J.; LI, H.; BAI, Z.; CHEN, X.; ZHANG, W.; ZHANG, F. Phosphorus dynamics: from soil to plant. Plant Physiology, v.156, p.997-1005, 2011.

SIMPSON, R. J.; OBERSON, A.; CULVENOR, R. A.; RYAN, M. H.; VENEKLAAS, E. J.; LAMBERS, H.; LYNCH, J. P.; RYAN, P. R.; DELHAIZE, E.; SMITH, F. A.; SMITH, S. E.; HARVEY, P. R.; RICHARDSON, A. E. Strategies and agronomic interventions to improve the phosphorus-use efficiency of farming systems. Plant and Soil. v.349, p.89-120, 2011.

SINGH, G.; KUMAR, D.; SHARMA, P.; KRAKAUER, N. Effect of organics, biofertilizers and crop residue application on soil microbial activity in rice - wheat and rice-wheat mungbean cropping systems in the Indo-Gangetic plains. Cogent Geoscience. v.1 p.185-196, 2015.

SOUZA, R. F.; FAQUIM, V.; TORRES, P. R. F.; BALIZA, D. P. Calagem e adubação orgânica: influência na adsorção de fósforo em solos. Revista Brasileira de Ciência do Solo, v.30, p.975-983, 2006.

TEIXEIRA, W. G.; SOUSA, R. T. X.; KORNDORFER, G. H. Resposta da cana-de-açúcar a doses de fósforo fornecidas por fertilizante organomineral. Bioscience Journal. v.30, p.1729-1736, 2014.

TORTORA, G. J.; FUNKE, B. R.; CASE, C. L. Microbiology an introduction, 12. ed. Boston: Pearson, 2016.

VINCENT, A. G.; TURNER B. L.; TANNER E. V. J. Soil organic phosphorus dynamics following perturbation of litter cycling in a tropical moist forest. European Journal of Soil Science. v.61, p.48-57, 2010.

ZHANG, H.; CHEN, C.; GRAY, E. M.; BOYD, S. E.; YANG, H.; ZHANG, D. Roles of biochar in improving phosphorus availability in soils: a phosphate adsorbent and a source of available phosphorus. Geoderma, v.276, p.1-6, 2016. 


\title{
Capítulo 20
}

\section{Tratamento de água residuária da suinocultura em sistemas alagados construídos cultivados com capim Jiggs}

\author{
Paola Alfonsa Vieira Lo Monaco¹, Gustavo Haddad Souza Vieira', Ismail Ramalho \\ Haddade$^{1}$, Sávio da Silva Berilli², Ana Paula Cândido Berilli², Rodrigo Junior Nandorf ${ }^{3}$, Lillya \\ Mattedi $^{3}$, Thiago Lopes Rozado ${ }^{4}$, Alberto Chambela Netto ${ }^{1}$
}

\section{Introdução}

A suinocultura é uma atividade pecuária que se expandiu muito nas últimas décadas, devido ao aumento na demanda de carnes e de derivados de suíno, sendo uma atividade importante do ponto de vista social, econômico e, especialmente, de fixação do homem no campo (MATOS et al., 2009), uma vez que gera emprego e renda para os produtores, principalmente de pequenas propriedades rurais (LIMA et al., 2019).

O desenvolvimento da suinocultura tem como fator de maior preocupação a quantidade de dejetos produzidos, que apresentam alto poder poluente, especialmente quando lançados sem tratamento em corpos hídricos.

De acordo com Diesel et al., (2002), as águas residuárias da suinocultura (ARS) apresentam principalmente matéria orgânica, organismos patogênicos, sólidos e nutrientes diversos como, nitrogênio, fósforo, potássio, sódio, cálcio, magnésio, manganês, ferro, cobre, zinco e outros elementos incluídos na dieta desses animais.

Quando essas águas residuárias são lançadas sem qualquer tratamento em corpos hídricos causam diversos impactos ambientais, afetando a qualidade da água e causando impactos à fauna e à flora. De acordo com Eustáquio Júnior et al. (2014), águas residuárias ricas em matéria orgânica, tal como a ARC, quando lançadas em corpos hídricos receptores, podem formar zonas anóxicas/anaeróbias, como resultado de sua estabilização bioquímica, podendo gerar, como subprodutos da degradação do material orgânico, metano, fenóis e ácido sulfídrico. Além disso, o aumento na concentração de nutrientes pode promover a eutrofização dessas águas, prejudicando o ecossistema aquático. Dessa forma,

1Drs. Professores do Instituto Federal do Espírito Santo - Campus Santa Teresa, Rod ES 080, km 93, São João de Petrópolis, CEP: 29650-000, Santa Teresa-ES. E-mail: paolalm@ifes.edu.br, ghsv@ifes.edu.br, ihaddade@ifes.edu.br; chambela@ifes.edu.br

2Drs. Professores do Instituto Federal do Espírito Santo - Campus de Alegre, Caixa Postal 47, CEP: 29500-000, Alegre-ES. E-mail: savio.berilli@ifes.edu.br; ana.berilli@ifes.edu.br

${ }^{3}$ Graduandos em Agronomia pelo Instituto Federal do Espírito Santo - Campus Santa Teresa, Rod ES 080, km 93, São João de Petrópolis, CEP: 29650-000, Santa Teresa-ES. E-mail: rodrigojrnandorf@gmail.com; lillyamattedi2013@gmail.com

${ }^{4}$ Me. Engenheiro Agrônomo do Instituto Federal do Espírito Santo - Campus Santa Teresa, Rod ES 080, km 93, São João de Petrópolis, CEP: 29650-000, Santa Teresa-ES. E-mail: thiagolr@ifes.edu.br 
torna-se fundamental o tratamento dessas águas antes de serem lançadas em corpos hídricos.

Existem diversos processos para o tratamento e/ou aproveitamento de efluentes, que em sua maioria apresentam elevadas eficiências, no entanto, necessitam de grandes investimentos. Por outro lado, pequenos agricultores familiares, principalmente aqueles que trabalham com sistemas agroecológicos de produção, muitas vezes carecem de recursos para empregarem métodos sofisticados no tratamento dos dejetos gerados em suas propriedades.

Dentre as diversas soluções propostas para o tratamento de águas residuárias em sistemas agroecológicos de produção, distingue-se a sua disposição em sistemas alagados construídos (SACs). De acordo com Matos et al. (2013), nestes sistemas, utiliza-se o meio suporte-planta-microrganismos para a depuração dos resíduos, sendo caracterizados por serem robustos, de baixo custo e de simples operação e manutenção. Tais aspectos os tornam ideais para aplicação em regiões carentes de saneamento básico, adequando-se perfeitamente às propriedades agrícolas do Espírito Santo, consideradas, em sua maior parte, como agricultura familiar.

Os SACs (Figura 1) são reservatórios preenchidos com materiais porosos, de alta condutividade hidráulica, geralmente constituídos por brita, que servem de suporte para o cultivo de macrófitas. No meio suporte, desenvolve-se um biofilme entremeado pelas raízes das plantas que proporciona a degradação de parte da matéria orgânica em solução, além da remoção, por meio de processos físicos, de sólidos sedimentáveis e sólidos suspensos. Assim, no sistema meio poroso-planta-microrganismos, ocorre a depuração dos resíduos (CHAGAS et al., 2012). A escolha da espécie vegetal é, juntamente com outras variáveis de dimensionamento, de fundamental importância para o sucesso do tratamento de águas residuárias em SACs (MATOS et al., 2009).

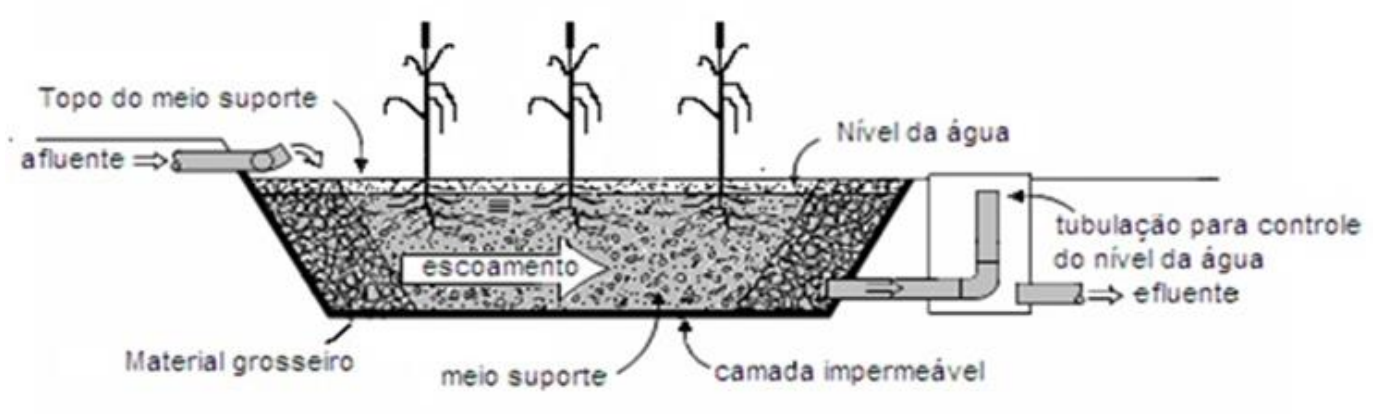

Figura 1. Sistema alagado construído de fluxo sub-superficial. Fonte: Kadlec e Walace (2009). 
As espécies vegetais a serem selecionadas para cultivos em SACs devem ser perenes, ter alta tolerância ao excesso de água e a ambientes eutrofizados, ser de fácil propagação e crescimento rápido, ser de fácil colheita e manejo e possuir alta capacidade de remoção de nutrientes e poluentes (MATOS et al., 2008). Além da alta produtividade de sua biomassa, elas favorecem processos microbiológicos e bioquímicos para a decomposição da matéria orgânica, mineralização de nutrientes e remoção de patógenos, bem como funcionam como intermediárias em processos físicos e químicos como filtração, adsorção, precipitação e sedimentação (SHELEF et al., 2013; FIA et al., 2017).

$\mathrm{Na}$ busca dos melhores desempenhos dos SACs para o tratamento de águas residuárias, pesquisadores têm estudado diferentes tipos de culturas nos SACs, principalmente gramíneas, em razão da alta produtividade e grande capacidade de remover nutrientes ( $N, P$ e K) e sódio da água residuária. Diversos trabalhos utilizando gramíneas forrageiras tropicais, como os capins tifton 85 (MATOS et al., 2010a e 2010 b; FIA et al., 2011; FIA et al., 2017; FIA, et al., 2020; MIRANDA et al., 2019; 2020) e elefante (MATOS, et al. 2008 e 2010a, MIRANDA et al., 2019; 2020), têm demonstrado elevada eficiência como extratores de nutrientes e poluentes de águas residuárias de suinocultura tratadas em SACs.

Dentre as gramíneas estudadas quem têm apresentando ótimos resultados em SACs, destaca-se o capim tifton-85, do gênero Cynodon. Na busca de outras forrageiras que também possam apresentar elevada eficiência de remoção de sólidos e nutrientes das águas residuárias de suinocultura em SACs, vislumbra-se a utilização do capim Jiggs, tendo por hipótese ser uma gramínea de elevada eficiência, por pertencer ao mesmo gênero do capim Tifton-85.

Guimarães (2012), ao avaliar e caracterizar a produtividade dos capins Tifton-85 e Jiggs, sob duas estratégias de manejo do pastejo, verificou que o capim Jiggs é igualmente produtivo ao capim Tifton-85 e pode apresentar algumas vantagens, por produzir maior proporção de material verde com mesma proporção de folhas.

Poczineket al. (2016), ao avaliarem a produtividade e as características bromatológicas dos estratos superior e inferior de gramíneas perenes em sistema contínuo de cortes, As cv. Jiggs e Tifton 68 apresentaram a maior produção de fitomassa acumulada. Já a cv. Tifton 85 foi responsável pelos maiores níveis de proteína bruta $(\mathrm{PB})$, enquanto os teores de carboidratos estruturais mantiveram padrão constante, tanto no estrato superior quanto no inferior, em sistema de quatro cortes sucessivos.

Carvalho (2011), ao avaliar as características estruturais e produção de pastagem dos capins Tifton-85 e Jiggs submetidos a três frequências de colheita, verificaram que os dois cultivares apresentaram os maiores acúmulos de forragem total nasfrequências de 28 e 42 
dias de rebrotação, tendo o capim Jiggs alcançado maior acúmulo (22,6 Mg MS ha-1) comparado com o capim Tifton-85 (21,8 Mg MS ha-1).

Em razão de ser do mesmo gênero do capim Tifton, o qual tem apresentado ótimos resultados na eficiência de remoção de poluentes em SACs, acredita-se que o capim Jiggs seja, por hipótese, tão eficiente quanto o capim Tifton-85.

Em razão da escassez de dados a respeito dessa gramínea em SACs, objetivou-se, com a realização deste trabalho, avaliar a eficiência de sistemas alagados construídos, cultivados com capim Jiggs (Cynodondactylon (L.) Pers. Cvjiggs), operados com diferentes taxas de carregamento orgânico, no tratamento de água residuária de suinocultura.

\section{Metodologia}

O experimento foi implantado e conduzido na suinocultura do Instituto Federal do Espírito Santo - Campus Santa Teresa.

Inicialmente, a água residuária da suinocultura era proveniente de baias do setor de gestação e maternidade da suinocultura. Posteriormente, optou-se por utilizar a água residuária das baias do setor de terminação, por ser uma água com carga orgânica maior. Em ambos os casos, a água residuária era coletada por meio de um maconel e transferida para um reservatório de polietileno, com capacidade de 2000 litros, onde era armazenada.

$\mathrm{Na}$ tabela 1 apresentam-se as concentrações médias dos diversos atributos da água residuária de suinocultura, utilizada durante o período experimental.

Tabela 1. Concentrações médias dos atributos da água residuária da suinocultura utilizada durante o período experimental.

\begin{tabular}{|c|c|c|c|c|c|c|}
\hline $\mathrm{pH}$ & Turbidez & DBO & $\begin{array}{c}\text { Sólidos } \\
\text { Totais }\end{array}$ & Sólidos Fixos & Sólidos Voláteis & $\begin{array}{c}\text { Sólidos } \\
\text { Suspensos }\end{array}$ \\
\hline & UNT & & $\ldots \ldots \ldots \ldots \ldots$ & ...............mg L- & …................... & $\ldots \ldots \ldots$ \\
\hline 7,86 & 566,0 & 360 & $3.367,2$ & $2.110,66$ & $1.175,3$ & 450,0 \\
\hline
\end{tabular}

Fonte: Os Autores.

Do reservatório de 2000 litros, a água residuária era conduzida, por gravidade, para quatro reservatórios de 100 litros que abasteciam os SACs.

Para a montagem dos SACs, foram utilizados recipientes do tipo "coxo", confeccionados em polietileno de alta densidade (PEAD), com dimensões 23 de altura, $38,7 \mathrm{~cm}$ de largura e $180 \mathrm{~cm}$ de comprimento. Foram colocados drenos de saída com flange e tubo de PVC de 32 $\mathrm{mm}$, contendo uma mangueira de $32 \mathrm{~mm}$ de diâmetro, por onde era descarregado o efluente. 
Como meio suporte, foi utilizada a brita \# 0 (diâmetro - D60 =7,0 mm, Coeficiente de Uniformidade $\mathrm{D} 60 / \mathrm{D} 10$ = 1,6 e volume de vazios de 45\%), até a altura de $21 \mathrm{~cm}$, passando cada coxo a ter um volume útil de $0,14 \mathrm{~m}^{3}$.

As mudas de capim Jiggs ((Cynodondactylon (L.) Pers. Cvjiggs) foram plantadas no SAC obedecendo uma densidade de 4 propágulos por cova, sendo utilizadas 15 covas por SAC.

Na figura 2 está apresentada a bancada experimental, contendo o reservatório de 2000 litros, os 4 reservatórios de $100 \mathrm{~L}$ e os 4 coxos com brita e capim plantado, utilizados como sistema alagados construído.

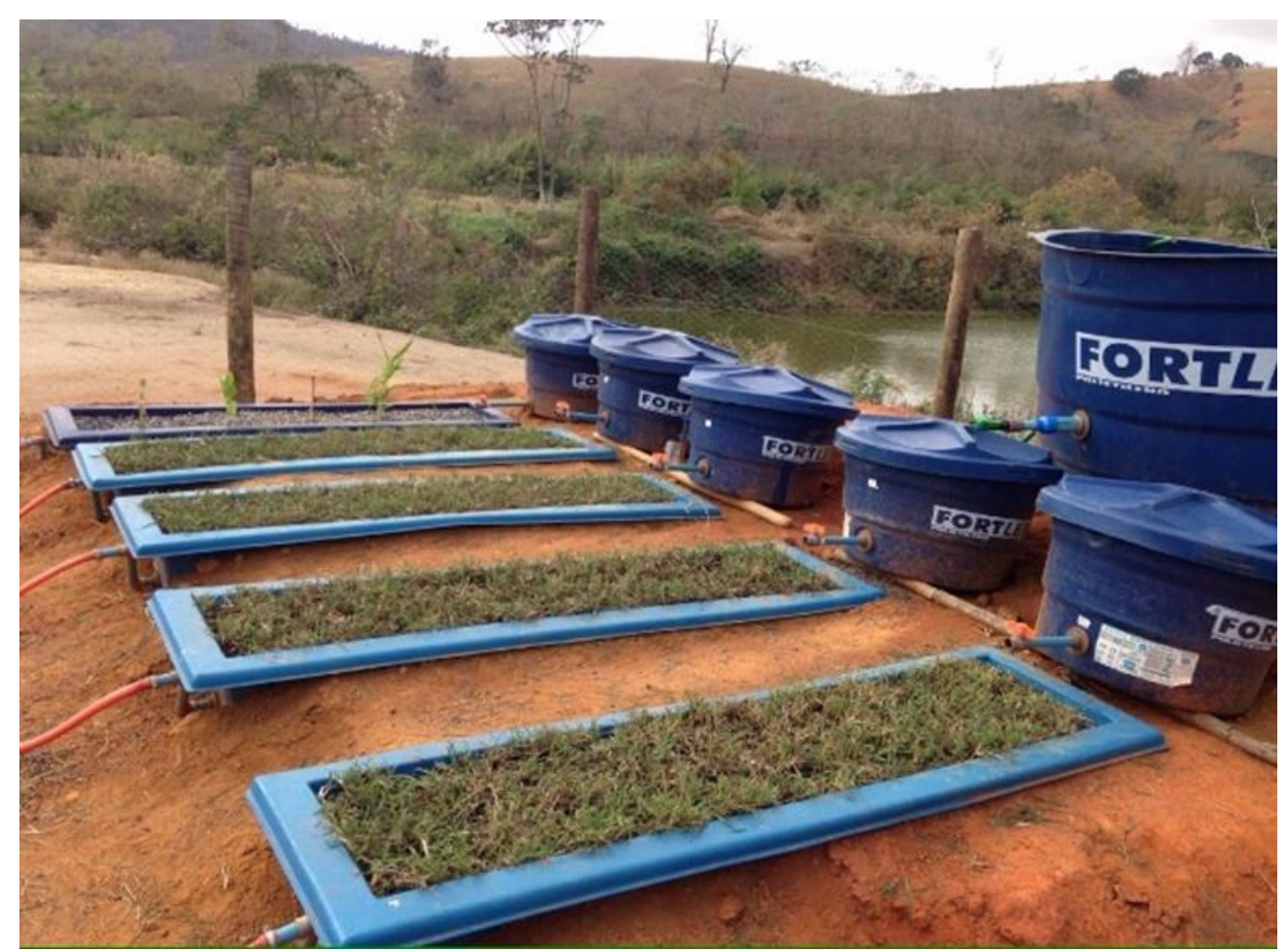

Figura 2. Bancada experimental do tratamento da água residuária de suinocultura. Fonte: Os Autores.

Após o plantio das mudas, os leitos dos SACs foram preenchidos até a altura de $25 \mathrm{~cm}$ com água residuária de suinocultura, para iniciar a adaptação das plantas ao meio suporte, assim permanecendo por 60 dias, com a finalidade de adaptação das plantas ao novo meio suporte e ocorrer a formação do biofilme. Após esse período de adaptação do sistema, realizou-se um corte do capim para dar início à fase experimental de monitoramento, aplicando-se os tratamentos. A fase experimental teve duração de 3 meses de monitoramento, além do período de adaptação.

O experimento foi realizado no Delineamento Inteiramente Casualizado (DIC), com 4 tratamentos (4 taxas de carregamento orgânico), uma espécie vegetal (capim Jiggs) e 5 repetições. Os quatro SACs foram submetidos a4 (quatro) taxas de carregamento orgânico 
(TCO) de água residuária de suinocultura: 100; 200; 300 e $400 \mathrm{Kg} \mathrm{ha}^{-1} \mathrm{~d}^{-1}$ de DBO, baseando-se no valor médio da Demanda Bioquímica de Oxigênio (DBO) da água residuária.

Na tabela 2 apresenta-se a média das vazões, taxas de carregamento orgânico e tempos de detenção hidráulica durante o período de aplicação da água residuária aos SACs.

Tabela 2. Média das vazões $(Q)$, taxas de carregamento orgânico (TCO) e tempos de detenção hidráulico $(\mathrm{Td})$ durante o período de aplicação da água residuária aos SACs.

\begin{tabular}{lrcc}
\hline SACs & $\mathrm{Q}\left(\mathrm{m}^{3} \mathrm{~d}^{-1}\right)$ & $\mathrm{TCO}\left(\mathrm{kg} \mathrm{de} \mathrm{DBO} \mathrm{ha}^{-1} \mathrm{~d}^{-1}\right)$ & $\mathrm{Td}(\mathrm{dias})$ \\
\hline SAC 1 & 0,032 & 109,2 & 1,8 \\
SAC 2 & 0,065 & 218,4 & 0,9 \\
SAC 3 & 0,097 & 327,6 & 0,6 \\
SAC 4 & 0,129 & 436,8 & 0,45 \\
\hline
\end{tabular}

Fonte: Os Autores.

A taxa de aplicação da água residuária foi controlada, diariamente, por meio de uma válvula instalada na caixa de $100 \mathrm{~L}$ posicionada à montante dos SACs, sendo as medições, para ajuste das vazões, efetuadas pelo método direto, utilizando-se uma proveta, duas vezes ao dia.

Para avaliar a eficiência dos sistemas, determinou-se o $\mathrm{pH}$ e a turbidez e analisou-se as concentrações de sólidos totais e sólidos em suspensão no afluente e no efluente aos SACs, a cada 15 dias, durante o funcionamento do sistema, perfazendo um total de cinco amostras analisadas. $\mathrm{O}$ pH e a turbidez foram determinados por meio de um peagâmetro e um turbidímetro de bancada, respectivamente e os sólidos totais e os sólidos em suspensão foram determinados pelo método gravimétrico. Todas as análises foram feitas no Laboratório de Qualidade de Água do Ifes - Campus Santa Teresa, em conformidade com a metodologia adotada por Matos (2015).

A eficiência remoção de poluentes foi calculada a partir das concentrações e vazões afluente e efluente, obtidas nas diversas ocasiões em que foram coletadas as amostras, utilizando, para isso, a Equação 1.

Eficiência de remoção $(\%)=\left[\frac{\left(C_{A} \times Q_{A}\right)-\left(C_{E} \times Q_{E}\right)}{\left(C_{A} \times Q_{A}\right)}\right] \times 100$

Em que:

$\mathrm{C}_{\mathrm{A}}$ : concentração afluente aos SACs;

$Q_{A}$ : vazão afluente aos SACs;

$C_{B}$ : concentração efluente aos SACs;

$Q_{B}$ : vazão efluente aos SACs. 
Realizou-se o ajuste de equações matemáticas relacionando-se as médias das eficiências de remoção das variáveis analisadas em função das taxas de carregamento orgânicas aplicadas, tendo-se considerado satisfatório o ajuste que proporcionasse comportamento biológico explicável, apresentasse um coeficiente de determinação maior que $70 \%$ e apresentasse significância mínima de $10 \%$ de probabilidade nos coeficientes.

As análises estatísticas foram realizadas por meio do programa SAS 9.0 (2011).

\section{Resultados e discussão}

Nas figuras 3, 4 e 5 apresentam-se as eficiências de remoção da turbidez, sólidos suspensos e sólidos totais, respectivamente, em função das diferentes taxas de carregamento orgânico aplicadas aos SACs.

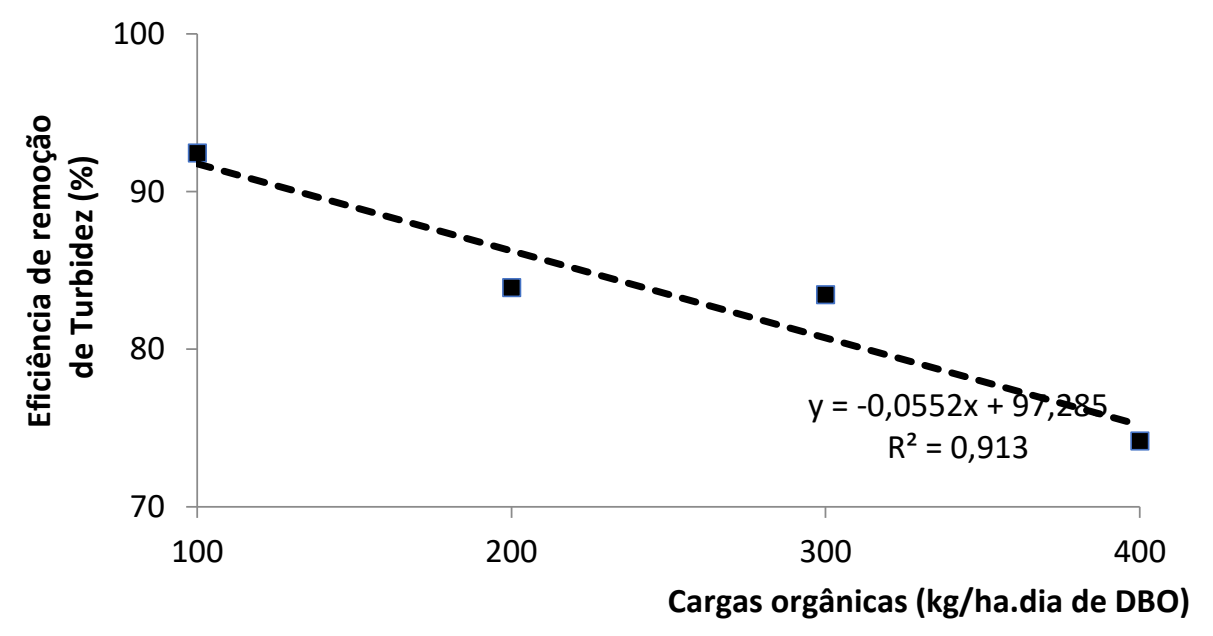

Figura 3. Eficiência de remoção da turbidez em função das diferentes taxas de carregamento orgânico aplicadas aos SACs.

Fonte: Os Autores. 


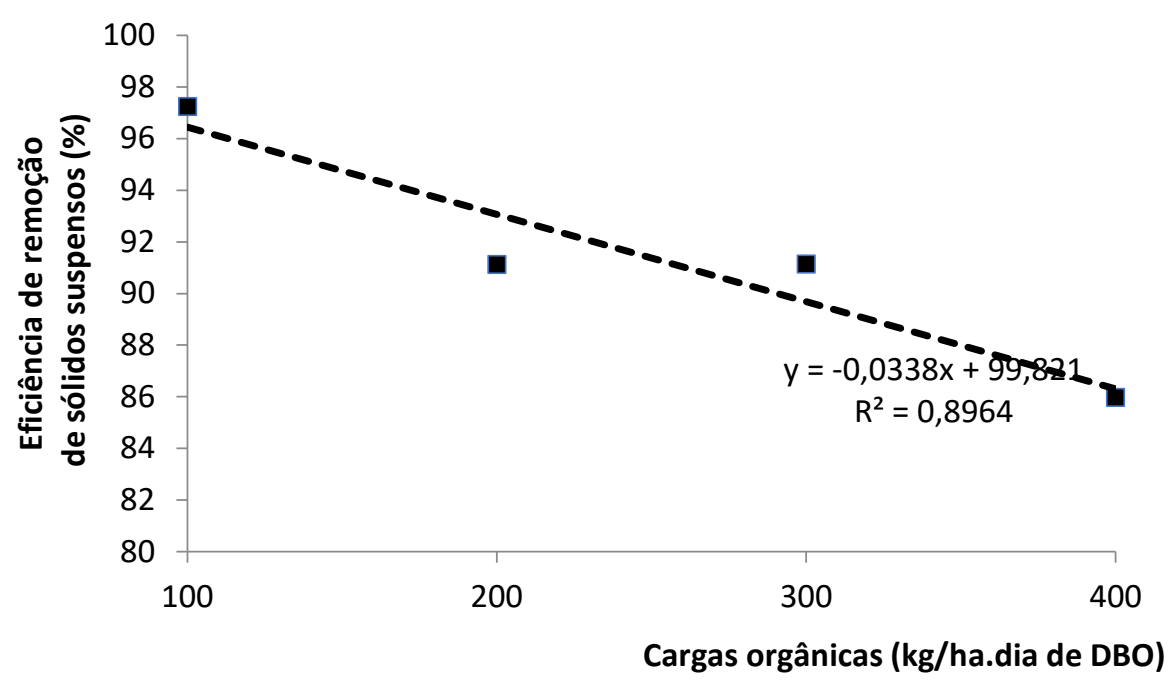

Figura 4. Eficiência de remoção de sólidos suspensos em função das diferentes taxas de carregamento orgânico aplicadas aos SACs.

Fonte: Os Autores.

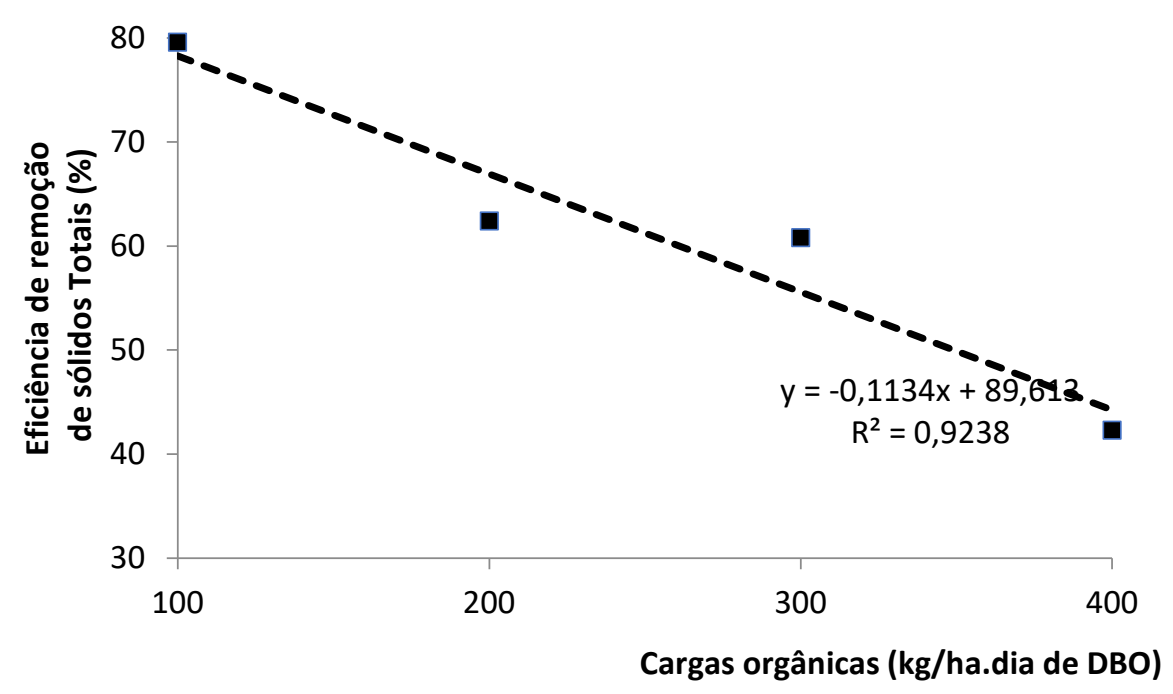

Figura 5. Eficiência de remoção de sólidos totais em função das diferentes taxas de carregamento orgânico aplicadas aos SACs.

Fonte: Os Autores.

De acordo com as figuras 3, 4 e 5 observa-se um ajuste linear decrescente da eficiência média de remoção dos parâmetros analisados em função do aumento das taxas de carregamento orgânico (TCO) aplicadas. Em todos os ajustes foram obtidos elevados coeficientes de determinação $\left(R^{2}>0,896\right)$.

A turbidez é um parâmetro de qualidade de água associada à presença de sólidos suspensos (SS) presentes na água (PRATA et al., 2013), de modo que quanto maior a concentração de sólidos suspensos presentes na água, maior será a turbidez.

De acordo com Metcalf e Eddy (2003), os SACs são eficientes na remoção de SS em decorrência da sedimentação nos interstícios, retenção por restrição ao escoamento 
(filtração) e adesão aos grânulos do material suporte. Corroborando com tal afirmação, observa-se uma elevada remoção da turbidez (Figura 3), dos sólidos suspensos (Figura 4) e dos sólidos totais (Figura 5) pelos SACs, principalmente pelo SAC 1, que recebeu a menor TCO (100 kg de DBO ha-1 dia $\left.^{-1}\right)$.

Um dos fatores que contribuíram para a elevada eficiência do SAC 1 foi o maior tempo de detenção hidráulica em que foi submetido (Tabela 2), proporcionando assim, maior tempo para que ocorressem os processos de sedimentação e filtração de sólidos.

Brasil et al. (2007), ao utilizarem SACs cultivados com Taboa no tratamento de esgoto doméstico, com tempos de detenção hidráulica (TDH) de 1,9 e 3,8 dias, também obtiveram uma maior remoção de turbidez (86\%) para o SAC submetido ao maior TDH, comparado com o SAC submetido ao menor TDH (80\%). Quanto à remoção de SS, os autores obtiveram uma remoção de $91 \%$ para ambos os tempos.

Diferente do que ocorreu neste trabalho, Matos et al. (2010b) verificaram que o modelo quadrático foi o que proporcionou melhor ajuste para a estimativa da eficiência na remoção poluentes da água residuária de laticínios em SACs cultivados com capim Tifton. Os modelos obtidos por esses autores indicaram que a eficiência na remoção do poluente tende a aumentar com o aumento na taxa de aplicação, até ser alcançado um máximo, a partir do qual passa a ocorrer decréscimo na eficiência. Já Prataet al. (2013) não verificaram diferença estatística na eficiência de remoção de SST do esgoto sanitário em SACs cultivados com lírio amarelo, com o aumento da carga aplicada.

Deve ser levado em consideração que apesar da TCO de $100 \mathrm{~kg}$ de DBO ha-1 $\mathrm{dia}^{-1}$ ter apresentado os maiores valores de eficiência de remoção de turbidez e de sólidos suspensos em relação aos demais, os SACs que receberam 200, 300 e até mesmo $400 \mathrm{~kg}$ de DBO há ${ }^{-1}$ dia $^{-1}$ também proporcionaram valores significativos na remoção de todos os parâmetros avaliados. Os SACs 1, 2, 3 e 4 proporcionaram eficiências na remoção de turbidez de aproximadamente $92 \%$, 85\%, 85\% e 74\%, respectivamente de 97\%, 91\%, 91\% e $86 \%$ na remoção de sólidos suspensos, respectivamente e de $80 \%, 64 \%$, $63 \%$ e $43 \%$ respectivamente. Acredita-se, também, que as elevadas remoções obtidas por todos os SACs, de um modo geral, possam estar associadas às elevadas temperaturas ocorridas durante o período experimental (média de $26,56^{\circ} \mathrm{C}$ no mês de setembro e $27,49^{\circ} \mathrm{C}$ no mês de outubro), as quais podem ter contribuído para a eficiência de sedimentação, em razão da menor viscosidade da água.

Comparando-se com outros estudos que avaliaram SACs submetidos a elevadas cargas orgânicas, os valores de eficiência de remoção de SST obtidos neste trabalho foram bastante semelhantes aos obtidos por outros autores, indicando que estes sistemas proporcionam, de fato, elevadas remoções de sólidos em suspensão. Matos et al. (2010a), obtiveram eficiências de 85, 93, 90 e 89\% na remoção de SST, em SACs cultivados com 
taboa, alternanthera, tifton e SAC misto (cultivados com taboa, alternanthera e tifton), respectivamente, no tratamento de águas residuárias de suinocultura, com TCO média de $154,8 \mathrm{~kg} \mathrm{ha}^{-1} \mathrm{~d}^{-1}$ de DBO. Comparando-se com os dados obtidos por Matos et al. (2010b), foram superiores, já que os autores obtiveram eficiência de 64,6\% em SAC cultivado com capim tifton-85 e 64,3\% em SAC cultivado com capim elefante, aplicando TCO de $130 \mathrm{~kg}$ $\mathrm{ha}^{-1} \mathrm{~d}^{-1}$ de $\mathrm{DBO}$, no tratamento de água residuária de laticínios.

Com os resultados obtidos neste trabalho, verifica-se que os sistemas alagados construídos cultivados com capim Jiggs são eficientes na remoção de sólidos e turbidez, mostrando-se como uma boa opção no tratamento de águas residuárias da suinocultura, minimizando assim, os impactos ambientais, se for lançado em corpos hídricos. Outra opção interessante é aproveitar o efluente dos SACs para fertirrigação, já que a elevada eficiência de remoção de sólidos minimiza o risco de entupimento em sistemas de irrigação por aspersão e localizada. Além disso, possibilita a colheita de biomassa utilizada para alimentação animal, reduzindo os custos para o produtor, tornando a atividade sustentável.

\section{Considerações finais}

De acordo com os resultados obtidos neste trabalho, pode-se concluir que:

- Os sistemas alagados construídos cultivados com capim Jiggs proporcionaram eficiências de remoção de 74 a 92\% de turbidez, 86 a 97\% de sólidos suspensos e 44 a $80 \%$ de sólidos totais.

- A aplicação de uma taxa de carregamento orgânico equivalente a $100 \mathrm{~kg}$ de DBO ha-1 dia $^{-1}$ proporcionou a maior eficiência de remoção de todos os parâmetros avaliados;

- A eficiência na remoção de turbidez, sólidos suspensos e sólidos totais decresceu com o aumento da TCO aplicada.

\section{Agradecimentos}

Os autores agradecem ao CNPq pelo financiamento da pesquisa. 


\section{Referências}

BRASIL, M. S.; MATOS, A. T.; SOARES, A. A. Plantio e desempenho fenológico da taboa (Thypha sp.) utilizada no tratamento de esgoto doméstico em sistema alagado construído. Engenharia Sanitária e Ambiental, v. 12, n. 3, p. 266-272, 2007.

CARVALHO, M. S. S. Desempenho agronômico e análise de crescimento de capins do gênero Cynodon em resposta à frequência de corte. Piracicaba, 2011. Dissertação (Mestrado em Ciência animal e pastagens) - Escola Superior de Agricultura "Luiz de Queiroz", Piracicaba, Universidade de São Paulo, 2011.

CHAGAS, R. C.; MATOS, A. T.; CECON, P. R.; LO MONACO, P. A. V.; ZAPAROLI, B. R. Remoção de coliformes em sistemas alagados construídos cultivados com lírio amarelo (Hemerocallis flava). Engenharia na Agricultura, v. 20, n. 2, p. 142-150, 2012.

DIESEL, R.; MIRANDA, C. R.; PERDOMO, C. C. Coletânea de tecnologias sobre dejetos de suínos. EMBRAPA-CNPSA/EMATER-RS: Concórdia, v. 14. Concórdia. 2002. 31 p.

EUSTÁQUIO JÚNIOR, V.; MATOS, A. T.; LO MONACO, P. A. V.; MATOS, M. P. Eficiência de sistemas de aeração em cascatas no tratamento de águas residuárias do café. Coffee Science, Lavras, v. 9, n. 4, p. 435-444, 2014.

FIA, F. R. L.; MATOS, A. T.; FIA, R.; BORGES, A. C.; BAPTESTINI, G. C. F. Phosphorus dynamics in constructed wetlands systems treating swine wastewater. Engenharia Sanitária e Ambiental, v. 25, n. 1, p. 79-86, 2020.

FIA, F. R. L.; MATOS, A. T.; FIA, R.; LAMBERT, T. F.; MATOS, M. P. Remoção de nutrientes por Typhalatifolia e Cynodon spp. cultivadas em sistemas alagados construídos. Revista Ambi-água, v. 6, n. 1, p. 77-89, 2011.

FIA, F. A. L. R.; MATOS, A. T.; FIA, R.; BORGES, A. C.; CECON, P. R. Efeito da vegetação em sistemas alagados construídos para tratar águas residuárias da suinocultura. Engenharia Sanitária e Ambiental, v. 22, n. 2, p. 303-311, 2017.

GUIMARÃES, M. S. Desempenho produtivo, análise de crescimento e características produtivas do dossel de dois capins do gênero Cynodon sob duas estratégias de pastejo intermitente. Piracicaba, 2012. Dissertação (Mestrado em Ciências) - Escola Superior de Agricultura “Luiz de Queiroz", Piracicaba, Universidade de São Paulo, 2012.

KADLEC, R. H.; WALACE, S. D. Treatment wetlands. 2. ed., New York: New York, 2009. 1076p.

LIMA, C. J. G. S.; PEREIRA, L. P.; SANTOS, T. O. S.; PINTO, S. N.; RODRIGUES, A. C.; NUNES, L. A. P. L. Soil changes and yield of maize fertilized with swine wastewater. Revista Caatinga, v. 32, n. 1, p. 167-178, 2019.

MATOS, A. T. Manual de análise de resíduos sólidos e águas residuárias. 1. ed. Viçosa: UFV, 2015. 149p.

MATOS, A. T.; ABRAHÃO, S. S.; BORGES, A.C.; MATOS, M. P. Influência da taxa de carga orgânica no desempenho de sistemas alagados construídos cultivados com forrageiras. Engenharia Sanitária e Ambiental, v. 15, n. 1, p. 83-92, $2010 \mathrm{~b}$. 
MATOS, A. T.; ABRAHÃO, S. S.; PEREIRA, O. G. Desempenho agronômico do capim tifton 85 (Cynodon spp.) cultivados em sistemas alagados construídos utilizados no tratamento de água residuária de laticínios. Ambi-Água, v. 3, n. 01, p. 43-53, 2008.

MATOS, A. T.; CHAGAS, R. C.; AZEVEDO, A. A.; LO MONACO, P. A. V.; ZAPAROLI, B. R. Desempenho agronômico do lírio amarelo cultivado sob diferentes taxas de aplicação de esgoto doméstico em sistemas alagados construídos. Engenharia na Agricultura, Viçosa, v. 21 , n. 01, p. 79-88, 2013.

MATOS, A. T.; FREITAS, W. S.; LO MONACO, P. A. V. Capacidade extratora de diferentes espécies vegetais cultivadas em sistemas alagados utilizados no tratamento de águas residuárias da suinocultura. Ambi-Água, v. 4, n. 2, p. 31-45, 2009.

MATOS, A. T.; FREITAS, W. S.; LO MONACO, P. A. V. Eficiência de sistemas alagados construídos na remoção de poluentes de águas residuárias da suinocultura. Ambi-Água, v.5, n.2, p.119-132, 2010a.

METCALF e EDDY. Wastewater engineering: treatment and reuse. 4. ed. New York: New York, 2003. 1408p.

MIRANDA, S. T.; MATOS, A. T.; MATOS, M. P.; SARAIVA, C. B.; TEIXEIRA, D. L. Influence of the substrate type and position of plant species on clogging and the hydrodynamics of constructed wetland systems. Journal of Water Process Engineering, v. 31, p. 1-8, 2019.

MIRANDA, S. T.; MATOS, A. T.; MATOS, M. P.; SARAIVA, C. B. Eficiência de sistemas alagados construídos de escoamento subsuperficial horizontal considerando diferentes materiais suporte e posição de cultivo das espécies vegetais. Revista Ambiente \& Água, v. 15, n. 2, p. 1-13, 2020.

PRATA, R. C. C.; MATOS, A. T.; CECON, P. R.; LO MONACO, P. A. V.; PIMENTA, L. A. Tratamento de esgoto sanitário em sistemas alagados construídos cultivados com lírio amarelo. Engenharia Agrícola, v. 33, n. 6, p. 1144-1155, 2013.

POCZYNEK, M.; NEUMANN, M.; HORST, E. H.; LEÃO, G. F. M.; POCZYNEK, M.; UENO, R. K. Capacidade produtiva e qualidade nutricional de gramíneas perenes submetidas a sistema contínuo de cortes. Arquivo Brasileiro de Medicina Veterinária e Zootecnia, v. 68, n. 3, p. 785-794, 2016.

SAS Institute Inc. Statistical analysis system user's guide. Version 9.0 ed. Cary, 2011. $513 p$.

SHELEF, O.; GROSS, A.; RACHMILEVITCH, S. Role of plants in a constructed wetland: current and new perspectives. Water, v. 5, n. 2, p. 405-419, 2013. 


\title{
Capítulo 21
}

\section{Resíduos da vitivinicultura como componente de substratos para produção de mudas de pepino}

\author{
Paola Honorato Salla ${ }^{1}$, Paola Alfonsa Vieira Lo Monaco², Larissa lonara Silva Paula ${ }^{1}$, \\ Gustavo Haddad Souza Vieira², Ismail Ramalho Haddade², Sávio da Silva Berilli ${ }^{3}$, Ana Paula \\ Candido Gabriel Berilli ${ }^{3}$, Lillya Mattedi ${ }^{4}$, Rodrigo Junior Nandorf ${ }^{4}$, Alberto Chambela Neto ${ }^{2}$
}

\section{Introdução}

A vitivinicultura tem sido uma atividade de grande importância econômica e social para algumas regiões brasileiras, principalmente daquelas localizadas no sul do país, onde se concentra o maior volume de produção de uva, vinho e demais derivados.

Nas últimas décadas, esta atividade tem se expandido para outras regiões, inclusive de clima tropical, como no estado do Espírito Santo (MELLO, 2012). De acordo com Wurz et al. (2017), a importância do setor para estas regiões está inteiramente relacionada à sustentabilidade das pequenas e médias empresas rurais, que produzem uva de mesa e uva para processamento, bem como daquelas que atuam no sistema de vinificação, contribuindo com a geração de emprego e renda para a economia de tais regiões.

Com a expansão desta atividade, a geração de resíduos tem crescido consideravelmente durante o processamento da matéria prima. De acordo com Zhang et al. (2017), após o processo de vinificação sobram diversos resíduos, tais como: bagaço de uva, engaço, borras de vinho e lodo. Destes materiais, o bagaço de uva é o principal componente, representando cerca de $62 \%$ do total de resíduos orgânicos (RUGGIERI et al., 2009), sendo constituído principalmente por cascas, sementes e resíduos de polpa (ZOCCA et al., 2007). As cascas representam, em média, $82 \%$ do peso seco do bagaço, contendo uma grande quantidade de compostos fenólicos, incluindo antocianinas, ácidos hidroxicinâmicos, catequinas e flavonóis (ROCKENBACH et al., 2011).

\footnotetext{
1Engenheira Agrônoma pelo Instituto Feral do Espírito Santo - Campus Santa Teresa, Rod ES 080, km 93, São João de Petrópolis, CEP: 29650-000, Santa Teresa-ES. Email: paola.hsalla@gmail.com; larissaionarasilvapaula@gmail.com

${ }^{2}$ Drs. Professores do Instituto Federal do Espírito Santo - Campus Santa Teresa, Rod ES 080, km 93, São João de Petrópolis, CEP: 29650-000, Santa Teresa-ES. E-mail: paolalm@ifes.edu.br; ghsv@ifes.edu.br; ihaddade@ifes.edu.br; chambela@ifes.edu.br ${ }^{3}$ Drs. Professores do Instituto Federal do Espírito Santo - Campus de Alegre, Caixa Postal 47, CEP: 29500-000, Alegre-ES. E-mail: savio.berilli@ifes.edu.br; ana.berilli@ifes.edu.br

${ }^{4}$ Graduandos em Agronomia pelo Instituto Federal do Espírito Santo Campus Santa Teresa, Rod ES 080, km 93, São João de Petrópolis, CEP: 29650-000, Santa Teresa-ES. E-mail: lillyamattedi2013@gmail.com; rodrigojrnandorf@gmail.com
} 
Muitas vezes, esses resíduos não são tratados ou aproveitados, apresentando uma disposição ambientalmente inadequada, com potenciais riscos de contaminação dos solos e de águas superficiais e subterrâneas. Por outro lado, Schaffer et al. (2013) apontam que os resíduos da vitivinicultura têm potencial para ser utilizado com fins agrícola, indicando que $\mathrm{N}$ e $\mathrm{K}$ são os nutrientes presentes em maiores quantidades nestes resíduos, além de teores bastante elevados de matéria orgânica.

O estado do Espírito Santo, em especial na região Serrana, apresenta também grande destaque na produção de hortaliças. Além de ser responsável por abastecer praticamente todo o estado, a produção de hortaliças é uma das principais fontes de renda para os agricultores da região, principalmente aqueles de agricultura familiar. Dentre as hortaliças produzidas em elevada quantidade na região Serrana do Espírito Santo destaca-se o pepino.

Para o bom desenvolvimento dessa hortaliça, é de suma importância a produção de mudas de boa qualidade, cuja etapa é uma das mais importantes do sistema produtivo, influenciando diretamente o desempenho nutricional e produtivo das plantas.

Um dos fatores relacionados à qualidade de mudas é o tipo de substrato utilizado. De acordo com Meneghelli et al. (2017), este deve apresentar características físicas e químicas que proporcionem bom desenvolvimento das mudas, resultando em plantas sadias e vigorosas. Além disso, é importante que na escolha dos materiais para compor os substratos sejam levados em consideração sua disponibilidade na região e o custo de obtenção (LIMA et al., 2010).

Os substratos que geralmente são utilizados para a produção de mudas de hortaliças são os comerciais, no entanto, constituem-se em um custo a mais na etapa de produção de formação de muda. Considerando que a maior parte do cultivo de hortaliças no Brasil é realizada por agricultores familiares, Meneghelli et al. (2018), reforçam que estes custos com substratos levam a uma diminuição na rentabilidade do investimento, sugerindo a necessidade de se buscar novas fontes alternativas de substratos.

Assim, com a necessidade de reduzir custos com os substratos comerciais e aproveitar a disponibilidade de resíduos da vitivinicultura gerados na região, algumas pesquisas têm sido realizadas com diferentes combinações de substratos comerciais e resíduos do processo de vinificação em mudas de hortaliças e frutas, tais como nos trabalhos de Carmona et al. (2012) e Pinter et al. (2019). Pinter et al. (2019), ao avaliarem o uso de composto de resíduos da vinificação como substrato para mudas de alface, tomate, pimenta e melão, verificaram elevado potencial de uso desses resíduos, principalmente quando misturados com o substrato comercial. De maneira semelhante, Carmona et al. (2012), ao estudarem o uso do composto de resíduos da vitivinicultura como substratos para o cultivo em plantas 
ornamentais, verificaram que o composto não possui características limitantes para seu uso como meio para o cultivo de plantas ornamentais em recipiente e pode substituir substratos convencionais, como a turfa e a fibra de coco.

Assim, em função de cada espécie deve-se verificar qual o melhor substrato, que proporciona a formação de plantas de melhor qualidade para transplantação. Nesse sentido, acredita-se que os resíduos da vitivinicultura podem ser um componente promissor na substituição de parte do substrato comercial utilizado na produção de outras mudas, tais como as de pepino, cujas proporções necessitam de experimentação.

Além de reduzir os custos decorrentes da aquisição de substratos comerciais, o aproveitamento desses resíduos como componente de substratos é uma forma de minimizar o impacto ambiental causado pelo descarte inadequado dos mesmos no ambiente.

Objetivou-se, com a realização desse trabalho, avaliar a potencialidade de utilização dos resíduos da vitivinicultura na composição de substratos para produção de mudas de pepino.

\section{Metodologia}

O experimento foi implantado e conduzido no viveiro de produção de mudas no Instituto Federal do Espírito Santo - Campus Santa Teresa, Espírito Santo, Brasil. A hortaliça utilizada no experimento foi o pepino (Cucumis sativus L.).

O resíduo utilizado no substrato alternativo para produção de mudas de hortaliças foi proveniente da vinificação da uva, denominado como "bagaço de uva" - BU, sendo composto por casca (epiderme) e sementes de uva Grano d'Oro (Vitis Labrusca), clone da variedade Bordô. O resíduo foi coletado na vinícola "Cantina Matiello", localizada no município de Santa Teresa, estado do Espírito Santo, Brasil. O bagaço foi apenas seco ao sol e triturado em liquidificador industrial, antes da mistura, não havendo qualquer peneiramento.

A caracterização química e físico-química do BU foi realizada no Laboratório de Qualidade de Água e Resíduos Sólidos do Ifes - Campus Santa Teresa, seguindo-se metodologia descrita por Matos (2015). A análise química consistiu na determinação do pH, por meio de um peagâmetro de bancada, e na quantificação das concentrações de carbono orgânico facilmente oxidável $\left(\mathrm{CO}_{\mathrm{fo}}\right)$, nitrogênio total $\left(\mathrm{N}_{\mathrm{T}}\right)$, nitrogênio amoniacal $\left(\mathrm{N}_{\mathrm{a}}\right)$ e fósforo (P). A análise físico-química consistiu na determinação da condutividade elétrica (CE), por meio de um condutivímetro de bancada, na proporção v:v de $10 \mathrm{~cm}^{3}: 25 \mathrm{~cm}^{3}$. Na tabela 1 apresenta-se a caracterização química e físico-química do bagaço de uva. 
Tabela 1. Caracterização química e físico-química do bagaço de uva.

\begin{tabular}{clllll}
\hline $\mathrm{pH}$ & $\mathrm{CE}$ & $\mathrm{CO}_{\text {fo }}$ & $\mathrm{N}_{\text {TOTAL }}$ & $\mathrm{N}_{\text {amoniacal }}$ & $\mathrm{P}_{\text {TOTAL }}$ \\
\cline { 2 - 5 } 3,4 & $\mathrm{dS} \mathrm{m}{ }^{-1}$ & $--1,84$ & 0,19 & 0,396
\end{tabular}

$\mathrm{Em}$ que, $\mathrm{pH}$ - potencial hidrogeniônico; $\mathrm{CE}$ - condutividade elétrica; $\mathrm{CO}_{\mathrm{Fo}}$ - carbono orgânico facilmente oxidável; NTOTAL - nitrogênio total; Namonicacal - nitrogênio amoniacal e PTOTAL - fósforo total. Fonte: Os Autores.

O delineamento experimental adotado foi o inteiramente casualizado (DIC), com seis tratamentos e seis repetições. Cada unidade experimental continha 16 (dezesseis) mudas, totalizando 576 (quinhentos e setenta e seis) mudas. Para cada unidade experimental foram avaliadas 8 mudas, totalizando 288 (duzentos e oitenta e oito) mudas.

O experimento consistiu na aplicação dos seguintes tratamentos:

T0: $0 \%$ de bagaço de uva $+100 \%$ de Bioplant ${ }^{\circledR}$ (testemunha);

T1: $10 \%$ de bagaço de uva $+90 \%$ de Bioplant $\AA$;

T2: $20 \%$ de bagaço de uva $+80 \%$ de Bioplant ${ }^{\circledR}$;

T3: $30 \%$ de bagaço de uva $+70 \%$ de Bioplant ${ }^{\circledR}$;

T4: $40 \%$ de bagaço de uva $+60 \%$ de Bioplant ${ }^{\circledR}$;

T5: $50 \%$ de bagaço de uva $+50 \%$ de Bioplant ${ }^{\circledR}$

O tratamento T0 foi considerado como o tratamento convencional, em razão de ser tradicionalmente utilizado pelos produtores da região. O semeio foi feito em bandejas de isopropileno com 128 células, colocando-se 1 semente por célula, à profundidade de $1 \mathrm{~cm}$. $\mathrm{A}$ irrigação foi realizada diariamente, duas vezes ao dia, com o auxílio de um regador

As mudas foram produzidas a partir de sementes híbridas "BONANZA F1", do grupo variedade caipira e avaliadas 13 dias após a semeadura (DAS).

Como variáveis biométricas, avaliou-se o número de folhas, altura da planta, comprimento da raiz, diâmetro do coleto, massa seca da parte aérea e massa seca da raiz. Dentre as análises gravimétricas, foram avaliadas a massa seca da parte aérea, massa seca da raiz e massa seca total. Além dessas variáveis, foi determinado também o Índice de Qualidade de Dickson (IQD).

Para obtenção dos comprimentos e dos diâmetros do coleto utilizou-se uma régua milimetrada e um paquímetro digital de precisão, respectivamente. Cada muda foi dividida em parte aérea e raiz através de um corte no coleto. Para a obtenção da massa seca da raiz, as mesmas foram cuidadosamente lavadas e, posteriormente, acondicionadas em sacos de papel e alocadas em estufa com circulação de ar forçada a $65^{\circ} \mathrm{C}$ por 72 horas. Em 
seguida, foi realizada a pesagem dos materiais em balança eletrônica de precisão de 0,01 $\mathrm{g}$. As análises biométricas e gravimétricas foram analisadas no Laboratório de Qualidade de Água e Resíduos Sólidos do Ifes - Campus Santa Teresa.

$O$ índice de qualidade de Dickson (IQD) foi determinado em função da altura da parte aérea $(H)$, do diâmetro do coleto (DC), do peso de matéria seca da parte aérea (PMSPA) e do peso de matéria seca das raízes (PMSR), por meio da Equação 1 (Dickson et al., 1960):

$$
I Q D=\frac{P M S T(g)}{(H(c m) / D C(m m))+} \quad \text { Equação (1) }
$$

Em que: IQD = Índice de qualidade de Dickson, PMST = Peso da matéria seca total (g), $\mathrm{H}=$ altura $(\mathrm{cm}), \mathrm{DC}=$ diâmetro do coleto $(\mathrm{mm}), \mathrm{PMSPA}=$ Peso da matéria seca da parte aérea $(\mathrm{g})$ e PMSR $=$ Peso da matéria seca da raiz $(\mathrm{g})$.

Todas as variáveis avaliadas foram submetidas aos testes de normalidade (Shapiro-wilk) e de homocedasticidade (Levene), estes, pressupostos para a validação de suas análises de variância. As variáveis que atenderam os pressupostos de normalidade e homocedasticidade foram submetidas ao teste Dunnett. Aquelas que não atenderam, foram submetidas ao teste dos sinais. Para todos os procedimentos foi adotado um "a" igual a 0,05. Para os procedimentos estatísticos foi utilizado o software Rstudio (R Development Core Team, 2019).

\section{Resultados e discussão}

$\mathrm{Na}$ tabela 2 estão apresentadas as médias da altura de plantas $(\mathrm{H})$, do comprimento de raiz (CR), do diâmetro de coleto (DC), do número de folhas (NF), do peso de matéria seca de parte aérea (PMSPA), do peso da matéria seca de raiz (PMSR), do peso da matéria seca total (PMST) e do Índice de Qualidade de Dickson (IQD), em mudas de pepino, avaliadas aos 13 DAS, além do $\mathrm{pH}$ e condutividade elétrica (CE) dos substratos, em função dos tratamentos contendo níveis crescentes de bagaço de uva e decrescentes de substrato comercial (T1 ao T6), bem como o uso exclusivo de substrato comercial (T0). 
Tabela 2. Médias das variáveis analisadas em mudas de pepino e no substrato, aos 13 DAS, em função dos tratamentos contendo níveis crescentes de bagaço de uva /decrescentes de substrato comercial (T1 ao T6) e o uso exclusivo do substrato comercial (T0).

\begin{tabular}{|c|c|c|c|c|c|c|c|c|c|c|}
\hline TRATAMENTO & $\begin{array}{c}\mathrm{H} \\
(\mathrm{cm})\end{array}$ & $\begin{array}{l}\text { CR } \\
(\mathrm{cm})\end{array}$ & $\begin{array}{c}\mathrm{DC} \\
(\mathrm{mm})\end{array}$ & NF & $\begin{array}{c}\text { PMSPA } \\
(\mathrm{g})\end{array}$ & $\begin{array}{c}\text { PMSR } \\
(g)\end{array}$ & $\begin{array}{c}\text { PMST } \\
(\mathrm{g})\end{array}$ & IQD & $\begin{array}{c}\text { CE } \\
\left(\mathrm{dS} \mathrm{m}^{-1}\right)\end{array}$ & $\mathrm{pH}^{*}$ \\
\hline Controle (T0) & $8,04 \mathrm{~B}$ & $6,75 \mathrm{~B}$ & $2,19 \mathrm{~B}$ & 3,29 & $0,070 \mathrm{~B}$ & $0,0183 \mathrm{~B}$ & $0,0845 B$ & $0,0113 \mathrm{~B}$ & $0,176 \mathrm{~B}$ & $6,13 \mathrm{~B}$ \\
\hline $10 / 90 \%(\mathrm{~T} 1)$ & $9,87 \mathrm{~A}$ & $7,86 \mathrm{~A}$ & $3,04 \mathrm{~A}$ & 3,18 & $0,103 \mathrm{~A}$ & $0,0361 \mathrm{~A}$ & $0,1391 \mathrm{~A}$ & $0,0222 A$ & $0,206 B$ & $6,63 \mathrm{~B}$ \\
\hline $20 / 80 \%$ (T2) & $10,2 \mathrm{~A}$ & $7,68 \mathrm{~B}$ & $2,56 \mathrm{~B}$ & 3,09 & $0,113 \mathrm{~A}$ & $0,0442 A$ & $0,1570 A$ & $0,0241 \mathrm{~A}$ & $0,386 \mathrm{~A}$ & $7,07 \mathrm{~A}$ \\
\hline $30 / 70 \%$ (T3) & $10,2 \mathrm{~A}$ & $7,20 \mathrm{~B}$ & $2,72 \mathrm{~A}$ & 3,09 & $0,097 \mathrm{~A}$ & $0,0437 \mathrm{~A}$ & $0,1403 \mathrm{~A}$ & $0,0233 A$ & $0,458 \mathrm{~A}$ & $7,30 \mathrm{~A}$ \\
\hline 40/60\% (T4) & $9,83 \mathrm{~A}$ & $7,16 \mathrm{~B}$ & $2,70 \mathrm{~A}$ & 3,19 & $0,088 \mathrm{~A}$ & $0,0404 \mathrm{~A}$ & $0,1287 A$ & $0,0222 A$ & $0,391 \mathrm{~A}$ & $7,43 \mathrm{~A}$ \\
\hline 50/50\% (T5) & $9,93 \mathrm{~A}$ & $7,14 \mathrm{~B}$ & $2,58 \mathrm{~B}$ & 3,13 & $0,085 \mathrm{~B}$ & $0,0435 \mathrm{~A}$ & $0,1285 \mathrm{~A}$ & $0,0220 \mathrm{~A}$ & $0,300 \mathrm{~A}$ & $7,52 \mathrm{~A}$ \\
\hline Valor de P & 0,007 & 0,12 & 0 & 0,703 & 0 & 0 & 0,001 & 0 & 0 & 0 \\
\hline $\mathrm{CV}(\%)$ & 10,36 & 9,79 & 10,27 & 7,68 & 0,00 & 26,19 & 0,00 & 20,85 & 24,00 & 3,52 \\
\hline
\end{tabular}

Nota: As letras maiúsculas em cada coluna comparam cada um dos tratamentos com o controle, pelo teste Dunnet ao nível de $5 \%$ de probabilidade. *As letras maiúsculas em cada coluna comparam cada um dos tratamentos com o controle, pelo teste dos sinais ao nível de $5 \%$ de probabilidade (variáveis resposta que não atenderam principalmente ao pressuposto de homocedasticidade).

Fonte. Os Autores.

De acordo com a tabela 2, verifica-se que para a variável altura de planta $(H)$, todos os tratamentos com níveis crescentes de bagaço de uva e decrescentes de substrato comercial (T1 ao T5) foram estatisticamente superiores $(p \leq 0,05)$ quando comparados ao uso exclusivo de substrato comercial (tratamento controle). Os resultados obtidos neste trabalho foram superiores aos alcançados por Almeida et al. (2018), que ao testarem níveis crescentes de moinha de café e decrescentes de Bioplant®, em substratos compostos por casca de arroz carbonizada $(40 \%)$, fibra de coco $(15 \%)$, casca de ovo $(5 \%)$ na produção de mudas de pepino, não obtiveram valores maiores que $9,72 \mathrm{~cm}$, aos 21 DAS. Guisolfi et al. (2018), ao avaliarem as variáveis de crescimento de mudas de pepino produzidas em substratos com diferentes composições de resíduos agrícolas, obtiveram valor máximo em torno de 11,8 $\mathrm{cm}$. Há de se ponderar que os autores avaliaram as mudas aos 23 DAS, tempo superior quando comparado ao tempo de avaliação deste trabalho (13 DAS).

Segundo Souza et al. (2013), a raiz é uma variável que permite maior exploração das plantas pelo substrato, refletindo numa maior taxa de absorção de água e nutrientes. Há uma relação direta entre a quantidade de raiz e nutrientes disponíveis, no intervalo entre o transplante e a formação de novas raízes. As mudas ao serem transplantadas para o campo, quando apresentam alguma restrição no desenvolvimento do sistema radicular, possuem dificuldade de compensar a evapotranspiração, mesmo a água sendo fornecida em quantidades suficientes para o bom desenvolvimento das plantas (ECHER et al., 2007). 
De acordo com a tabela 2, somente o tratamento T1 (10/90) foi estatisticamente superior $(p \leq 0,05)$ ao controle, sendo que os demais não apresentaram diferença significativa no comprimento de raiz. Nesse sentido, o substrato contendo $50 \%$ de BU $+50 \%$ de SC pode ser recomendável para produção das mudas de pepino, quando comparado com o uso exclusivo do substrato comercial (T0).

Silva et al. (2014), ao testarem o uso de substrato à base de esterco ovino na produção de mudas pepino, obtiveram valores de CR entre $7,52 \mathrm{~cm}$ a $8,68 \mathrm{~cm}$, sendo que no tratamento indicado o valor foi de $8,65 \mathrm{~cm}$. Porém, há de se ponderar que os mesmos realizaram suas avaliações aos 43 DAS e as avaliações deste trabalho foram feitas aos 13 DAS. Assim, a diferença apresentada entre os valores encontrados é consideravelmente pequena em relação à diferença de tempo de avaliação.

O diâmetro do coleto é um fator de grande importância para determinar o momento de transplantio das mudas para o campo (KRAUSE et al., 2017). Quando comparado com o controle (Tabela 2), os tratamentos T1 (10/90), T3 (30/70) e T4 (40/60) foram estatisticamente superiores $(p \leq 0,05)$, enquanto que os tratamentos T2 (20/80) e T5 $(50 / 50)$ não apresentaram diferença significativa $(p>0,05)$. Os valores de diâmetro do coleto encontrados neste trabalho foram próximos aos apresentados por Almeida et al. (2018), que obtiveram valor máximo de 2,74 mm, aos 21 DAS.

O número de folhas de uma planta apresenta grande importância, uma vez que influencia diretamente na realização da fotossíntese através da captação de luz. Para esta variável não houve diferença significativa entre os tratamentos T0 a T5 $(p>0,05)$. Silva et al. (2014) recomendaram o substrato contendo proporções de 1:1 de esterco ovino e solo na produção de mudas com qualidade de pepino, obtendo-se valores médios de número de folhas inferiores (1,98 un.) quando comparados com os obtidos neste trabalho (Tabela 2).

A massa de matéria seca da planta é um fator importante para determinar a quantidade de nutrientes que têm sido absorvidos pela planta, refletindo no seu desenvolvimento de biomassa (COSTA et al., 2013).

No caso o peso de matéria seca da parte aérea (PMSPA), apenas o tratamento T5 $(50 / 50)$ não apresentou diferença significativa $(p>0,05)$ quando comparado à testemunha. Todos os outros (T1 a T4) apresentaram-se significativamente superiores ao tratamento controle $(p \leq 0,05)$. Os valores encontrados de PMSPA (Tabela 2$)$ neste trabalho podem ser considerados satisfatórios quando comparados com outros autores, tais como Costa et al. (2013), que ao avaliarem diferentes proporções de composto de areia no substrato, obtiveram valor máximo de 0,056 g, aos 20 DAE. Almeida et al. (2018) não obtiveram 
valores superiores a 0,067 $\mathrm{g}$ de PMSPA em mudas de pepino, aos $21 \mathrm{DAS}$, cultivadas em substrato com níveis crescentes de moinha de café.

As raízes são as responsáveis pela interação do substrato com a planta, e este deve propiciar o desenvolvimento do sistema radicular ao longo de toda a célula, tornando o enraizamento uniforme (MENEGHELLI et al., 2018). De acordo com a tabela 2, verifica-se que todos os tratamentos com níveis crescentes de bagaço de uva e decrescentes de substrato comercial (T1 ao T5) foram estatisticamente superiores $(p \leq 0,05)$ quando comparado ao uso exclusivo de substrato comercial (tratamento controle), para a variável peso da matéria seca de raiz. Os valores obtidos neste trabalho $(0,036$ a 0,044 g) foram superiores aos encontrados por Guisolfi et al. (2018), que ao avaliarem as variáveis de crescimento e a qualidade de mudas de pepino produzidas em substratos com diferentes proporções crescentes de moinha/decrescentes de casca de arroz (0/40; 10/30; 20/20; $30 / 10$ e $40 / 0 \%$ ) e proporções fixas de fibra de coco (15\%), casca de ovo (5\%) e casca de pinus (40\%), obtiveram valor máximo de $0,037 \mathrm{~g}$.

Em relação ao peso de matéria seca total (PMST), cada um dos tratamentos com níveis crescentes de bagaço de uva apresentou valores estatisticamente superiores $(p>0,05)$ em relação à testemunha (Tabela 2). Os valores obtidos nesse trabalho $(0,128$ a $0,157 \mathrm{~g})$, quando se utilizou bagaço de uva na composição do substrato, foram superiores aos encontrados por Cerqueira et al. (2015). Os autores obtiveram valor máximo de 0,065 g, em mudas de pepino, cultivadas em diferentes tipos de substrato e recipientes, aos 19 DAS. Gazola et al. (2013), trabalhando com germinação e crescimento inicial de plântulas de pepino em substratos comerciais, verificaram resposta significativa da produção de matéria seca total (MST) das mudas em função dos substratos avaliados.

A variável Índice de Qualidade de Dickson é um dos índices mais utilizados para avaliar a qualidade de mudas, uma vez que leva em consideração a produção da matéria seca da parte aérea, das raízes e total, a altura e o diâmetro de coleto das plantas (DICKSON et al., 1960). Recomenda-se o uso de um substrato cuja proporção de bagaço de uva não propicie um IQD significativamente inferior ao controle. Para a variável IQD, todos os tratamentos contendo níveis crescentes de bagaço de uva no substrato foram estatisticamente superiores, quando comparados ao controle (T0). Neste caso, o substrato contendo $50 \%$ de bagaço de uva e $50 \%$ de substrato comercial é o mais apropriado para a produção de mudas de pepino.

Todos os tratamentos, à exceção de T1, proporcionaram valores de condutividade elétrica no substrato superiores $(p \leq 0,05)$ quando comparado com a testemunha. Este comportamento já era esperado em razão da elevada condutividade elétrica do resíduo (Tabela 1). De acordo com Cavins et al. (2000), um substrato com CE entre 0,76 a 1,25 dS 
$\mathrm{m}^{-1}$ apresenta salinidade adequada ao desenvolvimento da maioria dos cultivos. Os mesmos autores classificam CE em níveis: muito baixo $\left(0\right.$ a $\left.0,25 \mathrm{dS} \mathrm{m}^{-1}\right)$, baixo $\left(0,26\right.$ a $\left.0,75 \mathrm{dS} \mathrm{m}^{-1}\right)$, normal $\left(0,76\right.$ a $\left.1,25 \mathrm{dS} \mathrm{m^{-1 }}\right)$, alto $\left(1,26\right.$ a $\left.1,75 \mathrm{dS} \mathrm{m}^{-1}\right)$, muito alto $\left(1,76\right.$ a 2,25 dS $\left.\mathrm{m}^{-1}\right) \mathrm{e}$ extremo (acima de 2,25 dS $\mathrm{m}^{-1}$ ). Nesse caso, pode-se dizer que valores encontrados em todos os tratamentos, até mesmo no T3, não proporciona riscos de causar prejuízos ao desenvolvimento das mudas.

$\mathrm{O}$ pH do resíduo, apesar de apresentar um valor baixo (Tabela 1), ao ser misturado com o substrato comercial, a sua mineralização levou ao aumento de valor de $\mathrm{pH}$, tornando a mistura com um pH entre 6,63 e 7,52, faixa acima do ideal nas maiores concentrações. De acordo com Kampf (2000), o valor ideal de pH está situado entre 5,2 e 5,5 para substratos de base orgânica e entre 6 e 7 para aqueles de base mineral. Embora os valores obtidos estejam acima do valor recomendável, não houve prejuízos ao desenvolvimento da muda.

De um modo geral, o bagaço de uva proporcionou melhoria na qualidade de mudas de pepino, o que pode ser atribuído ao elevado conteúdo de nutrientes no resíduo, notadamente o fósforo (Tabela 1). A aplicação do fósforo é imprescindível na formação de mudas, verificando-se que o mesmo estimula o crescimento inicial das raízes (MELO et al., 2007 apud SOUZA, 1993). Segundo Silva et al. (2017) apud Haag et al. (1973), esse nutriente possui grande relevância no que se diz respeito ao crescimento inicial das plantas em geral atuando em processos de armazenamento, transferência de energia e absorção ativa de outros nutrientes.

Os resultados obtidos nesse trabalho indicam que qualquer um dos tratamentos com os substratos contendo níveis crescentes de bagaço de uva e decrescentes de substrato comercial podem substituir o uso exclusivo de substrato comercial, sem que haja prejuízos à qualidade de mudas de pepino. Diante do exposto, em razão da elevada disponibilidade de resíduos de vitivinicultura na região, o uso do substrato contendo $50 \%$ de bagaço de uva e $50 \%$ de substrato comercial torna-se conveniente, podendo reduzir os custos na etapa de produção de mudas de pepino.

\section{Considerações finais}

Para produção de mudas de pepino recomenda-se o uso do substrato composto por $50 \%$ de bagaço de uva e $50 \%$ de substrato comercial.

O incremento de bagaço de uva na composição do substrato proporciona o aumento de $\mathrm{pH}$ e da condutividade elétrica. 


\section{Agradecimentos}

Os autores agradecem à Pró-Reitoria de Pesquisa e Pós-graduação do Ifes, pela bolsa de iniciação científica concedida à primeira autora, à Cantina Matiello, pelo apoio e fornecimento dos resíduos, e à COOPEAVI de Santa Teresa, pelo fornecimento do substrato comercial ES.

\section{Referências}

ALMEIDA, K. M.; LO MONACO, P. A. V.; HADDADE, I. R.; KRAUSE, M. R.; GUISOLFI, L. P.; MENEGHELLI, L. A. M. Efeito de diferentes proporções de moinha de café na composição de substratos alternativos para produção de mudas de pepino. Revista de Ciências Agroveterinárias, Lages, SC, v. 17, p. 515-522, 2018.

CARMONA, E.; MORENO, M. T.; AVILÉS, M.; ORDOVÁS, J. Use of grape marc compost as substrate for vegetable seedlings. Scientia Horticulturae, v. 137, p. 69-74, 2012.

CAVINS, T. J.; WHIPKER B. E.; FONTENO, W. C.; HARDEN, B.; McCALL, I.; GIBSON, J. L. Monitoring and managing $\mathrm{pH}$ and $\mathrm{EC}$ using the pour thru extraction method. Horticulture Information Leaflet/ NCSU, Raleigh, n. 590, 2000. Disponível em: $<$ https://projects.ncsu.edu/project/hortsublab/pdf/PourThru_Master_HIL.pdf >. Acesso em: 24 jul. 2019.

CERQUEIRA, F. B.; FREITAS, G. A.; SANDI, F.; CARNEIRO, J. S. S. D. A.; GIACOMINI, I.; NERES, J. C. I. Substratos e recipientes no desenvolvimento de mudas de pepino em alta temperatura. Global Science Technology, Rio Verde, v. 8, n. 2, p. 61-73. 2015.

COSTA, L. A. M. DE; COSTA, M. S. S. M. DE; PEREIRA, D. C.; BERNARDI, F. H.; MACCARI, S. Avaliação de substratos para a produção de mudas de tomate e pepino. Revista Ceres, v. 60, p. 675-682, 2013.

DICKSON, A.; LEAF, A. L.; HOSNER, J. F. Quality appraisal of white spruce and white pine seedling stock in nurseries. The Forestry Chronicle, v. 36, n. 1, p. 10-13, 1960.

ECHER, M. M.; GUIMARÃES, V. F.; ARANDA, A. N.; BORTOLAZZO, E. D.; BRAGA, J. S. Avaliação de mudas de beterraba em função do substrato e do tipo de bandeja. Semina: Ciências Agrárias, v. 28, n. 1, p. 45-50, 2007.

GAZOLA, R. N.; CASTILHO, R. M. M.; DINALLI, R. P.; CELESTRINO, T. S.; MÓdENA, C. M. Germinação e crescimento inicial de plântulas de pepino em substratos comerciais. Tecnologia \& Ciência Agropecuária, v. 7, p. 25-30, 2013.

GUISOLFI, L. P.; LO MONACO, P. A. V.; HADDADE, I. R.; KRAUSE, M. R.; MENEGHELLI, L. A. M.; ALMEIDA, K. M. Production of cucumber seedlings in alternative substrates with different compositions of agricultural residues. Caatinga, Mossoró, v. 31 n. 3, p. 791-797, 2018. 
KÄMPF, A. N. Seleção de materiais para uso como substrato. In: KÄMPF, N. A; FERMINO, M. H. (Eds.). Substratos para plantas: a base da produção vegetal em recipientes. Porto Alegre: Gênesis, 2000. p. 139-145.

KRAUSE, M. R.; LO MONACO, P. A. V.; HADDADE, I. R.; MENEGHELLI, L. A. M.; SOUSA, T. D. Aproveitamento de resíduos agrícolas na composição de substratos para produção de mudas de tomateiro. Horticultura Brasileira, v. 35, n. 2, p. 293-298, 2017.

LIMA, R. L. S. D.; SEVERINO, L. S.; PEREIRA, W. E.; LUCENA, A. M. A.; CHEYI, H. R.; ARRIEL, N. H. C. Comprimento das estacas e parte do ramo para formação de mudas de pinhão-manso. Revista Brasileira de Engenharia Agrícola e Ambiental, Campina Grande, v. 14, n. 11, p. 1234-1239, 2010.

MATOS, A. T. Manual de análise de resíduos sólidos e águas residuárias. Viçosa: Editora UFV, 1. ed., 2015. 149p.

MELLO, L. M. R. Vitiviniculura brasileira: panorama 2011. Bento Gonçalves: EMBRAPA Uva e Vinho, 2012. 4p. (Comunicado Técnico 115).

MELO, A. S.; COSTA, C. X.; BRITO, M. E. B.; VIÉGAS, P. R. A.; JÚNIOR, C. D. S. Produção de mudas de mamoeiro em diferentes substratos e doses de fósforo. Revista Brasileira de Ciências Agrárias. v. 2, n. 4, p. 257-261, 2007.

MENEGHELLI, L. A. M.; LO MONACO, P. A. V.; HADDADE, I. R.; MENEGHELLI, C. M.; ALMEIDA, K. M. Agricultural residues as a substrate in the production of eggplant seedlings. Horticultura Brasileira, v. 35, n. 4, p. 527-533, 2017.

MENEGHELLI, L. A. M.; LO MONACO, P. A. V.; KRAUSE, M. R.; MENEGHELLI, C. M.; GUISOLFI, L. P.; MENEGASSI, J. Resíduos agrícolas incorporados a substrato comercial na produção de mudas de repolho. Revistade Ciências Agroveterinárias, Lages, SC, v. 17, p. 491-497, 2018.

PINTER, I. F.; AGUADO, G. D.; DE BIASI, F.; FERNÁNDES, A. S.; MARTINEZ, L.; ULIARTE, E. M. Performance of grape marc and organic residues compost as substrate in lettuce (Lactuca sativa) seedlings. Revista de la Facultad de Ciencias Agrarias, v. 51, n. 2, p. 261-269, 2019.

R DEVELOPMENT CORE TEAM. R: A language and environment for statistical computing. $\mathrm{R}$ foundation for statistical computing, Vienna, Austria, 2019. Disponível em: <https://www.rproject.org/>. Acesso em: 03 dez. 2019.

ROCKENBACH, I. I.; RODRIGUES, E.; GONZAGA, L. V.; CALIARI, V.; GENOVESE, M. I.; GONÇALVES, A. E. S. S.; FETT, R. Phenolic compounds content and antioxidant activity in pomace from selected red grapes (Vitis vinifera L. and Vitis labrusca L.) widely produced in Brazil. Food Chemistry, London, v. 127, n. 1, p. 174-179, 2011.

RUGGIERI, L.; CADENA, E.; MARTINEZ-BLANCO, J.; GASOL, C. M.; RIERADEVALL, J.; GABARRELL, X.; GEA, T.; SORT, X.; SÁNCHEZ, A. Recovery of organic wastes in the Spanish wine industry. Technical, economic and environmental analyses of the composting process. Journal of Cleaner Production, v. 17, n. 1, p. 830-838, 2009.

SCHAFFER, N.: TORNIQUIST, C. G.; MANFROI, V. Resíduos de vinificação com potencial de uso agrícola. In: CONGRESSO BRASILEIRO DE CIÊNCIA DO SOLO, 34, 2013, Florianópolis. Anais... Florianópolis: SBCS, 2013. p. 1-4. 
SILVA, E. F. DA; SOUZA, E. G. F.; SANTOS, M. G.; ALVES, M. J. G.; JÚNIOR, A. P. B.; SILVEIRA, L. M. DA.; SOUSA, T. P. DE. Qualidade de mudas de pepino produzidas em substratos à base de esterco ovino. Agropecuária Científica no Semiárido, v. 10, p. 93-99, 2014.

SILVA, M. R. R. DA.; IGNACIO, L. A. P.; SILVA, G. A. DA. Desenvolvimento de mudas de maracujá amarelo em função de diferentes doses fósforo reativo. Revista de AgronegócioReagro, Jales, v. 6, n. 1, p. 41-50, 2017.

SOUZA, E. G. F.; BARROS JÚNIOR, A. P.; SILVEIRA, L. M.; SANTOS, M. G.; SILVA, E. F. Emergência e desenvolvimento de mudas de tomate IPA 6 em substratos, contendo esterco ovino. Revista Ceres, v. 60, p. 902-907, 2013.

WÜRZ, D. A.; FILHO, J. L. M.; BEM, B. P. DE.; ALLEBRANDT, R.; OUTEMANE, M.; RUFATO, L. Panorama e perspectivas da comercialização de espumantes no Brasil. In: II Simpósio Internacional de Inovação em Cadeia Produtivas do Agronegócio - Universidade De Caxias do Sul, 2016, Caxias do Sul - RS. Anais... Caxias do Sul: 2017. p. 103-110.

ZHANG, N.; HOADLEY, A.; PATEL, J.; LIM, S.; LI, S. Sustainable options for the utilization of solid residues from wine production. Waste management, v. 60, p. 173-183, 2017.

ZOCCA, F.; LOMOLINO, G.; CURIONI, A.; SPETTOLI, P.; LANTE, A. Detection of pectin methyl esterase activity in presence of methanol during grape pomace storage. Food Chemistry, London, v. 102, n. 1, p. 59-65, 2007. 


\title{
Capítulo 22
}

\section{Reaproveitamento do lodo de curtume como fonte de adubação alternativa para produção de mudas de café conilon no estado do Espírito Santo}

\author{
Leonardo Martineli1, Sávio da Silva Berilli², Lucas Alves Rodrigues³, Ana Paula Cândido \\ Gabriel Berilli2, Paola Alfonsa Vieira Lo Monaco ${ }^{4}$, Gustavo Haddad Souza Vieira ${ }^{4}$
}

\section{Introdução}

O lodo de curtume é um resíduo industrial que apresenta potencial de uso como um adubo agrícola alternativo, pois é rico em vários nutrientes importantes para as plantas como o nitrogênio, fósforo, potássio, enxofre e magnésio (SELBACH et al., 1991). Em alguns estados brasileiros já existem normativas que estabelecem critérios para a utilização do lodo de curtume na agricultura, como é o caso de São Paulo, que tem normas estabelecidas pela COMPANHIA AMBIENTAL DO ESTADO DE SÃO PAULO (CETESB). No entanto, outros estados, como o Espírito Santo, são mais restritivos quanto à utilização desse resíduo e, não possuem legislação própria para sua utilização. Dessa forma, nos últimos anos, buscou-se realizar estudos que pudessem esclarecer os critérios necessários de utilização desses resíduos nas atividades agrícolas como um adubo alternativo, principalmente para a cultura do café conilon no estado do Espírito Santo, com intuito de gerar informações importantes para que o Estado poça estabelecer suas próprias normativas para o uso desse resíduo.

A maior parte dos estudos mencionados busca por formas de utilização desse resíduo como componente do substrato para produção de mudas de café conilon. Visto que, a utilização de resíduos industriais de interesse agrícola, em substratos de mudas de plantas arbóreas ou arbustivas, como o café conilon, constitui-se em uma interessante alternativa para o uso de resíduos potencialmente poluentes, como é o caso do lodo de curtume, considerando que a forma como são implantadas as lavouras permite a distribuição diluída e sistematizada nos plantios, proporcionam a redistribuição desses resíduos na natureza, de forma ecológica e coerente com o uso dos recursos naturais disponíveis no Planeta (COSTA

${ }^{1}$ Me. em Agroecologia pelo Programa de Pós-Graduação em Agroecologia do Instituto Federal do Espírito Santo - Campus de Alegre, Caixa Postal 47, CEP: 29500-000, Alegre-ES Email: leonardo.martineli@ifes.edu.br

${ }^{2}$ Drs. Professores do Instituto Federal do Espírito Santo - Campus de Alegre, Caixa Postal 47, CEP: 29500-000, Alegre-ES. E-mail: savio.berilli@ifes.edu.br; ana.berilli@ifes.edu.br

${ }^{3} \mathrm{Me}$. em Agroecologia pelo Programa de Pós-Graduação em Agroecologia do Instituto Federal do Espírito Santo - Campus de Alegre, Caixa Postal 47, CEP: 29500-000, Alegre-ES. E-mail: rodriguesdelazari.edu@gmail.com

${ }^{4}$ Drs. Professores do Instituto Federal do Espírito Santo - Campus Santa Teresa, Rod ES 080, km 93, São João de Petrópolis, CEP: 29650-000, Santa Teresa-ES. E-mail: paola.monaco@ifes.edu.br; ghsv@ifes.edu.br. 
et al., 2001). De maneira que, a utilização desses resíduos industriais na forma de substratos para produção de mudas é uma alternativa para tornar o processo produtivo mais sustentável, uma vez que contribui para redução e eliminação de um dos problemas ambientais decorrentes da atividade humana (ALVES e BARBOSA, 2013).

O Espírito Santo é um estado, notadamente, voltado para a atividade agrícola cafeeira, principalmente o café conilon e, a demanda por mudas dessa espécie tem sido frequente, visto que grande parte dos cafezais capixabas são frequentemente substituídos por novas lavouras com materiais genéticos melhorados e maior tecnologia (FERRÃO et al., 2017). Para atender esta demanda, produtores de mudas de café vêm buscando alternativas para diminuir custos de produção, de modo que estudos sobre a utilização de adubos alternativos seria uma opção interessante para promover a sustentabilidade da atividade permitindo aos viveiristas reduzirem custos. Neste contesto, diversos estudos já foram realizados utilizando o lodo de curtume no substrato para produção de mudas de café conilon (BERILLI et al., 2014; BERILLI et al., 2015; BERILLI et al., 2016; BERILLI et al., 2018; QUARTEZANI et al., 2018a; QUARTEZANI et al., 2018b).

Este capítulo terá como objetivo, tratar da importância da cultura do café conilon para o estado do Espirito Santo, bem como, reunir informações de pesquisas já realizadas sobre o potencial de uso do lodo de curtume como um adubo alternativo para produção de mudas dessa variedade café.

\section{A cafeicultura conilon no estado do Espírito Santo}

A mais de um século o café conilon está inserido na história do Espírito Santo. Sua introdução no Estado teve início no ano de 1912, quando o então governador Jerônimo Monteiro trouxe as primeiras mudas e sementes, que foram plantadas na cidade de Cachoeiro de Itapemirim, na região Sul do estado (DA SILVA et al., 2017). Entretanto, passaram-se décadas até que a cultura do café conilon se estabelecesse definitivamente no Estado, tendo sua grande expansão por terras capixaba ocorrido apenas a partir da década de 60, principalmente, por consequência da crise mundial do café arábica, que levou à erradicação de grande parte das lavouras capixabas dessa variedade (SCHMIDT et al., 2004).

Segundo De Muner (2017), a implementação das ações do Plano de Renovação e Revigoramento das Lavouras Cafeeiras do estado do Espírito Santo, aplicado partir de 1971, levou ao surgimento das primeiras lavouras tecnificadas de café conilon no município de São Gabriel da Palha, expandindo-se, posteriormente, para todas as regiões do Estado. Desde então, essa nova variedade de café passou a ganhar força com o surgimento e crescimento da indústria de cafés solúveis, bem como o emprego dessa espécie em 
misturas com o café arábica, sendo um dos principais fatores responsáveis pelo desenvolvimento da cultura no estado do Espírito Santo (FERRÃO, 2004).

A partir dos fatos já relatados, a atividade de cafeicultura conilon no estado do Espírito Santo se desenvolveu de forma tão expressiva que tornou-se sua principal atividade agrícola, levando o Estado, que ocupa apenas 0,5\% do território nacional, a ser, atualmente, o maior produtor nacional de café conilon. Segundo dados da COMPANHIA NACIONAL DE ABASTECIMENTO - CONAB, o Espírito Santo produziu um total de 13,4 milhões de sacas beneficiadas no ano de 2019, sendo 10,4 milhões referentes ao café conilon, representando aproximadamente $70 \%$ da produção nacional dessa variedade de café (CONAB, 2020). Estudos mostram que o café conilon é a principal fonte de renda em $80 \%$ das propriedades rurais capixabas localizadas em terras quentes, responsável por 35\% do PIB agrícola, sendo que, atualmente, o Estado conta com aproximadamente 283 mil hectares plantados com café conilon, distribuídos por cerca de 40 mil propriedades rurais em 63 municípios, com aproximadamente 78 mil famílias produtoras (INCAPER, 2020).

A necessidade de se aumentar a produtividade das lavouras cafeeiras no Estado, fez com que diversos estudos fossem realizados na busca pelo aprimoramento de novas tecnologias. A partir de 1985, em virtude da importância social e econômica dessa cultura e dos principais problemas encontrados na produção do café Conilon, o INSTITUTO CAPIXABA DE PESQUISA, ASSISTÊNCIA TÉCNICA E EXTENSÃO RURAL (INCAPER) iniciou um programa de melhoramento da espécie, visando, sobretudo, disponibilizar aos cafeicultores capixabas materiais genéticos mais adequados às suas necessidades, uma vez que até aquela época, as variedades usadas pelos produtores eram propagadas por meio de sementes, com grande heterogeneidade das plantas com relação à produção e outras características, causando dificuldade de manejo, baixo potencial geral de produção e uma qualidade inferior do produto final (FERRÃO et al., 2017).

O sucesso de uma lavoura cafeeira, com certeza, passa pela escolha adequada dos melhores materiais genéticos para a região, assim como, pela qualidade das mudas a serem plantadas. Segundo Braun et al. (2009), a produção de mudas de alta qualidade genética e fitossanitária constitui-se um requisito indispensável para alcançar elevadas produtividades na agricultura, de maneira que estas mudas devem ser produzidas dentro de padrões mínimos de qualidade para se obter sucesso no empreendimento. Tatagiba et al. (2010) afirmam que o primeiro passo para a formação de uma lavoura cafeeira produtiva é a produção de mudas sadias e vigorosas. Contudo, uma boa produção de café também depende, em grande parte, de tratos culturais adequados e de fatores fisiológicos e ambientais favoráveis ao desenvolvimento da cultura (EFFEGEN et al., 2008; TAQUES e DADALTO, 2017). 
Um dos grandes desafios da agricultura moderna é, sem dúvidas, a manutenção da sustentabilidade das lavouras, e para o café conilon do Espírito Santo, não é diferente. A cultura se estabeleceu no Estado num período de pós-guerra mundial, conhecido como Revolução Verde, que teve papel fundamental no avanço de pesquisas e aporte de tecnológico para a cultura. Entretanto, as tecnologias desenvolvidas para o café conilon, tornaram a atividade excessivamente dependente de insumos industrializados, como é caso dos fertilizantes convencionais, tornando o custo de produção mais elevado, sem falar no custo ambiental causado pelo uso excessivo desses insumos. Autores como Gronroos et al. (2006), veem preocupação a grande quantidade de energia investida na produção de alimentos, pois muitas vezes tem sido maior que o retorno conseguido em valor energético dos produtos, gerando balanço negativo dos sistemas comprometendo sua sustentabilidade.

Uma alternativa para dar maior sustentabilidade para a cafeicultura conilon no Espírito Santo pode estar na utilização de fontes alternativas de nutrientes para as plantas, como por exemplo, resíduos da própria atividade agrícola ou mesmo das indústrias que processão produtos da agricultura, pois normalmente representam um menor custo para os produtores, bem como, permitem um tratamento integral a todos os elementos dos agroecossistemas, aliando estratégias de reutilização de materiais e energia à redução, ou mesmo, à eliminação de insumos convencionais dos sistemas de cultivo, consequentemente levando também a uma redução dos impactos ambientais causados pela atividade cafeeira conilon.

\section{Uso do lodo de curtume na produção de mudas de café conilon}

O lodo de curtume é um resíduo industrial que tem origem no processo de tratamento dos efluentes gerados na produção do couro. Segundo Claas e Maia (1994), para cada pele processada são gerados, em média, $12 \mathrm{~kg}$ de lodo de curtume desidratado. Sendo estes lodos, constituídos de materiais orgânicos de origem animal misturados com sais inorgânicos, e alguns desses componentes presentes em sua composição são nutrientes essenciais para as plantas (nitrogênio, cálcio, enxofre, fósforo, magnésio e potássio), enquanto outros são considerados agentes corretivos da acidez do solo (carbonatos, hidróxidos de cálcio e sulfetos) (SELBACH et al., 1991). Sendo assim, o lodo de curtume torna-se um adubo alternativo em potencial para as plantas por apresentar características agronômicas favoráveis.

O uso agrícola de resíduos industriais no solo como fonte de nutrientes e matéria orgânica para as plantas é reconhecido há décadas pela ciência como algo positivo. De maneira que diversos resíduos são recomendados pelo valor corretivo e fertilizante que estes apresentam, bem como pela capacidade da macro e microbiota do solo em decompor 
os materiais orgânicos. É necessário, entretanto, estudar as alterações nas propriedades do solo e a resposta das plantas para avaliar o potencial fertilizante de alguns resíduos e a possível contaminação do ambiente causada por elementos tóxicos (FERREIRA et al., 2003).

Segundo Konrad e Castilhos (2002) e Ferreira et al. (2003), o uso agrícola do lodo de curtume pode contribuir para a melhoria da fertilidade dos solos e nutrição das plantas, além de representar uma forma de disposição do resíduo no meio ambiente. Neste contexto, Wad (2005) entende que os solos constituem o melhor e mais seguro meio para a disposição de resíduos, pois são capazes de melhor oxidar e precipitar os poluentes contidos nestes resíduos e removê-los da cadeia alimentar, de modo mais seguro que o ar ou a água. $\mathrm{O}$ uso do solo pode ser recomendado como depurador de cargas orgânicas, em decorrência dos mecanismos intrínsecos à sua organização, baseados em uma perfeita interação da atividade biológica e de suas propriedades físico-químicas (BORGES, 2003).

Quanto a esses aspectos mencionados anteriormente, deve-se destacar a necessidade de critérios técnicos para aplicação desses resíduos na agricultura, uma vez que tal prática, quando utilizada de forma inadequada, pode ocasionar sérios danos ambientais, comprometendo o uso agrícola dessas áreas de forma sustentável. De modo que, estudos envolvendo o uso de resíduos da indústria na agricultura são tidos como importantes ferramentas para possibilitar seu emprego de forma segura para o meio ambiente.

Com relação ao uso do lodo de curtume na fertilização das mudas de café conilon (Coffea canephora), os trabalhos encontrados relatam o potencial promissor de uso deste resíduo. Entretanto, estes mesmos trabalhos também relatam a ocorrência de alguns efeitos tóxicos que causam estresse nas plantas. Por exemplo, Berilli et al. (2014) realizaram um estudo usando doses de lodo de curtume desidratado e adubação convencional e relataram que o uso de lodo de curtume acima de $40 \%$ apresentou distúrbios fisiológicos que comprometem o funcionamento do fotossistema II, sendo que, para os autores estes efeitos possivelmente estão relacionados à presença do cromo e/ou sódio na composição do lodo de curtume.

Buscando uma solução para os problemas encontrados no lodo de curtume, Berilli et al. (2018) realizaram um estudo utilizando diferentes doses de húmus (10\%, 20\%, 30\% e 40\%) misturadas a uma dose fixa de $30 \%$ de lodo de curtume desidratado, e perceberam que o uso em conjunto do húmus associado ao lodo de curtume melhora a eficiência do substrato de produção de mudas de café conilon.

O lodo de curtume também é encontrado na forma líquida, e pode ser usado para a fertilização das plantas por via foliar, como mostra um estudo realizado por Salles et al. (2018), que teve como objetivo avaliar a eficiência do lodo de curtume líquido como alternativa de adubação foliar em mudas de café conilon. O estudo mostrou que a 
fertilização com lodo de curtume diluído acima de 14,23 $\mathrm{ml} \mathrm{L}^{-1}$ apresentou efeitos tóxicos às mudas de café conilon, entretanto, as doses entre 8,80 e $14,23 \mathrm{ml} \mathrm{L}^{-1}$ apresentaram resultados satisfatórios e mostraram potencial de utilização para a produção de mudas de café conilon, na ocasião, os autores também suspeitaram que os resultados negativos encontrados nas doses acima de $14,23 \mathrm{ml} \mathrm{L}^{-1}$ de lodo de curtume sejam causados pela presença, em excesso, dos elementos cromo e sódio no lodo.

Apesar dos trabalhos citados relatarem benefícios na utilização dos resíduos de curtume nas suas diferentes formas e doses, notadamente, esses também fazem referências às características negativas do lodo de curtume, as quais são normalmente relacionadas e/ou atribuídas ao conteúdo de cromo e sódio contidos nestes lodos. Dessa maneira, Martineli (2019) buscou desvendar os efeitos dos elementos cromo e sódio presente no lodo de curtume, sobre parâmetros fisiológicos e anatômicos de mudas de café conilon, utilizando uma dose de $40 \%$ de lodo de curtume misturada ao substrato, e avaliando de que forma esses elementos podem influenciar no desenvolvimento das mudas. $O$ estudo revelou que a presença do elemento sódio $(\mathrm{Na})$, causa danos severos à fisiologia e anatomia das mudas de café conilon, prejudicando o seu desenvolvimento. Já com relação ao elemento cromo (Cr), o autor não verificou efeitos negativos nas plantas, porém revela uma ação atenuadora em relação aos efeitos negativos ligados ao sódio no substrato. Martineli (2019) ainda destacou a possibilidade de o elevado valor de $\mathrm{pH}$ do lodo de curtume $(12,3)$ ser o principal responsável por grande parte dos efeitos deletérios relatados nos trabalhos estudados.

\section{Considerações finais}

O uso do lodo de curtume como um adubo alternativo para produção de mudas de café conilon, em alguns estudos demonstrou resultados positivos, que de fato, confirmam seu potencial como um adubo inovador, mostrando ser um produto promissor a ser utilizado.

A utilização deste resíduo industrial como parte dos substratos para produção de mudas conilon tende a ser uma alternativa para tornar o processo produtivo mais sustentável, uma vez que contribui para redução dos custos destinados a aquisição de adubos convencionais, ao mesmo tempo em que promover a eliminação de um grave problema ambiental decorrente da atividade humana.

É necessária, entretanto, a realização de novos estudos que busquem por formas de mitigação dos efeitos deletérios causados pelo lodo de curtume às mudas de café conilon, que possam viabilizar a recomendação desse resíduo para ser usado como um fertilizante alternativo na produção de mudas de café conilon. 


\section{Referências}

ALVES, V. C.; BARBOSA, A. S. Práticas de gestão ambiental das indústrias coureiras de Franca-SP. Gestão \& Produção, v. 20, n. 4, 2013.

BERILLI, S. S.; QUIUQUI, J. P. C.; REMBINSKI, J.; SALLA, P. H. H.; BERILLI, A. P. C. G.; LOUZADA, J. M. Utilização de lodo de curtume como substrato alternativo para produção de mudas de café conilon. Coffee Science, Lavras, v. 9, n. 4, p. 472-479, out./dez. 2014.

BERILLI, S. S.; BERILLI, A. P. C. G.; CARVALHO, A. J. C.; FREITAS, S. J.; FONTES, P. S. F. Níveis de cromo em mudas de café conilon desenvolvidas em substrato com lodo de curtume como adubação alternativa. Coffee Science, Lavras, v. 10, n. 3, p. 320-328, jul./set. 2015.

BERILLI, S. S.; ZOOCA, A. A. F.; REMBINSKI, J.; SALLA, P. H. H.; ALMEIDA, J. D.; MARTINELI, L. Influência do acúmulo de cromo nos índices de compostos secundários em mudas de café conilon. Coffee Science, Lavras, v. 11, n. 4, p. 512-520, out. / dez. 2016.

BERILLI, S. S.; MARTINELI, L.; FERRAZ, T. M.; FIGUEIREDO, F. A. M. M. A.; RODRIGUES, W. P.; BERILLI, A. P. C. G.; SALES, R. A.; FREITAS, S. J. Substrate stabilization using humus with tannery sludge in conilon coffee seedlings. Journal of Experimental Agriculture International, v. 21, p. 1-10, 2018.

BORGES, J. D. Efeitos do lodo de curtume nas culturas do milho (Zea mays L.) e do capim braquiarão [Brachiaria brizanta (Hochst ex A. Rick) Sapf.] cultivar marandu em Latossolo vermelho-amarelo. Goiânia, 2003. 244 f. Tese (Doutorado em Agronomia). Universidade Federal de Goiás, Goiânia - Go, 2003.

BRAUN, H.; ZONTA, J. H.; LIMA, J. S. S.; REIS, E. F.; SILVA, D. P. Desenvolvimento inicial do café conillon (Coffea canephora Pierre) em solos de diferentes texturas com mudas produzidas em diferentes substratos. Idesia, v. 27, n. 3, p. 35-40, 2009.

CLAAS, I. C.; MAIA, R. A. M. Manual básico de resíduos industriais de curtume. Porto Alegre: Senai, 1994. 664p.

COMPANHIA NACIONAL DE ABASTECIMENTO. Acompanhamento da safra brasileira de café - Safra 2019, Brasília, v. 4, p. 21, dez. 2020.

COSTA, C. N.; CASTILHOS, D. D.; CASTILOS, R. M. V.; KONRAD, E. E.; PASSIANOTO, C. C.; RODRIGUES, C. G. Efeito de adição de lodo de curtume sobre as alterações químicas do solo, rendimento de matéria seca e absorção de nutrientes em soja. Revista Brasileira de Agrociência, Pelotas, v. 7, n. 3, p. 189-191, 2001.

DA SILVA, A. E. S; MASO, L. J.; COSTA, E. B.; BASSANI, L. A.; GALEANO, E. A. V. Importância econômica e social do café conilon no Estado do Espírito Santo. In: FERRÃO, R. G.; FONSECA, A. F. A.; BRAGANÇA, S. M.; FERRÃO, M. A. G.; DE MUNER, L. H. (Eds.). Café conilon, 2. ed. Vitória: INCAPER, p. 56-67.

DE MUNER, L. H.; CAPORAL, F. R.; FORNAZIER, M. J.; RONCA, P. P. F.; BRANDO, J. A. P.; PADOVAN, M. P. Cafeicultura sustentável do conilon. In: FERRÃO, R. G.; FONSECA, A. F. A.; BRAGANÇA, S. M.; FERRÃO, M. A. G.; DE MUNER, L. H. (Eds.). Café conilon, 2. ed. Vitória: INCAPER, 2017. p. 621-653. 
EFFEGEN, T. A. M.; PASSOS, R. R.; LIMA, J. S. S.; BORGES, E. N.; DARDENGO, M. C. J. D.; REIS, E. F. Atributos químicos do solo e produtividade de lavouras de cafeeiro conilon submetidas a diferentes tratos culturais no sul do Estado do Espírito Santo. Bioscience Journal, v. 24, n. 2, p. 7-18, 2008.

FERRÃO, R. G. Biometria aplicada ao melhoramento genético do café conilon. Viçosa, 2004. 256 f. Tese (Doutorado em Genética e Melhoramento) - Universidade Federal de Viçosa, Viçosa - MG, 2004.

FERRÃO, R. G.; FERRÃO, M. A. G.; FONSECA, A. F. A.; VOLPI, P. S.; VERDIN FILHO, A. C.; TÓFFANO, J. L.; TRAGINO, P. H.; BRAGANÇA, S. M. Cultivares de café conilon. In: FERRÃO, R. G.; FONSECA, A. F. A.; BRAGANÇA, S. M.; FERRÃO, M. A. G.; DE MUNER, L. H. (Eds.). Café conilon, 2. ed. Vitória: INCAPER, 2017. p. 219-241

FERREIRA, A. S.; CAMARGO, F. A. O.; TEDESCO, M. J.; BISSANI, C. A. Alterações de atributos químicos e biológicos de solo e rendimento de milho e soja pela utilização de resíduos de curtume e carbonífero. Revista Brasileira de Ciência do Solo, v. 27, p. 755763, out./dez. 2003.

GRÖNROOS, J.; SEPPÄLÄ, J.; VOUTILAINEN, P.; SEURI, P.; KOIKKALAINEN, K. Energy use in conventional and organic milk and rye bread production in Finland. Agriculture, Ecosystems \& Environment, v. 117, n. 2-3, p. 109-118, 2006.

INSTITUTO CAPIXABA DE PESQUISA, ASSISTÊNCIA TÉCNICA E EXTENSÃO RURAL. Disponível em: <https://incaper.es.gov.br/cafeicultura-conilon>, Acesso em: 20 ago. 2020.

KONRAD, E. E.; CASTILHOS, D. D. Alterações químicas do solo e crescimento do milho decorrente da adição do lodo de curtume. Revista Brasileira de Ciência do Solo, v. 26, p. 257-265, 2002.

MARTINELI, L. Influência do cromo e sódio presentes no lodo de curtume desidratado, no desenvolvimento e fisiologia das mudas de café conilon. Alegre, 2019. Dissertação (Mestrado em Agroecologia), Instituto Federal do Espírito Santo- campus de Alegre, AlegreES, 2019.

QUARTEZANI, W. Z.; SALES, R. A.; PLETSCH, T. A.; BERILLI, S. S.; NASCIMENTO, A. L.; HELL, L. R.; MANTOANELLI, E.; BERILLI, A. P. C. G.; SILVA, R. T. P.; TOSO, R. Conilon plant growth response to sources of organic matter. African Journal of Agricultural Research, v. 13, n. 4, p. 181-188, 2018a.

QUARTEZANI, W. Z.; SALES, R. A.; BERILLI, S. S.; PLETSCH, T. A.; RODRIGUES, W. P.; CAMPOSTRINI, E.; BERNARDO, W. P.; OLIVEIRA, E. C.; HELL, L. R.; MANTOANELLI, E. Effect of different sources of organic matter added to the substrate on physiological parameters of clonal plants of conilon coffee. Australian Journal of Science, v. 08, p. 1328$1334,2018 \mathrm{~b}$.

SALES, R. A.; ROSSINI, F. P.; BERILLI, S. S.; GALVÃO, E. R.; MENDES, T. P.; BERILLI, A. P. C. G.; SALLES, R. A.; SALES, R. A.; QUARTEZANI, W. Z.; FREITAS, S. J. Foliar fertilization using liquid tannery sludge in conilon coffee seedlings production. Journal of Experimental Agriculture International, n. 22, n. 2, p. 1 - 8, 2018.

SELBACH, P. A.; TEDESCO, M. J.; GIANELLO, C. Descarte e biodegradação de lodos de curtume no solo. Revista do Couro, v. 4, n. 1, p. 51-62, 1991. 
SCHMIDT, H. C.; DE MUNER, L. H.; FORNAZIER, M.J. (Eds.). Cadeia produtiva do café arábica da agricultura familiar no Espírito Santo. Vitória: INCAPER, 2004. 52p.

TAQUES, R. C.; DADALTO, G. G. Zoneamento agroclimátológico para a cultura do café Conilon no Estado do Espírito Santo. In: FERRÃO, R. G.; FONSECA, A. F. A.; BRAGANÇA, S. M.; FERRÃO, M. A. G.; DE MUNER, L. H. (Eds.). Café conilon, 2. ed. Vitória: INCAPER, 2017. p. 69-79.

TATAGIBA, S. D.; SANTOS, E. A.; PEZZOPANE, J. E. M.; REIS, E. F. Mudas de Coffea canephora cultivadas sombreadas e a pleno sol. Revista Engenharia na AgriculturaReveng, v. 18, n. 3, p. 219-226, 2010.

WAD, P. G. S. Lodo de curtume: alternativa na recuperação de áreas degradadas. Agronline, out. $2005 . \quad$ Disponível em: <http://www.agronline.com.br/artigos/artigo.php?id=262>. Acesso em: 05 jul. 2020. 


\title{
Capítulo 23
}

\section{Uso do vinhoto associado ao lodo de curtume como fertilizante foliar na produção de mudas de café conilon}

\author{
Lucas Alves Rodrigues ${ }^{1}$, Sávio da Silva Berilli², Ana Paula Candido Gabriel Berilli², Waylson \\ Zancanella Quartezani ${ }^{3}$, Laís Gertrudes Fontana Silva ${ }^{4}$, Nadhyla Pião Felberg ${ }^{5}$, Paola \\ Alfonsa Vieira Lo Monaco ${ }^{6}$, Gustavo Haddad Souza Vieira ${ }^{6}$
}

\section{Introdução}

O cultivo do café conilon destaca-se no Espírito Santo influenciando a economia de mais de $80 \%$ dos municípios do estado. A previsão atual para as espécies de conilon é uma produção entre 9,01 e 10,67 milhões de sacas e para o arábica entre 4,01 e 4,77 milhões de sacas, o que resulta em uma produção total entre 13,02 e 15,44 milhões de sacas, colocando o Estado em posição de destaque na economia brasileira e internacional (CONAB, 2020).

Esse destaque da cafeicultura no Espírito Santo nos últimos anos deve-se à reforma do parque cafeeiro, às adaptações dos atuais sistemas de plantio e ao aumento da área plantada. Essas adaptações da produção nacional de café exigiram grandes quantidades de mudas (DARDENGO et al., 2013).

No que diz respeito à produção de mudas, a qualidade depende do estabelecimento de boas taxas de sobrevivência. Plantas bem nutridas demonstram rápido crescimento inicial, além de reduzir custos com práticas de replantio. A formação da cultura do café é influenciada pela qualidade das mudas, elas devem apresentar desenvolvimento vigoroso e um sistema radicular bem formado (MARTINS et al., 2015).

Devido às adaptações aos atuais sistemas de plantio, a produção de mudas de café conilon no estado do Espírito Santo está em constante crescimento, seja para produção

\footnotetext{
${ }^{1}$ Me. em Agroecologia pelo Programa de Pós-Graduação em Agroecologia do Instituto Federal do Espírito Santo - Campus de Alegre, Caixa Postal 47, CEP: 29500-000, Alegre-ES. E-mail: rodriguesdelazari.edu@gmail.com

${ }^{2}$ Drs. Professores do Instituto Federal do Espírito Santo - Campus de Alegre, Caixa Postal 47, CEP: 29500-000, Alegre-ES. E-mail: savio.berilli@ifes.edu.br; ana.berilli@ifes.edu.br

${ }^{3}$ Dr. Professor do Instituto Federal do Espírito Santo - Campus Montanha, CEP: 29890-000, Montanha-ES. E-mail: waylson.quartezani@ifes.edu.br

${ }^{4}$ Mestranda pelo Programa de Pós-Graduação em Agricultura Tropical da Universidade Federal do Espírito Santo, CEP: 29932-540, São Mateus-ES. E-mail: laiisfontana@hotmail.com

${ }^{5}$ Graduada em Agronomia pelo Instituto Federal do Espirito Santo - Campus Itapina, CEP: 29717-000, Itapina-ES. E-mail: nadhyla.felberg@gmail.com

${ }^{6}$ Drs. Professores do Instituto Federal do Espírito Santo - Campus Santa Teresa, Rod ES 080, km 93, São João de Petrópolis, CEP: 29650-000, Santa Teresa-ES. E-mail: paola.monaco@ifes.edu.br; ghsv@ifes.edu.br.
} 
doméstica, seja para comercialização de mudas. Os viveiristas utilizam fertilizantes foliares comerciais que têm boa aceitação no mercado e são considerados de boa qualidade para manter a produção de mudas com desenvolvimento vigoroso, no entanto, implicam altos custos de produção.

Nesse contexto, é possível identificar que nos últimos anos fontes alternativas de resíduos industriais ou agroindustriais tem sido palco de inúmeros estudos, destacando-se como uma solução para tornar ambas as atividades ecologicamente corretas e mais sustentáveis, pois visa eliminar um problema ambiental na indústria, pelo fato de serem aproveitados e dispostos de maneira harmônica no meio ambiente e, ao mesmo tempo, promover a redução dos custos de produção da agricultura, beneficiando toda a cadeia, do produtor ao consumidor (MENEGHELLI et al., 2016).

Para tornar o processo de produção mais sustentável e econômico, é necessário realizar pesquisas voltadas ao uso de resíduos, por exemplo, o lodo de curtume bovino e vinhoto produzido pelas destilarias de cachaça, que têm potencial como fertilizantes foliares na produção de mudas de café conilon.

O lodo de curtume mencionado acima resulta do processamento do couro, composto por sais inorgânicos misturados com materiais orgânicos de origem animal. Alguns desses componentes presentes em sua composição são considerados agentes corretivos da acidez do solo (carbonatos, hidróxidos de cálcio e sulfetos) enquanto outros são nutrientes para as plantas (nitrogênio, cálcio, enxofre, fósforo, magnésio e potássio) (BERNARDI et al., 1991). Nesse contexto, o lodo de curtume, por apresentar características agronômicas favoráveis, torna-se uma fonte potencial de fertilização alternativa para as plantas.

Outro resíduo mencionado é o vinhoto, destacando-se por seu valor nutricional. Em geral, os macronutrientes presentes nesse resíduo seguem uma ordem decrescente de concentração, potássio $(K)$, enxofre $(S)$, cálcio $(\mathrm{Ca})$, nitrogênio $(\mathrm{N})$, magnésio $(\mathrm{Mg})$ e fósforo (P) (ROSSETTO et al., 2008). A viabilidade do uso desse resíduo como fertilizante foi demonstrada inicialmente na década de 1950 no cultivo de cana-de-açúcar (SCHULTZ et al., 2010).

O vinhoto é de fácil acesso no estado do Espírito Santo. O município de São Roque do Canaã se destaca na produção de cachaça, responsável por cerca de trinta destilarias, das quais vinte e três são registradas na prefeitura. Nesse sentido a produção de cachaça artesanal é uma das principais fontes da economia local. Nos últimos vinte anos, o vinhoto dessas destilarias foi descartado no rio Santa Maria, principal fonte de abastecimento do município (FREITAS et al., 2010).

Nesse contexto, observado o potencial e disponibilidade dos resíduos em estudo, o presente trabalho buscou avaliar o efeito da adubação foliar com a mistura de lodo de 
curtume associado ao vinhoto na forma liquida em diferentes concentrações na produção de mudas de café conilon.

\section{Metodologia}

O estudo foi realizado no Instituto Federal do Espírito Santo - Campus Itapina, localizado no município de Colatina, região noroeste capixaba, com coordenadas geográficas de $19^{\circ}$ 32 ' 22" de latitude sul; $40^{\circ} 37^{\prime}$ '50" de longitude oeste e altitude de 71 metros. O experimento foi conduzido em viveiro de propagação de mudas de café conilon dotado de sistema de microaspersão, mantendo-se a tensão de água no substrato próximo a capacidade de campo.

O arranjo experimental utilizado foi em delineamento inteiramente casualizado, sendo 6 tratamentos e 10 repetições, com 10 plantas em cada parcela, resultando em um total de 600 plantas no experimento $(6 \times 10 \times 10)$.

Os tratamentos consistiram em diferentes doses de vinhoto e lodo de curtume líquido diluído em água. As doses foram determinadas em função da quantidade de nitrogênio presente em cada resíduo (Tabela 1).

Tabela 1. Análise química do vinhoto e lodo de curtume.

\begin{tabular}{lcc}
\hline Parâmetro Analisado & Amostra Vinhoto $(\mathrm{mg} / \mathrm{L})$ & Amostra Lodo de Curtume $(\mathrm{mg} / \mathrm{L})$ \\
\hline Nitrogênio & 483,00 & $2.233,00$ \\
Fósforo & 47,00 & 559,00 \\
Potássio & $1.258,00$ & 122,00 \\
Cálcio & 210,00 & $9.000,00$ \\
Magnésio & 127,00 & $1.718,00$ \\
Enxofre & 275,00 & $3.697,00$ \\
Ferro & 19,00 & - \\
Zinco & 4,00 & - \\
Cobre & 2,00 & - \\
Manganês & 9,00 & - \\
Boro & 2,00 & 61,00 \\
Sódio & - & $3.500,00$ \\
Cromo & - & $1.875,00$ \\
\hline
\end{tabular}

Fonte: Os Autores.

Inicialmente foi calculada a quantidade (em gramas) de nitrogênio presente em 1 litro de ureia, utilizando-se a concentração de $0,45 \mathrm{~g} \mathrm{~N} / \mathrm{L}$, como tratamento convencional. O cálculo da quantidade (em gramas) de nitrogênio total $(\mathrm{Nt})$ repetiu-se para cada resíduo, constatando-se 2,23 g Nt/L no lodo de curtume e 0,483 g Nt/L no vinhoto. Em seguida para a efetiva realização das soluções adotou-se a formula:

$$
C i . V i=C f . V f
$$


Ci - Concentração inicial (nitrogênio total presente nos resíduos);

Vi - Volume inicial (1 litro);

Cf - Concentração final (Ureia $=0,45 \mathrm{gN} / \mathrm{L})$;

Vf - Volume final (quantidade total da solução resíduo + água).

Após a realização desse cálculo para todas as concentrações, obtém-se o volume final de todos os tratamentos, sendo assim subtraindo o volume final do inicial encontra-se a quantidade de água a ser acrescentada para cada tratamento.

$$
V a=V f-V i
$$

Va - Volume de água;

$\mathrm{Vf}$ - Volume final (quantidade total da solução resíduo + água);

$\mathrm{Vi}$ - Volume inicial (nitrogênio total presente nos resíduos).

Além dos tratamentos com os resíduos, também foi aplicada uma solução de ureia e $\mathrm{KCl}$ (adubação química nitrogenada e potássica) tida como adubação foliar convencional (FERRÃO et al., 2012), conforme descrito na tabela 2.

Tabela 2. Descrição dos tratamentos.

\begin{tabular}{|c|c|c|}
\hline Tratamentos & Descrição & $\begin{array}{c}\text { Volume de Calda } \\
\text { (Vinhoto+Lodo+Água) }\end{array}$ \\
\hline & $\begin{array}{l}\text { Tratamento com adubação química } \\
\text { nitrogenada e potássica (1grama/Litro) }\end{array}$ & \\
\hline T2 (90\%V+10\%L) & $\begin{array}{r}\text { Tratamento com } 90 \\
\text { de lodo } 0\end{array}$ & $\begin{array}{l}0,9 \text { litros de vinhoto }+0,1 \text { litros de } \\
\text { lodo }+0,46 \text { litros de água }\end{array}$ \\
\hline T3 (75\%V+25\%L) & $\begin{array}{l}\text { Tratamento com } 75 \% \text { de vinhoto }+25 \% \\
\text { de lodo de curtume }\end{array}$ & $\begin{array}{l}0,75 \text { litros de vinhoto }+0,25 \text { litros de } \\
\text { lodo }+1,04 \text { litros de água }\end{array}$ \\
\hline $\mathrm{T} 4(50 \% \mathrm{~V}+50 \% \mathrm{~L})$ & $\begin{array}{l}\text { Tratamento com } 50 \% \text { de vinhoto }+50 \% \\
\text { de lodo de curtume }\end{array}$ & $\begin{array}{l}0,5 \text { litros de vinhoto }+0,5 \text { litros de } \\
\text { lodo }+2,01 \text { litros de água }\end{array}$ \\
\hline T5 (25\%V+75\%L) & $\begin{array}{l}\text { Tratamento com } 25 \% \text { de vinhoto }+75 \% \\
\text { de lodo de curtume }\end{array}$ & $\begin{array}{l}0,25 \text { litros de vinhoto }+0,75 \text { litros de } \\
\text { lodo }+2,98 \text { litros de água }\end{array}$ \\
\hline T6 (10\%V+90\%L) & $\begin{array}{c}\text { Tratamento com } 10 \% \text { de vinhoto }+90 \% \\
\text { de lodo de curtume }\end{array}$ & $\begin{array}{l}0,1 \text { litros de vinhoto }+0,9 \text { litros de } \\
\text { lodo }+3,56 \text { litros de água }\end{array}$ \\
\hline
\end{tabular}

Fonte: Os Autores.

O plantio foi realizado no dia 09 de dezembro de 2018 com mudas de café conilon (Coffea canephora Pierre), cultivar clonal Vitória Incaper 8142 (clone 8). A produção se deu a partir de estacas obtidas do tecido adulto de ramos ortotrópicos, oriundos de lavouras com bom aspecto fitossanitário e nutricional. Ramos, retirados das plantas-mães, foram encaminhados para a casa de vegetação, local onde houve a eliminação de $30 \mathrm{~cm}$ das extremidades dos ramos ortotrópicos.

Em seguida houve a padronização das estacas, com 6 a $8 \mathrm{~cm}$ de altura, folhas com 1/3 do limbo foliar, ramos plagiotrópicos e acima da inserção do par de folhas com $1 \mathrm{~cm}$. O plantio das estacas foi realizado em sacolas de polietileno de $600 \mathrm{ml}$ previamente enchidas 
com o substrato (mistura recomendada) com 30 dias de antecedência (FERRÃO et al., 2012).

A adubação foliar foi aplicada quatro vezes com intervalo de 30 dias, sendo a primeira realizada 30 dias após o plantio das mudas, utilizando-se um pulverizador borrifador manual costal com capacidade de 5 litros, o mesmo é ideal para aplicação de fertilizantes. 0 experimento teve duração de 150 dias, período indicado para o transplantio das mudas de café conilon.

As avaliações de desenvolvimento foram realizadas mensalmente até 0 fim do experimento, as primeiras avaliações ocorreram 60 dias após o plantio das estacas, sendo repetidas a cada mês, contudo as últimas ocorreram aos 150 dias após o plantio das estacas, momento em que o experimento foi encerrado em campo.

As características avaliadas foram: área foliar $(\mathrm{AF}) \mathrm{em} \mathrm{cm}^{2}$, altura da planta $(\mathrm{AP}) \mathrm{em} \mathrm{cm}$; comprimento da raiz $(C R)$ em $\mathrm{cm}$; diâmetro do caule $(\mathrm{DCA})$ em $\mathrm{mm}$; diâmetro da copa (DCO) em cm e número de folhas (NF).

Após as mudas atingirem tamanhos apropriados para o plantio, aos 150 dias, foram realizadas as análises gravimétricas: massa fresca da parte aérea e do sistema radicular, massa seca da parte aérea e do sistema radicular (sendo que para isso, as amostras foram colocadas em estufa de circulação forçada a $70^{\circ} \mathrm{C}$ durante 72 horas e posterior pesagem em balança analítica de precisão). A metodologia utilizada foi semelhante à utilizada por Oliveira et al. (2014), Crispim et al. (2015) e Almeida et al. (2017).

Após a obtenção desses dados realizou-se o cálculo do Índice de Qualidade de Dickson (IQD) (DICKSON et al., 1960), obtido pela equação:

$$
I Q D=\frac{(M S R+M S P A)}{\left(\frac{A P}{D C}\right)+\left(\frac{M S P A}{M S R}\right)}
$$

Onde:

IQD = Índice de qualidade de Dickson;

$\mathrm{MSR}=$ Massa seca da raiz $(\mathrm{g})$;

MSPA = Massa seca da parte aérea $(g)$;

$\mathrm{AP}=$ Altura da planta $(\mathrm{cm})$;

$\mathrm{DC}=$ Diâmetro do caule $(\mathrm{mm})$.

Nos últimos anos, para avaliação da qualidade de mudas de hortaliças, muito tem se utilizado o IQD (MARIANI et al., 2014; COSTA et al., 2015). Por ser uma medida integrada, - IQD representa, simultaneamente, todas as características avaliadas (MARANA et al., 2008). 
Ao fim do experimento também foram feitas as avaliações fisiológicas: extração de clorofilas, índices de clorofila e compostos secundários com equipamentos de colorimetria (SPAD-502® - Minolta).

Para a avaliação indireta do teor de clorofila, foi utilizado o aparelho SPAD, realizando em três pontos de medições na folha, utilizando-se a média das avaliações, sendo esta etapa realizada em campo na parte da manhã, entre as $8 \mathrm{~h}$ e $11 \mathrm{~h}$. Ainda foi realizada uma amostragem foliar para ser quantificado os teores foliares de clorofila, com base na metodologia proposta por PORRA et al. (1989), onde serão quantificados os teores de clorofila total, clorofila a e clorofila b em função dos tratamentos.

Os dados foram submetidos ao teste $F$, havendo significância, foi realizada a análise de regressão. Não havendo significância na regressão, realizaram-se os testes de médias, esses foram comparados pelo teste de Dunnett a $5 \%$ de probabilidade em relação ao tratamento convencional (Nitrogênio), com auxílio do programa estatístico $R$ ( $R$ core team, 2016).

\section{Resultados e discussão}

\section{Análises de desenvolvimento}

Através dos dados obtidos na análise de regressão foi possível calcular as estimativas de concentrações ótimas para o vinhoto Xv (\%Vinhoto) e lodo de curtume Xv (\%Lodo de curtume) e valores máximos (Yv) dos parâmetros de desenvolvimento avaliados (Tabela 3).

Tabela 3. Concentrações ótimas estimadas para o vinhoto Xv (\%Vinhoto) e lodo de curtume Xv (\%Lodo de curtume) e valores máximos (Yv) estimados para cada parâmetro avaliado.

\begin{tabular}{ccccccc}
\hline & NF & AP & DCo & DCa & AF & CR \\
\cline { 2 - 7 } & Unidade & $----(\mathrm{cm})$ & \multicolumn{2}{c}{$(\mathrm{mm})$} & $\left(\mathrm{cm}^{2}\right)$ & $(\mathrm{cm})$ \\
\hline Xv Vinhoto & 50,4 & 48,7 & 66,0 & 61,3 & 50,1 & 44,0 \\
Xv Lodo de curtume & 49,6 & 51,3 & 34,0 & 38,7 & 49,9 & 56,0 \\
Yv & 6,6 & 6,12 & 15,57 & 2,4 & 47,65 & 19,72 \\
\hline
\end{tabular}

NF: Número de Folhas, AP: Altura da Planta, DCo: Diâmetro da Copa, DCa: Diâmetro do Caule, AF: Área Foliar, CR: Comprimento da Raiz.

Fonte: Os Autores.

\section{Altura da planta e comprimento da raiz}

Nos parâmetros altura da planta (AP) e comprimento da raiz (CR), observou-se que a tendência de um melhor desenvolvimento está relacionada com concentrações que permaneceram próximas do pico das curvas de regressão. O ponto máximo estimado para 
AP foi na concentração de $48,7 \%$ vinhoto $+51,3 \%$ lodo de curtume. As misturas que se destacaram para CR foram as que apresentam concentrações próximas do pico estimado da curva de regressão $44 \% \mathrm{~V}+56 \% \mathrm{~L}$ (Tabela 3). Justificando um potencial de crescimento superior aos tratamentos que se aproximam dessas proporções (Figura 1).
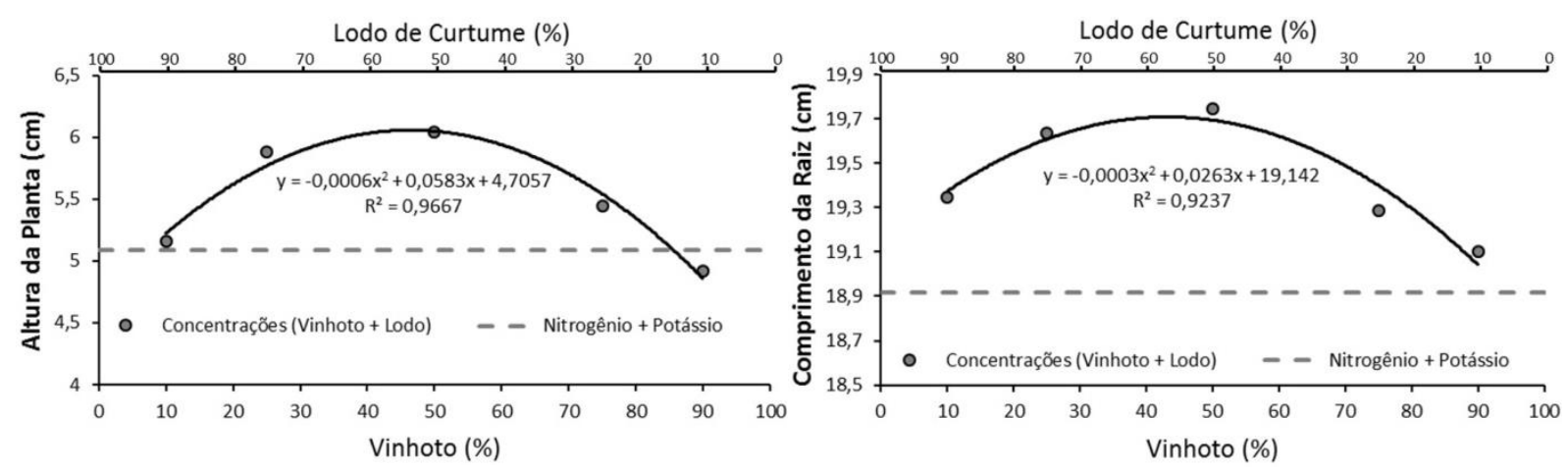

Figura 1. Regressão linear para os parâmetros altura da planta e comprimento da raiz. Fonte: Os Autores.

Segundo Berilli et al. (2014), a altura das plantas é umas das principais características em que os produtores de mudas de café conilon utilizam para determinar o ponto de comércio, sendo que nesse experimento as mudas produzidas com uso de vinhoto associado ao lodo de curtume como adubo foliar alternativo apresentaram crescimento considerável, demonstrando altura de até $6,1 \mathrm{~cm}$, tamanho aceitável pelos produtores da região norte do Espirito Santo.

Apesar da importância do nitrogênio e do potássio no cultivo do café, tanto no crescimento estrutural da planta quanto nos processos fotossintéticos, ainda é necessário fornecer os outros nutrientes essenciais, como fósforo e cálcio, que têm funções principalmente no desenvolvimento do sistema radicular (MESQUITA et al., 2016). Essa necessidade de fósforo e cálcio, especialmente na fase inicial do cultivo do café, foi apresentada na figura 1, onde o comportamento dos dados demonstra um desenvolvimento radicular superior nas concentrações envolvendo as misturas entre os dois resíduos estudados, sendo que eles possuem concentrações consideráveis desses dois elementos em suas composições (Tabela 1) e estão evidentemente disponíveis para absorção das plantas.

$\mathrm{Na}$ literatura é possível encontrar diversos valores para altura das mudas, assim sendo resultados demonstrados por Berilli et al. (2014) apresentam crescimento de até $5,7 \mathrm{~cm}$ de altura em mudas de café conilon cultivadas em substrato com adição de lodo de curtume desidratado. Também avaliando mudas de café conilon sob diferentes fontes de matéria orgânica Quartezani et al., (2018) encontraram um crescimento médio de 4,05 cm para 
altura das mudas cultivadas com $15 \%$ de lodo de curtume, enquanto que Sales et al. (2018) utilizando lodo de curtume liquido para fertilização de mudas de café conilon encontraram altura máxima das plantas em $24,5 \mathrm{~cm}$, nesse caso, as diferenças entre recipientes de cultivos, adubações, genótipos, ambientes e luminosidades podem estar relacionados às diferenças nos desenvolvimentos das mudas entre os experimentos.

\section{Número de folhas e área foliar}

Para o número de folhas (NF), observa-se um crescimento gradual até o ponto máximo da curva de regressão $50,4 \%$ de vinhoto $+49,6 \%$ lodo de curtume, com posterior decréscimo. Em relação à área foliar (AF) o ponto máximo estimado foi na concentração $50,1 \%$ de vinhoto $+49,9 \%$ lodo de curtume (Tabela 3 ), com posterior decréscimo (Figura 2 ).
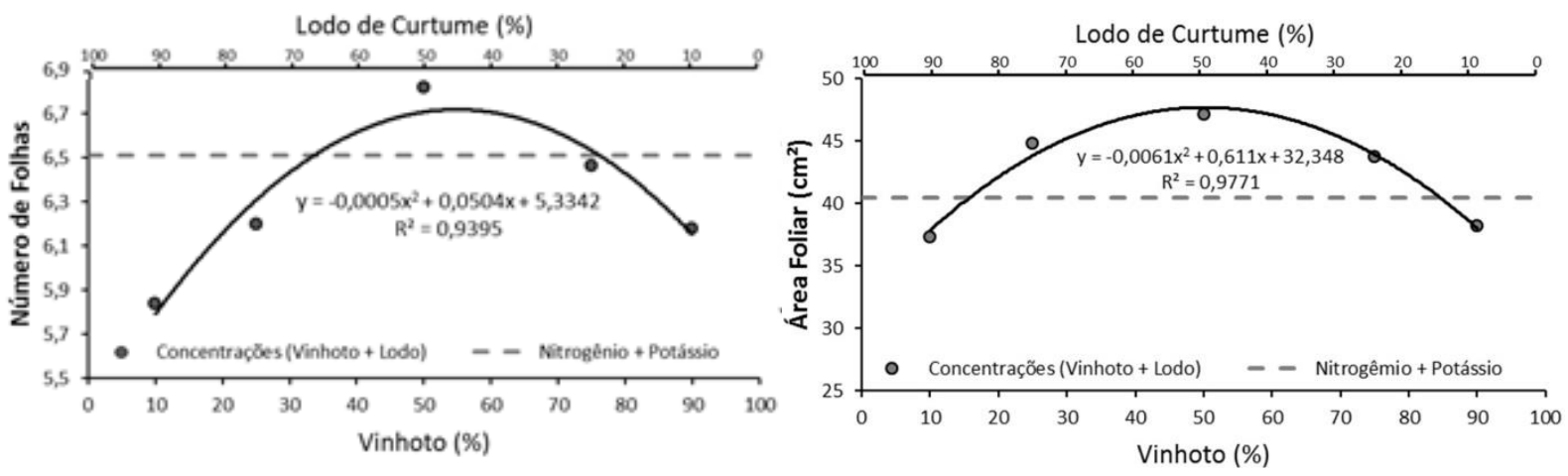

Figura 2. Regressão linear para os parâmetros número de folhas e área foliar. Fonte: Os Autores.

Como visto na figura 2, em relação ao $\mathrm{NF}$, o tratamento $\mathrm{N}+\mathrm{K}$ esteve próximo do pico da curva de regressão, com resultado inferior apenas em relação à concentração dos resíduos na proporção de $50 \%$ entre ambos. O bom desenvolvimento do número de folhas está relacionado ao nitrogênio, que atua no aumento da vegetação e formação de folhas verdes, e ao potássio, que atua na fotossíntese, respiração e circulação de seiva na planta, além da formação de amido nas folhas (SANTOS, 2015), essa é uma possível explicação para o resultado expressivo do tratamento convencional.

Embora quase todos os tratamentos que envolvem os resíduos não tenham apresentado resultados superiores ao $\mathrm{N}+\mathrm{K}$ para o número de folhas (Figura 2), o mesmo não ocorreu para a área foliar. Apenas as concentrações de resíduos nas proporções de $10 \% \mathrm{~V}+90 \% \mathrm{~L}$ e $90 \% \mathrm{~V}+10 \% \mathrm{~L}$ demonstraram resultados inferiores, sendo esses bem próximos do tratamento convencional. Nessa perspectiva, fica claro que as proporções entre os resíduos proporcionaram às plantas uma área foliar maior, logo, uma maior produção de fotoassimilados, partindo do pressuposto que a área foliar é um dos principais responsáveis 
pela fotossíntese e pode ser caracterizada, de acordo com Silva et al. (2011), como indicativo de produtividade.

Berilli et al. (2014) estudando o uso de lodo de curtume na cultura do café conilon, observaram resultados inferiores para o número de folhas em mudas cultivadas com lodo desidratado quando comparado ao substrato convencional, sendo a presença de nutrientes insuficientes no lodo um possível fator, principalmente o nitrogênio que diminui por volatilização, esta é uma explicação plausível para o mesmo evento neste experimento.

\section{Diâmetro da copa e diâmetro do caule}

O ponto máximo estimado para diâmetro da copa (DCo) foi na concentração $66 \% \mathrm{~V}+$ $34 \% \mathrm{~L}$, enquanto que para o parâmetro diâmetro do caule (DCa), o ponto máximo estimado da curva de regressão foi na concentração de $61,3 \% \mathrm{~V}+38,7 \% \mathrm{~L}$ (Tabela 3 ). Isso pode ser explicado pela presença dos demais nutrientes necessários para o desenvolvimento das plantas presentes nos resíduos em estudo (Tabela 1), por exemplo: nitrogênio, fósforo, potássio, cálcio, magnésio entre outros.
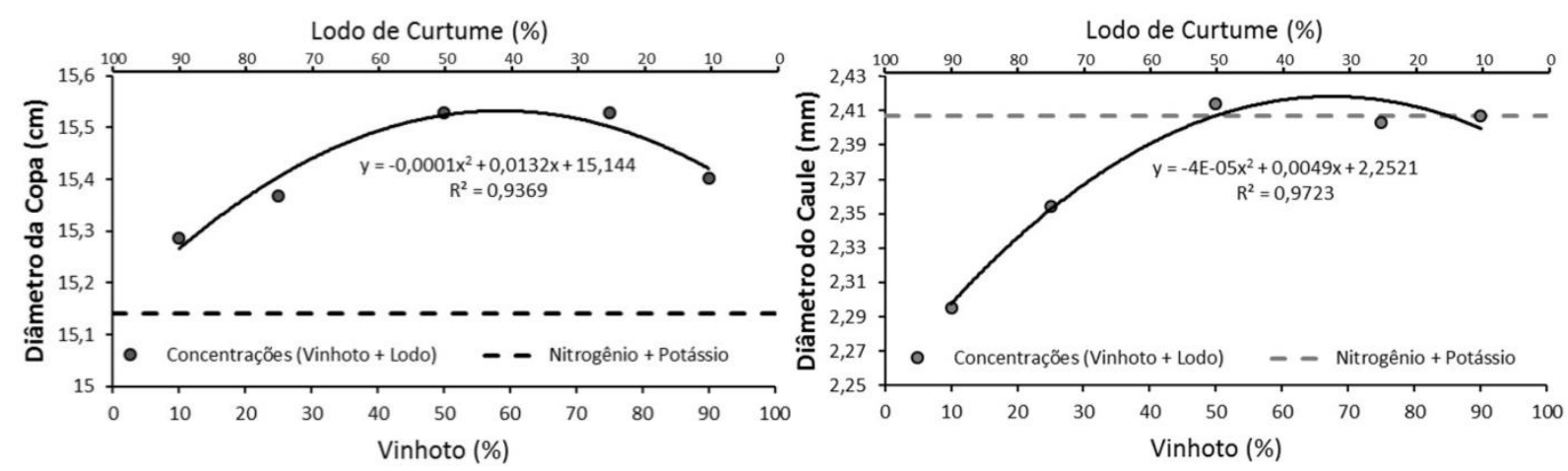

Figura 3. Regressão linear para os parâmetros diâmetro da copa e diâmetro do caule. Fonte: Os Autores.

Os ganhos observados para DCo provavelmente foram ocasionados pela disponibilidade de nitrogênio presente nos resíduos utilizados, sendo este elemento responsável pela produção de fitomassa (REBOUÇAS et al. 2010).

O diâmetro do caule, mesmo no pico máximo estimado na curva de regressão, permaneceu próximo do resultado do tratamento com $\mathrm{N}+\mathrm{K}$, no entanto, o uso dos resíduos pode proporcionar às plantas um pequeno ganho nessa característica quando comparado ao tratamento convencional, exceto nas concentrações de $10 \% \mathrm{~V}+90 \% \mathrm{~L}$ e $25 \% \mathrm{~V}+75 \%$ L. Esse resultado pode ser explicado pelo alto teor de potássio presente no vinhoto. Estudos com doses crescentes de potássio na cultura do manjericão resultaram na redução do 
diâmetro do caule (ARAÚJO et al., 2011), este comportamento pode estar relacionado a uma possível resposta da planta à saturação de potássio.

\section{Análises gravimétricas}

Através dos dados obtidos na análise de regressão foi possível calcular as estimativas de concentrações ótimas para o vinhoto Xv (\%Vinhoto) e lodo de curtume Xv (\%Lodo de curtume) e valores máximos (Yv) para os parâmetros gravimétricos avaliados (Tabela 4).

Tabela 4. Concentrações ótimas estimadas para o vinhoto Xv (\%Vinhoto) e lodo de curtume Xv (\%Lodo de curtume) e valores máximos (Yv) estimados para cada parâmetro avaliado

\begin{tabular}{|c|c|c|c|c|c|c|}
\hline & MFPA & MSPA & MFR & MSR & MST & IQD \\
\hline & \multicolumn{5}{|c|}{----------------- (g) ----------------- } & Índice \\
\hline Xv Vinhoto & 71,0 & 55,0 & 73,3 & 57,5 & 67,0 & 92,8 \\
\hline Xv Lodo de curtume & 29,0 & 45,0 & 26,7 & 42,5 & 33,0 & 7,2 \\
\hline$Y_{\mathbf{v}}$ & 4,65 & 1,54 & 1,86 & 0,67 & 2,27 & 0,47 \\
\hline
\end{tabular}

Fonte: Os Autores.

\section{Massa fresca e seca da parte aérea}

Para o parâmetro massa fresca da parte aérea (MFPA), é possível observar um comportamento crescente na curva de regressão, até o ponto máximo estimado de $71 \%$ vinhoto $+29 \%$ lodo de curtume com posterior decréscimo. Em relação à massa seca da parte aérea (MSPA) o pico da curva de regressão foi estimado na concentração de $55 \% \mathrm{~V}+$ 45\% L (Tabela 4), responsável pelo melhor ganho de massa, sendo que os resultados para o pico das curvas de regressão supracitadas ultrapassam o ganho registrado pelo tratamento convencional (Figura 4).
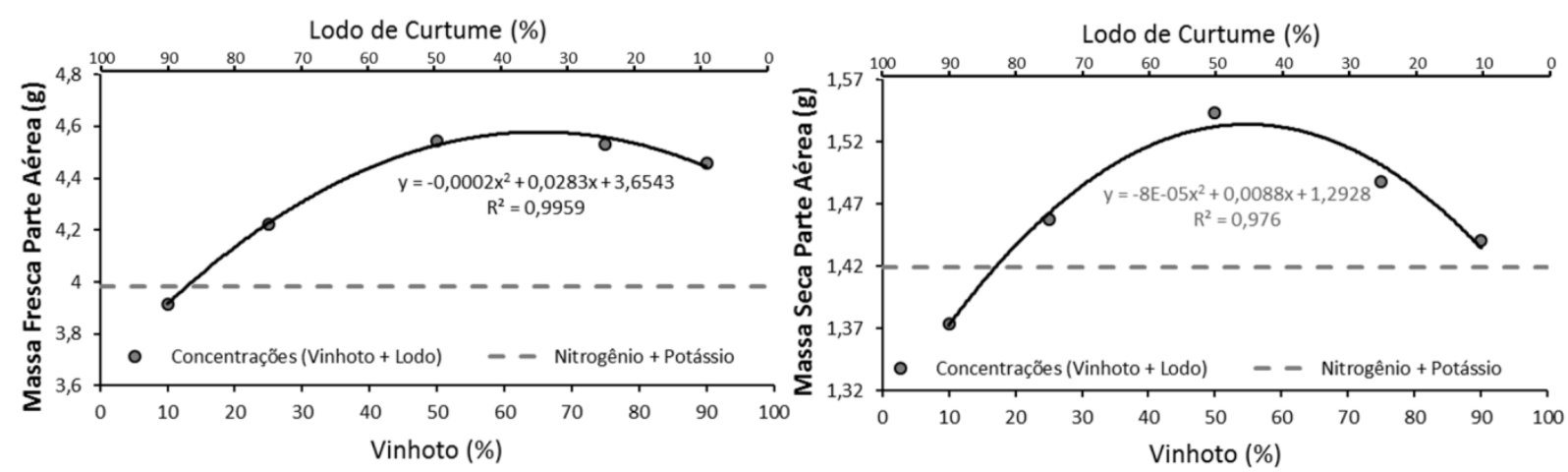

Figura 4. Regressão linear para o parâmetro massa fresca e seca da parte aérea. Fonte: Os Autores. 
Esses resultados expressivos para as concentrações entre lodo de curtume e vinhoto quando comparados ao tratamento $\mathrm{N}+\mathrm{K}$ pode estar relacionado com os nutrientes presentes nos dois resíduos em estudo (Tabela 1), e essências para o desenvolvimento das plantas de café conilon, como: nitrogênio, fosforo, potássio, cálcio, magnésio, enxofre entre outros.

No entanto, para as características de massa fresca e seca da parte aérea da parte aérea, somente o tratamento com concentração em 10\% de vinhoto $+90 \%$ de lodo de curtume apresentou resultado inferior ao observado no tratamento convencional $(\mathrm{N}+\mathrm{K})$, demonstrando que concentrações inferiores a $25 \% \mathrm{~V}+75 \% \mathrm{~L}$ comprometem $\mathrm{O}$ desenvolvimento das mudas para as condições desse experimento.

Os valores encontrados nesse experimento para massa fresca e seca total da parte aérea estão próximos dos experimentos realizados por alguns autores que trabalharam com a produção de mudas de café conilon sob diferentes resíduos, incluso em todos lodo de curtume, variando de 2,06 a 3,2g para massa fresca da parte aérea e 0,2 a 0,9g para massa seca da parte aérea (BERILLI et al., 2014; BERILLI et al., 2018; QUARTEZANI et al., 2018).

Esse comportamento inferior na concentração que possui maior quantidade de lodo de curtume (90\%) tanto para massa fresca quanto seca da parte aérea pode estar relacionado a alguns fatores referentes ao lodo de curtume, como insuficiência de nutrientes, mesmo que tenha quantidade considerável de elementos essenciais para as plantas (Tabela 1), ou devido à presença de sódio que pode causar desequilíbrio osmótico no substrato ou devido à presença de elementos fitotóxicos, como o cromo (BERILLI et al., 2015).

\section{Massa fresca e seca da raiz}

Avaliando a curva de regressão em relação ao tratamento $\mathrm{N}+\mathrm{K}$ observa-se o pico estimado da curva de tendência na concentração de $73,3 \% V+26,7 \% \mathrm{~L}$ para massa fresca da raiz (MFR) e na proporção de $57,5 \% \mathrm{~V}+42,5 \% \mathrm{~L}$ para massa seca da raiz (MSR), sendo assim as concentrações que estão próximas dessas estimativas apresentaram os melhores resultados para ganho de massa radicular (Tabela 4). Isso indica que o lodo de curtume associado ao vinhoto não comprometeu o sistema radicular da muda, promovendo um bom desenvolvimento do sistema radicular, o que pode estar relacionado com a disponibilidade de vários nutrientes presentes em ambos os resíduos (Tabela 1). Ainda avaliando essa relação, é plausível afirmar que as proporções com maior concentração de vinhoto em relação ao lodo apresentaram os melhores ganhos no parâmetro MFR e MSR (Figura 3), resultado esse também observado para massa fresca e seca da parte aérea conforme apresentado e discutido anteriormente. 

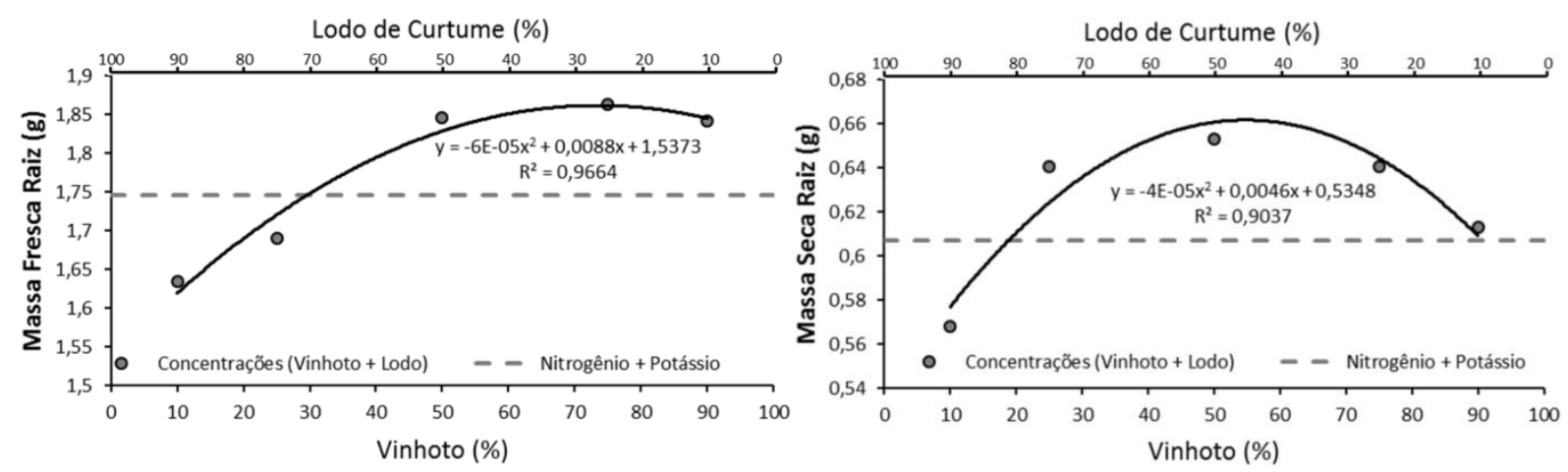

Figura 5. Regressão linear de segunda ordem para o parâmetro massa fresca da raiz. Fonte: Os Autores.

Vale ressaltar que os resultados menos favoráveis para o ganho de massa radicular foram estimados até a concentração de $40 \% \mathrm{~V}+60 \% \mathrm{~L}$, sendo que as demais concentrações avaliadas que envolvem a mistura dos resíduos apresentaram resultados superiores quando comparadas ao tratamento convencional $(\mathrm{N}+\mathrm{K})$ conforme observado pela curva de tendência.

Possivelmente, doses inferiores a $25 \%$ vinhoto $+75 \%$ lodo de curtume são insuficientes na liberação de nutrientes, o que compromete o desenvolvimento das mudas quando comparadas ao tratamento convencional $(\mathrm{N}+\mathrm{K})$ no quesito produção de massa radicular, o que pode estar relacionado ao acúmulo de cromo e sódio fornecido pelo lodo de curtume, causando prejuízos fisiológicos às mudas e comprometendo seu desenvolvimento.

Segundo Berilli et al. (2015), avaliando os níveis de cromo em diferentes partes de mudas de café produzidas por substrato à base de lodo de curtume, detectou que a presença desse metal pesado que possivelmente causa fitotoxidade, dificultando o desenvolvimento normal das mudas.

Resultados semelhantes aos identificados nesse experimento também podem sem observados por alguns autores, onde as doses de lodo de curtume sólido como substrato para produção de mudas de café conilon interferiram no ganho de massa das mudas sendo a presença de cromo e sódio um possível fator, interferindo no desequilíbrio osmótico, na fitotóxidez e no aumento da salinidade (BERILLI et al., 2014; 2015).

\section{Índice de qualidade de Dickson}

Para o parâmetro do índice de qualidade de Dickson (IQD), foi possível analisar nos dados de regressão e identificar que a curva de regressão se comportou de forma crescente seguindo do ponto com maior concentração de lodo de curtume no sentido do acréscimo de vinhoto (Figura 6), sendo que o ponto máximo estimado para curva de tendência foi na concentração de $92,8 \% \mathrm{~V}+7,2 \% \mathrm{~L}$ (Tabela 4). 


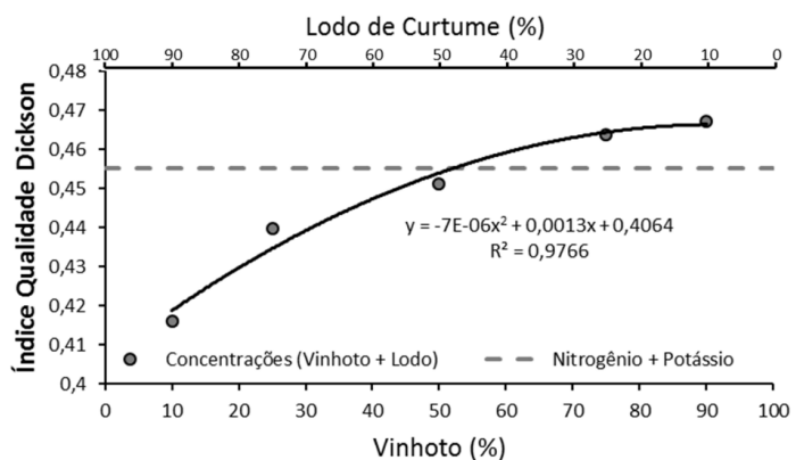

Figura 6. Regressão linear para o parâmetro índice de qualidade Dickson. Fonte: Os Autores.

É possível observar também na figura 5 que os tratamentos em concentrações superiores a $50 \%$ de vinhoto apresentaram qualidade de mudas superior ao tratamento convencional.

\section{Análises fisiológicas}

Através dos dados obtidos na análise de regressão foi possível calcular as estimativas de concentrações ótimas para o vinhoto Xv (\%Vinhoto) e lodo de curtume Xv (\%Lodo de curtume) e valores máximos (Yv) para os parâmetros fisiológicos avaliados (Tabela 5).

Tabela 5. Concentrações ótimas estimadas para o vinhoto Xv (\%Vinhoto) e lodo de curtume Xv (\%Lodo de curtume) e valores máximos (Yv) estimados para cada parâmetro avaliado.

\begin{tabular}{ccccc}
\hline & Chl a & Chl b & Chl t & SPAD \\
\cline { 2 - 5 } & & $-----\left(\mathrm{mmol} \mathrm{m}^{-2}\right)$ & $---{ }^{--}$ & índice \\
\hline Xv Vinhoto & 42,0 & 46,0 & 43,0 & 43,0 \\
Xv Lodo de curtume & 58,0 & 54,0 & 57,0 & 57,0 \\
Yv & 390 & 107 & 496 & 21 \\
\hline
\end{tabular}

Fonte: Os Autores.

\section{Clorofila a e b}

Observa-se na tabela 5 que o uso de diferentes concentrações entre o vinhoto e o lodo de curtume não causou grandes discrepâncias entre os resultados para os teores de clorofila. Geralmente são encontradas maiores diferenças entre esses pigmentos fotossintéticos, quando expostos a diferentes níveis de luminosidade ou a compostos tóxicos, conforme observado por Siebeneichler et al. (2008).

Os resultados mais promissores em relação ao tratamento convencional $(\mathrm{N}+\mathrm{K})$ se estabeleceram nas concentrações mais próximas do valor máximo estimado para curva de tendência (Tabela 5), para o teor de clorofila a (Chl a) a estimativa foi em $42 \% \mathrm{~V}+58 \% \mathrm{~L}$ e 
para clorofila b (Chl b) foi estimado na concentração de $46 \%$ de vinhoto $+54 \%$ de lodo de curtume conforme mostra o pico da curva de tendência (Figura 7).
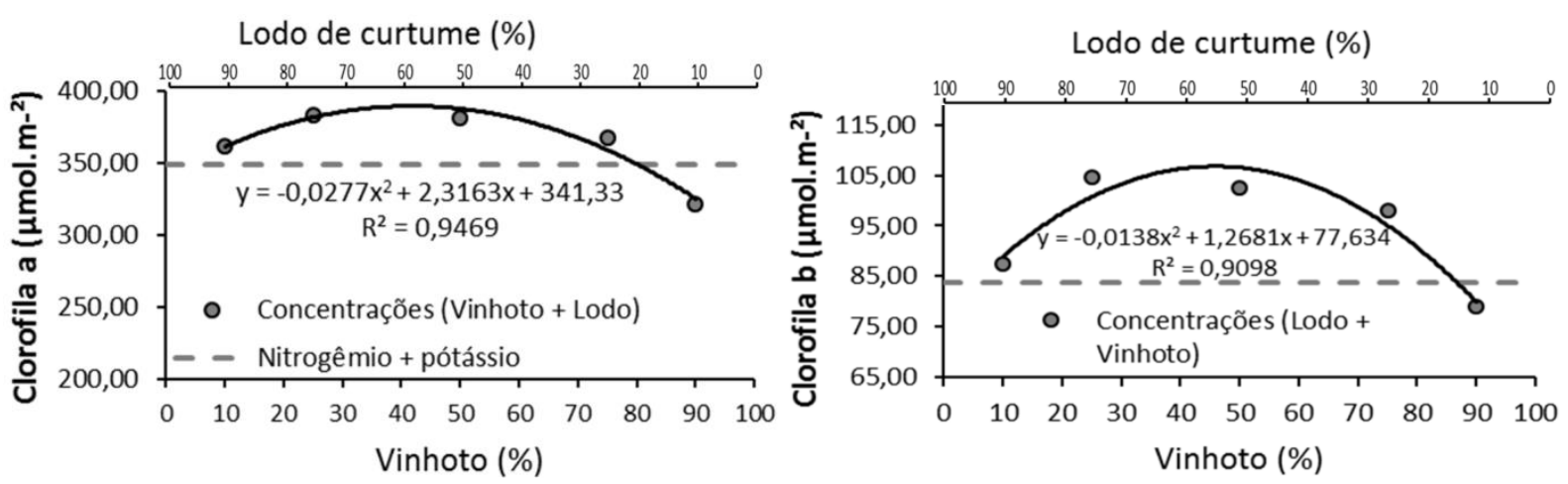

Figura 7. Regressão linear para o parâmetro clorofila a e b.

Fonte: Os Autores.

É possível observar na figura 7 que apenas o tratamento com concentração de $90 \%$ vinhoto $+10 \%$ lodo permaneceu abaixo dos valores encontrados para o tratamento convencional. Uma possível explicação é o alto teor de potássio presente no vinhoto, o mesmo é essencial para cultura do café, porém em maior quantidade para plantas mais velhas, sendo assim pode ter ocorrido um desequilíbrio entre o potássio e o cálcio gerando um estres nas mudas gerando assim menor produção de clorofila a nessa concentração.

De acordo com Siebeneichler et al. (2008), é comum encontrar maiores diferenças entre esses pigmentos fotossintéticos quando expostos a diferentes níveis de luminosidade ou mesmo na presença de elementos considerados tóxicos para as plantas, como é o caso do cromo e do sódio presentes no lodo de curtume (Tabela 1).

A maior proporção de clorofila b encontrada em relação ao $\mathrm{N}+\mathrm{K}$ é de grande importância, pois permite capturar uma quantidade maior de luz incidente no local de ação dos fotossistemas e, assim, proporcionar uma maior formação de ATP e NADPH que serão utilizados pela planta no processo de fotossíntese, aumentando assim seu rendimento quântico (WHATLEY e WHATLEY, 1982).

\section{Clorofila total}

A clorofila total possui relação direta com a clorofila a e clorofila b, representa o somatório das mesmas, sendo assim os resultados expressados pela curva de tendência possui características semelhantes às já identificadas anteriormente na $\mathrm{Chl}$ a e Chl b, sendo observados os melhores teores nas concentrações que se aproximam do pico estimado para curva de tendência em $43 \%$ de vinhoto $+57 \%$ de lodo de curtume, quando comparadas ao tratamento convencional $(N+P)$. A curva de regressão em relação ao índice SPAD se 
comportou de maneira semelhante aos já observados para a clorofila a, clorofila b e clorofila total, o pico da curva foi estimado na concentração de $43 \%$ vinhoto $+57 \%$ lodo de curtume (Figura 8).
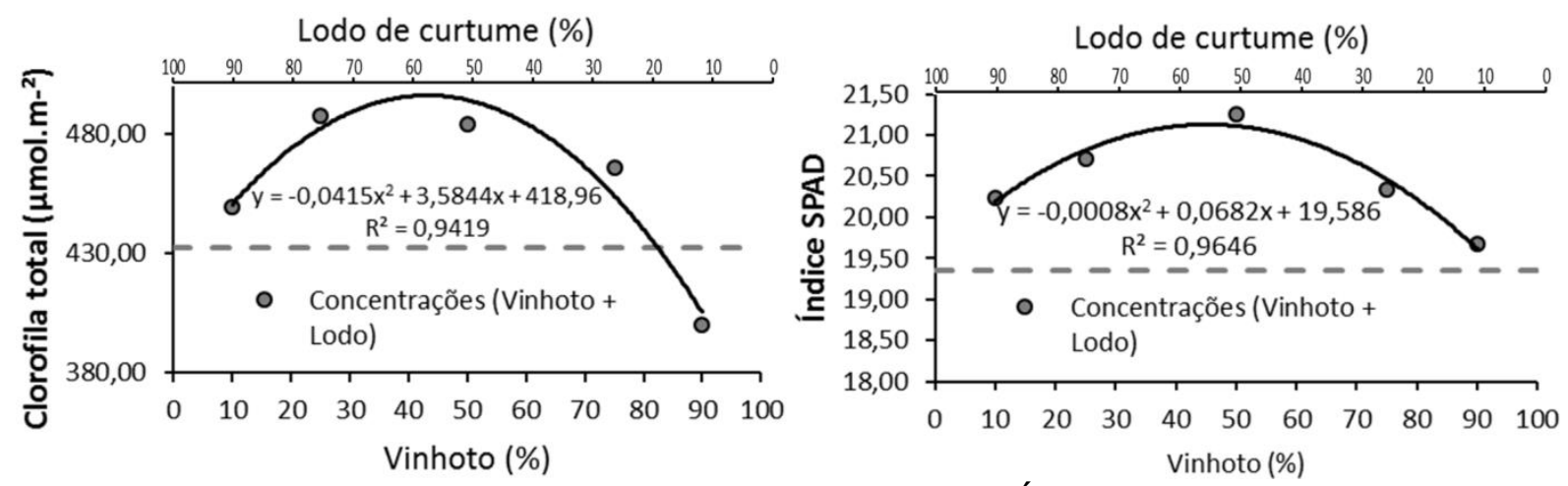

Figura 8. Regressão linear para o parâmetro clorofila total e Índice SPAD.

Fonte: Os autores.

Os tratamentos envolvendo os resíduos que demonstraram os menores níveis de clorofila total foram estimados para concentrações a partir de $75 \% \mathrm{~V}+25 \% \mathrm{~L}$, com valores superiores apenas em relação à água pura. Ao se comparar o conteúdo de Chl t para os tratamentos envolvendo as misturas entre resíduos ( $V$ e $L$ ) em relação ao $\mathrm{N}+\mathrm{K}$, valores mais baixos foram observados apenas nas concentrações estimadas acima de $80 \% \mathrm{~V}+$ $20 \% \mathrm{~L}$, com valores mais altos para as demais concentrações.

Vale ressaltar que os resultados encontrados para os teores totais de clorofila em todos os tratamentos foram semelhantes aos já observados nas figuras 1 e 2 , onde os teores de clorofila a e b foram avaliados respectivamente.

Para clorofila total, foram observados resultados promissores nessa comparação entre clorofila a e b, este resultado indica que o teor de clorofila da folha também se correlaciona positivamente com o teor de carotenoide.

O medidor portátil de clorofila permite leituras instantâneas da intensidade da cor verde da folha (teor relativo de clorofila) sem destruí-la. Os valores são calculados pelo equipamento com base na quantidade de luz transmitida pela folha, em dois comprimentos de onda, com diferentes absorvâncias de clorofila. (TORRES NETTO et al., 2005; AMARANTE et al., 2010).

Como o conteúdo de clorofila é o material que define o índice SPAD, justifica-se a semelhança entre os resultados observados para os conteúdos de clorofila (Chl a, Chl b e Chl t) em relação ao SPAD, o equipamento serviu ao objetivo de dar confiabilidade à técnica de estimativa de conteúdo de clorofila (SPAD) para diferenciar cultivares. 


\section{Considerações finais}

Nas concentrações estimadas para o ponto máximo das curvas de regressão entre $44 \%$ vinhoto $+56 \%$ lodo de curtume e $66 \%$ vinhoto $+34 \%$ lodo de curtume, o uso do vinhoto acrescido de lodo de curtume como adubo foliar, apresenta vantagens para 0 desenvolvimento das mudas de café conilon.

Baseado nas estimativas dos pontos máximos das curvas de tendência, o uso de lodo de curtume associado ao vinhoto entre as concentrações de $55 \%$ vinhoto $+45 \%$ lodo de curtume e $73,3 \%$ vinhoto $+26,7 \%$ lodo de curtume mostrou-se eficiente na obtenção de características gravimétricas.

Para os teores de clorofilas, as misturas entre os resíduos baseados nos valores máximos estimados para tendência da curva foram entre a proporção de $42 \% \mathrm{~V}+58 \% \mathrm{~L}$ e $46 \% \mathrm{~V}+54 \% \mathrm{~L}$, indicando que os benefícios do vinhoto associado ao lodo de curtume geraram ganhos de clorofila em mudas de café conilon.

A variação apresentada pelo índice SPAD foi a mesma encontrada para os níveis de clorofila total $(\mathrm{Chl} \mathrm{t})$, revelando a eficiência do equipamento nas análises de clorofila e confirmando os resultados encontrados na análise destrutiva.

Uma vantagem da utilização do lodo de curtume associado ao vinhoto é que pelo fato de serem resíduos que não possuem custos para aquisição, quando utilizado em locais de cultivo próximo às fontes de geração desses resíduos, os custos de produção podem ser minimizados.

O uso do vinhoto associado ao lodo como fertilização foliar promoveu vários benefícios quando comparado à adubação foliar química tradicional para a produção de mudas dessa espécie. Vale ressaltar que os possíveis limitantes do lodo de curtume, em especial o cromo e o sódio, não afetaram nos aspectos analisados nesse experimento nas mudas de café conilon.

De forma geral, as concentrações de lodo de curtume associado ao vinhoto proporcionaram efeitos positivos para o pegamento e sobrevivência das mudas de café conilon visto que a taxa de mortalidade das mudas não foi significativa.

\section{Agradecimentos}

À Fundação de Amparo à Pesquisa e Inovação do Espírito Santo (FAPES), o Conselho Nacional de Desenvolvimento Científico e Tecnológico (CNPq), ao Instituto Federal do Espirito Santo (Ifes), a Empresa Capixaba Couros LTDAME e a Cachaçaria Artesanal Torrezani, pelo apoio financeiro e parceria. 


\section{Referências}

ALMEIDA, R. N.; FERRAZ, D. R.; SILVA, A. S.; CUNHA, E. G.; VIEIRA, J. C.; DA SILVA SOUZ, T.; DA SILVA BERILL, S. Utilização de lodo de curtume em complementação ao substrato comercial na produção de mudas de pimenta biquinho. Scientia agraria, v. 18, n. 1, p. 20-33, 2017.

AMARANTE, C. V. T.; STEFFENS, C. A.; SANGOI, L.; ZANARDI, O. Z.; MIQUELOTO, A.; SCHWEITZER, C. Quantificação de clorofilas em folhas de milho através de métodos ópticos não destrutivos. Revista Brasileira de Milho e Sorgo, Sete Lagoas, v. 9, n. 1, p. 3950, 2010.

ARAÚJO, G. S.; MATSUMOTO, S. N.; SANTOS, M. A. F.; CÉSAR, F. R. C. F.; BONFIM, J. A. Crescimento de manjericão conduzido em cultivo protegido condicionado às doses de nitrogênio e doses supra ótimas potássio. Revista Ambiência, v. 7, p. 265-277, 2011.

BERILLI, S. D. S.; QUIUQUI, J. P. C.; REMBINSKI, J.; SALLA, P. H. H.; BERILLI, A. P. C. G.; LOUZADA, J. M. Utilização de lodo de curtume como substrato alternativo para produção de mudas de café conilon. Coffee Science, Lavras, v. 9, n. 4, p. 472-479, out./dez. 2014.

BERILLI, S. D. S.; BERILLI, A. P. C. G.; CARVALHO, A. J. C. D.; FREITAS, S. D. J.; CUNHA, M. D.; FONTES, P. S. F. Níveis de cromo em mudas de café conilon desenvolvidas em substrato com lodo de curtume como adubação alternativa. Coffee Science, Lavras, v. 10, n. 3, p. 320-328, jul./set. 2015.

BERILLI, S. S.; DE SALES, R. A.; PINHEIRO, A. P. B.; PEREIRA, L. C.; GOTTARDO, L. E.; BERILLI, A. P. C. G. Componentes fisiológicos e crescimento inicial de mudas de palmeiragarrafa em resposta a substratos com lodo de curtume. Scientia Agraria, v. 19, n. 1, p. 94$101,2018$.

BERNARDI, C. M.; PIRES, D. C. A. S.; SELBACH, P. A. Descarte e biodegradação de lodos de curtume no solo. Salão de Iniciação Científica (3.: 1991: Porto Alegre). [Resumos]. Porto Alegre: UFRGS, 1991.

COMPANHIA NACIONAL DE ABASTECIMENTO - CONAB. Bienalidade positiva impulsiona safra de café no país e aumenta produção. Disponível em: $<$ https://cast.conab.gov.br/?p=archive\&cat=safra_de_cafe>. Acesso em: 09 fev. 2020.

COSTA, E.; PRADO, J. C. L.; CARDOSO, E. D.; BINOTTI, F. F. S. Substrate from vermiculite and cattle manure for ornamental pepper seedling production. Horticultura Brasileira, v. 33, n. 2, p. 163-167, 2015.

CRISPIM, J. G.; RÊGO, E. R.; PESSOA, A. M. S.; RÊGO, M. M. Utilização de substratos alternativos na produção de pimenteira ornamental (Capsicum sp. L.). Cadernos de Agroecologia, v. 10, n. 2, p. 33-38, 2015.

DICKSON, A.; LEAF, A. L.; HOSNER, J. F. Quality appraisal of white spruce and white pine seedling stock in nurseries. The Forestry Chronicle, v. 36, n. 1, p. 10-13, 1960.

DARDENGO, M. C. J.; SOUSA, E. F. D.; REIS, E. F. D.; GRAVINA, G. D. A. Crescimento e qualidade de mudas de café conilon produzidas em diferentes recipientes e níveis de sombreamento. Coffee Science, Lavras, v. 8, n. 4, p. 500-509, out./dez. 2013 
FERRÃO, R. G.; FONSECA, A. F. A.; FERRÃO, M. A. G.; VERDIN-FILHO, A. C.; VOLPI, P. S.; MUNER, L. H. Café conilon: técnicas de produção com variedades melhoradas-4a Edição-Revisada e Ampliada. Circular técnica, n. 03-I, p. 74, 2012.

FREITAS, G.; OLIVEIRA, L. C.; RIBEIRO, M. L.; GALLO, Z. Fertirrigação com vinhaça no município de São Roque do Canaã-Es. Revista Brasileira Multidisciplinar, v. 13, n. 1, p. 158-165, 2010.

MARANA, J. P.; MIGLIORANZA, É.; FONSECA, É. D. P.; KAINUMA, R. H. Índices de qualidade e crescimento de mudas de café produzidas em tubetes. Ciência Rural, Santa Maria, v. 38 , n. 1, p. 39-45, 2008.

MARIANI, A. MOTTA, I. S.; PADOVAN, M. P.; CARNEIRO, L. F.; COSTA, K. F.; SANTOS, M. C. S. Substratos alternativos com húmus de minhoca na produção de mudas de chicória. Cadernos de Agroecologia, v.9, n.4, p. 1-9, 2014.

MARTINS, L. D.; MACHADO, L. D. S.; TOMAZ, M. A.; DO AMARAL, J. F. T. The nutritional efficiency of Coffea spp. A review. African Journal of Biotechnology, v.14, n. 9, p. 728734, 2015.

MENEGHELLI, C. M.; MONACO, P. A. V. L.; HADDADE, I. R.; MENEGHELLI, L. A. M.; KRAUSE, M. R. Resíduo da secagem dos grãos de café como substrato alternativo em mudas de café conilon. Coffee Science, Lavras, v. 11, n. 3, p. 330 - 335, jul./set. 2016.

MESQUITA, C. M.; REZENDE, J. E.; CARVALHO, J. S.; FABRI JÚNIOR, M. A.; MORAES, N. C.; DIAS, P. T.; ARAÚJO, W. G. Manual do café: manejo de cafezais em produção. Belo Horizonte: Emater-MG, 2016.

OLIVEIRA, F. A.; MEDEIROS, J. F.; LINHARES, P.S. F.; ALVES, R. C.; MEDEIROS, A. M. A.; OLIVEIRA, M. K. T. Produção de mudas de pimenta fertirrigadas com diferentes soluções nutritivas. Horticultura Brasileira, v. 32, n. 4, p. 458-463, 2014.

PORRA, R. J.; THOMPSON, W. A.; KRIEDEMANN, P. E. Determination of accurate extinction coefficients and simultaneous equations for assaying chlorophylls $a$ and $b$ extracted with four different solvents: verification of the concentration of chlorophyll standards by atomic absorption spectroscopy. Biochimica et Biophysica Acta (BBA)Bioenergetics, v. 975, n. 3, p. 384-394, 1989.

QUARTEZANI, W. Z.; DE SALES, R. A.; PLETSCH, T. A.; DA SILVA BERILLI, S. A.; NASCIMENTO, A. L., HELL, L. R.; TOSO, R. Conilon plant growth response to sources of organic matter. African Journal of Agricultural Research, v. 13, n. 4, p. 181-188, 2018.

REBOUÇAS, J. R. L.; DIAS, N. D. S.; GONZAGA, M. I. D. S.; GHEYI, H. R.; NETO, O. N. D. S. Crescimento do feijão-caupi irrigado com água residuária de esgoto doméstico tratado. Revista Caatinga, v. 23, n. 1, p. 97-102, 2010.

ROSSETTO, R.; DIAS, F. L. F.; VITTI, A. C.; DINARDO-MIRANDA, L. L. Fertilidade do solo, nutrição e adubação. Cana-de-açúcar, v. 1, p. 221-238, 2008.

SALES, R. A.; ROSSINI, F. P.; BERILLI, S. S.; GALVÃO, E. R.; MENDES, T. P.; BERILLI, A. P. C. G.; JESUS FREITAS, S. Foliar fertilization using liquid tannery sludge in conilon coffee seedlings production. Journal of Experimental Agriculture International, p. 1-8, 2018. 
SANTOS, J.C.F. Principais funções dos nutrientes do café. Revista Cafeicultura. 2005. Não paginado. Disponível em: <https://revistacafeicultura.com.br/?mat=3699> Acesso em: 16 jun. 2018.

SCHULTZ, N.; LIMA, E.; PEREIRA, M. G.; ZONTA, E. Efeito residual da adubação na canaplanta e da adubação nitrogenada e potássica na cana-soca colhidas com e sem a queima da palhada. Revista Brasileira de Ciência do Solo, v. 34, n. 3, p. 811-820, 2010.

SIEBENEICHLER, S. C.; FREITAS, G. A. D.; SILVA, R. R. D.; ADORIAN, G. C.; CAPELLARI, D. Características morfofisiológicas em plantas de Tabebuia heptaphyilla (vell.) tol. em condições de luminosidade. Acta amazonica, v. 38, n. 3, p. 467-472, 2008.

SILVA, W. Z.; BRINATE, S. V. B.; TOMAZ, M. A.; AMARAL, J. F. T.; RODRIGES, W. N.; MARTINS, L. D. Métodos de estimativa de área foliar em cafeeiro. Revista Enciclopedia Biosfera, 2011.

TORRES NETTO, A.; CAMPOSTRINI, E.; OLIVEIRA, J.G.; BRESSAN-SMITH, R.E. Photosynthetic pigments, nitrogen, chlorophyll a fluorescence and SPAD-502 readings in coffee leaves. Scientia Horticulturae, Amsterdam, v. 104, n. 2, p. 199-209, 2005.

WHATLEY, J. M.; WHATLEY, F. R. A luz e a vida das plantas. São Paulo: EPU-EDUSP, 1982. $101 \mathrm{p}$. 


\title{
Capítulo 24
}

\section{Gerenciamento de resíduos da cadeia produtiva de pescado e seu uso sustentável}

\author{
Paola de Oliveira Santos ${ }^{1}$, João Victor Nascimento Tardim', Venan Vieira dos Anjos ${ }^{1}$, Layon \\ Carvalho de Assis ${ }^{1}$, Joyce Garcia Silva ${ }^{1}$, Luiza Aparecida Campos de Paula², Silvia Pope de \\ Araújo $^{3}$, Leonardo Demier Cardoso ${ }^{4}$, Alberto Chambela Neto ${ }^{5}$, Pedro Pierro Mendonça ${ }^{6}$
}

\section{Introdução}

Devido ao aumento da população mundial e a preocupação com melhores hábitos alimentares, o consumo de pescado cresceu exponencialmente nos últimos anos. A américa latina vem aumentado sua exportação e é esperado um aumento de $49 \%$ na produção pesqueira até $\mathrm{o}$ ano de 2030, passando de 2,7 para 4 milhões de toneladas (FAO, 2016).

Define-se o pescado como animais aquáticos destinados a alimentação humana (BRASIL, 2017), e pode ser comercializado inteiro ou processado. A cadeia produtiva aquícola, do início ao final, gera resíduos, logo, o aumento da produção e comercialização resulta no proporcional aumento dos resíduos que podem chegar a mais de $20 \%$ da massa total produzida de pescado.

Resíduos são qualquer produto excedente de qualquer processo de produção e industrialização e podem ser na forma sólida, gasosa e líquida, sendo a maior parte deles liquido e sólidos. Estes resíduos, quando descartados de forma inadequada são potenciais causadores de alterações ambientais. De acordo com a ABNT (2004), os resíduos sólidos são divididos em duas classes. Classe I: Compreende resíduos perigosos por apresentarem potencial tóxico ao ambiente e saúde humana e os de classe II: Compreende os resíduos solúveis em água e com alto potencial de degradação, e com maior possibilidade de reaproveitamento.

${ }^{1}$ Graduandos em Engenharia de Aquicultura pelo Instituto Federal do Espírito Santo - Campus de Alegre. Caixa Postal 47, CEP: 29500-000. Alegre -ES. E-mail: paolamanfredini111@gmail.com; jvntardim@gmail.com; vieira.venan@gmail.com; layoncdeassis@gmail.com; joyce_g_silva@hotmail.com

${ }^{2}$ Mestranda em Ciências Veterinárias pela Universidade Federal do Espírito Santo - Campus Alegre. Email: luzpaula.campos@gmail.com

${ }^{3}$ Doutoranda em Ciências de Alimentos pela Universidade Federal do Rio de Janeiro. E-mail: silviapopedearaujo@gmail.com

${ }^{4}$ Dr. Professor do Instituto Federal do Espírito Santo - Camus Piúma. E-mail: leonardodemier@hotmail.com

${ }^{5}$ Dr. Professor do Instituto Federal do Espírito Santo - Campus Santa Teresa, Rod ES 080, km 93, São João de Petrópolis, CEP: 29650-000, Santa Teresa-ES. E-mail: chambela@ifes.edu.br

${ }^{6}$ Dr. Professor do Instituto Federal do Espírito santo - Campus de Alegre. Caixa Postal 47, CEP: 29500000. Alegre-ES. E-mail: ppierrom@gmail.com 
A maior parte dos resíduos sólidos provenientes do pescado está na classe II, e são na sua maioria, escamas, espinhas, vísceras e carcaça. O artigo 3ํㅡ da lei ํㅜ 12.305 de 02 de agosto de 2010 (BRASIL, 2010), regulamenta que os resíduos sólidos devem ser tratados, o que inclui a reutilização, reciclagem, compostagem, recuperação e aproveitamento energético ou outras destinações admitidas pelos órgãos competentes do SISNAMA. Kubitza e Campos (2006), separaram os resíduos da cadeia produtiva do pescado em resíduos com potencial para aproveitamento na alimentação animal, como por exemplo as espinhas, escamas e vísceras, que podem ser transformadas em farinhas e óleo para a fabricação de rações, e os resíduos com potencial para alimentação humana que se resume nas carcaças que podem ser utilizadas na produção de alimentos embutidos.

O resíduo líquido do pescado é referente aos efluentes da produção. Este efluente geralmente possui alta carga de nitrogênio proveniente do elevado teor de proteínas das rações, e quando entra em contato com rios e córregos geralmente causam o afloramento de organismos fotossintetizantes, que podem aumentar a demanda bioquímica de oxigênio, diminuir a saturação da água e ocasionar a morte de outros organismos (HENRY-SILVA e CAMARGO, 2018). Estes efluentes podem ser tratados em unidades de tratamento de água ou usados na fertirrigação de culturas.

Para dar continuidade no crescimento da aquicultura com bases sustentáveis, é importante que se desenvolva técnicas de gerenciamento de resíduos, que acompanhe este crescimento. Assim este capítulo abordará metodologias para o reaproveitamento dos resíduos oriundos da produção e processamento de pescados.

\section{Gerenciamento de resíduos}

\section{Sistemas de recirculação de água}

Uma das alternativas para diminuir o aporte de efluentes no meio ambiente é a implantação de sistemas de recirculação (Figura 1). Estes sistemas utilizam de mínima renovação de água, o que pode reduzir até $70 \%$ do uso de água e consequente redução do descarte de água com elevados níveis de nutrientes (CORSO, 2010). 


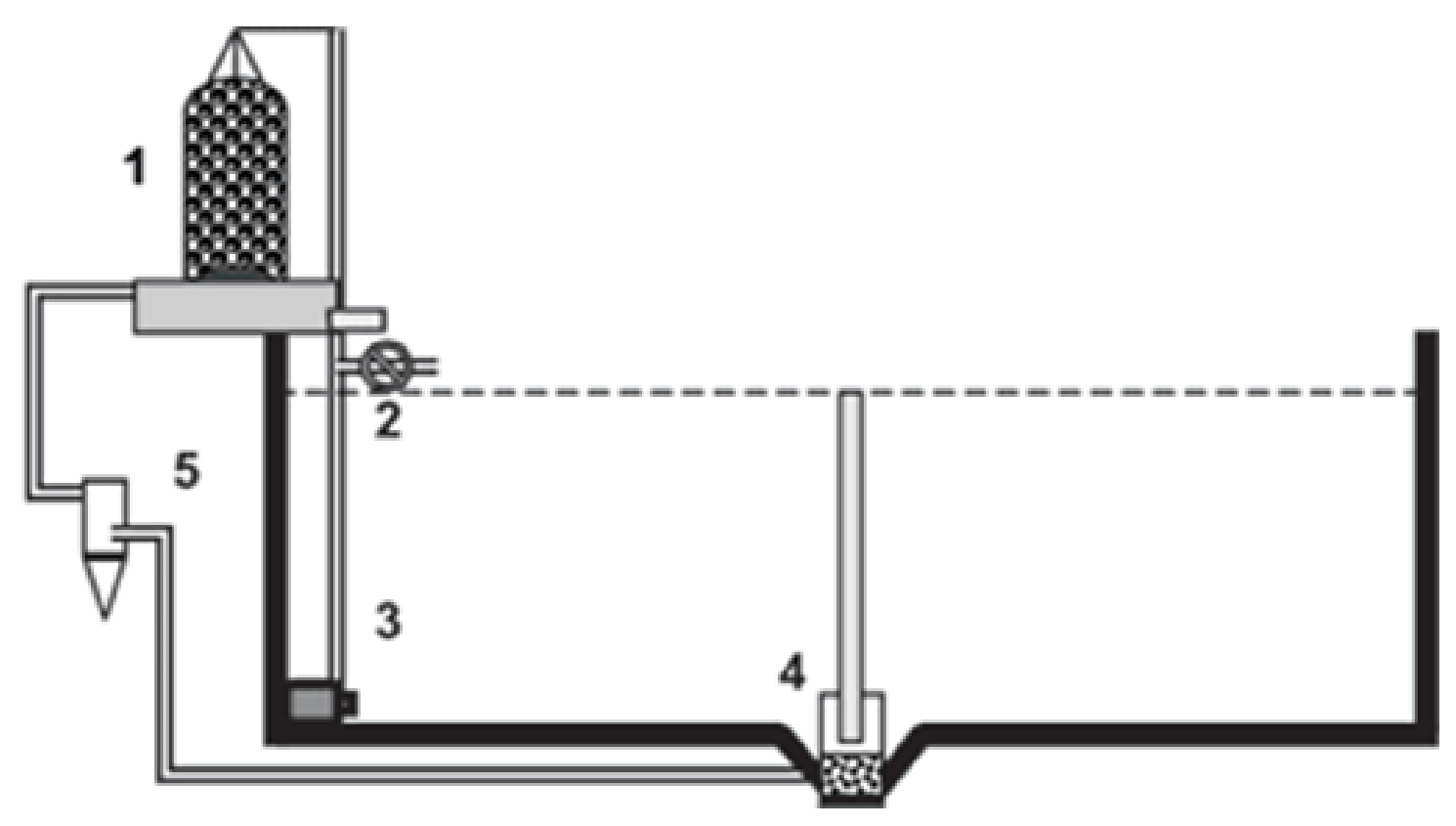

Figura 1. Tanque com sistema individual de tratamento e recirculação de água 1. Filtro biológico 2. Registro - retorno de parte da água bombeada e aeração 3. Bomba submersa 4. Dreno central 5. Coletor de sólidos e retorno da sobra de água.

Fonte: Kubitza (2006).

A desvantagem deste tipo de sistema, é que necessita de altos investimentos para sua implantação, que demanda de uso contínuo de aeradores, excelentes sistemas de filtragem e monitoramento intenso. A vantagem é que atendendo todos os requisitos, é possível criar peixes em alta densidade de estocagem. Uma alternativa para implantação destes sistemas é trabalhar com espécies de alto valor agregado para recuperar o investimento (KUBITZA, 2006).

\section{Tratamento de efluentes utilizando plantas aquáticas}

O tratamento de águas residuais tem como objetivo diminuir a carga de nutrientes e substâncias tóxicas que podem afetar negativamente o meio ambiente (FRANÇA et al., 2014). Uma das formas de reduzir a carga de nutrientes destes efluentes é o tratamento da água utilizando plantas aquáticas (Figura 2). Estas plantas funcionam como o substrato de um filtro biológico, onde os microrganismos aderidos a raiz da planta e ao entorno (rizosfera) purificam o efluente (NAIME e GARCIA, 2005). 


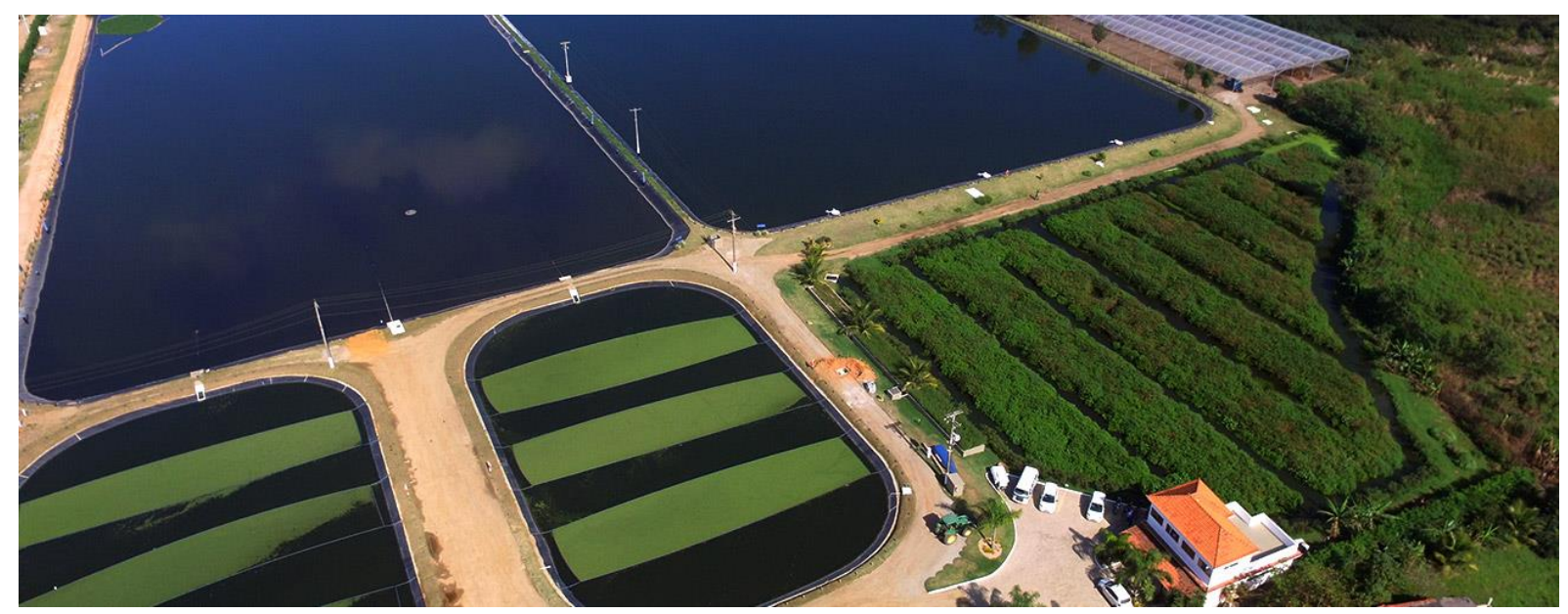

Figura 2. Unidade de tratamento de efluentes utilizando plantas aquáticas. Fonte: ABCON (2018).

Para que este método tenha eficácia é importante garantir que as plantas velhas e mortas sejam retiradas do sistema, pois no momento em que ela se decompõe os nutrientes voltam ao corpo d'água. As plantas retiradas do sistema são ricas em nutrientes, e podem ser reutilizadas na fertilização agrícola (ABCON, 2018).

\section{Compostagem e fertilizantes}

A demanda no consumo de organismos aquáticos vem crescendo exponencialmente com o aumento da população ao redor do mundo gerando grandes quantidades de resíduo orgânico (Figura 3), sólido e líquido, gerando importantes problemas ambientais, causado pelo descarte inadequado no meio ambiente desses resíduos.

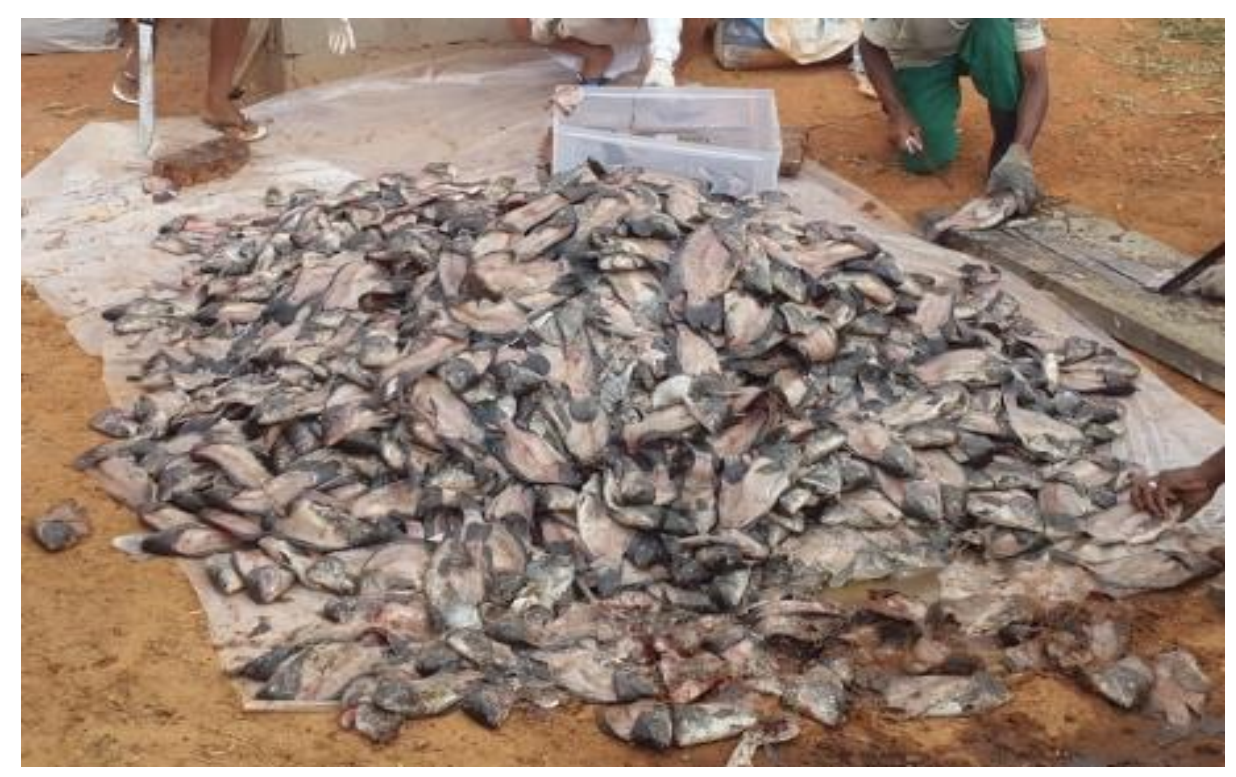

Figura 3. Fotografia ilustrativa dos resíduos gerado após o processamento do pescado. Fonte: Os Autores. 
A indústria de processamento de pescado e peixarias geram grandes quantidades de sobras de peixes, crustáceos e moluscos (resíduos sólidos), que em sua maioria, são descartados sem nenhum tratamento ou planejamento para reaproveitamento, assim como na maioria das produções animais ainda hoje (VALENTE et al., 2016).

Por ser de origem orgânica as vísceras, sangue, nadadeiras, carapaça, conchas, escamas e carcaça possuem grandes concentrações de nitrogênio e fósforo, que por sua vez podem ser utilizados como fertilizantes ou adubos orgânicos. Para esse tipo de reaproveitamento ou transformação desse resíduo solido, a técnica da compostagem surge como uma alternativa sustentável para a destinação correta de resíduos do pescado (NASCIMENTO et al., 2018).

A compostagem (Figura 4) é o processo de biodegradação da matéria orgânica, na qual as bactérias realizam a degradação e mineralização dos compostos orgânicos gerando calor que servem como antisséptico contra a proliferação de patógenos (DINIZ FILHO et al., 2007).

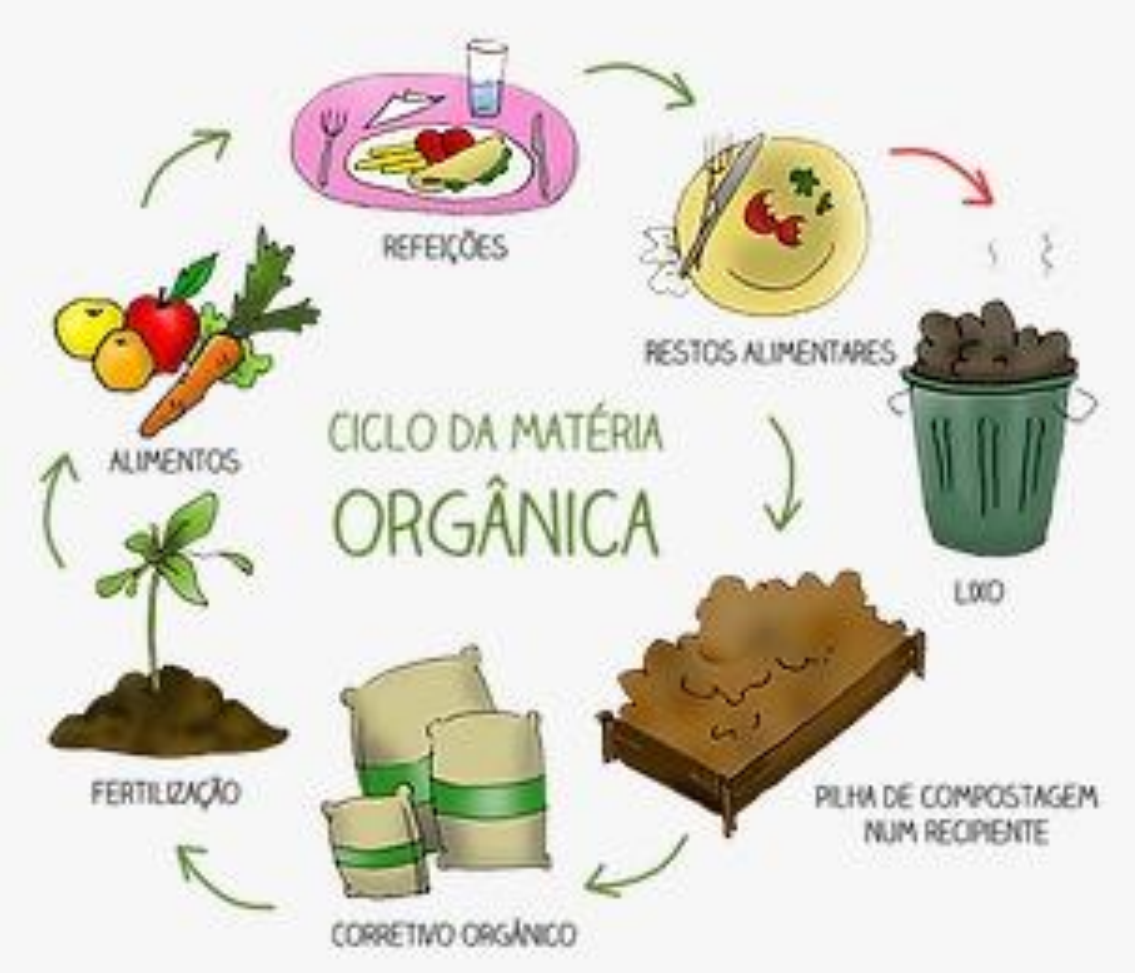

Figura 4. Desenho esquemático simples do processo de compostagem.

Fonte: Sathler (2018).

O processo da compostagem pode variar conforme o uso de diferentes fontes orgânicas, apresentando resultados distintos (Figura 5). No trabalho de Sanes et al. (2015) foi utilizado duas fontes de vegetais em processos separados, casca de arroz in natura e casca esgotada de acácia. Foram trabalhadas em baias de alvenaria, sem contato com o solo. Cada fonte vegetal de Carbono $(C)$ seguiu os seguintes preparos: a casca de arroz seguiu o procedimento 
de 3:1 (a cada $3 \mathrm{~kg}$ de resíduo de peixe adiciona um $1 \mathrm{~kg}$ de casca de arroz), para casca de acácia foi realizado dois trabalhos, no primeiro $2: 1$ sendo $(2 \mathrm{~kg}$ de sobra de pescado para 1 kg de casca de acácia), já o segundo trabalho foi de 1:1 sendo (1 kg de sobra de pescado para $1 \mathrm{~kg}$ de casca de acácia). Foi adicionado água, mantendo a umidade de $60 \%$ e quando a temperatura chegava a $70^{\circ} \mathrm{C}$ eram revolvidas e para evitar insetos e pássaros foi telado 0 local. O composto a base de casca de arroz mostrou baixa eficiência, apresentando níveis inferiores de nutriente e em especial o nitrogênio. Segundo os autores, a sílica componente química da casca de arroz não permitiu o desenvolvimento de microrganismos para decomposição. Já o composto a base de casca de acácia mostrou bons resultados com elevados valores de nutrientes nos dois trabalhos, sendo o segundo com melhor aproveitamento, a partir daí foi dado início ao preparo do fertilizante. Foram feitas duas soluções: água, compostagem da mistura de casca de acácia e açúcar mascavo que serviu de alimento para as bactérias, sendo testado em dois níveis de porcentagem $16 \%$ e $33 \%$ de compostagem, a qual foram submetidos às condições aeróbico e anaeróbico. Observou-se que o teste de $16 \%$ nas condições anaeróbias foi eficiente em comparação aos outros testes de $33 \%$ e nas condições de aeróbicas e anaeróbicas (SANES et al., 2015).

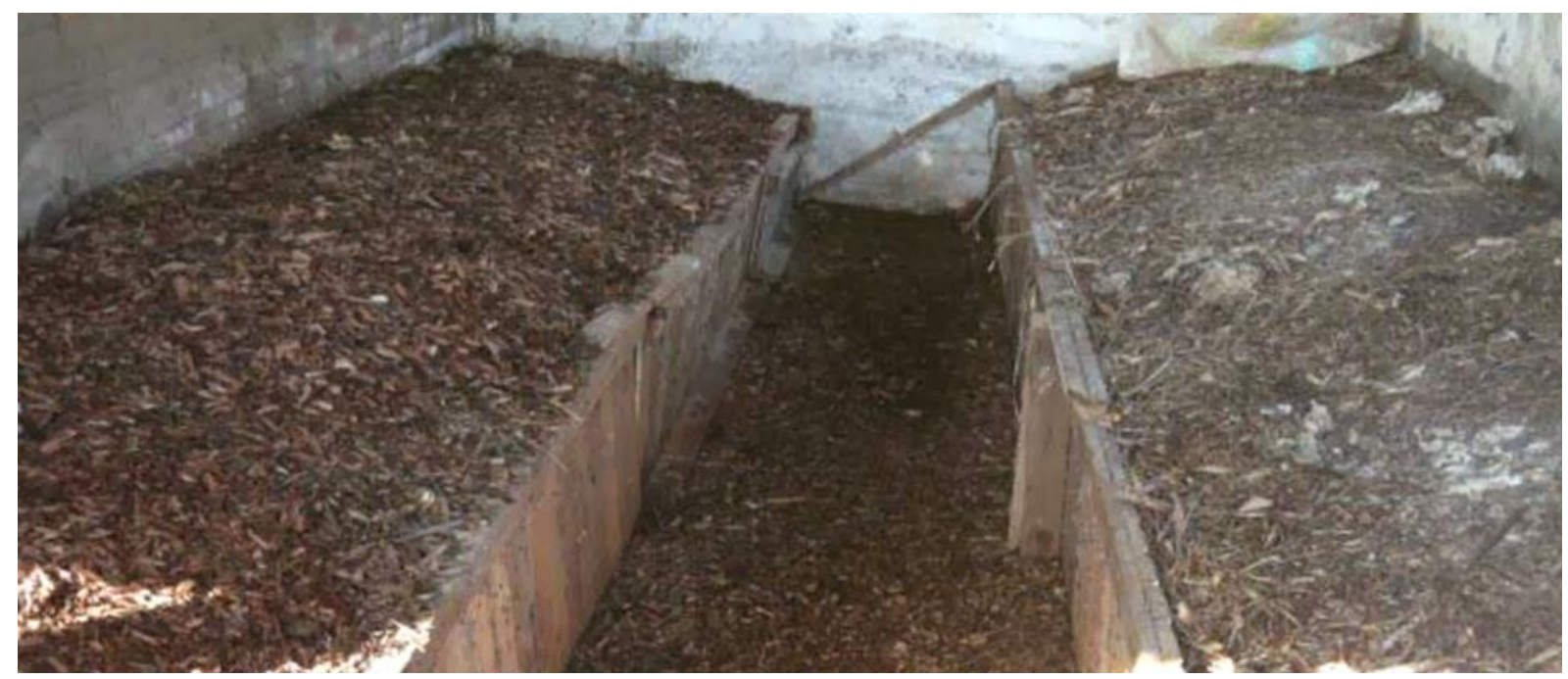

Figura 5. Fotografia de uma baia de alvenaria com a composteira em pleno funcionamento. Fonte: COPEL (2018).

Outra atividade da produção de pescado, a pesca extrativista em ambiente marinho, também gera grande quantidade de resíduo, além do descarte inadequado da fauna acompanhante. Com intuito de entender possibilidades de transformação com estes resíduos Lopes et al. (2017) testaram o processo de compostagem com duas proporções distintas de resíduos e fontes de carbono (1:3 e 1:1). Ao final dos três meses de testes os autores 
concluíram não ser possível o uso do composto como fertilizante, devido a baixa relação C:N e outros fatores como composição mineral presente no composto final.

\section{Farinha de peixe}

A farinha de peixe é subproduto obtido através do processamento do pescado de produção e captura. Produzida a partir do cozimento do peixe integral, dos resíduos ou de ambos, ou após a extração do óleo (SANTOS et al., 2013). Na indústria de processamento de pescado cerca de $60 \%$ é aproveitado na alimentação humana, enquanto boa parte é destinada a resíduos (Vísceras, Cabeça e nadadeiras), desse resíduo, 76\% são aproveitado na forma de farinha e óleo de peixe (ARRUDA, 2004; FAO, 2016). Quando não são devidamente aproveitados, acabam sendo depositados irregularmente, se tornando um fator de poluição ambiental (KOTZAMANIS et al., 2001). O aproveitamento dos resíduos do ciclo de produção do pescado é pouco significativo no Brasil, sendo um problema para planta industrial.

A produção de farinha de peixe proveniente da aquicultura, além de suprir a demanda crescente de proteína na nutrição animal, reduz o descarte e consequentemente o impacto desse resíduo quando descartado (ROSSATO et al., 2013). Segundo Boscolo et al. (2011) os resíduos do cultivo de Tilápia-do-nilo (Oreochromis niloticus) representam em torno de $65 \%$ do total da matéria prima.

Entretanto os resíduos de origem animal fornecem uma boa fonte de energia e nutrientes, tendo grande potencial para a indústria de alimentação animal (BORGHESI et al., 2007), e o a farinha de peixe vem sendo utilizada na dieta animal, devido as proteínas musculares do pescado apresentarem elevado valor biológico, em decorrência da alta sensibilidade á hidrolise e por apresentar composição balanceada em aminoácidos, como metionina e cisteína, os quais costumam ser limitantes em proteínas de origem vegetal (NEVES et al., 2004).

Dentre os alimentos inclusos na alimentação animal, a farinha de peixe é largamente utilizada na aquicultura como fonte proteica e mineral, servindo de base alimentar para diversas espécies nativas e exóticas, devido ao seu bom equilíbrio de aminoácidos e por apresentar boa palatabilidade (BOSCOLO et al., 2011; FARIA et al., 2001). Uma vez que na dieta os peixes necessitam de altos valores proteicos, variando de 24 a 55\% de proteína bruta (SANTOS, 2017). A farinha dos resíduos de filetagem de tilápia tem uso na aquicultura evidenciado por Boscolo et al. (2011), onde utilizou, com inclusão de até 13,52\% na alimentação de alevinos de tilápia-do-Nilo e verificou melhora no desempenho e deposição corporal de nutrientes. 
Além da nutrição animal, a farinha de peixe vem sendo introduzida na alimentação humana, por seu alto valor nutricional, rico em gorduras poli-insaturadas (Ômega 3), vitaminas A, D, complexo B, B12 e minerais, entre eles cálcio, ferro, fósforo, zinco e selênio, e por apresentar baixo valor calórico. Seu uso vem sendo testado em produtos alimentícios, como a elaboração de pão francês utilizando 5 a 15\% de farinha de tilápia, massa de lasanha com inclusão de até $15 \%$ de farinha de tilápia e atum, macarrão com $20 \%$ de farinha de tilápia, entre outros produtos como biscoitos, todos com analises sensoriais testados e boa aceitação do consumidor (CHAMBO e SOUZA, 2018).

Tavares et al. (2010), avaliaram o uso de farinha de matrinxã (Brycon lundii) como substituto da farinha de trigo na formulação de pães de forma, e concluiu que é possível a substituição de 5 a 10\%, aumentando o valor nutricional e inovando nas características sensoriais. Caldos e canjas elaborados a partir de farinhas aromatizadas de peixes defumados foram testados para serem inseridas em merenda escolar, assim enriquecendo o alimento e contribuindo para melhoria na alimentação, tendo boa aceitabilidade pelos consumidores.

No norte do Brasil o uso do piracuí, farinha de pirarucu (Arapaima gigas) é culturalmente utilizado, sendo largamente comercializado em feiras e supermercados (SILVA, 2013). O aproveitamento da farinha de peixe se torna uma alternativa para dar destino ao subproduto do processamento do pescado, reduzindo potenciais impactos ambientais e agregando valores nutricionais na dieta humana e animal.

\section{Óleo de peixe}

O óleo de peixe é um produto obtido simultaneamente a produção de farinha de peixe ou produzida através da silagem ácida do pescado, representa a principal opção no aproveitamento do resíduo de pescado, possuindo aporte nutricional principalmente de ácidos graxos poli-insaturados, da família de ácidos graxos ômega 3, derivados do ácido a-linolênico, os quais desempenha funções biológicas importantes, além da composição rica em triacilgliceróis, lipídeos oxidados e lipídeos polares (SEGURA, 2012). Devido a sua composição, o óleo de peixe é empregado como matéria prima nos mais diversos setores, sendo usado principalmente nas fábricas de curtumes, tintas, vernizes, lubrificantes, selante, entre outros (MENEGAZZO et al., 2015).

$\mathrm{Na}$ alimentação animal, o óleo de peixe representa boa opção para ser inserida na dieta como fonte energética e de ácidos graxos essenciais, Sanches et al. (2014) avaliaram o uso de óleo de peixe na dieta de garoupa verdadeira (Epinephelus marginatus), concluindo que 
com o acréscimo de 4\% na ração comercial utilizada, melhorou o desempenho produtivo, sendo indicada para o crescimento da espécie.

O uso do óleo de peixe vem sendo utilizado na indústria farmacêutica devido aos seus efeitos benéficos. Mund (2004) avaliou a suplementação humana com óleo de peixe para redução de crescimento de tumores, concluindo que a utilização do composto foi capaz de reduzir peso tumoral, além de aumentar a taxa de apoptose e peroxidação lipídica.

Outra alternativa encontrada para a utilização do óleo de peixe é a fabricação de biodiesel. Gomes et al. (2015) utilizaram material lipídico extraído das vísceras de sardinha (Sardinella brasiliensis) para fabricação de biodiesel, o óleo apresentou rendimento de $18,75 \%$ do peso inicial das sardinhas, considerado como bom produto para fabricação de biodiesel. O uso de biodiesel e outros produtos utilizando o óleo de peixe como matéria prima, é uma alternativa de combustível renovável para a matriz energética e redução dos descartes do processamento do pescado.

\section{Considerações finais}

Os resíduos podem ser encaminhados (vendidos ou não) para unidades de tratamento, onde é feito seu reaproveitamento, como farinhas, óleos e etc. As variadas formas de gerenciamento destes resíduos mostram que é possível desenvolver a atividade aquícola, de forma sustentável, minimizando os danos ambientais por ela causados.

\section{Referências}

ASSOCIAÇÃO BRASILEIRA DAS CONCESSIONÁRIAS PRIVADAS DE SERVIÇOS PÚBLICOS DE ÁGUA E ESGOTO - ABCON. Águas de Juturnaíba trata esgoto com plantas aquáticas e sem produtos químicos, Disponível em: $<$ http://abconsindcon.com.br/noticias/aguas-de-juturnaiba-trata-esgoto-com-plantasaquaticas-e-sem-produtos-quimicos/>. Acesso em: 17 de jul. 2020.

ASSOCIAÇÃO BRASILEIRA DE NORMAS TÉCNICAS - ABNT. NBR 10004: resíduos sólidos: classificação. Rio de Janeiro, 2004. 71p.

ARRUDA, L. F. Aproveitamento do resíduo do beneficiamento da tilápia do Nilo (Oreochromis niloticus) para obtenção de silagem e óleo como subprodutos. Piracicaba, 2004. 91 f. Dissertação (Mestrado em Ciência e Tecnologia de Alimentos). Universidade de São Paulo, Piracicaba, 2004.

BORGHESI, R.; ARRUDA, L. D.; OETTERER, M. A silagem de pescado na alimentação de organismos aquáticos. Boletim CEPPA, v. 25, n. 2, p. 329-339, 2007.

BOSCOLO, W. R.; SIGNOR, A.; FREITAS, J. D.; BITTENCOURT, F.; FEIDEN, A. Nutrição de peixes nativos. Revista Brasileira de Zootecnia, v. 40 (supl. especial), p.145-154, 2011. 
BRASIL. Lei no 12.305, de 2 de agosto de 2010. Disponível em: <http://www.planalto.gov.br/ccivil_03/_ato20072010/2010/lei/l12305.htm>. Acesso em: 16 de jul. 2020.

BRASIL. Ministério da Agricultura e do Abastecimento (BRASIL). Decreto no 9013, de 29 de março de 2017.2 Disponível em: <https://www.planalto.gov.br/ccivil_03/_ato20152018/2017/decreto/d9013.htm>. Acesso em: 16 jul. 2020.

CHAMBO, A. P. S.; SOUZA, M. L. R. Farinha de peixe e sua inclusão em alimentos cotidianos. Panorama da Aquicultura. Rio de Janeiro, v. 28, n. 165, p. 50-57, 2018.

COMPANHIA PARANAENSE DE ENERGIA - COPEL. Gerenciamento de resíduos. 2018. Disponível em: <https://www.copel.com/hpcopel/hotsite_caxias/gerenciamento.html> Acesso em: 30 ago. 2020.

CORSO, M. N. Uso de sistemas com recirculação em aquicultura. Porto Alegre, $201036 \mathrm{f}$. Trabalho de conclusão de curso (Graduação em medicina veterinária) - Faculdade de Medicina Veterinária, UFRGS, Porto Alegre, 2010.

DINIZ FILHO, E. T., MESQUITA, L. D., OLIVEIRA, A. D., NUNES, C. G. F., LIRA, J. D. A prática da compostagem no manejo sustentável de solos. Revista Verde de Agroecologia e Desenvolvimento Sustentável, v. 2, n. 2, p. 27-36, 2007.

FARIA, A. C. E. A.; HAYASHI, C.; GALDIOLI, E. M.; SOARES, C. M. Farinha de peixe em rações para alevinos de tilápia do Nilo, Oreochromis niloticus (L.), linhagem tailandesa. Acta Scientiarum. Animal Sciences, v. 23, p. 903-908, 2001.

FOOD AND AGRICULTURE ORGANIZATION (FAO). The State of World Fisheries and Aquaculture: contributing to food security and nutrition for all. Roma, FAO, 2016. 200 p.

FRANÇA, J. B. A.; MORAES, T. V.; VAZ, D. C.; FERREIRA, A. A.; SOARES, F. A. L. Tratamento de efluente doméstico com macrófitas aquáticas para reuso na fertirrigação. Irriga, v. 1, p. 85-93, 2014.

GOMES, A. F; SANTOS, A. G. D; SOUZA, L. D; PINTO, C. H. C; MATIAS, L. G. O; BEATRIZ, A. Síntese e caracterização de biodiesel com material lipídico extraído das vísceras da Sardinella brasiliensis. Revista Geintec, v. 5, n. 2, p. 2181-2194, 2015.

HENRY-SILVA, G. G.; CAMARGO, A. F. M. Impacto das atividades de aquicultura e sistemas de tratamento de efluentes com macrófitas aquáticas-relato de caso. Boletim do Instituto de Pesca, v. 34, p. 163-173, 2018.

KOTZAMANIS, Y. P.; ALEXIS, M.N.; ANDRIOPOULOU, A. Utilization of waste material resulting from trout processing in gilthead brean (Sparus aurata) diets. Aquaculture Research, v. 32 (suppl.1), p. 288-295, 2001.

KUBITZA, F. Sistemas de recirculação: sistemas fechados com tratamento e reuso da água. Panorama da Aqüicultura, v. 16, n. 95, p. 15-22, 2006.

KUBITZA, F.; CAMPOS, J. L. O aproveitamento dos subprodutos do processamento de pescado. Panorama da Aquicultura, v. 16, p. 23-29, 2006. 
LOPES, I. G.; VIDOTTI, R. M.; MARTINS, A. L. M. Compostagem orgânica: método eficiente para a gestão de resíduos de animais da aquicultura. Pesquisa e Tecnologia, v. 14, p. 1-6, 2017.

MENEGAZZO, M. L.; LUCAS, B. F.; ALCADE, L. B.; Maria Eugenia PETENUCCI, M. E.; FONSECA, G. G. Production of biodiesel via methyl and ethyl routes from Nile tilapia and hybrid sorubim crude oils. Journal of Environmental Chemical Engineering, v. 3, n. 1, p. 150-154, 2015.

MUND, R. C. Suplementação crônica com óleo de peixe reduz a taxa de crescimento do tumor de Walker 256: identificação dos mediadores participantes neste processo. Curitiba, 2004. 63 f. Dissertação (Mestrado em Biologia celular) - Universidade Federal do Paraná, Paraná, 2004.

NAIME, R.; GARCIA, A. C. Utilização de enraizadas no tratamento de efluentes agroindustriais. Estudos Tecnológicos, v. 1, p. 9-20, 2005.

NASCIMENTO, M. S; PEREIRA, S. J. B.; SANTOS, R. F; VIEIRA, A, M. Avaliação e caracterização do processo de compostagem de resíduos de peixes. PUBVET, v. 12, p. 133, 2018.

NEVES, R. A. M.; DE MIRA, N. V. M.; MARQUEZ, U. M. Caracterização de hidrolisados enzimáticos de pescado. Food Science and Technology, v. 24, n. 1, p. 101-108, 2004.

ROSSATO, S.; PRETTO, A.; FREITAS, I. L. D.; BATTISTI, E. K.; LAZZARI, R.; RADUNZ NETO, J. Incorporação de farinhas de resíduos de Jundiá na dieta: bioquímica plasmática, parâmetros hepáticos e digestivos. Ciência Rural, v. 43, n. 6, p. 1063-1069, 2013.

SANCHES, E. G.; DA COSTA SILVA, F.; LEITE, J. R.; SILVA, P. K. A.; KERBER, C. E.; DOS SANES, F. S. M., STRASSBURGER, A. S., ARAÚJO, F. B., MEDEIROS, C. A. B. Compostagem e fermentação de resíduos de pescado para produção de fertilizantes orgânico. Semina: Ciências Agrárias, v. 36, n. 3, p. 1241-1251, 2015.

SANES, F. S. M., STRASSBURGER, A. S., ARAÚJO, F. B.; MEDEIROS, C. A. B. Compostagem e fermentação de resíduos de pescado para produção de fertilizantes orgânico. Semina: Ciências Agrárias, v. 36, n. 3, p. 1241-1251, 2015.

SANTOS E. L.; CAVALCANTI, M. C. D. A.; FREGADOLLI, F. L.; MENESES, D. R.; TEMOTEO, M. C.; LIRA, J. E.; FORTES, C. R. Considerações sobre o manejo nutricional e alimentar de peixes carnívoros. Revista Eletrônica de Nutrição, v. 11, n. 2, p. 2314-2351, 2013.

SANTOS, F. W. B. Nutrição de peixes de água doce: definições, perspectivas e avanços científicos. In: I Simpósio de nutrição e alimentação animal, 2017, Fortaleza. Anais. p. 25-61. 2017.

SATHLER, J. Compostagem: você sabe o que é? CONCRETA CONCULTORIA E SERVIÇOS. 2018. Disponível em: <https://tinyurl.com/y6pquw5k>. Acesso em: 29 de ago. 2020.

SEGURA, J. G. Extração e caracterização de óleos de resíduos de peixes de água doce. Pirassununga, 2012. 93. f. Dissertação (Mestrado em Qualidade e Produtividade Animal) São Paulo, 2012. Tese de Doutorado. Universidade de São Paulo, 2012. 
TAVARES, T. S.; BASTOS, S. C.; PIMENTA, M. E. S. G.; PINHEIRO, A. C. M.; FABRICIO, L. F. F.; LEAL, R. S. Perfil sensorial de pão de forma enriquecido com farinha de matrinxã (Brycon lundii). In: Congresso de Pós-Graduação DA UFLA, 19, Reunião regional as SBPC, 2010, Lavras. Anais. p. 1-4, 2010.

VALENTE B. S.; XAVIER E. G.; PEREIRA H. D. S.; TABELEÃO, P.M.V. Compostagem de resíduos da filetagem de pescado marinho e casca de arroz. Revista Brasileira de Saúde e Produção Animal, v.17, p. 237-248, 2016. 


\section{Capítulo 25}

\section{Aplicação de ingredientes alternativos na formulação de rações para peixes de corte na perspectiva agroecológica}

João Victor Nascimento Tardim ${ }^{1}$, Paola de Oliveira Santos ${ }^{1}$, Venan Vieira dos Anjos ${ }^{1}$, Layon Carvalho de Assis ${ }^{1}$, Joyce Garcia Silva ${ }^{1}$, Luiza Aparecida Campos de Paula ${ }^{2}$, Silvia Pope de Araújo $^{3}$, Leonardo Demier Cardoso ${ }^{4}$, Alberto Chambela Neto ${ }^{5}$, Pedro Pierro Mendonça ${ }^{6}$

\section{Introdução}

A incorporação e o desenvolvimento de sistemas de produção de alimentos menos impactantes sobre o meio ambiente, economicamente viáveis, socialmente justos e, portanto, mais sustentáveis, é uma forma de garantir a manutenção dos recursos naturais e o desenvolvimento sustentável do país e das suas populações. O enfoque Agroecológico considera o agroecossistema de forma integrada, buscando sua sustentabilidade, ou seja, com o menor impacto ambiental possível. Para Gliessman (2005), o agroecossistema deve ser proporcionar uma estrutura com a qual é possível analisar os sistemas de produção de alimentos como um todo, incluindo seus conjuntos complexos de insumos e produção, bem como as interconexões entre as partes que o compõem. A agroecologia permite a integração de três componentes da sustentabilidade: fundamentação dos princípios ecológicos, viabilidade econômica e equidade social (GLIESSMAN, 2009).

Desenvolver sistemas menos impactantes sobre a natureza, mais sustentáveis, e acessíveis a todos, é uma forma de garantir a manutenção dos recursos e desenvolvimento destas atividades e das populações que delas dependem. Uma vez, que a produção de alimentos, sua exploração por meio de atividades extrativistas, geram efeitos ambientais, seja na redução da fauna e da flora. A intensificação ecológica é um novo conceito na agricultura que aborda o duplo desafio de manter um nível de produção suficiente para

1,Graduandos em Engenharia de Aquicultura pelo Instituto Federal do Espírito Santo - Campus de Alegre, Caixa Postal 47, CEP: 29500-000, Alegre-ES E-mail: jvntardim@gmail.com; paolamanfredini111@gmail.com; vieira.venan@gmail.com; layoncdeassis@gmail.com; joyce_g_silva@hotmail.com

${ }^{2}$ Mestranda em Ciências Veterinárias pela Universidade Federal do Espírito Santo - Campus de Alegre, Caixa Postal 16, CEP: 29500-000, Alegre-ES. E-mail: luzpaula.campos@gmail.com

${ }^{3}$ Doutoranda pelo Programa de Ciências de Alimentos da Universidade Federal do Rio de Janeiro. E-mail: silviapopedearaujo@gmail.com

${ }^{4} \mathrm{Dr}$. Professor do Instituto Federal do Espírito Santo - Camus Piúma. E-mail: leonardodemier@hotmail.com

${ }^{5}$ Dr. Professor do Instituto Federal do Espírito Santo - Campus Santa Teresa. Rod ES 080, km 93, São João de Petrópolis, CEP: 29650-000, Santa Teresa-ES. E-mail: chambela@ifes.edu.br

${ }^{6}$ Dr. Professor do Instituto Federal do Espírito santo - Campus de Alegre. Caixa Postal 47, CEP: 29500-000. Alegre -ES. E-mail: ppierrom@gmail.com 
atender às necessidades das populações humanas e respeitar o meio ambiente, a fim de conservar o mundo natural e a qualidade de vida humana (AUBIN et al., 2019).

Métodos aprimorados de produção agrícola de alimentos e o aumento da renda per capita média levaram a diminuição da fome global no último meio século, apesar da duplicação da população mundial. A população global deverá aumentar em 2,3 bilhões de pessoas até 2050 , exigindo um aumento estimado de $70 \%$ na produção de alimentos. No entanto, a produção mundial de alimentos está enfrentando um desafio maior, pois os métodos anteriormente utilizados para intensificar a agricultura logo não serão mais uma opção. Em particular, a proteína é um dos principais nutrientes que serão escassos no futuro. Fontes alternativas de proteína e métodos de produção são necessárias para atender a demanda dos consumidores e aos requisitos globais previstos de proteína (GODFRAY et al., 2010; BLEAKLEY et al., 2017).

O elevado consumo de proteína leva o ser humano a investir cada vez mais em técnicas de criação de gado, onde se utiliza imensa área de solo para pastagem, além de outros cultivos que são destinados à alimentação complementar desses animais. A produção agrícola, também é outra opção para a obtenção de proteína, que depende de melhoramento genético, onde exigem elevados gastos com sementes, adubações do solo, irrigação e o uso de pesticidas no combate as pragas. Segundo a Organização das Nações Unidas para a Alimentação e a Agricultura (FAO, 2018), o cultivo de peixes representa cerca de $49 \%$ da produção aquícola mundial. Devido à crescente demanda de proteína e energia para a dieta animal e a busca pela substituição de aditivos sintéticos por ingredientes naturais e alternativos cresce a cada vez mais. O crescente consumo de proteína animal gera enorme busca por novas fontes de proteína adequadas para a produção de alimentos (KOVAČ et al., 2013).

As rações para peixes seguem exigências de quantidades de proteína dietética podendo conter de 28 a 50\% de proteína bruta, dependendo da fase de desenvolvimento e do sistema de cultivo. Atualmente usa-se principalmente milho e soja que são produtos produzidos principalmente para consumo humano, o que eleva o seu valor no mercado. E a farinha de peixe, que é um subproduto proveniente do processamento, podendo, portanto, oscilar de acordo com a produção do pescado. Mas, com a expansão da aquicultura no mundo, a utilização de alimentos alternativos para melhor eficiência de utilização e maior produção tem crescido ao longo do tempo, buscando por uma minimização dos custos com as rações. De acordo com Meurer et al. (2000), o estudo dos alimentos alternativos procura dar subsídios para a produção de ração, além de mais baratas, de mesma qualidade nutricional, proporcionando desempenho produtivo equivalente aquelas formuladas com alimentos convencionas, e que sejam menos impactantes ao meio ambiente. 
A procura por ingredientes alternativos, buscando uma produção em perfeita harmonia com o meio ambiente, utilizando praticas que procuram se assemelhar às condições naturais dos organismos, tem se tornando uma pratica econômica alternativa e sustentável. Ainda existem muitas questões à serem elucidadas para que se alcance maior eficiência produtiva, caso da alimentação, manejo, bem-estar animal e controle do efluente produzido.

Neste sentido, o presente capítulo objetivou-se mostrar a utilização de ingredientes alternativos na formulação de rações, como prática econômica e ambientalmente sustentável.

\section{Manejo nutricional dos animais}

A nutrição de peixes relacionada a crescimento, desenvolvimento e reprodução, é parecida com a de animais terrestres. Em ambiente natural os animais adquirem os nutrientes necessários se alimentando de outros animais frutos e plantas, porém em ambiente de cultivo eles não têm acesso a estes alimentos, necessitando do fornecimento de ração adequada a suas exigências nutricionais. Existe grande variedade de hábitos alimentares de peixes, mas podemos dividir em três grupos: os carnívoros, que se alimentam de outros peixes, insetos e pequenos gastrópodes, os herbívoros, que se alimentam de frutos plantas e algas, e os onívoros, que se tem hábito tanto carnívoro quanto herbívoro. A má formulação da ração pode diminuir o desempenho zootécnico dos animais, levando ao aumento dos gastos com a produção e diminuindo a margem de lucro (RIBEIRO et al., 2012).

Os animais requerem proteínas, aminoácidos, lipídios, carboidratos, fibras, vitaminas e minerais em suas dietas. Os tipos e quantidades de cada um desses nutrientes variam, não somente entre as espécies, mas dentro das espécies, com a idade, funções produtivas e condições ambientais, por exemplo, o peixe jovem, em crescimento ativo, requer nível mais alto de proteína que um peixe adulto (SANTOS, 2017). No entanto, essas necessidades não estão bem estabelecidas para grande maioria das espécies cultivadas ou potencialmente para a piscicultura. Desse modo, as fontes de energia presentes nos alimentos são proteínas, lipídios e carboidratos. Esses devem estar balanceados nas dietas, para que o peixe possa encontrar nutriente e energia necessária para seu desenvolvimento.

Atualmente a formulação de dietas para animais tem sido feita visando as exigências energéticas. A relação energia/proteína, que e um dos itens de fundamental importância para a nutrição animal, para os peixes é o ponto que merece atenção prioritária na determinação das exigências nutritiva de uma espécie (RIBEIRO et al., 2012). Os peixes 
carnívoros parecem exigir maior relação energia/proteína e que os herbívoros podem se desenvolver em níveis energéticos mais baixos.

\section{Proteína e aminoácidos}

Os peixes exigem uma maior quantidade de proteína dietética, comparados aos outros animais. Dependendo da fase de desenvolvimento, do ambiente e da espécie as rações para peixes contêm entre 28 a $50 \%$ de proteína bruta (PB). A implementação da proteína na dieta animal é de suma importância, pois são estruturas responsáveis pelo desenvolvimento muscular, e de alguns mecanismos de defesa do organismo do animal. É fundamental que o desenvolvimento zootécnico dos animais sejam satisfatório, para isso as dietas devem ser fornecidas de maneira adequada dos nutrientes, por isso torna-se necessário conhecer as exigências proteica do animal para cada fase de cultivo e uma ração bem formulada e analisada a nível nutricional se torna importante para que os animais tenham um desempenho zootécnico satisfatório. Os peixes não necessariamente precisam de uma quantidade elevada de proteínas em sua alimentação, desde que os aminoácidos certos estejam presentes em quantidade adequada para deposição de proteínas corporais (FURUYA, 2013). O grupo de aminoácidos não essenciais são aqueles os quais são sintetizados pelo organismo em quantidade suficiente para a demanda e os essenciais, que por não seres sintetizados na quantidade necessária devem ser, essencialmente, disponibilizados na ração (WU, 2013). Os peixes necessitam de proporções adequadas de aminoácidos essenciais e não essenciais na ração, para que haja deposição de proteína muscular e corporal (WILSON, 2002).

A realização da avaliação dos perfis e a biodisponibilidade dos aminoácidos essenciais e não essenciais, como lisina, metionina, treonina e triptofano são consideradas de suma importância, pois eles são os mais limitantes em rações para peixes. Alimentos de origem animal e vegetal podem ser utilizados na alimentação de peixes e substituir parcial ou totalmente os alimentos de origem animal tradicionalmente utilizado nas rações para aquicultura.

\section{Carboidratos e lipídios}

Os carboidratos representam excelentes fontes de carbono e energia alimentação dos peixes. A fonte de carboidratos para a formulação de rações depende da disponibilidade e custo da matéria prima na região onde o processamento está sendo executado. No entanto, a seleção da fonte de carboidratos e as proporções empregadas na formulação devem ser 
compatíveis com as exigências do peixe e as características da matéria prima. Em geral, os peixes não requerem fontes de carboidratos especifica, mas podem apresentar uma redução moderada na taxa de desenvolvimento quando alimentadas com dietas livres de carboidratos (HONORATO et al., 2013; ZHOU et al., 2013).

A principal fonte de carboidrato são os alimentos de origem vegetal, contudo peixes tem a capacidade reduzida de metabolizar estes ingredientes. Apesar disso os carboidratos são indispensáveis na dieta, pois garante que o animal deixe de usar proteínas para a obtenção de energia, resguardando-as para seu crescimento e desenvolvimento (BOSCOLO et al., 2011). O milho moído e uma das principais fontes energéticas para peixes onívoros e herbívoros, mas sua inclusão na dieta deve levar em conta não apenas acessibilidade e a viabilidade econômica, mas o teor de umidade e a presença de micotoxinas e resíduos de pesticidas. $O$ uso do sorgo na alimentação dos peixes é mais comum que o do milho, mas pode ser problemático devido à presença de taninos que são tóxicos para os peixes. Devese notar, no entanto, que variedades de sorgo que produzem níveis mais baixos de tanino estão atualmente disponíveis. Farelo de arroz e subprodutos de arroz, como farelo de arroz desengordurado e farelo de arroz com gérmen, podem substituir outros grãos em formulações de ração para peixes. Portanto, é melhor usar farelo de arroz estabilizado que tenha sido tratado termicamente para desativar as lipoxidases responsáveis pela rancificação e, assim, prolongar a vida de prateleira. A farinha de mandioca é uma matériaprima barata e abundante que é rica em carboidratos. Além disso, o material tem um efeito aglutinante que é altamente desejável para formulações de ração para aquicultura, uma vez que reduz a dissolução de sólidos na água, evitando assim a perda de nutrientes e proporcionando uma utilização mais completa da ração pelos peixes (SEIXAS et al., 1997).

Os lipídios são responsáveis por fornecer energia ao animal, e, são mais metabolizáveis pelos peixes. Fornecem energia e ácidos graxos essenciais para os peixes e desempenham um papel importante na absorção e transporte de vitaminas lipossolúveis (RIBEIRO et al., 2012). A utilização dos lipídios nas rações apresenta vários benefícios que estão relacionados ao valor energético, onde os peixes conseguem metabolizar estes compostos, e a suas exigências nutricionais já estão bem definidas na literatura. Assim como os demais animais, os peixes são incapazes de produzir ácidos graxos da família ômega-9, ômega-6 e ômega-3 que devem ser supridas pela sua dieta. As fontes ricas em ácidos graxos monoinsaturados e poli-insaturados, ômega 6 são retiradas de óleos de oliva, de milho e de soja. Dessa forma, os ácidos oleico, linoleico e a-linolênico, precursores destas famílias, são essenciais para estes animais. Fontes de ácidos graxos poli-insaturados ômega 3 são os óleos de linhaça e de peixe (GUNSTONE et al., 1994). 
As algas também são boas fontes de lipídios para a alimentação dos peixes, uma vez que são fontes de ácidos graxos monoinsaturados e poli-insaturados. Radmann e Costa (2008), estudaram o conteúdo lipídico e composição de ácidos graxos de diferentes microalgas, encontraram 25 a 73\% de ácido linolênico na biomassa de S. maxima. Peixes de água doce, possuem uma serie de enzimas capazes de modificar o perfil da dieta e dos ácidos graxos, bem como dos produtos de sua biossíntese (RIBEIRO et al., 2012). Esta capacidade permite a inclusão, na alimentação, de óleos vegetais, incluindo as microalgas, desde que contenham quantidade adequada de ácido $\alpha$-linolênico, que será então convertido em EPA e DHA pelo sistema enzimático do peixe. Muitas espécies podem transformar determinado ácido graxo em seu correspondente de cadeia, mais longa, por exemplo, o ácido a-linolênico (C18:3 n-3), pode ser convertido em EPA (C20:5 n-3) e este ainda pode originar o DHA (C22:6 n-3) (MARTIN et al., 2006).

\section{Ingredientes alternativos}

A procura por alimentos alternativos cresce cada vez mais, dando subsídios para a obtenção de rações mais baratas e de valor nutricional proporcionando desempenho produtivo igual àquelas formuladas com alimentos convencionais. O desafio da aquicultura está relacionado à viabilidade econômica e alternativas sustentáveis para a substituição, em parte, de alimentos como farinha e óleo de peixe, que são utilizados em grande escala na produção de rações. Os peixes cultivados, em geral, necessitam dos mesmos nutrientes exigidos pelos animais terrestres para funções fisiológicas como crescimento e reprodução. Esses nutrientes são obtidos pela ingestão de alimentos naturais disponíveis no ambiente e das rações comerciais fornecidas aos animais criados em cativeiros (ROTTA, 2003; GATTLIN III et al., 2007).

A pesquisa relacionada à produção de dietas com ingredientes alternativos para aquicultura cresce cada vez mais, direcionando à procura de ingredientes substituir matérias primas de origem aquática. Para ocorrer às substituições, os ingredientes devem possui características de adequação nutricional, fáceis manuseio, boa porcentagem de proteína, transporte e estocagem, perfil favorável de aminoácidos, baixo teor de fibra, alta digestibilidade dos nutrientes e palatabilidade, podendo ser de origem vegetal ou animal (GATLIN III et al., 2007; GLENCROSS et al., 2007; BRINKER e REITER, 2011). A utilização de subprodutos agroindustriais e resíduos pode ser uma alternativa viável para a substituição de ingredientes convencionais, com o intuito de diminuir os custos de produção e promover sustentabilidade (CHO e KAUSHIK, 1990) Pesquisas visam obter informações necessárias para a formulação de rações que possam atender as exigências para as 
espécies cultivadas. A escolha de ingredientes alternativos deve ser feita com base nas características inerentes ao animal, hábitos alimentares, funções fisiológicas, reprodução e crescimento. Além disso, o baixo preço dos produtos é essencial para a inclusão em rações para cultivos (NAYLOR et al., 2009; CYRINO et al., 2010). A inclusão de proteínas e óleos de origem vegetal é amplamente utilizada nas formulações de rações aquícolas, existem várias fontes proteicas que podem ser substitutos da farinha de peixe, como grão oleaginoso (soja e canola), e grãos de cereias (milho e trigo), estes elementos têm sido considerados como novas opções viáveis em busca de sustentabilidade (DIAS et al., 2009; PEZZATO et al., 2009).

Segundo Santos et al. (2015), os ingredientes mais utilizados na formulação de rações devido a disponibilidade no mercado são farinha de sangue, farinha de penas, farelo de soja, farelo de trigo, farinha de peixe e farinha de milho. A produção destes ingredientes resulta em grande impacto ambiental e social, onde os gastos com a nutrição em sistema piscícola podem ultrapassar $70 \%$ do custo da produção (LEONARDO, 2018). A busca por novas fontes que possam substituir a ração comercial, atender as demandas nutricionais dos animais e além de baratear o custo de produção se torna um desafio para pesquisadores que atuam na área da nutrição animal. Para redução dos impactos ambientais e de custos na produção, uma alternativa é a utilização de rações formuladas com ingredientes alternativos. Para incrementar rações com novos ingredientes é preciso fazer avaliação da absorção nutricional com destaque para digestibilidade proteica e energética destes alimentos (BOSCOLO et al., 2011; SANTOS et al., 2015). Com perspectivas promissoras de continuo crescimento na produção das fontes proteicas de origem vegetal, tem se preconizado o uso das mesmas para compor rações comerciais em substituição às farinhas de origem animal.

A utilização dos subprodutos oriundos da agroindústria de frutas apresenta-se como boa alternativa na alimentação dos peixes. No nordeste brasileiro a procura por fontes alternativas tem encontrado nestas fontes boa alternativa para substituição de alguns cereais tradicionais. Após seu processamento, de 4 a $12 \%$ de matéria seca são descartados, ocorrendo a perda de nutrientes que poderiam ser reaproveitados (MANTOVANI et al., 2004; SANTOS et al., 2009). Vários autores testaram novas fontes de alimentos, para substituição de ingredientes tradicionais. Nas fases de alevinagem da tilápia, Melo et al (2012) propõem a substituição do farelo de milho, por farinha de manga (Mangifera indica $L$ ) que apresenta índices superiores de frutose, de 2,3 a 3,1\% quando comparada com o milho. Jesus et al. (2011), utilizaram farelo da vagem de Algaroba (Prosopis juliflora), uma leguminosa arbórea nativa de regiões áridas e semiáridas, como fonte alternativa para incrementar a ração, e constatou eficácia na adição de ate $20 \%$ sem o comprometimento dos parâmetros zootécnicos. Lazzari et al. (2018) empregaram o uso de 
resíduos de fruticultura ( Goiaba, laranja, uva e figo) na dieta de juvenis de Piava (Leporinus obtusidens) e obtiveram resultados positivos na utilização dessas fontes de resíduo, utilizando as proporções 7, 10, 8 e 7\% de uva, figo, laranja e goiaba, respectivamente, sem ocasionar disparidades nos parâmetros de crescimento e composição corporal, além de concluírem que o uso dos resíduos de figo, uva e goiaba proporciona melhor eficiência alimentar a longo prazo. Anselmo (2008) avaliou o uso de alguns desses resíduos na alimentação de juvenis de tambaquis (Colossoma macropomum), entre eles o uso de jenipapo, fruto do jenipapeiro (Genipa americana), podendo ser utilizada como fonte alternativa de proteína na dieta de juvenis de tambaqui, com inclusão de $30 \%$. Pereira Junior et al. (2008) avaliaram a substituição do farelo de milho por resíduo gerado da farinha de mandioca, em juvenis de tambaquis e concluíram a viabilidade da substituição total do farelo de milho, sem comprometer variáveis de desempenho, entre eles conversão alimentar e mortalidade, além de baratear o custo da ração e consequentemente reduzir o preço de venda da carne do Tambaqui. Lopes et al. (2010) e constataram que o uso do farelo de babaçu pode ser incrementado em até $12 \%$ na ração, sem comprometer os índices zootécnicos. Todas essas alternativas foram comprovadas como ótima fonte energética e que não apresentam prejuízos no desempenho dos peixes.

Quando se trata de alimentos alternativos para nutrição, também se destacam as microalgas que fornecem quantidades significativas de quase todos os nutrientes necessários para peixes, outros animais e até mesmo para os seres humanos. Todas as espécies de microalgas têm seu próprio perfil nutritivo, sendo provedoras de excelentes compostos, como proteínas, lipídios e carboidratos, além de minerais, vitaminas e antioxidantes, essenciais para as condições da saúde, uma vez que apresentam papel importante para nutrição (DINESHBABU et al., 2019).

A crescente população mundial e a consequente deficiência no suprimento de proteínas para a nutrição humana levam a atividade aquícola explorar novas alternativas como fontes de proteínas. Isso impulsionou o desenvolvimento de estratégias de cultivo aprimoradas para a produção de biomassa de algas em grande densidade celular (OLAIZOLA, 2003). O uso de microalgas como ingrediente alimentar é muito promissor, como alternativa de culturas alimentares básicas, como soja e milho, contribuindo com a cadeia alimentar humana e para a sustentabilidade da agricultura. No entanto, ainda estamos para alcançar o máximo possível de exploração comercial sustentável dessa biomassa algacea. A utilização das microalgas como alimento para peixes ou suplemento alimentar pode reduzir a elevada demanda da aquicultura baseada em farinha de peixe (DINESHBABU et al., 2019). As microalgas apresentam características nutricionais compatíveis com farinha de peixe e óleo de peixe, colocando-as com potencial substituto destes ingredientes nas rações para animais aquáticos, ou como suplemento alimentar. 
A expansão na pesquisa sobre a utilização desta biomassa para alimentos e rações tem crescido bastante ao longo dos anos (CHEW et al., 2017). A imensa biodiversidade e a variabilidade da composição da biomassa decorrente das condições de crescimento, aliadas às tecnologias de cultivo em grande escala, têm apontado a produção de biomassa tanto para uso na elaboração de alimentos quanto para a obtenção de compostos naturais com alto valor no mercado mundial (DERNER et al., 2006). As microalgas são cultivadas para a utilização na aquicultura, e cada vez, mais tem aumentado os estudos sobre o seu uso como alimentos funcionais. Isso se deve as suas características nutricionais, como a sua composição da parede celular, formada por polissacarídeo, os tipos e quantidades de lipídeos, a conformação de diferentes aminoácidos e a presença de pigmentos e micronutrientes (VILLARRUEL-LÓPEZ et al., 2017). A figura 1 demonstra o mercado para os produtos derivados de algas, mostrando seus principais compostos e áreas de aplicações destes produtos obtidos a partir das algas. Como podemos observar vários destes produtos podem ser aplicados na nutrição animal.

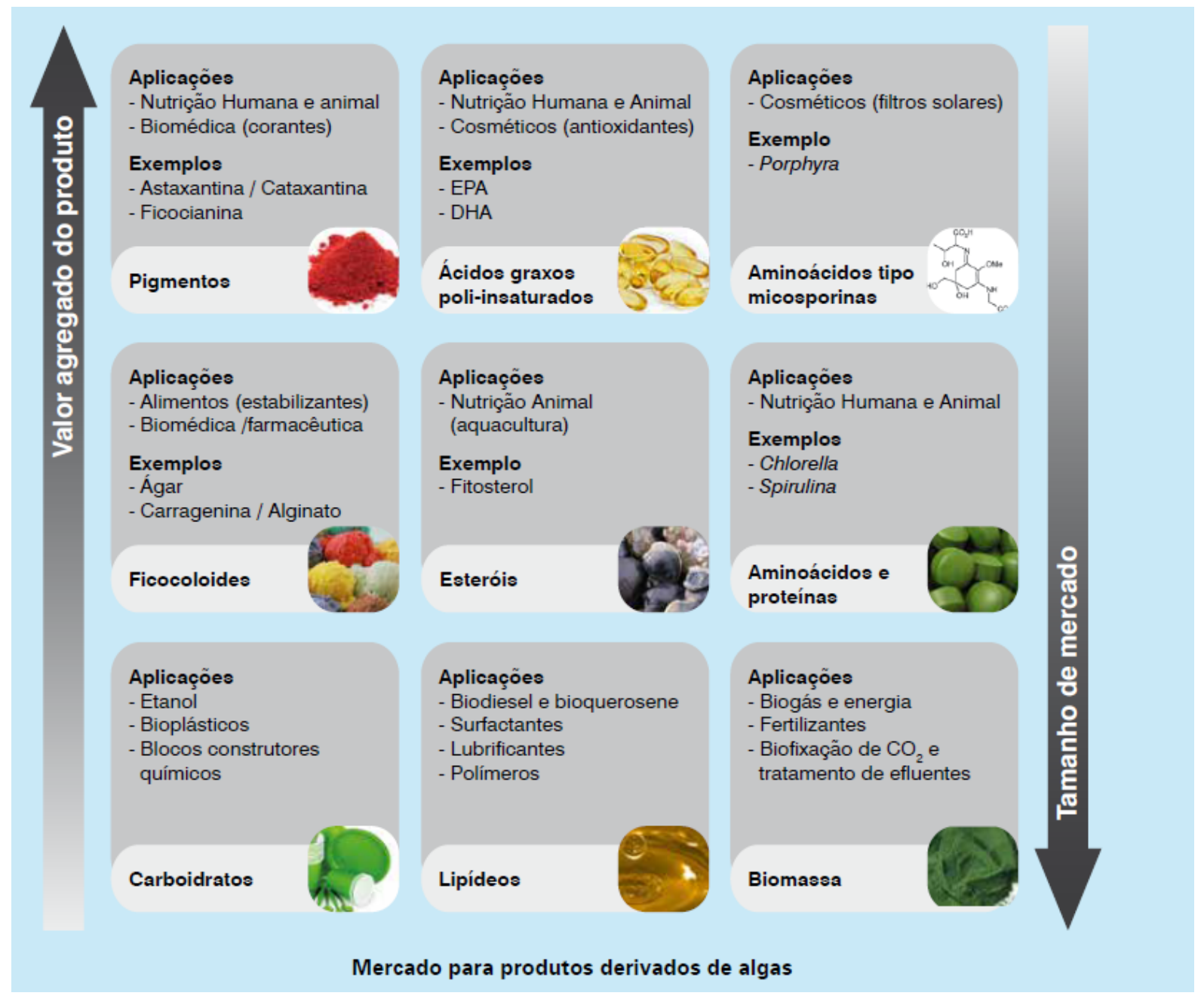

Figura 1. Panorama do mercado para produtos derivados de algas e suas aplicações. Fonte: Embrapa Agroenergia (2016). 
$\mathrm{Na}$ alimentação animal, os valores nutritivos das microalgas variam de acordo com a espécie utilizada e a forma de manipulação do cultivo, e também da própria adaptação animal aos ingredientes (MADEIRA et al., 2017). Estudos têm sugerido que as algas podem ser utilizadas como fontes proteicas em forma de suplemento ou substituindo fontes convencionais, como farelo de soja e farinha de peixe (BECKER, 1994; SPOLAORE et al., 2006). Várias espécies de microalgas apresentam alto teor de proteína, sendo um dos principais fatores que favorecem sua utilização na produção de rações (KOVAČ et al., 2013). A utilização de espécies de microalgas na dieta dos peixes pode levar a redução de $50 \%$ em seu preço e aumentar o valor nutricional. Geralmente, e utilizado numa combinação de duas ou mais espécies de microalgas para a formulação de uma dieta. Podem ser utilizadas como alimento para larvas e moluscos juvenis e peixes, e também para criação de zooplâncton necessário para alimentação de animais juvenis (CHEN, 2003).

Os gêneros de microalgas mais utilizados na aquicultura são Spirulina, Clhorella, Tetraselmis, Isochrysis, Pavlova, Phaeodactylum, Nannochloropsis, Skeletonema e Thalassiosira. A Spirulina é amplamente utilizada em rações na aquicultura, particularmente na alimentação de peixes tropicais, devido as suas grandes quantidades de pigmentos (RICHMOND, 1988). Palmegiano et al., (2005) demonstram que os peixes alimentados com ração a base de Spirulina obteve melhor crescimento.

A substituição da farinha de peixe ou outra fonte nutricional de proteínas, como por exemplo o farelo de soja, por Spirulina na mesma proporção, como alimento funcional foi considerado por apresentarem propriedades bioativas, com o objetivo principal de melhorar a saúde, a qualidade e a resistência dos peixes. Por tanto, é notável que o uso de Spirulina em dietas para aquicultura tenha sido amplamente estudado, principalmente na última década (ROSAS, et al., 2019). A figura 2 mostra um cultivo em reatores da microalga Spirulina máxima sendo realizado para a produção de ração suplementada com a biomassa para ser utilizada na alimentação de alevinos. 


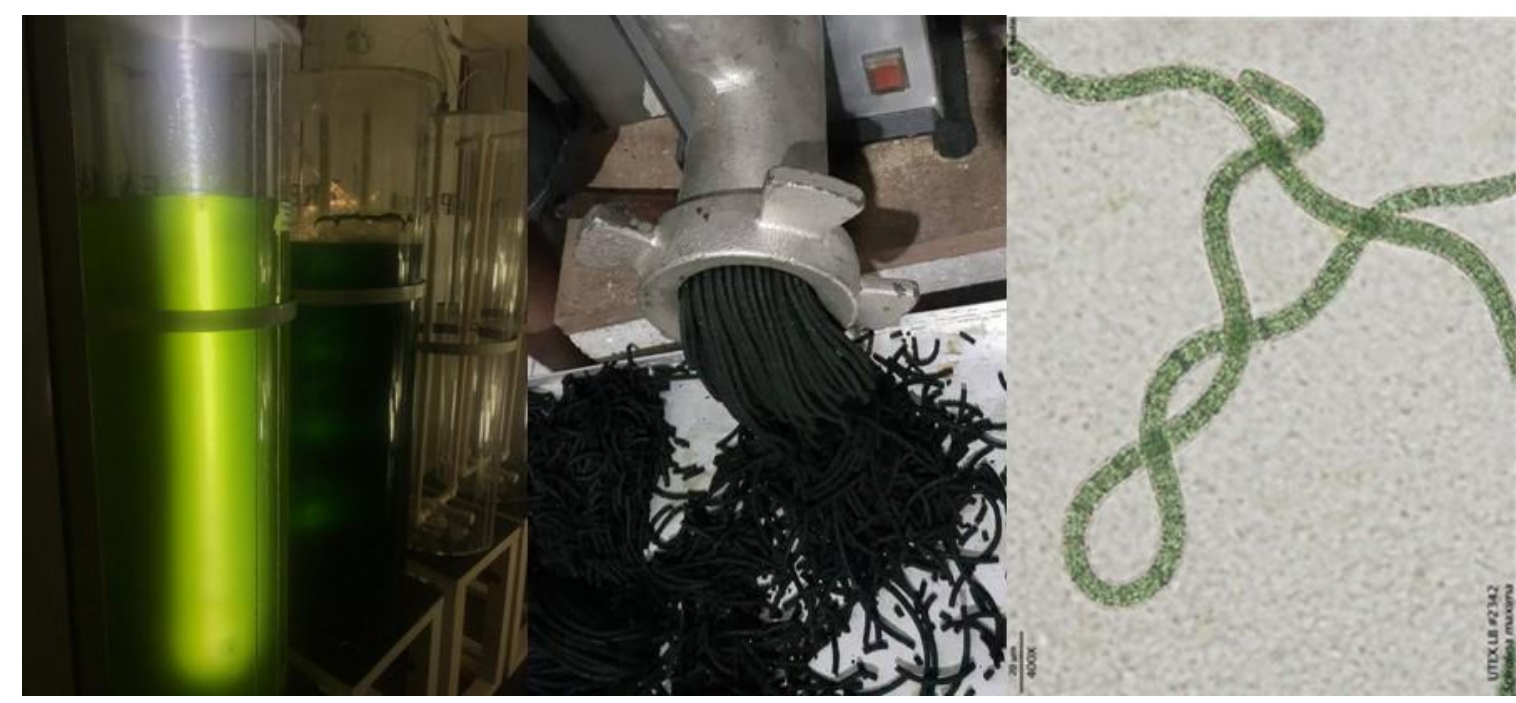

Figura 2. Cultivo de Spirulina máxima para obtenção de biomassa e fabricação de ração para peixe com a biomassa algacea.

Fonte: Os Autores.

A indústria da aquicultura para manter a sustentabilidade, depende da disponibilidade de alimentos de alta qualidade que sejam nutricionalmente equilibrados e com preço competitivo. A alta densidade populacional de peixes exige o uso de alimentos que proporcionem alta densidade nutricional, digestibilidade e palatabilidade, simultaneamente gerando quantidade mínima de resíduos ricos em fósforo e nitrogênio (ARTURO, 2019). Devido a isso, a preocupação de que os sistemas intensivos de produção empregados na piscicultura moderna sejam prejudiciais ao meio aquático. De fato, a busca por ingredientes alternativos cresce cada vez mais, fazendo com que o setor manufatureiro esteja sempre sob pressão para desenvolver formulações de rações que gerem o mínimo de resíduos. A seleção de ingredientes para formulação de rações, como proteínas de origem animal ou vegetal, carboidratos, lipídios (óleo de peixe ou vegetal), vitaminas, agentes aromatizantes e compostos bioativos, é importante considerar o destino desses componentes no ambiente aquícola. Assim, a formulação de alimentos adequados requer conhecimento detalhado sobre as necessidades nutricionais específicas das espécies-alvo, bem como as características de disponibilidade e processamento dos ingredientes (ARTURO, 2019).

Visando maximizar lucros e reduzir impactos ambientais, insumos utilizando ingredientes alternativos se torna boa opção e o Brasil apresenta grande quantidade e diversidade de substitutos para os ingredientes usualmente utilizados na aquicultura. 


\section{Impactos sociais gerados a partir ingredientes alternativos}

A produção mundial da indústria da aquicultura atingiu 114,5 milhões de toneladas de peso vivo em 2018. A produção total consistiu em 82,1 milhões de toneladas de animais aquáticos. Uma das razões para esse aumento é o crescimento global do consumo per capita de produtos de peixes. A FAO relatou que a produção global atingiu cerca de 171 milhões de toneladas em 2016, com a aquicultura representando $47 \%$ do total, podendo chegar a 53\% se houver redução do uso de ingredientes não alimentares, incluindo redução de farinha e óleo de peixe. Devido ao aumento da demanda e pela lucratividade através da alta produção, o uso de ração aumentou de 8 para 48 milhões de toneladas. Por esses motivos, é necessária a pesquisa de ingredientes alternativos que possam manter esse crescimento (FAO, 2018; FAO, 2020).

A figura 3 mostra o gráfico deste crescimento tanto em produção quanto na importância do impacto social que a aquicultura gera. Pode-se destacar também a crescente demanda na produção das algas como alimento alternativo para a aquicultura.

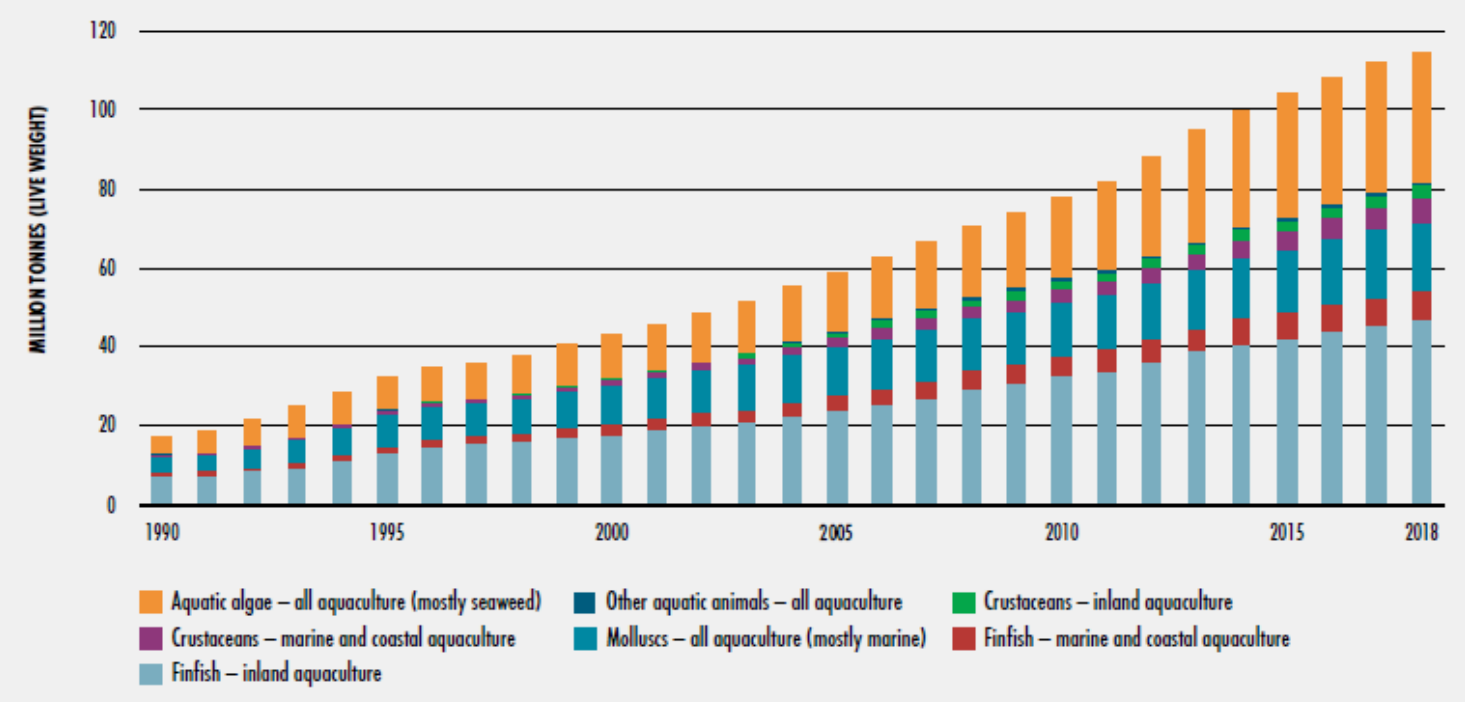

Figura 3. Produção Mundial de Aquicultura de animais aquáticos e algas, 1990 a 2018. Fonte: FAO (2020).

Devido a grande demanda da população mundial pela proteína de organismos aquáticos, aumentou a procura por insumos na área da aquicultura para alimentação dos animais. Como consequência alavancou o mercado de trabalho no setor de produção de grãos para formulação de ração de boa qualidade, movimentando vários setores da cadeia produtiva em especial a matéria prima para a formulação de ração, promovendo pesquisas de ponta para observar quais ingredientes possuem melhor aproveitamento na nutrição dos animais. Devido a isso os agricultores, a agricultura familiar e empreendedores, viram nova 
oportunidade para crescerem e se desenvolver perante o mercado em crescimento (NUNES et al., 2017; FAO, 2020).

As vantagens econômicas e nutricionais da substituição de matérias-primas na alimentação dos peixes são influenciadas pelas técnicas de processamento utilizadas para melhorar a disponibilidade e digestibilidade dos nutrientes e aumentar a palatabilidade da ração. Além disso, o processo de produção deve garantir o equilíbrio do produto em relação à razão de formulação, minerais e aminoácidos essenciais. A produção de rações para diferentes espécies, em diferentes fases de crescimento, é fator importante vinculado à qualidade dos ingredientes na formulação das dietas.

Dentro deste cenário, para contribuir com o crescimento da aquicultura no país, é importante considerar a produção da ração com matérias-primas de qualidade, que garantam a perfeita interação metabólica e consequente eficiência de aproveitamento dos constituintes nutricionais para o seu uso na aquicultura. Porém ao mesmo tempo, se faz necessário a busca por ingredientes alternativos para que haja um equilíbrio na produção e na sustentabilidade do meio ambiente. É de fundamental importância superar aspectos econômicos ligados á disponibilidade das matérias-primas, como exemplo a utilização de novas fontes proteicas, considerando que a ração é o insumo com maior custo de produção na aquicultura entre 40 a $80 \%$ dependendo do empreendimento (BOSCOLO et al., 2004; CUZON et al., 2004).

\section{Considerações finais}

Os avanços em nutrição de peixes e sistemas de produção têm contribuído para redução significativa nos impactos ambientais. Porém, os principais avanços na nutrição de peixes ainda ocorrem para algumas espécies de alto valor econômico, como por exemplo, o salmão e o camarão. Esses avanços devem ser extrapolados para cultivo dos demais grupos de organismos aquáticos, dando mais compreensão da fisiologia e bioquímica nutricional das diferentes espécies. A busca por ingredientes que apresentem menor utilização de água para sua produção e substitutos alternativos para os ingredientes de alto custo, levando à melhor composição alimentar, incluindo a redução da farinha de peixe com adição de minerais, aminoácidos e fontes de origem vegetal, como a utilização das algas por exemplo.

Muitos desafios ainda existem quanto à nutrição e à alimentação para o setor da aquicultura. Dentre eles, o grande número de espécies dificulta o progresso para obtenção de formulações que atendam às exigências nutricionais. Devem se atentar, além da abordagem nutricional, para os aspectos econômicos e ambientais. Esse desafio leva a busca constante de abordagens inovadoras, que aliem a nutrição tradicional à 
sustentabilidade ambiental. A integração de tecnologias emergentes com abordagens clássicas e a formulações alimentares e espécies adequadas, devem ser adotadas, para aumentar a eficiência da produção e sustentabilidade, além de assegurar o sucesso continuo da aquicultura.

\section{Referências}

ANSELMO, A. A. S. Resíduos de frutos amazônicos como ingredientes alternativos em rações extrusadas para juvenis de tambaqui (Colossoma macropomum). Manaus - AM, 2008. 45f. Dissertação (Mestrado em Biologia de Água Doce e Pesca Interior) - BADPI, INPA/UFAM, Manaus- AM, 2008.

ARTURO, M. A. Formulação e avaliação físico-química e tecnológica de rações extrusadas para peixes. Seropédica-RJ, 2019. 77f. Tese (Doutorado em Ciência e Tecnologia de alimentos) - Programa de pós-graduação em ciência e tecnologia de alimentos. Universidade Federal Rural do Rio de Janeiro. Seropédica-RJ, 2019.

AUBIN, J.; CALLIER, M.; REY-VALLETE, H.; MATH, S.; WILFART, A.; LEGENDRE, M.; SLEMBROUCK, J.; CARUSO, D.; CHIA, E.; MASSON, G.; BLANCHETON, J. P.;EDIWARMAN; HARYADIS, J.; PRIHADI, T. H.; CASACA, J. M.; TAMASSIA, S. T. J.; TOCQUEVILLE, A.; FONTAINE, P. Implementing ecological intensification in fish farming: definition and principles from contrasting experiences. Reviews in Aquaculture, v. 11, p. 149-167, 2019.

BECKER, E. W. Microalgae biotechnology and microbiology. Cambridge University Press, U.K, 1994. 293p.

BLEAKLEY, S.; HAYES, M. Algal proteins: extraction, application and challenges concerning production. Foods, v. 6, n. 5, p. 33, 2017.

BOSCOLO, W. R.; HAYASHI, C.; MEURER, F.; FEIDEN, A.; BOMBARDELLI, R. A. Digestibilidade aparente da energia e proteína das farinhas de resíduo da filetagem da tilápia do Nilo (Oreochromis niloticus) e da corvina (Plagioscion squamosissimus) e farinha integral do camarão canela (Macrobrachium amazonicum) para a tilápia do Nilo. Revista Brasileira de Zootecnia, v. 33, p. 8-13, 2004.

BOSCOLO, W. R.; SIGNOR, A.; de FREITAS, J. M. A.; BITTENCOURT, F., FEIDEN, A. Nutrição de peixes nativos. Revista Brasileira de Zootecnia, v. 40, p. 145-154, 2011.

BRINKER, A.; REITER, R. Fish meal replacement by plant protein substitution and guar gum addition in trot feed. Part I: effects on feed utilization and fish quality. Aquaculture, v. 310, p. 350-360, 2011.

CHEN, Y. C. Immobilized Isochrysis galbana (Haptophyta) for long-term storage and applications for feed and water quality control in clam (Meretrix lusoria) cultures. Journal of Applied Phycology, v. 15, p. 439-444, 2003.

CHEW, K. W.; YAPA, J. Y.; SHOW, P. L.; SUAN, H.; JUAN, J. C.; LING, T. C.; LEE, D.; CHANG, J. Microalgae biorefinery: high value products perspectives. Bioresource Technology, v. 229, p. 53-62, 2017. 
CHO, C.; KAUSHIK, S. J. Nutritional energetics in fish: energy and protein utilization in rainbow trout (Salmo gairdneri). World Review of Nutrition and Dietetics Home, v. 61, p. 132-172. 1990.

CUZON, G.; LAWRENCE, A.; GAXIOLA, G.; ROSAS, C.; GUILLAUME, J. Nutrition of Litopenaeus vannamei reared in tanks or in ponds. Aquaculture, v. 235, n. 1-4, p. 513-551, 2004.

CYRINO, J. E. P.; BICUDO, A. J. A.; SADO, R. Y.; BORGHESI, R.; DAIRIKI, J.K. A psicicultura e o ambiente - 0 uso de alimentos ambientalmente corretos em piscicultura. Revista Brasileira de Zootecnia, v. 39, p. 68-87, 2010.

DERNER, R. B.; OHSE, S.; VILLELA, M.; CARVALHO, S. M.; FETT, R. Microalgas, produtos e aplicações. Ciência Rural, v. 36, n. 6, p.1959-1967, 2006.

DIAS, J.; CONCEIÇÃO, L. E. C.; RIBEIRO, A. R.; BORGES, P.; VALENTE, L. M. P.; DINIS, M. T. Practical diet with low fish-derived protein is able to sustain growth performance in gilthead seabream (Sparus aurata) during the grow-out phase. Aquaculture, v. 293, p. 255$262,2009$.

DINESHBABUA, G.; GOSWAMIA, G.; KUMARA, R.; SINHAA, A.; DAS, D. Microalgae nutritious, sustainable aqua-and animal feed source. Journal of Functional Foods, v. 62, p. 103545, 2019.

EMBRAPA AGROENERGIA. Agroenergia em Revista: microalgas. Brasilia, Distrito Federal. $\quad$ v. $4, \quad$ n. $10,2016 . \quad$ Disponível $\quad$ em: <http://ainfo.cnptia.embrapa.br/digital/bitstream/item/153095/1/Agroenergia-Revistamicroalgas-ed10-red.pdf> Acesso em: 17 jul. 2020.

FOOD AND AGRICULTURE ORGANIZATION - FAO. The state of word fisheries and aquaculture. 2020. Sustainability in action. Rome. Disponivel em: <https://doi.org/10.4060/ca92229en>. Acesso em: 17 jul. 2020.

FOOD AND AGRICULTURE ORGANIZATION - FAO. The State of world fisheries and aquaculture 2018 - meeting the sustainable development goals. The state of the world series of the food and agriculture organization of the united nations aquaculture, v. 35 , n. 227, 2018.

FURUYA, W. M. Exigências nutricionais e alimentação da tilápia. In: FRACALOSSI; CYRINO. NUTRIAQUA: nutrição e alimentação de espécies de interesse para aquicultura brasileira 1ed. Florianópolis SC: Copiart Ltda, p. 255-268, 2013.

GATLIN III, D. M.; BARROWS, F. R.; BROWN, P, P. Expanding the utilization of sustainable plant products in aquafeeds: a review. Aquaculture Research, v. 38, p. 551-579, 2007.

GLENCROSS, B. D.; BOOTH, M.; ALLAN, G. L. A feed is only as good as it ingredients - a review of ingredient evaluation strategies for aquaculture feeds. Aquaculture Nutrition, v. 13, p. 17-34, 2007.

GLIESSMAN, S. R. Agroecologia: processos ecológicos em agricultura sustentável. 4. ed. Porto Alegre, RS: UFRGS, 2009. 658p. 
GLIESSMAN, S. R. Agroecologia: processos ecológicos em agricultura sustentável. 3. ed. Porto Alegre, RS: UFRGS, 2005. 653p.

GODFRAY, H.C.J.; BEDDINGTON, J.R.; CRUTE, I.R.; HADDAD, L.; LAWRENCE, D.; MUIR, J.F.; PRETTY, J.; ROBINSON, S.; THOMAS, S.M.; TOULMIN, C. Food security: The challenge of feeding 9 billion people. Science, v. 327, p. 812-818, 2010.

GUNSTONE, F. D.; HARWOOD, J. L.; PADLEY, F. B. Marine oils: fish and whale oils. In: GUNSTONE, F. D. The lipid handbook. London: Chapman e Hall, 1994. p.167-171.

HONORATO, C. A.; ALMEIDA, L. C.; MORAES, G. Processamento de dieta- seus efeitos no aproveitamento de carboidratos para peixes. Revista Electronica Nutritime, v. 10, p. 2700 2715, 2013.

JESUS, L. S. F. D.; AZEVEDO, R. V. D.; CARVALHO, J. S. O.; TAVARES BRAGA, L. G. Farelos da vagem da algaroba e da folha da mandioca em rações para juvenis de tilápia do Nilo mantidos em água salobra. Revista Brasileira de Saúde e Produção Animal, v. 12, n. 4, 2011.

KOVAČ, D. J.; SIMEUNOVIC, J. B.; BABIC, O. B.; MISAN, A. C.; MILOVANOVIC, I. L. J. Algae in food and feed. Food Feed Research, v. 40, p. 21-31, 2013.

LAZZARI, R.; UCZAY, J.; RODRIGUES, R. B.; PIANESSO, D.; ADORIAN, T. J. T. J.; MOMBACH, P. I. Utilização de resíduos de frutas em dietas para piava. Boletim do Instituto de Pesca, v. 41, n. 2, p. 227-237, 2018.

LEONARDO, F. A.; BACCARIN, A. E.; FILHO, J. D. S.; SCORVO, C. M. D. F. Custo de produção da tilápia-do-nilo (Oreochromis niloticus) e do pacu (Piaractus mesopotamicus) no vale do Ribeira, estado de São Paulo. Informações Econômicas, v. 48, p. 21-33, 2018.

LOPES, J. M.; PASCOAL, L. A. F.; SILVA FILHO, F. P. D.; SANTOS, I. B.; WATANABE, P. H.; ARAUJO, D. D. M.; OLIVEIRA, P. D. S. Farelo de babaçu em dietas para tambaqui, Revista Brasileira de Saúde e Produção Animal, v. 11, n. 2, p. 519-526, 2010.

MADEIRA, M. S.; CARDOSO, C.; LOPES, P. A.; COELHO, D.; AFOSO, C.; BANDARRA, C.; PRATES, J. A. M. Microalgae as feed ingredients for livestock production and meat quality: A review. Livestock Science, v. 205, p. 111-121, 2017.

MANTOVANI, J. R.; CORRÊA, M. C. M.; DA CRUZ, M. C. P.; FERREIRA, M. E.; NATALE, $W$. Uso fertilizante de resíduo da indústria processadora de goiabas. Revista Brasileira de Fruticultura, v. 26, p. 339-342, 2004.

MARTIN, C. A.; ALMEIDA, V. V.; RUIZ, M. R.; VISENTAINER, J. E. L.; MATSHUSHITA, M.; SOUZA, N. E.; VISENTAINER, J. V. Ácidos graxos poli-insaturados ômega-3 e ômega-6: importância e ocorrência em alimentos. Revista de Nutrição. v. 19, n. 6, p. 761-770, 2006.

MELO, J. F. B.; SEABRA, A. G. L.; SOUZA, S. A., SOUZA, R. C.; FIGUEIREDO, R. A. C. R. Substituição do farelo de milho pela farinha de manga no desempenho da tilápia-do-nilo. Arquivo Brasileiro de Medicina Veterinária e Zootecnia, v. 64, n. 1, p. 177-182, 2012.

MEURER, F.; HAYASHI, C.; SOARES, C. M.; BOSCOLO, W. R. Utilização de levedura spray dried na alimentação de alevinos de tilápia do Nilo (Oreochromis niloticus L.). Acta Scientiarum, v. 22, n. 2, p. 479-484, 2000. 
NAYLOR, R. L.; HARDY, R. W.; BUREAU, D. P.; CHIU, A.; ELLIOT, M.; FARRELL, A. P.; FORSTER, I.; GATLIN, D. M.; GOLDBURG, R. J.; HUA, K.; NICHOLS, P. D. Feeding aquaculture in an era of finite resource. PNAS, v. 106, n. 36, p. 15103-15110, 2009.

NUNES, J. S.; MARTINS, S. R.; BORBA, M. R.; MUELBERT, B. Sustentabilidade de agroecossistemas familiares com produção de peixes na perspectiva agroecológica. Revista Brasileira de Agroecologia, v. 12, n. 4, p. 275-286, 2017.

OLAIZOLA, M. Comercial development of microalgal biotechnology: from the test tube to the marketplace. Biomolecular Engineering, v. 20, p. 459-466, 2003.

PALMEGIANO, G. B.; AGRADI, E.; FORNERIS, G.; GAI, F.; GASCO, L.; RIGAMONTI, E.; ZOCCARATO, I. Spirulina as a nutrient source in diets for growing sturgeon (Acipenser baeri). Aquaculture Research, v. 36, p.188-195, 2005.

PEREIRA JUNIOR, G. P.; PEREIRA, E. M. O.; FILHO, M. P.; BARBOS, P. S.; SHIMODA, E.; BRANDÃO, L. V. Desempenho produtivo de juvenis de tambaqui (Colossoma macropomum Cuvier, 1818) alimentados com rações contendo farinha de crueira de mandioca (Manihot esculenta, Crantz) em substituição ao milho (Zea mays). Acta Amazônica, v. 43, n. 2, p. 217-226, 2008.

PEZZATO, L. E.; BARROS, M. M.; FURUYA, W. M. Valor nutritivo dos alimentos utilizados na formulação de rações para peixes tropicais. Revista Brasileira de Zootecnia, v. 38, p. 43-51. 2009.

RADMANN, E. M.; COSTA, J. A. V. Conteúdo lipídico e composição de ácidos graxos de microalgas expostas aos gases $\mathrm{CO} 2$, $\mathrm{SO}$ e NO2. Revista Química Nova, v. 31, n. 7, p. 1609-1612, 2008.

RIBEIRO, P. A. P.; MELO, D. C.; COSTA, L. S.; TEIXEIRA, E. A. Manejo nutricional e alimentar de peixes de água doce. Belo Horizonte: Universidade Federal de Minas Gerais, 2012. $91 p$.

RICHMOND, A.; Spirulina. In: BOROWITZKA, A., BOROWITZKA, L. Microalgal biotechnology. Cambridge University Press, United Kingdom, 1988. p. 83-121.

ROSAS, V. T.; MONSERRAT, J. M.; BESSONART, M.; MAGNONE, L.; ROMANO, L. A.; TESSER, M. B. Comparison of $\beta$-carotene and spirulina (Arthrospira platensis) in mullet (Mugil liza) diets and effects on antioxidant performance and fillet colouration. Journal of Applied Phycology, v. 31, p. 2391-2399, 2019.

ROTTA, M. A. Aspectos gerais da fisiologia e estrutura do sistema digestório dos peixes relacionados a piscicultura. Corumbá: EMBRAPA, 2003. 48p.

SANTOS, E. L.; LUDKE, M. D. C. M.; BARBOSA, J. M.; RABELLO, C. B. V.; LUDKE, J. V. Digestibilidade aparente do farelo de coco e resíduo de goiaba pela tilápia do Nilo (Oreochromis niloticus). Revista Caatinga, v. 22, n. 2, p. 175-180, 2009.

SANTOS, E. L.; BEZERRA, K. S.; SOARES, E. C. S.; SILVA, T. J.; FERREIRA, C. H. L. H.; SANTOS, C. C. S.; SILVA, C. F. Desempenho de alevinos de tilápia do Nilo alimentados com folha de mandioca desidratada na dieta. Arquivo Brasileiro de Medicina Veterinária e Zootecnia, v. 67, n. 5, p. 1421-1428, 2015. 
SANTOS, F. W. B. Nutrição de peixes de água doce: definições, perspectivas e avanços científicos. In: I Simposio de nutrição e alimentação animal. Fortaleza-CE. 2017.

SEIXAS, F. J. T.; ROSTAGNO, H. S.; QUEIROZ, A. C.; EUCLYDES, R. F.; BARBARINO JUNIOR, P. Avaliação do desempenho de pó larvas de camarão de água doce Macrobachium roserbergii alimentado com dietas balanceadas contendo diferentes substâncias aglutinantes. Revista Brasileira Zootecnia, v. 26, p. 638-644, 1997.

SPOLAORE, P.; JOANNIS-CASSAN, C.; DURAN, E.; ISAMBERT, A. Commercial applications of microalgae. Journal Bioscience Bioengineering, v. 101, n. 2, p. 87-96, 2006.

VILLARRUEL-LÓPEZ, A.; ASCENCIO, F.; NUNO, K. Microalgae, a potential natural functional food source - a review. Polish Journal of Food and Nutrition Science, v. 67, p. 251-263, 2017.

WILSON, R. P. Amino acids and proteins. In: HALVER, J. E.; HARDY, R. W. Fish nutrition, Amsterdam: Academic Press, 2002, p. 143-179.

WU, G. Amino acids: biochemistry and nutrition. New York: CRC Press, 2013. 503p.

ZHOU, C.; LIU, B.; XIE, J.; GE, X.; XU, P.; ZHOU, Q.; PAN, L.; CHEM, R. Effect of dietary carbohydrate level on growth performance, blood chemistry, hepatic enzyme activity, and growth hormone gene expression in Wuchang bream (Megalobrama amblycephala). Journal Aquaculture, v. 65, p. 1-8, 2013. 


\title{
Capítulo 26
}

\section{Uma alternativa para o bem-estar de vacas leiteiras: uso de óleos essenciais para o controle da mastite e carrapatos}

\author{
Grazielli de Paula Pirovani ${ }^{1}$, Wesley Braga de Aguiar ${ }^{1}$, Aparecida de Fátima Madella-
}

Oliveira $^{2}$

\section{Introdução}

A pecuária de leite é uma das atividades do agronegócio mais importantes no Brasil, com uma participação expressiva no produto interno bruto (PIB) da pecuária, é incontestável sua influência nas atividades econômicas e na geração de empregos no país. Podemos destacar ainda neste cenário, a importância que o bem-estar animal vem ganhando nos últimos anos em relação a exigência dos países importadores, fazendo com que o tema ganhasse atenção dos produtores rurais, garantindo assim, animais com condições mínimas de qualidade de vida, atendendo os compromissos sociais e ambientais firmados, com foco na reestruturação da cadeia de produção visando o bem-estar e lucratividade com qualidade do produto final.

Dentre os principais entraves para a bovinocultura leiteira que afetam o bem-estar animal gerando consequentemente prejuízos significativos estão a mastite e as infestações pelo por carrapatos.

Na produção leiteira, um dos problemas sanitário e econômico de maior relevância é a ocorrência de mastite nas vacas em lactação. É a doença que mais causa prejuízos aos rebanhos leiteiros, os quais poderiam ser minimizados, em grande parte, com a prevenção. Pois pelo menos $20 \%$ das vacas em produção, apresentam algum tipo de mastite em um ou mais quartos do úbere, sendo que somente $3 \%$ aparecem sob a forma clínica (BRITO e BRITO, 2004).

Entende-se por mastite bovina os processos inflamatórios de cunho infeccioso, causados, principalmente, por Staphylococcus spp. e Streptococcus spp., sendo o primeiro o maior agente causador, prevalecendo em casos de manifestações clínicas e subclínicas. Já os tratamentos mais comuns no caso da mastite bovina são baseados na infusão intramamária de agentes antimicrobianos, mas as taxas de cura com estas drogas não são sempre efetivas, verificando-se grandes variações na eficiência do tratamento para os diferentes agentes

\footnotetext{
${ }^{1}$ Mestrandos em Agroecologia pelo Programa de Pós-Graduação em Agroecologia do Instituto Federal do Espírito Santo - Campus de Alegre, Caixa Postal 47, CEP: 29500-000, Alegre - ES. E-mail: grazipirovani@gmail.com; wesleyaguiarbraga@gmail.com

${ }^{2}$ Dra. Professora do Instituto Federal do Espírito Santo - Campus de Alegre, Caixa Postal 47, CEP: 29500-000, Alegre-ES. E-mail: amadella@ifes.edu.br
} 
causadores de mastite. Além disso, a utilização de antibióticos pode levar à seleção de bactérias resistentes e à presença de resíduos no leite (ZAFALON et al., 2007).

Um outro problema é a infestação de bovinos leiteiros por ectoparasitas, como o carrapato Rhipicephalus (Boophilus) microplus, conhecido como carrapato duro ou carrapato-do-boi, culmina à pecuária no Brasil, onde as condições climáticas do país tropical propiciam o desenvolvimento desses parasitas por praticamente todos os meses do ano, aumentando os gastos com carrapaticidas, antibióticos e mão de obra no seu controle.

A utilização de produtos químicos é uma das principais formas de controle do carrapato e mastite bovina, realizada na maioria das vezes de maneira indevida e indiscriminada. $\mathrm{O}$ uso dos produtos químicos pode causar graves intoxicações nos animais, nos seres humanos e no ambiente, devido ao fator residual na natureza provocando bem-estar mais pobre do que de animais saudáveis. Além disso, segundo Campos et al. (2012) outro grave problema são os resíduos nos produtos de origem animal, que vem originando grande inquietação por parte da população e órgãos do governo.

Devido ao impacto negativo provocado pela mastite e carrapatos a produção compostos de origem vegetal podem constituir alternativa no controle desta enfermidade e desses parasitas. O método alternativo é o uso de plantas medicinais que surge como uma proposição de resgate à cultura, além disso, outra vantagem implica na matéria-prima necessária, que geralmente encontra-se disponível nas respectivas propriedades rurais (ARCEGO, 2005), apresentam baixo custo, fácil utilização e considerada uma alternativa sustentável ao pecuarista.

Entre esses compostos, destacam-se os óleos essenciais. Eles auxiliam no controle de doenças e parasitas, sem trazer danos ao meio ambiente e com um custo mais barato se comparado aos métodos tradicionais. Nesse contexto, o uso de compostos fitoterápicos se constitui em uma importante estratégia considerando que os óleos essenciais presentes nas plantas desempenham papel de proteção contra bactérias, vírus, fungos e servem para atrair ou repelir insetos (BAKKALI et al., 2007).

Assim, objetivou-se trazer alternativas com o uso de produtos naturais para a bovinocultura leiteira no controle de mastite e carrapatos, associado ao bem-estar animal e a redução de uso indiscriminado de produtos químicos que provocam resistência de bactérias e carrapatos, acarretando prejuízos para produtor.

\section{Mastite}

A mastite é uma inflamação da glândula mamária, decorrente de uma infecção causada por um agente patógeno que adentra na glândula mamária pelo orifício do teto (principal via 
de infecção) ou pelo sangue (ex. Mycoplasma), causando danos no tecido e alterações físicoquímicas do leite. É uma doença cara e complexa, com origem, gravidade e resultados variáveis, dependendo do patógeno e do ambiente exposto (THOMPSON-CRISPI et al., 2014).

São vários fatores que podem desencadear a mastite: baixa imunidade (RUPP e BOICHARD, 2003) mudanças do estado fisiológico durante as diferentes fases da lactação (GOFF, 2006) os fatores ambientais e manejo. Segundo Derakhshani et al. (2018) devido ao importante papel que cada um dos fatores mencionados acima tem na modulação homeostase do úbere, pode-se postular que eles também têm direta / indireta influência na composição da microbiota do úbere (Figura 1).

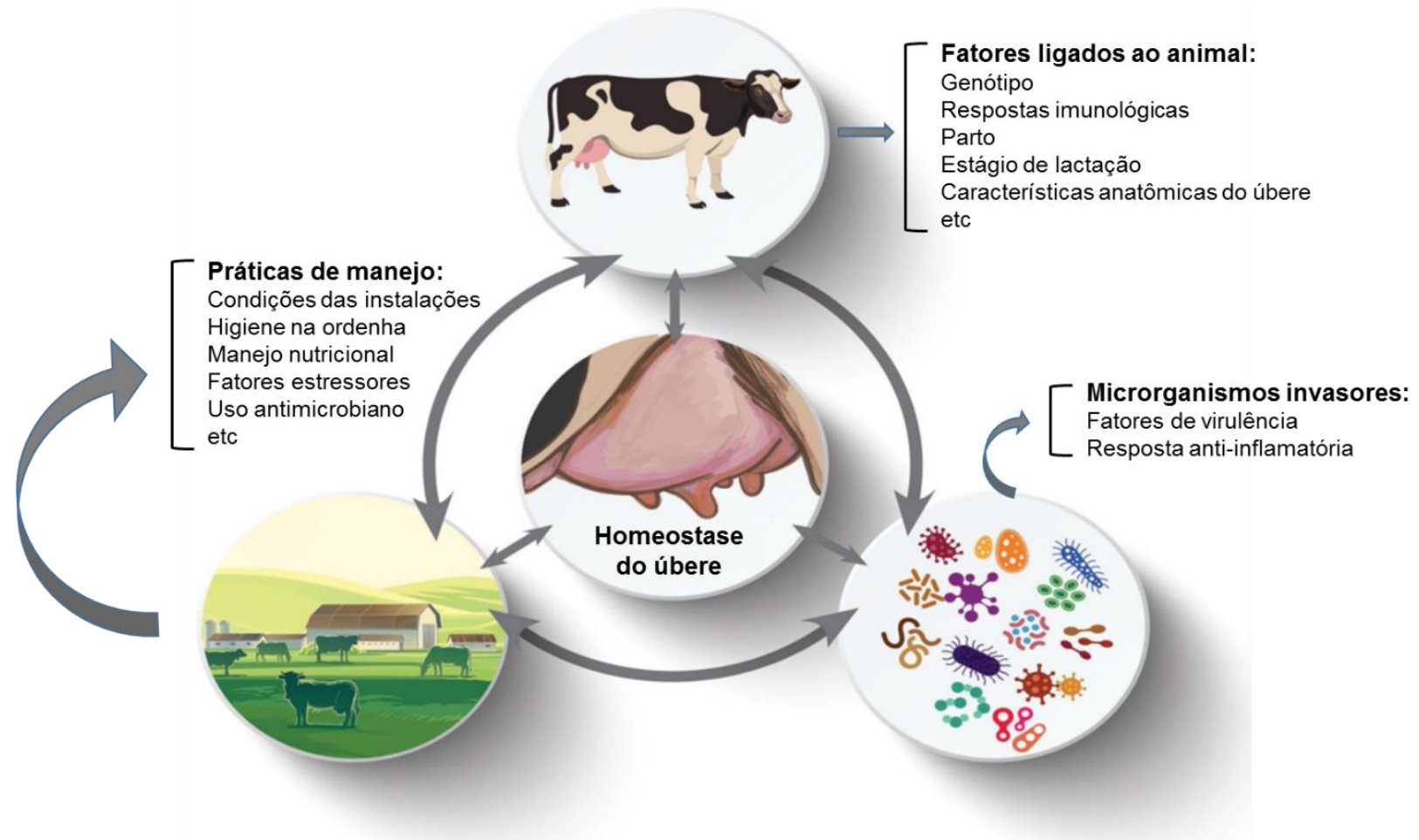

Figura 1. Determinantes da homeostase do úbere. Os mecanismos de defesa do úbere contra a colonização microbiana são modulados por uma complexa rede de interação entre $(A)$ fatores ligados ao animal; (B) microrganismos invasores; e (C) práticas de manejo.

Fonte: Adaptado de Derakhshani et al. (2018).

O tratamento da mastite é um dos fatores de maior impacto econômico na produção leiteira, representado pelo custo de medicamento, mão-de-obra e descarte de leite. A mastite afeta diretamente o bem-estar de vacas leiteiras e merece atenção por parte dos produtores e pesquisadores da área, devendo ser prevenida e quando diagnosticada sua ocorrência, tratada o mais brevemente possível, buscando evitar o processo doloroso. 


\section{Carrapatos}

Os carrapatos, são originários da Ásia, tiveram sua expansão em virtude das expedições exploratórias com a transferências de animais e mercadorias registrados na história (Gomes, 1998). Também conhecidos pelo nome científico Rhipicephalus microplus, é o principal ectoparasita hematófago dos bovinos, encontrados em diversas regiões do país (ANDREOTTI, 2010).

Esse carrapato possui um ciclo parasitário do tipo monóxeno, necessita de apenas um hospedeiro para completar seu ciclo de vida, no qual a fêmea, no animal, após ser fecundada por um macho e realizar o repasto sanguíneo, cai ao solo, procurando um lugar escuro para a postura, com umidade e temperatura ideais. Após cerca de um mês no verão e dois a três meses no inverno, as larvas eclodem, sobem no capim e ficam juntas na ponta da folha aguardando a passagem do hospedeiro (VERÍSSIMO, 2013); quando este passa e esbarra em uma aglomeração de larvas, elas rapidamente se espalham por seu corpo (Figura 2).

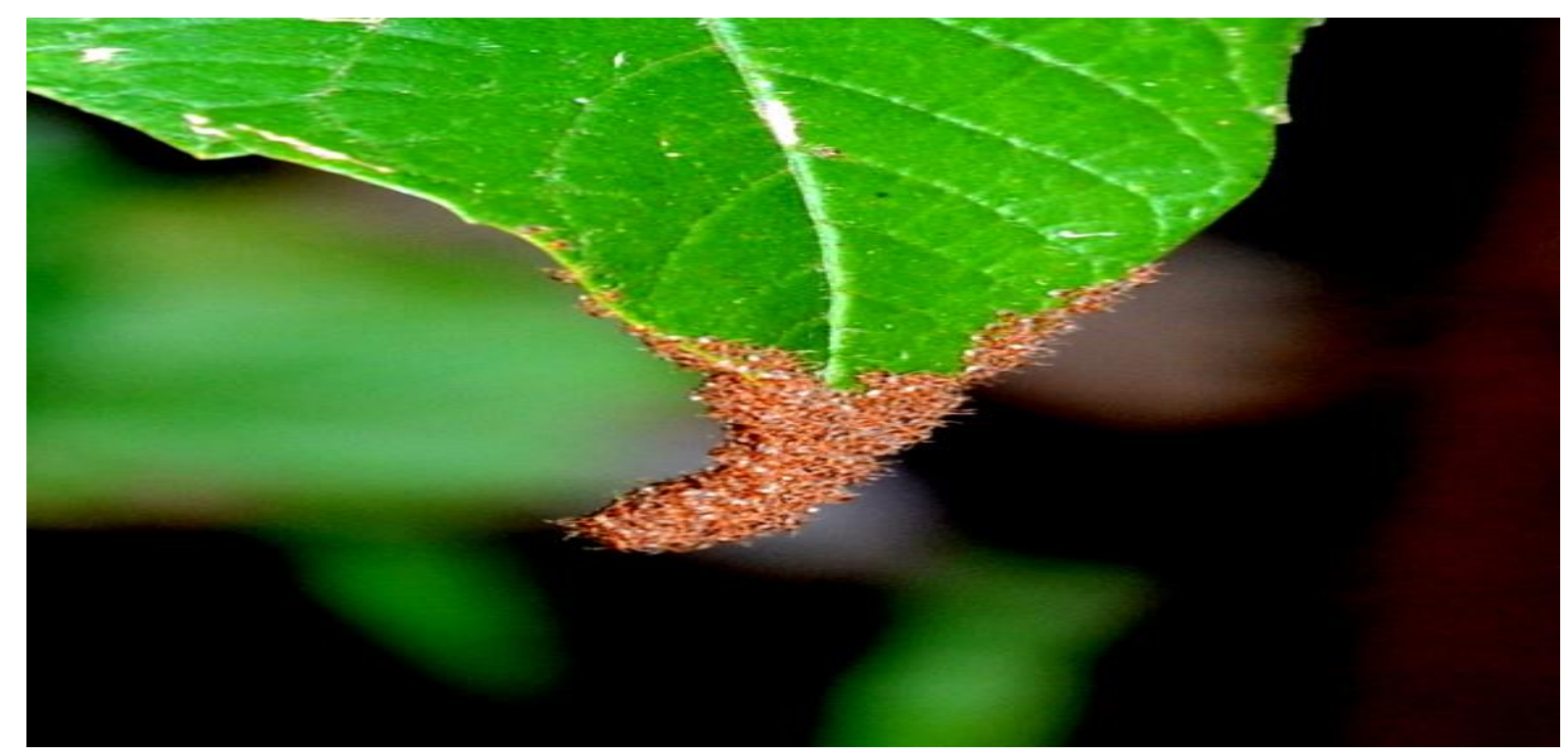

Figura 2. Larvas de Rhipicephalus (B.) microplus na pastagem à espera do hospedeiro. Fonte: EMPRESA BRASILEIRA DE PESQUISA AGROPECUÁRIA - EMBRAPA. 


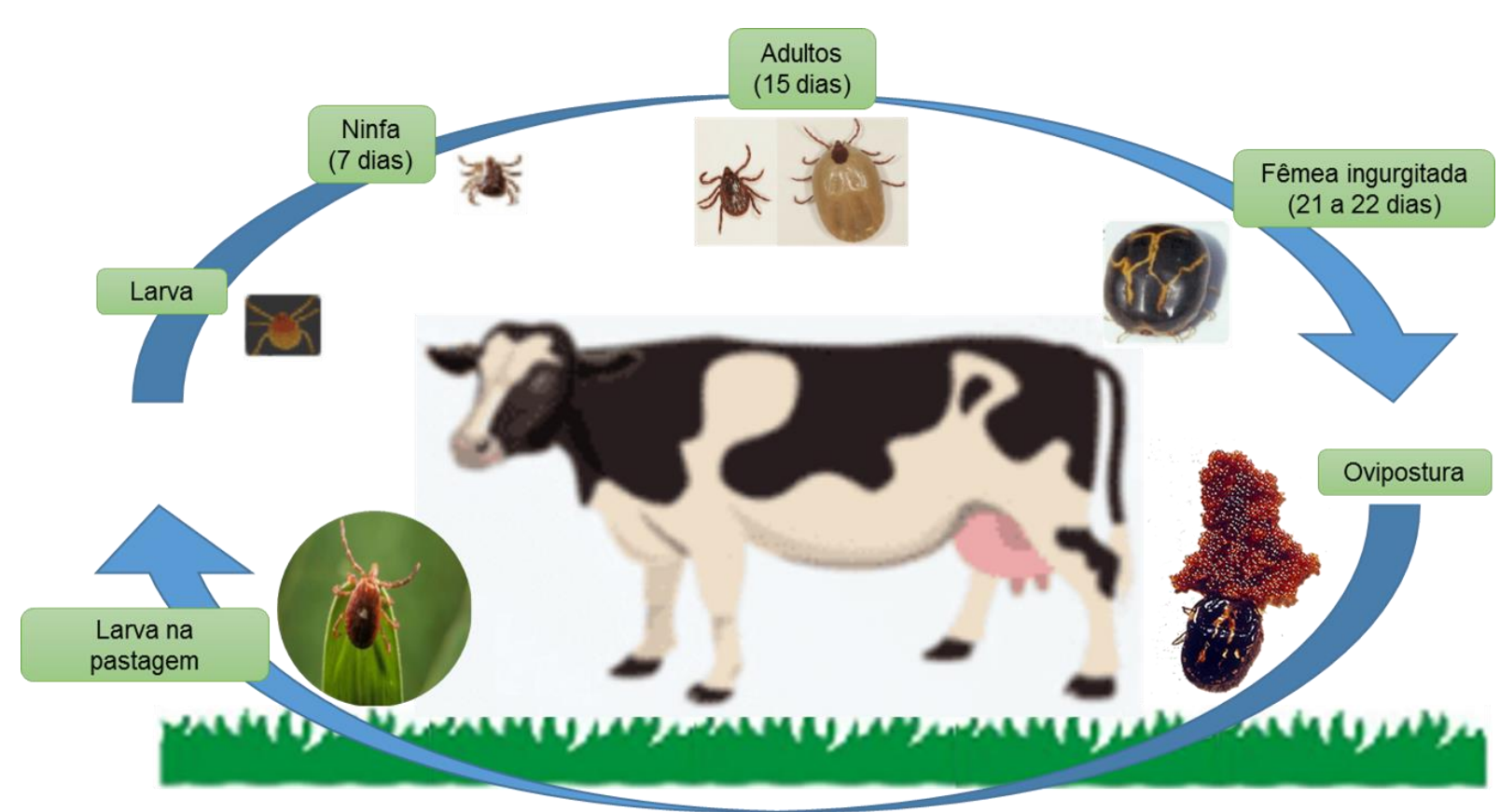

Figura 3. Esquema simplificado do ciclo de vida Rhipicephalus microplus, carrapato-do-boi. Fase parasitária no hospedeiro: larva, ninfa e adultos; Fase de vida livre no solo: fêmeas, ovos e larvas.

Fonte: Os Autores.

No Brasil, o carrapato é um dos principais problemas do produtor, sendo as fêmeas maior parte de problema, em função da grande quantidade de sangue que ingerem quando estão no hospedeiro, tantos os machos como as fêmeas inoculam substâncias que podem causar coceira, diminuição do apetite (FURLONG, 2005), além da grande quantidade de ovos que conseguem colocar durante seu ciclo de vida livre no ambiente.

E também servem como o principal vetor de agentes infecciosos como a tristeza parasitária, complexos de doenças transmitidas pelo protozoário Babesia bovis, Babesia bigemina (ALMEIDA et al., 2006) e a anaplasmose causada por uma bactéria do gênero Anaplasma (Anaplasmose), ambas apresentam alta morbidade e alta mortalidade, afetando a produção de carne e leite (KIKUGAWA, 2009), além de prejuízos relacionados com despesas de mão de obra, instalações, carrapaticidas e equipamentos para aplicação dos mesmos (ANDREOTTI, 2010).

O controle é baseado no uso intensivo de carrapaticidas quando o gado apresenta altamente infestações de carrapatos, se tornando muitas vezes irreversível (ANDREOTTI et al., 2016). A aplicação se faz por meio de pulverização, imersão e outras formas, sendo a manual a mais indicada para pequenas propriedades e os banhos com imersão indicados para aquelas com grande número de animais, seguindo as recomendações técnicas do fabricante para retardar o surgimento de populações resistentes. A resistência pode-se detectada por testes denominados biocarrapaticidas (GOMES, 1998). 
Uma das dificuldades encontradas pelos produtores no controle desse parasita é o fato de apenas 5\% dos carrapatos são encontrados no hospedeiro e 95\% estão no meio ambiente, dificultando seu controle, uma vez que, o controle químico é utilizado no animal, via contato ou injetável, não no controle no meio ambiente, podendo ser utilizados cruzamentos com raças bovinas resistentes e rotação de pastagens para minimizar os impactos gerados ao produtor e ao ambiente.

Rebanho com carrapatos é sinônimo de prejuízo, seja monetário ou relacionado ao bemestar do animal. Uma vaca com infestação moderada de carrapatos, por exemplo, perde até uma arroba por ano (GRISI et al., 2014).

\section{Plantas medicinais}

Durante muito tempo, o uso de plantas medicinais foi o principal recurso terapêutico utilizado para tratar a saúde das pessoas e de suas famílias. Entretanto, com os avanços ocorridos no meio técnico-científico, sobretudo no âmbito das ciências da saúde, novas maneiras de tratar e curar as doenças foram surgindo. Uma dessas maneiras consiste no uso de medicamentos industrializados, gradativamente introduzidos no cotidiano das pessoas modernas, através de campanhas publicitárias que prometiam curar as mais diversas doenças. Desde então, o uso de plantas medicinais vem sendo substituído pelos medicamentos alopáticos (ALVIM et al., 2004).

No Brasil, mesmo com o incentivo da indústria farmacêutica para a utilização de medicamentos industrializados, grande parte da população ainda utiliza de práticas complementares para cuidar da saúde, como o uso das plantas medicinais, empregadas para aliviar os sintomas de algumas enfermidades. Atualmente, as mudanças econômicas, políticas e sociais que eclodiram no mundo influenciaram não só na saúde das pessoas como também nos modelos de cuidado. O uso terapêutico de recursos naturais utilizados no cuidado humano, que antes estava situado às margens das instituições de saúde, hoje tenta legitimar-se nesse meio dominado pelas práticas alopáticas (ALVIM et al., 2004).

As plantas medicinais são definidas como toda e qualquer espécie de planta que é empregada para fins terapêuticos, sejam elas cultivadas ou não (BRANDELLI, 2017). A utilização dessas pode ocorrer de forma integral ou com partes dela, utilizando-se, por exemplo, da casca, folhas, caules, raízes, flores, sementes ou frutos. Outra definição de planta medicinal é enunciada por Almassy et al. (2005), a qual é compreendida como qualquer espécie vegetal que é administrada ao homem ou animal, por meio de alguma via e de modo consequente desempenhe algum tipo de ação terapêutica. 
O conhecimento das propriedades terapêuticas das plantas faz parte da cultura oral, que tem sido transmitida de geração em geração, e para que ela não se perca é preciso que seja feito um resgate desse Patrimônio Imaterial. O conhecimento sobre plantas medicinais representa muitas vezes o único recurso terapêutico de muitas comunidades e grupos étnicos. O uso de plantas no tratamento e na cura de enfermidades é tão antigo quanto a espécie humana. Ainda hoje, nas regiões mais pobres do país e até mesmo nas grandes cidades brasileiras, as plantas medicinais são comercializadas em feiras livres, mercados populares e encontradas em quintais residenciais (LÓPEZ, 2006).

Com o passar dos anos, a utilização das plantas medicinais se tornou um hábito para o povo brasileiro e foi difundida para o tratamento de diversos tipos de doenças, verminoses e parasitoses, tanto humana, quanto animal. Segundo Santos-Lima et al. (2016) a riqueza de espécies vegetais presentes no ecossistema brasileiro colaborou com a ampliação da utilização de plantas medicinais como recurso medicinal no tratamento das mais diversas patologias, inclusive no controle de parasitas, sejam eles internos ou não.

A tendência observada para a fitoterapia é que esta, assim como no passado, desempenhará um papel cada vez mais importante na assistência à saúde da população. Desta forma, não se pode negar a importância da avaliação dos efeitos terapêuticos dos fitoterápicos, através de estudos envolvendo um número significante de pessoas (CALIXTO, 2000).

Diversos estudos utilizando plantas medicinais, tanto em forma de extratos como em forma de óleo essencial tem sido realizado no controle de carrapatos e mastite bovinas, o que representa não apenas uma forma alternativa de minimizar os entraves à pecuária nacional causado por esses organismos, mas também significa o anseio da sociedade em reduzir a utilização de produtos que colaboram com a degradação socioambiental.

\section{Uso do óleo essencial como alternativa}

As propriedades antimicrobianas e a identificação de componentes ativos de vários óleos essenciais têm sido demonstradas. Devido às suas diversas propriedades antissépticas, os óleos essenciais eram utilizados antigamente como antimicrobianos, analgésicos, sedativos, anti-inflamatórios e anestésicos. Tais características não mudaram muito nos últimos tempos, exceto pelo fato de que, nos dias atuais, os efeitos antimicrobianos destes óleos se tornaram mais conhecidos, devido aos estudos de seus mecanismos de ação (COSTA et al., 2005; LIMA et al., 2006).

São compostos complexos, voláteis, caracterizados por apresentar odor forte e são produzidos pelas plantas como metabólitos secundários, geralmente obtidos por meio de Tópicos em Agroecologia, volume II 
arraste a vapor ou hidro destilação. Além disso, os óleos essenciais podem ser sintetizados por todos os órgãos das plantas, tais como brotos, flores, folhas, caules, galhos, sementes, frutos, raízes, madeira ou cascas, e são armazenados em células secretoras, cavidades, canais, células epidérmicas ou tricomas glandulares (BAKKALI et al., 2008).

Pesquisadores têm extraído óleos essenciais de diversas plantas tais como: $O$. vulgare (orégano), T. vulgaris (tomilho), C. zeylanicum (caneleira), Lippia alba, Ocimum basilicum (manjericão) e Salvia offiicinalis (sálvia), os quais mostraram atividade antimicrobiana frente a vários microrganismos,

Com isso alguns trabalhos têm como proposta investigar o uso de plantas medicinais, incluindo seus óleos essenciais para o tratamento da mastite bovina. Dentre eles destacamse o estudo da atividade antibacteriana do óleo de canela-da-china (Cinnamon cassia) e de capim-limão (Cymbopogon citrates) contra patógenos causadores de mastite (AIEMSAARD et al., 2011; ZHU et al., 2016). A espécie C. citratus (erva-cidreira) tem apresentado ação inibitória sobre uma grande variedade de bactérias Gram-positivas e Gram-negativas (EKPENYONG, et al., 2015). Cardoso et al. (2015) descreve as propriedades inseticida, acaricida, antimalárica e antimicrobiana do óleo essencial de pau-de-incenso ( $T$. riparia).

Perini (2013), analisou in vitro os óleos essenciais de canela, cravo-botão, capim-limão, tomilho-branco e citronela e observou que tem grande potencial inibidor frente Staphylococcus aureus e Streptococcus agalacti. A autora sugere que pode ser uma alternativa para o uso in vivo.

Da mesma forma, produtos naturais derivados de plantas podem servir como uma alternativa para o controle de carrapatos e pode ser benéfico não só para reduzir os problemas enfrentados pelos acaricidas comerciais, tais como o desenvolvimento de resistência e a contaminação ambiental. Assim, várias pesquisas têm sido realizada com óleos essenciais de plantas in vitro, para o controle do carrapato, como: capim-limão (Cymbopogon citratus), patchouli (Pogostemon cablin), cravo-da-india (Syzygiu aromatium), eucalipto (Corymbia citriodora) e outros, respectivamente (CAMPOS, 2012; SANTOS e VOGEL, 2012; FERREIRA, 2016) e em condições in vivo pode-se relatar trabalhos com eucalipto (Eucalyptus globulus), (RODRIGUES, 2018), folha de Neen (Azadirachta indica) (ZAMAN et al., 2012) e outros.

Estudos realizados por Rodrigues (2018) sugere que in vivo sejam realizados a fim de esclarecer se névoas de produtos naturais, oriundos do óleo de eucalipto, quando utilizados com maior frequência e aplicações estratégicas, podem controlar o carrapato-do-boi, sem a necessidade da utilização de carrapaticidas químicos convencionais.

A utilização de óleos essenciais de plantas pode ser considerada uma alternativa sem risco ambiental por não apresentar efeitos secundários. No entanto, o principal desafio para utilização desses óleos essenciais está na dificuldade de transposição da eficácia obtida in 
vitro para o campo. E isso, segundo Borges et al. (2011) está na preparação de formulações apropriadas que podem estar relacionadas à variabilidade na composição química de plantas de uma mesma espécie, devido a fatores diversos, que ainda precisam ser solucionados.

O carrapato bovino Rhipicephalus microplus é considerada uma das pragas mais destrutivas para a indústria pecuária em partes tropicais e subtropicais do mundo. O potencial para desenvolver acaricidas à base de plantas para controlar infestações por $R$. microplus é fundamental para manter a produtividade do rebanho bovino, reduzir perdas econômicas e reduzir o uso excessivo de acaricidas químicos sintéticos (KHAN et al., 2019).

Nesse contexto, o uso de compostos fitoterápicos se constitui em uma importante estratégia considerando que os óleos essenciais presentes nas plantas desempenham papel de proteção contra bactérias, vírus, fungos e servem para atrair ou repelir insetos (BAKKALI et al., 2007).

\section{Considerações finais}

Várias pesquisas têm utilizados plantas medicinais na forma de extrato ou óleo essencial, esses produtos proporcionam resultados positivos gerando, bem-estar animal, assim promovendo um maior rendimento por agregar valor ao produto e uma produção de qualidade de carne e leite livre de resíduos, seguindo a tendência do mercado devido a seu apelo socioambiental.

Os óleos essenciais podem ser utilizados como uma ferramenta no auxílio de prevenção de muitas doenças e parasitas das vacas leiteiras, proporcionando um bom bem-estar. Como toda técnica, ela não é perfeita e necessita de muitos estudos e melhorias, porém nos últimos anos cada vez mais trabalhos estão sendo publicados comprovando sua eficiência.

Acredita-se que, com o tempo e com o crescente número de publicações de trabalhos, as plantas medicinais se concretizarão com fundamentos científicos e, consequentemente, será abordada com maior frequência no meio acadêmico e, assim, melhor reconhecida pela sociedade. 


\section{Referências}

AIEMSAAED, J.; AIUMLAMAI, S.; AROMDEE, C.; TAWEECHAISUPAPONG, S.; KHUNKITTI, $W$. The effect of lemongrass oil and its major components on clinical isolate mastitis pathogens and their mechanisms of action on Staphylococcus aureus DMST 4745. Research in Veterinary Science, v. 91, n. 3, p. 31-37, dec. 2011.

ALMASSY, J. A. A.; LOPES, R. C; ARMOND, C.; SILVA, F.; CASALI, V. W. D. Folhas de chá: plantas medicinais na terapêutica humana. Viçosa: UFV, 2005. 233p.

ALMEIDA, M. B.; TORTELLI, F. P.; RIET-CORREA, B.; FERREIRA, J. L. M., SOARES, M. P.; FARIAS, N. A. R.; RIET-CORREA, F.; SCHILD, A. L. Tristeza parasitária bovina na região sul do Rio Grande do Sul: estudo retrospectivo de 1978-2005. Pesquisa Veterinária Brasileira, v. 26, n. 4, p. 237-242, 2006.

ALVIM, N. A. T.; FERREIRA, M. de A.; GOULART, P. de F.; VIVEIROS, A. A. Tecnologias na enfermagem: o resgate das práticas naturais no cuidado em casa, na escola e no trabalho. In: FIGUEIREDO, N. M. A. (Org.). Tecnologias e técnicas em saúde: como e porque utilizá-las no cuidado de enfermagem. São Paulo: Difusão Editora; 2004. p.338-55.

ANDREOTTI, R. Situação atual da resistência do carrapato-do-boi Rhipicephalus (Boophilus) microplus aos acaricidas no Brasil. Campo Grande, MS: Embrapa Gado de Corte, $2010 . \quad 36 \quad$ p. 2 Disponível em: http://www.infoteca.cnptia.embrapa.br/infoteca/handle/doc/871264/>. Acesso em: 11 jul. 2020.

ANDREOTTI, R.; KOLLER, W. W.; GARCIA, M. V. (Eds.). Carrapatos: protocolos e técnicas para estudo. 1. ed. Brasília: Embrapa, 2016. 217p.

ARCEGO, M.S.C. Plantas medicinais no controle de doenças no gado leiteiro. São João da Urtiga: EMATER-RS, 2005.

BAKKALI, Y.; RUIZ-SANTAELLA, J. P.; OSUNA, M. D.; WAGNER, J.; FISCHER, A. J.; PRADO, R. D. Late watergrass (Echinochloa phyllopogon): mechanisms involved in the resistance to fenoxaprop-p-ethyl. Journal of Agricultural and Food Chemistry. v. 55, p. 4052-4058, 2007.

BAKKALI, F.; AVERBECK, S.; AVERBECK, D.; IDAOMAR, M. Biological effects of essential oils - a review. Food and Chemical Toxicology, Oxford, v. 46, n. 2, p. 446-475, Feb. 2008.

BRANDELLI, C. L. C. Plantas medicinais: histórico e conceitos. In: MONTEIRO, S.C.; BRANDELLI, C.L.C. (Orgs). Farmacobotânica: aspectos teóricos e aplicação. Porto Alegre: Artmed, 2017.

BRITO, M. A. V. P; BRITO, J. R. F. Gado de leite: mastite e qualidade do leite. 2. ed. Brasília: EMBRAPA, 2004. p.190 - 202. (Coleção 500 perguntas, 500 respostas)

BROOM, D. M. Indicators of poor welfare. British Veterinary Journal, v.142, p. 524-526, 1986.

BROOM, D. M. 1; MOLENTO, C. F. M. Bem-estar animal: conceito e questões relacionadas revisão. Archives of Veterinary Science. v. 9, n. 2, p. 1-11, 2004. 
CALIXTO, J. B. Efficacy, safety, quality control, marketing and regulatory guidelines for herbal medicines (phytotherapeutic agents). Brazilian Journal Medical and Biological Research, n. 33, v. 2, p. 179-189. 2000.

CARDOSO, B. M.; MELLO, T. F. P.; LOPES, S. N.; DEMARCHI, I. G.; LERA, D. S. L.; PEDROSO, R. B.; CORTEZ, D. A.; GAZIM, Z. C.; ARISTIDES, S. M. A.;SILVEIRA, T. G. V.; LONARDONI, M. V. C. Antileishmanial activity of the essential oil from Tetradenia riparia obtained in different seasons. Mem Inst Oswaldo Cruz, Rio de Janeiro, v. 110, n. 8, p. 10241034, 2015.

CAMPOS, R. N. S.; BACCI, L.; ARAÚJO, A. P. A.; BLANK, A. F.; ARRIGONI-BLANK, M. F.; SANTOS, G. R. A.; RONER, M. N. B. Óleos essenciais de plantas medicinais e aromáticas no controle do carrapato Rhipicephalus microplus. Archivos de Zootecnia, v. 61, n. 12, p. 6778, 2012.

COSTA, J. G. M.; RODRIGUES, F. F. G.; ANGÉLICO, E. C.; SILVA, M. R.; MOTA, M. L.; SANTOS, N. K. A.; CARDOSO, A. L. H.; LEMOS, T. L. G. Estudo químico- biológico dos óleos essenciais de Hyptis martiusii, Lippia sidoides e Syzigium aromaticum frente às larvas do Aedes aegypti. Revista Brasileira de Farmacognosia, São Paulo, v. 15, n. 4, p. 304-309, out./dez. 2005.

CUNHA, A. P., ROQUE, O. R.; NOGUEIRA, M. T. Plantas aromáticas e óleos essenciais: composição e aplicações. Lisboa: Fundação Calouste Gulbenkian. 2012. 678p.

DERAKHSHANI H.; FEHR, K.B.; SEPEHRI, S.; FRANCOZ, D.; DE BUCK, J.; BARKEMA, H. W.; PLAIZIER, J. C.; KHAFIPOUR, E. Invited review: microbiota of the bovine udder: contributing factors and potential implications for udder health and mastitis susceptibility. Journal Dairy Science, v. 101, p. 10605-10625, 2018.

EKPENYONG, C. E.; AKPAN, E.; NYOH, A. Ethnopharmacology, phytochemistry, and biological activities of Cymbopogon citratus (DC.) stapf extracts Chinese, Journal of Natural Medicines, v. 13, n. 5, p. 0321-0337, 2015.

FERREIRA, F. M; TOKARS, E. Uso de óleos essenciais na massagem relaxante corporal. Revisão de literatura. Curso de Tecnologia em Estética e Imagem Pessoal, Universidade Tuiuti do Paraná. Curitiba (PR), 2016.

FURLONG, J.; PRATA, M. C. A. Conhecimento básico para o controle do carrapato dos bovinos. In: FURLONG, J. (Org.). Carrapatos: problemas e soluções. Juiz de Fora: Embrapa Gado de Leite, 2005, p. 9-20.

GOMES, A. O carrapato do boi Boophilus: ciclo, biologia, epidemiologia, patogenia e controle. In: KESSLER, R.H.; SCHENK, M.A.M. Carrapato, tristeza parasitaria e tripanossomose dos bovinos. Campo Grande. M.S.: Embrapa CNPGC, 1998. p. 9-44.

GRISI, L.; LEITE, R. C.; MARTINS J. R. S.; BARROS A. T. M.; ANDREOTTI R.; CANÇADO P. H. Reassessment of the potential economic impact of cattle parasites in Brazil. Revista Brasileira de Parasitologia Veterinária, v. 23, n. 2, p. 150-156, 2014.

INSTITUTO BRASILEIRO DE GEOGRAFIA E ESTAÍSTICA - IBGE. Sistema IBGE de recuperação automática - SIDRA. Pesquisa Trimestral do Leite - 4ํำ trimestre 2017. Disponível em: <http://www.sidra.ibge.gov.br/>. Acesso em: 11 jul. 2020. 
KIKUGAWA, M. M. Tristeza parasitária bovina (babesiose $\mathbf{x}$ anaplasmose). Disponível em: <http://https://arquivo.fmu.br/prodisc/medvet/mmk.pdf.>. Acesso em: 15 agosto 2020.

KHAN, H.; SUREDA, A.; BELWAL, T; ÇENTINKAYA, S.; SUNTAR, I.; TEJADA, S.; DEVKOTA, H. P.; ULLAH, H.; ASCHNER, M. Polyphenols in the treatment of autoimmune diseases. Autoimmunity Reviews, v. 18, p. 647-657, 2019.

LIMA, I. O.; OLIVEIRA, R. A. G. O; LIMA, E. O.; FARIAS, N. M. P.; SOUZA, E. L. Atividade antifúngica de óleos essenciais sobre espécies de Candida. Revista Brasileira de Farmacognosia, São Paulo, v. 16, p. 197-201, 2006.

LÓPEZ, C. A. A. Considerações gerais sobre plantas medicinais. Universidade Estadual de Roraima - UERR. Revista Ambiente: Gestão e Desenvolvimento, v. 1, n. 1, p. 19-27, 2006.

PERINI, R.; VEICSTEINAS, A. Heart rate variability and autonomic activity at rest and during exercise in various physiological conditions. European Journal of Applied Physiology, v. 90, p. 317-25, 2013.

PINHEIRO, A. A.; BRITO, F. I. Bem-estar e produção animal. Sobra: EMBRAPA, 2009.

RODRIGUES, L. Toxicidade do odor de óleos essenciais de Eucalyptus globulus e Corymbia citriodora sobre o carrapato Rhipicephalus microplus. Nova Odessa, 2018. 74 f. (Dissertação Mestrado) - Instituto de Zootecnia, Nova Odessa, 2018.

RUPP, R., BOICHARD, D. Genetics of resistance to mastitis in dairy cattle. Veterinary Research, v. 34, p. 671-688, 2003.

SANTOS, F. C. C.; VOGEL, F. S. F. Avaliação in vitro da ação do óleo essencial de capim limão (Cymbopogon citratus) sobre o carrapato bovino Rhipicephalus (Boophilus) microplus. Revista Brasileira de Plantas Medicinais, Botucatu, v. 14, n. 4, p. 712-716, 2012.

SANTOS-LIMA, T. M.; SANTOS, D. R. V.; SOUZA, R. M.; BASTOS, N. G.; VANNIERSANTOS, M. A.; NUNES, E. S.; DIAS-LIMA, A. G. Plantas medicinais com ação antiparasitária: conhecimento tradicional na etnia Kantaruré, aldeia Baixa das Pedras, Bahia, Brasil. Revista Brasileira de Plantas Medicinais, v. 18, n. 1, p. 240-247, 2016.

SRANDELLI, C. L. C. Plantas medicinais: histórico e conceitos. In: MONTEIRO, S.C.; SRANDELLI, C. L. C. (Orgs). Farmacobotânica: aspectos teóricos e aplicação. Porto Alegre: Artmed, 2017.

TAAVONI, S.; DARSAREH, F.; JOOLAEE, S.; HAGHANI, H. The effect of aromatherapy massage on the psychological symptoms of postmenopausal Iranian women. Complementary Therapies in Medicine, v. 21, p. 158-163, 2013.

THOMPSON-CRISPI, K, H.; ATALLA, F.; MIGLIOR, B.A.; MALLARD. Bovine mastitis: Frontiers in immunogenetics, v. 5, p. 493, 2014.

VERISSIMO, C. J. Fatores que afetam a fase de vida livre de carrapatos. In: VERISSIMO, C. J. (Org.). Controle de carrapatos nas pastagens. 1.ed. Nova Odessa: Instituto de Zootecnia, 2013, v. 1. p. 2-17.

ZAFALON, L. F.; NADER FILHO, A.; OLIVEIRA, J. V.; RESENDE, F. D. Mastite subclínica causada por Staphylococcus aureus: custo-benefício da antibioticoterapia de vacas em 
lactação. Arquivo Brasileiro de Medicina Veterinária e Zootecnia, Belo Horizonte, v. 59, n. 3, p. 577-585, jun. 2007.

ZHU, H.; DU, M.; FOX, L.; ZHU, M. Bactericidal effects of Cinnamon cassia oil against bovine mastitis bacterial pathogens. Food Control, v. 66, p. 291-299, ago. 2016. 